\title{
KRIEGSVERBRECHEN, RESTITUTION, PRÄVENTION
}

Aus dem Vorlass von Benjamin B. Ferencz

Herausgegeben von

Constantin Goschler, Marcus Böick,

Julia Reus

ARCHIV JÜDISCHER GESCHICHTE UND KULTUR BAND 4 
V\&R 


\title{
Archiv \\ jüdischer Geschichte und Kultur
}

\author{
Archive of \\ Jewish History and Culture
}

Band/Volume 4

Vandenhoeck \& Ruprecht
Im Auftrag

der Sächsischen Akademie

der Wissenschaften zu Leipzig

On behalf of the

Saxonian Academy of

Sciences and Humanities at Leipzig

herausgegeben/edited

von/by Dan Diner

Redaktion/editorial staff

Stefan Hofmann

Markus Kirchhoff

Marcel Müller

Momme Schwarz

Georg Wehse 


\section{Kriegsverbrechen, Restitution, Prävention Aus dem Vorlass von Benjamin B. Ferencz}

Herausgegeben von

Constantin Goschler, Marcus Böick, Julia Reus 
Das »Archiv jüdischer Geschichte und Kultur« ist Teil des Forschungsvorhabens »Europäische Traditionen - Enzyklopädie jüdischer Kulturen« der Sächsischen Akademie der Wissenschaften zu Leipzig und wird im Rahmen des Akademienprogramms von der Bundesrepublik Deutschland und dem Freistaat Sachsen gefördert. Das Akademienprogramm wird koordiniert von der Union der deutschen Akademien der Wissenschaften.

\section{Mit 16 Abbildungen}

Bibliografische Information der Deutschen Nationalbibliothek:

Die Deutsche Nationalbibliothek verzeichnet diese Publikation in der Deutschen Nationalbibliografie; detaillierte bibliografische Daten sind im Internet über https://dnb.de abrufbar.

(C) 2019, Vandenhoeck \& Ruprecht GmbH \& Co. KG, Theaterstraße 13, D-37073 Göttingen

$$
\text { (C) (1) } \Theta \Theta
$$

Das Werk ist als Open-Access-Publikation im Sinne der Creative-Commons-Lizenz BY-NC-ND International 4.0 (»Namensnennung - Nicht kommerziell - Keine Bearbeitung «) unter dem DOI 10.13109/9783666311161 abzurufen. Um eine Kopie dieser Lizenz zu sehen, besuchen Sie https://creativecommons.org/licenses/by-nc-nd/4.0/. Jede Verwertung in anderen als den durch diese Lizenz erlaubten Fällen bedarf der vorherigen schriftlichen Einwilligung des Verlages.

Satz: textformart, Daniela Weiland, Göttingen

Vandenhoeck \& Ruprecht Verlage | www.vandenhoeck-ruprecht-verlage.com

ISSN 2566-6673

ISBN (Print) 978-3-525-31116-5

ISBN (PDF) 978-3-666-31116-1

https://doi.org/10.13109/9783666311161 


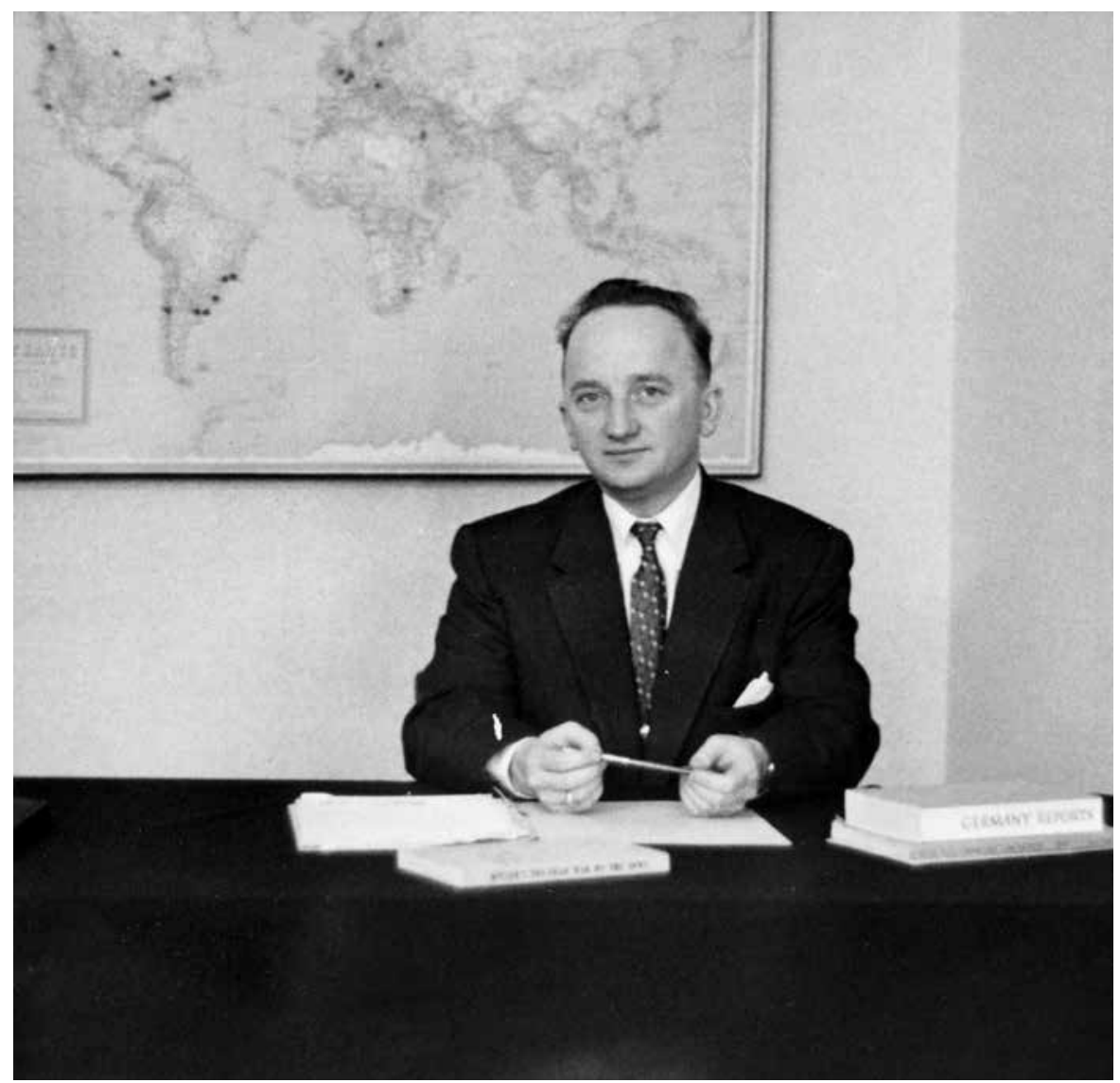

Benjamin B. Ferencz, 1955, Nürnberg (USHMM RG 12.019.28) 



\section{Inhalt}

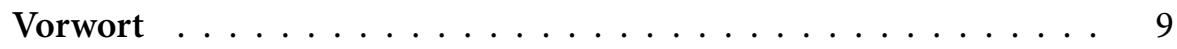

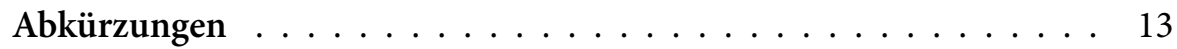

I. Einleitung $\ldots \ldots \ldots \ldots \ldots \ldots \ldots \ldots$

1. Vom »Zivilisationsbruch« zur Zivilisierung durch Verrechtlichung . . . . . . . . . . . . . 15

2. Biografie und Wirken . . . . . . . . . . . . . . 20

2.1 Kindheit, Jugend und Studium _ . . . . . . . . . . 20

2.2 Vom Nachschubsoldaten zum Ermittler von Kriegsverbrechen . . . . . . . . . . . . . . 23

2.3 Ermittler und Ankläger in den Nürnberger

Nachfolgeprozessen . . . . . . . . . . . . . . 25

2.4 Restitution und Entschädigung . . . . . . . . . . . 28

2.5 Rückkehr in die Vereinigten Staaten und Anwaltstätigkeit . . 33

2.6 Friedenssicherung und Publizistik . . . . . . . . . . 37

2.7 Das Ende des Kalten Kriegs und der Internationale

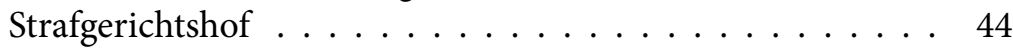

3. Die Benjamin B. Ferencz Collection und die Auswahlkriterien dieser Edition . . . . . . . . . . . . . . . 46

4. Zum Aufbau dieser Edition . . . . . . . . . . . . . . . . 49

5. Editorische Prinzipien $\ldots \ldots \ldots \ldots \ldots$

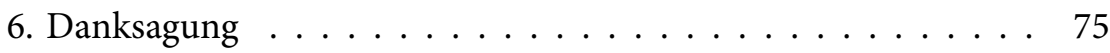

7. Liste der Dokumente . . . . . . . . . . . . . . . . . 77

8. Abbildungsverzeichnis _ . . . . . . . . . . . . . 87

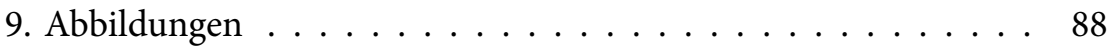


II. Quellen . . . . . . . . . . . . . . . . . . . . 97

Editorische Zeichen . . . . . . . . . . . . . . . 98

1. Tagebuch und Privatkorrespondenz im Zweiten Weltkrieg . . . . 99

2. Der ehemalige Nürnberger Ankläger: Rückblicke und Interventionen . . . . . . . . . . . . . . 143

3. Die Organisation der Restitution: JRSO, URO, JCC . . . . . . . . 219

4. Entschädigung jüdischer Zwangsarbeiter durch die deutsche Industrie . . . . . . . . . . . . . . . . 245

5. Entschädigung für Opfer medizinischer Humanexperimente . 363

6. Restitution für B'nai B'rith in Deutschland und den Vereinigten Staaten . . . . . . . . . . . . . 407

7. Entschädigungsverhandlungen mit der DDR . . . . . . . 423

8. Ausbau der bundesdeutschen Entschädigung für jüdische Opfer des Nationalsozialismus . . . . . . . . . . . 489

9. Weltfrieden und internationale Strafjustiz . . . . . . . . . . 559

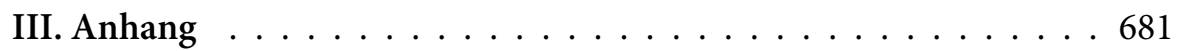

Abkommen, Deklarationen und Gesetze . . . . . . . . . . . 683

Bibliografie . . . . . . . . . . . . . . . . . 685

Register . . . . . . . . . . . . . . . . 6 698 


\section{Vorwort}

Mit der Quellenedition Kriegsverbrechen, Restitution, Prävention. Aus dem Vorlass von Benjamin B. Ferencz erscheint ein weiterer Band der Reihe »Archiv jüdischer Geschichte und Kultur« im Rahmen des an der Sächsischen Akademie der Wissenschaften angesiedelten Projekts »Europäische Traditionen - Enzyklopädie jüdischer Kulturen«. Die Reihe ist repräsentativen Archivalien aus den Bereichen jüdischer Rechts-, Diplomatie-, Politik- und Wissensgeschichte gewidmet. Dabei wird der allgemeinen Bedeutung der jüdischen Erfahrung für die Ausbildung einer universellen, sich internationalisierenden Rechts- und Moralkultur besonderes Augenmerk zuteil. In der Person von Benjamin B. Ferencz, seinem Werk und Wirken, ist diese Konstellation in besonderer Weise präsent.

Ferencz zählt zu jenen Juristen, Aktivisten und Sachwaltern einer kompensatorischen Gerechtigkeit, die angesichts des katastrophischen Geschehens des 20. Jahrhunderts entscheidend zur Ausbildung eines universellen Menschenrechtsregimes, der Institutionalisierung und Fortbildung einer internationalen Strafgerichtsbarkeit sowie der Durchsetzung einer exemplarischen Restitutionspraxis beigetragen haben. Dies gilt auch für Persönlichkeiten jüdischer Herkunft und Zugehörigkeit wie Hersch Lauterpacht, Raphael Lemkin oder Jacob Robinson, die von einer Existenzerfahrung geprägt waren, die biografisch auf die krisengeschüttelte Zwischenkriegszeit zurückweist und sich im nationalstaatlich zerklüfteten, nachimperialen mittel- und ostmitteleuropäischen Kulturraum abspielte.

Von letzterem Personenkreis unterscheidet sich Ferencz, trotz erheblicher gemeinsamer Schnittmengen an den zu bewältigenden rechtlichen Problemlagen, in mancherlei Hinsicht. Diese Differenz ist in erster Linie generationell bedingt. Der deutlich jüngere Ferencz, im rumänisch gewordenen Siebenbürgen zu Beginn der Zwischenkriegszeit geboren, wanderte schon als Kind mit seinen Eltern in die Vereinigten Staaten aus. Aufgewachsen in New York, erfolgte seine juristische Prägung durch die stark zivilrechtlich orientierte amerikanische Rechtstradition und ihre Verhandlungskultur. So ist er in seiner biografischen, vor allem professionellen Erfahrung vor allem Amerikaner, wenn auch einer, dem die europäischen Verhältnisse bestens vertraut wurden. Während die der oben erwähnten Gruppe zugehörigen jüdischen Juristen kontinental geprägt waren und dabei wesentlich von Fragen des individuellen wie kollektiven Rechtsschutzes in jener besonderen Konstellation 
der Zwischenkriegszeit ausgingen, war er mit den durch die nachfolgende Katastrophe aufgeworfenen rechtspolitischen und den sie begleitenden Verfahrensfragen befasst. So war er weniger mit der Abwendung von, denn mit der Bewältigung bereits erfolgter Staatsverbrechen konfrontiert. Prägend für sein Wirken war die Tätigkeit als junger Ankläger in einem Nürnberger Nachfolgeverfahren, dem Einsatzgruppenprozess, und in den Jahrzehnten danach spielte er eine tragende Rolle bei der Kompensation von den unter nationalsozialistischer Herrschaft angerichteten Schäden. Werk und Wirken von Ferencz bilden ein Monument der juristischen Aufarbeitung der Konkursmasse des Zweiten Weltkriegs und der in seinem Schatten verübten Massenverbrechen. Sein Name steht für die großen Fragen von Retribution, Restitution und Kompensation in der Nachkriegszeit ebenso wie für die Etablierung einer neuen Rechtskultur und einer ihr verpflichteten, internationalen Moral.

In Werk und Wirken von Ferencz sticht eine weitere Besonderheit heraus: die sich in seiner Person realisierende Verknüpfung von partikularer Anspruchserhebung mit einer universellen Präventionskultur. Als partikular versteht sich die von Ferencz über eine lange Dauer leitend betriebene Restitution jüdischen Eigentums, vornehmlich in Deutschland. Dabei wurde er zum herausragenden Sachwalter eines jüdischen Kollektivanspruchs insofern, als das präzedenzlose Phänomen eines absoluten Genozids, die Ausrottung ganzer Familienverbände, Fragen des Rechtstitels an dem erbenlos gewordenen Eigentum der Ermordeten aufwarf, zu deren Einforderung die Konstruktion eines Kollektivsubjekts im Sinne eines jüdischen Volks erforderlich wurde, das mittels jüdischer Nachfolgeorganisationen handelte. Als Repräsentant derartiger Körperschaften wurde Ferencz gleichsam zum Beauftragten des jüdischen Volks in Deutschland. Dass er an der Gestaltung des Luxemburger Abkommens von 1952 zwischen der Bundesrepublik Deutschland und dem jüdischen Volk, vertreten durch den Staat Israel und die Conference on Jewish Material Claims Against Germany, teilhatte, ist für sein Wirken signifikant.

Gleichwohl erschöpft sich Ferencz' Selbstverständnis in Rechtsschöpfung und Rechtspflege nicht in der Rolle eines jüdischen Sachwalters. Davon zeugt zunächst sein Engagement für verschiedene Opfergruppen bei der Einforderung von Entschädigungszahlungen für nationalsozialistische Verbrechen. Vor allem aber wird dies durch sein Wirken im Bereich der Prävention künftiger Massenverbrechen deutlich, in dem im Übrigen immer wieder seine amerikanische Prägung aufscheint. Als ein Jahrzehnt nach Ende des Kalten Kriegs der Internationale Strafgerichtshof in Den Haag eingerichtet wurde, in dem Delikte des Völkermords, der Verbrechen gegen die Menschlichkeit sowie Kriegsverbrechen, hernach auch Verbrechen der Aggression zu verhandeln 
sind, schloss sich für Ferencz der Kreis, der mit seinem Auftritt in Nürnberg als Ankläger im Einsatzgruppenprozess begonnen hatte. Die Strafverfolgung von Massenverbrechen war endgültig universell geworden.

Die vorliegende Edition, herausgegeben von Constantin Goschler, Marcus Böick und Julia Reus, präsentiert eine Vielzahl von Quellen zur Person und zu sämtlichen Tätigkeitsbereichen von Benjamin B. Ferencz. Den Herausgebern möchte ich an dieser Stelle ebenso danken wie der wissenschaftlichen Redaktion des Projekts »Europäische Traditionen - Enzyklopädie jüdischer Kulturen«, in erster Linie Stefan Hofmann, dem leitenden Redakteur des Bandes, sowie Markus Kirchhoff, Marcel Müller, Momme Schwarz und Georg Wehse, die mit verschiedenen Arbeitsschritten befasst waren.

Dan Diner

Herausgeber der Reihe 



\section{Abkürzungen}

ADIR Association nationale des anciennes déportées et internées de la Résistance

AJDC American Jewish Joint Distribution Committee; auch: JDC, Joint

ASIL American Society of International Law

BDI Bundesverband der Deutschen Industrie

BEG Bundesgesetz zur Entschädigung für Opfer der nationalsozialistischen Verfolgung

CC Conference on Jewish Material Claims Against Germany; auch: Claims Conference, Jewish Claims Conference, JCC

CT Compensation Treuhand

HIAS Hebrew Immigrant Aid Society

ILC International Law Commission

IMT International Military Tribunal/Internationales Militärtribunal

JCC Conference on Jewish Material Claims Against Germany; auch: Jewish Claims Conference, Claims Conference, CC

JDC Joint Distribution Committee; auch: AJDC, Joint

JRSO Jewish Restitution Successor Organization

JTC Jewish Trust Corporation

NYANA New York Association for New Americans

OCCWC Office of the US Chief of Counsel for War Crimes

URO United Restitution Organization

USHMM Unites States Holocaust Memorial Museum

USIP United States Institute of Peace

WAL World Association of Lawyers

WPLC World Peace Through Law Center 



\title{
I. Einleitung
}

\author{
Constantin Goschler
}

\section{Vom »Zivilisationsbruch« zur Zivilisierung durch Verrechtlichung}

Der amerikanische Jurist Benjamin B. Ferencz, bekannt geworden als »der letzte Mann von Nürnberg «, ${ }^{1}$ verkörpert wie kaum ein anderer globale Entwicklungen im Umgang mit staatlicher Gewalt gegen Individuen und ihren Folgen in der zweiten Hälfte des 20. und zu Beginn des 21. Jahrhunderts. Aus seiner Erfahrung als US-amerikanischer Soldat im Zweiten Weltkrieg und der Auseinandersetzung mit deutschen Kriegsverbrechen, die 1948 im Nürnberger Einsatzgruppenprozess gipfelte, gewann der Sohn transsilvanischjüdischer Migranten einen zutiefst pessimistischen Blick auf die im Kontext militärischer Konflikte freigesetzte menschliche Gewaltbereitschaft. In verschiedenen Funktionen widmete er sich der strafrechtlichen Verfolgung nationalsozialistischer Täter sowie der Entschädigung der Opfer. Die Erfahrung des Vietnamkriegs bedeutete eine weitere Zäsur: Schon immer war es Ferencz vor allem um Prävention und nicht um Vergeltung gegangen, und so engagierte er sich seit den 1970er Jahren zunehmend dafür, völkerrechtliche Konfliktlösungsinstrumente zu schaffen, die den Frieden sichern sollten. »Make law not war ${ }^{2}$ lautete seine Ultima Ratio und mit dieser umgewandelten Hippieparole attackierte er das eherne Prinzip der nationalen Souveränität.

Ferencz ist somit ein bedeutender Akteur im Prozess der "Verrechtlichung der Welt«, also der Übertragung von Rechtsstaatlichkeit in den Bereich der internationalen Beziehungen seit $1945 .^{3}$ Dazu gehören vor allem die globale Karriere der Menschenrechte, der internationalen Strafjustiz und

1 Siehe etwa Mareike Aden, Ben Ferencz. Der letzte Mann von Nürnberg, Deutschlandfunk, 15. September 2016, <http://www.deutschlandfunk.de/ben-ferencz-der-letztemann-von-nuernberg.1773.de.html?dram:article_id=365892> (17. März 2018).

2 Benjamin B. Ferencz, Make Law Not War, in: The World Today 54 (1998), H. 6, 152 f.

3 Stefan-Ludwig Hoffmann (Hg.), Moralpolitik. Geschichte der Menschenrechte im 20. Jahrhundert, Göttingen 2010. Siehe auch Tanja Abendschein-Angerstein, Internationale Verrechtlichung, in: Informationen zur politischen Bildung, 325 (2015), $10-16$. 
der Restitution. Diese Entwicklungen charakterisieren den Aufschwung der Moralpolitik in der zweiten Hälfte des 20. Jahrhunderts, ${ }^{4}$ die das neuzeitliche Axiom einer amoralischen Staatsräson herausforderte. Gleich in doppelter Hinsicht steht Ferencz damit für das Spannungsverhältnis von Individuum und Völkerrecht. Erstens wollte er mithilfe international verbindlicher Regelungen und Sanktionsmechanismen staatliche Gewaltakte an Individuen, wie sie insbesondere im Zusammenhang von Kriegen auftreten, bestrafen, entschädigen und möglichst auch verhindern. Damit gehört er einer nach 1945 erstarkenden völkerrechtlichen Bewegung an, die die internationalen Beziehungen einer übergeordneten regulierenden Instanz unterwerfen und zugleich die Rechte von Individuen stärken wollte. Gewissermaßen handelte es sich hier um die liberale Antithese zu der von dem deutschen Staatsrechtler Carl Schmitt in den 1930er Jahren auf die Spitze getriebenen Konzeption des souveränen Staats. Der Ausgang der von Ferencz als unausweichlich angesehenen Entwicklung hin zu einem die nationale Souveränität beschränkenden internationalen Recht ist jedoch bis zum heutigen Tag offen. Daher lässt sich sein Beitrag zu diesem Prozess noch nicht endgültig beurteilen.

Zweitens exemplifizieren seine Person und sein Wirken die Möglichkeiten und Grenzen der Gestaltungsmacht individueller Akteure bei der Weiterentwicklung des Völkerrechts in einem von nationalstaatlichen Interessen dominierten System internationaler Beziehungen. So bezog sich ein 2015 veröffentlichtes Filmporträt von Ferencz mit dem Titel A Man Can Make a Difference ${ }^{5}$ auf ein persönliches Motto des Protagonisten, das auf diesen $\mathrm{Zu}$ sammenhang abzielt. Jenseits des hier formulierten ethischen Anspruchs an die persönliche Verantwortung des Einzelnen für den Gang der Welt verweist sein Beispiel in analytischer Perspektive auf den Aufstieg nichtstaatlicher Akteure und Netzwerke sowie auf die zunehmenden medialen Einflussmöglichkeiten im Bereich der internationalen Beziehungen seit 1945. Dabei setzte

4 Moralpolitik als politisches Feld betrifft Entscheidungen, bei denen es um grundlegende gesellschaftliche Werte geht. Moralpolitik als Handlungsform bedeutet vor allem, dass ihre Akteure ein moralisches Framing politischer Themen vornehmen und dadurch politische Fragen in einen Konflikt über verschiedene Wertorientierungen transformieren. Siehe Christoph Knill/Caroline Preidel/Kerstin Nebel, Einleitung. Moralpolitik als Analysegegenstand, in: Christoph Knill u.a. (Hg.), Moralpolitik in Deutschland. Staatliche Regulierung gesellschaftlicher Wertekonflikte im historischen und internationalen Vergleich, Wiesbaden 2015, 15-24, hier 15f.; vgl. auch Hoffmann (Hg.), Moralpolitik; José Brunner/Constantin Goschler/Norbert Frei (Hg.), Die Globalisierung der Wiedergutmachung. Politik, Moral, Moralpolitik, Göttingen 2013.

5 A Man Can Make a Difference (Ullabritt Horn, Deutschland 2015). 
Ferencz insbesondere seine Tätigkeit als Ankläger im Nürnberger Einsatzgruppenprozess als symbolisches Kapital ein, wobei sich diese Strategie erst mit einigem zeitlichen Abstand als wirksam erwies.

Auch Wahrnehmung, Stilisierung und Selbstinszenierung von Ferencz haben sich über die Jahre hinweg verschoben. Aus einem Don Quijote im Kampf gegen die Windmühlen staatlicher Souveränität wurde ein David, der den Leviathan mit der Schleuder des Rechts attackiert. Hinter solchen heroischen Bildern verbergen sich Jahrzehnte harter administrativer und juristischer Arbeit bei der amerikanischen Militärregierung und in jüdischen Organisationen, der Aufbau eines weitgespannten Netzwerks von Spezialisten des Völkerrechts und nicht zuletzt beharrlicher Lobbyismus bei internationalen Organisationen, gepaart mit kontinuierlicher Medienarbeit. Hinzu tritt eine sehr persönliche Eigenschaft von Ferencz: sein ungebrochener historischer Optimismus, wonach sich staatliche Gewalt, namentlich Kriege und Völkermorde, in Zukunft durch Verrechtlichung der internationalen Beziehungen einhegen lassen würden. Er steht somit für den mehr als herausfordernden Versuch, den Prozess der Zivilisation gegen den »Zivilisationsbruch» (Dan Diner) zu retten.

Der Übergang der Wahrnehmung von Ferencz als einer Person der Zeitgeschichte hin $\mathrm{zu}$ einem historischen Untersuchungsgegenstand vollzieht sich graduell. Die einzige bislang zu seiner Person erschienene Biografie beschränkt sich weitgehend darauf, seinen launigen autobiografischen Blog, die »Benny Stories $"{ }^{6}$ in der dritten Person wiederzugeben. Dies ist insofern verständlich, als es sich bei Tom Hofmann, dem Autor dieses Buchs, um einen angeheirateten Cousin von Ferencz handelt, der sich am Genre der Familienchronik orientiert. ${ }^{7}$ Vor allem in zwei Forschungsfeldern wurde Ferencz bislang aber bereits ausführlicher thematisiert. Erstens besitzt er mittlerweile einen festen Platz in der Literatur zum internationalen Strafrecht seit 1945. Besondere Schwerpunkte bilden die Nürnberger Nachfolgeprozesse ${ }^{8}$ sowie

6 Siehe die etwa 2005 verfassten und im Internet unter dem Titel »Benny Stories« veröffentlichten Erinnerungen: Benjamin B. Ferencz, A Visionary for World Peace. Stories of the Life and Times of Benjamin B. Ferencz, <http://www.benferencz.org/ stories.html> (13. Dezember 2018).

7 Tom Hofmann, Benjamin Ferencz. Nuremberg Prosecutor and Peace Advocate, Jefferson, N. C./London 2014.

8 Ralf Ogorreck/Volker Rieß, Fall 9: Der Einsatzgruppenprozeß (gegen Otto Ohlendorf und andere), in: Gerd R. Ueberschär (Hg.), Der Nationalsozialismus vor Gericht. Die alliierten Prozesse gegen Kriegsverbrecher und Soldaten 1943-1952, Frankfurt a. M. 1999, 164-175; Annette Weinke, Die Nürnberger Prozesse, München 2006; Hilary Earl, The Nuremberg SS-Einsatzgruppen Trial, 1945-1958. Atrocity, Law, and 
die Entstehung des Internationalen Strafgerichtshofs und damit zusammenhängend auch das Konzept des Genozids. ${ }^{9}$ Dabei erscheint Ferencz in einer doppelten Rolle - einerseits als Untersuchungsobjekt, andererseits als Akteur, der mit eigenen Beiträgen in die Forschung hineinwirkt. Dieser Umstand ist vor allem darauf zurückzuführen, dass die Historisierung seiner Tätigkeitsfelder bereits zu Lebzeiten einsetzte.

Diese Beobachtung gilt in gleicher Weise für einen zweiten Forschungsbereich, nämlich die Restitution und Entschädigung für jüdische Opfer des Nationalsozialismus, wofür sich der umstrittene Quellenbegriff der »Wiedergutmachung « eingebürgert hat. ${ }^{10}$ Dabei interessierte bislang besonders Ferencz' Wirken im Zusammenhang mit der Rückerstattung jüdischen Eigentums, ${ }^{11}$

History, New York 2009; Kim C. Priemel/Alexa Stiller (Hg.), NMT. Die Nürnberger Militärtribunale zwischen Geschichte, Gerechtigkeit und Rechtsschöpfung, Hamburg 2013; Thomas Darnstädt, Nürnberg. Menschheitsverbrechen vor Gericht 1945, München/Berlin 2015.

9 Gary Jonathan Bass, Stay the Hand of Vengeance. The Politics of War Crimes Tribunals, Princeton, N. J./Oxford 2000; John Hagan, Justice in the Balkans. Prosecuting War Crimes in the Hague Tribunal, Chicago, Ill./London 2003; Mark Lattimer/Philippe Sands (Hg.), Justice for Crimes Against Humanity, Oxford/Portland, Oreg., 2003; Dominik J. Schaller/Jürgen Zimmerer (Hg.), The Origins of Genocide. Raphael Lemkin as a Historian of Mass Violence, New York 2009; Michael Bazyler, Holocaust, Genocide, and the Law. A Quest for Justice in a Post-Holocaust World, New York 2016; Douglas Irvin-Erickson, Raphaël Lemkin and the Concept of Genocide, Philadelphia, Pa., 2017; Philippe Sands, Rückkehr nach Lemberg. Über die Ursprünge von Genozid und Verbrechen gegen die Menschlichkeit. Eine persönliche Geschichte, Frankfurt a.M. 2018.

10 Zur Diskussion des Begriffs »Wiedergutmachung siehe vor allem Ludolf Herbst, Einleitung, in: Ludolf Herbst/Constantin Goschler (Hg.), Wiedergutmachung in der Bundesrepublik Deutschland, München 1989, 7-32, hier 8-10; Constantin Goschler, Wiedergutmachung. Westdeutschland und die Verfolgten des Nationalsozialismus 1945-1954, München 1992, 25; Aleida Assmann/Ute Frevert, Geschichtsvergessenheit - Geschichtsversessenheit. Vom Umgang mit deutschen Vergangenheiten nach 1945, Stuttgart 1999, 57; Hans Günter Hockerts, Wiedergutmachung in Deutschland. Eine historische Bilanz 1945-2000, in: Vierteljahrshefte für Zeitgeschichte 49 (2001), H. 2, 167-214, hier vor allem $167 \mathrm{f}$. Siehe zu diesem Themenfeld vor allem Constantin Goschler, Schuld und Schulden. Die Politik der Wiedergutmachung für NS-Verfolgte seit 1945, Göttingen 22008; Regula Ludi, Reparations for Victims in Postwar Europe, Cambridge, Mass., u. a. 2012.

11 Jürgen Lillteicher, Raub, Recht und Restitution. Die Rückerstattung jüdischen Eigentums in der frühen Bundesrepublik, Göttingen 2007; Tobias Winstel, Verhandelte Gerechtigkeit. Rückerstattung und Entschädigung für jüdische NS-Opfer in Bayern und Westdeutschland, München 2006; Jason Lustig, Who Are to Be the Successors 
den Verhandlungen zwischen der Bundesrepublik, Israel und der Jewish Claims Conference in Wassenaar 1952, ${ }^{12}$ der Auseinandersetzung um die Entschädigung von Opfern medizinischer Humanexperimente $e^{13}$ sowie den Verhandlungen der Jewish Claims Conference mit der DDR. ${ }^{14}$ Besonders deutlich wird seine doppelte Rolle als »teilnehmender Beobachter« im Bereich der Zwangsarbeiterentschädigung und ihrer wissenschaftlichen Behandlung, die er selbst mit einer mittlerweile klassischen Darstellung eröffnete. ${ }^{15}$

In diesen Forschungsfeldern werden jeweils wichtige Einzelaspekte der Tätigkeit von Ferencz beleuchtet. Bislang fehlt jedoch eine Untersuchung, die diese vielfältigen Facetten in einen übergeordneten thematischen und analytischen Zusammenhang stellt. Es bleibt also vor allem die Aufgabe, seine Bedeutung für die völkerrechtlichen Entwicklungen in der Auseinander-

of European Jewry? The Restitution of German Jewish Communal and Cultural Property, in: Journal of Contemporary History 52 (2017), H. 3, 519-545; Ruth Schreiber, New Jewish Communities in Germany after World War II and the Successor Organizations in the Western World, in: Journal of Israeli History 18 (1997), H. 2/3, 167-190; Ayaka Takei, The »Gemeinde Problem«: The Jewish Restitution Successor Organization and the Postwar Jewish Communities in Germany, 1947-1954, in: Holocaust and Genocide Studies 16 (2002), H. 2, 266-288; Norman Bentwich, The United Restitution Organization 1948-1968. The Work of Restitution and Compensation for Victims of Nazi Oppression, London 1969.

12 Nana Sagi, Wiedergutmachung für Israel. Die deutschen Zahlungen und Leistungen, Stuttgart 1981; Yeshayahu A. Jelinek, Deutschland und Israel 1945-1965. Ein neurotisches Verhältnis, München 2004, vor allem 161-250; Niels Hansen, Aus dem Schatten der Katastrophe. Die deutsch-israelischen Beziehungen in der Ära Adenauer und David Ben Gurion. Ein dokumentierter Bericht, Düsseldorf 2002; Goschler, Schuld und Schulden; Dan Diner, Rituelle Distanz. Israels deutsche Frage, München 2015.

13 Stefanie Michaela Baumann, Menschenversuche und Wiedergutmachung. Der lange Streit um Entschädigung und Anerkennung der Opfer nationalsozialistischer $\mathrm{Hu}$ manexperimente, München 2009.

14 Angelika Timm, Jewish Claims Against East Germany. Moral Obligations and Pragmatic Policy, Budapest 1997, 94-113; Angelika Timm, Alles umsonst? Verhandlungen zwischen der Claims Conference und der DDR über »Wiedergutmachung « und Entschädigung, Berlin 1996, 19-30; Stefan Meining, Kommunistische Judenpolitik. Die DDR, die Juden und Israel, Hamburg 2002.

15 Benjamin B. Ferencz, Less than Slaves. Jewish Forced Labor and the Quest for Compensation, Cambridge, Mass., 1979; dt.: Lohn des Grauens. Die Entschädigung jüdischer Zwangsarbeiter. Ein offenes Kapitel deutscher Nachkriegsgeschichte, Frankfurt a. M./New York 1986. Zur Historisierung seiner Tätigkeit im Bereich der Zwangsarbeiterentschädigung siehe vor allem Goschler, Schuld und Schulden; Henning Borggräfe, Zwangsarbeiterentschädigung. Vom Streit um »vergessene Opfer« zur Selbstaussöhnung der Deutschen, Göttingen 2014. 
setzung mit massenhafter staatlicher Gewalt gegen Zivilisten im Allgemeinen sowie mit nationalsozialistischen Verbrechen und ihren Opfern im Besonderen zu untersuchen und dies mit Fragen jüdischer Erfahrung im 20. Jahrhundert zu verbinden. Der vorliegende Band möchte vor allem einen Anstoß dazu liefern, sich weiter mit dem Wirken von Ferencz in diesen Problemfeldern $\mathrm{zu}$ beschäftigen und damit auch wichtige Einsichten in diese Zusammenhänge zu gewinnen.

\section{Biografie und Wirken}

\subsection{Kindheit, Jugend und Studium}

Benjamin B. Ferencz wurde am 11. März 1920 in Ciolt geboren, einem transsilvanischen Dorf in einem Gebiet, das bis zum Ersten Weltkrieg zu Ungarn gehört hatte und dann von Rumänien erobert wurde. Wenige Monate nach seiner Geburt, am 4. Juni 1920, besiegelte der Vertrag von Trianon, dass Ungarn große Teile seines bisherigen Staatsgebietes verlor. Für die ursprünglich aus Österreich-Ungarn stammende Familie Ferencz bedeutete dies, dass sie nun dem Staat Rumänien angehörte. Im folgenden Jahr wanderten seine Eltern zusammen mit ihm und seiner drei Jahre älteren Schwester in die Vereinigten Staaten aus, um dem in Ungarn und Rumänien gleichermaßen grassierenden Antisemitismus zu entkommen. In New York führte die Familie das Leben mittelloser Einwanderer. Feuchte Kellerwohnungen, große Enge, ständiger Mangel und allgegenwärtige Kriminalität prägten Kindheit und Jugend von Ferencz. Seine frühen Jahre im New Yorker Stadtteil Hell's Kitchen benannte er in seinen aus dem Abstand von rund 80 Jahren verfassten Erinnerungen retrospektiv als prägende Erfahrung, die ihm zugleich die fundamentale Bedeutung des Rechts nahegebracht hätte: »The basement at 346 West 56th Street became my preschool kindergarten. It was there that I learned to muse about life and death, the spirit of free enterprise, business ethics, the perils of gambling and alcoholism, the advantages of law over crime, and similar subjects taught primarily in the school of hard knocks. «16 Gegenüber dem hier dominierenden Gesetz der Straße tritt in den Erinnerungen von Ferencz ein anderer Aspekt seiner Prägungen deutlich in den Hintergrund: Sein in der Kindheit entwickeltes Verhältnis zum Judentum

16 Ferencz, Benny Stories, Story 1: Starting Life in America; vgl. auch Hofmann, Benjamin Ferencz, hier vor allem 15-17. 
beschreibt er als eher oberflächlich. Er wurde in die elementaren jüdischen Riten eingewiesen, ohne jedoch eine tiefere religiöse Bindung zu entwickeln. ${ }^{17}$

Nach der einvernehmlichen Scheidung seiner Eltern, die in Ungarn in traditioneller Weise von ihren Familien verheiratet worden waren und nun neue, selbstgewählte Ehen eingingen, zog Ferencz mit seiner Mutter in die Bronx um, wo er verschiedene öffentliche Schulen besuchte. Zuvor war seine Einschulung noch wegen mangelnder Englischkenntnisse zurückgestellt worden, wurde doch zu Hause vorwiegend Jiddisch, aber auch Rumänisch und Ungarisch gesprochen. ${ }^{18}$ Die Große Depression von 1929 warf seine Familie wieder in die Armut zurück, aus der sie sich eben erst ein Stück hatte befreien können. Ferencz hatte jedoch das Glück, von seinen Lehrern für die Townsend Harris Preparatory School vorgeschlagen zu werden, wo begabte Schüler kostenfrei unterrichtet wurden und Aussicht auf einen Studienplatz am College of the City of New York (CCNY) hatten. Diese öffentlich finanzierten Institutionen boten für junge Menschen, die aus armen Verhältnissen stammten, die Möglichkeit des sozialen Aufstiegs. Ferencz wurde 1937 am CCNY angenommen und befasste sich dort vor allem mit Soziologie und Kriminologie. Später erinnerte er sich, dass er besonders die in Kindheit und Jugend hautnah erlebte Jugendkriminalität gerne eindämmen wollte.

Ferencz' intellektuelle Prägung in den späten 1930er Jahren erfolgte in der Ära des New Deal, der die Tradition des amerikanischen liberalen Progressivismus in sich aufgenommen hatte. ${ }^{19} \mathrm{Zu}$ seinen politischen Aktivitäten während der Zeit am College zählte, dass er sich an einigen Demonstrationen gegen den deutschen Faschismus beteiligte. Allerdings blieb Deutschland, wie er später schilderte, in diesen Jahren für ihn eine ferne Vorstellung, wobei er darauf verzichtete, rückwirkend darüber zu spekulieren, inwieweit er sich an diesen Demonstrationen im Bewusstsein seiner jüdischen Herkunft beteiligt hatte. ${ }^{20}$ Seine Begegnung mit den während der Studienzeit am CCNY gleichfalls stark verbreiteten sozialistischen und kommunistischen Ideen bestärkte ihn eher in seiner liberalen Grundhaltung, wonach das $\mathrm{Zu}$ sammenleben freier Individuen durch die Herrschaft des Gesetzes geregelt sein sollte. Ferencz präferierte das Recht als Mittel zur Lösung sozialer und politischer Konflikte gegenüber der von Vertretern linker Weltanschauungen am CCNY propagierten Gewalt, die sie, wie er schreibt, sich vor allem gegenseitig zugedacht hätten. Damit schildert er Kommunisten und Sozialisten in

17 Ferencz, Benny Stories, Story 1.

18 Ebd.

19 Daniel T. Rodgers, Atlantic Crossings. Social Politics in a Progressive Age, Cambridge, Mass., 2000, 409-484.

20 Ferencz, Lohn des Grauens, 13. 
seinen Erinnerungen gewissermaßen als Wiedergänger der von ihm früher erlebten Jugendgangs mit ihren Bandenkämpfen und Gewaltritualen. Selbst also eher sozialreformerisch als sozialrevolutionär gesinnt, engagierte er sich während seines Studiums in Programmen zur Resozialisierung jugendlicher Straftäter. ${ }^{21}$

1940 schloss Ferencz das Studium am CCNY mit einem Bachelor of Social Sciences ab und bewarb sich anschließend erfolgreich an der prestigeträchtigen Harvard Law School. Dies war angesichts der damaligen Aufstiegsbarrieren für Einwandererkinder eine außergewöhnliche Bildungskarriere. Allerdings musste er parallel zu seinem Studium weiterhin erfindungsreich und gelegentlich auf juristisch fragwürdige Weise - etwa als Ghostwriter fremder Abschlussarbeiten - für ausreichende Mahlzeiten sorgen. ${ }^{22}$ Seine persönlichen sozialen Erfahrungen bewahrten ihn jedenfalls vor blindem Rechtspositivismus. So betont er in seiner biografischen Selbstdeutung nicht nur die eigene Leistung, sondern beschreibt neben der wichtigen Rolle von Zufällen immer wieder überlebensnotwendige Regelverstöße. Auch in Harvard interessierte er sich zunächst vor allem für das Problem der Jugendkriminalität und der vorbeugenden Verbrechensbekämpfung und verfolgte damit seine sozialreformerischen Ambitionen weiter. Er wurde studentischer Mitarbeiter des Kriminologen Sheldon Glueck - ein jüdischer Immigrant aus dem vor dem Ersten Weltkrieg noch zum Russischen Reich gehörenden Warschau -, der wenig später mit einer gemeinsam mit seiner Frau durchgeführten Langzeitstudie über Faktoren, die zu Straffälligkeit führen, bekannt wurde. Unter dem Eindruck der schrecklichen Vorgänge in seiner alten Heimat während des Zweiten Weltkriegs wandte er sich jedoch Fragen der künftigen Verfolgung und Bestrafung von Kriegsverbrechern zu. Für ein Buch Gluecks zu diesen Themen, das 1944 erschien, ${ }^{23}$ exzerpierte Ferencz Literatur. So arbeitete sich der angehende Jurist selbst intensiv in das damals erst neu entstehende Gebiet der internationalen Strafjustiz ein und sah dabei zum ersten Mal Dokumente über die Ermordung von Juden in Polen durch die deutschen Besatzer. ${ }^{24}$

21 Ferencz, Benny Stories, Story 8: Life at City College and the Beginnings of Romance.

22 Siehe dazu und zum Folgenden Ferencz, Benny Stories, Story 9: Lessons Learned at Harvard Law School.

23 Sheldon Glueck, War Criminals. Their Prosecution and Punishment, New York 1944.

24 Ferencz, Lohn des Grauens, 13. Das von Ferencz gesammelte und von Glueck in seinem Buch über deutsche Kriegsverbrechen verwendete Material stammte vor allem aus den von der polnischen Exilregierung erstellten Dokumentationen der deutschen Verbrechen im besetzten Polen, insbesondere Polish Ministry of Information (Hg.), The Black Book of Poland, New York 1942 sowie Republic of Poland Ministry of Foreign Affairs (Hg.), German Occupation of Poland. Extract of Note Addressed to 


\subsection{Vom Nachschubsoldaten zum Ermittler von Kriegsverbrechen}

Nachdem Ferencz sein Studium in Harvard 1943 mit einem Bachelor of Laws abgeschlossen hatte, wurde er als einfacher Soldat zum $115^{\text {th }}$ Anti-Aircraft Artillery Gun Battalion eingezogen. Es handelte sich um eine der damals modernsten Luftabwehreinheiten der US-Armee, die sich auf die Invasion in Frankreich vorbereitete. ${ }^{25}$ Zuvor hatte sich Ferencz vergeblich freiwillig für andere militärische Aufgaben beworben, die ihn stärker interessierten. Doch für den militärischen Nachrichtendienst kam er nicht in Frage, weil seine Naturalisierung als Amerikaner nicht lange genug zurücklag, und für die Air Force reichte seine Körpergröße nicht aus. ${ }^{26}$ Die Armeezeit, zunächst auf Übungsplätzen in den Vereinigten Staaten, dann seit Ende 1943 in Großbritannien, war von Monotonie und Schikanen geprägt, in denen sich der Hass einiger seiner vorgesetzten Offiziere auf höher gebildete Rekruten ebenso manifestierte wie Rassismus und Antisemitismus. Aus diesen Gründen, aber auch, weil er sich als einfacher Nachschubsoldat unterfordert fühlte, bemühte sich Ferencz mehrfach vergeblich darum, in eine andere Einheit versetzt zu werden, in der er seine Qualifikationen besser einbringen könnte. Im Juli 1944 nahm er schließlich an der Landung in der Normandie und der Befreiung Frankreichs teil. Sein Bataillon half die Angriffe der deutschen Luftwaffe auf die alliierten Truppen abzuwehren, während diese die sich eilig zurückziehende Wehrmacht verfolgten.

Als sich seine Einheit der westlichen Grenze des Deutschen Reichs näherte, erhielt Ferencz endlich eine neue Aufgabe zugewiesen, was er auf eine Empfehlung seines ehemaligen akademischen Lehrers Glueck zurückführte. Im Dezember 1944 wurde er zur Judge Advocate Section im Hauptquartier der von General Patton geleiteten Dritten US-Armee abkommandiert, die eine Einheit zur Untersuchung deutscher Kriegsverbrechen aufbaute. ${ }^{27}$ Nun-

the Allied and Neutral Powers, New York 1942. Aufgrund des Zeitpunkts der Veröffentlichung war dort die systematische Ermordung der jüdischen Bevölkerung in Vernichtungslagern noch nicht dokumentiert.

25 Siehe dazu Chip Chapin (Hg.), The Story of the 115th A.A.A. Gun Battalion, 2001, $<$ http://www.115th-aaa-gun-bn.com/Story/frontcover.php> (10. Dezember 2018).

26 Benjamin B. Ferencz, From Nuremberg to Rome: A Personal Account, in: Mark Lattimer/Philippe Sands (Hg.), Justice for Crimes Against Humanity, Oxford/Portland, Oreg., 2003, 31-45, hier 32.

27 Ferencz, Benny Stories, Story 17: Farewell Artillery, Hello General Patton; Ferencz, From Nuremberg to Rome, 32 f.; Library of Congress, 2011525367, Clio E. Straight, Report of the Deputy Judge Advocate for War Crimes, European Command. June 1944 to July 1948, hier vor allem 21. 
mehr mit Offiziersrang ausgestattet, untersuchte er zunächst als Teil eines kleinen War Crimes Investigation Teams Morde an notgelandeten alliierten Flugzeugbesatzungen oder gefangengenommenen US-Soldaten. Als die auf das deutsche Reichsgebiet vordringenden Alliierten zahlreiche Konzentrationslager befreiten, gehörte Ferencz zu den ersten Soldaten, die mit den Schrecken in Buchenwald, Mauthausen, Ebensee und Dachau konfrontiert waren. In den befreiten Lagern sicherte er Beweise der deutschen Verbrechen, beschlagnahmte Akten und protokollierte Häftlingsaussagen. Zudem war er daran beteiligt, den nationalsozialistischen Kunstraub in Europa aufzuklären. In seiner Funktion als Ermittler von Kriegsverbrechen nahm er auch an den in Dachau von amerikanischen Militärkommissionen durchgeführten Prozessen gegen die Verantwortlichen für die Ermordung notgelandeter amerikanischer Flugzeugbesatzungen sowie gegen SS-Wachpersonal teil. ${ }^{28}$ Er sprach später offen an, dass er unter dem unmittelbaren Eindruck der deutschen Gräuel bei seinen Verhören Aussagen gelegentlich auch mithilfe massiver Drohungen erlangt hatte. Selbstkritisch thematisierte er die großen Schwierigkeiten rechtsstaatlicher Verfahren kurz nach Kriegsende, die er gleichwohl als die bessere Alternative zum umstandslosen Erschießen der Täter betrachtete. ${ }^{29}$

Ende 1945 wurde Ferencz demobilisiert und kehrte nach New York zurück. Seine dreijährige Dienstzeit in der US-Armee resümierte er später als "the most miserable experience of my life «, weshalb er seither fest entschlossen gewesen sei, künftige Kriege zu verhindern. ${ }^{30}$ Die Schrecken des Kriegs und der in seinem Kontext begangenen deutschen Verbrechen hatten sich ihm unauslöschlich eingeprägt - noch Jahrzehnte später weinte er, wenn er davon erzählte. ${ }^{31}$ Diese Erfahrungen verarbeitete er innerhalb seines in Harvard erworbenen juristischen Deutungsrahmens, und hier lag zugleich die Wurzel seines späteren Aktivismus. ${ }^{32}$ Von Glueck, der an der Ausarbeitung des Statuts

28 Ferencz, Benny Stories, Story 19: Trials by U.S. Military Commissions; ebd., Story 20: Investigating Nazi Concentration Camps; ebd., Story 21: Looking for Hitler and Looted Art; Hofmann, Benjamin Ferencz, 46-89; Ferencz, Lohn des Grauens, 15; vgl. auch Ute Stiepani, Die Dachauer Prozesse und ihre Bedeutung im Rahmen der alliierten Strafverfolgung von NS-Verbrechen, in: Ueberschär (Hg.), Der Nationalsozialismus vor Gericht, 227-239.

29 Ferencz, From Nuremberg to Rome, 33; Hagan, Justice in the Balkans, 20-22.

30 Ferencz, Benny Stories, Story 22: Getting Home as a Stowaway.

31 Stefan Willeke, »Wer lügt, wird erschossen«. Benjamin Ferencz, der letzte noch lebende Chefankläger der Nürnberger Kriegsverbrecherprozesse, über die Suche nach Hitler und die fatale Kriegslogik von Donald Trump, in: Die Zeit, 28. März 2018, 12.

32 Hagan, Justice in the Balkans, 42. 
des Nürnberger Internationalen Militärgerichtshofs beteiligt war, übernahm er die Prinzipien des »liberal legalism « (John Hagan), der statt auf Abrechnung und Vergeltung von Kriegsverbrechen auf internationale Rechtsstaatlichkeit setzt. Damit unterscheidet sich der Ansatz des liberalen Legalismus von der Denkschule des Realismus, die Außenpolitik grundsätzlich als einen amoralischen Kampf konkurrierender nationaler Interessen versteht, da in der internationalen Sphäre keine oberste, einhegende Gewalt existiere. Aus einer realistischen Perspektive lassen sich die innerhalb von Staaten möglichen Rechtsverhältnisse nicht ohne weiteres auf die internationalen Beziehungen übertragen, weshalb die Bestrafung von Kriegsverbrechen letztlich eher eine Frage der Macht als des Rechts bleibt. Die Verfechter des liberalen Legalismus hingegen wollen die im Inneren liberaler Staaten herrschenden rechtlichen Prinzipien auf die internationalen Beziehungen übertragen, wozu eine überstaatliche Instanz geschaffen werden müsse, um dies zu garantieren. ${ }^{33}$ In den kommenden Jahren wuchs Ferencz immer mehr in die Rolle des Praktikers hinein, der diese theoretischen Ideen Gluecks umzusetzen suchte. ${ }^{34}$

\subsection{Ermittler und Ankläger in den Nürnberger Nachfolgeprozessen}

Ein überraschendes Stellenangebot des amerikanischen Kriegsministeriums durchkreuzte die Pläne von Ferencz, nach seiner Demobilisierung im Zivilleben als Anwalt Fuß zu fassen. Im Anschluss an den Prozess vor dem Internationalen Militärgerichtshof in Nürnberg gegen die Hauptkriegsverbrecher sollten vor einem amerikanischen Tribunal weitere Gruppen angeklagt werden, die als wesentliche Stützen des nationalsozialistischen Systems und seiner Verbrechen angesehen wurden..$^{35}$ General Telford Taylor, der Leiter des dafür zuständigen Office of the US Chief of Counsel for War Crimes (OCCWC), benötigte Personal zur Vorbereitung der Nürnberger Nachfolgeprozesse und weitete seine Suche nach geeigneten Mitarbeitern auf juristische Fakultäten und Rechtsanwaltskanzleien in den Vereinigten Staaten aus. Unter anderem überredete er Ferencz, der über die dringend gesuchte juristische Expertise zu Kriegsverbrechen verfügte, in seinen Diensten nach Deutschland zurückzukehren. ${ }^{36}$ Dieser heiratete zunächst seine langjährige Jugendfreundin Gertrude Fried, die daraufhin ihr Studium am Hunter College in

33 Bass, Stay the Hand of Vengeance, 16-20.

34 Hagan, Justice in the Balkans, 22.

35 Priemel/Stiller (Hg.), NMT; Weinke, Die Nürnberger Prozesse, 59-98.

36 Ferencz, Benny Stories, Story 24: Detained for Impersonating an Officer; Hofmann, Benjamin Ferencz, 105-118; Ferencz, Lohn des Grauens, 15. 
New York abbrach. Im April 1946 reisten die beiden auf getrennten Routen nach Nürnberg. Aus den seiner Frau versprochenen kurzen Flitterwochen in Europa wurden allerdings insgesamt zehn Jahre in Deutschland. Bald nach der Ankunft erfolgte Ferencz' Ernennung zum Leiter der Berliner Außenstelle des OCCWC. In der zerstörten Reichshauptstadt führte er ein Rechercheteam aus 50 Personen (darunter auch seine Frau Gertrude), das nach Beweismaterial zur Vorbereitung der neuen Nürnberger Anklagen suchte und entsprechende Materialien auswertete. ${ }^{37}$ Einen Höhepunkt bildete der Fund eines vollständigen Satzes der »Ereignismeldungen « der Einsatzgruppen der Sicherheitspolizei und des SD. Darin hatten die deutschen Täter ihre Mordaktionen in der Sowjetunion während des Kriegs detailliert dokumentiert, wodurch der Anklage bislang nicht verstandene Zusammenhänge des nationalsozialistischen Gewaltgeschehens offenbar wurden. ${ }^{38}$

Ferencz drängte erfolgreich darauf, dass auf Grundlage dieses einzigartigen Beweismaterials Anklage gegen 24 Kommandeure der Einsatzgruppen erhoben wurde - mehr Personen fanden auf den Anklagebänken im Nürnberger Gerichtssaal nicht Platz. Im Mai 1947 wechselte er von Berlin nach Nürnberg in die Rolle des Hauptanklägers im »Fall IX: Die Vereinigten Staaten von Amerika gegen Otto Ohlendorf et al. ${ }^{39}{ }^{39} \mathrm{Zu}$ Prozessbeginn im September trug er die Anklageschrift vor, übergab dann aber die weitere Verhandlung an seinen Kollegen James Heath, vorgeblich um den in der deutschen Öffentlichkeit beharrlich verbreiteten Gerüchten entgegenzutreten, dass es sich bei diesem wie anderen alliierten Prozessen um eine jüdische Racheaktion handle. ${ }^{40}$ Der Einsatzgruppenprozess wurde in mehrfacher Hinsicht bedeutend. Bei den rund eine Million Opfern, über die hier gesprochen wurde, handelte es sich zumeist um sowjetische Juden, die in Massenerschießungen ermordet worden waren. So zielte dieser Prozess als einziger in der

37 Siehe Organigramme des OCCWC in Priemel/Stiller (Hg.), NMT, 828f.; Ferencz, Benny Stories, Story 26: Life in Berlin 1946; Ferencz, From Nuremberg to Rome, 35 f.; Earl, The Nuremberg SS-Einsatzgruppen Trial, 75-79.

38 Hilary Earl, Beweise, Zeugen, Narrative: Der Einsatzgruppen-Prozess und die historische Forschung zur Genese der »Endlösung«, in: Priemel/Stiller (Hg.), NMT, 127-157, hier 127 und 134.

39 Benjamin B. Ferencz, The Einsatzgruppen Trial, in: Herbert R. Reginbogin/Christoph J. M. Safferling (Hg.), The Nuremberg Trials. International Criminal Law Since 1945. 60th Anniversary International Conference/Die Nürnberger Prozesse. Völkerstrafrecht seit 1945. Internationale Konferenz zum 60. Jahrestag, München 2006, 153-163; Ferencz, From Nuremberg to Rome, 36 f.; Earl, The Nuremberg SS-Einsatzgruppen Trial; Ogorreck/Rieß, Fall 9: Der Einsatzgruppenprozeß, 780.

40 Jonathan A. Bush, New Dealer, Flüchtlinge und Radikale? Die Nürnberger Ankläger im Profil, in: Priemel/Stiller (Hg.), NMT, 547-585, hier 557. 
unmittelbaren Nachkriegszeit direkt auf den Holocaust und prägte überdies dessen künftige historiografische Deutung. Dazu trug auch bei, dass der Angeklagte Otto Ohlendorf - ehemals Befehlshaber der Einsatzgruppe D und Amtschef des SD-Inland im Reichssicherheitshauptamt (RSHA) - vor Gericht zu einer Art Kronzeuge aufstieg.

Während des Einsatzgruppenprozesses stand jedoch zunächst vor allem das juristische Ergebnis im Vordergrund. Ferencz stützte sich deshalb auf die vom Internationalen Militärgerichtshof in Nürnberg erprobten juristischen Kategorien und Beweisverfahren - mit einer wichtigen Ausnahme: In seinem Eröffnungsplädoyer charakterisierte er die Taten der Einsatzgruppen ausdrücklich als Genozid und griff damit den kurz zuvor durch den polnisch-jüdischen Juristen Raphael Lemkin geprägten Begriff auf. Lemkin, der anders als die meisten seiner Angehörigen der Ermordung durch die Einsatzgruppen entkommen war, hatte während des Prozesses gegen die Hauptkriegsverbrecher weitgehend vergeblich für dieses neue juristische Konzept geworben. Anders als die vom Alliierten Kontrollrat etablierte juristische Kategorie der »Verbrechen gegen die Menschlichkeit« stellte der Begriff »Genozid» den Angriff auf Gruppen und nicht auf Individuen in den Mittelpunkt. ${ }^{41}$ Ferencz gebrauchte ihn um den besonderen Charakter der Taten der Einsatzgruppen, die vor allem die jüdische Bevölkerung der eroberten Gebiete im Osten systematisch ermordet hatten, zu beschreiben. Doch subsumierte er dieses von ihm zunächst ausführlich beschriebene Verbrechen in seiner abschließenden Begründung sowohl unter das Delikt eines Kriegsverbrechens als auch eines Verbrechens gegen die Menschlichkeit: "So here the killing of defenseless civilians during a war may be a war crime, but the same killings are part of another crime, a graver one if you will, genocide - or a Crime against Humanity. ${ }^{42}$ Somit gebrauchte er in Nürnberg und in späteren Jahrzehnten die rechtsphilosophisch konträr begründeten Konzepte der Verbrechen gegen die Menschlichkeit und des Genozids eher ergänzend als alternativ.

Aus Gründen der Prozessökonomie verzichtete Ferencz im Einsatzgruppenprozess fast vollständig auf Zeugen der Anklage. Stattdessen setzte er auf die überwältigende Wucht der vorliegenden schriftlichen Beweise und machte gleichzeitig geltend, dass die Zeugen unter der Last der Kreuzverhöre durch die Verteidiger kaum in der Lage gewesen seien, konsistente Aussagen

41 Siehe dazu Sands, Rückkehr nach Lemberg, vor allem 393-395, 411, 433-442, 451-453, 455, 461 f., 477-479 und 502.

42 Staatsarchiv Nürnberg, KV-Prozesse, Fall 9, Be-24, Opening Statement for the United States of America, Nurnberg, 29. September 1947, Benjamin B. Ferencz, Chief Prosecutor, 27. 
zu liefern. ${ }^{43}$ Diese Prozessstrategie führte zwar dazu, dass fast ausschließlich die Täter vor Gericht zu Wort kamen. Doch war sie insofern erfolgreich, als das Gericht in seinem im April 1948 verkündeten Urteil nahezu durchgehend die von der Anklage geforderten hohen Strafen verhängte. Letztlich wurden von den ausgesprochenen 14 Todesurteilen jedoch nur vier vollstreckt - unter den 1951 in Landsberg am Lech Hingerichteten befand sich auch Ohlendorf. ${ }^{44}$

Nach dem Ende des Einsatzgruppenprozesses arbeitete Ferencz einige Monate für General Taylor als Executive Counsel. In dieser Funktion war er vor allem mit der Abwicklung der letzten Fälle und schließlich des OCCWC betraut. Unter anderem kümmerte er sich um den Verbleib der umfangreichen Prozessunterlagen der Nürnberger Militärtribunale, die später in die Edition der Nürnberger Prozesse eingingen. ${ }^{45}$ Schon früh erkannte Ferencz die künftige geschichtspolitische Bedeutung von Quellenüberlieferungen, die dabei helfen konnten, das internationale Recht weiterzuentwickeln.

\subsection{Restitution und Entschädigung}

Ferencz und seine Frau hatten geplant, nach der Abwicklung des OCCWC 1948 in die Vereinigten Staaten zurückzukehren. Ein neues Stellenangebot führte jedoch dazu, dass sie bis 1954 zunächst weiter in Nürnberg blieben, wo auch ihre vier Kinder geboren wurden; anschließend verbrachten sie zwei weitere Jahre in Frankfurt am Main. Im August 1948 wurde Ferencz zum Leiter der deutschen Vertretung der in New York ansässigen Jewish Restitution Successor Organization (JRSO) bestellt. Seine Tätigkeit wechselte somit von der strafrechtlichen Verfolgung der deutschen Täter zur Restitution und Entschädigung für jüdische Opfer des Nationalsozialismus. Er stattete sich selbst mit dem Titel »Generaldirektor « aus - in der Annahme, dass eine Kombination aus »General« und »Direktor« bei den Deutschen maximalen Eindruck machen würde. ${ }^{46}$

Das am 10. November 1947 von der US-Militärregierung in ihrem Machtbereich erlassene Rückerstattungsgesetz Nr. 59 (USREG) verwirklichte eine zentrale Forderung amerikanischer jüdischer Organisationen. Das soge-

43 Earl, Beweise, Zeugen, Narrative, 142-153; Ferencz, Benny Stories, Story 33: The Biggest Murder Trial in History.

44 Priemel/Stiller (Hg.), NMT, $781 \mathrm{f}$.

45 Nuernberg Military Tribunals, Trials of War Criminals Before the Nuernberg Military Tribunals Under Control Council Law No. 10, Nuernberg October 1946-April 1949, 15 Bde., Washington, D. C., 1949-1953.

46 Ferencz, Benny Stories, Story 38: Restitution of Confiscated Property. 
nannte erbenlose jüdische Eigentum - es handelte sich um den Besitz ermordeter jüdischer Familien und aufgelöster jüdischer Organisationen - sollte nicht auch noch dem für diese Taten verantwortlichen deutschen Staat zufallen. Stattdessen sei dieses Vermögen einer jüdischen Nachfolgeorganisation zu übertragen, um es für den Wiederaufbau jüdischen Lebens - außerhalb Deutschlands, vor allem in Palästina beziehungsweise in Israel - zu verwenden. Zu diesem Zweck hatte eine Gruppe amerikanischer und internationaler jüdischer Organisationen die JRSO gegründet. ${ }^{47}$ Unter Leitung von Ferencz suchte diese in der US-Zone sowie im amerikanischen Teil Berlins systematisch nach erbenlosem jüdischem Eigentum, wozu vor allem Grundstücke, Immobilien und Friedhöfe, aber auch rituelle Gegenstände zählten. Ferencz ließ systematisch Grundbücher nach Eigentumstransfers in der Zeit des Nationalsozialismus durchsuchen, bei denen die Namen der Vorbesitzer jüdisch klangen. Am letzten Tag der Anmeldefrist reichte die JRSO schließlich 163000 Ansprüche ein; darunter waren allerdings oft Dubletten bereits von den ehemaligen Besitzern oder ihren Erben gestellter Forderungen. ${ }^{48}$ Die Bestrebungen zur Restitution trafen vielfach auf heftigen Widerstand der gegenwärtigen deutschen Besitzer des vormals jüdischen Eigentums, die sich in lautstarken Interessenverbänden organisierten. Dabei ging es gleichermaßen um Eigentumsrechte wie auch um die Bewertung der nationalsozialistischen Vergangenheit. ${ }^{49}$

Hinzu kam ein scharfer Konflikt der JRSO mit den nach 1945 wiedergegründeten jüdischen Gemeinden. In letzteren dominierten oftmals Flüchtlinge aus dem östlichen Europa, während die ehemaligen deutschen Juden, die infolge ihrer Emigration die Verfolgung überlebt hatten, gleichfalls auf Unterstützung durch die JRSO hofften. Der Streit um das Eigentum der ehemaligen jüdischen Gemeinden in Deutschland - die JRSO sprach bezeichnenderweise von einem "Gemeindeproblem « - drehte sich somit vor allem darum, inwieweit eine Kontinuität von den jüdischen Vorkriegsgemeinden zu den viel kleineren Nachkriegsgemeinden bestand. Deren Existenzrecht wurde von jüdischen Organisationen in Israel und der Diaspora, die vor allem das jüdische Volk als legitimen Erben des jüdischen Eigentums betrachteten, teils energisch bestritten. So berührte diese Kontroverse um die Ziele der Restitu-

47 Saul Kagan/Ernest H. Weismann, Report on the Operations of the Jewish Restitution Successor Organization 1947-1972, New York o. J. [1973]; Goschler, Schuld und Schulden, 107-110; Lillteicher, Raub, Recht und Restitution, 357-398.

48 Ferencz, Benny Stories, Story 38; Kagan/Weismann, Report on the Operations, $6 \mathrm{f}$.

49 Siehe vor allem Lillteicher, Raub, Recht und Restitution, 135-178 und 357-398; Winstel, Verhandelte Gerechtigkeit; Goschler, Schuld und Schulden, 100-121. 
tion nicht zuletzt die Frage, wo jüdisches Leben künftig stattfinden sollte und ob dies auch in Deutschland möglich sei. ${ }^{50}$

Ferencz verfolgte in diesen Auseinandersetzungen zwei Hauptziele. Erstens wollte er verhindern, dass der deutsche Staat von den unter nationalsozialistischer Herrschaft begangenen Untaten auch noch profitierte. Zweitens war er bestrebt, möglichst schnell flüssiges Kapital zum Wiederaufbau jüdischen Lebens zu mobilisieren. Diese Überlegungen führten schließlich zu Globalabkommen mit den vier Ländern der ehemaligen amerikanischen Besatzungszone (Bremen, Hessen, Baden-Württemberg, Bayern) und Westberlin, mit denen 1951/1952 die restlichen Forderungen der JRSO auf erbenloses jüdisches Eigentum für rund 48 Millionen DM pauschal abgelöst wurden. Damit versuchten die deutschen Länder zugleich auch die in der deutschen Nachkriegsgesellschaft weit verbreitete Verärgerung über die von alliierten Gesetzen geprägte Rückerstattung jüdischen Eigentums abzufedern. ${ }^{51}$ Zwar erhielt die JRSO insgesamt nur einen kleineren Teil der Summe, während der größere Teil an individuelle jüdische Erben sowie westdeutsche jüdische Gemeinden ging. Doch zog sie den Großteil der öffentlichen Kritik in der Bundesrepublik auf sich und wurde dort zum Symbol der von den Alliierten oktroyierten Restitution. ${ }^{52}$ Nach den Nürnberger Prozessen stand Ferencz somit als Leiter der JRSO zum zweiten Mal im Fokus deutschen vergangenheitspolitischen Unmuts.

1951 erklärte sich Bundeskanzler Konrad Adenauer zu Gesprächen mit dem Staat Israel und Vertretern der jüdischen Diaspora über materielle Wiedergutmachungsleistungen der Bundesrepublik für jüdische Opfer des Nationalsozialismus bereit. Mehrere jüdische Organisationen aus aller Welt gründeten als gemeinsame Interessenvertretung die Conference on Jewish Material Claims Against Germany (kurz: Jewish Claims Conference, JCC). Als diese vor dem ersten Treffen mit der deutschen Delegation ihre Verhandlungspositionen klärte, war Ferencz einer der nach London eingeladenen

50 Goschler, Wiedergutmachung, 172-180; Michael Brenner/Norbert Frei, Zweiter Teil: 1950-1967. Konsolidierung, in: Michael Brenner (Hg.), Geschichte der Juden in Deutschland von 1945 bis zur Gegenwart. Politik, Kultur und Gesellschaft, München 2012, 153-293, vor allem 153-182; Lustig, Who Are to Be the Successors of European Jewry?; Schreiber, New Jewish Communities in Germany after World War II; Takei, The »Gemeinde Problem«.

51 Kagan/Weismann, Report on the Operations, 8-10; Ferencz, Benny Stories, Story 41: Bulk Settlements for Property Claims; Winstel, Verhandelte Gerechtigkeit, 237-267; Schreiber, New Jewish Communities in Germany after World War II, $181 \mathrm{f}$.

52 Goschler, Wiedergutmachung, 182. 
Experten. ${ }^{53}$ Angesichts der massiven Kritik aus jüdischen Kreisen, sich überhaupt auf solche Gespräche mit den Deutschen einzulassen und damit »Blutgeld « für die Millionen ermordeter Juden zu verlangen, verteidigte er dieses Vorgehen. Als Jurist waren ihm solche Übersetzungsvorgänge von moralischer Schuld in materielle Schulden geläufig, wenngleich er stets ein feines Gespür für die sich hier öffnenden Abgründe behielt. ${ }^{54}$

Ferencz gehörte als Rechtsberater auch der Delegation der Jewish Claims Conference an, die unter großen Sicherheitsvorkehrungen seit März 1952 mit Vertretern der Bundesrepublik im niederländischen Wassenaar verhandelte. Die außerordentlich schwierigen und teilweise dramatischen Gespräche endeten schließlich am 10. September mit der Unterzeichnung eines umfangreichen Abkommens durch den deutschen Bundeskanzler, den israelischen Außenminister Moshe Sharett sowie den Präsidenten der JCC Nahum Goldmann in Luxemburg. Ferencz gehörte zu den Teilnehmern der Unterzeichnungszeremonie, die durch »rituelle Distanz« (Dan Diner) der jüdischen gegenüber der deutschen Seite geprägt war. Sie war Ausdruck der unauflösbaren Spannung zwischen den unermesslichen Dimensionen des Verbrechens und den mit den Deutschen vereinbarten konkreten materiellen Leistungen. Neben einem Vertrag mit Israel über eine Globalentschädigung in Höhe von drei Milliarden DM wurden zwei Protokolle mit der Jewish Claims Conference unterzeichnet. Protokoll Nr. 1 enthielt die ausgehandelten Grundsätze zur Verbesserung der bestehenden individuellen Entschädigungs- und Rückerstattungsgesetze; Protokoll Nr. 2 legte eine von der JCC zu verwaltende Globalentschädigung in Höhe von 450 Millionen DM fest. ${ }^{55}$

In den folgenden Jahren arbeitete Ferencz intensiv daran, die in Luxemburg erzielten Wiedergutmachungsvereinbarungen mit der Bundesrepublik umzusetzen. Dazu gehörte vor allem das 1953 erlassene Bundesergänzungsgesetz zur Entschädigung für Opfer der nationalsozialistischen Verfolgung, auf dem auch das 1956 in Kraft getretene und bis 1965 mehrfach novellierte Bundesgesetz zur Entschädigung für Opfer der nationalsozialistischen Verfolgung (Bundesentschädigungsgesetz, BEG) basierte. ${ }^{56}$ Unter der Leitung von Ferencz, der 1950 gerade erst 30 Jahre alt geworden war, beeinflussten jüdische Juristen nicht nur die weitere Entwicklung der Entschädigungs-

53 Ferencz, Benny Stories, Story 42: A Treaty to Compensate Victims.

54 Siehe dazu Goschler, Schuld und Schulden, 163.

55 Siehe insbesondere Sagi, Wiedergutmachung für Israel; Jelinek, Deutschland und Israel 1945-1965, vor allem 161-250; Hansen, Aus dem Schatten der Katastrophe, 155-366; Goschler, Schuld und Schulden, 159-175; Diner, Rituelle Distanz.

56 Hockerts, Wiedergutmachung in Deutschland, 182-185; Goschler, Schuld und Schulden, 181-203. 
gesetzgebung, sondern sorgten auch dafür, die daraus resultierenden Ansprüche praktisch umzusetzen und jüdischen Verfolgten zu ihrem Recht zu verhelfen. Zusätzlich zur Leitung der JRSO in Deutschland übernahm Ferencz 1953 die Stellung als Direktor der Jewish Claims Conference für Deutschland. ${ }^{57}$

Im Jahr darauf wurde er zudem Verwaltungsdirektor der 1948 in London als internationale privatrechtliche Organisation gegründeten United Restitution Organization (URO). Diese bot den in aller Welt lebenden jüdischen Verfolgten des Nationalsozialismus bei ihren Rückerstattungs- und Entschädigungsansprüchen juristische Beratung und Unterstützung und unterhielt dazu Büros in einer Vielzahl von Ländern. Zuvor waren das bisher schon eng zusammenarbeitende Legal Aid Department der JRSO und die URO unter einem gemeinsamen Dach zusammengefasst worden. Mit dieser organisatorischen und personellen Veränderung verstärkte sich auch der Einfluss der amerikanischen jüdischen Organisationen gegenüber den bislang in der URO dominierenden jüdischen Emigranten aus Deutschland. ${ }^{58}$ Unter Leitung von Ferencz wuchs seit Mitte der 1950er Jahre ein gewaltiger Apparat heran. 1955 wurden bereits rund 65000 Antragsteller von etwa 700 teils in Deutschland, teils in internationalen Außenstellen arbeitenden Mitarbeitern betreut, und diese Zahlen stiegen später noch beträchtlich an. ${ }^{59}$ Die Arbeit der URO trug erheblich dazu bei, dass im Lauf vieler Jahre zahlreiche jüdische Überlebende ihre Entschädigungsansprüche realisieren konnten.

Ferencz leitete damit Mitte der 1950er Jahre die drei wichtigsten jüdischen Organisationen in Deutschland auf dem Feld der Wiedergutmachung. Dies verdankte sich seinem organisatorischen Geschick, brachte ihm aber finanziell wenig ein. Er erhielt lediglich ein einziges - nicht besonders üppiges Gehalt für seine Tätigkeit bei der JRSO. ${ }^{60}$

57 Zur Jewish Claims Conference siehe Ronald W. Zweig, German Reparations and the Jewish World. A History of the Claims Conference, London/Portland, Oreg., ${ }^{2} 2001$; Marilyn Henry, Confronting the Perpetrators. A History of the Claims Conference, London/Portland, Oreg., 2007.

58 Hans Günter Hockerts, Anwälte der Verfolgten. Die United Restitution Organization, in: Herbst/Goschler (Hg.), Wiedergutmachung in der Bundesrepublik Deutschland, 249-271, hier 254 und $256 \mathrm{f}$.

59 Ebd., 260; Bentwich, The United Restitution Organization 1948-1968, 27-30.

60 Ferencz, Benny Stories, Story 44: Implementing Compensation Agreements. 


\subsection{Rückkehr in die Vereinigten Staaten und Anwaltstätigkeit}

Nicht zuletzt wegen seines mageren Einkommens plante Ferencz schließlich, die Leitungspositionen in den drei jüdischen Organisationen aufzugeben. Vor allem aber war ihm und seiner Frau Gertrude dringend daran gelegen, ihre vier Kinder nicht in Deutschland einschulen zu lassen, »in the land that held so many nightmares «. ${ }^{61}$ So kehrten sie im Frühjahr 1956 nach Amerika zurück. Ferencz zog mit seiner Familie nach New Rochelle, einem Vorort von New York, um sich nun, mit zehnjähriger Verzögerung, eine Existenz als Rechtsanwalt aufzubauen. Dies erwies sich jedoch als äußerst schwierig. Anfang 1958 beschloss er einen Brief, in dem er rückblickend seine Karriere in Deutschland beschrieb, mit der bitteren Bemerkung: »Can it be that at age 37 my future is behind me? « ${ }^{62} \mathrm{Um}$ überhaupt eine finanzielle Basis zu haben, blieb er für ein bescheidenes Gehalt weiter als Rechtsberater für die URO sowie die Jewish Claims Conference tätig. Dies bedeutete auch künftig regelmäßige Reisen nach Deutschland und zu den über die ganze Welt verstreuten Büros der URO. ${ }^{63}$

Nach seiner Rückkehr in die Vereinigten Staaten vertrat er bis Mitte der 1960er Jahre unter anderem die Entschädigungsforderungen der Jewish Claims Conference für jüdische Zwangsarbeiter gegen namhafte deutsche Industriefirmen und Unternehmer wie I. G. Farben in Liquidation, Krupp, Flick, AEG/Telefunken und Rheinmetall. ${ }^{64}$ Dafür qualifizierten ihn seine große Erfahrung mit den deutschen Wiedergutmachungsgesetzen sowie die Tätigkeit als Ermittler und Ankläger in den Nürnberger Nachfolgeprozessen, wo einige dieser Unternehmen bereits angeklagt worden waren. Während sich Ferencz in Nürnberg jedoch noch auf die Autorität eines amerikanischen Strafgerichts gegenüber deutschen Angeklagten stützen konnte, hatte er zwischen 1955 und 1965 als Rechtsvertreter der JCC außergerichtliche Verhandlungen mit selbstbewussten Justiziaren deutscher Industrieunternehmen zu führen, denen der Kalte Krieg mächtig den Rücken stärkte.

Im Zusammenhang mit der Auseinandersetzung um die Entschädigung von Zwangsarbeitern zog Ferencz eine strenge Trennlinie zwischen den von ihm im Auftrag der JCC vertretenen Ansprüchen bekennender Juden und

61 Ebd., Story 46: Returning Home to New York in 1956.

62 Dokument 20.

63 Hofmann, Benjamin Ferencz, 177.

64 Siehe dazu die von ihm selbst verfasste ausführliche Darstellung Ferencz, Lohn des Grauens. 
denen nicht-bekennender Juden. ${ }^{65}$ Dies ergab sich aus seinem anwaltlichen Mandat und nicht aus weltanschaulichen oder religiösen Präferenzen.

Zur selben Zeit stellte Ferencz sein umfangreiches Wissen als Entschädigungsanwalt auch einer Verfolgtengruppe zur Verfügung, in der polnische, katholische Frauen dominierten. Seit 1957 stand er in engem Kontakt mit Caroline Ferriday, der Vorsitzenden der amerikanischen Verfolgtenorganisation Friends of ADIR, Inc., ${ }^{66}$ die sich für die Entschädigungsansprüche zumeist weiblicher Opfer medizinischer Humanexperimente in deutschen Konzentrationslagern einsetzte. Zusammen mit ihr organisierte er das Ravensbrueck Lapins Project, das 35 Frauen, die im Konzentrationslager Ravensbrück Opfer derartiger medizinischer Praktiken geworden waren, in die Vereinigten Staaten einlud und durch verschiedene publizistische und politische Aktionen auf ihr Schicksal und ihre daraus resultierenden Forderungen aufmerksam machte. ${ }^{67}$ Aufgrund des Drucks der öffentlichen Meinung in Amerika gab die deutsche Regierung ihren Widerstand gegen Entschädigungsleistungen für Opfer medizinischer Humanexperimente seit 1960 schrittweise auf - eine Entwicklung, an der Ferencz erheblich beteiligt war. ${ }^{68}$

65 Constantin Goschler, Streit um Almosen. Die Entschädigung der KZ-Zwangsarbeiter durch die deutsche Nachkriegsindustrie, in: Dachauer Hefte 2 (1986), 175-194, hier 184; Katharina Stengel, Hermann Langbein. Ein Auschwitz-Überlebender in den erinnerungspolitischen Konflikten der Nachkriegszeit, Frankfurt a.M./New York 2012, 232-237. Die JCC definierte »bekennende Juden« als Personen, die während ihrer Verfolgung oder zum Zeitpunkt der Antragstellung auf Entschädigung einer jüdischen Gemeinde angehörten. Diese Gruppe wurde von sonstigen jüdischen Opfern abgegrenzt, um sich nicht der nationalsozialistischen Kategorien zu bedienen und den zu vertretenden Personenkreis einzuschränken. In der bundesdeutschen Entschädigungspraxis war dagegen von "Glaubensjuden « und »Nicht-Glaubensjuden" die Rede, wobei sich letztere Kategorie insbesondere auf Angehörige christlicher Glaubensgemeinschaften bezog, die von den Nationalsozialisten aufgrund ihrer Herkunft als Juden verfolgt worden waren.

66 Bei der ADIR (Association nationale des anciennes déportées et internées de la Résistance) handelt es sich um eine 1945 gegründete Vereinigung weiblicher ehemaliger politischer Häftlinge aus Frankreich. Siehe Debra Workman, Engendering the Repatriation: The Return of Female Political Deportees to France Following the Second World War, in: The Proceedings of the Western Society for French History 35 (2007), 263-275.

67 Paul Weindling, Nazi Medicine and the Nuremberg Trials. From Medical War Crimes to Informed Consent, Basingstoke/New York 2004, 338; Baumann, Menschenversuche und Wiedergutmachung, 113-117.

68 Baumann, Menschenversuche und Wiedergutmachung, vor allem 117-178. 
Indem er die öffentliche Meinung in den Vereinigten Staaten wirkungsvoll für seine Arbeit mobilisierte, erscheint Ferencz als ein Vorgänger amerikanischer Anwälte wie Michael Hausfeld und Edward Fagan, die seit den 1990er Jahren international bekannte deutsche Unternehmen verklagten und dabei zu Prominenz gelangten. Beide kamen aus der Bürgerrechtsbewegung der Vereinigten Staaten der 1960er Jahre und nutzten nach dem Ende des Kalten Kriegs das Instrument der Sammelklagen, das in den 1970er Jahren durch den Ausbau der Verbraucherschutzgesetzgebung entstanden war. Mithilfe dieses juristischen Hebels konnten sie deutsche sowie andere europäische Großunternehmen vor amerikanischen Gerichten verklagen. ${ }^{69}$ Ferencz hingegen hatten diese Rechtsmittel in den 1950er und 1960er Jahren noch nicht zu Verfügung gestanden. So musste er innerhalb der eingeschränkten juristischen und sonstigen Möglichkeiten agieren, die ihm die damalige Situation bot. Er vermochte zwar die amerikanische Öffentlichkeit und ein Stück weit auch politische Kontakte zu mobilisieren, konnte aber seine Fälle nicht vor amerikanische Gerichte tragen. Dies vertiefte die Kluft zwischen seiner bescheidenen Rolle als Anwalt in New York und seiner exponierten Stellung bei internationalen Wiedergutmachungsverhandlungen.

Nach seiner Rückkehr in die Vereinigten Staaten 1956 vollzog Ferencz zunächst einen schwierigen beruflichen Spagat. Zum einen vertrat er die Jewish Claims Conference oder das Ravensbrueck Lapins Project auf internationalem Parkett, womit er allerdings seinen Lebensunterhalt nicht sichern konnte. Zum anderen schlug er sich zu Hause mühselig in den Niederungen des Anwaltsberufs herum. Seine vorherigen Tätigkeiten für die amerikanische Militärregierung wie für jüdische Organisationen halfen kaum dabei, im harten New Yorker Anwaltsgeschäft Fuß zu fassen. Er war nicht in professionellen Netzwerken etabliert und vor allem besaß er keinen zahlungskräftigen Kundenstamm. So akzeptierte Ferencz nach seiner Ankunft in New York zunächst eine schlecht bezahlte Stelle in einer Kanzlei, machte sich bald darauf selbstständig, blieb damit allerdings erfolglos. Neben bescheidenen Mandaten für Scheidungen und andere Allerweltsfälle charakterisierte seine Situation auch, dass er Mitglied einer lokalen Reformsynagoge wurde, was freilich wenig mit einer Zuwendung zur Religion zu tun hatte. Er hoffte auf diesem Wege vor allem neue Kunden zu werben. ${ }^{70}$

Nach einer langen beruflichen Durststrecke halfen Ferencz schließlich doch noch seine alten Kontakte aus der Zeit in Deutschland. 1964, er war mittlerweile 44 Jahre alt, offerierte ihm sein ehemaliger Nürnberger Vor-

69 Siehe dazu Michael R. Marrus, Some Measure of Justice. The Holocaust Restitution Campaign of the 1990s, Madison, Wis., 2009.

70 Hofmann, Benjamin Ferencz, 175-177. 
gesetzter Telford Taylor in seiner kleinen New Yorker Kanzlei die Position seines soeben verstorbenen Sozius. Auch der ehemalige General und Leiter des OCCWC hatte zuvor erfahren, wie schwierig es für die einstigen »Nürnberger « war, in den Vereinigten Staaten wieder beruflich Fuß zu fassen, wo ihre Konkurrenten ihre Karrieren schon seit 1945 aufgebaut hatten. ${ }^{71}$ Mit der gemeinsam mit Taylor betriebenen Kanzlei besaß Ferencz endlich ein solides berufliches Standbein, wobei er sich als Spezialist für hoffnungslose, aber moralisch gerechtfertigte Fälle zu etablieren vermochte. ${ }^{72}$ Mitte der 1960er Jahre hatte er also seine berufliche Situation in Amerika stabilisiert. In der Bundesrepublik verkündete damals Bundeskanzler Ludwig Erhard in seiner Regierungserklärung das "Ende der Nachkriegszeit" und artikulierte damit eine in diesem Land weitverbreitete Erwartung. Das Feld der Wiedergutmachung war ein Beispiel dafür. So wurde 1965, bei der letztmaligen Novellierung des Bundesentschädigungsgesetzes, dieses demonstrativ als "Schlussgesetz« ausgewiesen. ${ }^{73}$ Auch Ferencz rechnete zu dieser Zeit damit, dass seine Tätigkeit auf diesem Gebiet beendet sein würde ${ }^{74}$ - tatsächlich wurde diese mehr und mehr zu einem Nebenerwerb.

Dank seiner Expertise in Rückerstattungsfragen konnte Ferencz einen lukrativen Auftrag in einem benachbarten Rechtsgebiet akquirieren, der seine finanzielle Situation erheblich verbesserte. Nachdem er bereits die Restitutionsansprüche des deutschen Ablegers der jüdischen Wohlfahrtsorganisation B'nai B'rith in Deutschland erfolgreich durchgesetzt hatte, erteilte ihm die amerikanische Zentrale der Vereinigung ein umfangreiches Mandat, um deren Forderungen nach Rückerstattung ihres im Zweiten Weltkrieg in Europa geraubten Eigentums zu vertreten. Durch den gelungenen Einsatz für eine Änderung des US-amerikanischen War Claims Act zugunsten von B'nai B'rith und anderer karitativer und konfessioneller Organisationen erhielt diese seit 1970 über eine halbe Million Dollar zusätzlich, wobei Ferencz sieben Prozent Erfolgshonorar zustanden. ${ }^{75}$ Zudem war er gegen ein

71 Ferencz, Benny Stories, Story 46.

72 Hofmann, Benjamin Ferencz, 180.

73 Hockerts, Wiedergutmachung in Deutschland, 187-190; Goschler, Schuld und Schulden, 273-288.

74 Hofmann, Benjamin Ferencz, 180.

75 Siehe Dokument 102; USHMM, Benjamin B. Ferencz Collection (nachfolgend: BBF Collection), RG 12.011.05^10, Benjamin B. Ferencz an Harry Greenberg und Mr. Ellsworth G. Stanton III (Coordinating Council of Religious Welfare Agencies), 10. Oktober 1970 sowie auch die zum Teil ungenauen Schilderungen bei Ferencz, Benny Stories, Story 47: Creative Approach to Law Practice; Hofmann, Benjamin Ferencz, $180-183$. 
jährliches Honorar von 10.000 beziehungsweise später 15.000 Dollar weiter für die Jewish Claims Conference und die URO tätig ${ }^{76}$ und reiste in dieser Funktion regelmäßig nach Deutschland. Insbesondere verhandelte er seit Mitte der 1970er Jahre im Auftrag der JCC mit Vertretern der DDR über Entschädigungsleistungen für im nationalsozialistischen Herrschaftsgebiet verfolgte Juden - die deutsche Wiedervereinigung beendete diese Gespräche allerdings 1990, ohne dass eine Lösung gefunden worden wäre. ${ }^{77}$

\subsection{Friedenssicherung und Publizistik}

Die rechtspolitischen Interessen von Ferencz hatten sich in der zweiten Hälfte der 1960er Jahre in eine neue Richtung verschoben. Sein Blick wandte sich immer mehr von der strafrechtlichen Ahndung der Kriegsverbrechen im Zweiten Weltkrieg und der Wiedergutmachung für den Holocaust hin zur Verhinderung neuer Kriege und Genozide. Die Ursache dafür war in erster Linie seine Beschäftigung mit dem Vietnamkrieg. Vor allem das 1968 von US-Truppen verübte Massaker von My Lai warf für ihn die Frage auf, inwieweit die Bestrafung von Kriegsverbrechen nicht nur eine Angelegenheit der Vergangenheit sei. ${ }^{78}$ Hinzu kam 1969 eine schwere Herzattacke auf einer Reise nach Puerto Rico, die ihm eine Nahtoderfahrung bescherte und seinen Erinnerungen zufolge den letzten Ausschlag dafür gab, sich zu überlegen, was er mit seinem restlichen Leben anfangen wolle. 1970, mit 50 Jahren, beschloss er, seine Arbeit neu auszurichten und sich künftig hauptsächlich Fragen der internationalen Friedenssicherung zu widmen. Zudem war er mittlerweile seiner lange drängenden materiellen Sorgen enthoben und konnte sich eine wenig materiellen Gewinn versprechende ideelle Tätigkeit nunmehr auch leisten. ${ }^{79}$

Ferencz suchte zunächst Rat bei einigen Freunden und Fachleuten, um sich auf dem Feld der Friedenssicherung zu orientieren..$^{80}$ Dazu gehörten der litauisch-amerikanische Jurist, Historiker und Politiker Jacob Robinson, der zu dieser Zeit Israel im Rechtskomitee der Vereinten Nationen repräsentierte, der französische jüdische Jurist René Cassin, der für seine Mitautorschaft bei der Allgemeinen Erklärung der Menschenrechte der Vereinten Nationen 1968

76 Siehe Dokument 152.

77 Ferencz, Benny Stories, Story 45: Some Unanticipated Consequences; Goschler, Schuld und Schulden, 403-406.

78 Ebd., Story 51: A Mélange of Vignettes, Vignette One: Vietnam War on Mock Trial.

79 Ebd., Story 53: Contemplating Life and Death in Puerto Rico.

80 Siehe hierzu und zum Folgenden ebd., Story 54: Starting a New Career. 
mit dem Nobelpreis geehrt worden war, sowie sein ehemaliger Vorgesetzter und jetziger Kollege Telford Taylor. Letzterer empfahl ihm, Kontakt mit dem Professor für Internationales Recht der Yale Law School Myres Smith McDougal aufzunehmen, damals einer der maßgeblichen Theoretiker des Völkerrechts. In der Folge richtete Ferencz sein Interesse vor allem auf die Vereinten Nationen, wo er den Status eines akkreditierten Non-Governmental Observer erlangte. Er richtete sich in der UN-Bibliothek häuslich ein und studierte intensiv das Archiv des Völkerbunds, während er gleichzeitig regelmäßig Sitzungen der Vereinten Nationen in New York und Genf besuchte. Auf diese Weise verschaffte er sich umfassendes Wissen über die Geschichte der völkerrechtlichen Friedenssicherung. Zugleich baute er ein internationales Netzwerk aus einschlägigen Forschern auf diesem Gebiet auf, darunter auch Mitarbeiter des Heidelberger Max-Planck-Instituts für ausländisches öffentliches Recht und Völkerrecht. In seinen Erinnerungen kommentierte er sein verändertes Interesse: »I justified such diversions by rationalizing that if I could help build a world free of Holocausts, it might be more valuable than trying to squeeze additional reparations from Germany. Some of my former colleagues thought I had gone nuts. ${ }^{81}$ Die rückblickende Schilderung, wie er in den 1970er und 1980er Jahren angesichts seiner Rolle als Ein-Mann-Lobby für den Weltfrieden von vielen als Don Quijote belächelt wurde ${ }^{82}$ spiegelt ein wenig seine Darstellung Raphael Lemkins, der während der Prozesse gegen die Hauptkriegsverbrecher auf den Fluren des Nürnberger Gerichtsgebäudes herumgeirrt sei und dort die Anwesenden von dem von ihm entwickelten Konzept des Genozids zu überzeugen gesucht habe. ${ }^{83}$

Zunächst bedeutete diese neue Mission vor allem harte Arbeit. Ferencz studierte intensiv die Defizite der kollektiven Friedenssicherungsmechanismen der Vereinten Nationen, die - verkörpert in der Institution des Sicherheitsrats - die nationale Souveränität der Großmächte unangetastet ließen. Die Nürnberger Prozesse und die Vereinten Nationen waren beide nach 1945 zum Zweck der künftigen Friedenssicherung etabliert worden, doch hatte sich dabei von Anfang an ein grundsätzlicher Gegensatz entwickelt. "Nürnberg", so Annette Weinke, »erhob den Anspruch, der staatlichen Gewaltausübung rechtliche Grenzen zu setzen; die Vereinten Nationen hingegen rückten ungeachtet aller anderslautenden Rhetorik die Macht des Nationalstaats in den Mittelpunkt der Nachkriegsordnung. ${ }^{84}$ Ferencz versuchte demgegenüber

81 Ebd.

82 Ebd., Story 59: Writing for World Peace.

83 Ebd., Story 34: Mass Murderers Seek to Justify Genocide.

84 Annette Weinke, »Von Nürnberg nach Den Haag«? Das internationale Militärtribunal in historischer Perspektive, in: Justizministerium des Landes NRW (Hg.), 
den ursprünglichen Impuls der Nürnberger Prozesse fortzuführen, der auf eine "rechtsgestützte Friedensordnung unter amerikanischer Hegemonie ${ }^{85}$ hinauslief, wobei er keinesfalls die Vereinigten Staaten von der Anwendung dieser Spielregeln auszunehmen gedachte. ${ }^{86}$ In zahlreichen Publikationen, die er in den folgenden zwei Jahrzehnten verfasste, widmete er sich der Frage, wie ein Eingreifen der Vereinten Nationen in Fällen internationaler Aggression auch gegen die Interessen einzelner mächtiger Staaten möglich sein könnte. ${ }^{87}$ Zugleich suchte er seine Ideen auf persönlichem Wege unter den UNDelegierten zu verbreiten, was aber für gewöhnlich an den diplomatischen Routinen scheiterte. ${ }^{88}$

Den Auftakt einer in den folgenden Jahren von Ferencz verfassten Trilogie zum Thema Friedenssicherung bildete 1975 das zweibändige Werk Defining International Aggression. The Search for World Peace. ${ }^{89} \mathrm{Im}$ Jahr zuvor hatte die Generalversammlung der Vereinten Nationen eine umfassende Definition von internationaler Aggression verabschiedet, ${ }^{90}$ deren Umsetzung in die Praxis allerdings weiterhin von den Interessen der fünf ständigen Mitglieder des Sicherheitsrats abhängig blieb. Dies enttäuschte die Erwartungen von Ferencz und anderen Anhängern der Abschaffung des bestehenden Vetorechts der Großmächte sowie des Ausbaus der Vereinten Nationen zu einer Weltregierung. $\mathrm{Zu}$ diesen zählte auch der renommierte Spezialist für internationales Recht und Professor an der Harvard-Universität Louis B. Sohn, der Ferencz bei seinen Publikationen zu diesem Thema unterstützte. Auf rund 1300 Buchseiten dokumentierte und kommentierte Ferencz in Defining International Aggression die Bemühungen des Völkerbunds und der Vereinten Nationen zur Einhegung internationaler Aggression nach dem Ersten und Zweiten Weltkrieg.

Die Arbeit auf dem Gebiet der Friedenssicherung wurde durch ein Buch zum Thema der Wiedergutmachung unterbrochen, zu dem ihn der israeli-

Leipzig - Nürnberg - Den Haag. Neue Fragestellungen und Forschungen zum Verhältnis von Menschenrechtsverbrechen, justizieller Säuberung und Völkerstrafrecht, Düsseldorf 2008, 20-33, hier 32.

85 Ebd., 28.

86 Ferencz, Benny Stories, Story 56: Aggression Defined by Consensus.

87 Siehe dazu die umfangreiche Zusammenstellung der Bücher, Artikel, Reden und Videos von Benjamin B. Ferencz auf seiner Homepage <http://www.benferencz.org/ index.html\#media> (12. April 2018).

88 Ferencz, Benny Stories, Story 56.

89 Benjamin B. Ferencz, Defining International Aggression. The Search for World Peace. A Documentary History and Analysis, 2 Bde., Dobbs Ferry, N. Y., 1975.

90 United Nations General Assembly, A/RES/3314, Definition of Aggression, New York, 14. Dezember 1974. 
sche Historiker Yehuda Bauer angeregt hatte. 1979 publizierte Ferencz Less Than Slaves. Jewish Forced Labor and the Quest for Compensation, ${ }^{91}$ wozu Telford Taylor ein Vorwort beigesteuert hatte. Auf breiter Quellenbasis schildert er darin seine Auseinandersetzung mit deutschen Industrieunternehmen um Entschädigungsleistungen für jüdische Zwangsarbeiterinnen und Zwangsarbeiter in den 1950er und 1960er Jahren. Die 1981 unter dem Titel Lohn des Grauens erschienene deutsche Ausgabe, die das Thema im Untertitel als ein "offenes Kapitel der deutschen Nachkriegsgeschichte « bezeichnete, ${ }^{92}$ befeuerte in der Bundesrepublik die damals einsetzende Debatte um die sogenannten "vergessenen Opfer" des Nationalsozialismus und trug paradoxerweise dazu bei, dass jüdische NS-Verfolgte künftig eher marginalisiert wurden. So standen in dieser Kontroverse vor allem Homosexuelle, Opfer von Zwangssterilisation, Sinti und Roma, Deserteure und andere Gruppen im Vordergrund, die bislang nicht als Verfolgte des Nationalsozialismus anerkannt und deshalb überwiegend nicht entschädigt worden waren. Im Zusammenhang der damals aufkommenden Identitätspolitik diente der Opferstatus dieser Menschen insbesondere dazu, ihre gruppenbezogene gesellschaftliche Diskriminierung in der Gegenwart zu bekämpfen.${ }^{93}$ Ferencz selbst hatte sein Interesse am Thema der Wiedergutmachung trotz des großen Erfolgs seines Buchs jedoch weitgehend verloren und zog es vor, sich künftig hauptsächlich auf seine völkerrechtlichen Arbeiten zur Friedenssicherung zu konzentrieren.

1980 veröffentlichte er als zweiten Teil seiner Weltfriedenstrilogie An International Criminal Court. A Step Toward World Peace. ${ }^{94}$ Ein Jahr nachdem Truppen der Sowjetunion in Afghanistan einmarschiert waren und damit den sogenannten zweiten Kalten Krieg ausgelöst hatten, kritisierte er darin nicht nur das Festhalten am Prinzip nationaler Souveränität bei der Friedenssicherung, wie es vor allem im Vetorecht der Großmächte im Sicherheitsrat zum Ausdruck kam, sondern forderte zudem die Einrichtung eines internationalen Strafgerichtshofs. Dies stützte sich nicht nur auf seinen Glauben an die präventive Wirkung des Rechts, sondern vor allem auch auf seinen historischen Optimismus bezüglich eines wenn auch sehr langsamen Fortschritts

91 Ferencz, Less than Slaves.

92 Ferencz, Lohn des Grauens.

93 John Torpey, Introduction. Politics and the Past, in: John Torpey (Hg.), Politics and the Past. On Repairing Historical Injustices, Lanham, Md., u. a. 2003, 1-34, hier 10; Goschler, Schuld und Schulden, 301; Borggräfe, Zwangsarbeiterentschädigung, 126-190.

94 Benjamin B. Ferencz, An International Criminal Court. A Step Toward World Peace. A Documentary History and Analysis, 2 Bde., London/Rom/New York 1980. 
auf diesem Gebiet: »Signs of progress can not be belittled or ignored. I am not ready to believe that man is doomed to self-destruction. ${ }^{95}$ Ausführlich schilderte Ferencz die lange historische Entwicklungslinie einer solchen Fortschrittsgeschichte des Rechts und bekräftigte sein liberales Credo, »that it is possible to replace the law of force by the force of law «. ${ }^{96}$

Den dritten Teil seiner jeweils zweibändigen Trilogie zum Thema Friedenssicherung bildete schließlich das 1983 erschienene Werk Enforcing International Law. A Way to World Peace, für das Louis B. Sohn wie schon bei einigen der vorangegangenen Bücher ein Vorwort verfasst hatte. ${ }^{97}$ Ferencz begründete darin seine Idee der Evolution des Rechts wiederum mit einer weitgespannten historischen Dokumentation, mit der er zu zeigen suchte, wie sich der Gedanke der Durchsetzung des internationalen Rechts vom 16. Jahrhundert bis zur Gegenwart allmählich immer weiter ausgebreitet habe. Methodisch gingen die insgesamt sechs Bände dieser Trilogie jeweils in ähnlicher Weise vor. In einer langen historischen Darstellung wurden völkerrechtliche Quellen umfassend ausgebreitet und kommentiert. Ferencz hatte in diesen Büchern gewissermaßen seinen Zettelkasten annotiert und daraus einen Gesetzeskommentar zur Evolution des internationalen Rechts der Friedenssicherung verfasst.

Da ihm klar war, dass diese mit völkerrechtlichen Details angefüllten dickleibigen Bände kaum über einen engen Kreis von Experten hinaus wahrgenommen würden, entschloss er sich, seine Thesen in populärer Form zu verpacken und hoffte damit ein größeres Publikum zu erreichen. Ein erster Versuch in dieser Richtung war das 1985 veröffentlichte Buch A Common Sense Guide to World Peace, ${ }^{98}$ in dem er seine Überlegungen zum Weltfrieden auf 129 Seiten zusammenfasste. Die zentrale Botschaft lautete, dass sich die Menschheit langsam, aber letztlich unaufhaltsam auf eine rationale Weltordnung und damit zugleich auf die friedliche Regulierung von Konflikten zubewege. ${ }^{99}$ Für die Zukunft forderte er - gewissermaßen als zivilgesellschaftliche Alternative zum UN-Sicherheitsrat - einen aus »renowned thinkers, spiritual, community and business leaders « zusammengesetzten »Permanent Council of Peace« ${ }^{100}$ Ein derartiges Gremium sollte über alle

95 Ebd., Bd. 1, XIII.

96 Ebd., 2.

97 Benjamin B. Ferencz, Enforcing International Law. A Way to World Peace. A Documentary History and Analysis, 2 Bde., London/Rom/New York 1983.

98 Benjamin B. Ferencz, A Common Sense Guide to World Peace, London/Rom/New York 1985.

99 Ebd., XI.

100 Ebd., 90. 
ideologischen Konflikte hinweg agieren können, indem es vom »Common Sense" geleitet würde - letzteres bezog sich explizit auf Thomas Paines 1776 erschienene gleichnamige Schrift ${ }^{101}$ und somit auf die Gründungsgeschichte der Vereinigten Staaten. In einer Situation weitverbreiteter Ängste vor einem globalen Atomkrieg in der westlichen Welt entwarf Ferencz hier eine antipolitische Vision des Wegs zum Weltfrieden. Diese war in ein Bewusstsein unentrinnbarer globaler Interdependenz wie in ein liberales, teleologisches Modell des Fortschritts eingebettet.

Aus diesem Buch resultierte eine Zusammenarbeit mit dem New-AgeBestsellerautor Ken Keyes jr., der sich nach der Lektüre von A Common Sense Guide to World Peace an Ferencz wandte. Der infolge einer früheren Polioerkrankung fast vollständig gelähmte Keyes war erfolgreicher Verfasser psychologischer Selbsthilfebücher wie dem Handbook to Higher Consciousness, aber auch einer Schrift, die Wege aus der Bedrohung des Atomkriegs aufzuzeigen suchte. ${ }^{102} 1988$ veröffentlichten der Vorkämpfer für den Weltfrieden und der Protagonist der »Science of Happiness « gemeinsam ein knapp gehaltenes Büchlein mit dem Titel PlanetHood. The Key to Your Survival and Prosperity, ${ }^{103}$ von dem etwa eine Million Exemplare verbreitet wurden. Auf 188 Seiten bot es Lösungen für die wesentlichen Fragen des modernen (amerikanischen) Menschen: »Do You Want to - Reduce Your Tax Burden? Create Worldwide Prosperity? - Eliminate International War? - Rescue the Environment? - Stop Terrorists and Hostaging? - Preserve Liberty and Freedom? - Give Your Children a Future? - Reform the United Nations to Enforce International Law? ${ }^{104}$ Die Publikation wurde zumindest in friedensbewegten Milieus breit rezipiert, zumal sie auch eine französische und spanische Ausgabe erlebte. »PlanetHood», so Ferencz, »was a simple >outreach book.< It did more to educate the general public than all of my heavy tomes. $"{ }^{105} \mathrm{Die}$ im Stil populärer Lebensberatungsliteratur aufgemachte Publikation entwirft die Utopie einer demokratischen Weltrepublik, die mit einer Weltverfassung, Weltgesetzen und einem Weltgerichtshof ausgestattet sein, dauerhaften Frieden und Wohlstand herstellen solle und die, wie ein Rezensent feststellte,

101 Ebd., 1.

102 Ferencz, Benny Stories, Story 60: Reaching Out for the Public.

103 Benjamin B. Ferencz/Ken Keyes Jr., PlanetHood. The Key to Your Survival and Prosperity, Coos Bay, Oreg., 1988; frz.: Planethood, ou, Les citoyens du monde. La clé pour réaliser la paix et l'abondance planétaires pour tous dès aujourd'hui, Knowlton, Que., 1989; span.: Comunidad planetaria, Madrid 1992.

104 Ferencz/Keyes Jr., PlanetHood.

105 Ferencz, Benny Stories, Story 60. 
das Verfassungsmodell der Vereinigten Staaten auf die gesamte Welt ausweitet. ${ }^{106}$ So erträumte sich Ferencz Amerika zwar nicht in der Rolle eines »liberalen Leviathan $«,{ }^{107}$ doch lieferte es ihm zumindest die Blaupause dafür. Insbesondere im Kalten Krieg konnten solche Überlegungen unrealistisch erscheinen, setzten sie doch voraus, dass der Rest der Welt bereit sein würde, das politische Modell der Vereinigten Staaten zu übernehmen. Nach der wenig später einsetzenden Auflösung des Ostblocks harmonierte diese Auffassung jedoch hervorragend mit dem für einige Zeit weit verbreiteten Glauben an die kommende globale Dominanz des westlichen liberal-demokratischen Gesellschaftsmodells, der in Francis Fukuyamas 1989 erstmals formulierter These vom »Ende der Geschichte ${ }^{108}$ einen geschichtsphilosophischen Bezugspunkt fand.

In all diesen Jahren schrieb Ferencz zur Popularisierung seiner Ideen zum Weltfrieden rastlos Bücher, Artikel und Leserbriefe, gab Rundfunkinterviews, hielt landauf, landab Vorträge vor einem meist kleinen friedensbewegten Publikum, diskutierte auf Konferenzen, in Seminaren sowie Podiumsgesprächen und besuchte gleichzeitig weiterhin regelmäßig Versammlungen der Vereinten Nationen. ${ }^{109}$ Zudem unterrichtete er von 1985 bis 1990 an der Pace University in New York einen Kurs zum Thema »The International Law of Peace«, wofür er statt eines Honorars den mäßig ehrenvollen Titel eines Adjunct Professor erhielt. 1990, mit nunmehr 70 Jahren, gab er die Lehrtätigkeit wieder auf und versuchte stattdessen an der Pace University ein Peace Institute zu etablieren. ${ }^{110}$ Höhepunkt der dortigen Aktivitäten war ein im selben Jahr veranstaltetes gemeinsames Kolloquium amerikanischer und sowjetischer Experten, das sich der Suche nach rechtlichen Lösungen zur Friedenssicherung widmete, jedoch wenig Ergebnisse zeitigte. ${ }^{111}$ Vor allem scheiterten aber seine Bemühungen um eine adäquate finanzielle Ausstattung der Einrichtung. So blieb das Institut, in dem auch seine Frau unbezahlt mit-

106 John H. McNeill, Book Review: Planethood: The Key to Your Survival and Prosperity, in: The American Journal of International Law 85 (1991), H. 1, $227 \mathrm{f}$.

$107 \mathrm{Zu}$ diesem Begriff siehe G. John Ikenberry, Liberal Leviathan. The Origins, Crisis, and Transformation of the American World, Princeton, N. J., 2011; Samuel Moyn, Human Rights and the Uses of History, New York/London 2014, 122.

108 Francis Fukuyama, The End of History?, in: The National Interest 16 (1989), 3-18.

109 Ferencz, Benny Stories, Story 60.

110 Ebd., Story 58: Teaching for Peace.

111 Die Protokolle dieser Begegnung lassen sich nachlesen in Benjamin B. Ferencz (Hg.), World Security for the 21st Century: Challenges and Solutions. A Colloquium Between American and Soviet Legal Experts, Dobbs Ferry, N. Y., 1991. 
arbeitete, letztlich ein bescheidenes Familienunternehmen, das er Mitte der 1990er Jahre wieder einschlafen ließ. ${ }^{12}$

\subsection{Das Ende des Kalten Kriegs und der Internationale Strafgerichtshof}

Ferencz richtete seine Energien stattdessen nochmals auf ein neues Buchprojekt, das als Opus Magnum seine bisherigen Überlegungen bündeln sollte. 1994 erschien New Legal Foundations for Global Survival. Security Through the Security Council. ${ }^{113}$ Wie zuvor beschrieben, hatte er 1985, kurz vor dem Ende des Kalten Kriegs, seine Hoffnungen noch auf einen »Permanent Council of Peace " gesetzt, also auf einen nichtstaatlichen Honoratiorenclub. Im Zeichen der menschenrechtsorientierten Agenda des seit 1993 regierenden US-Präsidenten Bill Clinton, die nach dem Ende des Kalten Kriegs für einige Zeit als alternative Legitimationsquelle der Pax Americana diente, rückte Ferencz dagegen wieder den Sicherheitsrat der Vereinten Nationen in das Zentrum seiner Überlegungen und setzte damit auf staatliche Akteure. Die vom Sicherheitsrat autorisierte Intervention unter Führung der Vereinigten Staaten im Anschluss an die irakische Invasion in Kuwait 1990 demonstrierte für ihn die kollektiven Handlungsmöglichkeiten dieses internationalen Gremiums, auch wenn ihn das Ausmaß der eingesetzten militärischen Gewalt störte. Zugleich leitete er aus den Bürgerkriegen der 1990er Jahre mit Millionen von Toten und Flüchtlingen wie in Jugoslawien, Ruanda, Somalia und Haiti die Notwendigkeit entschlossenen internationalen Handelns ab, um eine friedliche Weltordnung durchzusetzen.

$\mathrm{Zu}$ diesem Zweck forderte er eine Reform der bestehenden Struktur des Sicherheitsrats der Vereinten Nationen, um größere Handlungsfähigkeit herzustellen. Neben der Ächtung von militärischer Gewalt und der Forderung nach kollektiver Abrüstung bildeten für ihn internationale Strafgerichtsbarkeit, aber auch soziale Gerechtigkeit wichtige Elemente einer künftigen Friedensordnung. Um diese umsetzen zu können, gehörten für Ferencz eindeutige rechtliche Normen, Gerichte zur Überprüfung ihrer Einhaltung und robuste Instrumente zu deren Durchsetzung unverzichtbar zusammen. Neben einem Internationalen Strafgerichtshof und einer internationalen Streitmacht forderte er unter anderem ein Welttribunal für soziale Gerechtigkeit. ${ }^{114}$ So integrierte er in seinem letzten großen Buch zum Thema

112 Ferencz, Benny Stories, Story 59: The Pace Peace Center.

113 Benjamin B. Ferencz, New Legal Foundations for Global Survival. Security Through the Security Council, Dobbs Ferry, N. Y., 1994.

114 Ebd. 
Weltfrieden schließlich auch ein zentrales Element der sozialistischen Menschenrechtskonzeption in seine liberale Grundposition. ${ }^{115}$

Hatte Ferencz in den 1980er Jahren oftmals als einzelgängerischer, wenn nicht gar seltsamer Utopist gegolten, so begann sich dies in den 1990er Jahren allmählich zu ändern: Nun verwandelte er sich in der Außenwahrnehmung zum kühnen Visionär des internationalen Rechts. Ähnlich wie Raphael Lemkin zur Symbolfigur für die UN-Genozidkonvention geworden war, geschah dies mit Ferencz für den Internationalen Strafgerichtshof. Nachdem der Sicherheitsrat der Vereinten Nationen bereits ad hoc Strafgerichtshöfe für Jugoslawien (1993) und Ruanda (1994) eingesetzt hatte, entstand nach dem Ende des Kalten Kriegs eine breite Bewegung aus Regierungen und NGOs zur Einrichtung eines ständigen Internationalen Strafgerichtshofs. ${ }^{16}$ Ferencz, der seine eigene Rolle als »Non-Governmental Individual ${ }^{117}$ interpretierte, war an diesem Prozess vor allem als Beobachter beteiligt. Zugleich wurde er zu einer wichtigen Symbolfigur, eignete er sich doch hervorragend für jene Erfindung einer Tradition, die eine direkte Entwicklungslinie von den Nürnberger Prozessen zum Internationalen Strafgerichtshof behauptete. ${ }^{118}$ Als 1998 in Rom eine große Staatenkonferenz zusammenkam, um in fünfwöchigen Verhandlungen das Statut des Internationalen Strafgerichtshofs auszuhandeln, wurde Ferencz eingeladen, vor Beginn der eigentlichen Verhandlungen eine Rede zu halten. Vor den dort versammelten Delegierten wiederholte er sein Credo: »[W]ithout clear international laws, courts and effective enforcement there can be no deterrence, no justice and no world peace. Justice, reconciliation and rehabilitation are needed to bind up the wounds of humankind. $\aleph^{119}$

Fünf Jahre später wurde der Internationale Strafgerichtshof feierlich eröffnet. Abermals hielt Ferencz eine Ansprache, was einerseits eine persönliche Ehrung bedeutete und andererseits die angestrebte symbolische Verbindung

115 Vgl. dazu Jennifer Amos, Unterstützen und Unterlaufen. Die Sowjetunion und die Allgemeine Erklärung der Menschenrechte, 1948-1958, in: Hoffmann (Hg.), Moralpolitik, 142-168; Stefan Troebst, "Sozialistisches Völkerrecht" und die sowjetische Menschenrechtsdoktrin, in: Norbert Frei/Annette Weinke (Hg.), Toward a New Moral World Order? Menschenrechtspolitik und Völkerrecht seit 1945, Göttingen 2013, 94-104.

116 Siehe Cenap Çakmak, A Brief History of International Criminal Law and International Criminal Court, Basingstoke/New York 2017, 101-134.

117 Ferencz, Benny Stories, Story 64: Setting the Scene for Progress.

118 Vgl. dazu auch Weinke, »Von Nürnberg nach Den Haag«, 21.

119 Siehe Benjamin B. Ferencz, Ferencz Addresses Rome Conference, Juni 1998, <http:// benferencz.org/lectures.html\#rome > (6. April 2018). Siehe dazu auch Ferencz, Benny Stories, Story 65: What Really Happened in Rome. 
von Den Haag mit Nürnberg erneut bekräftigte. Diesmal positionierte er sich jedoch als kritischer Patriot: Scharf kritisierte er, dass seine eigene Regierung den Internationalen Strafgerichtshof abgelehnt hatte und appellierte zugleich an die besseren Traditionen der Vereinigten Staaten, ${ }^{120}$ die er seit Jahrzehnten im Sinne des liberalen Legalismus weiterzuentwickeln gesucht hatte. Zwar war er nicht unmittelbar in die Entstehung und Tätigkeit des Internationalen Strafgerichtshofs eingebunden, aber er gab sich in seinem mittlerweile neunten und zehnten Lebensjahrzehnt auch nicht mit der Rolle als Symbolfigur zufrieden. Er kritisierte seine eigene Regierung nicht nur immer wieder scharf für ihren Widerstand gegen die internationale Strafgerichtsbarkeit, sondern verurteilte etwa auch den 2003 von den Vereinigten Staaten zusammen mit Großbritannien geführten Krieg gegen den Irak als Angriffskrieg. ${ }^{121}$ So ist er bis ins höchste Alter ein kritischer Kommentator der Gegenwart und ein für die multilaterale Verrechtlichung der internationalen Beziehungen eintretender Friedensaktivist geblieben. ${ }^{122}$

\section{Die Benjamin B. Ferencz Collection und die Auswahlkriterien dieser Edition}

Im Oktober 1994, im Alter von 74 Jahren, übergab Ferencz dem Archiv des United States Holocaust Memorial Museum (USHMM) in Washington, D. C. seinen Vorlass, der Dokumente und materielle Artefakte aus den Jahren 1919 bis 1994 enthält. Das seither dort aufbewahrte Material umfasst 170 Boxen, die über 24 Regalmeter Akten enthalten, 282 Fotografien, 65 Video- und Audiokassetten mit Interviews, eine Anzahl von repräsentativen Geschenken sowie 27 Bände der Dokumentation der Nürnberger Prozesse. Diese Materialien, die durch einige von den National Archives abgegebene Teile seiner persönlichen Papiere ergänzt wurden, bilden heute im USHMM die Benjamin B. Ferencz Collection, 1919-1994. Ferencz legte fest, dass die auf Mikrofiche verfilmten Dokumente auf Kosten des USHMM großzügig an

120 Siehe Benjamin B. Ferencz, Remarks Made at the Opening of the ICC, März 2003, $<$ http://benferencz.org/lectures.html\#remarks> (6. April 2018). Siehe dazu auch Ferencz, Benny Stories, Story 67: The Overdue Baby is Born.

121 Ebd.

122 Siehe dazu die umfangreiche Sammlung der Artikel und Reden von Benjamin B. Ferencz auf seiner Homepage, <http://http://benferencz.org/index.html\#media> (6. April 2018). 
interessierte Institutionen in aller Welt in Kopie verteilt würden ${ }^{123}$ - davon profitierten auch die Ruhr-Universität Bochum und die Herausgeber dieses Bands.

Die in diesem Buch vorgelegte Edition ist das Produkt eines mehrfachen Auswahlprozesses, dessen Konsequenzen stets mitbedacht werden müssen. Zunächst konnte Ferencz nur über diejenigen Unterlagen verfügen, die sich in seinem privaten Besitz befanden, sodass diese nicht alle seine Tätigkeiten abdecken. Diese Einschränkung betrifft insbesondere jenen Bereich, der gewissermaßen den Kern des Mythos um seine Person darstellt: die Nürnberger Nachfolgeprozesse. Darüber hinaus ist davon auszugehen, dass er selbst eine gestaltende Auswahl vornahm und auf diese Weise sein in Forschung und Öffentlichkeit entstehendes Bild zu beeinflussen suchte. Schließlich mussten die Herausgeber angesichts des großen Umfangs des Vorlasses und der begrenzten Seitenzahl, die dieser Edition zur Verfügung steht, konsequent auswählen, um zu bestimmen, welche Dokumente aufgenommen werden sollten - dies war vor allem ein schwieriger und gelegentlich schmerzhafter Streichungsprozess. Dabei wurde darauf verzichtet, Dokumente außerhalb der Benjamin B. Ferencz Collection zu integrieren, etwa um die in manchen Bereichen bestehenden Lücken zu schließen. Dies hätte nicht nur zu einer Hybridisierung des zugrunde liegenden Quellenkorpus geführt, sondern zugleich die Auswahlproblematik weiter verschärft. Das bedeutet zugleich, dass die Edition mit Quellen aus dem Jahr 1994 endet, also zu einem Zeitpunkt, als der Wandel in der Wahrnehmung von Ferencz von einem gelegentlich belächelten Außenseiter hin zu einer vielfach geehrten Symbolfigur einsetzte.

Der zentrale Anspruch dieser Edition, der auch mit dem spezifischen Charakter der Benjamin B. Ferencz Collection verbunden ist, besteht darin, die biografische Entwicklung und die zentralen Arbeitsgebiete des Protagonisten in seiner Beschäftigung mit den Folgen vergangener und der Prävention künftiger internationaler staatlicher Gewalt in ihrem Zusammenhang greifbar zu machen. Dabei werden einzelne, besonders signifikante Vorgänge und Aspekte herausgegriffen, ohne dass es möglich oder auch nur angestrebt wäre, diese jeweils vollständig zu dokumentieren. Vielmehr soll die vorgenommene Auswahl systematische Einsichten in Konzeption und Praxis der mit Ferencz verbundenen juristischen und rechtspolitischen Aktivitäten ermöglichen.

Der Schwerpunkt seiner Tätigkeiten verschob sich von der Ahndung von Kriegsverbrechen und der Entschädigung der Opfer hin zur Prävention. Befasste sich Ferencz zunächst vorrangig damit, den Folgen staatlicher Gewalt

123 USHMM Archives, BBF Collection, Finding Aid, RG-12. Siehe auch den Onlinekatalog, <https://collections.ushmm.org/search/catalog/irn508300> (6. April 2018). 
mithilfe von Strafrecht und Restitution zu begegnen, engagierte er sich später vor allem dafür, Frieden durch internationales Recht zu sichern. Die Art und Weise, wie sich diese Themenbereiche in seiner Person verschränkten, ist gewiss einmalig. Doch standen seine Aktivitäten im Kontext verschiedener zentraler Entwicklungstendenzen nach 1945, die darauf zielten, staatliche Gewaltausübung - vor allem in Gestalt von Kriegen - durch das Völkerrecht zu begrenzen. Bei allem Respekt vor der enormem Lebensleistung von Ferencz soll weder seine Person zu einem Monument stilisiert noch die von ihm selbst geförderte teleologische Deutung "von Nürnberg nach Den Haag « unterstützt werden.

Als erster Gesichtspunkt für die Quellenauswahl war zunächst die Frage nach dem »Wertehimmel « bestimmend, der sein Denken und Handeln prägte. Dabei stand sowohl der normative Letztbezug seiner juristischen und politischen Tätigkeiten und Visionen im Zentrum als auch, inwiefern dieser mit spezifischen Aspekten seiner jüdischen Zugehörigkeit verbunden war. Ausgewählt wurden hierzu Dokumente, welche die Prägung durch seine jüdische Herkunft verdeutlichen, vor allem aber seine Verankerung in einem liberalen Wertehorizont mit progressivistischen Wurzeln thematisieren. In diese Kategorie fallen zudem Dokumente, die seine Auseinandersetzung mit selbsterlebtem oder selbstbeobachtetem Antisemitismus und Rassismus belegen.

Zweitens war die Frage nach den sich wandelnden Handlungsräumen von Ferencz bestimmend, mit denen jeweils unterschiedliche Quellen der Autorität verbunden waren. Denn diese veränderten sich in Abhängigkeit davon, ob er in der Uniform der siegreichen US-Armee, im Geschäftsanzug als Repräsentant jüdischer Organisationen in Deutschland oder später in Nadelstreifen als juristischer Spezialist und privater Lobbyist für völkerrechtliche Instrumente der Friedenssicherung auftrat.

Ein dritter Auswahlaspekt, der gleichfalls auf die Umstände seines Wirkens zielt, bezog sich auf die Netzwerke, die Ferencz im Verlauf der Jahrzehnte aufbaute und die er über verschiedene Tätigkeitsfelder hinweg immer wieder aktivierte. Hierzu gehörten neben wichtigen Funktionären der Jewish Claims Conference und anderer jüdischer Organisationen insbesondere sein einstiger Vorgesetzter in Nürnberg und späterer New Yorker Anwaltskollege Telford Taylor sowie der amerikanische Hohe Kommissar für Deutschland John J. McCloy. Seit den 1970er Jahren wurde Ferencz auch Teil eines internationalen völkerrechtlichen Netzwerks, das eine wichtige Rolle bei der konzeptionellen Vorbereitung einer internationalen Strafjustiz einnahm.

Viertens wurden die Dokumente im Hinblick auf die Frage ausgewählt, wie Ferencz im Verlauf seiner Tätigkeit symbolisches und politisches Kapital sammelte oder auch generierte und wie er es über verschiedene Felder hinweg einsetzte. Dies betrifft insbesondere die Art und Weise, wie er seine kurz- 
fristige Tätigkeit als Hauptankläger im Nürnberger Einsatzgruppenprozess später präsentierte. Immer wieder stellte er sich öffentlich als Ankläger im »biggest murder trial in history « ${ }^{124}$ dar. Sein Auftritt im Fall IX der Nürnberger Militärtribunale wurde in späteren Jahren zum Kern des von ihm selbst tatkräftig mitentwickelten Mythos um seine Person, bei dem er gelegentlich von einem Ankläger der Nürnberger Nachfolgeprozesse unter anderen zum letzten lebenden Ankläger der Nürnberger Prozesse überhaupt wurde.

Fünftens ging es bei dieser Dokumentenauswahl vor allem darum, grundsätzliche Einsichten darüber zu ermöglichen, wie rechtliche und politische Auseinandersetzungen auf den hier ins Auge gefassten Tätigkeitsfeldern - der Ahndung nationalsozialistischer Verbrechen, der Restitution und Entschädigung, der Friedenspolitik und schließlich dem internationalen Strafrecht geführt wurden und wie sich diese im Lauf der Jahrzehnte veränderten.

Die Dokumente sollen also nicht nur einen Blick auf Ferencz eröffnen, sondern auch auf die Strukturen, innerhalb derer er sich bewegte, und die Menschen, mit denen er sich auseinandersetzte. Insofern hoffen die Herausgeber vor allem darauf, dass die getroffene Dokumentenauswahl dabei hilfreich sein kann, die Grenzen und Möglichkeiten individuellen Handelns auf dem komplexen Gebiet der internationalen Moralpolitik im 20. Jahrhundert zu erschließen.

\section{Zum Aufbau dieser Edition}

Die in dieser Edition präsentierten Dokumente wurden in neun thematische Kapitel gegliedert, die aus den erwähnten Gründen nicht alle der im vorangestellten biografischen Abriss angesprochenen Aspekte gleichermaßen abdecken. Das erste Kapitel enthält Auszüge aus dem von Ferencz während seines Militärdienstes im Zweiten Weltkrieg geführten Tagebuch sowie einen der in dieser Zeit an seine spätere Frau Gertrude Fried geschriebenen Briefe. Ferencz war zunächst einfacher Soldat und später sogenannter T/5 (ein Dienstgrad für technische Spezialisten) beim $115^{\text {th }}$ Anti-Aircraft Artillery Gun Battalion, bevor er kurz vor Kriegsende zur War Crimes Section versetzt wurde. Mit Blick auf seinen späteren Werdegang lässt sich an diesen Dokumenten zweierlei ablesen: Einerseits scheint dort manches auf sein späteres rechtspolitisches Engagement vorauszudeuten. Andererseits zeigen sie immer wieder, wie sehr seine Zukunft von schlichten Zufällen abhing und bewahren damit davor, hier irgendeine Form von Bestimmung herauszulesen.

124 Ferencz, Benny Stories, Story 33. 
Die ausgewählten Dokumente im ersten Kapitel zeigen einen selbstbewussten jungen Harvard-Absolventen, der davon frustriert war, wie die US-Armee seine Talente mit sinnlosen Tätigkeiten vergeudete. Immer wieder beklagte er sich darüber, dass seine unmittelbaren Vorgesetzten seine Versuche sabotiert hätten, zu einem Offizierslehrgang versetzt zu werden. Zudem sinnierte er in seinem Kriegstagebuch wie in seinen Briefen an Gertrude über die grundsätzliche Bedeutung des Zweiten Weltkriegs, der von den Vereinigten Staaten als Kampf zwischen Demokratie und Diktatur geführt würde, während gleichzeitig Rassentrennung und Rassismus im eigenen Land ignoriert werde. Immer wieder monierte Ferencz, der sich selbst als einen "civilian in uniform ${ }^{125}$ beschrieb, den Fatalismus seiner Kameraden, die zwar bereit seien, im Krieg zu sterben, aber nicht dazu, über dessen Zweck nachzudenken. So sorgte er sich zwar zu keinem Zeitpunkt um den alliierten Sieg über die Achsenmächte, dafür aber umso mehr, dass der kommende Frieden verspielt werden könnte, weil sich niemand für die erforderlichen gesellschaftlichen und politischen Veränderungen interessiere. ${ }^{126}$

Seine Aufzeichnungen aus dem Kriegsdienst, der ihn im Tross seines Luftabwehrbataillons über verschiedene Ausbildungslager in den Vereinigten Staaten zur Vorbereitung der Invasion nach Großbritannien, von dort auf die Schlachtfelder in Frankreich und Luxemburg und zuletzt ins besetzte Deutschland führte, enthalten aufschlussreiche Einblicke in die gewaltige alliierte Kriegsmaschinerie und den Kriegsalltag. Ferencz verknüpfte darin Beobachtungen zu Gesellschaft, Politik und Sexualität. Seine Aufzeichnungen beleuchten nicht zuletzt die während und nach dem Krieg aus den Fugen geratene Geschlechterordnung in Europa. Die US-Soldaten begegneten dort einer zu Hause ungewohnten sexuellen Freizügigkeit, wobei sich, wie Ferencz schildert, Konflikte daraus ergaben, dass die in Amerika herrschende Rassentrennung in Großbritannien nicht in derselben Weise galt. Weiße GIs mussten auf dem erotischen Markt mit schwarzen GIs konkurrieren. Das führte bei öffentlichen Tanzveranstaltungen in Manchester zu gewaltsamen Konflikten zwischen beiden Gruppen. ${ }^{127}$ Schilderungen der Grausamkeit des Kriegs und amouröser Gelegenheiten wechseln so einander ab. ${ }^{128}$ Dabei lässt Ferencz keinen Zweifel daran, dass letztere nicht allein der Dankbarkeit der Befreiten in Frankreich beziehungsweise der Anbiederung der Besiegten in Deutschland, sondern neben kriegsbedingtem Männermangel oft der drückenden mate-

125 Dokument 1, Eintrag vom 27. März 1944.

126 Siehe vor allem Dokument 3 sowie Dokument 1, Eintrag vom 22. April 1944.

127 Siehe Dokument 1, Einträge vom 20. Dezember 1943 und 27. Dezember 1943.

128 Vgl. zu diesem Spannungsverhältnis auch Dagmar Herzog (Hg.), Brutality and Desire. War and Sexuality in Europe's Twentieth Century, Basingstoke/New York 2009. 
riellen Not der Frauen geschuldet waren, was die Grenzen der Freiwilligkeit verschwimmen ließ.

Mit dem Ende des Kriegs rücken Begegnungen mit den Zeugnissen der deutschen Verbrechen einerseits und mit der deutschen Bevölkerung andererseits immer stärker ins Zentrum seiner Aufzeichnungen. Erschüttert beschreibt er die Exhumierung ermordeter amerikanischer Soldaten und die nachfolgenden Verhöre der verdächtigten Deutschen, das Grauen der befreiten Konzentrationslager, aber auch die gelegentlich ausbrechende grausame Rache befreiter Häftlinge am SS-Wachpersonal sowie deutsche Selbstexkulpationsversuche. Während damals viele Erklärungen für die Gewaltexzesse im Nationalsozialismus auf ein besonderes deutsches Wesen abhoben, bezog Ferencz das Verhalten der Deutschen gegenüber den Juden eher auf ein universelles Verhaltensmuster: »Thoughtless yes, but people are that way. They may have inwardly deplored the plight of the Jews, but they took no more action than the average Northerner who deplores the treatment of the Negro in America. « ${ }^{129}$ Er übte auch scharfe Kritik an alliierten Misserfolgen bei der Aufklärung und strafrechtlichen Verfolgung von Kriegsverbrechen, die er auf die Eigenart militärischer Organisationen zurückführte, Aufgaben nach Dienstrang statt nach Qualifikation zu verteilen. So notierte er bereits einen Tag vor dem Ende des Zweiten Weltkriegs: »War crimes work is being completely messed up by a group of high-ranking incompetent officers who have been charged with the job. I am already convinced that the result will be a big farce. « ${ }^{130}$ Während sein Urteil stets moralisch eindeutig blieb und keinen Zweifel an der Verantwortung für die deutschen Kriegsverbrechen zuließ, warf sich für ihn damit zugleich eine grundsätzliche Frage auf. So charakterisierte er die mit dem Krieg einhergehende menschliche Verrohung und die mit militärischer Organisation verbundene Unfähigkeit, kompetente Personen an die richtige Stelle zu bringen, als ein universelles Problem, dessen Überwindung die eigentliche Herausforderung für die Nachkriegszeit bedeute.

Im zweiten Kapitel steht die Rolle von Ferencz als ehemaliger Nürnberger Ankläger im Mittelpunkt. Während die Benjamin B. Ferencz Collection kaum Überreste seiner Tätigkeit beim Internationalen Militärgerichtshof enthält, findet sich dort umso mehr davon, was nach einer klassischen Unterscheidung der Quellenkunde als Tradition bezeichnet wird. Deshalb wurden hier einige Rückblicke und öffentliche Interventionen $\mathrm{zu}$ den Nürnberger Nachfolgeprozessen in den Band aufgenommen. In diesen Dokumenten wird deutlich, in welcher Weise sich Ferencz später öffentlich und privat auf seine Tätigkeit als Hauptankläger im Einsatzgruppenprozess bezog. Zudem

129 Dokument 2, Eintrag vom 11. Juni 1945.

130 Dokument 2, Eintrag vom 7. Mai 1945. 
bietet die Auswahl einen Einblick, wie er sich nachträglich zur Bedeutung der Nürnberger Prozesse stellte.

»Nürnberg « bedeutete für Ferencz gleichermaßen soziales und symbolisches Kapital. Zum einen nutzte er das dort entstandene Netzwerk - das heißt die aus dem Zusammenhang seiner Tätigkeit im Stab Telford Taylors resultierenden Kontakte - immer wieder für spätere berufliche Tätigkeiten und zunehmend für rechtspolitische Aktivitäten. Zum anderen verwies er oftmals auf seine ehemalige Rolle als Hauptankläger im Einsatzgruppenprozess, um öffentliche Aufmerksamkeit für rechtspolitische Anliegen zu finden. ${ }^{131}$ Seit Ende der 1940er Jahre hatten sich jedoch auch in den Vereinigten Staaten vor allem konservative Stimmen kritisch gegen die Nürnberger Prozesse gewandt, da nun nicht mehr länger Deutschland, sondern die Sowjetunion als Hauptfeind galt. ${ }^{132}$ Ferencz konnte sich daher vor allem in den 1950er Jahren nicht ohne weiteres öffentlich mit seiner Rolle als Nürnberger Ankläger schmücken, sondern musste diese eher rechtfertigen. Die Ideen des liberalen Legalismus hatten im Kontext der Nürnberger Prozesse einen vorübergehenden Höhepunkt erlebt, um anschließend im Kalten Krieg vom traditionellen außenpolitischen Establishment, zu dem auch der Hohe Kommissar für Deutschland John J. McCloy gehörte, wieder vollständig marginalisiert zu werden. ${ }^{133}$

1951 hatte McCloy mit seiner Entscheidung über die Gnadengesuche von 89 in Landsberg einsitzenden Häftlingen, die als deutsche Kriegsverbrecher verurteilt worden waren, die Auseinandersetzung um die Legitimität der Nürnberger Prozesse angeheizt. Er reduzierte einen großen Teil der Strafen und bestätigte allein fünf der 15 ursprünglich verhängten Todesurteile. Kurz darauf wurden diese vollstreckt, vor allem gegen einige der im Einsatzgruppenprozess Verurteilten. Ferencz, der es vorgezogen hätte, die in den Nürnberger Prozessen zu Haftstrafen verurteilten deutschen Kriegsverbrecher auf irgendeinen entlegenen Außenposten der US-Armee zu verbringen, ${ }^{134}$ befasste sich intensiv mit der rechtspolitischen Bedeutung der Strafen wie der Begnadigungen. Er betrieb in späteren Jahren sogar intensive Archivstudien, um den Umgang McCloys mit den deutschen Gnadengesuchen aufzuklären, der seit den späten 1960er Jahren zunehmend auch als politisches Entgegen-

131 Siehe etwa Dokument 6.

132 Frank M. Buscher, The U.S. War Crimes Trial Program in Germany, 1946-1955, New York 1989, 29-44 und 160; Thomas Alan Schwartz, Die Begnadigung deutscher Kriegsverbrecher. John J. McCloy und die Häftlinge von Landsberg, in: Vierteljahrshefte für Zeitgeschichte 38 (1990), H. 3, 375-414.

133 Hagan, Justice in the Balkans, 37.

134 Siehe Dokumente 6 und 7. 
kommen zugunsten der Westintegration der Bundesrepublik kritisiert wurde. ${ }^{135}$ Ferencz wies den Vorwurf der Siegerjustiz als rein demagogisch zurück und lehnte das Prinzip der Vergeltung ausdrücklich ab. Demgegenüber beharrte er auf dem präventiven Charakter der in Nürnberg verhängten Strafen, gerade auch im Einsatzgruppenprozess, da sie verhindern sollten, dass sich ähnliche Verbrechen künftig wiederholten. Zwar war es ihm etwas unbehaglich, als ehemaliger Hauptankläger die persönliche Verantwortung für die hohe Zahl der in diesem Prozess verhängten Todesstrafen zu tragen. Doch bildete die Exekution der Nürnberger Angeklagten für ihn kein prinzipielles ethisches Tabu - vor allem dann, wenn diese ihre Taten keinesfalls bereuten, wofür exemplarisch Otto Ohlendorf stand. ${ }^{136}$ Der Gedanke der Rehabilitierung war bei dieser besonderen Tätergruppe dagegen ohnehin von vornherein für abwegig befunden worden. ${ }^{137}$

Im Lauf der Jahre verschoben sich für Ferencz die Prioritäten in seiner Beschäftigung mit Kriegsverbrechen immer mehr von der Bestrafung über die Restitution zur Prävention. So schlug er 1960 dem israelischen Justizminister Pinchas Rosen vor, den vom Mossad aus Argentinien nach Israel entführten Adolf Eichmann in Deutschland und nicht in Israel vor Gericht zu stellen, da er sich davon den größeren rechtspädagogischen Nutzen versprach. ${ }^{138}$ Rosen lehnte den Vorschlag aus vielerlei Gründen ab - unter anderem, weil der bundesdeutschen Regierung nach seiner sicheren Kenntnis eine derartige Geste alles andere als willkommen gewesen wäre. ${ }^{139}$ Auch wenn es also in der damaligen politischen Situation als aussichtslos erscheinen mochte, interpretierte Ferencz somit die Nürnberger Prozesse im Sinne eines universalistischen Prinzips. Sie sollten nicht einfach ein vergangenes Verbrechen abschließen, sondern vor allem in eine Zukunft weisen, in der Kriegsverbrechen und Angriffskriege generell geächtet sein würden. Deshalb begrüßte er es, als die Vereinten Nationen 1951 erstmals über die Idee eines internationalen Strafgerichtshofs berieten. ${ }^{140}$ Dieses Konzept bestimmte auch 1966 seine Reaktion auf nordvietnamesische Drohungen, amerikanische Bomberpiloten wegen Kriegsverbrechen anzuklagen: »American outrage at the proposal may have been misunderstood as a hypocritical repudiation of principles, which our Government espoused at the Nuremberg trials. The United States never

135 Siehe Dokument 14.

136 Siehe Dokument 5.

137 Schwartz, Die Begnadigung deutscher Kriegsverbrecher, 391.

138 Siehe Dokument 8.

139 Siehe Dokument 9.

140 Siehe Dokument 6. 
maintained that the Nuremberg strictures applied only to our enemies. $\aleph^{141}$ Sein vorübergehender Optimismus, dass sich die Vereinigten Staaten einem internationalen Strafgerichtshof unterwerfen würden, wurde allerdings später fortlaufend gedämpft. Dies beschrieb ein grundsätzliches Problem seines Ansatzes wie des liberalen Legalismus überhaupt: Wie sollte eine Macht legitimiert sein, der sich alle Staaten unterwerfen würden, sofern man das Recht nicht als politisch neutrale Institution begriff?

Das dritte Kapitel bezieht sich auf die Tätigkeit von Ferencz als Leiter jüdischer Organisationen im Bereich der Rückerstattung und Entschädigung und umfasst die Jahre 1951 bis 1983. Der Schwerpunkt der Auswahl liegt auf Dokumenten, die einen Überblick bieten beziehungsweise allgemeine Einschätzungen von Ferencz über die dort geleistete Arbeit betreffen. Dies entspricht dem Umstand, dass er ein halbes Jahrzehnt lang die JRSO, die URO und das Deutschlandbüro der Jewish Claims Conference parallel leitete und so weniger mit dem operativen Geschäft als mit strategischen Fragen betraut war. Auffällig ist hier, dass er zwar aufgrund seiner beruflichen Funktion als jüdischer Repräsentant wahrgenommen wurde, ${ }^{142}$ aber im Grunde wie ein Anwalt agierte, dem es in erster Linie um die Durchsetzung der Rechtsansprüche seiner Klienten geht - was bedeuten konnte, dass er jüdischen Opfern des Nationalsozialismus mitteilen musste, dass für ihre menschlich verständlichen Forderungen keine gesetzliche Grundlage existierte. ${ }^{143}$ Dass nicht der deutsche Staat oder die deutsche Gesellschaft von der Ermordung ganzer jüdischer Familien bis auf den letzten Erben profitieren dürfe, erschien ihm in erster Linie als eine Frage der juristischen Fairness. Das Ziel, ehemals jüdisches Eigentum in Deutschland möglichst schnell liquide zu machen, um damit dringend benötigte Hilfsgüter für jüdische Emigranten in Israel zu finanzieren, war für ihn gleichfalls weniger Ausdruck einer zionistischen Mission, sondern vor allem eine humanitäre Frage: »We have begged for permission to spend the recovered funds on pre-fabricated houses or medical equipment which could be sent to Israel where Germany's victims dwell in tents on barren plains. This has been refused since the German economy (where you may purchase without limitation mink coats, caviar, imported champaign [sic] and every other luxury) must be protected. $^{144}$ In seiner Arbeit als leitender Funktionär jüdischer Organisationen zeigt sich, dass er seine jüdische Herkunft eher mit der Zugehörigkeit zu einer Schicksalsgemeinschaft und weniger mit der Religion verband. Dabei war seine Tätigkeit auch Gegen-

141 Dokument 11.

142 Siehe Dokument 7.

143 Siehe etwa Dokument 26.

144 Dokument 15. 
stand innerjüdischer Konflikte, die sich vor allem an der Frage entzündeten, wem das Erbe der deutschen jüdischen Vorkriegsgemeinden zustand.

Die ausgewählten Dokumente unterstreichen schließlich die Schwierigkeit des mehrfachen Rollenwechsels. Ferencz hatte seit 1945 in der Uniform der US-Armee Kriegsverbrecher verfolgt und dann in Diensten jüdischer Organisationen Restitution und Entschädigung administriert, bevor er 1956 wieder an die amerikanische Ostküste zurückkehrte. Er hatte ein Land verlassen, in dem ein Emigrantenkind in Harvard studieren konnte und dessen Präsident bis vor kurzem der progressivistische Sozialreformer Franklin D. Roosevelt gewesen war. Nun kehrte er in ein verändertes Land zurück, in dem Senator Joseph McCarthy in den vergangenen Jahren intensiv Kommunisten und ihre angeblichen Fellowtraveller verfolgt hatte - sein ehemaliger Vorgesetzter und späterer Kanzleipartner Telford Taylor hatte Hunderte von ihnen verteidigt. ${ }^{145}$ Zudem hatten die Absolventen seiner Generation längst ihre Karrieren aufgebaut, während er vom »Generaldirektor « zum Rechtsanwaltsnovizen abstieg und eine sechsköpfige Familie ernähren musste. Die Tätigkeit auf dem Gebiet der Restitution und Entschädigung im Auftrag jüdischer Organisationen blieb für ihn daher noch jahrzehntelang ein wichtiger Brotberuf, wenngleich ein wenig einträglicher.

Eine besondere Bedeutung hatte dabei Ferencz' Engagement für die Entschädigungsforderungen jüdischer Zwangsarbeiterinnen und Zwangsarbeiter an die deutsche Industrie. Dies steht im Mittelpunkt des vierten Kapitels, das Dokumente aus den Jahren 1958 bis 1990 versammelt. In den 1950er und 1960er Jahren klagten wiederholt ehemalige Zwangsarbeiter vor deutschen Zivilgerichten, um für entgangenen Lohn und durch ihre Arbeit erlittene Gesundheitsschäden entschädigt zu werden. Die Musterklage eines ehemaligen Zwangsarbeiters gegen die I. G. Farben in Liquidation erweckte zunächst Hoffnung. 1953 war Norbert Wollheim, ein deutscher Jude, der eine wichtige Rolle beim Aufbau der jüdischen Nachkriegsgemeinden in der britischen Besatzungszone gespielt hatte, vor dem Landgericht Frankfurt am Main erfolgreich: In erster Instanz wurden ihm 10.000 DM Schmerzensgeld für die erlittenen körperlichen und gesundheitlichen Schäden infolge seiner in Auschwitz-Monowitz geleisteten Zwangsarbeit zugesprochen. ${ }^{146}$ Als I. G. Farben i. L. jedoch mit massivem juristischem Aufgebot in Revision ging, überforderte dies Wollheim finanziell. Daraufhin beteiligte sich die Jewish Claims Conference an dem Rechtsstreit und beauftragte Ferencz mit dieser

145 Siehe Dokument 16.

146 Ferencz, Lohn des Grauens, 60-64; Wolfgang Benz, Der Wollheim-Prozeß. Zwangsarbeit für I. G. Farben in Auschwitz, in: Herbst/Goschler (Hg.), Wiedergutmachung in der Bundesrepublik Deutschland, 303-326, hier $311 \mathrm{f}$. 
Aufgabe. 1955 legte das Oberlandesgericht Frankfurt am Main den Prozessparteien schließlich einen Vergleich nahe. ${ }^{147}$ Zwei Jahre später erklärten sich die Erben des deutschen Chemiegiganten zur Zahlung von insgesamt 30 Millionen DM bereit. Zehn Prozent des Betrags wollte I. G. Farben i. L. für nichtjüdische Zwangsarbeiter zurückbehalten, während der Rest über die JCC an jüdische Zwangsarbeiter verteilt werden sollte. ${ }^{148}$ Zudem beschloss der Deutsche Bundestag eigens ein Gesetz, wonach Gläubiger der I. G. Farben i. L. ihre Ansprüche gegen den Konzern nur bis zu einer Ende 1957 ablaufenden Schlussfrist anmelden konnten ${ }^{149}$ - dies zielte auf ehemalige Zwangsarbeiter.

Ferencz trat im Auftrag der Jewish Claims Conference an weitere deutsche Unternehmen heran, um Entschädigungen für jüdische Zwangsarbeiter zu fordern. Der zivilrechtliche Klageweg erwies sich jedoch als weitgehend aussichtslos, auch wenn die deutschen Richter diese Ansprüche im Prinzip anerkannten. Doch sofern frühere Zwangsarbeiter einem ehemaligen Feindstaat des Deutschen Reichs oder einem von diesem besetzten Staat angehörten, blockierte das Londoner Schuldenabkommen von 1953, das die finanziellen Vor- und Nachkriegsverbindlichkeiten der Bundesrepublik regelte, ihre Forderungen. Artikel 5(2) dieses Vertragswerks bestimmte, dass die »Prüfung der aus dem Zweiten Weltkrieg herrührenden Forderungen von Staaten, die sich mit Deutschland im Kriegszustand befanden oder deren Gebiet von Deutschland besetzt war, und von Angehörigen dieser Staaten gegen das Reich und im Auftrage des Reichs handelnde Stellen oder Personen [...] bis zur endgültigen Regelung der Reparationsfrage zurückgestellt « ${ }^{150}$ wurden. Da darunter auch die Ansprüche ausländischer Zwangsarbeiter fielen, mussten diese auf den Abschluss eines Friedensvertrags warten. Forderungen deutscher Kläger dagegen scheiterten vor Gericht, weil die Verjährungsfristen bereits verstrichen waren. Nach etlichen frustrierenden Gerichtsurteilen charakterisierte Ferencz 1957 diese juristische Zwickmühle treffend: »The Supreme Court therefore says that either you are too late or you are too early." ${ }^{151}$

147 Benz, Der Wollheim-Prozeß, 320.

148 Ferencz, Lohn des Grauens, 72-74.

149 Deutscher Bundestag, Gesetz über den Aufruf der Gläubiger der I. G. Farbenindustrie Aktiengesellschaft in Abwicklung, Bonn, 27. Mai 1957.

150 Abkommen über deutsche Auslandsschulden. London, 27. Februar 1953, hier Art. 5(2) 338. Siehe dazu Goschler, Schuld und Schulden, 152-159 sowie Ursula Rombeck-Jaschinski, Das Londoner Schuldenabkommen. Die Regelung der deutschen Auslandsschulden nach dem Zweiten Weltkrieg, München 2005.

151 Dokument 69. 
Da sich die Ansprüche jüdischer Zwangsarbeiterinnen und Zwangsarbeiter also nicht gerichtlich durchsetzen ließen, musste die Jewish Claims Conference direkt mit den betroffenen Unternehmen verhandeln. Dabei knüpfte Ferencz in mehrfacher Hinsicht an seine Nürnberger Erfahrungen an. Insbesondere bediente er sich des für die Nürnberger Prozesse gesammelten Beweismaterials, wozu er nicht nur auf seine umfangreichen eigenen Kenntnisse zurückgriff, sondern auch sein altes persönliches Netzwerk nutzte, um die weit verstreuten Unterlagen aufzutreiben: »Do you have, or do you know where I can obtain the materials I need to build my bonfire? ${ }^{152}$ Die Strategie, die Firmen mithilfe der alten Prozessunterlagen unter Druck zu setzen, ließ sich im Fall von I. G. Farben i. L. und Krupp, die in Nürnberg exemplarisch angeklagt worden waren, gut umsetzen. Aber bei anderen Unternehmen, die damals unbehelligt geblieben waren, fehlte dieser Hebel. Auf die immer wiederkehrenden Klagen solcher Firmen, wie AEG und Telefunken, dass sie selbst gezwungen gewesen seien, Häftlinge zu beschäftigen, diese gut behandelt, ihnen sogar das Leben gerettet hätten und außerdem ihre Fabriken von den Russen übernommen worden seien, reagierte Ferencz lakonisch: »I wiped away my tears and remembered the good old days in Nuremberg. " ${ }^{153}$ $\mathrm{Zu}$ seinem Vorgehen gehörte auch, dass er vor Beginn der Verhandlungen jeweils die nationalsozialistische Vergangenheit leitender Manager dieser Unternehmen anhand der im Berlin Document Center aufbewahrten Unterlagen überprüfen ließ. ${ }^{154}$

$\mathrm{Da}$ es sich nur als begrenzt wirkungsvoll erwies, die deutschen Unternehmen mit historischem Beweismaterial zu konfrontieren, blieb als Ultima Ratio lediglich die Drohung, ihre Aktivitäten während des Nationalsozialismus und ihr damaliges Leitungspersonal zu skandalisieren, wobei es meist bei der bloßen Drohung blieb. Der wunde Punkt der deutschen Seite war vor allem das damals noch ungeklärte Problem der im Zweiten Weltkrieg beschlagnahmten deutschen Auslandsvermögen in den Vereinigten Staaten. ${ }^{155}$ Ferencz nutzte deshalb insbesondere seine guten Kontakte zu Jack Raymond, einem Journalisten von The New York Times, und zur Public-Relations-Abteilung von B'nai B'rith, um verdeckte Kampagnen gegen deutsche Unternehmen zu führen. Diese antworteten mit ähnlichen Mitteln und heuerten

152 Dokument 30.

153 Dokument 37.

154 Siehe Dokumente 47 und 54.

155 Vgl. Hans-Dieter Kreikamp, Deutsches Vermögen in den Vereinigten Staaten. Die Auseinandersetzung um seine Rückführung als Aspekt der deutsch-amerikanischen Beziehungen 1952-1962, Stuttgart 1979. 
ihrerseits den PR-Spezialisten Julius Klein in Amerika an. ${ }^{156}$ Besonders intensiv setzte Ferencz das Instrument der Kampagnenpolitik in der Auseinandersetzung mit Rheinmetall ein. Das deutsche Rüstungsunternehmen reagierte empfindlich auf negative Public Relations in den Vereinigten Staaten, da es gerade vor dem Abschluss eines großen Auftrags mit dem Pentagon stand. Ferencz mobilisierte Medien und Kongressabgeordnete und kontaktierte auch konkurrierende amerikanische Waffenproduzenten, um Rheinmetall unter Druck zu setzen. Die hart geführte Auseinandersetzung endete 1966 schließlich damit, dass Rheinmetall 2,5 Millionen DM für ehemalige jüdische Zwangsarbeiter überwies. Das Unternehmen sah sich allerdings lediglich als Opfer einer Erpressung und erkannte damit keine eigene Verantwortung für das Schicksal seiner ehemaligen Zwangsarbeiter an. ${ }^{157}$

Bis 1962 schlossen nach jahrelangem Streit neben I. G. Farben i.L. die Firmen Krupp, AEG und Siemens ähnliche Vereinbarungen mit der Jewish Claims Conference. Am Ende konnte die damit beauftragte Compensation Treuhand 52 Millionen DM an knapp 15000 jüdische Zwangsarbeiterinnen und Zwangsarbeiter verteilen. ${ }^{158}$ Mit diesen Vereinbarungen erkannten die betroffenen Unternehmen jedoch keinerlei rechtliche oder moralische Verpflichtung an. Im Nachhinein erscheinen die Verhandlungen zwischen ihnen und der JCC wie eine Neuauflage der Nürnberger Prozesse unter umgekehrten Vorzeichen. Die Anwälte der deutschen Unternehmen, von denen manche Ferencz schon als Nürnberger Verteidiger bekannt waren, agierten so, als sei nun die Chance zu einem juristischen Rückspiel gekommen, bei dem sie die besseren Karten in der Hand zu haben glaubten. Die von allen betroffenen Unternehmen zunächst grundsätzlich geteilte Ablehnung einer Verantwortung für das Schicksal der bei ihnen im Zweiten Weltkrieg beschäftigten Zwangsarbeiter und der gelegentlich offen ausgedrückte Zynismus und unterschwellige Antisemitismus seiner Verhandlungspartner trafen Ferencz hart. Während der Verhandlungen mit Rheinmetall, wo er die alten nationalsozialistischen Manager weiter am Wirken sah, schrieb er 1966: »They would have desired to spit in the Jewish face and have me go away quietly, and they fiercely resented my assurance that I was not so inclined. $\ll^{159}$

Seit 1963 versuchte die Jewish Claims Conference auch den Unternehmer Friedrich Flick zu einer Entschädigung für ehemalige jüdische Zwangsarbeiterinnen und Zwangsarbeiter der Dynamit Nobel AG zu bewegen. Flick hatte

156 Siehe etwa Dokumente 58-61 sowie Ferencz, Lohn des Grauens, 174-183.

157 Siehe Dokumente 55-57. Vgl. auch Ferencz, Lohn des Grauens, 165-193.

158 Eine Aufstellung über die genauen Beträge und ihre Aufteilung findet sich bei

Ferencz, Lohn des Grauens, $264 \mathrm{f}$.

159 Dokument 61. 
die Mehrheit an diesem Unternehmen erworben, das während des Zweiten Weltkriegs in verschiedenen Munitionswerken jüdische Zwangsarbeiter eingesetzt hatte. ${ }^{160}$ Jahrelang verzögerte er die Verhandlungen und als er 1972 starb, stand eine Einigung immer noch in weiter Ferne. Daran hatte weder der Einsatz prominenter Unterstützer wie $\mathrm{McCloy}^{161}$ noch die Vorlage umfangreicher Beweisdokumente etwas ändern können. Dieser Einzelfall erhellt ein zentrales Motiv der Auseinandersetzung über die Zwangsarbeiterentschädigung zwischen der JCC und der deutschen Industrie. Für die betroffenen deutschen Industriellen stand nicht in erster Linie das geforderte Geld im Vordergrund, sondern vor allem die Frage, ob auf diesem Wege die Ergebnisse der Nürnberger Prozesse und das dort gefällte Verdikt über die Rolle der Industrie im Nationalsozialismus anerkannt würden oder nicht. Sie wollten nun aus einer mittlerweile erheblich gestärkten Position heraus ihren immer schon vertretenen Standpunkt durchsetzen, wonach sie keine Kriegsverbrechen begangen hätten. Umgekehrt bildete dies für Ferencz die Prämisse der Verhandlungen. Neben der finanziellen Entschädigung für jüdische Zwangsarbeiterinnen und Zwangsarbeiter kämpfte er somit auch einen vergangenheitspolitischen Kampf um die Legitimität der Nürnberger Prozesse, womit nicht zuletzt die Integrität seiner eigenen Position und Person verbunden war.

Das fünfte Kapitel dokumentiert, wie sich Ferencz für die Opfer der von deutschen Ärzten im Zweiten Weltkrieg durchgeführten medizinischen Humanexperimente engagierte. Dabei handelte es sich vor allem um Frauen aus dem östlichen Europa - darunter viele polnische Katholikinnen. Sein Engagement für Verfolgte des Nationalsozialismus orientierte sich somit weder an nationalen, noch an religiösen oder sonstigen Präferenzen. Insbesondere Geschädigte aus Ländern des sogenannten Ostblocks konnten in den 1950er Jahren keinerlei Kompensationszahlungen oder auch nur Unterstützungsleistungen von der Bundesrepublik erwarten - und erst recht nicht von der DDR. Nachdem die amerikanische Philanthropin Caroline Ferriday 1957 Ferencz kontaktiert hatte, begann er sich intensiv für diese Gruppe einzusetzen. ${ }^{162}$ Während er in den Verhandlungen mit deutschen Industrieunternehmen die Entschädigungsforderungen jüdischer Zwangsarbeiter als Anwalt vertrat, präsentierte er sich hier eher in der Rolle eines Schlichters. ${ }^{163}$ Als solcher vermittelte er zwischen den Konfliktparteien, wobei er allerdings gezielt medialen Druck aufbaute. Dabei setzte er vor allem darauf, dass die Bundesregierung

160 Siehe Dokumente 46-47, 52-53, 60, 66, 71 und 76 sowie Ferencz, Lohn des Grauens, 195-227.

161 Siehe Dokument 71.

162 Siehe dazu Baumann, Menschenversuche und Wiedergutmachung, 116 und $118 \mathrm{f}$.

163 Siehe Dokument 83. 
gegenüber der öffentlichen Meinung in den Vereinigten Staaten äußerst empfindlich war. Gemeinsam mit Norman Cousins, dem Herausgeber der New Yorker Wochenzeitschrift Saturday Review, organisierte Ferencz das Ravensbrueck Lapins Project. Im Zuge dieser Kampagne unternahmen 29 polnische, katholische Frauen, die im Konzentrationslager Ravensbrück für medizinische Experimente missbraucht worden waren, 1959/1960 eine Vortragsreise durch die Vereinigten Staaten, um öffentlich auf ihr Schicksal aufmerksam zu machen und damit den Widerstand der deutschen Regierung gegen Entschädigungszahlungen an diese Opfergruppe zu zermürben. ${ }^{164}$

Bis dahin hatte die Bundesrepublik die in den Staaten des Warschauer Pakts lebenden Verfolgten des Nationalsozialismus der Logik des Kalten Kriegs unterworfen und sich geweigert, Entschädigungsleistungen an diese auch nur in Betracht zu ziehen. Das Ravensbrueck Lapins Project trug entscheidend dazu bei, dass Bonn diese Haltung schließlich aufgab und den Kabinettsbeschluss von 1951, der lediglich Nothilfen in wenigen Fällen vorgesehen hatte, 1960 erheblich erweiterte. Diese neue Regelung sah vor, dass nun in Osteuropa lebende Opfer medizinischer Versuche ebenfalls Leistungen zwischen 25.000 und 40.000 DM erhalten konnten, die vom Internationalen Roten Kreuz verteilt werden sollten. ${ }^{165}$ Ferencz engagierte sich zudem dafür, dass dieses Abkommen wirkungsvoll umgesetzt wurde. So bemühte er sich etwa um einen fairen Umtauschkurs für die Antragstellerinnen und Antragsteller oder auch um ein Globalabkommen für die Ravensbrueck Lapins. ${ }^{166}$ Während die deutsche Seite Einzelfallentscheidungen bevorzugte, entsprach es dem vom amerikanischen Rechtssystem geprägten Ansatz von Ferencz, durch Globalabkommen kollektive Lösungen auszuhandeln, um auf diese Weise die Abwicklung zu beschleunigen. Eine unverkennbare Genugtuung empfand er in solchen Fällen, in denen die deutsche Bürokratie Globallösungen abgelehnt hatte, nur um dann später durch Einzelfallentscheidungen ein Vielfaches ausgeben zu müssen: »Hoorah! The next time the Finance Ministry tells you their troubles, you can tell them that's what they can expect if they don't accept my terms. ${ }^{167}$

Bei den Verhandlungen mit der deutschen Industrie über die Zwangsarbeiterentschädigung, die gleichfalls um 1960 stattfanden, gewann Ferencz den Eindruck, dass die Gegenseite in ihm gelegentlich eine jüdische Nemesis

164 Siehe vor allem Dokument 83 sowie Baumann, Menschenversuche und Wiedergutmachung, 112-123.

165 Weindling, Nazi Medicine and the Nuremberg Trials, 338 f.; Baumann, Menschenversuche und Wiedergutmachung, $57 \mathrm{f}$. und 132.

166 Siehe Dokumente 95 und 96.

167 Dokument 95. 
sah. Als er mit der deutschen Regierung über die Entschädigung für medizinische Experimente verhandelte, wurde dagegen ein anderer Vorwurf laut. Weil er sich für Opfer hinter dem Eisernen Vorhang einsetzte, galt er in Bonn gelegentlich als kommunistischer Sympathisant. ${ }^{168}$ Beide Vorwürfe, die zusammengenommen das Bild eines jüdisch-kommunistischen Fellowtravellers entwarfen, verrieten mehr über mancherorts in Deutschland gärende Vorstellungen als über Ferencz. Er selbst differenzierte seine eigenen Bewertungen sehr präzise, und so bat er 1962 Caroline Ferriday darum, ihre öffentlichen Vorwürfe an die Bundesrepublik zu mäßigen: »In truth, it should also be said that the opposition came from a small nucleus, which successfully blocked action for a long time, but we did have many friends, as subsequent events showed, and to talk about the Germans` without any distinction is perhaps unfair. ${ }^{169}$

Das sechste Kapitel versammelt Dokumente zur Tätigkeit von Ferencz für den deutschen Ableger der jüdischen Wohltätigkeitsorganisation B’nai B’rith, für die er Mitte der 1950er Jahre ein umfangreiches Rückerstattungsprogramm entwarf und über 15 Jahre hinweg umsetzte. ${ }^{170}$ Die alliierten Restitutionsgesetze zu implementieren erwies sich immer wieder als schwierig, etwa im Fall des 1938 enteigneten Berliner Logengebäudes von B'nai B'rith in der Kleiststraße 10, wo sich heute der Sitz der populärwissenschaftlichen Bildungseinrichtung Urania befindet. Nach dem Krieg wurde das Gebäude zwar aus dem zwischenzeitlichen Besitz der Gestapo zurückerstattet, doch den geplanten Verkauf verhinderten finanzielle Gegenforderungen der Berliner Verwaltung, die enorme Renovierungskosten in Rechnung stellte. Die Verhandlungen von Ferencz mit dem damaligen Berliner Oberbürgermeister Willy Brandt zeigen, dass es bei der Umsetzung der Rückerstattung immer wieder darum ging, die grundsätzliche vergangenheitspolitische Dimension dieses vermögensrechtlichen Vorgangs zu verdeutlichen. ${ }^{171}$

Die Wiedergutmachungsgesetze umzusetzen erwies sich als nicht weniger aufwendig als diese auszuhandeln. Dies gilt auch für den Konflikt um die Erfüllung eines 1959 im Rahmen des Bundesrückerstattungsgesetzes von Ferencz initiierten Globalabkommens über zehn Millionen DM, in dem die Verbindlichkeiten des Deutschen Reichs gegenüber dem deutschen Ableger von B'nai B'rith abgefunden wurden. ${ }^{172}$ Ferencz nutzte dabei nicht allein sein

168 Siehe Dokumente 84, 91 und 95.

169 Dokument 94.

170 Siehe Dokument 102.

171 Siehe Dokumente 98 und 99.

$172 \mathrm{Zu}$ dem 1959 abgeschlossenen Globalabkommen zwischen der Bundesrepublik und B'nai B'rith siehe die Unterlagen im USHMM, BBF Collection, RG 12.003.01*06 sowie RG 12.003.01*07. 
enormes juristisches Wissen, sondern pflegte zudem seine langfristig entstandenen Kontakte mit der deutschen Ministerialbürokratie und Politik. So plante er etwa 1966 detailliert das Besuchsprogramm von Ernst Féaux de la Croix, der im Bundesfinanzministerium für Restitution und Entschädigung zuständig war, und Martin Hirsch, dem ehemaligen Vorsitzenden des Wiedergutmachungsausschusses des Bundestags, die von der Jewish Claims Conference nach New York eingeladen worden waren, und vergaß dabei nicht, an ein Souvenir für deren mitreisende Ehefrauen zu denken. ${ }^{173}$

In seiner Tätigkeit für B’nai B’rith agierte Ferencz als geschickter Lobbyist, indem er den persönlichen Kontakt mit politischen Entscheidungsträgern suchte und strategische Allianzen schmiedete. Besonders virtuos betrieb er dies zugunsten der aus dem War Claims Act von 1962 resultierenden Forderungen der B'nai-B'rith-Zentrale in den Vereinigten Staaten. Das Gesetz regelte die Entschädigung amerikanischer Vermögensverluste im Ausland, die durch feindliche Aktionen im Zweiten Weltkrieg entstanden waren. Dazu sollte das in den Vereinigten Staaten während des Kriegs als Feindvermögen beschlagnahmte deutsche Eigentum unter den verschiedenen Gläubigergruppen aufgeteilt werden. ${ }^{174}$ Ferencz vertrat die Ansprüche der amerikanischen B'nai B'rith auf das vor 1945 konfiszierte Eigentum ihrer Logen in Europa. Da der War Claims Act jedoch die Forderungen nichtkommerzieller karitativer und konfessioneller Organisationen gegenüber denjenigen kommerzieller Gläubigergruppen drastisch benachteiligte, initiierte er einen Coordinating Council of Religious \& Welfare Agencies, der 29 nordamerikanische Kirchen und Wohltätigkeitsorganisationen zusammenschloss. Gestützt auf dieses breite interkonfessionelle Bündnis bearbeitete er jahrelang systematisch Kongressabgeordnete und erreichte schließlich, dass der War Claims Act 1970 zugunsten dieser Gläubigergruppe geändert wurde, ${ }^{175}$ wodurch B'nai B'rith eine vorteilhaftere Entschädigungsquote erhielt.

173 Siehe Dokument 101. Zur Rolle von Ernst Féaux de la Croix und Martin Hirsch im Zusammenhang der Wiedergutmachung siehe Goschler, Schuld und Schulden, $140 \mathrm{f}$., 150 f., 220 f., 223 f., 230, 232, 238-249, 255, 258f., 263-265, 268-276, 279-284, 286 f., $305,312-315,324,326,328,332,343$; Susanna Schrafstetter, Verfolgung und Wiedergutmachung. Karl M. Hettlage: Mitarbeiter von Albert Speer und Staatssekretär im Bundesfinanzministerium, in: Vierteljahrshefte für Zeitgeschichte 56 (2008), H. 3, 431-466, vor allem 456-459, 461-463.

174 Martin Domke, The War Claims Act of 1962, in: The American Journal of International Law 57 (1963), H. 2, 354-372.

175 United States Congress, Public Law No. 91-571, An Act to Amend Section 213 (a) of the War Claims Act of 1948 With Respect to Claims of Certain Non-Profit Organizations and Certain Claims of Individuals, Washington, D. C., 24. Dezember 1970. 
Das siebte Kapitel dokumentiert, wie sich Ferencz jahrelang vergeblich bemühte, auch die DDR zu einer Globalentschädigung für jüdische Opfer des Nationalsozialismus zu bewegen. Die Gespräche begannen 1973 anlässlich des gleichzeitigen Beitritts der Bundesrepublik und der DDR zu den Vereinten Nationen und endeten 1990 mit der deutschen Wiedervereinigung. ${ }^{176}$ Die Jewish Claims Conference engagierte Ferencz zu Beginn dieser Kampagne als eine Art Sonderberater, wobei er gleichzeitig auch für die Zwangsarbeiterentschädigung zuständig blieb. ${ }^{177}$ Er stürzte sich mit großer Energie auf diesen neuen Auftrag, organisierte zahlreiche Besprechungen der JCC mit weiteren jüdischen Organisationen sowie mit dem State Department und anderen US-Ministerien, um auf diese Weise eine gemeinsame Verhandlungsfront zu schmieden. Gleichzeitig präsentierte er die Forderungen der JCC immer wieder DDR-Diplomaten in New York, wobei er von Einladungen zum Mittagessen im Harvard oder Princeton Club bis zur zufälligen Begegnung in der Cafeteria oder Herrentoilette im UN-Hauptgebäude jede sich bietende Gelegenheit nutzte. ${ }^{178} \mathrm{Er}$ stützte seine Verhandlungsstrategie zum einen auf das Luxemburger Abkommen von 1952, das ihm als Vorbild und Legitimation der Forderungen der Jewish Claims Conference diente. Zum anderen versuchte er das vermutete Interesse der DDR an der Meistbegünstigungsklausel, also den Verzicht auf benachteiligende Zollbestimmungen für ihre Exporte in die Vereinigten Staaten, als politischen Hebel anzusetzen. Auch das State Department ließ sich dafür gewinnen, doch brachte dieses zugleich Forderungen, das Eigentum amerikanischer Staatsbürger in der DDR gleichfalls zu entschädigen, mit in das Verhandlungspaket ein. ${ }^{179}$

Die Regierung der DDR lehnte es allerdings ab, direkt mit der Jewish Claims Conference zu sprechen und verwies sie stattdessen an das Komitee der Antifaschistischen Widerstandskämpfer. Mehrfach verhandelte Ferencz deshalb in Ostberlin bei Kaffee und Cognac mit Vertretern des Komitees. ${ }^{180}$ Aber auch dies änderte nichts daran, dass letztlich beide Seiten jahrelang gebetsmühlenartig ihre Argumente wiederholten. Die von Ferencz beharrlich

Siehe dazu Dokument 102 sowie USHMM, BBF Collection, RG 12.011.05^10, Benjamin B. Ferencz an Harry Greenberg und Mr. Ellsworth G. Stanton III (Coordinating Council of Religious Welfare Agencies), 10. Dezember 1970.

176 Siehe dazu Timm, Jewish Claims Against East Germany, 94-113; Timm, Alles umsonst?, 19-30; Meining, Kommunistische Judenpolitik, 247-258; Goschler, Schuld und Schulden, 403-406.

177 Siehe Dokument 106.

178 Siehe Dokumente 109 und 123.

179 Siehe Dokumente 105-106, 108, 113, 119, 122, 124-125 und 128.

180 Siehe Dokumente 114, 116 und 118. 
vorgetragene Position der JCC lautete zugespitzt »Wassenaar plus Meistbegünstigung «. Im Gegenzug für an das Abkommen zwischen der Bundesrepublik, Israel und der JCC von 1952 angelehnte Leistungen der DDR sollten dieser also Zollerleichterungen im Handel mit den Vereinigten Staaten gewährt werden. Demgegenüber antworteten die ostdeutschen Vertreter mit der Formel »Potsdam plus Antifaschismus«. Erstens habe die DDR ihre aus dem Potsdamer Abkommen resultierenden Reparationspflichten erfüllt und zweitens sei die Bekämpfung und Überwindung des Faschismus die Grundlage dieses Staats. ${ }^{181}$ Der Versuch der ostdeutschen Führung, die Angelegenheit 1976 mithilfe einer vom Komitee der Antifaschistischen Widerstandskämpfer geleisteten Spende in Höhe von einer Million Dollar an die Jewish Claims Conference zu beenden, scheiterte. Zwar plädierte Ferencz dafür, gewissermaßen den kleinen Finger zu nehmen, um auf diese Weise vielleicht am Ende doch noch die ganze Hand zu fassen zu bekommen. Doch die JCC beschloss stattdessen das Geld abzuweisen, weil der Betrag nicht angemessen sei. ${ }^{182}$

In den folgenden Jahren bearbeitete Ferencz seine ostdeutschen Gesprächspartner, eine Entschädigungssumme von 100 Millionen Dollar an die Jewish Claims Conference zumindest prinzipiell anzuerkennen. Dabei warb er mit der Aussicht, dass sich die Entschädigungsleistungen vollständig aus den prospektiven Handelserleichterungen mit den Vereinigten Staaten finanzieren ließen. Angesichts des seit Beginn der 1980er Jahre sich wieder verschärfenden Ost-West-Konflikts sanken die Chancen dafür jedoch zusehends. Ein Tiefschlag für die Bemühungen von Ferencz war schließlich das Bombenattentat auf die Berliner Diskothek La Belle 1986, ${ }^{183}$ bei dem drei Menschen ums Leben kamen und das vor allem amerikanischen Soldaten gegolten hatte. Der DDR wurde eine Mitschuld an dem terroristischen Anschlag zugewiesen, was die ohnehin schwach ausgeprägte Neigung des republikanisch dominierten US-Kongresses, Handelserleichterungen für die DDR zuzustimmen, weiter verringerte. 1988 räumte Ferencz schließlich ein, dass der bisherige, gemeinsam mit dem State Department verfolgte Ansatz » Jewish claims, US claims, and Trade Agreement « als Paket zu behandeln, gescheitert sei: "So far, it [the Claims Conference] has nothing concrete to show after almost 15 years of quiet diplomacy. « ${ }^{184}$ Ferencz, dessen erklärtes Motto es war, niemals aufzugeben, sah nun keinen Weg mehr, die Zwickmühle kollidieren-

181 Siehe Dokumente 109, 120 und 128.

182 Siehe Dokumente 116-118.

183 Siehe Dokument 125.

184 Dokument 128. 
der realpolitischer Interessen zwischen den Vereinigten Staaten und der DDR mithilfe der moralisch begründeten Forderungen der JCC zu öffnen.

Bald darauf setzte jedoch der rapide politische Niedergang der DDR ein, was die Verhandlungen grundlegend veränderte. Die Erklärung der ersten demokratisch gewählten Volkskammer vom 12. April 1990, in der unter anderem eine Entschuldigung für die Verbrechen an den Juden und die Bereitschaft zu Entschädigungsleistungen ausgesprochen worden war, ${ }^{185}$ nahm Ferencz zum Anlass, einen Paradigmenwechsel vorzuschlagen: "Experience has shown that pressing Jewish claims into a strict German legal mold took over 40 years and produced a morass of inequity. We should move away from a legal approach to a social approach. Whatever is requested should be clear, justifiable and capable of quick administration. ${ }^{186}$ Eine Vereinbarung, die angesichts der für $1991 \mathrm{zu}$ erwartenden Vereinigung der DDR mit der Bundesrepublik kaum noch ohne deren Zustimmung zu erreichen sei, sollte einen Betrag von fünf Milliarden DM, verteilt auf 10 Jahre umfassen. Die Verhandlungen, an denen Ferencz dann nicht mehr beteiligt war, wurden schließlich zu einem Gegenstand des deutschen Vereinigungsprozesses und zuletzt von der Bundesrepublik zu Ende geführt. ${ }^{187}$ Zuvor musste er aber noch die Mitarbeiter im New Yorker Büro der Jewish Claims Conference beruhigen. Denn im September 1990 drohte ein deutschsprachiger Anrufer, dem langjährigen Geschäftsführer und Vizepräsidenten der JCC Saul Kagan die Kehle durchzuschneiden, falls er nach Deutschland käme. ${ }^{188}$ Auch wenn dies ein Einzelfall war, so gehörte er zur Atmosphäre, die diejenigen umgab, die sich für die Entschädigung jüdischer Opfer des Nationalsozialismus einsetzten.

Die Dokumente im achten Kapitel zeigen Ferencz im Kontext der Praxis der Entschädigung jüdischer Opfer des Nationalsozialismus durch die Bundesrepublik. Dabei vertrat er unterschiedliche Organisationen als Anwalt. Die Auswahl setzt mit dem Jahr 1965 ein, in dem das Bundesentschädigungsgesetz (BEG) abschließend novelliert und zugleich ostentativ mit dem Zusatz "Schlussgesetz« versehen wurde. ${ }^{189}$ Angesichts des komplexen Themenfelds können die hierzu ausgewählten Dokumente lediglich einige Schlaglichter setzen. Ein erstes Problemfeld bezieht sich auf die Kontroverse um die Forderungen jüdischer und israelischer Krankenhäuser und Wohlfahrtsorganisationen für die Behandlungskosten jüdischer Verfolgter des Nationalsozia-

185 Volkskammer, Antrag aller Fraktionen der Volkskammer der DDR zu einer gemeinsamen Erklärung, Berlin, 12. April 1990.

186 Siehe Dokument 130.

187 Goschler, Schuld und Schulden, 422-428.

188 Siehe Dokument 131.

189 Siehe dazu Goschler, Schuld und Schulden, 273-288. 
lismus. Ferencz vertrat in dieser Auseinandersetzung mit einigen deutschen Landesentschädigungsämtern, die vielfach die Kostenübernahme ablehnten, die New York Association for New Americans (NYANA) sowie die Hebrew Immigrant Aid Society (HIAS). ${ }^{190}$ Beide Organisationen unterstützten vor allem, aber nicht ausschließlich, jüdische Flüchtlinge bei der Eingliederung in die Vereinigten Staaten, darunter auch viele Holocaustüberlebende. Die von Ferencz geführten Verhandlungen über die Entschädigung von Gesundheitsschäden jüdischer Verfolgter deuten darauf hin, dass sich nach dem Erlass des Bundesentschädigungs-Schlussgesetzes 1965 in deutschen Ministerien und Behörden eine Schlussstrichmentalität ausbreitete. ${ }^{191}$ Dieser Themenbereich entwickelte sich seit den späten 1960er Jahren immer mehr zum zentralen Aspekt des Entschädigungsrechts, wobei insbesondere die Frage der Anerkennung von Spätschäden einen ständigen Streitpunkt bildete. Ferencz las Einzelfälle stets vor dem Hintergrund dessen, was er bei der Befreiung deutscher Konzentrationslager 1945 selbst gesehen hatte und empörte sich daher über die in manchen Begründungen der deutschen Bürokratie zutage tretende Ignoranz gegenüber dem Schicksal jüdischer Antragssteller. Einen besonders drastischen Fall kommentierte er 1974 knapp: »Wiedergutmachung! Ugh! « ${ }^{192}$

Die Haupttätigkeit von Ferencz als Entschädigungsanwalt erfolgte im Dienst der Jewish Claims Conference. Seine dichte Korrespondenz vor allem mit Saul Kagan in New York und Ernst Katzenstein, der Ferencz als Leiter des Frankfurter Büros der JCC gefolgt war, macht die täglichen Routinen und Probleme der Entschädigungspraxis greifbar. Während bei der JCC eine außergewöhnlich starke personelle Kontinuität herrschte, gab es in der deutschen Politik und Bürokratie eine stärkere Fluktuation. Ferencz verkörperte zunehmend eine Art von institutionellem Gedächtnis der Wiedergutmachung, hatte er doch noch selbst die grundlegenden Vereinbarungen mitverhandelt, deren Verständnis nach seinem Eindruck auf deutscher Seite nun zunehmend verloren ging. Ihm zufolge führte vor allem seit den 1970er Jahren der Generationenwechsel in der Bundesrepublik dazu, dass das persönliche Verantwortungsgefühl für die nationalsozialistischen Verbrechen immer stärker nachließ. Konkret kollidierten etwa die Vorstellungen darüber, wofür die 1952 in Luxemburg vereinbarte Globalentschädigung von 450 Millionen DM für die JCC eigentlich bestimmt gewesen sei. Ebenso uneinig war man sich über den im selben Abkommen zugunsten der nicht-bekennenden Juden vorgesehenen Anteil von 50 Millionen DM. ${ }^{193}$

190 Siehe vor allem Dokumente 132-134 sowie 136-138.

191 Siehe dazu etwa Dokument 143.

192 Dokument 146.

193 Siehe Dokument 151. Siehe dazu auch Goschler, Schuld und Schulden, 296 f. und 327. 
Während die deutsche Seite seit dem Bundesentschädigungs-Schlussgesetz auf dem bevorstehenden Abschluss der Wiedergutmachung beharrte, galt für die Jewish Claims Conference, dass die Aufgabe solange fortgeführt werden müsse, wie notleidende jüdische Opfer des Nationalsozialismus existierten. ${ }^{194}$ Ein besonderes Problem in dieser Hinsicht bildeten die nach 1965 aus dem Ostblock ausgewanderten Juden, von denen viele während des Zweiten Weltkriegs verfolgt worden waren. Nach jahrelangen Verhandlungen beschloss das Bundeskabinett schließlich 1980 für diese Gruppe noch einmal einen Härtefonds von 400 Millionen DM einzurichten und zusätzlich 40 Millionen DM für den Zentralrat der Juden in Deutschland bereitzustellen. Während die administrative Bearbeitung der Fälle der JCC übertragen wurde, liefen die Gelder über die Konten des Zentralrats. Nach dem Tod des Zentralratsvorsitzenden Werner Nachmann 1988 wurde publik, dass dieser die Situation ausgenutzt hatte, um seine maroden Privatfirmen finanziell über Wasser zu halten, wodurch ein Schaden von 30 Millionen DM entstanden war. ${ }^{195}$ Ferencz organisierte maßgeblich das Krisenmanagement der Jewish Claims Conference, die durch den »Fall Nachmann « in schwere Turbulenzen geriet. Dabei vertrat er die Linie, dass die deutsche Ministerialbürokratie ihre Aufsichtspflicht verletzt habe, während die JCC und die von ihnen vertretenen jüdischen Opfer des Nationalsozialismus gemeinsam betroffen seien. Die medialen Auswirkungen dieser Affäre versuchte er aktiv zu begrenzen. ${ }^{196}$

Finanzielle Fragen stehen in den edierten Dokumenten oftmals im Zentrum. Dazu gehört nicht nur der ständige Kampf mit der deutschen Entschädigungsbürokratie um die Leistungen für Juden, die während des Nationalsozialismus verfolgt worden waren, sondern auch immer wieder der Streit um Anwaltshonorare für Ferencz ${ }^{197}$ sowie die Finanzierung der Jewish Claims Conference und der URO. Beide Organisationen konnten in den 1980er Jahren nur noch mühsam ihre Verwaltungskosten decken, weshalb Ferencz immer wieder Reformen anmahnte. ${ }^{198} 1990$ zog er sich nach jahrzehntelangem Engagement für die JCC zurück. Mittlerweile über 70 Jahre alt, wollte er nicht für die nach dem Ende der deutschen Teilung aufkommenden umfangreichen neuen Forderungen eintreten und sich stattdessen stärker auf seine Familie und sein Engagement für den Weltfrieden konzentrieren. ${ }^{199}$ Zudem

194 Siehe Dokument 150.

195 Constantin Goschler/Anthony Kauders, Dritter Teil: 1968-1989. Positionierungen, in: Brenner (Hg.), Geschichte der Juden in Deutschland, 295-378, hier 336-340.

196 Siehe Dokumente 155-157.

197 Siehe Dokument 152.

198 Siehe Dokument 153.

199 Siehe Dokument 160. 
kritisierte er die Verkrustung der für die Entschädigung jüdischer Verfolgter tätigen Organisationen. Einem Bericht über die Überprüfung des New Yorker URO-Büros an Saul Kagan fügte er nicht nur Grüße zum Valentinstag, sondern auch ein zusammenfassendes Postskriptum hinzu: "In 1990, it cost the URO about \$75,000 total to handle the HF [Hardship Fund] claims, which produced URO income of about $\$ 90,000$. $\aleph^{200}$ In einem persönlichen Brief an den Anwalt und langjährigen Mitarbeiter der URO Werner Wolff beklagte Ferencz 1993, dass der institutionelle Selbsterhaltungstrieb immer stärker die ursprüngliche Aufgabe überwuchere, armen und hilflosen Antragstellern zu helfen: »What I see as URO's future is an organization competing to grab clients in order to gain enough profit to keep its bureaucracy going. ${ }^{201} \mathrm{Kri}-$ tisch sah Ferencz aber auch das Revival der Jewish Claims Conference nach der deutschen Wiedervereinigung, die durch die neue Welle an Rückerstattungsund Entschädigungsregelungen wieder aufgeblüht war: »I have lost all respect for the Jewish organizations which are the self-declared spokesmen of the Jewish people. [...] I fear that the Claims Conference will sink in the morass it is creating for itself. It all makes me so unhappy that I don't want to see it. I want to be completely removed from all of it. I hope I am wrong and that my child will live and be well and happy. But I shall be happier if I consider my job done and wish all of those who come after me the very best of luck. ${ }^{202}$ Diese Kritik trug er aber loyalerweise nicht in die Öffentlichkeit, wo die Jewish Claims Conference einige Jahre später zum Gegenstand heftiger Angriffe wurde. ${ }^{203}$

Die Dokumente im neunten und letzten Kapitel zeigen Ferencz schließlich als einen wichtigen Akteur innerhalb des transnationalen juristischen Felds, auf dem Verfechter des internationalen humanitären Rechts und der Menschenrechte zusammentrafen. ${ }^{204}$ Durch die politischen Kontroversen um den Vietnamkrieg seit der zweiten Hälfte der 1960er Jahre gelangten die Anhänger des liberalen Legalismus, die gewaltsame Konflikte und ihre Folgen durch Institutionalisierung einer internationalen Gerichtsbarkeit regeln wollten, allmählich wieder aus der Bedeutungslosigkeit heraus, in die sie im Kalten Krieg geraten waren. Vermehrt schlossen sich renommierte Juristen

200 Dokument 161.

201 Dokument 162.

202 Dokument 162.

203 Den Höhepunkt dieser Auseinandersetzung markierte die Debatte um das Buch von Norman G. Finkelstein, Die Holocaust-Industrie. Wie das Leid der Juden ausgebeutet wird, München 2001. Siehe dazu Ernst Piper (Hg.), Gibt es wirklich eine Holocaust-Industrie? Zur Auseinandersetzung um Norman Finkelstein, Zürich 2001; Petra Steinberger (Hg.), Die Finkelstein-Debatte, München 2001.

204 Hagan, Justice in the Balkans, 37. 
dieser Gruppe an, die zunehmend von Medien und Stiftungen unterstützt wurde und sich insgesamt stärker professionalisierte. Das hier allmählich vor allem in den Vereinigten Staaten entstehende transnationale Netzwerk der "Experten der Grausamkeit « war jetzt nicht mehr länger in erster Linie eine Angelegenheit von Immigranten der ersten Generation, zu denen neben Ferencz auch sein Lehrer Sheldon Glueck sowie der Völkerrechtsexperte M. Cherif Bassiouni gehörten, sondern rekrutierte sich zunehmend aus den elitärsten juristischen Fakultäten der Vereinigten Staaten. ${ }^{205}$ Allerdings blieb Ferencz in zweierlei Hinsicht wichtig für diese Bewegung: zum einen als Aktivist, zum anderen als Fackelträger. In dieser ihm seit den 1990er Jahren zugewiesenen Rolle, die er gern übernahm, trug er gewissermaßen das Erbe von Nürnberg in die neue Ära der internationalen Strafjustiz. ${ }^{206}$

Der Vietnamkrieg war ein zentrales Ereignis für den Aufstieg des rechtlichen Humanitarismus und auch für die Entwicklung von Ferencz war das Ereignis entscheidend. 1971 veröffentlichte The New York Times Auszüge aus den sogenannten Pentagon-Papieren, die belegten, dass die amerikanische Öffentlichkeit bewusst über die politischen Motive ihrer Regierung für das militärische Engagement in Vietnam getäuscht worden war. ${ }^{207}$ In einem gleichfalls in dieser Zeitung abgedruckten Leserbrief kritisierte Ferencz das Handeln der Regierung: »The record now seems clear that we betrayed our ideals as we arrogantly applied our power to further our political goals. [...] The saddest mistake America made was to try to use military might as a substitute for the rule of law. $\aleph^{208}$ Ferencz trug seinen Protest nicht auf die Straße, sondern in den Gerichtssaal - zumindest versuchte er dies. Am 29. März 1971 wurde William Calley, der befehlshabende Offizier des Massakers von My Lai, wegen der Tötung von 28 »Asiaten « von einem Militärgericht zu lebenslanger Haft verurteilt, die bereits am nächsten Tag von Präsident Nixon in Hausarrest umgewandelt wurde. Drei Jahre später begnadigte er ihn dann ganz. ${ }^{209}$ Während die öffentliche Meinung in den Vereinigten Staaten sich vor allem zugunsten von Calley aussprach, plante Ferencz zusammen mit

205 Ebd., vor allem 35-37.

206 Frédéric Mégret, International Criminal Justice as a Juridical Field, in: Champ Pénal/ Penal Field 13 (2016), Abs. 19, <http://journals.openedition.org/champpenal/9284> (1. Februar 2019).

207 David Rudenstine, The Day the Presses Stopped. A History of the Pentagon Papers Case, Berkeley, Calif./Los Angeles, Calif./London 1996.

208 Dokument 166.

209 Michal R. Belknap, The Vietnam War on Trial. The My Lai Massacre and the CourtMartial of Lieutenant Calley, Lawrence, Kans., 2002, 191-256; Bernd Greiner, Krieg ohne Fronten. Die USA in Vietnam, Hamburg 2007, $493 \mathrm{f}$. 
einigen Gleichgesinnten eine Zivilrechtsklage gegen ihn und seine Vorgesetzten, um Entschädigungen für die Opfer zu fordern: »The primary objective would be to emphasize and draw public attention to the fact that there may be personal financial responsibility for human rights violations, and that the Human Rights Conventions provide for compensation as one of the rights of the victim. ${ }^{210}$ Auch wenn die Klage schließlich nicht zugelassen wurde, ${ }^{211}$ verknüpften sich mit dieser Initiative zentrale Anliegen von Ferencz: »A topic which comes to mind at the moment is Nurnberg [sic] - Past, Present and Future - to explain what it was about, how it relates to Vietnam, Calley, etc., and the hopes for a permanent court for international crimes. $\ll^{212}$

Die Debatten um den Vietnamkrieg fungierten für Ferencz als ein Katalysator, um seine Nürnberger Erfahrungen in völkerrechtliche und politische Bemühungen zur Etablierung eines internationalen Strafgerichtshofs zu übersetzen, die seit Anfang der 1970er Jahre in den Vereinigten Staaten zunehmend an Bedeutung gewannen. Er engagierte sich in dem entstehenden Netzwerk strafrechtlicher Organisationen, die dem liberalen Legalismus eine breitere Basis verschafften. Dazu gehörten die 1970 von Robert Woetzel gegründete Foundation for the Establishment of an International Criminal Court $^{213}$ sowie das Committee for an International Criminal Court der World Association of Lawyers (WAL), dessen Chairman Ferencz wurde. Die WAL war wiederum mit dem World Peace Through Law Center (WPLC) verbunden. ${ }^{214}$ Hinzu kamen enge Beziehungen zur Association Internationale de Droit Pénal und ihrem Präsidenten M. Cherif Bassiouni, ${ }^{215}$ der Anfang der 1990er Jahre eine Schlüsselrolle bei der Einrichtung eines Internationalen Strafgerichtshofs für Jugoslawien spielte. ${ }^{216}$ Seit Anfang der 1970er Jahre nahm Ferencz schließlich auch regelmäßig als Nichtregierungsbeobachter an Sitzungen des Special Committee to Define Aggression der Vereinten Nationen in New York und Genf teil. Mit seinen juristischen Mitstreitern innerhalb

210 Dokument 167.

211 Siehe Dokument 169.

212 Dokument 168. Vgl. auch Telford Taylor, Nuremberg and Vietnam. An American Tragedy, Chicago, Ill., 1970; Benjamin B. Ferencz, War Crimes Law and the Vietnam War, in: American University Law Review 17 (1968), H. 3, 403-423. Zu dem Zusammenhang siehe auch Marion Breunig, Von Nürnberg nach Vietnam: Das »Russell-Tribunal « von 1967 in historischer Perspektive, in: Manfred Berg/Philipp Gassert (Hg.), Deutschland und die USA in der Internationalen Geschichte des 20. Jahrhunderts. Festschrift für Detlev Junker, Stuttgart 2004, 115-136.

213 Siehe dazu Dokumente 163 und 164.

214 Siehe Dokumente 174 und 175.

215 Siehe Dokumente 178-180.

216 Hagan, Justice in the Balkans, 6 und 33-35. 
dieses Netzwerks diskutierte Ferencz insbesondere, wie die in Nürnberg angewandten Prinzipien zur Grundlage der Konfliktvermeidung in den internationalen Beziehungen werden könnten. Eine erste schwierige Frage in diesem Zusammenhang war, wie der Begriff der Aggression definiert werden sollte. Eine noch größere Herausforderung bedeutete die Etablierung eines internationalen Strafgerichtshofs, der die Ahndung von Kriegsverbrechen auch durchsetzen würde, ${ }^{217}$ da sich hier unmittelbar die Frage nach dem Verhältnis von Macht und Recht stellte.

1976 war Ferencz an der Gründung der National Peace Academy Campaign beteiligt, einer Graswurzelkampagne, die als Gegenstück zu den bereits mehrfach existierenden Militärakademien ein staatlich finanziertes Friedensforschungsinstitut forderte. Schließlich sah sich US-Präsident Ronald Reagan widerwillig zu einem taktischen Zugeständnis an die auch in den Vereinigten Staaten erstarkte Friedensbewegung gezwungen: 1984 genehmigte er die Etablierung des United States Institute of Peace (USIP), das weltweit gewaltsame Konflikte erforschen und verhindern sollte. ${ }^{218}$ Als im folgenden Jahr ein elfköpfiger Vorstand des mit einem millionenschweren Etat ausgestatteten Instituts durch Reagan ernannt werden sollte, betrieb Ferencz Lobbyarbeit in eigener Sache und ermunterte einige einflussreiche Persönlichkeiten dazu, sich für seine Nominierung einzusetzen - dies blieb jedoch erfolglos. ${ }^{219}$ Nach jahrelanger Verzögerung nominierte Präsident Reagan stattdessen lediglich ausgewiesene außenpolitische Falken, Vertreter eines scharfen außenpolitischen Realismus, für die Leitungspositionen dieser von ihm wenig geliebten Einrichtung, in deren Aufsichtsrat satzungsmäßig ohnehin der Verteidigungsminister, der Außenminister und der Präsident der National Defense University saßen. ${ }^{20}$ So beschloss Ferencz nun, sein eigenes Friedensinstitut zu gründen. Doch blieb das 1987 etablierte Pace Peace Center anders als das großzügig finanzierte USIP eine von ihm allein betriebene Briefkastenfirma ohne wesentliche Mittel, die an der Pace University nicht einmal über einen eigenen Schreibtisch verfügte. ${ }^{221}$

All diese Aktivitäten waren von einer ausgiebigen Publikationstätigkeit begleitet. ${ }^{222}$ Aus dieser lässt sich erkennen, dass Ferencz im Grunde von einer erneuerten liberalen Pax Americana träumte. Voraussetzung dafür sei

217 Siehe Dokumente 173, 179-180, 186-187, 190 und 223.

218 Siehe Dokument 191. Siehe dazu auch Michael D. English, The United States Institute of Peace. A Critical History, Boulder, Colo., 2018, vor allem 133-146.

219 Siehe etwa Dokument 191.

220 English, The United States Institute of Peace, 144.

221 Siehe hier vor allem Dokumente 220 und 228.

222 Siehe Dokumente 173 und 177-181. 
allerdings die Rückbesinnung der Vereinigten Staaten auf die Nürnberger Prinzipien, die sodann im globalen Maßstab universalisiert werden müssten: "In short, in my view, it is not so much U.S. policy toward the UN that needs reassessment as U.S. policy itself. Once that is clarified, every means, bilateral, multilateral, UN and other agencies should become the instrumentality for regaining world leadership and acceptance of an articulated and reasonable world-order policy. ${ }^{223}$ Doch vor allem in den 1980er Jahren wurde er von der amerikanischen Außenpolitik in dieser Hinsicht zunehmend enttäuscht. So stützte sich seine Hoffnung, wonach sich der Sicherheitsrat der Vereinten Nationen doch noch zu einer nicht mehr länger vom Veto der Großmächte abhängigen friedenssichernden Institution wandeln könnte, am Ende des Jahrzehnts weniger auf US-Präsident Reagan als auf den Generalsekretär der KPdSU Michail Gorbatschow. Letzterer hatte im September 1987 in der Prawda unter dem Titel Realität und Garantien für eine sichere Welt Vorschläge für ein umfassendes System der internationalen Sicherheit veröffentlicht. ${ }^{24}$ Ferencz beklagte, dass diese Anregungen von der amerikanischen Presse weitgehend ignoriert und von der US-Regierung mit Skepsis und Missachtung bedacht worden seien. Zugleich appellierte er an die internationale Verantwortung der Vereinigten Staaten: »We cannot be a world leader simply by saying no. Our negativism was not consistent with our best traditions. $\ll^{225}$

Seit den 1980er Jahren bemühte sich Ferencz verstärkt darum, seine Vorstellungen zum Weltfrieden einem größeren Publikum nahezubringen. So publizierte er nicht nur umfangreiche völkerrechtliche Monografien und Aufsätze, sondern auch kurze, populär gehaltene Zusammenfassungen seiner Ideen, die er in Auflagen von mehreren hunderttausend Exemplaren an friedensbewegte Laien brachte. Hinzu kamen zahlreiche Vorträge, bei denen er sich normalerweise nicht an ein vorbereites Manuskript zu halten pflegte: "My usual procedure is to mix with the audience before the lecture and then to address the topics suggested. « $^{226}$ Den Höhepunkt seiner Popularisierungsbemühungen bildete sein in Zusammenarbeit mit dem Bestsellerautor Ken Keyes jr. 1988 veröffentlichtes Buch PlanetHood. The Key to Your Survival

223 Dokument 187.

224 Deutsche Übersetzung: Michail Gorbatschow, Realität und Garantien für eine sichere Welt - Vorschläge für ein effizienteres VN-System, in: Günther Doeker/Helmut Volger (Hg.), Die Wiederentdeckung der Vereinten Nationen. Kooperative Weltpolitik und Friedensvölkerrecht, Opladen 1990, 217-229.

225 Dokument 210. Siehe dazu auch Dokument 207.

226 Dokument 221. 
and Prosperity. ${ }^{227}$ In seiner umfangreichen Korrespondenz entwickelte er phantasievolle Vertriebswege zur Verbreitung seiner Medienprodukte. Einem Professor für Internationales Recht an der Universität von Iowa empfahl er: "You can use my video-tape to keep your class occupied when you don't feel like teaching. You can get as many free copies of PLANETHOOD as you can use effectively. Just dial 1-800 HATE WAR (The World Federalists in Washington DC) and they will send you cases of 100 for only the postage (about $\$ 10$ per case.) It's cheaper than a Xmas card, so give it way freely to all of your students, friends, relatives and enemies. BLESSED BE THE PEACEMAKERS!! ${ }^{228}$

Seit den 1990er Jahren wandte sich Ferencz auch an mehrere amerikanische Präsidenten. Ob letztere seine Briefe tatsächlich zur Kenntnis nahmen, ist ungewiss, Antworten sind jedenfalls nicht überliefert. Am 16. Januar 1991 - einen Tag bevor das von den Vereinigten Staaten geführte Bündnis die Operation Desert Storm gegen den Irak startete, der im Vorjahr Kuwait annektiert hatte - erteilte er Präsident George Bush außenpolitische Ratschläge. Diese zielten insbesondere darauf, nach der Zerstörung der Offensivkapazität des Irak keine Bodeninvasion vorzunehmen, die weitere Regelung des Konflikts und die Bestrafung Saddam Husseins unter die Obhut der Vereinten Nationen zu stellen und vor allem jegliche Antagonisierung der arabischen Welt zu vermeiden. ${ }^{22}$ Am 21. Januar 1993 appellierte er an George Bushs Nachfolger Bill Clinton, von dessen neuer Regierung er erhoffte, dass sie in den jugoslawischen Bürgerkrieg intervenieren würde: „Continuing mass rapes, >ethnic cleansing ‘ and other crimes against humanity must be stopped without delay." Indem er sich auf die Autorität als ehemaliger Nürnberger Ankläger berief, der bei der Befreiung vieler Konzentrationslager dabei gewesen und vom Ruf »Never Again!« angetrieben sei, mahnte er abermals, die Herrschaft der Gewalt durch die Herrschaft des Rechts zu ersetzen. ${ }^{230}$

Auch die Wirkung dieses Briefs an Präsident Clinton lässt sich schwer abschätzen. Doch unabhängig davon öffnete die Abneigung der amerikanischen Regierung, sich in die Balkankonflikte militärisch hineinziehen zu lassen, ein Gelegenheitsfenster, um das Konzept internationaler Strafjustiz zumindest begrenzt umzusetzen. Im Mai 1993 beschloss der Sicherheitsrat der Vereinten Nationen, einen Internationalen Strafgerichtshof für das ehemalige Jugoslawien (ICTY) einzusetzen, der die seit 1991 auf dem Gebiet des vormaligen sozialistischen Staats und insbesondere in Bosnien und Herzegowina began-

227 Ferencz/Keyes, PlanetHood.

228 Dokument 225.

229 Siehe Dokument 226.

230 Dokument 230. 
genen schweren Verstöße gegen das humanitäre Völkerrecht ahnden sollte. ${ }^{231}$ Wenig später fragte das Sekretariat der Vereinten Nationen bei Ferencz an, ob er bereit sei, am ICTY mitzuwirken. Dieser wollte gern als einer der elf Richter zur Verfügung stehen und bat daher eine Anzahl Freunde, die erforderliche Nominierung seiner Person durch das State Department zu unterstützen. ${ }^{232}$ Dazu kam es allerdings nicht, denn es lag nicht im außenpolitischen Interesse der Vereinigten Staaten und ebenso wenig Großbritanniens, Vertreter des liberalen Legalismus wie Ferencz oder Bassiouni in diese Positionen beim ICTY zu bringen. Der durch diese Gruppe vertretene strafrechtliche Ansatz zum Umgang mit militärischer Gewalt drohte in ihren Augen die diplomatischen Spielräume der Konfliktlösung zu verengen. ${ }^{233}$

Mit den vergeblichen Bemühungen von Ferencz, als Richter an den ICTY berufen zu werden, bricht die Überlieferung in der Benjamin B. Ferencz Collection ab - zu einem Zeitpunkt, als das Projekt des liberalen Legalismus einerseits erste Erfolge erzielte, die durch den von Ferencz personifizierten Rückbezug auf die Tradition von Nürnberg symbolisch legitimiert wurden. Andererseits deuteten sich bereits in der damaligen Situation die Ambivalenzen und Grenzen eines Ansatzes an, der das internationale Strafrecht als zentrales Mittel der Friedenssicherung zu privilegieren suchte. Insofern dient die in diesem Abschnitt getroffene Dokumentenauswahl auch nicht der Bestätigung einer erfundenen Traditionslinie von Nürnberg nach Den Haag, sondern vor allem einer reflektierten Bestandsaufnahme zum juristischen Feld der internationalen Strafjustiz. ${ }^{234}$

\section{Editorische Prinzipien}

Eine Edition ist gehalten, die Anforderungen sowohl authentischer Textüberlieferung als auch der Leserfreundlichkeit zu berücksichtigen. Für die gesamte Reihe Archiv jüdischer Geschichte und Kultur, in der dieser Band erscheint, wurde für die Wiedergabe der Quellentexte eine hohe Originaltreue fest-

231 United Nations Security Council, S/RES/827, International Criminal Tribunal for the Former Yugoslavia, New York, 25. Mai 1993. Siehe dazu auch Hagan, Justice in the Balkans, vor allem 36.

232 Siehe Dokument 232.

233 Hagan, Justice in the Balkans, $38 \mathrm{f}$. Vgl. dazu auch Mégret, International Criminal Justice; Bass, Stay the Hand of Vengeance, $214 \mathrm{f}$.

234 Siehe dazu vor allem die kritischen Bemerkungen bei Mégret, International Criminal Justice, Abs. 55. 
gelegt. Spezifische Eigenschaften der Texte (etwa Streichungen, nachträgliche Ergänzungen, Korrekturen) sowie Eingriffe der Herausgeber wurden mit editorischen Zeichen hervorgehoben, die der Übersicht zu Beginn des Quellenteils entnommen werden können. Auslassungen wurden mit [...] angezeigt und in Fußnoten erläutert. Typografische und grammatische Fehler wurden belassen und mit [sic] gekennzeichnet. Lediglich offensichtliche Schreib- und Tippfehler, eindeutige Fehler der Groß- und Kleinschreibung und der Interpunktion sowie variierende Schreibweisen von Namen wurden stillschweigend korrigiert. Solche Eingriffe in die originale Textgestalt geschahen jedoch äußerst zurückhaltend. Zweifelhafte Lesarten der Dokumente wurden durch editorische Zeichen angezeigt. Die genannten Personen werden bei der Erstnennung in einer Fußnote eingeführt. Hingegen wurde bei Akteuren, die für den Verständniszusammenhang irrelevant sind oder $\mathrm{zu}$ denen keine gesicherten Angaben zu ermitteln waren, auf Annotation verzichtet. Vereinzelt wurden zudem in den Dokumenten erwähnte Personen anonymisiert, vor allem wenn es sich um individuelle Antragssteller in Entschädigungsverfahren handelte. Im Personenregister im Anhang des Bands sind sämtliche namentlich erwähnten Personen mit den jeweiligen Seitenangaben verzeichnet. Abkürzungen und Akronyme wurden in der Regel bei ihrer erstmaligen Nennung im Fußnotenapparat aufgelöst. Häufig verwendete Abkürzungen wichtiger Institutionen wurden zusätzlich in eine Übersicht zu Beginn des Bands aufgenommen.

\section{Danksagung}

Die Auswahl und Transkription der Dokumente beschäftigte neben den drei Herausgebern über viele Jahre weitere Mitarbeiterinnen und Mitarbeiter an der Professur für Zeitgeschichte der Ruhr-Universität Bochum. Wir danken insbesondere Marlene Friedrich, Tobias Kreiten, Thorben Pieper, Christina Schröder und Felix Vonstein für ihre wertvolle Unterstützung bei der mühsamen Durchsicht und Transkription der auf Mikrofiche vorliegenden und oft schwer lesbaren Dokumente. Schließlich sind wir auch Dan Diner, dem Herausgeber der Reihe Archiv jüdischer Geschichte und Kultur und Leiter des Projekts »Europäische Traditionen - Enzyklopädie jüdischer Kulturen« der Sächsischen Akademie der Wissenschaften, sowie seinen Mitarbeiterinnen und Mitarbeitern sehr verpflichtet. Unser Dank gilt zuerst Stefan Hofmann, der diesen Band über viele Jahre hinweg intensiv begleitet hat. Sodann gilt er dem Leiter der Arbeitsstelle Markus Kirchhoff; er hat den vorliegenden Band in vielerlei Hinsicht unterstützt und uns geduldig zum Abschluss unserer 
Arbeit navigiert. Weiterhin danken wir Marcel Müller, Momme Schwarz und Georg Wehse, die einzelne Arbeitsschritte der Textredaktion übernommen, sowie Cyra Sommer und Tabea Schneider, die das Register erstellt und die Redaktion unterstützt haben. Das Leipziger Team hat uns nicht nur sehr geholfen, die editorische Gestaltung in den Griff zu bekommen, sondern durch stetige Nachfragen, Diskussionen und Vorschläge unseren Text wesentlich besser gemacht. Für die verbliebenen Fehler und Irrtümer stehen die Herausgeber selbst ein. 


\section{Liste der Dokumente}

\section{Kapitel 1: Tagebuch und Privatkorrespondenz im Zweiten Weltkrieg}

1 Kriegstagebuch von Benjamin B. Ferencz, Teil 1; Diverse Orte, 8. September 1943-11. Mai 1944

2 Kriegstagebuch von Benjamin B. Ferencz, Teil 2; Diverse Orte, 13. Mai 1944-15. August 1945

3 Brief von Benjamin B. Ferencz an Gertrude Fried; England, 20. April 1944

\section{Kapitel 2: Der ehemalige Nürnberger Ankläger: Rückblicke und} Interventionen

4 Leserbrief von Benjamin B. Ferencz an The New York Times; Berlin, 26. Juli 1949

5 Brief von Benjamin B. Ferencz an Nehemiah Robinson; o. O., 31. Juli 1950

6 Brief von Benjamin B. Ferencz an The New York Times mit Artikelentwurf; Nürnberg, 25. Februar 1951

7 Brief von Benjamin B. Ferencz an Telford Taylor; o. O., 17. Dezember 1951

8 Brief von Benjamin B. Ferencz an Pinchas Rosen; New York, 25. Mai 1960

9 Brief von Pinchas Rosen an Benjamin B. Ferencz; Jerusalem, 8. Juni 1960

10 Leserbrief von Benjamin B. Ferencz an The New York Times; New York, 29. August 1965

11 Leserbrief von Benjamin B. Ferencz an The New York Times. International Edition; Paris, 30./31. Juli 1966

12 Brief von Benjamin B. Ferencz an Michael G. Shanahan; New York, 7. Juli 1972

13 Brief von Benjamin B. Ferencz an John J. McCloy; New Rochelle, N. Y., 10. August 1983

14 Transkript von Gesprächen zwischen Benjamin B. Ferencz und John J. McCloy; New York, 24. April 1984 


\section{Kapitel 3: Die Organisation der Restitution: JRSO, URO, JCC}

15 Brief von Benjamin B. Ferencz an Andy Logan; o. O., 18. Mai 1951

16 Brief von Benjamin B. Ferencz an Telford Taylor; o. O., 28. Juni 1953

17 Brief von Benjamin B. Ferencz an Saul Kagan; o. O., 3. Juli 1955

18 Brief von Benjamin B. Ferencz an Freunde; New York, 16. April 1956

19 Brief von Benjamin B. Ferencz an Martin Sobotker; o. O., 22. Januar, 1957

20 Brief von Benjamin B. Ferencz an Eugene Kaufmann; o. O., 8. Januar 1958

21 Brief von Benjamin B. Ferencz an »Meckie«; New Rochelle, N. Y., 8. Februar 1975

22 Brief von Benjamin B. Ferencz an Eran Laor; o. O., 13. August 1983

\section{Kapitel 4: Entschädigung jüdischer Zwangsarbeiter durch die deutsche Industrie}

23 Brief von Benjamin B. Ferencz an Hans Reichmann; o. O., 25. Februar 1954

24 Brief von Benjamin B. Ferencz an Saul Kagan; Frankfurt am Main, 15. November 1954

25 Brief von Benjamin B. Ferencz an Henry Ormond; Frankfurt am Main, 25. Januar 1956

26 Brief von Benjamin B. Ferencz an Kent R.; o. O., 16. November 1956

27 Briefvon Benjamin B. Ferenczan Hendrik van Dam; o. O., 4. Dezember 1957

28 Brief von Benjamin B. Ferencz an die leitenden Funktionäre der Claims Conference; New York, 4. Juni 1958

29 Brief von Benjamin B. Ferencz an Saul Kagan; New York, 9. Juni 1958

30 Brief von Benjamin B. Ferencz an Drexel A. Sprecher; o. O., 20. Juni 1958

31 Brief von Benjamin B. Ferencz an Jacob Blaustein; o. O., 12. September 1958

32 Brief von Benjamin B. Ferencz an Ernst Katzenstein; New York, 22. März 1960

33 Brief von Benjamin B. Ferencz an Alfred L. Goldberger; o. O., 22. März 1960

34 Brief von Benjamin B. Ferencz an Mary S.; o. O., 25. April 1960

35 Brief von Benjamin B. Ferencz an Ernst Katzenstein; New York, 29. April 1960

36 Brief von Benjamin B. Ferencz an Ernst Katzenstein; o. O., 11. Mai 1960

37 Brief von Benjamin B. Ferencz an Ernst Katzenstein; New York, 11. Mai 1960

38 Brief von Benjamin B. Ferencz an Manfred Saalheimer; o. O., 6. Juni 1960

39 Brief von Benjamin B. Ferencz an Ernst Katzenstein; o. O., 17. November 1960 
40 Brief von Benjamin B. Ferencz an Ernst Katzenstein; o. O., 11. Januar 1961

41 Brief von Benjamin B. Ferencz an Ernst Katzenstein; o. O., 24. August 1961

42 Brief von Benjamin B. Ferencz an Ernst Katzenstein; o. O., 30. Juli 1962

43 Memorandum von Benjamin B. Ferencz; o. O., 7. November 1962

44 Brief von Benjamin B. Ferencz an Ernst Katzenstein; o. O., 10. Januar 1963

45 Brief von Benjamin B. Ferencz an Jacob Blaustein; o. O., 13. September 1963

46 Brief von Benjamin B. Ferencz an Ernst Katzenstein; o. O., 25. Oktober 1963

47 Brief von Benjamin B. Ferencz an Ernst Katzenstein; o. O., 6. November 1963

48 Brief von Benjamin B. Ferencz an Ernst Katzenstein; o. O., 30. Januar 1964

49 Brief von Benjamin B. Ferencz an Ernst Katzenstein; o. O., 28. April 1964

50 Brief von Benjamin B. Ferencz an Ernst Katzenstein; o. O., 6. Mai 1964

51 Brief von Benjamin B. Ferencz an Ernst Katzenstein; o. O., 15. Mai 1964

52 Brief von Benjamin B. Ferencz an Ernst Katzenstein; o. O., 16. Juni 1964

53 Brief von Benjamin B. Ferencz an Ernst Katzenstein; o. O., 18. Dezember 1964

54 Brief von Benjamin B. Ferencz an Hans Seidenberg; o. O., 21. Januar 1965

55 Memorandum von Benjamin B. Ferencz; o. O., 1. Februar 1965

56 Brief von Benjamin B. Ferencz an Ernst Katzenstein; o. O., 2. Februar 1965

57 Brief von Benjamin B. Ferencz an Ernst Katzenstein; o. O., 15. März 1965

58 Brief von Benjamin B. Ferencz an Ernst Katzenstein; o. O., 8. September 1965

59 Brief von Benjamin B. Ferencz an Saul Kagan; o. O., 22. November 1965

60 Brief von Benjamin B. Ferencz an Ernst Katzenstein; New York, 7. Februar 1966

61 Brief von Benjamin B. Ferencz an Philip M. Klutznick; o. O., 23. Februar 1966

62 Brief von Benjamin B. Ferencz an die Redaktion Der Spiegel; New York, 8. März 1966

63 Brief von Benjamin B. Ferencz an Ernst Katzenstein; o. O., 15. März 1966

64 Brief von Benjamin B. Ferencz an Ernst Katzenstein; o. O., 29. März 1966

65 Brief von Benjamin B. Ferencz an Ernst Katzenstein; o. O., 4. April 1966

66 Brief von Benjamin B. Ferencz an Ernst Katzenstein; o. O., 27. Mai 1966

67 Brief von Benjamin B. Ferencz an Felix L.; o. O., 11. Juli 1966

68 Brief von Benjamin B. Ferencz an Ernst Katzenstein; o. O., 13. Februar 1967

69 Brief von Benjamin B. Ferencz an Kurt Wehle; o. O., 17. Juli 1967

70 Brief von Benjamin B. Ferencz an Ernst Katzenstein; o. O., 14. August 1967

71 Brief von Benjamin B. Ferencz an Saul Kagan; o. O., 17. September 1969

72 Brief von Benjamin B. Ferencz an Tuviah Friedmann; o. O., 11. November 1970

73 Brief von Benjamin B. Ferencz an Hans Seidenberg; o. O., 25. Januar 1971 
74 Brief von Benjamin B. Ferencz an Hans Seidenberg; o. O., 13. Februar 1976

75 Brief von Benjamin B. Ferencz an Heinz Gerling; o. O., 26. Januar 1982

76 Brief von Benjamin B. Ferencz an Ernst Katzenstein; o. O., 5. März 1986

77 Brief von Benjamin B. Ferencz an Werner Wolff; New Rochelle, N.Y., 9. Februar 1987

78 Brief von Benjamin B. Ferencz an Saul Kagan; New Rochelle, N. Y., 14. März 1988

79 Brief von Benjamin B. Ferencz an Karl Brozik; New Rochelle, N.Y., 28. Juli 1990

\section{Kapitel 5: Entschädigung für Opfer medizinischer Humanexperimente}

80 Brief von Benjamin B. Ferencz an David Apter; New York, 15. April 1957

81 Brief von Benjamin B. Ferencz an Caroline Ferriday; o. O., 30. April 1957

82 Brief von Benjamin B. Ferencz an Caroline Ferriday; o. O., 7. August 1957

83 Memorandum von Benjamin B. Ferencz; o. O., 7. April 1959

84 Brief von Benjamin B. Ferencz an Norman Cousins; o. O., 24. April 1959

85 Brief von Benjamin B. Ferencz an Caroline Ferriday; o. O., 15. Oktober 1959

86 Brief von Benjamin B. Ferencz an Norman Cousins; New York, 13. Juli 1960

87 Brief von Benjamin B. Ferencz an Norman Cousins; o. O., 18. Juli 1960

88 Brief von Benjamin B. Ferencz an Norman Cousins; o. O., 26. Januar 1961

89 Brief von Benjamin B. Ferencz an Norman Cousins; o. O., 10. April 1961

90 Brief von Benjamin B. Ferencz an Marian Dobrosielski; o. O., 1. Mai 1961

91 Brief von Benjamin B. Ferencz an Karl Heinrich Knappstein; o. O., 7. Juni 1961

92 Brief von Benjamin B. Ferencz an Norman Cousins; New York, 8. September 1961

93 Brief von Benjamin B. Ferencz an Norman Cousins; New York, 29. September 1961

94 Brief von Benjamin B. Ferencz an Caroline Ferriday; o. O., 8. Januar 1962

95 Brief von Benjamin B. Ferencz an Ernst Katzenstein; o. O., 28. März 1968

96 Brief von Benjamin B. Ferencz an Karl Baum; o. O., 5. März 1970

97 Brief von Benjamin B. Ferencz an John Mendelsohn; o. O., 13. September 1983 


\section{Kapitel 6: Restitution für B'nai B'rith in Deutschland und den Vereinigten Staaten}

98 Brief von Benjamin B. Ferencz an Maurice Bisgyer; Berlin, 25. März 1958

99 Brief von Benjamin B. Ferencz an Willy Brandt; New York, 6. Juli 1959

100 Brief von Benjamin B. Ferencz an Philip M. Klutznick; o. O., 11. Dezember 1962

101 Brief von Benjamin B. Ferencz an Jay Kaufman; o. O., 7. April 1966

102 Brief von Benjamin B. Ferencz an William A. Wexler; New York, 28. Dezember 1970

\section{Kapitel 7: Entschädigungsverhandlungen mit der DDR}

103 Brief von Benjamin B. Ferencz an Ernst Katzenstein; o. O., 2. Januar 1973

104 Brief von Benjamin B. Ferencz an Charles Kapralik; o. O., 18. Februar 1973

105 Aktennotiz von Benjamin B. Ferencz; o. O., 7. März 1973

106 Brief von Benjamin B. Ferencz an Ernst Katzenstein; o. O., 9. März 1973

107 Brief von Benjamin B. Ferencz an Siegfried Roth; o. O., 18. Juni 1973

108 Brief von Benjamin B. Ferencz an Ernst Katzenstein; New York, 10. September 1973

109 Aktennotiz von Benjamin B. Ferencz; o. O., 21. November 1973

110 Brief von Benjamin B. Ferencz an Nahum Goldmann; o. O., 4. Dezember 1973

111 Brief von Benjamin B. Ferencz an Ernst Katzenstein; o. O., 2. Februar 1974

112 Memorandum von Benjamin B. Ferencz; o. O., 18. Juni 1974

113 Memorandum von Benjamin B. Ferencz; o. O., 21. Mai 1975

114 Memorandum von Benjamin B. Ferencz; o. O., 11. Dezember 1975

115 Brief von Benjamin B. Ferencz an Ernst Katzenstein; o. O., 28. September 1976

116 Memorandum von Benjamin B. Ferencz; o. O., 3. Dezember 1976

117 Brief von Benjamin B. Ferencz an Shabtai Rosenne; o. O., 9. September 1977

118 Memorandum von Benjamin B. Ferencz; o. O., 26. Oktober 1977

119 Memorandum von Benjamin B. Ferencz; New York, 20. Oktober 1978

120 Protokoll von Benjamin B. Ferencz; o. O., 22. September 1981

121 Memorandum von Benjamin B. Ferencz; New York, 26. Januar 1982

122 Memorandum von Benjamin B. Ferencz; New York, 30. September 1983

123 Memorandum von Benjamin B. Ferencz; o. O., 3. Oktober 1983

124 Memorandum von Benjamin B. Ferencz; o. O., 23. September 1985 
125 Memorandum von Benjamin B. Ferencz; o. O., 17. Juni 1986

126 Memorandum von Benjamin B. Ferencz; o. O., 21. September 1987

127 Brief von Benjamin B. Ferencz an Gerhard Herder; New Rochelle, N. Y., 12. Dezember 1987

128 Brief von Benjamin B. Ferencz an Saul Kagan; New Rochelle, N.Y., 1. September 1988

129 Brief von Benjamin B. Ferencz an Israel Miller; New Rochelle, N.Y., 5. April 1990

130 Memorandum von Benjamin B. Ferencz; o. O., 5. Juni 1990

131 Aktennotiz von Benjamin B. Ferencz; o. O., 7. September 1990

\section{Kapitel 8: Ausbau der bundesdeutschen Entschädigung} für jüdische Opfer des Nationalsozialismus

132 Brief von Benjamin B. Ferencz an Philip Soskis; New York, 9. November 1965

133 Brief von Benjamin B. Ferencz an James P. Rice; New York, 22. April 1966

134 Brief von Benjamin B. Ferencz an Philip Soskis und James P. Rice; o. O., 24. Mai 1966

135 Brief von Benjamin B. Ferencz an Charles Kapralik; o. O., 2. März 1967

136 Brief von Benjamin B. Ferencz an Ernst Katzenstein; o. O., 27. Dezember 1967

137 Briefvon Benjamin B. Ferenczan diverse Empfänger; New York, 7. Juni 1968

138 Brief von Benjamin B. Ferencz an Samuel Haber, Philip Soskis, Gaynor I. Jacobson und Charles Kapralik; New York, 19. November 1968

139 Brief von Benjamin B. Ferencz an Ernst Katzenstein; o. O., 5. Februar 1970

140 Brief von Benjamin B. Ferencz an Daniel Lack; o. O., 22. Februar 1971

141 Brief von Benjamin B. Ferencz an Daniel Lack; o. O., 6. Dezember 1971

142 Memorandum von Benjamin B. Ferencz; o. O., Oktober/November 1972

143 Memorandum von Benjamin B. Ferencz an Samuel L. Haber und Philip Soskis; New York, 12. November 1973

144 Brief von Benjamin B. Ferencz an Ernst Katzenstein; New Rochelle, N. Y., 7. März 1974

145 Brief von Benjamin B. Ferencz an Samuel L. Haber und Philip Soskis; New York, 19. Juli 1974

146 Brief von Benjamin B. Ferencz an Ernst Katzenstein; New York, 6. November 1974

147 Brief von Benjamin B. Ferencz an Ernst Katzenstein; New Rochelle, N. Y., 27. Februar 1975 
148 Brief von Benjamin B. Ferencz an Daniel Lack; o. O., 9. Dezember 1979

149 Brief von Benjamin B. Ferencz an Ernst Katzenstein; o. O., 13. Januar 1970

150 Brief von Benjamin B. Ferencz an Ernst Katzenstein; o. O., 1. Februar 1971

151 Brief von Benjamin B. Ferencz an Ernst Katzenstein; New York, 5. Februar 1974

152 Memorandum von Benjamin B. Ferencz; o. O., 3. Oktober 1983

153 Brief von Benjamin B. Ferencz an Saul Kagan; New Rochelle, N.Y., 5. Juni 1984

154 Brief von Benjamin B. Ferencz an Ulrich Herbert; New Rochelle, N.Y., 18. Oktober 1987

155 Aktennotiz von Benjamin B. Ferencz; o. O., 19. Mai 1988

156 Memorandum von Benjamin B. Ferencz an Israel Miller; New Rochelle, N. Y., 8. Juni 1988

157 Aktennotiz von Benjamin B. Ferencz; o. O., 28. Juni und 1. Juli 1988

158 Brief von Benjamin B. Ferencz an Israel Miller; New Rochelle, N.Y., 1. Juli 1988

159 Brief von Benjamin B. Ferencz an Israel Miller; New Rochelle, N.Y., 24. August 1988

160 Brief von Benjamin B. Ferencz an Saul Kagan; New Rochelle, N.Y., 14. April 1990

161 Brief von Benjamin B. Ferencz an Saul Kagan; New Rochelle, N. Y., 4. Februar 1991

162 Brief von Benjamin B. Ferencz an Werner Wolff; o. O., 4. Januar 1993

\section{Kapitel 9: Weltfrieden und internationale Strafjustiz}

163 Brief von Benjamin B. Ferencz an The Foundation for the Establishment of an International Criminal Court; o. O., 18. Juni 1970

164 Brief von Benjamin B. Ferencz an Sheila M. Woetzel; o. O., 1. Februar 1971

165 Brief von Benjamin B. Ferencz an Harold E. Hughes; o. O., 5. April 1971

166 Leserbrief von Benjamin B. Ferencz an The New York Times; New York, 18. Juni 1971

167 Memorandum von Benjamin B. Ferencz an Andrew F. Loomis, Bruce Rabb, Don Harkleroad und Hope Eastman; o. O., 11. August 1971

168 Brief von Benjamin B. Ferencz an Ved P. Nanda; o. O., 22. September 1971

169 Brief von Benjamin B. Ferencz an Hope Eastman; o. O., 22. November 1971

170 Brief von Benjamin B. Ferencz an Edward M. Kennedy; o. O., 1. Mai 1972

171 Leserbrief von Benjamin B. Ferencz an World Magazine; o. O., 13. September 1972 
172 Brief von Benjamin B. Ferencz an das Verteidigungsministerium der Vereinigten Staaten von Amerika; o. O., 1. April 1974

173 Briefvon Benjamin B. Ferencz an Charles S. Rhyne; New York, 3. März 1975

174 Brief von Benjamin B. Ferencz an Amelito R. Mutuc; o. O., 28. Januar 1976

175 Brief von Benjamin B. Ferencz an die argentinische Botschaft in Washington; New York, 23. Dezember 1976

176 Brief von Benjamin B. Ferencz an Hans-Heinrich Jescheck; o. O., 29. Mai 1978

177 Brief von Benjamin B. Ferencz an Robert Sand; o. O., 2. Juni 1978

178 Brief von Benjamin B. Ferencz an M. Cherif Bassiouni; o. O., 12. September 1978

179 Brief von Benjamin B. Ferencz an M. Cherif Bassiouni; o. O., 1. Oktober 1978

180 Brief von Benjamin B. Ferencz an M. Cherif Bassiouni; o. O., 17. November 1978

181 Brief von Benjamin B. Ferencz an Gerhardt Grebing; o. O., 9. Oktober 1979

182 Leserbrief von Benjamin B. Ferencz an The New York Times; New York, 21. Dezember 1979

183 Brief von Benjamin B. Ferencz an Ernst Katzenstein; o. O., 1. Februar 1980

184 Brief von Benjamin B. Ferencz an Seymour Rubin; o. O., 23. Februar 1980

185 Brief von Benjamin B. Ferencz an Patricia M. Mische; o. O., 10. März 1980

186 Brief von Benjamin B. Ferencz an Robert Rosenstock; o. O., 8. Mai 1980

187 Brief von Benjamin B. Ferencz an Sidney Liskofsky; o. O., 16. Oktober 1980

188 Brief von Benjamin B. Ferencz an Philip M. Klutznick; o. O., 6. April 1981

189 Brief von Benjamin B. Ferencz an Ved P. Nanda; o. O., 16. Dezember 1982

190 Brief von Benjamin B. Ferencz an Thomas M. Franck; New York, 28. August 1984

191 Brief von Benjamin B. Ferencz an Alfonse D’Amato; New Rochelle, N. Y., 24. Januar 1985

192 Brief von Benjamin B. Ferencz an Philip M. Klutznick; New Rochelle, N. Y., 31. Januar 1985

193 Brief von Benjamin B. Ferencz an John J. McCloy; o. O., 1. März 1985

194 Brief von Benjamin B. Ferencz an John J. McCloy; o. O., 4. April 1985

195 Brief von Benjamin B. Ferencz an Patricia M. Mische; New Rochelle, N. Y., 30. Mai 1985

196 Brief von Benjamin B. Ferencz an Soedjatmoko; New Rochelle, N.Y., 4. September 1985

197 Ankündigung einer Lehrveranstaltung von Benjamin B. Ferencz; o. O., Herbst 1985 
198 Brief von Benjamin B. Ferencz an Margaretha M. Henneberry; o. O., 22. Oktober 1985

199 Brief von Benjamin B. Ferencz an Judith Tritschler; New Rochelle, N. Y., 20. November 1985

200 Brief von Benjamin B. Ferencz an Donald F. Keys; o. O., 16. Dezember 1985

201 Brief von Benjamin B. Ferencz an Kinhide Muskakoji; New Rochelle, N. Y., 21. Januar 1986

202 Brief von Benjamin B. Ferencz an Ulrich Albrecht; o. O., 26. Februar 1986

203 Brief von Benjamin B. Ferencz an Lucille Green; o. O., 26. Mai 1986

204 Brief von Benjamin B. Ferencz an Philip M. Klutznick; New Rochelle, N. Y., 12. Dezember 1986

205 Brief von Benjamin B. Ferencz an Patricia und Gerald F. Mische; New Rochelle, N. Y., 17. Dezember 1986

206 Brief von Benjamin B. Ferencz an Rozanne L. Ridgway; New Rochelle, N. Y., 29. Juni 1987

207 Brief von Benjamin B. Ferencz an James A. R. Nafziger; New Rochelle, N. Y., 18. Januar 1988

208 Brief von Benjamin B. Ferencz an John Lawrence Hargrove; New Rochelle, N. Y., 2. April 1988

209 Brief von Benjamin B. Ferencz an Daniel J. Monaco; White Plains, N. Y., 25. April 1988

210 Leserbrief von Benjamin B. Ferencz an The New York Times; New York, 22. Mai 1988

211 Brief von Benjamin B. Ferencz an Robert Pickus; White Plains, N. Y., 22. Juni 1988

212 Brief von Benjamin B. Ferencz an Samuel W. Lewis; White Plains, N. Y., 23. Juni 1988

213 Leserbrief von Benjamin B. Ferencz an The New York Times; White Plains, N. Y., 18. Oktober 1988

214 Brief von Benjamin B. Ferencz an Daniel J. Monaco; o. O., 8. Oktober 1988

215 Brief von Benjamin B. Ferencz an Ronald J. Glossop; New Rochelle, N. Y., 27. Januar 1989

216 Brief von Benjamin B. Ferencz an Elie Wiesel; New Rochelle, N.Y., 15. April 1989

217 Brief von Benjamin B. Ferencz an Rick Alexander; New Rochelle, N. Y., 12. Mai 1989

218 Brief von Benjamin B. Ferencz an Walter F. Hoffmann; White Plains, N.Y., 18. August 1989

219 Leserbrief von Benjamin B. Ferencz an The New York Times; New Rochelle, N. Y., 27. August 1989 
220 Bericht von Benjamin B. Ferencz; o. O., 28. August 1989

221 Brief von Benjamin B. Ferencz an John E. Brooks; New Rochelle, N. Y., 22. Oktober 1989

222 Brief von Benjamin B. Ferencz an Daniel P. Moynihan; White Plains, N. Y., 17. November 1989

223 Brief von Benjamin B. Ferencz an Mirtille Romegialli mit Memorandum; New Rochelle, N. Y., 12. Mai 1990

224 Brief von Benjamin B. Ferencz an Delia Chatoor; New Rochelle, N. Y., 21. Mai 1990

225 Brief von Benjamin B. Ferencz an Burns H. Weston; New Rochelle, N. Y., 4. Dezember 1990

226 Brief von Benjamin B. Ferencz an George H.W. Bush; New Rochelle, N. Y., 16. Januar 1991

227 Brief von Benjamin B. Ferencz an Daniel P. Moynihan; New Rochelle, N. Y., 3. August 1991

228 Brief von Benjamin B. Ferencz an Blaine Sloan; New Rochelle, N.Y., 24. Januar 1992

229 Brief von Benjamin B. Ferencz an Louis Henkin; New Rochelle, N.Y., 26. September 1992

230 Brief von Benjamin B. Ferencz an Bill Clinton; New Rochelle, N.Y., 21. Januar 1993

231 Brief von Benjamin B. Ferencz an Blaine Sloan; New Rochelle, N.Y., 5. April 1993

232 Brief von Benjamin B. Ferencz an diverse Empfänger; New Rochelle, N. Y., 3. Juni 1993 


\section{Abbildungsverzeichnis}

S. 5 Benjamin B. Ferencz, Nürnberg, 1955

Abb. 1 Benjamin B. Ferencz mit seiner Schwester Pearl und seinem Vater Joseph, wahrscheinlich New York, ca. 1926

Abb. 2 Benjamin B. Ferencz in Uniform der US-Armee, o. O., zwischen Oktober 1943 und Dezember 1944

Abb. 3 Benjamin B. Ferencz mit Karl Haberstock und einer Sekretärin, Würzburg, vermutlich 1945

Abb. 4 Benjamin B. Ferencz am Telefon, vermutlich Nürnberg, ca. 1947/1948

Abb. 5 Benjamin B. Ferencz berichtet über den Einsatzgruppenprozess, vermutlich Nürnberg, September 1947

Abb. 6 Mitarbeiter der JRSO bei einem Arbeitstreffen, Nürnberg, ca. 1949

Abb. 7 Gruppenfoto der Delegationen der JCC und des Staats Israel, Wassenaar, 1952

Abb. 8 Unterzeichnung des Luxemburger Abkommens, Luxemburg, 10. September 1952

Abb. 9 Benjamin und Gertrude Ferencz mit ihren Kindern, Frankfurt a. M., 1954

Abb. 10 Konferenz des JDC, Paris, 16. bis 19. Oktober 1955

Abb. 11 Benjamin B. Ferencz und seine Familie vor ihrem Haus in New Rochelle, N. Y., 1956

Abb. 12 Konferenz zu Antisemitismus in Deutschland, Amsterdam, 26. Januar 1960

Abb. 13 Meeting der JCC, London, 20. Juni 1978

Abb. 14 Konferenz des WPLC, Berlin, 1985

Abb. 15 Benjamin Ferencz, o. O., o. D. 


\section{Abbildungen}

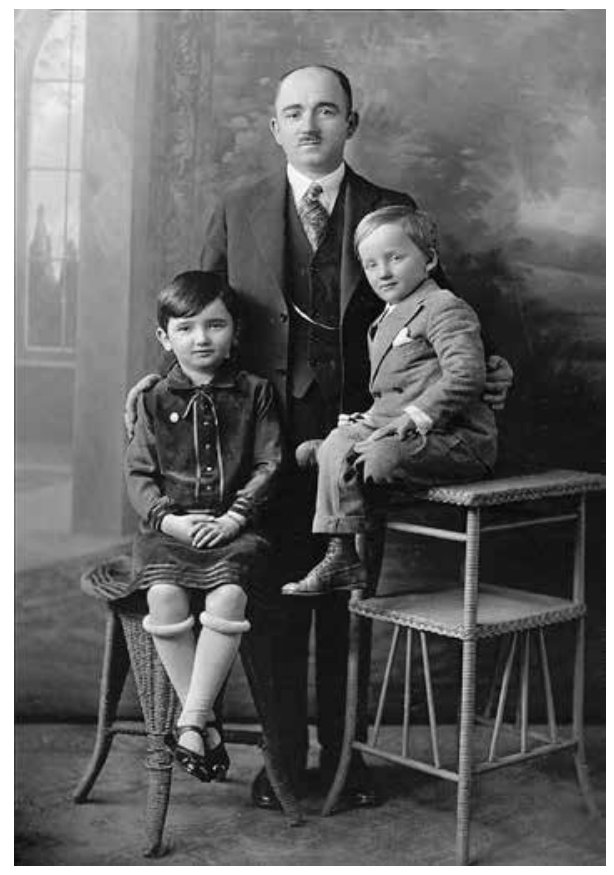

Abb. 1: Benjamin B. Ferencz (rechts) mit seiner älteren Schwester Pearl und seinem Vater Joseph, wahrscheinlich New York, ca. 1926 (USHMM RG 12.019.27)

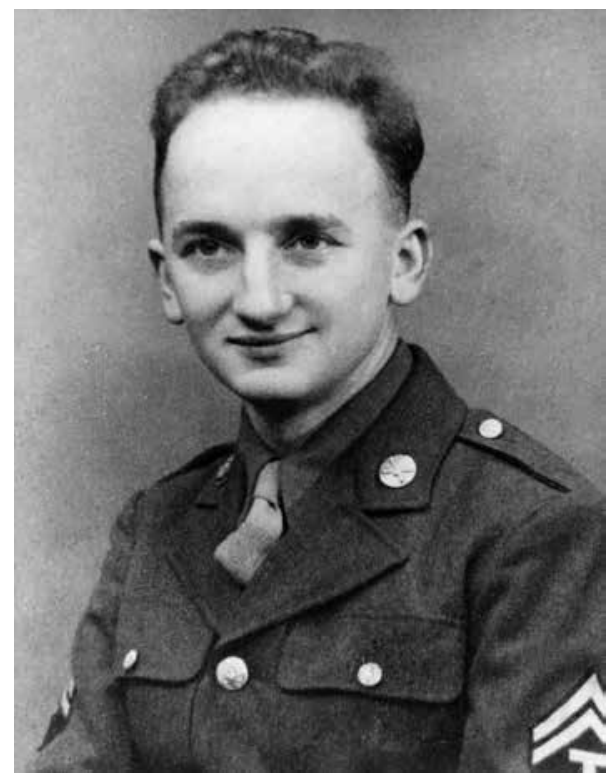

Abb. 2: Benjamin B. Ferencz in der Uniform der US-Armee im Rang eines Technician Fifth Grade (T/5), o. O., zwischen Oktober 1943 und Dezember 1944 (USHMM RG 12.019.28) 


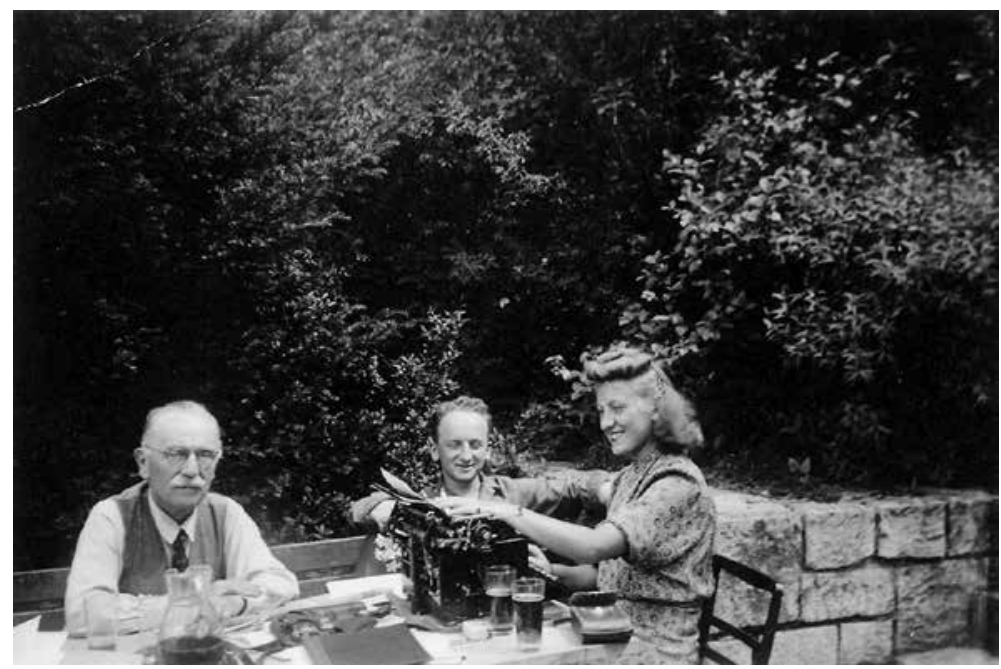

Abb. 3: Benjamin B. Ferencz (Mitte) und eine Sekretärin bei der Vernehmung von Hitlers Kunsthändler Karl Haberstock nach dessen Verhaftung durch die amerikanische Armee, Würzburg, vermutlich 1945 (USHMM RG 12.019.14)

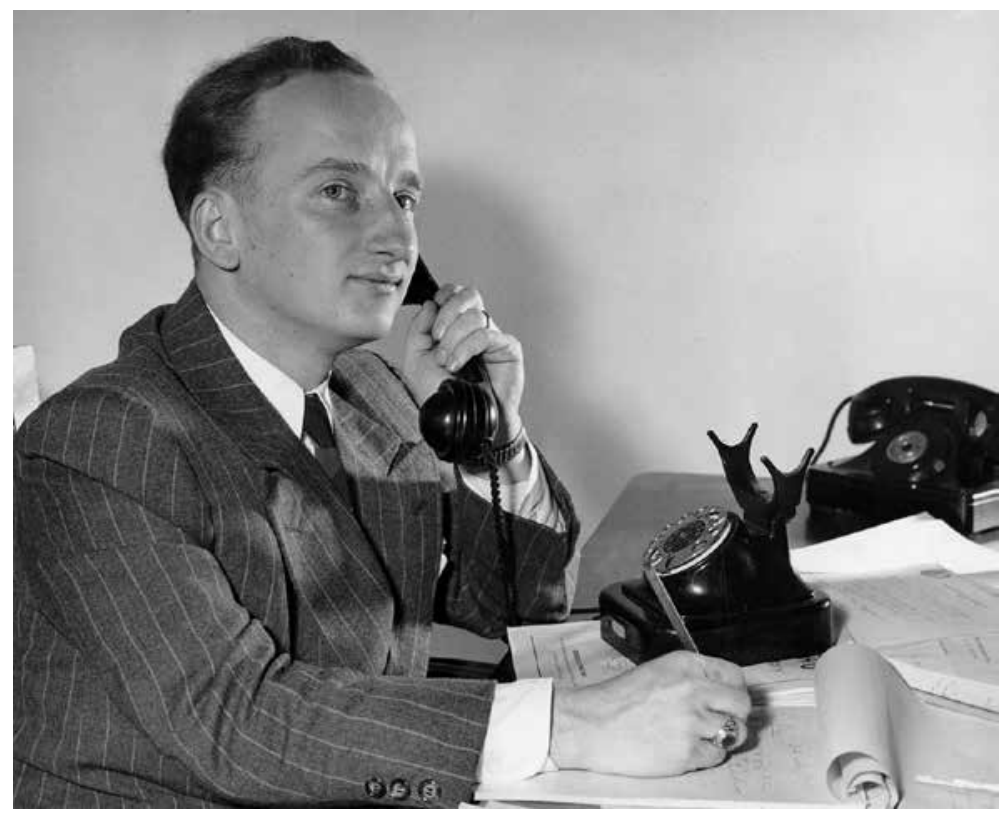

Abb. 4: Benjamin B. Ferencz am Telefon, wahrscheinlich während seiner Arbeit für das US Office of Chief of Counsel for War Crimes, vermutlich Nürnberg, ca. 1947/1948 (USHMM RG 12.019.29) 


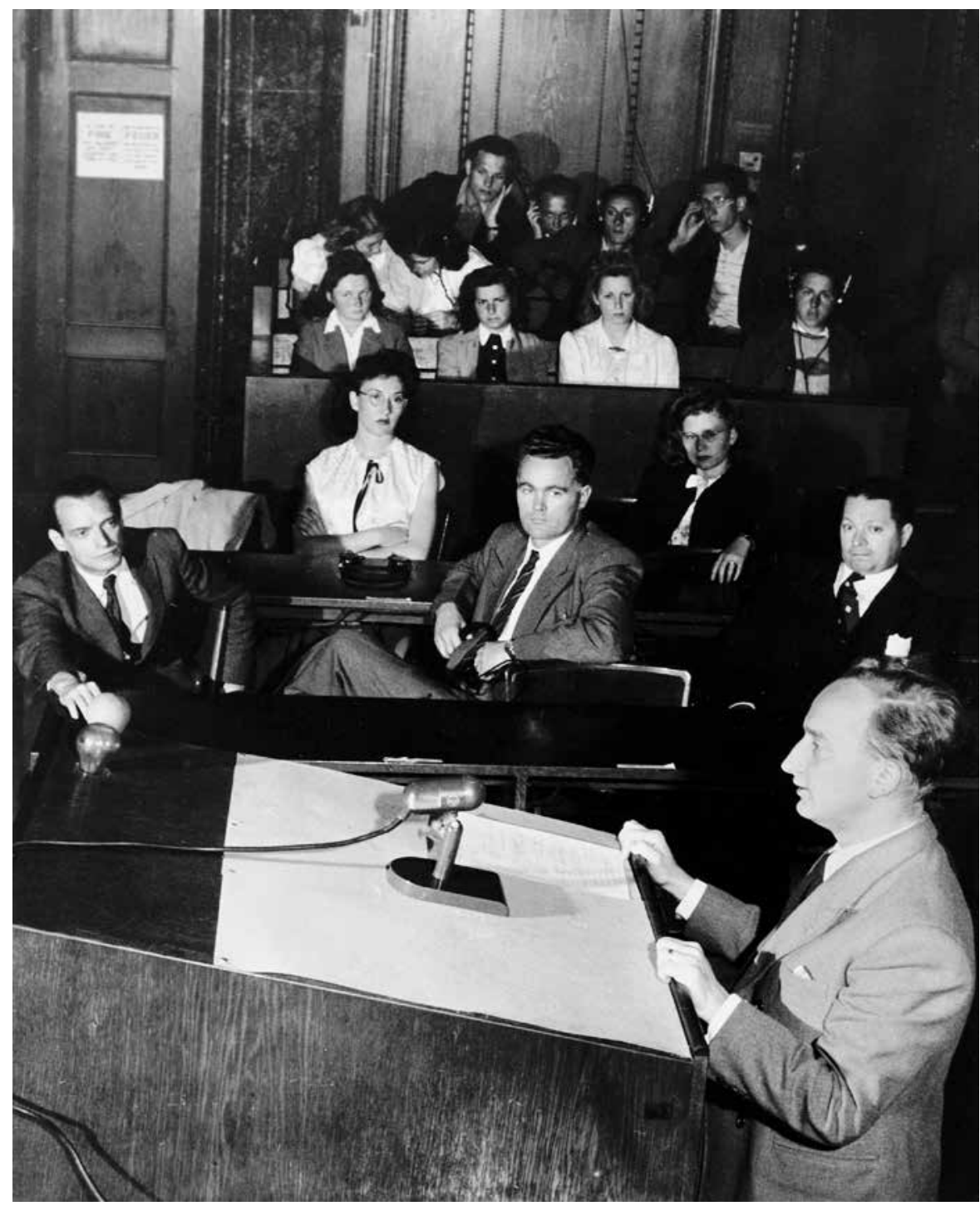

Abb. 5: Benjamin B. Ferencz stellt als Ankläger im Nürnberger Einsatzgruppenprozess seinen Fall vor, mit im Bild u. a. Drexel Sprecher (1. Reihe, Mitte) und Gertrude Ferencz (2. Reihe, rechts), Nürnberg, September 1947 (USHMM RG 12.019.15) 


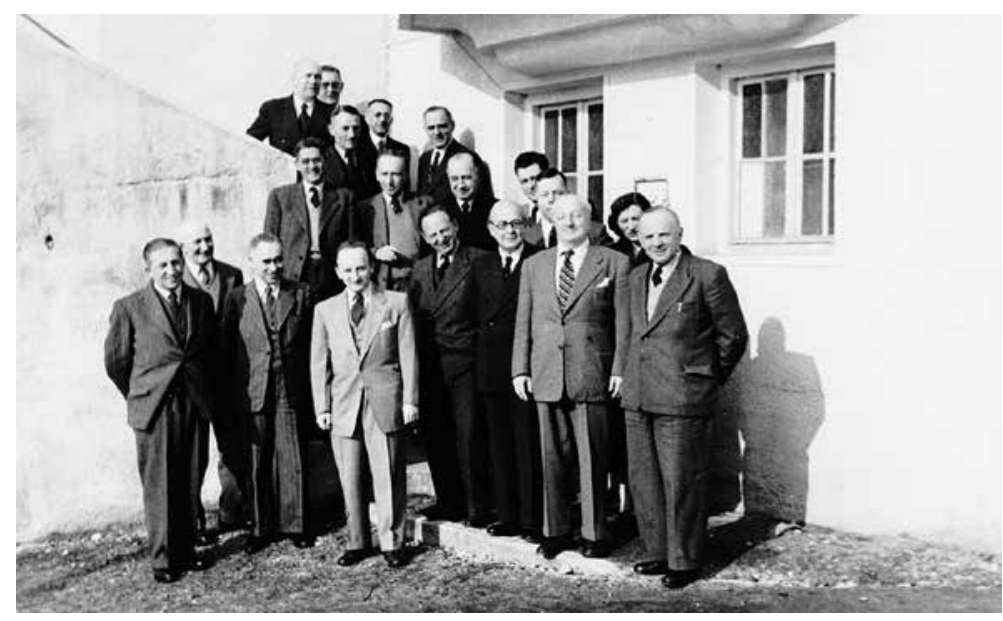

Abb. 6: Mitarbeiter der Jewish Restitution Successor Organization bei einem Arbeitstreffen, vorn in der Mitte im hellen Anzug Benjamin B. Ferencz, Nürnberg, ca. 1949 (USHMM RG 12.019.18)

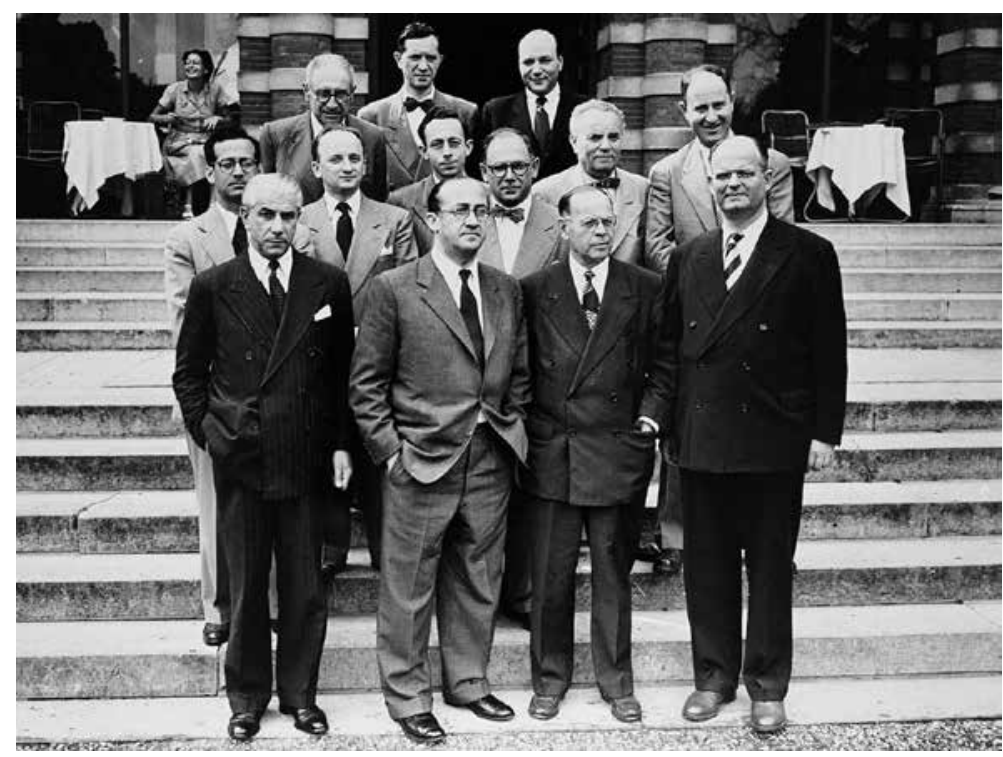

Abb. 7: Gruppenfoto der Delegationen der Jewish Claims Conference und des Staats Israel zu den Verhandlungen des Luxemburger Abkommens, (v.l.n.r.) vorn: Alex Easterman, Felix E. Shinnar, Moses A. Leavitt, Giora Josephthal; Mitte: Seymour Rubin, Benjamin B. Ferencz, Eli Nathan, Maurice Boukstein, Jacob Robinson, Gershon Avner; hinten: Fritz Goldschmidt, Nehemiah Robinson, Jerome J. Jacobson, (links im Hintergrund Helen Fink), Wassenaar, 1952 (USHMM RG 12.019.19) 


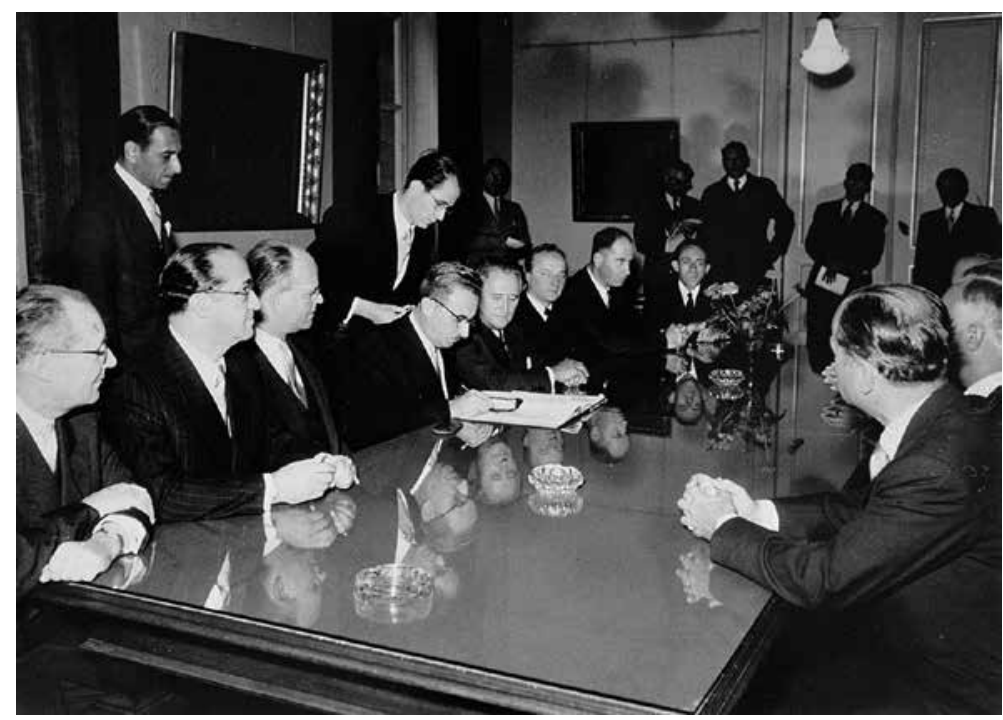

Abb. 8: Die Unterzeichnung des Luxemburger Abkommens am 10. September 1952, auf der linken Tischseite Vertreter der Delegationen Israels und der Jewish Claims Conference (ab 2. v.l.n.r.) Felix E. Shinnar, Giora Josephthal, Moshe Sharett, Nahum Goldmann, Benjamin B. Ferencz, Gershon Avner, Eli Nathan, Luxemburg (USHMM RG 12.019.19)

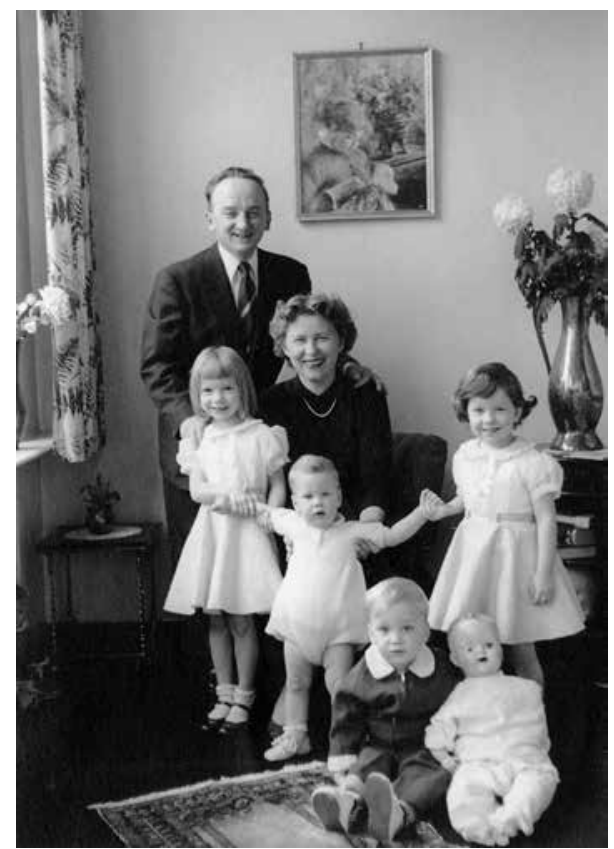

Abb. 9: Benjamin und Gertrude Ferencz mit ihren Kindern Carol (Keri), Nina, Robin und Donald, Frankfurt a.M., 1954 (USHMM RG 12.019.27) 


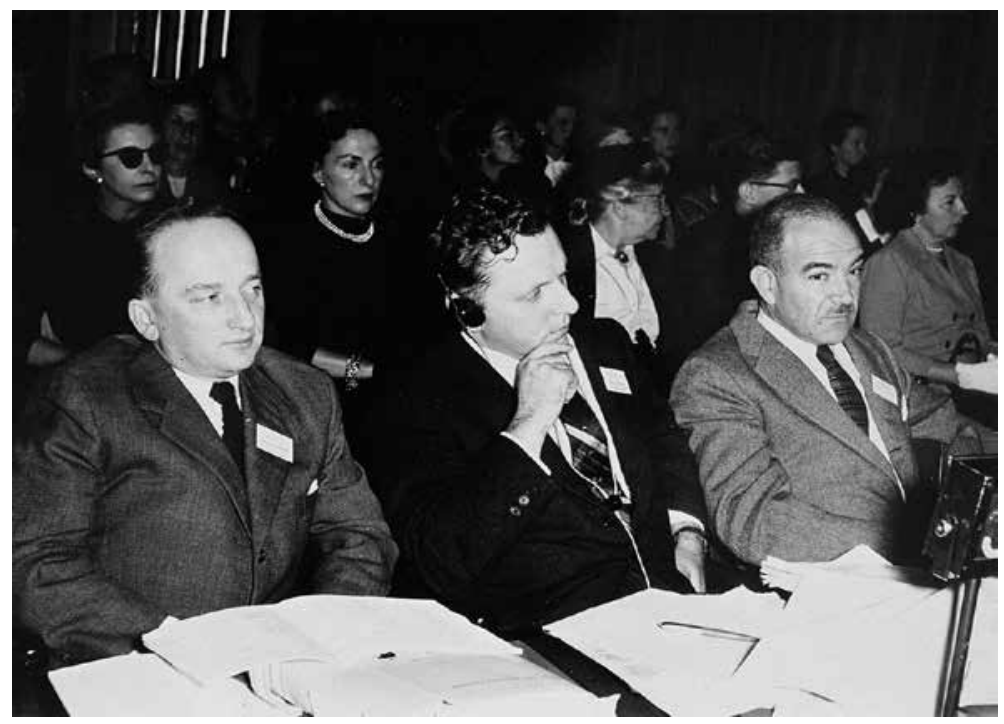

Abb. 10: Benjamin B. Ferencz mit Saul Kagan und Judah J. Shapiro bei einer Konferenz des American Joint Distribution Committee, Paris, 16. bis 19. Oktober 1955 (USHMM RG 12.019.20)

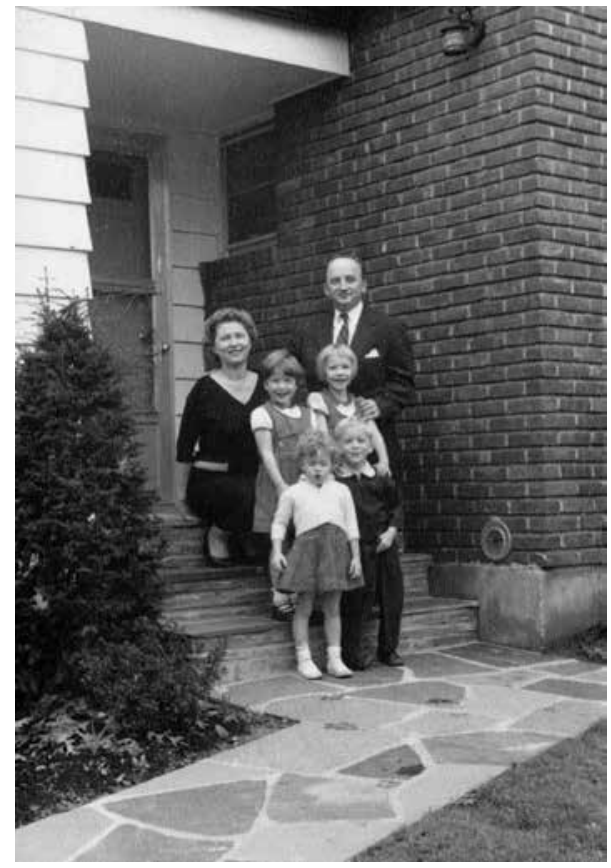

Abb. 11: Benjamin und Gertrude Ferencz mit ihren Kindern vor ihrem Haus in New Rochelle, N. Y., 1956 (USHMM RG 12.019.27) 


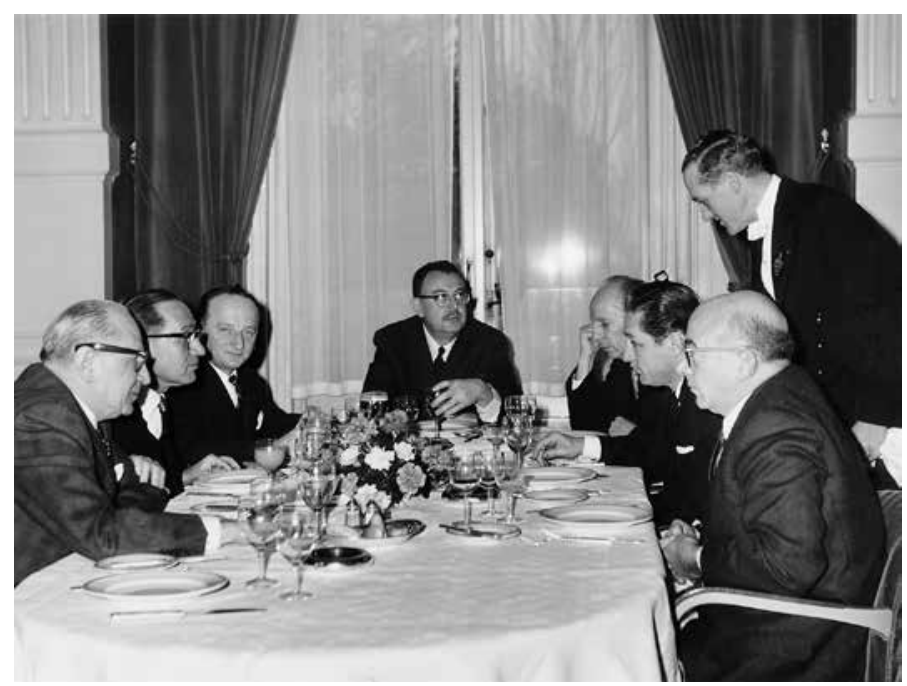

Abb. 12: Konferenz zu Antisemitismus in Deutschland, am Tisch (v.l.n. r.) Julius Klein, Philip M. Klutznick, Benjamin B. Ferencz, Saul Joftes, Maurice Bisgyer, Label A. Katz, Benjamin Epstein, Amsterdam, 26. Januar 1960 (USHMM RG 12.019.21)

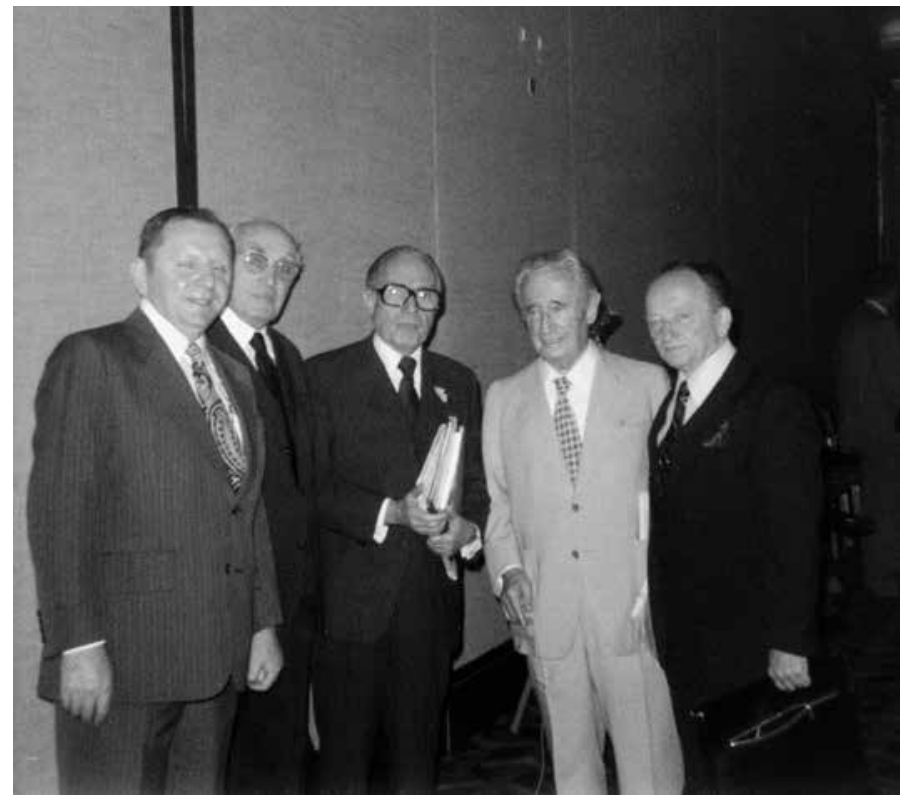

Abb. 13: Meeting der Jewish Claims Conference, (v.l.n. r.) Saul Kagan, Kurt May, Philip M. Klutznick, Nahum Goldman, Benjamin B. Ferencz, o. O., 20. Juni 1978, (USHMM RG 12.019.25) 


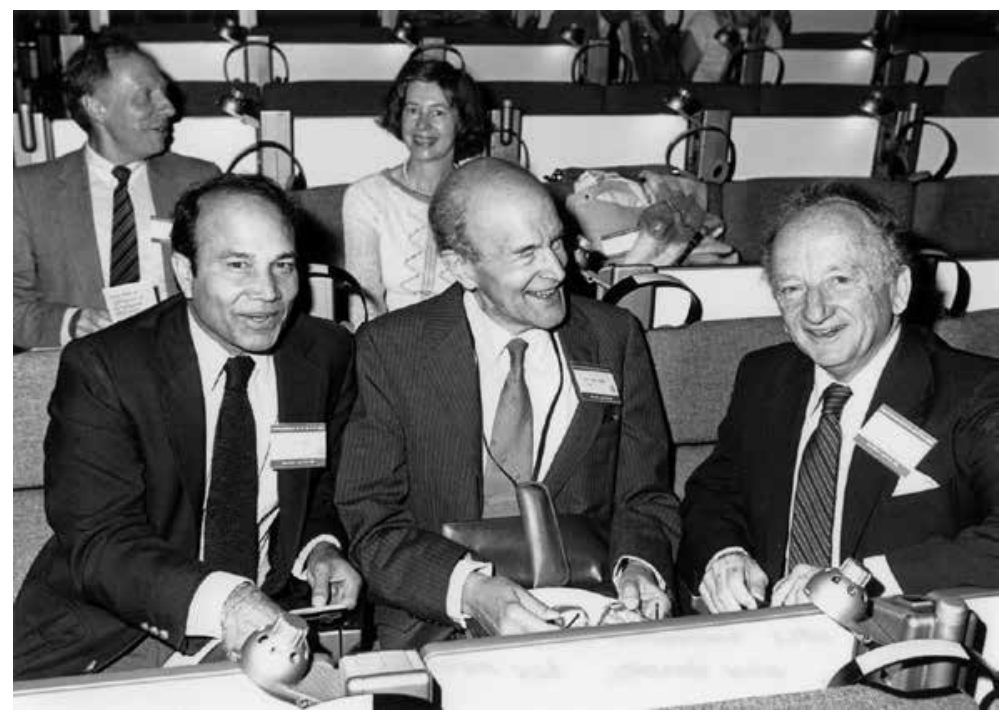

Abb. 14: Konferenz des World Peace Through Law Center, (v.l.n.r.) Ved P. Nanda, John Hazard, Benjamin B. Ferencz, Berlin, 1985 (USHMM RG 12.019.26)

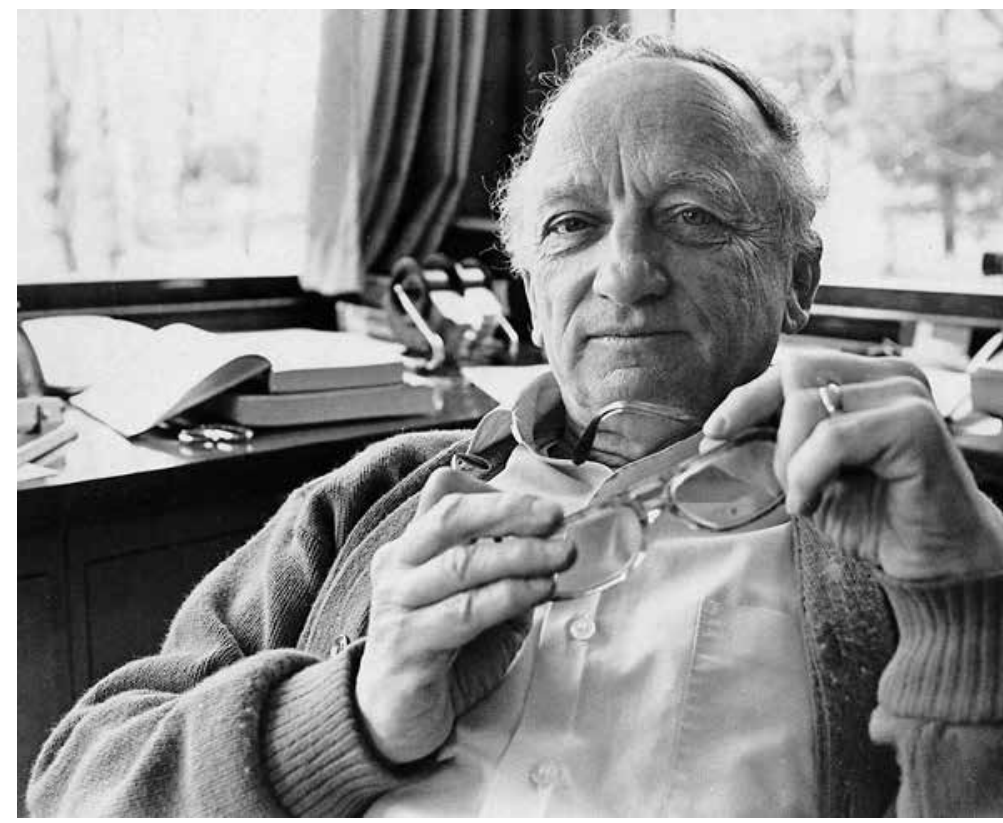

Abb. 15: Benjamin B. Ferencz, o. O., o. D. (USHMM RG 12.019.28) 



\section{Quellen}




\section{Editorische Zeichen}

Lesbarkeit:

$\begin{array}{ll}\# & \text { Unleserlicher Buchstabe } \\ \# \# \# & \text { Unleserliches Wort } \\ \stackrel{\circ}{\mathrm{X}} & \text { Zweifelhafte Lesung } \\ \diamond \diamond \diamond & \text { Dekoratives Element }\end{array}$

Paginierung:

$|\mathrm{x}|$

Paginierung des Originals

$\{|\mathrm{x}|\}$

Handschriftlich eingefügte Paginierung auf Originaldokument

$[|\mathrm{x}|]$

Von Herausgebern hinzugefügte Paginierung bei unpaginiertem Original

Unterstreichungen:

Unterstrichen Maschinenschriftlicher Text, der mit einer durchgängigen maschinenschriftlichen Linie unterstrichen wurde

Unterstrichen Maschinenschriftlicher Text, der mit einer gestrichelten maschinenschriftlichen Linie unterstrichen wurde

Unterstrichen Handschriftliche Unterstreichung

Korrekturen und Einfügungen:

Streichung Handschriftliche Streichung

Streichung Maschinenschriftliche Streichung

\#\#\# Streichung eines unleserlichen Worts

'Einfügung| Maschinenschriftliche Einfügung

\{Einfügung\} Handschriftliche Einfügung (auch Unterschriften)

[Einfügung] Einfügung der Herausgeber

Eckige Klammern im Original werden mit spitzen Klammern wiedergegeben. 
1. Tagebuch und Privatkorrespondenz im Zweiten Weltkrieg 



\section{Dokument 1}

Benjamin B. Ferencz

Diverse Orte, 8. September 1943 bis 11. Mai 1944

Kriegstagebuch, Teil 1, 120 Seiten; handschriftliche Eintragungen in ein Notizheft, handschriftliche Paginierung, beginnend auf Seite 3, jeweils auf der ungeraden Seite rechts oben, die letzten fünf Seiten unpaginiert

RG 12.001.01-02

[Ferencz beschreibt seine Einberufung und Ausbildung im 115 th Anti-Aircraft Artillery Gun Battalion der US-Armee sowie seine Probleme mit der militärischen Alltagskultur und dem dort verbreiteten Rassismus. Am 17. Dezember 1943, ab Seite 45 des Tagebuchs, beginnt ein neuer inhaltlicher Abschnitt mit der Einschiffung für die Überfahrt nach England, um dort auf die Invasion Frankreichs zu warten.]

[...]|1| Sept. $8-1943$

This is a fine time to start writing a log of my army career! More than 5 months have passed since my induction ${ }^{1}$ and this is the first notebook that has appealed to me. Perhaps it's just as well, for nothing of great importance has occurred.

A few things have made impressions on my mind which might amuse me in years to come, and that is the main reason for recording them here.

This has been my first visit to the "South" and from it I have already learned to love New York.

[|2|] Instead of spending my week-ends in camp or in Washington D. C., as almost all the fellows did, I've taken every opportunity to hitch-hike around the countryside and get acquainted with the people and customs.

I have probably seen more of "Southern Hospitality" than anyone in the barrack. There are too many soldiers around here to allow the people to open up their arms to all. Many, however, have opened up their palms, and the soldiers, including this one, resent $|3|$ it. The Southerners, well, many of them, are suspicious of "Yankees", but the one thing that has impressed me most deeply is the narrow prejudice so prevelant [sic] in these parts.

Church-going, peace-loving southerners are determined to "keep the nigga in his place" and it is a violent determination. Anyone championing

1 Ferencz begann, nach dem Studienabschluss an der Harvard Law School, seinen Militärdienst als Soldat im März 1943. Die ersten Monate der Grundausbildung verbrachte er in Camp Davis, North Carolina. Siehe dazu Hofmann, Benjamin Ferencz, $27 \mathrm{f}$. 
the come of "freedom for the Negro" is bitterly hated. Perhaps this will be the spark in the powder keg to set off the Spanish civil war in America.

[|4|] Children are more mature here than they are in the North. They don't seem to be coddled as much, and it's a good thing.

$9 / 10 /$

It did not take me long to become immune to army life. At first it was pretty depressing. It felt like a sentence to life imprisonment when my 1st Sgt. warned us, upon our arrival here at Camp Davis, that we could go nowhere, see no one, get no transfers, and no, no, no, everything. Though he $|5|$ has always tried to make things tough his effectiveness wore off in about two weeks.

My experience as a camp counselor, particularly at the Children's Village has come in most handy in adjusting to army life. ${ }^{2}$

The boys are prone to exaggerate the trials and tribulations of an army career. The "shots", details, obstacle courses and infiltration courses, 25-mile hikes etc. have been temporary inconveniences and nothing more. I don't feel like a hero just because I've completed $[|6|]$ my basic training.

In many respects $\{9 / 11\}$ I was lucky to be put to work as the Battalion Supply Clerk. There is very little work attached to the job; (typing and filing) and the company in the office is is pleasant. There is plenty of food for "noshing", and plenty of time to write letters, read, and loaf.

The fellows are a mixed crew. There are perhaps a half dozen who can be met on an intellectual $|7|$ level. The others find their chief interests in a woman and a bottle of beer. Comic books and spicy magazines are the chief reading matters. That sort of thinking seems to be contagious. Most of the fellows, beneath their loud facade, are young, immature, soft-hearted and afraid to think. Most of the boys in this Battalion come from New York so are probably above the average, but I wonder what sort of a world we can hope for these [|8|] men to make.

In a few days we will move out up Camp Davis, and "Good riddance!" say I. I have been approved for OCS. ${ }^{3}$ The Adjutant General was my 1st choice and $M{ }^{\prime}{ }^{4}$ next, for no particular reason. Wonder if I'll ever get to the school. [... $]^{5}$

2 Ferencz bezieht sich hier auf einen Sommerjob an der Reformschule in Dobbs Ferry während seiner Studienzeit. Als »Children's Village« wurde dort der Platz zum Nachsitzen bezeichnet. Siehe dazu die Ausführungen bei Hofmann, Benjamin Ferencz, 22.

3 Officer Candidate School.

4 Wahrscheinlich Military Police.

5 In den Einträgen vom 14., 17. und 21. September im Umfang von 3,5 Seiten berichtet Ferencz über den Umzug nach Camp Pickett, Virginia, sowie über einen kurzen Heimbesuch am vorangegangenen Wochenende. 
[|12|] [...]

Sept. 24.

The Camp Pickett library is really swell. Another good thing about the army is that it increases your appreciation of little things. Who would have thought a year ago, that I would find pleasure in putting my hand in warm water, or \{having\} a bed sheet, or a bed, or a coat hanger, or a million other things? No doubt my "appreciation course" in things I once took for granted has just begun.

|13| Managed to interview Lt. Col. Algy Hesler ${ }^{6}$ at the Camp Pickett Rehabilitation Center, rewriting an article for the Jour. Crim. Laws + Criminology. ${ }^{7}$ I hear that Liberty Magazine stole my thunder in this week's edition. Main purpose of the interview anyway was to test the opening for a transfer. He told me to see him next week. Certainly will be elsewhere next week, but we shall see what comes up to it. Probably nothing.

Sept. 28.

$[\ldots]^{8}$

|15| [...] Sorry I am missing most of the training for amphibious landings. It may be very important to me someday in the near future. I've complained to the first Sgt. about it, but he has a very nasty disposition - particularly toward someone he can't completely dominate - and I can't get a civil answer out of him. He keeps trying to belittle my Harvard education - guess it gives him an inferiority complex.

Cargo net scalling [sic] is interesting and [I] am glad [|16|] I'm getting at least that much training. My guess now is that we'll leave the U.S. just about Xmas time.

Oct. 2

I'm so disgusted tonight that I've just got to get it off my chest. This is the 3rd day weve been at Camp Bradford, Norfolk, Va. ${ }^{9}$ for amphibious training.

6 Algy Hesler (1889-1968) war Geschäftsführer des Camp Pickett Rehabilitation Center im Rang eines Colonels.

7 Siehe Benjamin B. Ferencz, Rehabilitation of Army Offenders, in: Journal of Criminal Law and Criminology 34 (1943-1944), H. 4, 245-247. Ferencz berichtet hier auf Grundlage seiner Erfahrungen im Camp Pickett, Virginia, von einem dort eingerichteten Rehabilitierungszentrum für Rekruten der US-Armee, die aufgrund von Anpassungsschwierigkeiten gegen die militärische Disziplin verstoßen hatten.

8 Einschub im Umfang von rund einer Seite. Ferencz beklagt sich dort, seine erworbenen Bildungsqualifikationen und Fähigkeiten bei der Armee nicht einbringen zu können.

9 Norfolk, Virginia. 
On the first day here we had to dig foxholes in the beach during a pouring rainstorm. It was plenty tough. But that's not what's bothering me. Yesterday we practiced jumping from $|17|$ the invasion boats with the surf and racing to the shore. The weather was nice so the trip to and from the larger ships was fun. But today - commando Benny spent his time raking leaves into big piles all around the area. It was easy alright but that's not my idea of army training. Tomorrow I will have K. P. ${ }^{10}-$ and $/{ }^{11}$

Oct. 3.

Lights went out at that last word. I am now goldbucking from the K.P. I mentioned. It just burns me up to have [|18|] to spend my time in the kitchen. Washing dishes and latrines is not my idea of amphibious training. I can't understand why the army doesn't hire old men, women, or 4F's ${ }^{12}$ for these minor details. To select "perfect specimens", who are vitally needed as fighting soldiers, and have them spend most of their time doing housekeeping seems to me to be the height of inefficiency. $[\ldots]^{13}|19|[\ldots]$ Recreational facilities are exceedingly limited. The only thing around seems to be a long beer line which keeps moving till they stop serving: It seems to be a custom in the army to "go out and have a few beers" whenever [|20|] the day's work is through. Perhaps it's the custom in civilian life too. I join them on occasion, and have one glass, but find no pleasure in the drink itself.

Oct. 13.

Many things have happened since the last entry. We returned to Camp Pickett and were glad to do it. I saw Col. Hesler again (see p.13) and though he was too timid to request my transfer, he encouraged me to do so. Submitted my request to Capt. Levene, citing many authorities to prove that it would |21| be the advantage of the service if I were sent to the Rehabilitation Center. Next day the Capt. disapproved the transfer citing a $13^{\text {th }}$ Corps. letter which prohibited transfers "to attend any schools". I checked the letter and my point, + tried to use reason. The Capt. evaded me + in response to my desperate request to see the Col. spoke to the Major who called me in. Though all of my actions had been quiet, gentlemanly and backed by printed authorities the

10 K. P. steht hier für kitchen police oder kitchen patrol und meint den Küchendienst in der Armee.

11 Der Eintrag bricht hier unvermittelt ab.

12 4F bezeichnet Personen, die als nicht für den Militärdienst geeignet eingestuft wurden.

13 Ferencz führt über etwa eine Seite seine Kritik fort, mehr Zeit mit sinnlosen Routineaufgaben zu verbringen als mit der Soldatenausbildung. 
Maj. gave me a sound [|22|] bombing out for causing so much trouble, insisted that we were completely frozen, that I had a job to do (typist) and to go along quietly. The stupidity of it all doesn't even keep me angry. I'm just disgusted. In a court of law I could present a brief and proof my point exclusively. Here the attitude of my "superior" officers (who should have the responsibility for corect [sic] classification) is "So here's a wise-guy, well we'll show him!" The futility of my $|23|$ efforts and situation is what distresses me most. People seem to love the status quo so much that they will go out of their way to block any efforts of change, no matter what the reason. Is it a wonder that world-improvement has come so slowly when the same psychology is prevalent everywhere?

Oct. 14

Was officially made a $\mathrm{T} / 5^{14}$ on the 6 th. I am not moved.

Managed to get home again on a week-end pass. As usual it was swell. You really learn [|24|] to appreciate a few hours with loved ones.

Yesterday Italy declared war on Germany. I don't think a Fascist nation can become a democracy by a simple declaration. Our State Dep't probably disagrees with me. Diplomatically it's swell, but I wonder what sort of a government will be set up in Italy. An unenlightened public can not be entrusted with the difficult task of re-organization, so the only hope lies in the benevolence of the officials in change. The greatest problem, (and in my $|25|$ opinion the chief clue) in establishing a decent system, is to replace the psychology of greed and hate with simple Christian ethics. It's a problem in "How to think" but no one seems concerned with a psychological reconstruction. The formal church has been handing out too much bugaboo and parasitism to be counted on for help. The politicians don't understand. The businessmen are not interested in world improvement, and the philosophers are locked in their ivory towers. I don't see how the [|26|] military war against Germany can be lost, but neither can I see that we are winning anything other than a military victory. Actually I don't think there can be such a thing as a "military victory", - for if that is all it is, it must be a loss.

The war against the Japanese appears to be getting tougher. Today the Japs "granted" the Philippines their independence - under a puppet gov't of course. At least the wily Japs are fighting with psychology as $|27|$ well as bullets. Now they can point out that the Americans never granted independence

14 T/5 war ein Dienstgrad in der US-Armee für technische Spezialisten während des Zweiten Weltkriegs, durch den diese entsprechend ihrer besonderen Fähigkeiten eingesetzt werden konnten. 
while the Japs did. ${ }^{15}$ Add to this the fact that Japan is economically binding her conquered territories to herself and it is not hard to see a long, if not completely futile, war.

Oct. 18.

Found out, by chance, over the weekend that my OCS application, though approved has been lying in a forgotten file in the office for the past 2 months. No wonder I was never called to [|28|] attend any classes! I'm just plain disgusted with the way things are done around here. There is no trace of my ASTP $^{16}$ papers or my request for transfer. They are probably lost or destroyed. The futility of my position is almost funny - but the joke's on me.

Last week I voted in a public election for the first time. Very few soldiers exercised their privilege. There's another hollow-shell! Much debate and blood-shed for the principle of free elections. Wonderful theory, but when it $|29|$ comes to casting the ballot not many people are interested. When they do vote it's along party lines or to please a political boss. The issues seem to be irrelevant. The main purpose for my voting in this small local election was to cast a vote against Aurelio ${ }^{17}$ for judge, for he has clearly been shown up as a corrupt crook nominated by gangsters. I'll bet even money that he gets elected. I'm reading Harold Ickes ${ }^{18}$ autobiography now and there is a lot in there to illustrate this point.

[|30|] Politics sounds like an interesting game. Perhaps I'll try my hand at it someday, for it will be fun to buck a crooked tide.

15 Die Philippinen waren in ihrem Unabhängigkeitskampf gegen die spanischen Kolonialherren (1896-1898) von den Vereinigten Staaten unterstützt worden. Im Anschluss hielten letztere sich jedoch nicht an ihre Zusage der Unterstützung der Unabhängigkeit und kontrollierten die Philippinen von 1902 bis 1946 als Kolonie. Ab 1916 erhielt das Land sukzessive Selbstverwaltungsrechte sowie die Zusicherung einer vollständigen Unabhängigkeit ab 1946. Im Zweiten Weltkrieg waren die Philippinen von 1942 bis 1945 von Japan besetzt.

16 Army Specialized Training Program.

17 Ferencz spielt hier auf den New Yorker Richter Thomas Aurelio (1891-1973) an. Dessen Nominierung für den Obersten Gerichtshof 1943 und die anschließende Wahl wurden von einem Skandal überschattet, der Aurelio in das Umfeld eines Mordfalls rückte.

18 Harold L. Ickes (1874-1952) war Mitglied der demokratischen New-Deal-Administration unter Präsident Roosevelt und dort von 1933 bis 1946 Innenminister. Die Autobiografie Ickes' erschien 1943 unter dem Titel The Autobiography of a Curmudgeon. 
Nov. 1.

Haven't made an entry in a long time. Last week we returned from New Point Comfort, ${ }^{19}$ Virginia, where we had gone for 5 days of firing. There was no job for me to do there, so the only problems for me were where to hide and how to have a good time. $[\ldots]^{20}$

[|34|] [...] The army is too big and too busy a place to treat soldiers as humans. Of necessity, I guess, the $|35|$ individual becomes a mere pawn in this bloody game, and the result is often a very callous soul. We forget that these are places where people are busy learning other things than "How to kill". We forget the sound of pleasant voices, polite requests, and the sound of children laughing. $[\ldots]^{21}$

$[|36|] \quad[\ldots]$

Nov. 3.

Couldn't make an entry.

Nov. 10.

Since last week we have been at Fort Dix, N. J. ${ }^{22}$ Seven months ago I didn't think I'd be back here again. This time I am here for a different purpose, however. We are preparing for overseas movement, and the day of our departure from the U.S. is not far off.

Before we left Pickett, I sneaked |37| home on a self-made "Jackrabbit" pass. As usual it was swell to be back. This past weekend I got a "legal" 3-day pass - undoubtedly the last one in the U.S. The fact that I'm able to get home, to Gerty, ${ }^{23}$ Mom + the rest, is by far the best part of my stay at Fort Dix. We are living in tents, with wooden floors and 5 men in each tent. It's not nearly

19 New Point Comfort bezeichnet einen Schießplatz 79 Meilen von Camp Pickett entfernt.

20 Knapp vierseitige Beschreibung der versteckten Freizeitaktivitäten, darunter auch der Besuch einer lokalen Schule, bei dem Ferencz einen Tag gemeinsam mit den dortigen Kindern und Lehrern verbringt. Wieder zurück im Camp schreibt er einen Brief an eine Lehrerin, deren Umgang mit den Kindern ihm imponierte und in dem er auf die Bedeutung ihrer Tätigkeit eingeht.

21 Halbseitiger Rückbezug auf den bereits beschriebenen Brief.

22 Gemeint ist die Militärbasis Fort Dix in Burlington County, New Jersey.

23 Gertrude Fried $\left({ }^{\star} 1920\right)$, verheiratete Ferencz, ist zu diesem Zeitpunkt die Verlobte von Benjamin B. Ferencz. Nach seiner Entlassung aus dem Armeedienst und der Rückkehr in die Vereinigten Staaten heiraten sie 1946. 
as bad as it sounds. We won't be here very long anyway. My best guess now is that I'll see New [|38|] Year's Eve in London. [... $]^{24}$

The Col. at the Pickett Rehabilitation Center made $|39|$ a formal request for my transfer. It was disapproved at this \#\# Hq. T.S. for me.

Nov. 26th

The last 2 weeks at Dix were really crammed full of work. It's no small job to prepare a battalion for overseas shipment. The magnitude of moving an army flooooํํ me.

We were checking our shortages, turning in equipment, and getting new things. The supply section really "went into battle". I was kept working, typing + checking supplies in and out, day and night. I was very [|40|] glad to be able to sneak home for a few hours and say "Goodbye" to the folks. Though I was pretty tired I really didn't mind the long hours of work. The only thing that really griped me was having to play personal lackey to a "superior" officer whom I consider nothing but a drunken whoremonger. I guess it's just part of the army and I shouldn't let it bother me - but sometimes it hurts. $[\ldots]^{25}$

\section{$|41|[\ldots]$}

Dec. 1.

Today we were alerted for movement to the port. Everything is packed and ready. I was again shown the army films "Why we fight". ${ }^{26}[|42|]$ They are an excellent series composed of newsreel shots + follow the theme set out by Wallace $^{27}$ of a free world vs. a slave world. Many of the scenes of sorrow + destruction brought tears to my eyes. The theatre was full of Negro troops and as I sat there I wondered how they were taking all of the talk about freedom. Though they were all around me I heard no comment. I wonder if they will continue to fight for freedom after the war is won. It seems very logical but

24 Kurzer Bericht über die Antwortschreiben zu seinem Brief an die von ihm besuchte Schule.

25 Rückblickende Beschreibung des Umzugs nach Camp Shanks, dem größten Einschiffungscamp der US-Armee während des Zweiten Weltkriegs in Orangetown, New York, sowie des dortigen Thanksgiving-Essens auf einer Seite.

26 Why We Fight war eine siebenteilige Propagandaserie, die mit Unterstützung des amerikanischen Kriegsministeriums produziert wurde. Die einzelnen Filme erschienen zwischen 1942 und 1945.

27 Wahrscheinlich ist der Publizist Wallace Carroll (1906-2002) gemeint. Er arbeitete nach dem Kriegseintritt der Vereinigten Staaten im US-Office of War Information in London und betonte, wie wichtig es sei, den amerikanischen Bürgern sowie ihren Verbündeten die US-amerikanische Kriegspolitik zu erklären. 
there may not be enough thinkers, $|43|$ who dare to put their thoughts into action to lead them. The way things are going on the political front at home + abroad it looks like either a civil war at home after the big war is brewing, or the liberal forces will be crushed without a struggle. Pathetic thought; isn't it! Perhaps thoughts like these account for my lack of emotion as we rear the gangplank.

Dec. 2.

Today saw the "Why we fight" film on the Battle of Russia. ${ }^{28}$ Though I'm sure much was omitted in the endeavor to avoid [|44|] politics the picture still packed a heavy wallop. I'm sure the Russians must regard with utter scorn the wailing complaint of Americans about high taxes, drafting fathers, rationing etc., and I don't blame them. Their sacrifices are undescribable and nothing I could ever do would match their gallantry. If the world is to be saved for decency, my thanks go first to the people of Russia.

|45| Dec. 17th -

Shall I call this "Chapter Two"? I am now in England.

We left Camp Shanks at 3 A. M. Sunday morning Dec. 5. Marching along silently I was impressed when we reached a cross-road and were joined by another long column of "combat loaded" soldiers. From their shoes, I could tell they were paratroops, men whose existence at Camp Shanks I had not even suspected, and who, at a given moment in the middle of the night, joined us to move to a [|46|] common destination 3,000 miles away.

The train ride to the N.Y. Port of Embarkation was a short one. A ferry carried us across to Pier 90 where our ship was waiting. As the ferry approached the dock, the sound of martial music brought the tired soldiers to their feet. The sleepy looking band changed the tune to swing, and probably kept grumbling under their breath. We hustled into the pier staggering under the load of all our army possessions. Women of the Red Cross were on hand |47| with chocolate bars, doughnuts, coffee, and tired but deliberately patient smiles "for the boys". The comfort they gave was very slight, but I admired their unselfish effort - and at 4 o'clock in the morning!

We were hurried aboard a ship, which at first stuck me as being a "tub". We went up the short gangplank so fast that I didn't even have time for an emotion. Huddled in the hold my original impression was emphasized. We were

28 The Battle of Russia (1943) war der fünfte von insgesamt sieben unter der Leitung von Frank Capra im Auftrag der US-Armee zwischen 1942 und 1945 gedrehten Propagandafilmen, mit denen für die Beteiligung der Vereinigten Staaten am Zweiten Weltkrieg geworben wurde. 
pushed into a small hold (G Deck to be exact - H was the absolute bottom!). [|48|] The "room" was filled by dining tables, which were to be "home" for the voyage. We eat ate on them, played on them, and slept on them. Hammocks could be slung from hooks dangling from the low ceiling. I used to sleep on my stomach. In a hammock, you sleep on your back, or else ... And you don't turn in your sleep! I got used to it.

The ship was the British liner "Strathnaver". Its maiden voyage to Australia had taken place in 1931 and she was a ship of some 23,000 tons. Thus, |49| the Strathnaver was neither old nor small, and by no means was she a "tub". We just happened to have one of the worst spots on the ship, but the upper decks (and the officer's cabins) were really very attractive. Of the voyage itself more tomorrow.

Dec. 19.

The trip itself was a pleasant one. The food was terrible and there were only two meals per day. Personally, I didn't mind it very much. Much to my surprise and delight, I was not sea-sick at all during the voyage.

A few days after we [|50|] embarked there were two attacks by submarines on convoys in the North Atlantic. Our radio reported 11 submarines sunk. It was also reliably reported on ship that we took a southern route and came up to Liverpool past Spain to fool the Nazis. It worked; we were not disturbed. Our Capt. informed some of the men that the convoy ahead of us and behind us were both attacked and that we were very fortunate in making the voyage without incident.

Once, down in the hold, the ship listed heavily and all of the lights $|51|$ suddenly went out. Though there were several hundred men crowded down there and it was pitch black no one made a sound and we all stood by waiting for orders. The lights came on again in a short while, but it showed the value of discipline in a situation, which might have been a panic.

Card playing, crap shooting and reading was the only recreation on board. I sampled all, came out about even and read a few good books.

The tedious boat drills, the gasoline-like water, the 4,000 troops on board, [|52|] are other things I remember.

The unappetizing food was rejected at meal time and at night the famished soldiers would go begging around the gallery. Natives from the Portuguese Indies, in little red turbans, could be bribed to bring food or drink. Whiskey sold at $\$ 8$ per pt., a handful of potatoes or a sandwich brought $\$ 1$. Pies sold as high as $\$ 5$ or whatever the natives could get. It was interesting psychologically to see the soldiers throw the food away at chow time then beg and offer their shirts for food $|53|$ that was no better, in a black market. The "black market" ran dry very soon and the men finally broke open a storehouse and stole crates 
of oranges and apples. No public mention was ever made of it. The reason seemed obvious to me. Our officers were living like kings. Neat cabins and staterooms, and elaborate dining room, a waiter for every table, French menus and fine food were part of the voyage for them. It would not have looked very good to have it known the "common" soldier had to [|54|] steal his crumbs.

On Dec. 16 we dropped anchor in the Bay of Liverpool. On the 17th we disembarked. Again the Red Cross was standing by. As we got into the strange British trains, 8 men to a compartment, women brought us doughnuts, coffee + cigarettes. It was a welcome gesture.

An hour later we arrived at Manchester where we were to be stationed. With weary feet we marched a few blocks through a large opening above which a huge sign announced: |55| "Zoological Park"! The place was Belle Vue, a tremendous amusement park, with roller coasters, tunnels, ferris wheels, and all the rest of a Coney Island. Our quarters were in a hastily converted exhibition hall and the whole battalion was under one roof. It was really like a large stable. We sleep in double-decker wooden frames in strawfilled mattress covers. It's not really bad, and considering the time + place I am more than satisfied.

Dec. 20

At an orientation lecture we were warned of two [|56|] things: The women around here are notoriously immoral and to expect the free intermingling of white girls and colored American troops.

I went to a dance, here in the park, the first night. There were girls galore. Many of them were very young though they looked and tried to look older. English girls in general do not seem very attractive to me. Since Manchester has many slums and Belle Vue is in the heart of one of them the girls looked very shabby. |57| Fingernails are dirty and clothing is well worn and patched. Prices in England are higher than they are in New York, and with the low wages paid here the condition of those I saw was easily understandable. "Tout comprendre c'est tout pardoner." Soap is difficult to get and the people show it. Girls could be "picked up" very easily and I have no doubt that their licentiousness is as originally indicated. I'd like to meet as many of those girls as I can, but that's where [|58|] it's going to end. This section is also noted for its high venereal disease rate and my interest in meeting and knowing different kind of people does not run that deeply.

What they told us about the social intermixture is also true. It was common at the dance to see white girls necking with Negros. I am surprised, if not amazed, at the apparently complete lack of prejudice. We were warned not to start any trouble. Our officers told us that in racial disputes $|59|$ the British gov't insisted on favoring the black if it should reach a court martial situation. 
Our officers gave us that orientation lecture apologetically, as if to say: "If you see Democracy in action boys, please don't start a riot."

I have already had several arguments on the subject. I just can't sit by quietly and listen to everyone talking about those black bastards and what should be done to them to keep them in their place. The Negro is in England f risking [|60|] his life for democracy, and though I'm not on the battlefront itself I'm in the fight also. It's very unfortunate that this particular fight has to be against my comrades in arms. I am busily engaged making enemies, but I think I've got the bible, Thomas Jefferson, ${ }^{29}$ the Declaration of Independence etc. behind me. Reason and logic doesn't help.

Dec. 27.

$[\ldots]^{30}$

[|62|] [...] What I feared when we first arrived I now see happening. There are race riots in Manchester. Censorship rules prohibit any mention of the race $|63|$ problem, so this little book will have to be my confidante.

As far as I can gather, Manchester had no initial bias against Negros. When colored troops were first stationed around here they were welcomed by the populace as "Black Yanks". White girls mixed freely with the colored boys.

It wasn't long before the more refined elements decided that most of the colored troops were not exactly Oxford grads, and they kept aloof. These who were less discriminating [|64|] continued the close association, much to the disgust or envy of the American whites.

For the past few months, many thousands of white troops have been pouring into this area. Tension has been growing. For example: the first night we were at Belle Vue there were about 50 Negros at the dance here. A few nights later there were only about 5 , who huddled close together and seldom went on to the floor. The Negros were being pushed out socially and they $|65|$ resented the snubbing, scowls, and insulting remarks of the Whites.

29 Thomas Jefferson (1743-1826) war Mitverfasser der Unabhängigkeitserklärung und dritter Präsident der Vereinigten Staaten von Amerika. Er kritisierte die Sklaverei und sprach sich für die Freilassung von Sklaven aus, besaß jedoch als Großgrundbesitzer selbst Sklaven. Siehe zu der Thematik Thomas Jefferson, Notes on the State of Virginia, Philadelphia, Pa., 1788.

30 Ferencz beschreibt auf zwei Seiten die hohen Preise in England, die den Einkauf von Weihnachtsgeschenken für seine Familie zu Hause unmöglich machen. Er verweist auf den Kriegszustand, der in England schon fünf Jahre andauert, sowie die ungewohnte Lebensumgebung, da das Camp direkt im Rotlichtviertel Manchesters errichtet wurde. 
Last night gangs of Negro hoodlums, in American uniforms, seized and beat up dozens of white soldiers. Hitler had a hey-day. There were a few serious casualties and it is rumored that a Negro was killed with a bayonet. The reaction among the men here is "Let's go out and wipe out those bastards", a typical mob psychology. The amount of our passes was cut down to 2,090 tonight and 40 [|66|] men from this Battalion alone are going out on special MP duty. We'll see what tomorrow brings.

Jan. 2 .

The fury seems to have spent itself in one night. Liverpool + Manchester were placed "out of bounds" for most white troops, everyone leaving on pass was searched for weapons, MP's were many and the passes few, so the New Year came in without additional conflict. Looks like it has blown over for a while.

As on Xmas, I spent New Year's Eve inside. I |67| wasn't really anxious to go out. On my last pass I encountered some female in the blackout who attempted to seduce me in the middle of the street. My appetite has not been so good lately. Being stationed at Belle Vue is like living in a free whorehouse.

No resolutions have been made for the New Year. But there's a wish to be home.

Applications for OCS etc. are again acceptable. I think I'll take another ride. Really don't expect anything to come of it. Never say "Die".

[|68|] Jan. $10-1944$

The game of "Ferencz tries - Ferencz is approved - Ferencz is forgotten" has started again.

Last week an order came through from General Devers, ${ }^{31}$ the commander of the $\mathrm{ETO}^{32}$ asking for the names of any men who could speak French + were qualified to run an employment office. I saw the bulletin + asked if my name had been submitted. I was told, evasively, that it had not. I insisted that I was qualified + the order was clear, so our personal officer $|69|$ said he would submit my name. Next day he evaded me + so far the next. When I could

31 General Jacob L. Devers (1887-1979) diente während des Zweiten Weltkriegs unter anderem als Befehlshaber der 6. Armee, die amerikanische und französische Streitkräfte vereinte.

32 ETO meint das European Theater of Operations, zum Teil mit der zusätzlichen Angabe United States Army (ETOUSA), dessen Kommandeur General Devers von Mai 1943 bis Januar 1944 war. ETO koordinierte die Militäroperationen in Teilen Europas zwischen 1942 und 1945. Der Begriff Theater of Operations bezeichnete in der US-Armee bestimmte Land- und Seegebiete, die im Rahmen von Militäroperationen eingenommen oder verteidigt werden sollten. 
corner him again he said the Major had told him to forget it all, and anyway it was now too late. Very decent!

Today my application for OCS reached the adjutants desk. Capt. Levene gave it the same approval he did the first time. The Adj., who is a regular fellow, warned me not to get my hopes up or expect anything. I don't - well, ... there's just a little spark of hope. $[\ldots]^{33}$

$[|72|] \quad[\ldots]$

Jan. 16.

$[\ldots]$

|73| [...] Went to a dance during the next week in one of the better dance halls in Manchester. The "respectable" girls won't have anything to do with "the Yanks". A few words during a dance can reveal a lot about a girls' attitude and character. Americans appear brazen and loud, and act as if the world has just been waiting for their appearance. This general attitude offends those who are more reserved and intelligent. Thus guys [|74|] like me are faced with a dilemma. The more refined girls aren't interested in "Yanks" and I'm not interested in any other type. I managed to corner one girl long enough to explain the situation. She seemed very nice and rather surprised that all Americans weren't alike. We are trying to make arrangements whereby a select group of her friends can meet a select group of mine. It's pretty lonely going out alone, and I imagine that $|75|$ some pleasant female would do wonders for my morale. More mail from that certain female at home would do more, but it seems to be very slow in getting here.

Jan. 26

$[\ldots]^{34}$

[|76|] [...] Was riled again today when Capt. Sloop objected to my using a letter of recommendation from him for an air corps application. I told him that my OCS papers had been lying on the Major's desk for 3 weeks without any action being taken. He spoke to the Adjutant, then returned + told me bluntly that every application I put in would be disapproved. Of course he couldn't give me a good reason for it, and I let |77| off some pretty nasty, but accurate, remarks about the patriotism vs. self-interest "conflict" among my officers. I was, and am, disillusioned and slightly nauseated by the attitude of

33 Knapp dreiseitige Beschreibung einer Pub-Szene, in der Ferencz eine Schlägerei zwischen amerikanischen Soldaten beendet.

34 Halbseitiger Verweis auf einen Tanzabend sowie eine Verabredung mit Engländerinnen aus dem Telegrafenamt. 
the men who are supposed to lead. This is the stuff cynics are made of, and I promised not to become that way. I am surely getting plenty of training in learning to take it on the chin. I may be a very unemotional apathetic person when this mess is over.

I'm submitting my [|78|] Aviation Cadet application - with a copy of Capt. Sloops letter of recommendation. $[\ldots]^{35}$

\section{|81| Feb. 19}

We are now "in action". Our gun batteries are in static defense position guarding airfields near the western coast of England. Hq. Btry. ${ }^{36}$ is located between the others, at Freckleton, again we are living in hutme[n]ts. Now that weve been here for two weeks I have a more definite impression. Since there are 16 fellows in my hut it's pretty hard to keep the place clean, - or quiet. Hence there's not a very home-like atmosphere. The regular double-decker steel beds are a definite improvement.

[|82|] Our location is near a large airbase, and there are dozens of small sites just like this one all around it. This must have been farm land in peaceful days, for the flat plains are very fertile and green even at this time of year. The soft ground couldn't stand our heavy vehicles and the result has been that each site is located in its own puddle of mud. Our mess hall is at another site, about 3 blocks away. Trudging through the ankle-deep mud $|83|$ to get there wasn't fun. We were issued galoshes and they were received with jubilation. Since we've been here the privates have spent most of their time "improving the area". The drainage and filling in of holes has helped considerably.

There's a very nice G. I. theatre right across the road. Outside of that there is no place to go without a pass. The small houses along the road are very neat, but it seems rather difficult to get to know the inhabitants. The Air Corps men have been here a [|84|] long time and seem well intrenched: There are still small farms all about and chickens and cows can be seen by looking out of the window.

Since we arrived here our duties have been multiplied. Every third day I have to stand guard at the driveway into our position. The senselessness of it gripes me. The solitary guard carries no ammunition. The sides and the seas are unguarded and anyone can easily slip in. If the enemy should penetrate

35 Im Eintrag zum 4. Februar schildert Ferencz seine erfolglosen Versuche, sich innerhalb der Armee auf andere Posten zu bewerben sowie weitere Treffen mit der bereits genannten Engländerin. 
this $|85|$ far, which is practically impossible, the sentry would be helpless and useless. Yet $1 / 3$ of my time is spent on guard. [... $]^{37}$

|89| Mar. 7.

Freckleton is gone. We are now at Camp Blandford, near the south-central part of England.

Before we left Freckleton I had had one more pass and had visited the town of Lancaster, about 30 miles north. My trip was made alone, and I hitch-hiked part of the way. Seeing the countryside was interesting and I met several interesting people. $[\ldots]^{38}$

[|90|] [...] Next day I visited an old castle in Lancaster. It was being used as billets for British troops and no visitors were allowed, but from what I could see from the outside, memories of "History I" and feudal days were brought back to me. |91| Also visited a beautiful old church, over 1,000 years old, and was deeply impressed. Inside I met a newspaper reporter from London and was engaged in conversation. We spent a few hours discussing the racial + other social problems. He was a very liberal, if not radical, fellow + it was very enlightening.

I was glad when we left Freckleton. The many hours spent on guard duty and as fireman in the boiler room were very boring.

We left by motor convoy and, after travelling a [|92|] short distance, stopped at a convoy camp near Preston. These camps are the equivalent of hostels in civilian life, or trailer camps, and just accommodate troops passing through.

Adjoining the camp was a Prisoner of War camp, full of Italian prisoners. Our boys crowded around the barbed wire fence and spoke to the prisoners in Italian. From what I could hear they seemed a group of typical young fascists, who, like everyone else, were fed up with war but whose political |93| opinions remained unchanged. Our Italian boys were very friendly and gave the prisoners cigarettes and bought brass rings from them at fancy prices. Not long ago these prisoners were killing Americans + Englishmen, but the naive Americans didn't seem to realize or care.

Stopped over at another convoy camp the next night, but nothing of especial interest occurred.

37 Knapp vierseitige Passage über unbeliebte Arbeitsdienste und ein weiteres Treffen mit der englischen Telegrafistin in Blackpool.

38 Hier berichtet Ferencz auf einer Seite, wie er eine junge Kanadierin kennenlernte und zu einem gemeinsamen Abendessen mit ihrer Familie eingeladen wurde. 
En route we passed numerous farms, and I was surprised that so small a country could have so many large fields. All land was either cultivated [|94|] or being used for grazing. England can't afford to waste much.

The old towns, made of heavy stone, with winding roads, and the fields of sheep, were all new things to me, and kept the trip interesting.

Camp Blandford is a large staging camp and we will only be here for a short while. So far it is not bad.

Mar. 17.

We are here for mobile training. $90 \mathrm{~mm}$. outfits must learn to move quickly or be destroyed and we sure can use $|95|$ the instruction. However, again a good theory is being inefficiently worked out. Our officers are attending lectures on convoy discipline and the like, but the training program for the man - remains on paper.

One of our batteries has already moved up "to the line". They are stationed near London and the first night there, enemy planes attacked. There was a fairly decent sized air-raid, but the battery was not yet prepared to fire and they just had "to take it".

We will all join them [|96|] soon, and it seems the War Dep't through a process of increasing risks is preparing the 115th for the big push.

The British Army shared this camp with the American, with the British doing most of the teaching. A program to familiarize the British Army with U.S. maps is in progress and a young British Sgt. has just spent 10 days in our office to learn about our supply system. To him it was a vacation and I doubt if he learned about supply, but it gave me the chance to $|97|$ learn much about the British.

Their humor is very definitely different from ours. Some of the difference can be accounted for by differences in language usage, but that's only part of it. It's still a cultural mystery to me.

Politically, it seems the British army is about as uninterested in the postwar world as the American + just as ignorant of the real issues at stake.

Blandford has plenty of cinemas and shows to make up for the lack of passes, but army camps no longer [|98|] make much of an impression on me.

\section{March 27}

One year has passed since I first raised my right hand to become a member of the Army of the United States.

I don't think I have changed much during that year. There has been a little disillusion added to my previous conception of my fellow men, but nothing that won't be erased after a short association with old friends. 
The travel and varied interminglings have undoubtedly $|99|$ broadened my perspective. The so-called hardships of army life have, of necessity, made me more tolerant. Being a prisoner of army regulations and of the frequent army stupidities has beaten me into a position where I accepted set-backs with a shrug of the shoulders. That may be of great value in civilian life.

I am still a civilian in uniform and hope to remain that way. But the end of the war is not yet in sight and I'm not too sure of myself if I must [|100|] continue this existence very much longer.

My one year in the service has been easy. I am thankful that I have not witnessed the casualties of war. The horrors are ahead, yet I am anxious to go forward, to hasten the day when I can go back.

April 17

We finally got that mobile training. It meant travelling around southern England, setting ourselves in position for a few hours then moving again: Our office in the field $|101|$ was a small tent, and since we only remained out for a day or a few days at a time, the work could be left back at the camp. I learned how to pitch a tent quickly and to sleep anywhere. Some of the evenings under the stars were really pleasant and I didn't mind the outdoor life. Even when it rained it was just another slight inconvenience and I appreciated the days of rest and the chance to catch up with some reading.

Now I suspect we have nothing to do but [|102|] wait for the invasion. If I were to guess, I'd say we should be in France at the end of June or perhaps sooner. Just for the record I'll guess that the invasion starts on May 29th. [... ${ }^{39}$

$[|103|] \quad[\ldots]$

April 22

Our outfitted [sic] is alerted and we are being rapidly prepared for the invasion. I think my last entry was very optimistic and put it off too long. The newspapers reported that 6,000 planes attacked communications lines of the enemy yesterday. Our assault troops can not be far behind.

[|104|] There is now an air of tenseness everywhere. On the eve of the greatest show on earth I find myself eager to get into it and have it over with. The preparations being made and completed are stupendous, but their significance is even more momentous.

Morale is very high, and it feels like the day before the big football game. Though there is an inevitable dread of all the horrors of war that have been described, I think everyone is $|105|$ looking forward to the attack with great

39 Hier rekapituliert Ferencz auf einer Seite seine vergeblichen Bewerbungsversuche auf andere Posten, deren Aussichtslosigkeit ihn resignieren ließ. 
confidence. Planes are in the air constantly, and military vehicles jam the roads. Boys coming back from Southampton and Poole say that long lines of ships can be seen waiting outside the harbors. We are being trained in gas defense, and when we cross the channel, we will all be dressed in our impregnated clothing. Vehicles are being waterproofed, and we are preparing to train in our overcoats and [|106|] other excess clothing and equipment. It is unmistakable.

On the post-war side the situation seems bleak. Those who are risking their lives don't care to find out why. In the barracks in spite of the high morale, there is an atmosphere of defeatism. There is much joking about how they will be conscientious objects in the next war, and how they will refuse to let their children enter the army. But they are convinced that the next war is $|107|$ inevitable and that there is nothing they can do about it. They are good-natured, intolerant and ignorant. An interesting combination. They feel they are being duped, and even when they repeat hackneyed slogans about this war (i.e. 4 freedom, return to normalcy etc.) they do not understand them, and they have no interest in trying to understand them. They are cheerful about facing death yet refuse to be inconvenienced by studying or discussing [|108|] what it is all about.

Our post-war era will be the most perverted and degenerated years in the history of modern man. The vast majority of the men I've seen in the army just don't give a good biddamn about anything but their personal pleasures. These sheep who survive the initial physical slaughter will bow their heads meekly on the political guillotine, or they will loudly follow the leader who promises the most $|109|$ advantages. To hell with ideals. In the war to some civilization ideals are a mockery. "Idealist" + "Noble" are epithets of decision. What a cynical age!

I still cling to the lofty sentiments which are supposed to motivate the army. The destruction of Fascism is the primary step towards giving us the opportunity to estate a better world. I hate the army and the military life, away from those you love and long to be with, and I don't want to [|110|] go through it again. Nor do I want my children to go through it. Therefore, I do all I can to make the first step a success, and hope that I will be able to do more in the more-important reconstruction.

This is as good a place as any to end this first volume, and I will continue to record these passing events in another little book. $[\ldots]^{40}$

40 Nach einer unbeschriebenen, aber paginierten Doppelseite werden auf zwei Seiten wichtige Daten und Stationen seit dem Beginn der Tagebuchaufzeichnungen aufgelistet. 


\section{Dokument 2}

Benjamin B. Ferencz

Diverse Orte, 13. Mai 1944 bis 15. August 1945

Kriegstagebuch, Teil 2, 120 Seiten; handschriftliche Eintragungen in ein Notizheft, handschriftliche Paginierung, beginnend auf Seite 3, jeweils auf der ungeraden Seite rechts oben

RG 12.001.01-03

[Der Soldat Ferencz setzt die Beschreibungen des militärischen Alltags sowie seiner privaten Ausflüge in England fort. Ab Seite 19, am 3. Juli 1944, erfolgt die Truppenverlagerung nach Frankreich. Das Kriegsende am 7. Mai 1945, die Besetzung Deutschlands sowie seine Erfahrungen in den War Crimes Investigation Teams bilden ab Seite 93 den letzten Abschnitt der Darstellungen.]

$[|1|]^{41}$

Benjamin B. Ferencz

Army Serial No.

32870400

Volume II - May 13, 1944

$|1|$ May $13^{\text {th }}$

This entry is an anti-climax. I was convinced that it would not be made until we arrived on French soil. We were prepared for an early cross-channel embarkation. The roads were crowded with troops moving towards the coast. Their vehicles, already waterproofed, bore on the mudshield, a large sticker announcing the size and weight of the vehicle. This was done to facilitate proper assignment to the invasion craft. Nearby Poole harbor was filled with LST's and [|2|] LCI's. ${ }^{42}$ The Germans cried out that invasion was imminent and bombed the harbor. I am now convinced that we were all fooled.

41 Die Seite dient als Deckblatt, dessen Rückseite unbeschrieben bleibt. Ferencz beginnt eine eigene Paginierung der Tagebuchseiten ab dem ersten Eintrag, die in der folgenden Textabbildung dargestellt wird.

42 Die Abkürzung LST meint Landing Ship, Tank. Damit sind spezielle Marineschiffe gemeint, die während des Zweiten Weltkriegs entwickelt wurden und das Ausschiffen von Streitkräften, Panzern etc. abseits von Hafenanlagen ermöglichten. LCI steht für Landing Craft, Infantry und bezeichnet amphibische Schiffe, die während des Zweiten Weltkriegs zur schnellen Landung von Infanterietruppen an Stränden eingesetzt wurden. 
It seems that our General Staff had prepared an elaborate feint. There will probably be other feints. One of them will be real.

Two days ago, we left Camp Bla[n]dford with regrets. We moved about 40 miles further inland to a large green plateau, - Salisbury plain. The nearest "town" to Stonehenge, in Wiltshire. We are a few hundred $|3|$ yards away from the world-famous Stonehenge shrine, from which it took its name. $[\ldots]^{43}$

$[|4|] \quad[\ldots]$

May 22

I visited London last week and saw all the sights a good tourist is expected to see. I was most $|5|$ impressed with the Poets Corner at Westminster Abbey, where the remains of all of England's greatest writers rested beneath my feet.

At Piccadilly Circus there is a "limb market" red-light district. Whores crowd the streets and whisper their prices in every eager ear. American soldiers outnumber the whores about 100 to 1 and are responsible for the exorbitant prices. The women seemed to average $\mathfrak{E} 6(\$ 24)$ for a night, and $£ 2$ for a brief session in a dark alley or a cab. It is the most "wide-open" [|6|] prostitution I have ever seen. I merely observed. Since it was commercialized it was even more flagrant than at Manchester. $[\ldots]^{44}$

[|8|] June 2

We are preparing to leave our encampment. For several days we have been on an alert, ready to move out within 6 hours. Now each vehicle is being loaded.

Assorted readings and discussions have given me some ideas of the overall plan for the invasion.

The initial assault will be made by specially trained assault troops. The combat engineers, the air-borne troops and the self-propelled light assault vehicles will lead the way. We are $|9|$ to be part of the assault troops.

In Sicily light $\mathrm{AA}^{45}(40 \mathrm{~mm})$ were in operation 20 minutes after the initial contact. $90 \mathrm{~mm}$ AA were in operation 2 hours after the touchdown.

Our mission will be to provide air defense as soon as there are sufficient troops landed to make a worthwhile target for enemy planes. We must be prepared to fire as Field Artillery or Anti-tank gun at any moment. We will be the sole beach defense against high flying aircraft.

43 Es folgt an dieser Stelle ein knapp zweiseitiger Bericht über die Geschichte von Stonehenge sowie zu der aktuellen Unterbringungssituation in Zelten.

44 Auf eineinhalb Seiten skizziert Ferencz den Besuch von General Timberland bei seiner Einheit. Dieser inspizierte die Vorbereitungen für die Invasion in Frankreich, die er für den Zeitraum der folgenden zwei Wochen ankündigt.

45 Anti-aircraft. 
[|10|] The assignment is not an easy one, and we will be moving in on D day. All organizations will be broken down into "Light Scale" and "Residue". The Light Scale will consist of the minimum amount of men and equipment to allow the batallion to function as a combat unit. They are not to be burdened with any administrative personnel or non-combat vehicles. The Residue will follow a few hours behind the Light Scale.

The Battalion Supply $|11|$ Office has been split. The Captain and the Tech. Sgt. will go ahead. The rest of the staff, including myself, will bring up the rear. I do not yet consider this as fortunate. I don't think we can tell until it's all over which group has the "safer" position. If the initial landing catches the Nazis by surprise enemy reinforcements may arrive just in line to catch the incoming residue. If I live through it, it will be an interesting experience.

[|12|] June 6th 1944

Today is D Day. Allied landings were made on the coast of France. We are still at our encampment, watching to pull out.

I have been on guard duty for the past 24 hours. At night I could see swarms of planes and gliders going overhead. It was obvious that there was a big raid in progress. As I write now the plane procession has been resumed.

At 7 a.m. I came off one of my shifts and |13| went to bed. At 9:30 I was excitedly awakened by my tent-mate who shook me and shouted: "The invasion has started, the invasion has started!" I jumped out as quickly as I could and joined a few others crouched beside the Battery radio in the Hq. tent. A brief announcement notified the world that the Big Battle had begun. In a few moments General Eisenhower ${ }^{46}$ read Communiqué No. 1, giving instructions to the people of occupied territories.

As I kneeled with my ear to the speaker, [|14|] there was a swell of emotions which filled my chest. It was an "all choked up" feeling, and if it weren't for the others present I know I would have cried.

Now that the "game" has started I feel a little disappointed at not being there for the opening whistle. I know I should be glad, and I'm safe this way, but it is undeniable that after all the training and waiting, and with the momentous significance of the event, I was eager to be in the thick of it. I $|15|$ have experienced the trained athlete's reaction after waiting breathlessly

46 Dwight D. Eisenhower (1890-1969) war als General der US-Armee und Oberbefehlshaber der alliierten Streitkräfte in Europa im Zweiten Weltkrieg unter anderem für die Landung in der Normandie verantwortlich und nahm am 7. Mai 1945 die Kapitulation Deutschlands entgegen. Von 1953 bis 1961 amtierte er als 34. Präsident der Vereinigten Staaten. 
for the big game of the season, and then at the crucial moment, instead of being put in he is ordered to the bench.

There is jubilation among the men. Convoys on the roads, and planes overhead receive our cheers. I guess everyone feels the same way about it as I do.

All of our English money has been turned in for conversion to the coin of our future "home". We are still waiting. Perhaps they will use us for a [|16|] new thrust some place else.

June 11.

Two days ago, our Light Scale left our encampment for the marshalling area. There they are to be briefed (given last minute instructions and have all plans based to them) and assigned to the invasion craft.

The Residue has been sitting around and waiting.

I have learned that on $\mathrm{D}$ day the 116th $\mathrm{AAA}^{47}$ went into action in our stead. How they were chosen and why we were left behind still remains a secret.

|17| June 16

We have been told that our outfit has been in France for the past several days. All our mail is being sent to them. We are still sitting around doing nothing but waiting.

July 1,1944

Yesterday, with much relief, we left Stonehenge. We are now in the marshalling area preparing for embarkation. Our money has been converted to Francs, and the large size of the 500 Franc note reminds me of a diploma from the Sorbonne. $[\ldots]^{48}$

$|19| \quad[\ldots]$

Juli 7th

On July 3rd, we left the marshalling area and boarded a Liberty Ship, the SS James B. Weaver at Falmouth harbor. There were about $500[|20|]$ assorted troops on board and with all of the equipment and vehicles the place was pretty crowded. We slept on canvas cots with which metal frames were two feet wide, and two men per cot. There were about 5 feet between each of the 4 tiers of beds and the human bodies were literally packed to the ceiling.

47 Anti-aircraft artillery.

48 Auf zwei Seiten beschreibt Ferencz den Tagesablauf bei der Verlagerung seiner Einheit in ein anderes Camp bei Falmouth im Südosten Englands. 
On the 4th of July we set sail for France. The sea was exceptionally calm as we sailed along the English coast toward Southampton. We were in a convoy of about |21| 30 ships. The nearest ship was another "Liberty Liner" - the Louis Kossuth. Our navel escort of cruisers and corvettes could be seen sailing all around us.

Shortly after embarking I was jarred in my bunk by about 10 large explosions: One of our corvettes had discovered a submarine stalking the convoy, and the depth charges that were dropped could be felt in every ship. There was no disturbance after that.

[|22|] The supposedly rough English Channel was like a Bronx Park lake, and the seasick pills and vomit bags that I had issued to everyone on board [of the] ship were completely wasted. No one seemed to mind the extravagance.

The sun was shining brightly all the way across and though we had all embarked wearing one or two sets of underwear (I had one summer and one winter set on) a complete suit of woolen OD's, ${ }^{49}$ covered |23| by a pair of fatigues, and topped by a Field Jacket, - most of us were soon stripped and sun-bathing on the deck.

At about 10:00 hours on the 4th of July we sailed into "Omaha Beach" on the Normandy coast. Hundreds of ships jammed the cleared areas. Hulks of sunken vessels could be seen protruding everywhere, but myriads of small landing craft skipped over the water, guiding the larger vessels to safety. [|24|] This was only one of several beaches we had established. The concentration of ships at this particular beach covered our area about 2 miles long. "Utah Beach" was about 10 miles further along the coast and we could see another huge armada assembled there. There were others too.

On the 5 th we disembarked. We transferred from the Liberty ship to small LCI's, and as we drew closer to the $|25|$ shore the scars of battle became more apparent. There were hundreds of wrecked ships of all sizes. Many of them had been ingeniously placed side by side (they almost appeared to be piled one on top of the other) to form a breakwater right before the shore shelf.

We touched shore at the same spot where our Light Scale had landed on $\mathrm{D}+6$. About 100 yards inland there was a large hill, where the German [|26|] Gunners had emplaced themselves to repel army landing. Now the hill was a shell-scarred mess. The well camouflaged positions had been blasted out. One huge concrete pillbox ${ }^{50}$ shore out. Its camouflage had been knocked off

49 Wahrscheinlich sind open drawlers gemeint. Es handelt sich um Unterwäsche, bei der die Beinnähte vorne und hinten nicht vollständig vernäht sind.

50 Als pillboxes wurden im Zweiten Weltkrieg kleine, flach gehaltene ebenerdige Bunker bezeichnet. 
and the steel reinforcement pro\#\#\# $\#^{51}$ like a shattered skeleton. The dead had been removed.

Hundreds of smaller landing craft were strewn about the beach. $|27|$ Some of them were very badly wrecked. Others just appeared to be resting on the sands after a tiring journey. The Engineers had dragged all of them together in bunches and congregations of these shattered heroes of the sea stood solemnly at regular intervals along the beach.

Dozens of former luxury liners had come into the improvised harbor with us and they were all busy unloading and sending their troops [|28|] ashore. Though a wharf had been erected of huge tin square containers, that have being [sic] used when we arrived, and the LCI on which I came ashore had to dock on the sands.

The ramp was lowered and our jeeps raced ashore, through about two feet of water.

I stepped out into the sea and waded ashore with the rest. It was more like a game to me than anything else. I was thrilled and delighted as I balanced $|29|$ my rifle on my head and husked the Atlantic Ocean.

No sooner move we ashore than a summer thunderstorm tore the heavens open. We might just as well have jumped into the sea head first, for a few minutes we were completely drenched.

Thousands of troops were lining up on shore. We marched in single file up the hill, which had suddenly grown much larger, on an improvised road. Here we had our first taste of French mind. We [|30|] waded and slid along. The long line of man slogging through the mud made an impressive silhouette along the mountains edge.

Along that muddy trail, we passed the shattered remains of German 88 positions. ${ }^{52}$ At the top of our long climb, the freshly painted crosses of a large American cemetery gave mute testimony to the fact that getting to that grave had not been easy.

The trucks churned up the muddy road and we plodded on. $|31|$ From the top of that remar[k]able hill I looked down on the busy beach. The barrage baloons [sic] that each ship carried made the sight very picturesque, as though silver fishes were flying over our craft. The only planes overhead were friendly ones. Along the top up that hill a landing strip had been constructed and there was a steady strew of ascending and descending P-47's.

Trucks from the Light Scale of our battery soon found us and picked us up. In about [|32|] 20 Minutes we were re-united with our battery. En route in

51 Das Wort ist im Original ausgeblichen und daher unleserlich.

52 Gemeint sind deutsche 8,8 cm Flugabwehrgeschütze, die im Zweiten Weltkrieg auch im Erdkampf insbesondere als Panzerabwehrgeschütze eingesetzt wurden. 
the pouring rain man had passed only one farm house that still stood intact. In its yard a middle-aged French woman stood smiling at the boys.

The winding trails led us to our new position - near St. Laurent-sur-Mer, between Bayeaux [sic] and Isigny. ${ }^{53}$ Troops were encamped everywhere, and our battery has located next to one of our gun batteries in a $|33|$ cow pasture. There was plenty of mud for all.

This was about the $3 \mathrm{rd}$ or 4 th position for our battalion. They had ended in the mopping up of Cherbourg and had served as front line ack-ack ${ }^{54}$ right behind the infantry. There had only been about a half dozen casualties and those from mines.

Now we are all together again, and ready to hit the line in full strength.

July 8 th

Here we are well dug in, and sandbagged [|34|] and things for me are comparatively quiet. During the day there is no activity, but at night the German planes come over, and our AA batteries open fire. One gun-position is only a few hundred feet away from my sand-bag fortified tent, and the nightly blasting disturbs my sleep. There is some danger from falling flak, but that's about all. At this nearest point the Germans are 15 miles away.

\section{|35| July 16}

Several days ago, we moved to a new position, near Carentaen..$^{55}$ The enemy is 5 miles away and there is more activity here. German planes have come over on several occasions and there has been score activity. Our guns are being used as field artillery to shell neighboring cities. German shell fire is returned on occasion, but so far hasn't reached us.

Here we sleep in $3 \mathrm{ft}$. deep dugouts, with plenty of sand bags all around. I hope the Germans never [|36|] launch any counterattack.

I've spoken to many French civilians already and have found it interesting and stimulating. Their hatred for the Germans is very vocal. What they actually feel is difficult to tell, but the more intelligent ones are relieved at our presence. Though the arrival of the Americans meant destruction of their homes, farms, etc., and pillaging by American, yes American troops, the French are glad to see the Germans routed. [... ${ }^{56}$

53 Gemeint ist der Ort Isigny-sur-Mer.

54 Abkürzung für anti-aircraft artillery.

55 Gemeint ist der Ort Carentan.

56 In einem Eintrag vom 28. Juli 1944 berichtet Ferenz auf knapp drei Seiten, wie er eine französische Familie kennenlernt sowie einen amerikanischen Flugzeugangriff auf deutsche Stellungen beobachtet. 
|39| [...]

Aug. 4

The Americans have launched a vast offensive. Our outfit was suddenly shifted from the 1st Army [|40|] to the Third US Army. At noon \{on 2 Aug.\} an announcement was made that we were to move out the next morning, to a spot near Cherbourg, for a few days bivouac, and then reassignment.

At 2 P.M. out of a clear blue sky, we received our march order. We were ordered to take up positions at the front.

We loaded our vehicles quickly. My French friends from the neighboring farm came over with a bottle of cognac and a box of eggs for me, |41| and I had to promise to return to visit them.

We moved toward the front with much eagerness and anticipation. // Interruption to take prisoners. //. Movement was slow + delayed. We passed town after town. That's what it said on the map. The huge piles of rubble were the only evidences. The city of Périers was completely leveled. About a week before we had fired into its heart using our guns as field artillery.

A full moon came out and we were still [|42|] trying to catch up with our tanks. In the distance we could hear a machine gun firing. Then we saw the planes. Perhaps a dozen planes - German planes - were dropping flares over the front. We could hear the bombs \#\#\# and Jerry ${ }^{57}$ seemed to have complete mastery of the air. We understood then why we were sent for so hurriedly.

The road was jammed with a steady stream of vehicles going forward. It was a perfect target for strafing, and Jerry didn't miss the |43| opportunity. As soon as the planes began dropping overhead and the planes started swooping, I left the truck and crouched near a ditch on the side of the road. I soon left it however, as I didn't like the smell. There was somebody or part of somebody lying there, and it wasn't pleasant company. I rejoined the others in the truck and watched the fireworks. Unfortunately, the Germans supplied most of it.

We pulled into an area past Avrances [sic]. The tanks had gone [|44|] through two days before, but from the many truckloads of prisoners passing it was apparent that there were still plenty of Germans in the area. We remained in that position for the rest of the night.

Before I could fall asleep on the ground, I was put on guard duty till daybreak. Managed to get about 2 hours sleep after that and then returned to guard duty.

There was a steady stream of tanks and supporting vehicles passing our position. Civilians walked by, $|45|$ and stood waving at the advancing troops. I spoke to many of these French civilians and exchanged good wishes. I engaged two young fellows and a girl in such conversation, and after about 15 minutes

57 Spitzname für deutsche Soldaten. 
they left and promised to return shortly. A little later they returned with another young fellow named Joseph. In very broken French Joseph told me that he was a Russian. A year ago, he had been taken prisoner by the Germans at Smolensk. He was 17 years old then and had been seized for [|46|] forced labor in France. When the Americans attacked Joseph seized the opportunity to escape. Now he was giving himself up to me and asking to be returned home.

I turned him over to the Battery Commander who took him to Group Hq. What happened to Joseph after that I will never know. In a few hours we moved on toward St. Hilaire. ${ }^{58}$

As we approached the front the scars of war became more vivid. The city of Periers was a[t] shambles, but \#\#\# that the $|47|$ Germans had not stopped to form determined resistance. Our tanks moved too fast for them to organize for a stiff fight. The most impressive part for me was that, along the roads, I saw parts of the German army - lying dead.

Their bodies were black and bloated, and I could smell them as I approached. There had been no time to bury them, and dozens lay strewn along the road to glory. Before I saw one, I thought I'd spit on him, but after one look I changed my mind. The truck [|48|] slowed down and I got a good look. A million maggots were craw[1]ing at his face, forming blacker splotches on the black background. It all seemed unhuman, unreal, and nauseating.

Aug. 5

Our new position guards the flank upon advancing tank colum[n]s. We are located on a farm again, and I had to chase the goats away before digging my foxhole.

German planes come over regularly. They bomb allied roads, bridges and troop $|49|$ concentrations. The Luftwaffe is not nearly as dead as I had imagined. When the anti-aircraft guns open fire, the sky is lit with an enormous display of fireworks. It's really pretty and exciting. It's also enjoyable to see the German planes go hurtling down in flames. Though there is danger of being strafed, or hit by flak or bombs, practically all of us find the show irresistible and spend part of our sleeping hours watching it. I am becoming accustomed to the noise now, and sleep when [|50|] ever possible.

As soon as we arrived here 5 Germans were taken prisoner on the roads near our encampment and were brought in to the battalion office. Two of them seemed to be about 16 years old. All were haggard, + tired looking. They

58 Gemeint ist wahrscheinlich Saint-Hilaire. Allerdings gibt es mehrere französische Gemeinde mit diesem Namen. 
seemed frightened. Today a German aviation mechanic was taken prisoner. The plane he was in was shot down by our batteries last night. He was 22 years old and very cocky. They took him away before I could form a more complete opinion.

|51| The Frenchmen are very friendly. Though everything they own may have been destroyed in the liberation, they still are overjoyed to receive us.

Aug. 15.

The Germans are retreating faster than we can keep up with them. We moved over 100 miles to a point near the town of Alençon. ${ }^{59}$ About 20 German divisions are encircled in this area and it's often difficult to discover just where the American or enemy lines are.

I was not happy to leave our last position. Though [|52|] I had become close friends with the farmer's family I had made other friends also, that were harder to break away from.

One day, while out hunting for a sniper one of my officers spotted two pretty girls near a French chatteau [sic]. He immediately called me, and we turned there together. It did not take long to get acquainted and to discover that the girls, aged 16 and 23, were daughters of the estate owner.

The place was really beautiful. The chatteau was set on the top of $|53|$ a mountain affording a view for hundreds of miles around. There were beautiful lawns, and a small lake nearby. We were invited to go swimming, and everyone was exceedingly cordial. Most of the household spoke a little English, and the 23-year-old girl, who was a college graduate, got along very well. Since she was intelligent, attractive, and just my size I found her to be an excellent swimming companion.

I returned on several occasions, with different [|54|] officers, to share the pleasure of the Chatteau du Gault. In spite of the fact that she was a devout catholic and very restrained in her conduct, Genevieve was charming.

The night before our departure I returned to the chatteau with Capt. Sloop. Drinks were served as usual (I still don't indulge) and the Capt. was feeling pretty well when one of the girls suggested that we take a walk. Genevieve led me to what was obviously a lover's cave around the lakes' edge. |55| There we managed to slip away from the others by swimming through the woods to a secluded spot. No sooner had we stopped to catch our breath than the lovely miss, whom I had never ever touched before, threw her arms around me and

59 Alençon wurde am 12. August 1944 von der französischen 2. Panzerdivision erobert und war damit die erste Stadt, die im Zweiten Weltkrieg von französischen Truppen befreit wurde. 
started kissing me passionately on the cheeks. Obvious inexperience. One thing led to the other, and it must be admitted that this surprise affair was very pleasant. That night we left for the front.

Travelling along the roads to our new position [|56|] was an unforgettable thrill. French men, women, and children, all dressed in their Sunday finery lined the roads to cheer us on. Flowers, apples, pears, cucumbers, squash, and cider were only some of the things they threw at us. Jubilation oozed from every pore as the population was being liberated. Destroyed German vehicles littered the route again, but this time there were no bodies lying around. The few Germans, who had resisted had been quickly buried.

|57| Our present location seems comparatively quiet. Since the population is not sure that the Nazis are out permanently, their joy is concealed, and at times I have even seen fear in their faces. As soon as we become acquainted, and they are re-assured all is well again. The landings on the Southern coast of France help make everyone happy.

\section{Sep. 13}

Since the last entry we have swept across France. The Germans have retreated in wild order and we have been in hot pursuit. [|58|] By this time practically all of France is liberated. The Northern and Southern armies have joined patrols, Paris has been freed, + the allies are well into Holland, Luxembourg, and Belgium. During this lightening advance I have been too engaged to make any entries.

After leaving Alençon we chased the Germans thru Le Mans, Orleans, Sens, Chataudun [sic], Vitry-le-Francois and now we are near St. Dizier. ${ }^{60}$ This sweep carried us completely across France, south of Paris and |59| across the Marne river. We are now waiting for the infantry to cross the Mosel river for our last push into Germany.

After the initial breakthrough near St. $\mathrm{Lo}^{61}$ the amount of Nazi opposition has been seriously limited. Though there were times when we were side by side with the infantry, we found France to be a hollow shell. The Germans left hurriedly for Germany - where we expect to meet again.

60 Ferencz' Einheit, das $115^{\text {th }}$ Anti-Aircraft Artillery Gun Battalion, rückte von der Küste über Le Mans ins Landesinnere vor und passierte auf dem Vormarsch Richtung Luxemburg zunächst Alençon, anschließend Châteaudun, Orléans, Sens und Vitryle-François. Mit dem beschriebenen Aufenthaltsort in der Nähe von Saint-Dizier ist entweder Joinville oder Neufchâteau gemeint.

61 Gemeint ist Saint-Lô. 
The French have been exuberant at our arrival. Where we have [|60|] been the first troop to stop, their joy was wild. I could have made hundreds of friends, but we only stopped for a few days at a time.

At Sens, which was a beautiful city oozing with hospitality, I found another chateau and a buxom little blonde. By this time, I have discovered that the problem d'amour in France is simply a problem of getting rid of the chaperons. The family and anyone else around clings to the desirable damsel |61| like a bunch of hungry leeches. The couple concerned did their damndest to get rid of the older folks and though that is almost impossible once it is accomplished the rest seems automatic. Most interesting folkways.

Militarily the pursuit has been boring and tiresome. We have taken a few prisoners + shot down some planes, but most of it has been digging in and moving on. The scent of blood is in our nostrils and we are all panting for the kill. [|62|] We know the Germans are defeated. Now we must defeat the Nazis before we can go home. Home. Home. Home. That is all that matters now.

\section{Sept. 17}

We advanced to the Moselle river without waiting for the infantry. Perhaps we were a little too fast, for as we approached the city of Charmes, clearing German road blocks in our path, someone suddenly realized that we were surrounded on three sides by Germans with the main body of Boche ${ }^{62}$ about $1 / 2$ mile $|63|$ away. We quickly retreated and took up a position amid many battalions of field artillery. The artillery were [sic] pounding a pocket in which were 500 German tanks. The infantry had not yet arrived.

Within two days the 313th Infantry regiment was stationed at our side, and the 19th Division posted on. The tanks put up a fight, and our batteries were called out for anti-tank fire.

All day the artillery pounds over our heads, [|64|] but the return fire of the Germans has ceased.

At first, we could see, hear, and feel German artillery returning our fire, but none of their shots came close enough to do any damage. The fact that the next shell might land at my side did not make much of an impression on me. Last night I was awakened by the shouts of the boys around me, and through the roar of cannon and machine gun fire I could hear them shouting $|65|$ about the German planes that were swooping down. I went back to sleep. In the morning I found out we had shot down three of them. $[\ldots]^{63}$

62 Französisch, abwertende Bezeichnung für Deutsche.

63 Es folgt ein knapp dreiseitiger Bericht darüber, wie sich der befreundete und Ferencz vorgesetzte Capt. Sloop beim Gewehrreinigen selbst verwundete. 
$[|68|] \quad[\ldots]$

Oct. 9

$[\ldots]^{64}|69|$ [...] Lunéville, pop. of 25,000 is part of Lorraine. The Germans never owned this city but it is not far from the German border. The difference in the general reception [|70|] we received was notable. The people were more restrained. The city is poorer than any place we've ever been, and there are more "cropped-heads" (collaborators, whose hair was clipped by the F.F.I. ${ }^{65}$ here than anywhere else.

The majority of the population hated the Germans however, and they greeted us with the usual joy. One family invited me to a "Liberation dinner" and it is a meal I won't soon forget. Rabbits baked in wine, all kinds of fish, roast chicken, champagne, + a dozen different drinks were only part of it. But they had been saving $|71|$ the ingredients of that meal for 4 years. I've been to their home for supper almost every day since we've been here, and I know that the feast was not an everyday occasion. A typical meal consists of soup, potatoes or macaroni, some bread and walnuts. Of course, I always bring more to the meal than I take with me.

It has been very pleasant to spend my evenings with the family. The father was a university professor for 20 years, the mother is a school teacher, and the 20 year-old daughter is an artist. Everything has [|72|] been very platonic but a wonderful interruption of army existence.

We are living in what was originally a French, + later a German, army post. The large stone barracks, with beds + straw mattresses are wonderful.

We have been here for about 2 weeks. The Germans have stiffened their resistance and the war in this sector has come to a halt. Not the war really, but our advance.

The Germans have been shelling Lunéville regularly. Today I went into town with the new $\mathrm{BC}^{66}$ (an |73| old friend) \{Capt. Klatte\} to buy vegetables. We had to cross a little bridge right near our barrack. About a minute after we passed, a German shell landed on the bridge. There were about 10 casualties including 3 Americans. Several French women, + children were killed. The scene was quite a mess.

I remained near the bridge to warn any of my comrades against an attempted crossing. The shelling continued intermittently, but there were no more direct hits - fortunately for me.

64 Zu Beginn des Eintrags am 9. Oktober kann Ferencz über den als Ersatz für Capt. Sloop eingetroffenen Capt. Levene berichten und freut sich zugleich über die Stationierung in der Stadt Lunéville.

65 Forces françaises de l'intérieur, Bezeichnung für französische Résistancegruppen.

66 Battery Commander. 
As one shell came [|74|] screaming over an ambulance started to cross the bridge. The shell turned out to be a dud, but it so frightened the driver that he swerved his speeding ambulance into an approaching jeep. Both vehicles were loaded and it was quite a collision. He missed me by a few feet and the impact of the crash threw one of the jeep occupants practically into my lap. The rest were strewn all over the sidewalk - bleeding and broken. I seized a 1 st aid packet from a nearby soldier $|75|$ and applied the bandage to the head of one of the boys. He had a wide gash in his forehead and it was bleeding like a fountain. Amid the danger of being shelled, the people taking cover, the soldiers summing back to their stations and the crashed vehicles with their injured occupants, I was considerably impressed by the situation. This was what war meant to the people lying around me. No theory in the world could be any compensation to them. $[\ldots]^{67}$

[|77|] [...] Dec. 3

For over a month I stayed in Enville. The town turned out to be as dead as I had expected. [... $]^{68}[|80|][\ldots]$ There wasn't enough work around to keep me busy, and time hung heavy on my hands. For want of anything better to do I put in a request for transfer.

Capt. Klatte, the new Battery Commander, took me to Third Army Hq. where I was interviewed by the Lt. Col. + Col. who run the Judge Advocate Section. ${ }^{69}$ They were very friendly, but explained that there were no openings available. They insisted, however, that I send my request, with a letter of recommendation + a copy $|81|$ of my J.C.L.+ $\mathrm{C}^{70}$ article up to them. I did, + less than 2 weeks later, as the 115 th was ready to leave for Saargamund [sic], ${ }^{71}$ in Germany, an order came through from higher Hq. to transfer me to the JA Section.

67 Im eineinhalbseitigen Eintrag vom 30. Oktober berichtet Ferencz über die Verlegung von Lunéville in ein Camp in der Nähe von Commercy.

68 Auf zweieinhalb Seiten beschreibt Ferencz, wie er Freundschaft mit den Kindern vor Ort schließt. Diese besuchen ihn regelmäßig und aufgrund des regen Kontakts wird für sie eine Thanksgiving-Feier mit Geschenken von Ferencz' Einheit organisiert.

69 Als Judge Advocate werden bei den US-Streitkräften die für rechtliche Angelegenheiten zuständigen Offiziere bezeichnet. Die Judge Advocate Section der von General Patton geleiteten Dritten US-Armee baute seit dem Sommer 1944 eine Einheit zur Untersuchung deutscher Kriegsverbrechen auf. Siehe Library of Congress, 2011525367, vor allem 21.

70 Siehe Benjamin B. Ferencz, Hostile French Civilians, in: Journal of Criminal Law and Criminology 35 (1944-1945), H. 4, 228-232.

71 Gemeint ist die Stadt Saargemünd oder französisch Sarreguemines. 
That was on Dec. $1+$ I was really surprised! I bid everyone a hasty farewell, + with beating heart left for Nancy, where Third Army Hq. is located.

I have been in the J.A. section for 2 days now, + so far have found everything wonderful. The officers $+\mathrm{EM}^{72}$ have been very [|82|] friendly + the atmosphere is more like that of a regular law office than an army position. Almost everyone around is a lawyer, or a court reporter, + the level of intelligence is immeasurably higher than in the 115th.

I am to work with 2 other fellows here, in writing reviews of the General Court-Martial cases. This entails a criticism of the procedure, laws + sentence applied, + is similar to the opinion of our appellate judge. Though there will be little free-time I know I am going to enjoy it. At long last I am working with laws again.

Jan. 12. 1945

I stayed in Nancy for a very pleasant month. The work in the office was, as I had expected, very interesting + pleasant. In addition to writing a few reviews and memoranda on legal problems I did research in international law and the problem of war criminals. I was also called upon to be French interpreter in interviewing civilian witnesses and in court. I travelled around, met dozen of interesting (even though disreputable) people + had much valuable [|84|] experience.

In Nancy I also became acquainted with "la vie française". The guard at the gate halted no one who knew the password, and passes were seldom hacked in town. Almost nightly Hal \#\#\# (the NYU lawyer who works in the office) and I took off to see what we could see + do. What we could do I was surprised! It's true what they say about French women! I think I met many girls in Nancy. I'm sure I knew every café. The orchestra would be playing in the large cafés and for a few francs you would $|85|$ be supplied with beer. The company was free, and there was plenty of it. What a life! $[\ldots]^{73}$

[|86|] [...]

Feb. 10

$[\ldots]^{74}|87|[\ldots]$

72 Enlisted Military.

73 Einseitige Beschreibung des Vormarschs von Nancy nach Esch an der Alzette in Luxemburg, um die deutschen Truppen an der Flanke anzugreifen.

74 Der Eintrag vom 10. Februar beginnt mit einer eineinhalbseitigen Beschreibung des Vormarschs von Esch in die Stadt Luxemburg am 4. Februar 1945. Ferencz berichtet zudem von den Menschen, die er zuvor in Esch kennengelernt hat. 
The city of Luxembourg [|88|] is the most picturesque city I've ever seen. A beautiful bridge (still called the "Adolf Hitler Bridge") spans a deep gorge, which shields sharp-sloping green hills. A semi-artificial winding stream flows down the center, and under smaller but similar bridges as far as the eye can see. The green woodlands reveal castle-like structures, bridal paths, and an array of mossy beauty in the chasm below. I'm looking forward to taking a walk along those paths on my next pass.

The bulge created by $|89|$ the German pushes has completely collapsed. They were being held on this side when the Russians launched a nightly offensive in the East which just sent the Nazis reeling. Now the Russians are massing on the Oder river, 40 miles from Berlin + Patton's ${ }^{75}$ gathered strength awaits the disappearance of the unconquerable mud.

March 26

$[\ldots]^{76}[|90|][\ldots]$

Brussels is the fastest town I've ever been in. It's worse than Piccadilly in London. Whores + pimps stopped me on every block. |91| Inflation has ruined the economy + the women have really been forced into prostitution to exist. Some of them were intelligent + pretty + it was quite pathetic. The city is ideal for spending lots of money in a life of wild dissipation. Had a pretty good time there.

The office work has changed + taken on a war interest. For the past several weeks I have been in charge of war crime prosecutions. It has meant directing investigations of reported atrocities, questioning witnesses + "gulling" the accused. The reports have been going forward to [|92|] higher Hq. where they can't make up their minds as to the disposition of the cases. So far no one has been tried and only the "small fry" have been caught or bothered. Again, I have been considering applying for a commission. I have been doing the job of a major and being only a T/5 has been a handicap in the work. Still the probability that officer will be kept over here longer than E. M. keeps my hands tied. I wouldn't trade all the rank in the army for the chance to go home sooner.

Militarily the situation $|93|$ has been wonderful. Though German shells from a $\mathrm{RR}^{77}$ gun landed a few blocks from here not long ago the casualties

75 George Smith Patton (1885-1945) war amerikanischer General, Kommandeur der Dritten US-Armee und Stratege des Panzerkriegs während des Zweiten Weltkriegs.

76 Der auf Seite 89 beginnende, einseitige Text umfasst die Bekanntschaft mit einer Luxemburger Familie, mit der Ferencz seinen Geburtstag verbrachte, bevor er zu einem dreitägigen Aufenthalt in Brüssel aufbricht.

77 Wahrscheinlich steht die Abkürzung für railroad gun (Eisenbahngeschütz). 
were light, and the JA section is intact. The Nazis have been beaten back over the Rhine + the Third Army has plunged after them. Again the Hq. is planning + preparing to follow the front + we will probably move very shortly: This time into Germany. The war here can not go on much longer.

\section{May 7 - 1945}

Tonight I heard on the radio that the war [|94|] is over! Germany has signed a complete surrender + all hostilities have ceased.

After the last entry we moved into Germany. Our first step was on the bombed city of Trier, where we stayed for about a week. While there I continued interesting war crimes investigations. One of the cases took me to a cemetery near Trier to dig up the bodies of 4 murdered soldiers in order to identify the victims. They had been underground for about 6 months + I had a colored crew to do the $|95|$ disinterring. The sight of the stinking beaten corpses stretched out along the grave's edge was not a pleasant one.

From Trier we moved to Frankfurt where we remained for perhaps two weeks. I again spent much time on the road having lots of fun investigating interesting cases. From Frankfurt we followed the front to Erlangen, near Nuremberg, and again set up in a German caserne.

My most interesting case to date was the Flossenburg Concentration [|96|] camp, and the death march in which about 3,000 people were murdered. ${ }^{78} \mathrm{I}$ saw more dead bodies than ever before + uncovered the mass graves where the brutal SS had thrown the miserable victims. To go into all the details would fill several of these volumes, and since this is the last such book I have the gory truth will have to be omitted.

In my travels I slept in German homes + spoke to many German people. The story they tell is that they $|97|$ believed in Hitler until the war came, + then when things started going badly, they realized the error of their ways but it was too late. The SS + Gestapo kept Hitler in power. I believed some of them.

I have seen the Russians killing + looting from the Germans. These poor people who were kept as slave-laborers for the Germans lost no opportunity

78 Vgl. dazu Toni Siegert, Das Konzentrationslager Flossenbürg. Ein Lager für sogenannte Asoziale und Kriminelle, in: Martin Broszat/Elke Fröhlich (Hg.), Bayern in der NS-Zeit, Bd. 2, Herrschaft und Gesellschaft im Konflikt, München/Wien 1979, 429-492; Peter Heigl, Konzentrationslager Flossenbürg in Geschichte und Gegenwart. Bilder und Dokumente gegen das zweite Vergessen, Regensburg 1989; Wolfgang Benz/Barbara Distel (Hg.), Flossenbürg. Das Konzentrationslager Flossenbürg und seine Außenlager, München 2007; KZ-Gedenkstätte Flossenbürg (Hg.), Konzentrationslager Flossenbürg 1938-1945. Katalog zur ständigen Ausstellung, Göttingen 2008 . 
to take what they needed from any German home + destroy what they could not use. I didn't blame the Russians or others [|98|] who had been prisoners of the Nazis, + had little sympathy for the Herrenvolk.

War crimes work is being completely messed up by a group of high-ranking incompetent officers who have been charged with the job. I am already convinced that the result will be a big farce.

Now that the war is over, I am anxious to see what will develop over here. The end of the struggle came as an anti-climax and no one seems much impressed.

\section{|99| June 11}

I have been around to many of the Nazi murder camps. Mauthausen was about the worst and my mind still refuses to believe the things I've seen. Thousands of women, old + young, and small children, thrown into a concentration camp to be killed. And the gas chambers, crematoriums, the beatings + tortures are all incredible. The emaciated skeletons at Ebensee, where thousands upon thousands were systematically starved to death, can never be forgotten. [|100|] At least I am getting a chance to see Germany + Austria. The work in the office is intolerable to me. Perhaps I am a case of "war fatigue" but I am very unhappy when I am confined to a desk and must observe practices which I consider idiotic. Travelling around is far more interesting + instructional.

I am now working on a case which involves billions of dollars' worth of art treasures. These were stolen from France + the other occupied countries $+|101|$ brought to German museums or the homes of prominent Nazis. It is fascinating. I am living in the castle of Baron von Pöelnitz $\left[\right.$ sic],${ }^{79}$ in regal manner, + gathering the evidence from Hitler's personal art dealer.

By this time I can speak German well enough to make myself understood on any subject. The non-fraternizåtioo ${ }^{80}$ policy I believe is both unjust and impracticable. ${ }^{81}$ It can not be enforced in the first place + works a hardship on the American troops and innocent Germans. [|102|] I am personally con-

79 Gerhard von Pölnitz war Offizier der Luftwaffe im Zweiten Weltkrieg und stand in engem geschäftlichem Kontakt mit den für die Nationalsozialisten arbeitenden Kunsthändlern Hildebrand Gurlitt und Karl Haberstock. Alle drei wurden am 14. April 1945 von der US-Armee im Schloss von Pölnitz verhaftet, wo eine große Menge an Kunstschätzen lagerte.

80 Wortende am Ende der Zeile gestaucht und schwer lesbar.

81 Die non-fraternization policy wurde 1944 von der alliierten Heeresleitung erlassen und verbot den freundschaftlichen Kontakt sowie Beziehungen zwischen westalliierten Soldaten und Deutschen. Das Fraternisierungsverbot wurde am 1. Oktober 1945 aufgehoben. 
vinced in spite of the concentration camps + other horrors I have witnessed, that there are millions of Germans who are good people. They went along with the Nazi party line + slogans the same as millions of people do back home. Thoughtless yes, but people are that way. They may have inwardly deplored the plight of the Jews, but they took no more action than the average Northerner who deplores the treatment of the Negro in America. |103| I have been showing the Germans the photos I have of the Nazi atrocities. I know that most of the people who see them are greatly shocked.

What is to happen to Germany now is the big question.

July 25

I am continuing work on the art treasures case and it has turned into my summer vacation. The priceless art treasures were stored in a salt mine at Alt Aussee [sic], ${ }^{82}$ Austria and we have set up an investigative Hq. nearby. The Office of Strategic Services ${ }^{83}$ is also working on the [|104|] case. One captain from the JA section, myself and 1 interpreter represent the army. We have about a half dozen "characters" under guard in the little villa we have taken over. They were all important cogs in the Nazi machine which cleverly and with apparent legality, deprived occupied Europe of all their art works. Speaking to the witnesses, before throwing them into an internment camp, has been most interesting since they are extremely intelligent and it's quite a job to outfox them and get to the truth.

The best part of the job $|105|$ down here, however, has been the place and the people around it. It is the most beautiful country I have ever been in. Here in the Tyrol and the Salzkammergut the towering snow-capped Alps drop sharply into serene blue lakes, and the countryside is bathed in the greenness of trees and plants. The wooden, balconied homes, with their gaily painted fronts, and the colorful clothing of the population, the short leather pants, green jackets and feathered felt caps of the men, + the colorful skirts of the women make the place exceedingly picturesque. And there is a [|106|] critical shortage of males. The men are still prisoners in allied PW camps, or were killed or lost in the war, and I have never seen such a land of lonely women. The non-fraternization policy completely collapsed. No soldier paid any attention to it and the authorities were forced to declare it out of existence. For the past month I have been living regally in this quiet paradise and, after each lounging day of interviewing witnesses or working on some of the paper work in the case, I take which the jeep (of the driver of which I $|107|$ am on this trip)

82 Gemeint ist Altaussee.

83 Das Office of Strategic Services (OSS) war von 1942 bis 1945 ein Nachrichtendienst des Kriegsministeriums der Vereinigten Staaten. 
and in company of one or two other soldiers tour the countryside and make friends. We have made several friends and it is perhaps ironic to be romancing with the still-Nazi wife of some ardent Nazi. American cigarettes, chocolate, + food are still a great attraction. Money here is practically worthless for no one wants to sell unless at fabulous black-market prices or in exchange for scarce commodities.

Being away from the office for so long has been like a vacation, for I am practically independent. On one of the trips back I [|108|] managed to be interviewed for a job with the United Nations Relief + Rehabilitation Admin. ${ }^{84}$ They had representatives at the Hq. interviewing applicants. They offered me a contract as Social Welfare Director at $\$ 4,000$ per yr. plus allowances. The job would have held the simulated rank of Lt. Col. but there was one hitch: - I had to get a release from the army. I put an application in for discharge; and returned to work in Austria. I have since learned that [the] Third Army has prohibited anyone with less than 85 points from initiating action for a position with UNRRA. |109| My position is that since they offered the contract UNRRA initiated the action. However, I know the Army by now - + so I have given up hope.

Now all I can do is pray that someday I too will be discharged. I am thoroughly disgusted with the army, the Judge Advocate Section + the way the war crimes work is being conducted by a group of overpaid fools. My 68 points does not give me much ground for optimism. If I am out of the army one year from today, I will be very happy. I have had too much of war and [|110|] the army and only want to go home.

\section{Augg: 15}

The end of the war against Japan has just been announced. It is my happiest day since I started these little books.

I had not dared to be so optimistic as to expect the end so soon. Everybody here is overjoyed. There has not been so much excitement since the invasion of France. Now I know it will not be too long before I can go home.

Millions have to be $|111|$ moved and food must be brought back to hungry Europe but now I expect to be home within a year. There is no rank, no grade, no job, no nothing the Army can offer me now to keep me in.

The news has really left me speechless. It still refuses to register on my mind.

84 Die United Relief and Rehabilitation Administration (UNRRA, 1943-1947) war eine von den Alliierten gegründete internationale Hilfsorganisation. Ihr Auftrag beinhaltete vor allem die Versorgung, Unterbringung und Repatriierung der zahlreichen Displaced Persons nach dem Zweiten Weltkrieg. 
It is a good place at this point to end this little volume. Perhaps I will continue to make notes until I finally arrive in that New York harbor again. Perhaps not, for [|112|] I know that until then nothing will seem very important. So I'll send this book to Gerty until I can return and join them again.

B.B.F.

Munich, Germany

\section{Dokument 3}

Benjamin B. Ferencz an Gertrude Fried

England, 20. April 1944

Maschinenschriftlicher Brief, 5 Seiten

$R G 12.001 .03 * 01$

[Ferencz beschreibt seiner Verlobten die alltäglichen Erfahrungen des Kriegs sowie die Anspannung unter den Soldaten angesichts der anstehenden Truppenverlagerungen von England nach Frankreich. Zugleich beschäftigt sich Ferencz mit der ungewissen Zukunft und der Frage, ob durch den Krieg ein gesellschaftlicher und politischer Wandel stattfinden wird.]

Dearest:

The lights in the barrack will soon be going out. I had hoped to spend a long time talking to you tonight dear, but there were so many distractions that the hours passed by unnoticed. The sun is still out, which will give you some indication of the kind of weather we are having, and a partial explanation for my mistaking the hour.

This afternoon's newspaper tells me that 6,000 aircraft have attacked the enemy. This is good news to everyone here, and the air is tense. It is like the few minutes before the big football game, and everyone looks for an excuse to shout. Not long ago a big formation of planes passed overhead. Two weeks ago they would have gone unnoticed. Tonight we all ran into the road, yelling "Come on Team!"

The picture we get of the war effort comes largely from the daily press. We are too busy with the important little details to take much notice of the picture being formed. Most of the fellows have only a vague knowledge of 
what is taking place on the battle-fronts, and it is only when each individual is called upon for an added inconvenience that he is aware of the fact that he is part of the big machine. The current news causes an air of excitement, and there is a slight constriction in the pit of the stomach.

As the hour draws near there are many who would prefer to win the war from England. We all know it is impossible. I am anxious $|2|$ now to get into it. Perhaps it is just a desire to hasten the inevitable, but I know that the sooner the big show starts the sooner will it all be over. Then we can go home.

It is interesting to me to notice the reaction of the men as they read of approaching events. There is much kidding. Each one feels excited, but morale is high. A friend asked me, on the show line the other day: "Why are they laughing?" It is a very serious matter, so forgive me sweetheart if I seem slightly morbid tonight. I am writing this because it is you. An army pamphlet discussed The Nature of a Free Man. It stressed the obligations of freedom, and the fact that wars can only give one side the opportunity to decide its own future. I raised the issue in the barracks and became deeply involved. The prevailing attitude is one of hopeless defeatism. Not on the military side of course, but the boys here think they are pawns of politicians, and there is just nothing they can do about it, so why bother with all this silly discussion. The world which made this war is the world to which each one hopes to return. Wars are inevitable they say, and anyway they will be too old for the next one, so why worry. There is no thought of social obligations, of consistent ethics, of purpose, of meaning. "Why are they laughing?"

I am struck with the fact, that these boys, and I believe they are a fair sampling of perhaps 10 million more, so cheerfully risk their lives, yet will not give one hour of their time to $|3|$ trying to learn what it is all about. Ten million men, armed to the teeth, shrug their shoulders and say: "There's nothing we can do about it!" Now perhaps more than ever, I understand how a mad fanatic like Hitler could seize his power. It is easy to risk death. It is difficult to think.

What a failure our educational system has been: The public reaction after the last war made "A world safe for democracy" a joke for cynics. Having been duped once, it became an axiom that we would be duped again. Having the axiom made it a reality. When men do not have faith to instill the desire for understanding, there are no ideals, there is no determination, and each man exists from day to day with the sheepish hope that tomorrow will be better. As millions of men stand ready to brutally slaughter millions of other men what an ironic picture this makes!

If I have painted things in a despairing light, dear, such was not my intent. The future is dark and difficult, but the world of tomorrow will be made by the few leaders. Perhaps America is too young, perhaps it is human nature, but I 
believe that the common man has not yet suffered enough to make the nature of his living one of his primary concerns. It is like the old doctor's saying that you do not know you have an organ until you have suffered a pain. Men is content with a mediocre living, and only $|4|$ when it becomes painful is he aware that there is a problem. America is still too rich, too far from the war. Miami is booming. The soldiers don't want to be bothered. It is a sad hope that soon they may learn.

I do what I can, where I can, and hope for the best. I am chained by my circumstances, however, and the satisfactions are limited. I have become detached from the total picture and find inner comfort in the fact of my own effort. Effort without achievement, however, is far from an ideal goal.

I can only urge each one to attack defeatism, and the appeasement that goes with it. Our generation is too easily led, and there is always the danger of misleading. It is not easy to stir up thought. It is sour medicine to persons not yet aware of an illness. Unless each man is to become a cynic and a sheep himself it is the only way. I cannot be led by the beatings of a hollow drum. If those who can understand will determine to exert united effort for common ideals nothing can stop them. Each can find his mental salvation in the attachment to that principle. The unburdened conscience of doing what I know must be right makes me look forward to the coming month. This in spite of the fact that when my friend asked "Why are they laughing?" I did not answer.

|5| Now the lights are already out in the barrack, and I have said things I had not planned to write when I sat down.

Will you forgive me sweetheart if I postpone the letter I had intended until tomorrow?

It's way past bed-time, so now it's good night my darling. I love you always, \{Ben\} 
2. Der ehemalige Nürnberger Ankläger: Rückblicke und Interventionen 



\section{Dokument 4}

Benjamin B. Ferencz an The New York Times

Berlin, 26. Juli 1949

Maschinenschriftlicher Leserbrief, 1 Seite

$R G 12.001 .03 * 07$

Berlin, 26 July 1949

The Editor

New York Times

Times Building,

329 W. 43rd St.

New York City, N.Y.

To the Editor of the New York Times:

A recent treacherous betrayal by US Military Government in Germany of the hopes of hundreds of thousands of Nazi victims should no longer be kept secret from the American public.

One of our earliest declared policies in Germany was that persecutees would receive compensation for the personal injuries they sustained. Military Government was directed to implement and carry out that policy. General Clay ${ }^{1}$ fully supported that objective and urged the Germans to enact suitable legislation themselves. After long negotiations, a law was enacted by the German Laenderrat which represents each Minister President of the US Zone and, through its Parliamentary Council, all the German political parties. ${ }^{2}$ This law granting a small measure of compensation for such things as loss of limbs,

1 Lucius D. Clay (1897-1978) war General der US-Armee und von 1947 bis 1949 Militärgouverneur der amerikanischen Besatzungszone in Deutschland.

2 Der Entwurf des Stuttgarter Länderrats für ein Entschädigungsgesetz der US-Zone stieß kurz vor seiner Verkündung unter anderem auf amerikanische und britische Bedenken, etwa wegen der unsicheren Finanzierungsgrundlage des Gesetzes. Der designierte amerikanische Hohe Kommissar John J. McCloy verhalf dem Gesetz schließlich gegen erhebliche politische Widerstände in Washington, London und seiner eigenen Administration zur Annahme. Nunmehr konnte der Länderrat das Entschädigungsgesetz der US-Zone (USEG) im August 1949 - noch vor dem Zusammentritt der ersten Bundesregierung - beschließen und rückwirkend zum 26. April 1949 in Bayern, Württemberg-Baden, Hessen und Bremen in Kraft treten lassen. Siehe Goschler, Schuld und Schulden, 92. 
concentration camp imprisonment, damage to health, loss of pensions etc. finally incorporated all of General Clay's suggestions and was submitted for the Military Government approval required before promulgation.

For four years these who had survived the Nazi terror were kept waiting for this elementary indemnification. To the amazement of the Germans and to the utter despair of the persecutees Major General George P. Hays, ${ }^{3}$ acting as Military Governor, refused to sign the legislation. The reasons given were that such matters should be handled by the forthcoming German Republic and that the financial burdens were more than could be borne by the US Zone Laender.

It is obvious to every serious official that these reasons are spurious and that the action of General Hays renders it almost impossible for such indemnification to take place. The law itself provided that payments would only be made insofar as funds were available and the new basic law for the new German Republic clearly places such legislation within the jurisdiction of the separate states. Furthermore, partial indemnification laws are already in effect in the other Zones, and even in the US Zone some German officials in recognition of this great moral obligation have begun making small payments to needy persecutees.

Thus upon his arrival, Mr. McCloy, ${ }^{4}$ the new High Commissioner, was presented by General Hays with a fait accompli which completely reversed the declared policy of the United States Government and which betrays fundamental concepts of decency and justice. It will be interesting to see what action Mr. McCloy will now take. ${ }^{5}$

Signed:

UNBIASED AMERICAN

Berlin, Germany

\{Pseudonym for B. Ferencz\}

3 George P. Hays (1892-1978) war General der US-Armee und ab 1947 Stellvertreter des amerikanischen Militärgouverneurs in Deutschland, Lucius D. Clay. Als dieser am 1. Juni 1949 aus dem Amt ausschied, vertrat Hays seine Position bis zum Amtsantritt des amerikanischen Hohen Kommissars in Deutschland John J. McCloy am 2. September 1949.

4 John J. McCloy (1895-1989) war amerikanischer Diplomat, Jurist und Präsidentenberater. Von 1949 bis 1952 war er als Hoher Kommissar für die US-Regierung in Deutschland tätig.

5 Siehe dazu Buscher, The U. S. War Crimes Trial Program in Germany, 29-44 und 160; Schwartz, Die Begnadigung deutscher Kriegsverbrecher, 375-414. 
You are not authorized to publish my name.

ELIZABETH W. MILLER (Miss)

I \& E Div. OMGUS

APO 742. US Army ${ }^{6}$

\section{Dokument 5}

Benjamin B. Ferencz an Nehemiah Robinson ${ }^{7}$

Ohne Ortsangabe, ${ }^{8}$ 31. Juli 1950

Maschinenschriftlicher Brief, 3 Seiten

$R G 12.002 .02 * 04$

[Ferencz beschreibt Aspekte des Nürnberger Einsatzgruppenprozesses, begründet die Auswahl der Angeklagten und schildert deren persönliche Haltungen während des Prozesses. Die Entscheidung über die Gnadengesuche der Landsberger Häftlinge steht zum Zeitpunkt des Briefs noch aus.]

Dr. Nehemiah Robinson

31 July $1950 \mathrm{BBF} / \mathrm{uk}^{9}$

World Jewish Congress

1834 Broadway

New York 23, N. Y.

Dear Dr. Robinson:

Your letter of 23 June 1950 requested some information about the attitude of the Einsatzgruppen defendants toward the task they performed and whether

6 Es handelt sich hierbei um die Kontaktdaten von Ferencz beim Militär. OMGUS steht für Office of Military Government for Germany, US und APO ist die Abkürzung des Army Post Office.

7 Nehemiah Robinson (1898-1964) war Jurist und seit 1947 Direktor des Institute of Jewish Affairs. Das Institut war 1941 zur Erforschung der politischen Situation der Juden seit dem Ersten Weltkrieg gegründet worden und beschäftigte sich intensiv mit dem Holocaust und seinen Folgen. Robinson war zudem seit 1941 als Rechtsberater für den Jüdischen Weltkongress tätig und 1952 an den Verhandlungen der JCC mit der Bundesrepublik in Wassenaar beteiligt.

8 Hier und in weiteren so gekennzeichneten Fällen war der Ort nicht zu ermitteln.

9 Wahrscheinlich Kürzel zur Zuordnung der Korrespondenz. 
they acted out of inner conviction, blind obedience, or because the lives of others had no meaning. ${ }^{10}$ You also asked whether they showed a sense of guilt or regret for the methodical slaying of over a million innocent \#\# human beings.

Your question cannot be answered generally, and I regret that at the moment I do not have the time for the careful examination of each defendant which would be necessary for a fair treatment of the questions. Some day I hope that I will write a more thorough examination of these problems, but I have been delaying it because of my own feeling that these matters are still too near to me and therefore the objectivity which should be applied might be lacking.

One point is clear as far as the 22 defendants ${ }^{11}$ in the Einsatzgruppen case are concerned, they were not men who were motivated by brutal impulses. They were not men with records of previous crime or sadism. I selected them as defendants because they held positions of leadership and the rank and file were never considered for inclusion in the indictment. As far as I know aside from these 22 leaders the balance of the some 3,000 members of the Einsatz units who for years had as their principal function the slaughter of innocent people have gone unpunished.

In my opinion the principal defendant Ohlendorf ${ }^{12}$ who admitted that his unit killed 90,000 Jews acted on the sincere conviction that what he was doing was right. You may recall from the testimony his explanation of why he had murdered Jewish babies. He was, he said, interested in the future security of Germany and the children realizing that their parents had been killed might constitute a future threat to Deutschland. Ohlendorf is the father

10 Der Einsatzgruppenprozess fand als Fall IX der zwölf Nürnberger Nachfolgeprozesse vom 15. September 1947 bis zum 10. April 1948 statt. Angeklagt waren ausschließlich hochrangige Verantwortliche der Einsatzgruppen, die für systematische Massenmorde an Juden und anderen Opfergruppen in den besetzten Gebieten verantwortlich gemacht wurden. Siehe ausführlich zum Prozess, den Angeklagten sowie den späteren Begnadigungen Ogorreck/Rieß, Fall 9: Der Einsatzgruppenprozeß; Earl, The Nuremberg SS-Einsatzgruppen Trial; Priemel/Stiller (Hg.), NMT.

11 Von den ursprünglich 24 Angeklagten waren einer durch Suizid vor Prozesseröffnung und ein anderer durch Krankheit aus dem Prozess ausgeschieden.

12 Otto Ohlendorf (1907-1951) war ein nationalsozialistischer Funktionär, der zwischen 1939 und 1945 als Leiter des Amts III (SD-Inland) im RSHA tätig war. Von Juni 1941 bis Juni 1942 war er Führer der Einsatzgruppe D, die unter seiner Leitung ca. 90000 Zivilisten in der Ukraine und auf der Krim ermordete. Im Nürnberger Einsatzgruppenprozess wurde er dafür zum Tode verurteilt und 1951 in Landsberg hingerichtet. 
of five children and I am sure that he is a fine parent. Immediately after his conviction I visited him in the death cell at Nuernberg. I asked him what his feelings were after the trial and his conviction. He told me that a great injustice had been $|2|$ done and that the Jews in America would suffer as a result of my action. It is impossible for the average American mind to comprehend such acts or thoughts without understanding the German racial theories and the joinder of such theories with a cold and purely materialistic logic. The result from their point of view is an ideal society of superior people. From the point of view of western philosophy and civilization the result is the perpetration of the most gruesome crimes against humanity. Some of the defendants, such as the defendant Naumann, ${ }^{13}$ continued to the end to deny that they had any knowledge or criminal association with the murders which took place. Jost ${ }^{14}$ and Blobel ${ }^{15}$ made similar pleas. The defendant $\# 5,{ }^{16}$ who was previously an ambassador and a professor, claimed that he was merely collecting cultural archives. The conduct of these men during the trial was absolutely shameless. To persist in maintaining their innocence in the face of overwhelming

13 Erich Naumann (1905-1951) war SS-Gruppenführer und von November 1941 bis April 1943 Kommandeur der Einsatzgruppe B, die in Weißrussland und Smolensk operierte. Im Nürnberger Einsatzgruppenprozess wurde er zum Tode verurteilt und 1951 hingerichtet.

14 Heinz Jost (1904-1964) war Jurist und SS-Brigadeführer. Nach Posten im SD und RSHA übernahm er 1942 für einige Monate das Kommando der Einsatzgruppe A und war Befehlshaber des SD und der SiPo in Riga. Im Nürnberger Einsatzgruppenprozess wurde er zu lebenslanger Haft verurteilt, 1951 erfolgte die Haftentlassung.

15 Paul Blobel (1894-1951) war SS-Standartenführer und während des Zweiten Weltkriegs Führer des Sonderkommandos 4a der Einsatzgruppe C, das in der Ukraine Massaker an Zivilisten beging und unter anderem in der Schlucht von Babi Jar 33771 Juden ermordete. Er wurde im Nürnberger Einsatzgruppenprozess 1948 zum Tode verurteilt und 1951 hingerichtet.

16 Die Raute steht an dieser Stelle als Nummernzeichen. Gemeint ist der Angeklagte Nr. 5 im Einsatzgruppenprozess, Franz Six (1909-1975). Six leitete seit 1935 die Presseabteilung im SD-Hauptamt und war in der nationalsozialistischen »Gegnerforschung" aktiv. 1937 wurde er in Königsberg zum Professor für Zeitungswissenschaft berufen und war ab 1940 als Dekan der Auslandswissenschaftlichen Fakultät der Berliner Universität und Leiter des Deutschen Auslandswissenschaftlichen Instituts tätig. Im April 1940 meldete sich Six zur Waffen-SS. Von Juni bis August 1941 kommandierte er eine Einheit der Einsatzgruppe B, die vor allem Kulturgüter plünderte. Ab April 1943 leitete er die Kulturpolitische Abteilung im Auswärtigen Amt. Im Einsatzgruppenprozess wurde Six zu 20 Jahren Haft verurteilt und im April 1953 vorzeitig aus der Haft entlassen. 
evidence of guilt, seems to require incredible gall or blind faith in the total stupidity of the judges. Naumann even admitted that the units under his command had carried out the executions but he, the commanding officer, knew nothing about them. After the trial I asked one of his subordinates what he thought about his "brave commanding officer". The subordinate, Klingelhoefer ${ }^{17}$ replied that "he was merely trying to save his skin".

Many of the defendants pleaded superior orders as a defense. If a man acts against his will, it is understandable that there be some mitigation for his offense. It is my sincere conviction, however, that none of the defendants in the Einsatzgruppen case acted against his will. It is true that there were Hitler orders directing the executions, but these orders did not coerce these particular defendants. I am deeply persuaded that they acted with a sense of pride in achievement, with eagerness, and devotion. The task was not easy, but they received their decorations for a job well done. The most striking fact which impressed me in the entire trial was the complete lack of any expressions of regret or remorse on the part of the defendants. No one believed that he could come forward and honestly state that he now realized that his Nazi sponsored actions were wrong. If anyone had thrown himself on the mercy of the court, I feel confident that his sentence would have been lightened. The only one who approached a semblance of decency was the defendant Klingelhoefer when he tried to commit suicide in his cell shortly before the trial began. He left a note stating that he realized for the first time after he received the indictment the full blasphemy which had been committed. His suicide attempt failed and during the trial he assumed the same pose as his comrades or he regained his Nazi conviction. Only after a tough cross-examination did he show signs of weakness. He had been arguing that the Jews killed by his commando were criminals or partisans but finally was forced into a bewildered admission that all the Jews were killed regardless of what they had or had not done. At that moment he again appeared shaken. I spoke to him as well the day after he was sentenced to death. I asked him for his views and he replied, "we have done certain things and now we must pay for them". The others continued their lies and evasion.

|3| It should be recalled that the Einsatzgruppen defendants were men of education and position. Most of them were lawyers. One had studied for the

17 Woldemar Klingelhöfer (auch Waldemar; ${ }^{\star} 1900$ ) war SS-Sturmbannführer und in Sonderkommandos der Einsatzgruppe B tätig. Im Nürnberger Einsatzgruppenprozess wurde er zum Tode verurteilt. 1951 wurde die Strafe in lebenslange Haft umgewandelt. 1956 wurde Klingelhöfer vorzeitig entlassen. 
ministry and one was even an opera singer. They were in a position to and did mould German thought. They were young men of influence and ability. They were and are the most dangerous element in Germany. ${ }^{18}$

Although it was on the 10th of April 1948 that 14 of the defendants were sentenced to death and the others to long terms, none of the executions has yet been carried out. The defendants are in the war crimes prison at Landsberg ${ }^{19}$ in Bavaria where their sentences are currently being examined by an advisory board on clemency for war criminals. It will be interesting to see what final action is taken.

Sincerely yours,

BENJAMIN B. FERENCZ

\section{Dokument 6}

Benjamin B. Ferencz an The New York Times

Nürnberg, 25. Februar 1951

Maschinenschriftlicher Brief, 1 Seite, mit Artikelentwurf, 14 Seiten; Anhang mit vom Brief unabhängiger Paginierung

$R G 12.002 .02 * 04$

[In dem Artikelentwurf nimmt Ferencz kritisch Stellung zu den Begnadigungen und Haftverkürzungen vieler Landsberger Häftlinge, die auch zahlreiche Verurteilte aus dem Einsatzgruppenprozess betrafen. Er endet mit einem Appell für einen internationalen Strafgerichtshof.]

18 Zum Personal der Einsatzgruppen siehe Helmut Krausnick/Hans-Heinrich Wilhelm, Die Truppe des Weltanschauungskrieges. Die Einsatzgruppen der Sicherheitspolizei und des SD 1938-1942, Stuttgart 1981; Ralf Ogorreck, Die Einsatzgruppen und die "Genesis der Endlösung", Berlin 1996; Peter Klein (Hg.), Die Einsatzgruppen in der besetzten Sowjetunion 1941/42. Die Tätigkeits- und Lageberichte des Chefs der Sicherheitspolizei und des SD, Berlin 1997; Klaus-Michael Mallmann/Jochen Böhler/Jürgen Matthäus, Einsatzgruppen in Polen. Darstellung und Dokumentation, Darmstadt 2008.

19 Die Gefangenenanstalt Landsberg diente von 1945 bis 1958 als amerikanisches War Criminal Prison No. 1. Dort waren auch die in Nürnberg verurteilten deutschen Kriegsverbrecher inhaftiert. Siehe Thomas Raithel, Das Landsberger Gefängnis vor und nach 1945, in: Volker Dotterweich (Hg.), Landsberg in der Zeitgeschichte - Zeitgeschichte in Landsberg, München 2010, 407-430. 


\author{
Benjamin B. Ferencz \\ 62 Thumenbergerweg \\ Nuremberg U. S. Zone Germany \\ February 25, 1951
}

Editor

New York Times Magazine Section

220 West 43rd Street

New York, N. Y.

Dear Sir:

I am attaching for your consideration, an article which deals with the recent clemency shown to the war criminals in the U.S. Zone of Germany. I trust you will find it suitable for use in the New York Times Magazine section.

Because the subject is of current interest, I would appreciate your cabling me collect if you decide you cannot use the article.

Biographical data which may be of interest include the following:

LLB Harvard, member of the New York Bar, served as Executive Counsel to Brig. Gen. Telford Taylor. ${ }^{20}$ Chief Counsel for War Crimes at Nuremberg, and Chief Prosecutor in the Nuremberg trial of U.S. vs Ohlendorf et al, called the "biggest murder trial in history". I am presently serving as the Director General of a charitable organization seeking to recover the heirless assets confiscated during the Nazi regime.

Very truly yours,

BENJAMIN B. FERENCZ

\title{
[|1|] CLEMENCY FOR MASS MURDERERS
}

Release of major war criminals emphasizes need for World Court

The clemency recently accorded Nazi Germany's major offenders has given the Soviet Union a powerful propaganda weapon in all the lands formerly occupied by the Third Reich. ${ }^{21}$ It has occasioned the cynical jest that in the

20 Telford Taylor (1908-1998) war ein amerikanischer Jurist und Experte für internationales Recht. Nach dem Zweiten Weltkrieg war er von 1946 bis 1949 als Hauptankläger in den Nürnberger Militärtribunalen der Amerikaner im militärischen Rang eines Brigadier General tätig.

21 Am 31. Januar 1951 bestätigte der amerikanische Hohe Kommisar McCloy fünf Todesstrafen gegen deutsche Kriegsverbrecher und wandelte zehn weitere in Haftstrafen 
new European Alliance America will supply the atom bombs, Britain the Navy and Germany the war criminals. Persons accustomed to the protection of law and order may ask to know why many mass murderers have managed to escape the gallows and how the scope of such follies may be limited or henceforth avoided.

It has almost been forgotten that following the conviction of Hermann Goering $^{22}$ and other top Nazi leaders by the International Military Tribunal, twelve other trials were conducted in Nuremberg. These subsequent proceedings before American judges sought to carry out international commitments that those responsible for the evil deeds of Nazi Germany would be brought to justice. It was felt that not merely the kleine mann, who knew nothing of the reasons for his country's action, should bear the burden of war, but punishment should fall on those leaders who had personally planned or brought about the vast havoc into which the world had been plunged. It was hoped thereby to establish some deterrent $|2|$ to the repetition of such barbarities.

Among the accused in the Nuremberg dock were leading physicians who had organized the program of fiendish medical experiments performed on helpless concentration camp inmates. Noted members of the German bench and bar who had made a travesty of the judicial process by converting the courts into an instrument of persecution were themselves called to trial. The mask of respectability was removed from these industrialists who had supported Hitler's aggressions and then exploited the slaves dragged from the conquered territories. The generals who disgraced an honorable profession by their calculated slaughter of hostages and prisoners were also condemned. Diplomats and ministers who had aided and abetted the mad Nazi design were confronted with their own treacherous proclamations. The SS leaders who had supervised the deliberate massacres and the operation of the concentration camps had to explain their own reports of their incredible deeds.

In open forum, with counsel of their own choice, and generous time to present their defense, these men were given "the kind of a trial which they,

um. Weitere 20 Haftstrafen wurden reduziert und 32 Häftlinge kamen frei. Siehe Buscher, The U.S. War Crimes Trial Program in Germany, 29-44 und 160; Schwartz, Die Begnadigung deutscher Kriegsverbrecher.

22 Der nationalsozialistische Politiker Hermann Göring (1893-1946) war unter anderem seit 1933 Preußischer Ministerpräsident, ab 1935 Oberbefehlshaber der Luftwaffe und seit 1936 Beauftragter für die Durchführung des Vierjahresplans. 1939 wurde er als Nachfolger Hitlers nominiert. Als ranghöchster nationalsozialistischer Politiker wurde er vom Internationalen Militärgerichtshof in Nürnberg 1946 zum Tode verurteilt. Am Vorabend seiner Hinrichtung beging er Suizid. 
in the days of [their] pomp and power, never gave to any man." ${ }^{23}$ Of the 177 persons thus tried at Nurnberg [sic] |3| 35 were acquitted, 24 were sentenced to death and the remainder received terms of imprisonment. ${ }^{24}$

While the proceedings against major offenders were in progress at Nuremberg, the U.S. Army was conducting independent war crimes trials on the site of the former Nazi charnel house at Dachau. ${ }^{25}$ Most of the accused in these hearings before American army officers were relatively unimportant persons who had carried out atrocities in concentration camps or committed crimes against Allied soldiers, such as the Malmedy massacre of U.S. troops and the slaying of captured fliers. ${ }^{26}$ Similar war crimes trials were conducted by the British and French in their zones in Germany, and Japanese offenders were tried at Tokyo.

The sentences of the subsequent Nuremberg and Dachau trials were subject to review by General Lucius D. Clay who was then Military Governor and commander of U.S. troops in Europe. The Dachau trials were also reviewed and the findings of guilt confirmed by special committees appointed by the Secretary of the Army and by Congress. General Clay reduced several of the Dachau sentences, including that of the notorious Ilse Koch, ${ }^{27}$ but with

23 Das Zitat stammt aus der Abschlusserklärung des amerikanischen Hauptanklägers Robert H. Jackson im Nürnberger Hauptkriegsverbrecherprozess. Siehe International Military Tribunal, Trial of the Major War Criminals Before the International Military Tribunal, Bd. 19, Nürnberg 1948, 399.

24 Siehe dazu die tabellarische Auflistung der Urteile der Nürnberger Nachfolgeprozesse bei Priemel/Stiller, NMT, 761-790.

25 Die Dachauer Prozesse bezeichnen 489 Verfahren, die zwischen 1945 und 1948 auf dem Gelände des ehemaligen Konzentrationslagers Dachau vor amerikanischen Militärgerichten verhandelt wurden und der Strafverfolgung nationalsozialistischer Verbrechen dienten. Mehr als die Hälfte der Verfahren waren sogenannte Konzentrationslagerprozesse, daneben wurden Ermordungen alliierter Flugzeugbesatzungen und Kriegsgefangener sowie Euthanasieverbrechen geahndet. Insgesamt waren 1672 Personen in den Prozessen angeklagt, von denen 426 zum Tode verurteilt wurden. 268 der Todesurteile wurden vollstreckt. Vgl. Robert Sigel, Die Dachauer Prozesse 1945-1948 in der Öffentlichkeit. Prozesskritik, Kampagne, politischer Druck, in: Jörg Osterloh/Clemens Vollnhals (Hg.), NS-Prozesse und deutsche Öffentlichkeit. Besatzungszeit, frühe Bundesrepublik und DDR, Göttingen 2011, 131-148, hier $133 \mathrm{f}$.

26 Im Zuge der sogenannten Ardennenoffensive hatten SS-Angehörige am 17. Dezember 194486 kriegsgefangene US-Soldaten in der Nähe von Malmedy, Belgien, erschossen. Im sogenannten Malmedy-Prozess in Dachau wurden die Verbrechen von Mai bis Juli 1946 verhandelt und alle 73 Angeklagten verurteilt. Vgl. Sigel, Die Dachauer Prozesse.

27 Ilse Koch (1906-1967) war die Ehefrau des Lagerkommandanten des Konzentrationslagers Buchenwald, Karl Otto Koch. Aufgrund ihres Verhaltens gegenüber den Gefan- 
only one exception, all of the Nuremberg sentences examined were approved. Seven of the Nuremberg "Doctors of Infamy" ${ }^{28}$ were hanged after appeals $|4|$ to the Supreme Court of the United States were denied, for lack of jurisdiction. Appeals by other defendants were lodged with the U.S. District Court in Washington.

When General Clay left Germany in the spring of 1949, the Nuremberg criminals came under the jurisdiction of the U.S. High Commissioner, Mr. John McCloy, who as Assistant Secretary of War in 1944 had helped formulate war crimes policies. To aid him in a further review of the Nuremberg sentences, Mr. McCloy voluntarily summoned to Germany a panel of distinguished and impartial persons to serve as his Advisory Board on Clemency. The Board studied the lengthy judgment, the petitions for clemency and all supporting documents submitted by the fifty defense lawyers who were heard. Each of the defendants was personally interviewed. The daily record of the trials was not read and apparently the vast amounts of official German documents submitted by the prosec[u]tion, were not examined. Although it had been repeatedly demonstrated during the trials that the accused submitted falsified records in their defense, no member of the prosecution was given an opportunity to refute the "new evidence" very belatedly discovered.

$|5|$ While these reviews were taking place, various German groups were vigorously acting on behalf of the convicted men. 'At Bonn' a discussion of Germany's willingness to join a European army was tabled and instead the demand was made that the Allied powers forego their rights to execute the condemned war criminals. At the gates of the war crimes prison, at Landsberg, a mob of 3,000 demonstrators shouted for the release of the prisoners. Jewish displaced persons from nearby Munich clashed with the crowd in bloody bare-knuckle fighting before a cordon of German police arrested the Jewish

genen erhielt sie den Beinamen »Hexe von Buchenwald «. 1947 wurde sie im Buchenwald-Prozess zu lebenslanger Haft verurteilt. Nach der vorzeitigen Entlassung 1949 wurde ein weiterer Prozess angestrebt und Koch 1951 erneut zu lebenslanger Haft verurteilt.

28 Doctors of Infamy war 1949 der Haupttitel der englischen Übersetzung der von Alexander Mitscherlich und Fred Mielke herausgegebenen Dokumentation des Nürnberger Ärzteprozesses. Die deutsche Fassung erschien zunächst 1947 unter dem Titel Das Diktat der Menschenverachtung. Die Ausgabe von 1949 trug den Titel Wissenschaft ohne Menschlichkeit. Seit 1960 wird das Buch unter dem Titel Medizin ohne Menschlichkeit vertrieben. Die englische Neuausgabe von 1962 ist mit The Death Doctors überschrieben. 
leaders "for their own protection". On a main street of Stuttgart, a band of youths painted "GERMANS PROTEST AGAINST FURTHER EXECUTIONS IN LANDSBERG". Prominent church leaders and the head of the German Freemasons urged clemency. A delegation of the leading political parties, led by the President of the Bundestag, ${ }^{29}$ called upon Mr. McCloy for a two hour conference to restate the case on behalf of the offenders. In view of the basic desire to weld Germany to the Western powers, these demands for leniency could not be lightly discarded. ${ }^{30}$

These protestations were reminiscent of German reaction when the Allies tried to punish perpetrators of World War I atrocities. Although the Treaty of Versailles had specifically recognized $|6|$ the Allied right to bring such malefactors to trial, less than a month after the Treaty was ratified, the lead of the Peace division of Germany's Foreign Office warned the Allies that -

"The entire German Volk, without regard to class or party is of the conviction that it is impossible to deliver up the so-called 'war criminals'.. The mere proposal of an order of this kind would create such a storm of indignation that the entire peace structure would be gravely threatened." ${ }^{31}$

The subsequent conviction before a German court at Leipzig of only six persons from the Allied list of 900 offenders and the very prompt release or mysterious escape of the criminals, including the U-Boat Commanders who had torpedoed hospital ships, was a tragic farce which understandably failed to deter the later commission of even greater wrongs. ${ }^{32}$

29 Gemeint ist Hermann Ehlers (1904-1954), der als Bundestagsabgeordneter der CDU im Oktober 1950 zum zweiten Bundestagspräsidenten der Bundesrepublik Deutschland gewählt wurde.

30 Vgl. dazu Schwartz, Die Begnadigung deutscher Kriegsverbrecher; Raithel, Das Landsberger Gefängnis.

31 Kurt von Lersner, Die Auslieferung der deutschen »Kriegsverbrecher «, in: Heinrich Schnee/Hans Draeger (Hg.), Zehn Jahre Versailles, Bd. 1: Der Rechtsanspruch auf Revision/Der Kampf um die Revision/Die wirtschaftlichen Folgen des Versailler Vertrages, Berlin 1929, 15-27, hier $22 \mathrm{f}$.

32 Auf Grundlage der Strafbestimmungen des Versailler Vertrags hatten die alliierten Siegermächte zunächst die Auslieferung des deutschen Kaisers sowie weiterer rund 900 wegen Kriegsverbrechen beschuldigter Personen gefordert, um ihnen den Prozess zu machen. Aufgrund heftiger Proteste vor allem im Deutschen Reich akzeptierten sie aber schließlich, dass stattdessen die deutsche Jurisdiktion Prozesse gegen eine kleine Auswahl der Beschuldigten führte. 1921/1922 wurden vor dem Leipziger Reichsgericht zwölf Fälle mit 17 Beschuldigten verhandelt, die mit zehn Verurteilungen und sieben Freisprüchen endeten. Der wegen der Versenkung des Lazarettschiffs Dover Castle angeklagte Oberleutnant Karl Neumann wurde freigesprochen, 
Ignoring the lessons of history, Mr. McCloy and the new army commander, General Handy, ${ }^{33}$ made a startling announcement on February 1, 1951. They declared that of the 101 Landsberg criminals whose cases were reviewed, 33 were to be released immediately. All but 7 of the 28 death sentences were commuted and 35 prison terms were diminished.

Among those returned to society were munitions king Alfred Krupp vom Bohlen [sic] $]^{34}$ and his eight top executives who had been condemned for their widespread and flagrant participation in the pro-|7|curement and shocking mistreatment of slave laborers. The forfeiture of the Krupp fortune which had been ordered by the Nuremberg tribunal was revoked. The wealthy 43 year-old Krupp was feted with flowers and a champagne party before driving off triumphantly. The thousands of persons who had barely survived the years of arduous labor and slow starvation, while under the whip of the Krupp guards, certainly did not share the jubilation.

The Krupp pardons were admittedly not prompted by a recognition of the innocens $\{c\}$ e of the officials concerned but by an attempt to archive "uniformity". It was pointed out that other convicted industrialists, such as Flick ${ }^{35}$

weil er einen höheren Befehl ausgeführt habe. Die Oberleutnants Karl Dithmar und John Boldt wurden wegen der Versenkung und der darauffolgenden Tötung von Überlebenden des Lazarettschiffs Llandovery Castle anstelle des angeklagten, aber flüchtigen Kommandanten Helmut Patzig zu vier Jahren Gefängnis verurteilt. Siehe Gerd Hankel, Die Leipziger Prozesse. Deutsche Kriegsverbrechen und ihre strafrechtliche Verfolgung nach dem Ersten Weltkrieg, Hamburg 2003, vor allem 19-73, 103, 420-422, 452-464.

33 Thomas T. Handy (1892-1982) war amerikanischer General und wurde 1949 der Nachfolger Lucius D. Clays als Oberbefehlshaber der US-Armee in Europa. In dieser Funktion milderte er 1951 die Haftstrafen vieler in den amerikanischen Nachkriegsprozessen verurteilter NS-Kriegsverbrecher.

34 Gemeint ist der deutsche Industrielle und Leiter der Friedrich Krupp AG Alfried Krupp von Bohlen und Halbach (1907-1967). Aufgrund der engen Beziehungen zwischen dem Unternehmen und dem nationalsozialistischen Regime sowie der Beschäftigung von Zwangsarbeitern während des Zweiten Weltkriegs wurde er im Nürnberger Krupp-Prozess zu zwölf Jahren Haft verurteilt. 1951 erfolgte die Begnadigung und Entlassung aus Landsberg. Siehe dazu Harold James, Krupp. Deutsche Legende und globales Unternehmen, München 2011, 183-246; Kim C. Priemel, Tradition und Notstand. Interpretations- und Konfliktlinien im Fall Krupp, in: Priemel/ Stiller (Hg.), NMT, 434-463.

35 Der deutsche Unternehmer und Förderer Hitlers Friedrich Flick (1883-1972) profitierte mit seinem Stahl- und Kohleunternehmen massiv von den guten Beziehungen zur nationalsozialistischen Führung, der »Arisierung « und der Ausbeutung von Konzentrationslagerhäftlingen und Zwangsarbeitern während des Zweiten Weltkriegs. 
and the directors of the I. G. Farben cartel, were already at large. It was not noted, however, that even in the best regulated society most offenders would have little difficulty in discovering instances of less severe punishment for similar crimes. The type of reasoning advanced to justify the Krupp releases would, if generally applied, be a most convenient method for promptly emptying most of the jails in the world.

Among those whose death sentence were commuted was SS Col. Walter Blume,${ }^{36}$ who commanded an extermination unit which murdered almost one thousand helpless people. The colonel "admired, $|8|$ adored and worshipped Hitler" and the tribunal found that "his only sense of guilt today is not that he brought about the death of innocent people, but that he could not execute the Fuehrers order (for the extermination of Jews and asocials) to its limit". ${ }^{37}$ A term of 25 years imprisonment was deemed adequate in this cast. Although the Nuremberg tribunal found that SS Col. Eugen Steimle ${ }^{38}$ "had authorized and approved of killings, in violation of law, and is guilty of murder", 39 his death sentence was reduced to 20 years imprisonment. The defendant Ernst Biberstein, ${ }^{40}$ whose sentence was commuted, had been in command of an extermination squad which murdered from 2,000 to 3,000 people. He admitted that:

Im Nürnberger Flick-Prozess wurde er zu sieben Jahren Haft verurteilt, aber bereits 1950 entlassen. Spätere Entschädigungsforderungen ehemaliger Zwangsarbeiter wies Flick zurück. Siehe Kim C. Priemel, Flick. Eine Konzerngeschichte vom Kaiserreich bis zur Bundesrepublik, Göttingen 2007; Norbert Frei u. a., Flick. Der Konzern. Die Familie. Die Macht, München 2009.

36 Walter Blume (1906-1974) war Jurist und SS-Standartenführer. Während des Zweiten Weltkriegs war er unter anderem Leiter des Sonderkommandos 7a innerhalb der Einsatzgruppe B. Im Nürnberger Einsatzgruppenprozess wurde er zum Tode verurteilt. Bereits Ende 1951 wurde Blume vorzeitig aus der Haft entlassen.

37 Vgl. The Einsatzgruppen Case. Individual Judgements: Walter Blume, in: Nuernberg Military Tribunals, Trials of War Criminals, Bd. 4, 529-532, hier 529.

38 Eugen Steimle (1909-1987) war Lehrer und SS-Standartenführer. Als Anführer zweier Sonderkommandos der Einsatzgruppen war er für Massenmorde in der Sowjetunion verantwortlich. Im Nürnberger Einsatzgruppenprozess wurde er zum Tode verurteilt. Die Strafe wurde 1951 in 20 Jahre Haft umgewandelt. 1954 erfolgte die vorzeitige Entlassung.

39 Vgl. The Einsatzgruppen Case. Individual Judgements: Eugen Steimle, in: Nuernberg Military Tribunals, Trials of War Criminals, Bd. 4, 539-541, hier 541.

40 Ernst Biberstein (bis 1941 Szymanowsky; 1899-1986) war ein evangelischer Theologe und als SS-Sturmbannführer Leiter des Einsatzkommandos 6 in der Ukraine. Im Nürnberger Einsatzgruppenprozess wurde er zum Tode verurteilt. 1951 wurde die Strafe in lebenslange Haft umgewandelt. 1958 folgte die Entlassung aus dem Gefängnis Landsberg. 
"I personally superintended an execution in Rostow which was performed by means of a gas truck. The persons destined for death - after their money and valuables (sometimes the clothes also) had been taken from them - were loaded into the gas truck which held between 50 and 60 people ... There was no physician present at unloading to certify that the people were really dead." ${ }^{41}$

Adolf Ott, ${ }^{42}$ whose commando admittedly carried out 80 to 100 executions, explained that he did not release some of the Jews when he had an opportunity to do so, because:

"I believe in such matters there is only one thing, namely, consistency. Either I must shoot them all whom I capture, or I have to release them all." ${ }^{33}$

Ott's death sentence was also commuted.

|9| Officers condemned for excessive reprisals were granted clemency because "they showed evidence of humane consideration". The fact that the criminals did not always $\{$ be $\}$ have as brutes became a cause for reward. In commuting sentences of some of the mass slayers even where no clemency had been recommended by the Advisory Board, Mr. McCloy explained, "though deeply guilty it can be said of them that their offenses as proven by the record were on a less imposing scale." ${ }^{44}$ It was thus advanced as a principle for clemency that a man who murders 1,000 people or only a family of five, shall receive a less $\{\mathrm{er}\}$ punishment then one who succeeds in slaying 50,000 . It was in ironic note that on the same day that the commutation of the sentences of Germany's mass murderers was announced, the United Press reported that seven young Americans had been sent to the electric chair in Virginia for the rape of a house wife.

The only note which dampened the general German rejoicing was the announcement that seven of the worst offenders would not be spared. Mr. McCloy confirmed the death sentences of SS Maj. Gen. Otto Ohlendorf and three other Einsatzgruppen leaders. ${ }^{45}$ These four men were selected from

41 Vgl. The Einsatzgruppen Case. Individual Judgements: Ernst Biberstein, in: Nuernberg Military Tribunals, Trials of War Criminals, Bd. 4, 542-545, hier 542.

42 Adolf Ott ( $\left.{ }^{\star} 1904\right)$ war SS-Obersturmbannführer und Kommandeur des Sonderkommandos 7b, das in Russland und Weißrussland zahlreiche Massenmorde beging. Das Todesurteil aus dem Nürnberger Einsatzgruppenprozess wurde 1951 in lebenslange Haft umgewandelt. 1958 erfolgte die vorzeitige Haftentlassung.

43 Vgl. The Einsatzgruppen Case. Individual Judgements: Adolf Ott, in: Nuernberg Military Tribunals, Trials of War Criminals Before, Bd. 4, 559-563, hier 562.

44 United States Office of the US High Commissioner for Germany, Landsberg. A Documentary Report, Frankfurt a. M. 1951, 8 f.

45 Bei den drei weiteren Verurteilten, deren Todesstrafe vollstreckt wurde, handelt es sich um Erich Naumann, Paul Blobel und Werner Braune. 
the 22 defendants, whose extermination squads, operating behind the lines of combat, systematically $|10|$ slaughtered the incredible total of over a million "so\{ra\}cially inferior" men, women and children. The sentence of Oswald Pohl, ${ }^{46}$ who supervised the administration of all concentration camps and the extermination of 56,000 Jews in the Warsaw ghetto, was also confirmed. The lives of these five men were to balance the score for the hundreds of thousands of families hurled into mass graves and pushed into the gas chambers and crematoria. General Handy ruled that two of the Dachau defendants would also have to pay the supreme penalty.

While the gallows were being prepared, the barrage for still further clemency was resumed. It was argued that the men awaiting death for several years had already suffered enough. Inasmuch as the delay had been brought about at the request of the condemned and in order to permit their many appeals, this sounded like the plea of the man who murdered his mother and father and then begged mercy on the ground that he was an orphan. The Brudershaft [sic], an organization of former German army officers, ${ }^{47}$ distributed 200,000 leaflets on behalf of the criminals. Defense lawyers for Ohlendorf issued public proclamations denying that the former SS General had confessed the murder of 90,000 people. $|11|$ The appeal which had been made by Brig. Gen. Telford Taylor, the Chief of Counsel at Nurnberg, to have the records of trial published so that Germans could be re-educated by German history (see New York Times Magazine Section May 28, 1950 ${ }^{48}$ had been pigeon-holed by the High Commission staff. With the official documents conclusively proving guilt,

46 Oswald Pohl (1892-1951) war SS-Obergruppenführer, General der Waffen-SS und Verwaltungschef des SS-Wirtschaftsverwaltungshauptamts und somit verantwortlich für das Konzentrationslagerwesen der Nationalsozialisten. Er wurde im Fall IV der Nürnberger Nachfolgeprozesse zum Tode verurteilt und 1951 hingerichtet.

47 Nach Kriegsende entstand unter Führung des früheren SS-Obersturmbannführers Alfred Franke-Gricksch und des früheren Wehrmachtsmajors Helmut Beck-Broichsitter unter der Bezeichnung »Bruderschaft« eine Kaderorganisation ehemaliger Wehrmachtsoffiziere, die eine antidemokratische und antiparlamentarische Neuordnung Deutschlands und Europas vorbereiten wollte. Siehe Richard Breitman/Norman J. W. Goda, Hitler's Shadow. Nazi War Criminals, U. S. Intelligence, and the Cold War, Washington, D. C., 2004, 58f.; Andreas Eichmüller, Die SS in der Bundesrepublik. Debatten und Diskurse über ehemalige SS-Angehörige 1949-1985, Berlin/Boston, Mass., 2018, $24 \mathrm{f}$.

48 Telford Taylor, Re-Educating Germany With Nazi History. A Prosecutor at Nuremberg Urges That Facts Disclosed There Be Used to Teach Democracy, in: The New York Times, 28. Mai 1950, 115. 
safely buried in the Pentagon files at Washington, the German public could not readily discover the truth. The "Working Girls for Truth and Justice", a German group led by the "Mother of Landsberg", Princess Elizabeth zu Isenburg, ${ }^{49}$ demanded that the government appeal to $\operatorname{Truman}^{50}$ against the scheduled hangings. Chancellor Adenauer ${ }^{51}$ sent a last-minute appeal to Mr. McCloy, who distressed and disillusioned, remained resolute.

Defense lawyers petitioned the Court of Appeals for a review of the negative decision of the District Court. On the basis of this appeal, the U.S. Solicitor-General advised on February 17, 1951 that the seven executions be stayed. Within a few days the Court of Appeals unanimously confirmed the District Court. Defense Counsel quickly appealed to the Supreme Court where at [the time of] this writing the matter is again under consideration. |12| Since men cannot easily detach themselves from the temper of the times in which they live, it is altogether fitting that judgments rendered in time of stress be dispassionately reviewed. It does not follow however, that the suffering caused by Germany's aggression gave rise to trials which should a priori be regarded as unfair. The large number of acquittals is in itself evidence of the objectivity of the judges. Whenever a felon is apprehended by the police, representing outraged and law-abiding society, it may be said that the "vanquished" culprit is in the hand of the "victor". Yet, no one would expect his release or reduction of sentence for that reason alone. As long as capital punishment exists anywhere in the world, the Nuremberg criminals should not be exempt. Portia's moving pleas that "earthly power doth then show likest God's when mercy seasons justice" ${ }^{52}$ should not obscure the fact that clemency to murderers is cruelty to future victims.

One of the most immediate postwar objectives of the Allied powers was to halt the spread of the ideology of hate which had terrorized the world. The men condemned at Nuremberg are those fanatics who willfully and enthusiastically embraced all of the perverted ideals of National Socialism.

49 Helene Elisabeth Prinzessin von Isenburg (1900-1974) war seit 1951 Präsidentin der Hilfsorganisation »Stille Hilfe«, die sich für die in Landsberg einsitzenden Kriegsverbrecher engagierte. Daher wurde sie auch als »Mutter der Gefangenen von Landsberg« bezeichnet.

50 Harry S. Truman (1884-1972) war von 1945 bis 1953 der 33. Präsident der Vereinigten Staaten.

51 Konrad Adenauer (1876-1967) war Jurist und in der Weimarer Republik Politiker der Zentrumspartei und Oberbürgermeister Kölns. 1946 wurde er erster Vorsitzender der neugegründeten CDU in der britischen Besatzungszone. 1949 bis 1963 war er der erste Bundeskanzler der Bundesrepublik Deutschland.

52 Das Zitat stammt aus einem Monolog der Figur Portia in Shakespeares Kaufmann von Venedig (Akt 4, Szene 1), in der sie Shylock um Gnade bittet. 
They are men of learning, influence and ability, who may well return to their former positions $|13|$ of leadership. The crimes are no less grave today and the perpetrators no less guilty than when they were condemned. The well intentioned though extreme generosity shown them is unfortunately regarded as a vindication of the Nazi deeds and thereby lends encouragement to those who still believe that perhaps Hitler was right.

The harm which has already been done can hardly be corrected but perhaps some useful lessons may be learned. It is hoped that American public indignation, so long dormant, will prevent any further wholesale whitewashing of these offenders and that those still in U.S. and Allied custody will not expect\{face $\}$ an easy escape. As Germany again acquires the status of a sovereign power, it is increasingly important that the inmates still remaining in Landsberg be removed from German control or influence. At a distant American army outpost, in the exile they have earned, these criminals may be beyond the reach of German pressure groups.

The ratification by twenty-seven nations of a pact to outlaw genocide and the considerations for a Bill of Human Rights represent the desperate striving of civilized man to put an end to some of the brutalities which have marred out times. ${ }^{53}$ The Nuremberg trials sought to establish, under international law, some deterrent $|14|$ to the repetition of mass cruelties but a law which is not enforced loses its meaning. International crimes must henceforth be regulated by a forum which will be free of the political dilemmas which have plagued even some of our most able statesmen.

The General Assembly of the United Nations has resolved that examination be made of the possibility of establishing an international judicial organ for the trial of persons charged with genocide or other international crimes. The creation of a world criminal court will be the subject of discussion in Geneva when the International Law Commission ${ }^{54}$ meets there in June. ${ }^{55}$ Those who have survived the agonies of Nazi tyranny and who have viewed

53 Am 11. Dezember 1946 wurde durch eine Erklärung der UN-Generalversammlung der Völkermord oder auch Genozid als ein Verbrechen verurteilt. Am 9. Dezember 1948 erfolgte die Verabschiedung der Völkermordkonvention - einen Tag vor der Allgemeinen Erklärung der Menschenrechte - durch die UN-Generalversammlung. In Kraft trat die Konvention zwei Jahre später, am 12. Januar 1951.

54 Die 1947 von der UN-Generalversammlung eingesetzte International Law Commission (ILC) erarbeitete Entwürfe zur Weiterentwicklung des internationalen Rechts.

55 Die dritte Sitzung der ILC fand vom 16. Mai bis 27. Juli 1951 in Genf statt. Themen waren unter anderem Gesetzesentwürfe zur Ahndung von Verstößen gegen den Frieden und Vorschläge für die Entwicklung einer internationalen strafrechtlichen Gerichtsbarkeit, die der UN-Generalversammlung zusammen mit einem Bericht vorgelegt wurden. Siehe Yearbook of the International Law Commission 3 (1951), 
with alarm the releases at Landsberg, will follow the progress of the Commission with interest and hope. A free and independent world tribunal for the prevention and punishment of crimes against humanity remains one of the basic needs of man.

\{Benjamin B. Ferencz

Nurnberg, Feb. 25 1951\}

\section{Dokument 7}

Benjamin B. Ferencz an Telford Taylor

Ohne Ortsangabe, 17. Dezember 1951

Maschinenschriftlicher Brief, 2 Seiten

$R G 12.001 .03 * 02$

Dear Telford:

December 17, 1951

PERSONAL \& CONFIDENTIAL

Although I know you are busy saving small business, you are the only one to whom I can turn on a problem of common concern. On several occasions McCloy has asked me what to do about the war criminals in the new contractual relationship with Germany. My first reply was to get them out of Germany and put them in an army camp somewhere. Apparently, our friend, Col. Raymond ${ }^{56}$ made a study of this some time ago and concluded that it was impossible. It is impossible for me to figure out why but if the colonel says so I guess it must be so. At least that's what McCloy thinks and is inclined to accept that view because he feels it would interfere with the "right" of the prisoners to receive visitors regularly. The next time the question was raised I suggested that McCloy turn our friends over to the French who could keep them in Strasboug [sic] and therefore it would be very convenient for the loyal followers to come and pay homage to them. McCloy seemed to like that

Bd. 2: Documents of the Third Session Including the Report of the Commission to the General Assembly, New York 1957.

56 John Raymond ( $\left.{ }^{\star} 1894\right)$ war ein amerikanischer Jurist. Ab 1948 wirkte er als Direktor der OMGUS-Rechtsabteilung und Rechtsberater des Außenministeriums der Vereinigten Staaten. 
better than my casual aside that they be dropped in the Rhine, but it seems that the French are not enthusiastic about acquiring these pets and some of the $\mathrm{HICOG}^{57}$ prison officials consider French treatment inhumane. ${ }^{58}$

When McCloy raised the problem with me a third time, I began to take him seriously and now I think he expects some sort of detailed recommendation. I strongly suspect that he connects my views with the "voice of the Jews" and would like to avoid any such repercussions as were brought about by his recent clemency actions. ${ }^{59}$

Incidentally, I notice in this morning's paper that a group of our Landsberg friends have been given their freedom as a Christmas present. These include Lammers, ${ }^{60}$ Randulic [sic] ${ }^{61}$ Gen. Fellmy, ${ }^{62}$ and Gottloeb-Berger $[\mathrm{sic}]{ }^{63}$ and three Einsatzgruppen boys, Schubert, ${ }^{64}$ Jost and Nosske. ${ }^{65}$ Schubert confessed to personally supervising the execution of about 800 Jews in a humane

57 Die High Commission for Occupied Germany nahm zwischen 1949 und 1955 die alliierten Kontrollrechte gegenüber der Bundesrepublik Deutschland wahr.

58 Vgl. dazu Claudia Moisel, Frankreich und die deutschen Kriegsverbrecher. Politik und Praxis der Strafverfolgung nach dem Zweiten Weltkrieg, Göttingen 2004.

59 Der Jüdische Weltkongress hatte die Entscheidung McCloys, eine Überprüfung der Nürnberger Urteile einzuleiten, kritisiert, weshalb letzterer mit dem Druck jüdischer Organisationen in dieser Frage rechnete. Siehe Schwartz, Die Begnadigung deutscher Kriegsverbrecher, 389.

60 Hans Lammers (1879-1962) war Richter und während des Nationalsozialismus Chef der Reichskanzlei. Im sogenannten Nürnberger Wilhelmstraßenprozess wurde er zu 20 Jahren Haft verurteilt und 1951 begnadigt.

61 Gemeint ist wahrscheinlich Lothar Rendulic (1887-1971). Rendulic war Generaloberst der Wehrmacht und wurde aufgrund der Ermordung von Zivilisten während des Zweiten Weltkriegs im Nürnberger Geiselmordprozess gegen die deutschen Generäle in Südosteuropa, dem siebten der zwölf Nürnberger Nachfolgeprozesse, zu 20 Jahren Haft verurteilt. 1951 wurde er aus Landsberg entlassen.

62 Hellmuth Felmy (1885-1965) war ein deutscher Offizier. Im Nürnberger Geiselmordprozess wurde er 1948 für seine Beteiligung an Kriegsverbrechen in Griechenland zu 15 Jahren Haft verurteilt, aber bereits 1951 aus der Haft entlassen.

63 Gottlob Berger (1896-1975) war SS-Obergruppenführer und ab 1940 Chef des SSHauptamts. Im Nürnberger Wilhelmstraßenprozess wurde er 1949 zu 25 Jahren Haft verurteilt, die 1951 auf zehn Jahre reduziert wurden. Allerdings kam er noch im selben Jahr frei.

64 Heinz Schubert (1914-1987) war SS-Obersturmführer und als Adjutant von Otto Ohlendorf im Zweiten Weltkrieg an den Verbrechen der Einsatzgruppe D beteiligt. Die Todesstrafe aus dem Nürnberger Einsatzgruppenprozess wurde 1951 in zehn Jahre Haft umgewandelt, kurz darauf erfolgte die Haftentlassung.

65 Gustav Nosske $\left({ }^{\star} 1902\right)$ war Jurist, SS-Obersturmbannführer und während des Zweiten Weltkriegs sowohl Führer des Einsatzkommandos 12 als auch im RSHA beschäf- 
manner to avoid the moral strain on the execution squad. You may recall that the deadline for cleaning up Simferopol was Christmas 1941 and that Schubert managed to kill all the Jews by then. ${ }^{66}$ So for Christmas 10 years later he goes Scot free. Who says there is no Santa Klaus? Nosske was the one whom the other defendants called the biggest bloodhound of all. The day after the sentences were imposed and Nosske only received 20 years. Now Nosske is free to join former Gen. Jost whose command ordered a fourth gas van when the three in operation executing women and children were insufficient to do the job properly. ${ }^{67}$ Noel, Noel, what the hell.

To get back to my story, I am inclined to recommend to McCloy when I get back on speaking terms with him, that there be a provision in the contractual agreement, retaining war criminals under a unilateral jurisdiction of those who sentenced them. To make this palatable, a covenant would have to be attached, outlining the principles for the $|2|$ further disposition of these gentlemen. I think it should provide for Landsberg to have, on the working level, a staff to be appointed by the German Ministry of Justice with the warden and supervisory staff appointed by the United States. This staff might consist of about 3 or 4 people but could be increased if the warden found it necessary. The supervision of the prison administration, as well as recommendations for future clemency or parole, would be up to a board consisting of the Legal Adviser to the Ambassador, a representative of the Department of the Army (who $\left\{\mathrm{ico}^{\circ} \mathrm{h}\right\}$ want $\{$ s $\}$ to retain control over the Dachau criminals), a professional U.S. penologist and a representative of the German Justice Ministry. The Board would also be responsible for following up on the 1,500 or so persons now in German jails by virtue of decisions of U.S. Military Government courts. Final authority would be vested in the Ambassador who would undoubtedly have to clear with the Department of State.

tigt. Im Nürnberger Einsatzgruppenprozess wurde er zu lebenslanger Haft verurteilt, jedoch bereits 1951 entlassen.

66 Im Dezember 1941 ermordete die von Otto Ohlendorf geleitete Einsatzgruppe D in Simferopol auf der besetzten Krim etwa 13000 Juden, Krimtschaken und »Zigeuner«. Siehe Andrej Angrick, Besatzungspolitik und Massenmord. Die Einsatzgruppe D in der südlichen Sowjetunion 1941-1943, Hamburg 2003.

67 Die Verurteilung Josts im Einsatzgruppenprozess stützte sich insbesondere auf die Bestellung eines neuen Gaswagens und von Ersatzschläuchen für drei bereits vorhandene Gaswagen im Bereich der in Weißrussland operierenden Einsatzgruppe A im Juni 1942. Siehe Michael Wildt, Generation des Unbedingten. Das Führungskorps des Reichssicherheitshauptamtes, Hamburg 2002, 761; Thilo Figaj, Heinz Jost und der Holocaust in Weißrussland 1942. Korrektur eines Täterbildes, Norderstedt 2018. 
The above represents a rough outline of my current thinking of what might be acceptable all around. I do not feel that it could be very much worse than the current farce but would welcome any views or suggestions you may have. Since all of this is more or less classified, please do not launch any public attacks without giving me a chance to take cover. If you do not answer quickly, there may not be anybody left to talk about.

I hope that Mary and the kids have gotten over the effects of their migration and that small business is booming again.

With best regards to the McHanesy [sic] ${ }^{68}$ and any other Nuernbergers about.

Cordially yours,

Benjamin B. Ferencz

Telford Taylor, Esq.

Small Defens\#e Plants Administration

Washington, D. C.

\section{Dokument 8}

Benjamin B. Ferencz an Pinchas Rosen ${ }^{69}$

New York, 25. Mai 1960

Maschinenschriftlicher Brief, 3 Seiten; gedruckter Briefkopf auf Seite 1, Kopfzeile aufjeder folgenden Seite (gedruckt: "TAYLOR, SCOLL, FERENCZ \& SIMON «, maschinenschriftlich: "Dr. Pinhas Rosen May 25,1960«)

$R G 12.003 .09 * 10$

[Ferencz wendet sich nach der Gefangennahme und Entführung Adolf Eichmanns durch den israelischen Geheimdienst an den israelischen Justizminister und gibt diesem Handlungsempfehlungen für das weitere juristische Vorgehen

68 Gemeint ist James M. McHaney (1919-1995). McHaney war amerikanischer Jurist, Hauptankläger im Nürnberger Ärzteprozess (Fall I) sowie Ankläger im Prozess gegen das Wirtschafts- und Verwaltungshauptamt der SS (Fall IV) und im Prozess gegen das Rasse- und Siedlungshauptamt der SS (Fall VIII).

69 Pinchas Rosen (1887-1978) war ein zionistischer Politiker und Jurist aus Deutschland, der 1926 ins britische Mandatsgebiet Palästina übersiedelte. 1948 war er an der Vorbereitung der israelischen Unabhängigkeitserklärung beteiligt und wurde kurz darauf zum ersten Justizminister Israels ernannt. Nach seiner ersten Amtszeit 1948 bis 1951 bekleidete er das Amt nochmals 1952 bis 1956 sowie 1958 bis 1961 . 
sowie mögliche Prozessoptionen. Auch hier sieht er die bestmögliche Lösung in einem internationalen Tribunal, da ein solches aber nicht existiert, schlägt Ferencz die Überstellung in die Bundesrepublik vor.]

|Jul. $\left.271960\right|^{170}$

\section{Taylor, Scoll, Ferencz \& Simon \\ Counselors At LaW}

Telford TAYlor

David E. SCOLL

Benjamin B. Ferencz

KenNeth Simon

Personal

Dr. Pinhas Rosen

Minister of Justice

Jerusalem, Israel

Dear Dr. Rosen:
400 Madison Avenue

New York 17, N. Y.

Murray Hill 8-8990

Cable Address: Lantalaw

May 25, 1960

The news of Adolf Eichmann's ${ }^{71}$ capture has electrified the world. As Chief Prosecutor at Nuremberg against the Einsatzgruppen, I know the reports flowing from Eichmann's office about the extermination of millions of Jews and had long been gnawed by the injustice that this man might have escaped. My first reaction of the news, therefore, was one of excitement and vicarious pride that Jewish forces had succeeded where everyone else had failed. This was followed quickly, however, by the realization of the heavy responsibility which the prisoner brings with him and it is because of this that I write to you now.

That you may not misunderstand my observations or motives, let me say at the outset that I have spent practically all of my adult life trying to

70 Eingangsstempel.

71 Adolf Eichmann (1906-1962) war SS-Obersturmbannführer und leitete die Organisation der Deportationen europäischer Juden in die nationalsozialistischen Konzentrations- und Vernichtungslager während des Zweiten Weltkriegs. Er wurde 1960 vom israelischen Geheimdienst in Argentinien aufgespürt und nach Israel entführt, wo er 1961 zum Tode verurteilt und 1962 hingerichtet wurde. 
do something about the terrible catastrophe which befell our people at the hands of the Third Reich. I entered many of the concentration camps with the American army while the crematoria were still warm. I was Executive Counsel at the subsequent Nuremberg War Crimes trials which provided an overall view of the Nazi machine and an insight into the minds of many of the mass murderers. I realize, however, that punishment or vengeance alone is not the ultimate goal and of equal importance is the need to provide redress for surviving victims insofar as it is humanly possible. I directed the JRSO, the $\mathrm{URO}$ and the Claims Conference in Germany for many years and still serve them in seeking compensation for the Nazi victims. ${ }^{72}$

Even more important than punishment or restitution is the need to do everything in our power to prevent a repetition of such devastating tragedies. At Nuremberg we tried to impress upon the world that there could be crimes against humanity requiring international censure but I must concede that this attempt has had but limited success. In a world full of strife and tensions the need to stress man's humanity to man receives little priority and, unfortunately, the responsibility for educating the world and, $|2|$ particularly, the Germans themselves, who have shut their eyes to their recent past, remains a great obligation.

I am deeply convinced that it would be a serious mistake to try Eichmann in Israel at this time. It would, of course, satisfy the understandable desire for vengeance which is a very real and important consideration. A trial in Israel, however, must evoke world reaction that it is unfair. Even though Nuremberg was a model of proper and fair judicial procedure, this slur has stained the Nuremberg record more persistently than any other and has diminished the force of what we tried to do. ${ }^{73}$ In retrospect, I think it would have been preferable had we been able to select a forum which would have been free of this objection. Where the temper of the public is inflamed against the

72 Die durch das Militärregierungsgesetz Nr. 59 etablierte JRSO war befugt, das erbenlose jüdische Eigentum zu beanspruchen und zu verteilen. Siehe zur JRSO sowie zur URO und JCC die Ausführungen in der Einleitung sowie Kagan/Weismann, Report on the Operations; Goschler, Schuld und Schulden, 107-110; Lillteicher, Raub, Recht und Restitution, 357-398.

73 Nicht nur in Deutschland, sondern auch in den Vereinigten Staaten, wo konservative Kreise zunehmend die kommunistische Gefahr an erste Stelle setzten, wurden die Nürnberger Prozesse vielfach als »Siegerjustiz« kritisiert. Dabei richteten sich die Vorwürfe nicht nur auf die Beteiligung der Sowjetunion, sondern gelegentlich auch auf die Rolle jüdischer Emigranten in den Prozessen. Siehe Buscher, The U.S. War Crimes Trial Program in Germany, 29-48; Schwartz, Die Begnadigung deutscher Kriegsverbrecher, 379-381; Weinke, Die Nürnberger Prozesse, 99-112. 
prisoner, he is entitled to a change of venue as a fundamental concept of justice. To deny Eichmann this right is to tarnish in advance the outcome of any proceedings against him.

I feel that the most appropriate forum for Eichmann's trial would be in West Germany. The West German government has earned this right and a trial in West Germany can, in my opinion, accomplish the most good. I feel it may be a dangerous mistake to turn our backs on the new and powerful German generation and the ones which will follow. We must help those who are willing to see and learn and provide them with the opportunity of understanding at first hand and in a manner acceptable to them the truth of their recent past. A trial of Eichmann in Germany can be that medium - a trial elsewhere can not. My colleague, the former General Telford Taylor who was Chief of Counsel for War Crimes and with whom I have discussed this matter, suggests an international tribunal under U.N. sponsorship if possible or under the old London Charter but neither of us sees this as a real possibility at this time. ${ }^{74}$ Perhaps it should be explored further for a U.N. tribunal sitting in Germany would certainly have much to commend it.

I am aware of the political difficulties contained in my suggestion that Eichmann be tried in Germany. In order to meet some of the objections it may be possible for the Israeli security forces to retain custody of Eichmann who will be "lent" to Germany solely for the purpose of standing trial. Israel could reserve the right to remove him to Israel for a subsequent trial at its option and it is even conceivable to me that an understanding could $|3|$ be reached with Germany that Eichmann's sentence would be served in Israel. I think this would be a particularly fitting end to his career.

Please pardon this intrusion in your affairs but I hope that you will understand the reasons which compel me to write and that you will give those thoughts your serious consideration.

Sincerely yours,

Benjamin B. Ferencz

BBF: js

74 Das Londoner Viermächte-Abkommen vom 8. August 1945, auch Londoner Charta oder Nürnberger Charta genannt, bildete die Grundlage für die rechtliche Ahndung der nationalsozialistischen Verbrechen durch die Alliierten. Neben dem Statut zur Bildung eines Internationalen Militärtribunals und dessen Prozessordnung prägte das Abkommen auch die rechtlichen Grundlagen der Nürnberger Nachfolgeprozesse. 


\section{Dokument 9}

Pinchas Rosen an Benjamin B. Ferencz

Jerusalem, 8. Juni 1960

Maschinenschriftlicher Brief, 3 Seiten; gedruckter Briefkopf auf jeder Seite (nur auf Seite 1 wiedergegeben)

$R G 12.003 .09^{\star} 10$

[In seinem Antwortschreiben weist der israelische Justizminister Pinchas Rosen Ferencz' Vorschläge und die Vorbehalte gegen einen Prozess gegen Eichmann in Israel zurück und nimmt Bezug auf einen Artikel der London Times, ${ }^{75}$ der zeitgleich zum Eintreffen von Ferencz' Brief erschien und ähnliche Bedenken äußert.]

$\diamond \diamond \diamond^{76}$

The Minister of Justice

שר המשפטים 77

Jerusalem, June 8, 1960.

$\{300 / 12\}^{78}$

Messrs. Taylor, Scoll, Ferencz \& Simon,

Counselors at Law,

400 Madison Avenue,

New York 17, N. Y.

U.S.A.

Dear Mr. Ferencz,

I have to acknowledge receipt of your letter of May 25, with reference to the trial of Eichmann. Permit me to voice the comment that your letter impresses by reason of its obvious sincerity. It is unnecessary to stress the interest I have found in its contents, but I should like to express my appreciation of your having sent it to me and of the spirit in which it is written.

However, I cannot agree with your conclusion, namely, that Adolf Eichmann should be handed over to West Germany for trial, notwithstanding the force of many of your arguments, and I should like to explain some of my reasons.

75 Anonymus, The Case of Adolf Eichmann, in: The Times, 25. Mai 1960, 13.

76 Staatswappen Israels.

77 Justizminister.

78 Vermutlich Aktenzeichen oder Vorgangsnummer des Empfängers. 
First and foremost, I must emphasize that the whole people of Israel are one in the belief that the trial of Eichmann in this country and by its judges is an historic act which is of immediate national and political importance to the Jewish people as a whole. I am aware that implicit in that statement you may find an indication that his trial will be a foregone conclusion. But my answer is that I have complete confidence in the judges of Israel and in the authorities concerned in the administration of justice as a whole, and I am absolutely assured that his case will be brought before the court paying strict attention to all his rights as an accused person, and will be judged with impartiality on the basis of the evidence led and on no other grounds whatsoever. I am proud to say that our judges have, in the past, proved their ability to rise above all emotion engendered by any situation and to withstand any pressure on their judgment which is irrelevant to the actual material brought before them, whether that pressure stems from public opinion or any other source.

|2| There are, however, further considerations which we have felt must be brought into account. Many of these were forcibly expressed in a leader in the "Times" of London, written, curiously enough, on the same date as that of your letter. Perhaps these arguments will sound more convincing if I bring them in the words of an outsider, and I shall therefore quote them here.

Firstly, says the leader in the "Times": "Israel, as a sovereign state, is entitled to treat any person physically within its territory in accordance with its own law. Its law has provided a process for the trial of Nazis and their collaborators for offences alleged to have been committed in a hostile country during the period of the Nazi regime. ... It is not disputed that a sovereign state may make laws having extra-territorial application, nor - though this is in ordinary circumstances to be deprecated - that its laws may have retrospective effect. More simply, a sovereign state is not answerable to any external authority for what it chooses to do to a person in its power."

The leader then deals with the following point and in these words: "Is there a moral case against the action Israel proposes to take? The charges against EICHMANN include crimes against the Jewish people and against humanity. These offences come within the category of "persecutions on political racial or religious grounds" for which, by Article 6 of the Nuremberg Charter of 1945, individuals may be held responsible, "whether or not in violation of the domestic law of the country where perpetrated". These last words clearly exclude the argument that EICHMANN should be handed over for trial by a German court. If he had fallen into the power of the Allies in time, he would presumably have been tried by the International Military Tribunal. That no longer exists; and no permanent international criminal court has been established to succeed it. The world is left with the concept of an "international" crime, but only national tribunals." 
And then the "Times" brings a precedent from England itself, and states: "Those who would reproach Israel for proceeding against a foreigner for crimes committed in a foreign country against people who, though coreligionists, were not Israeli subjects, may pause to consider the case of WILLIAM JOYCE. ${ }^{79} \mathrm{He}$ was technically an alien; the charges against him related to his conduct outside the realm. Nevertheless, his possession of a British passport was held to make him capable of the offence of high treason against the KING OF ENGLAND. The fact that one of $|3|$ the most learned judges of the ultimate tribunal thought the majority decision to be mistaken, and that it has since been criticized by many distinguished jurists, authorizes no foreign observer to dispute the right of the House of Lords to take its own view of the law. It is possible that EICHMANN may offer, mutatis mutandis, a plea in bar similar to that of WILLIAM JOYCE. If so, he may expect it to be carefully considered".

These arguments appear to me to contain the answer to most of the points in your letter. But I can add to them many other points that appear to me to be persuasive. I will, however, mention only two.

You yourself explain, as the "Times" does too, that it is impossible to bring Eichmann before an international tribunal. That is why you suggest his trial in West Germany. But I have reason to believe, and I ask you to accept that that belief is well-founded, that the West German authorities do not wish to take it upon themselves to try him. Your proposal will undoubtedly cause enormous difficulties at the very start before it can be put into execution.

Again, I must remind you that as long as eight years ago the Israel legislature put upon its statute-book a law dealing specifically with offenders of this kind, and for the worst of them laid down that if found guilty they should suffer sentence of death. West Germany adopted a law in 1949 completely abolishing the death penalty, and that law covers the present case. We in Israel have ourselves repealed the death penalty in most cases, but the present has been specifically and intentionally excluded from the operation of that repeal. It seems to me that to turn Eichmann over to West Germany in these circumstances would be to set at naught that intention, and I don't think we could consent to it.

79 William Joyce (1906-1946) war ein irisch-amerikanischer faschistischer Politiker, der als Jugendlicher nach Großbritannien gekommen war und 1933 durch Falschaussage einen britischen Pass erhalten hatte. Während des Zweiten Weltkriegs war er Rundfunksprecher für das deutsche Propagandaministerium und wurde 1946 wegen Hochverrats in Großbritannien verurteilt und hingerichtet. 
In the light of all this, I cannot concede that you are right in your suggestion. Although, as I have said, I must appreciate your letter, I still venture to express some surprise at some of the doubts you have brought forward. We have always believed in our moral justification and in our ability to try Eichmann properly and impartially, and I am convinced that we shall demonstrate this to the world at large.

Yours faithfully,

\{Pinhas Rosen\}

PINHAS ROSEN

MINISTER OF JUSTICE

\section{Dokument 10}

Benjamin B. Ferencz an The New York Times

New York, 29. August 1965

Gedruckter Zeitungsausschnitt (Leserbrief), ${ }^{80} 1$ Seite

$R G 12.001 .03^{*} 07$

$\underline{\text { The New York Times, Sunday, August 29, } 1965}$

To the Editor:

Auschwitz Trial ${ }^{81}$

The Auschwitz trial recently completed in Frankfurt is a tribute to the tribunal and to the Federal Republic of Germany. Its most significant contribution is its validation for the youth of Germany that the Nazi bestialities chronicled

80 Benjamin B. Ferencz, Auschwitz Trial, in: The New York Times, 29. August 1965, 13.

81 Der Frankfurter Auschwitz-Prozess fand vom 20. Dezember 1963 bis zum 20. August 1965 statt und wurde vom hessischen Generalstaatsanwalt Fritz Bauer initiiert. Dort mussten sich 22 ehemals im Konzentrations- und Vernichtungslager Auschwitz tätige Personen für ihre begangenen Verbrechen vor Gericht verantworten. Anders als bei den Nürnberger Prozessen wurde dort nach deutschem Strafrecht verhandelt. Siehe Rebecca Wittmann, Beyond Justice. The Auschwitz Trial, Cambridge, Mass./London 2005; Devin O. Pendas, Der Auschwitz-Prozess. Völkermord vor Gericht, München 2013; Raphael Gross/Werner Renz (Hg.), Der Frankfurter Auschwitz-Prozess (1963-1965). Kommentierte Quellenedition, 2 Bde., Frankfurt a. M./New York 2013. 
during the war crimes trials at Nuremberg were not, as has erroneously been alleged, exaggerations of vengeful victors applying ex post facto laws but rather an application of international justice and morality whose essence even the German criminal law has now confirmed.

Benjamin B. Ferencz

New York, Aug. 23, 1965

\section{Dokument 11}

Benjamin B. Ferencz an The New York Times. International Edition Paris, 30./31. Juli $1966^{82}$

Gedruckter Zeitungsausschnitt (Leserbrief), 1 Seite

$R G 12.001 .03 * 07$

Letters to The Editor of The Times

\{Paris Edition\}

War Crimes Trials Misunderstood

To The Editor:

Hanoi's recent threats to try American pilots as war criminals for bombing North Vietnam dramatically emphasized the need for an international criminal tribunal.

American outrage at the proposal may have been misunderstood as a hypocritical repudiation of principles, which our Government espoused at the Nuremberg trials. The United States never maintained that the Nuremberg strictures applied only to our enemies. Nazi criminals charged with initiating wars of aggression or crimes against humanity were presumed innocent until proved guilty. They were afforded open trials, with counsel of their choice, where all the arguments for their defense could be weighed in the court of world opinion.

82 Benjamin B. Ferencz, War Crimes Trials Misunderstood, in: The New York Times. International Edition, 30./31. Juli 1966, 4. 


\section{Renewed Effort Urged}

It is fortunate that Hanoi has apparently been persuaded by others that criminal charges against our airmen would be a further provocation. Let us delay no longer, however, and take steps to insure, that any accused are given the protection of the fair procedures laid down at Nuremberg. We would demonstrate our faith in the rule of law and the justness of our cause by renewed efforts to establish an international penal court where such charges brought by either side might be impartially adjudicated.

BENJAMIN B. FERENCZ

New York, July 25, 1966

\section{Dokument 12}

Benjamin B. Ferencz an Michael G. Shanahan ${ }^{83}$

New York, 7. Juli 1972

Maschinenschriftlicher Brief, 2 Seiten; gedruckter Briefkopf mit maschinenschriftlich eingefügtem Datum auf Seite 1

RG $12.002 .02^{*} 04$

\section{Taylor, Scoll, Ferencz \& Simon \\ Counselors At LaW}

Telford TAylor

OF COUNSEL

BENJAMIN B. FERENCZ

KenNeth Simon
LINCOLN BUILDING 60 EAST 42ND STREET

|July 7, 1972'

Mo 1-0934

Michael G. Shanahan

18467 40th Place N.E.

Seattle

83 Vermutlich ist Michael G. Shanahan (1940-2010) gemeint, der seit 1971 Präsident der Polizei der University of Washington war. Der Brief legt nahe, dass sich Shanahan zum Zeitpunkt der Korrespondenz noch im Studium befand. 
D̊e̊år Mํ..$^{84}$ Shanahan:

It was very imaginative of you to send me a tape recorder for my views on Herr [sic] Ohlendorf. Unfortunately, however, either I lack the imagination to make the thing work or it may have been damaged in transit. It arrived in apparent good order but nary a sound comes forth, so I hope that when you receive it back you will find that I simply forgot to press the widget and will be content with my own typing of some observations on your letter. (I am at home pretending to be on vacation.)

I shall be very glad to provide you with whatever information I have about Ohlendorf which may be useful. It would make matters much easier if I knew more precisely the thrust and content of your paper. If you can send me a copy of the draft or whatever you may have available, I will comment specifically on whatever points I believe may be of interest to you.

During the course of a 9 month trial I saw Ohlendorf almost every day and of course had ample opportunity to form my own judgments about his character and motivations. I agree with some of your observations but not with all of them. I do not believe that Ohlendorf was acting as he did solely because of superior orders. That argument applies only where a person is coerced into doing something which he would not have done on his own if he had a choice. In Ohlendorf's case I am completely convinced that he believed in the necessity and rightness of what he was doing. I vividly recall a conversation I had with him after he had been sentenced to death. I wanted to know whether this man, who admitted responsibility for 90,000 murders, had any feeling of remorse. I was not surprised that there was none. He felt that what he had done was right and told me specifically that future events would prove that he had been right. I have no doubt in my own mind that given the opportunity he would do it all again - if he thought Germany could in the end be victorious.

Ohlendorf did not picture himself as a ruthless killer. Nor should he be made to appear as an ordinary felon or madman. He was a man of great intellect and dedication. He was one of the very few men tried at Nurnberg [sic] who appeared to be telling the truth. He viewed his assignment as one which was difficult but necessary for the future well being of his country. The extermination of the Jews, including the old, sick, and the infants, was for him simply an unfortunate necessity since in his view they were enemies of the Reich.

84 Die Anrede ist zum Teil durch die Adresszeile überdruckt. 
|2| You must remember that Ohlendorf was the father of 5 children and I have no doubt that he was, to them, a kind man. (I believe that one of them became a priest and one committed suicide - possibly out of shame.) Mrs. Ohlendorf is alive and well in Germany and has nothing but the kindest memories of her late husband. She was recently interviewed by a Professor who found her quite charming and cooperative, - but unwilling to divulge the contents of letters which her husband sent her from the Russian front, and which I believe she still has in her possession.

Unfortunately, I do not have all of my records here at home but the Professor (whose name now escapes me) was writing a book for, I believe, Brandeis University where he lectured on the Holocaust. He did mention that one of his students was writing a paper on Ohlendorf, and perhaps you are the one - or you have a counterpart. If you are interested, I will search my records for more details.

You probably know that the Germans have been conducting war crimes trials against various Einsatzgruppen members. These trials have been taking place for years, and I appeared as a witness during such a trial in Darmstadt ${ }^{85}$ and have been in touch with the prosecution of a similar trial in Stuttgart, ${ }^{86}$ which is still in preparation. Although the prosecution was probably not much interested in the defendant's views of Ohlendorf, I have no doubt that some of their own observation and excuses will shed light on Ohlendorf as well. Of course, all those persons are still at large in Germany and could be

85 Im sogenannten Darmstädter Einsatzgruppenprozess verhandelte das dortige Landgericht zwischen 1965 und 1968 die Ermordung zehntausender jüdischer Männer, Frauen und Kinder durch das Sonderkommando 4a der Einsatzgruppe C in der Sowjetunion, das unter anderem auch für das Massaker von Babi Jar verantwortlich war. Siehe dazu Nathalie Gerstle, Callsen-Prozess (Babij Jar), in: Torben Fischer/Matthias N. Lorenz (Hg.), Lexikon der »Vergangenheitsbewältigung» in Deutschland. Debatten- und Diskursgeschichte des Nationalsozialismus nach 1945, Bielefeld ${ }^{3} 2015$, 154f.; Irmtrud Wojak, Fritz Bauer (1903-1968). Eine Biographie, München 2016, 393-402.

86 Möglicherweise meint Ferencz hier einen bereits abgeschlossenen Prozess am Landgericht Stuttgart, in dem zwischen 1968 und 1969 die Ermordung von hauptsächlich jüdischen Männern, Frauen und Kindern durch die Sonderkommandos 1005A und 1005B in der Ukraine verhandelt wurde. Siehe dazu Christiaan F. Rüter/ Dirk Welmoed de Mildt (Bearb.), Justiz und NS-Verbrechen. Sammlung deutscher Strafurteile wegen nationalsozialistischer Tötungsverbrechen 1945-1999, Bd. 31: Die vom 31. Oktober 1968 bis zum 14. März 1969 ergangenen Strafurteile, Amsterdam/München 2004, 694-798. Alternativ könnte sich Ferencz auch auf Ermittlungen der Zentralen Stelle der Landesjustizverwaltungen zur Aufklärung nationalsozialistischer Verbrechen in Ludwigsburg beziehen. 
approached or canvassed (with questionnaires or tape-recorders) if you really got ambitious [sic].

I don't think there is much more I can give you by way of a few general observations at this time. If you have specific questions do not hesitate to ask them and if I can shed some light I will be pleased to do so. [... $]^{87}$

I look forward to hearing further from you and hope that you will be able to send me a copy of whatever you're writing as well as some personal background on how you came to this bizarre topic.

With every good wish,

Cordially yours, ${ }^{88}$

P.S. Please write to my home

14 Bayberry Lane

New Rochelle, N. Y. 10804

\section{Dokument 13}

Benjamin B. Ferencz an John J. McCloy

New Rochelle, N. Y., 10. August 1983

Maschinenschriftlicher Brief, 2 Seiten; gedruckter Briefkopf mit maschinenschriftlich eingefügtem Datum auf Seite 1

RG $12.002 .02 * 11$

Benjamin B. Ferencz

Counsellor at Law

|August 10, 1983|

14 Bayberry Lane. New Rochelle, N. Y. 10804

914 632-3717

John J. McCloy

One Chase Manhattan Plaza

New York N.Y. 10005

87 Es folgt ein kurzer Absatz zur Bedienung des von Shanahan mitgesandten Stenocords.

88 Unterschrift fehlt auf Archivalie. 
Dear Mr. McCloy:

I enjoyed chatting with you on the phone this morning and I am writing because I share your apparent distress about some of the misinformation that continues to circulate regarding some of your past actions and attitudes. ${ }^{89} \mathrm{I}$ would consider it a privilege if I could help to set the record straight regarding those subjects of which I have personal knowledge.

Although, as a former prosecutor, I did not welcome the reduction in sentences of convicted war criminals, I never doubted that humanitarian considerations alone motivated your clemency decisions of 1951. It was apparent to me from our contacts during that trying period that you were struggling with a profound moral problem, involving life and death. When writing my book, Less Than Slaves, I searched for documentary evidence that might shed light on the reasons behind your action.

Your order establishing the Advisory Board on Clemency $<$ HICOG Staff Announcement No. 117, July 18, 1950> described the Board's powers and duties. The Board was NOT to consider "questions relating to the jurisdiction or composition of the tribunals" nor "to review the decisions of such tribunals on questions of law or fact." It was limited to considering petitions for clemency, taking into account "disparities among sentences for comparable offenses" and "the physical condition and family situation of particular defendants." It seemed clear to me that your instructions made plain that considerations of fairness and compassion were permissible to mitigate the Nuremberg sentences but not to repudiate them..$^{90}$

Furthermore, when I compared the recommendations of the Clemency Board with the final action that you ordered, it was clear to me that your decisions could not have been politically motivated by a desire to carry favor

89 Dies bezieht sich vor allem auf die Rolle McCloys bei der Begnadigung deutscher Kriegsverbrecher.

90 Ferencz zitiert in diesem Abschnitt Auszüge aus der genannten Anweisung McCloys zur Einrichtung eines Beratungsausschusses. Mit seiner Ernennung zum Hohen Kommissar war McCloy auch für die von US-Gerichten verurteilten Kriegsverbrecher in der Bundesrepublik zuständig. Da es von deutscher Seite starke, von einigen hochrangigen Politikern und Kirchenvertretern gestützte Kritik am Umgang mit den Kriegsverbrechern gab, rief McCloy eine Kommission ins Leben, die Empfehlungen zu den Begnadigungsgesuchen der Landsberger Häftlinge erarbeiten sollte. Sowohl die im August 1950 vorgelegten Empfehlungen als auch die in der Folge von McCloy ausgesprochenen Begnadigungen führten zu kontroversen Debatten. Siehe dazu Frank M. Buscher, Bestrafen und erziehen. »Nürnberg« und das Kriegsverbrecherprogramm der USA, in: Norbert Frei (Hg.), Transnationale Vergangenheitspolitik, Göttingen 2006, 94-139; Ferencz, Lohn des Grauens, $103 \mathrm{f}$. 
with the German government. Not only did you direct that five of the death sentences be carried out (despite very strong German protests), but in many instances you insisted upon harsher penalties than had been recommended by your Board! That was no way to win friends in Germany in 1951.

|2| I can not fail to remember the consistent support that you gave to the Jewish Restitution Successor Organization (JRSO) which recovered heirless Jewish property for the benefit of the survivors of Nazi persecution. The very important role that you played in encouraging Germany to adopt indemnification and restitution laws which have been of immense benefit to the survivors has not yet been adequately recorded. A 1980 publication by the Hebrew University <Nana Sagi, German Reparations, a History of the Negotiations $>^{91}$ correctly states that you "were always ready to be helpful" and "went beyond duties call" $<$ p. 190>.

My book, Less Than Slaves, pays inadequate tribute to your many efforts, as a private citizen, to persuade German industrialists to compensate some of their surviving slave laborers. All of these actions taken and supported by you, of which I have personal knowledge, reflect an attitude of sincere personal concern and a willingness to demonstrate the humanitarian considerations that $\operatorname{motiv}\{$ at $\}$ your behavior.

Those of us who are concerned with justice for the victims of Nazi persecution owe you more than we can repay. I would therefore be pleased if you could use this information in any way that may prove helpful.

With warm regards and every good wish,

Sincerely,

$\{$ Ben $\}$

\section{Dokument 14}

Benjamin B. Ferencz und John J. McCloy

New York, 24. April 1984

Maschinenschriftliches Transkript von auf Audiokassetten aufgezeichneten Gesprächen zwischen Ferencz und McCloy im Beisein von McCloys Assistentin Andrea Giles, 53 Seiten; Teil 1 (46 Seiten) mit Kopfzeile ab Seite 2 (»Interview with Mr. Ferencz April 24, 1984«), Teil 2 (7 Seiten mit neu beginnender Paginierung) mit Kopfzeile ab Seite 47 (»Lunch with Mr. Ferencz April 24, 1984«)

91 Nana Sagi, German Reparations. A History of the Negotiations, Jerusalem 1980; dt.: Wiedergutmachung für Israel. 
$R G 12.002 .02 * 12$

[AufEinladung von McCloy trifft sich Ferencz mit ihm zu einem etwa zweistündigen Gespräch, das der inhaltlichen Unterstützung eines von McCloy geplanten Buchprojekts dienen soll. Sie thematisieren McCloys Rolle bei Restitutionsfragen und den Begnadigungen von Kriegsverbrechern sowie die Hintergründe von Entscheidungsprozessen während McCloys Zeit als Hoher Kommissar in Deutschland. Zudem sprechen sie über Nürnberg als Präzedenzfall internationaler Gerichtsbarkeit und zeitgenössische Deutungen der Prozesse.]

INTERVIEW WITH MR. BENJAMIN FERENCZ

$\operatorname{rev}^{\prime} \mathrm{d}^{92} 9 / 13 / 84$

April 24, 1984

$[\ldots]^{93}|5|[\ldots]$

BF Do we want to discuss... I mean you're talking now about, you know, the influence on you in connection with the clemency for war criminals.

JJM I just wanted to point out that this reminded me that at the same time I was being importuned by the victims of Hitler, by von Schlabrendorff, ${ }^{94}$ particularly by Inge Scholl ${ }^{95}$ and by Puppi Sarre, ${ }^{96}$ to - for God's sake, Mr. McCloy (the women were talking to her) let's get rid of all of this. We've had enough of this. And these are the people that had really suffered.

92 Revised.

93 Das Gesprächstranskript beginnt mitten im Satz. In dem ausgelassenen Teil von Seite eins bis Mitte der fünften Seite beschreibt John J. McCloy seine Erinnerungen an Treffen mit ehemaligen Mitgliedern des deutschen Widerstands, etwa aus dem Umfeld der Gruppe Weiße Rose.

94 Fabian Graf von Schlabrendorff (1907-1980) war ein deutscher Jurist, Ordonanzoffizier und in Widerstandskreisen aktiv. Nach dem gescheiterten Attentat auf Hitler vom 22. Juli 1944 wurde er verhaftet und blieb bis zum Kriegsende in verschiedenen Haftstätten und Konzentrationslagern festgesetzt.

95 Inge Scholl (1917-1998) war eine deutsche Pädagogin und die Schwester von Hans und Sophie Scholl, die 1942 die studentische Widerstandsgruppe Weiße Rose gegründet hatten. Infolge der Verhaftung ihrer Geschwister 1943 wurden mehrere Mitglieder der Familie Scholl für einige Monate in Sippenhaft genommen.

96 Marie-Louise »Puppi« Sarre (1903-1999) war eine deutsche Bildhauerin und Sekretärin. Aufgrund ihrer Nähe zu Widerstandskreisen gegen die Nationalsozialisten war sie zwischen Herbst 1943 und April 1945 u. a. im Konzentrationslager Ravensbrück inhaftiert. Kurz vor Kriegsende gelang ihr die Flucht aus einem SS-Lazarett. 
BF There are others. I mean, if you are going to be citing, and you should be citing the people who approached you to show that they weren't all Nazi sympathizers, you had a delegation coming to you which was headed by Carlo Schmid ${ }^{97}$ who was a $6 \mid$ leading Social Democrat. He and several others (and I have a newspaper clipping on it and I brought it along so we can put it on the record here) visited you. Kurt Schumacher ${ }^{98}$ also said he was against the death penalty. He said, look, don't do anything to minimize the gravity of the crimes committed, but in our constitution we have outlawed the death penalty.

JJM Yes, I remember that.

BF And therefore, we ask you to please bear that in mind when you take your action. There were also groups of bishops, various church groups which came at the same time. Now, I had a conversation recently with a lady who is doing a television broadcast on my book LESS THAN SLAVES, and she raised this whole question. ${ }^{99}$ She said, well what about McCloy being visited by some group or other of generals who came and said that if he didn't release these criminals, or if he executed any of them, they wouldn't join NATO.

JJM They never made that threat.

BF I said, I never heard anything of that. And she said, oh yes, we have the minutes of the protocol of these generals, and she told me that they were some Gruppe from some place. I've forgotten now.

JJM Well maybe some generals, I didn't know any of. They never got to me.

BF She had this all down and she was sure it was so. And I said, look lady, I just never heard of such a thing, and as I know McCloy, I just can't believe that he would in any way be influenced by any

97 Der deutsche Jurist, Politikwissenschaftler und sozialdemokratische Politiker Carlo Schmid (1896-1979) war 1948/1949 an den Beratungen zum Grundgesetz der Bundesrepublik Deutschland beteiligt und amtierte 1949 bis 1966 als Vizepräsident des Deutschen Bundestags.

98 Der sozialdemokratische Politiker Kurt Schumacher (1895-1952) wurde aufgrund seiner Opposition zum Nationalsozialismus von 1933 bis 1943 in Konzentrationslagern inhaftiert. 1946 bis 1952 war er Parteivorsitzender der wiedergegründeten SPD in den Westzonen Deutschlands. Zudem war er von 1949 bis 1952 Fraktionsvorsitzender der SPD im Bundestag.

99 Wahrscheinlich ist die Journalistin und Publizistin Lea Rosh $\left({ }^{\star} 1936\right)$ gemeint, deren Dokumentarfilm Vernichtung durch Arbeit - KZ-Häftlinge für die deutsche Industrie auf Ferencz' Buch basierte und 1984 erstmals im deutschen Fernsehen gezeigt wurde. 
such approach. He would have thrown them out of the office. And she didn't like to hear that answer, frankly. I mean, she was unhappy with it. But, I just thought ... Maybe it is somewhere, you knew something that I hadn't heard about.

JJM I don't remember anything like that. I do remember Carlo Schmid. I remember the name and I remember old man Schumacher who was himself a wreck.

BF Yes, he was, sure. He was imprisoned and everything else and tortured and so on and so on. And these were big political leaders in Germany at the time.

|7| JJM Well, he was the opposite to Adenauer.

BF Well, I don't know if you have...

JJM At any rate. I'm not sure...

BF "Schumacher kommentiert Landsberger Demonstrationen," that's Schumacher comments on the Landsberger demonstrations. Everybody was protesting, marching up and down, and this also appeared in DIE NEUE ZEITUNG. ${ }^{100}$ I think if you're going to do the research on this book, you had better xerox this.

And I've got another one here - "Delegation des Bundestages eroertert mit McCloy das Problem der Landsberger Haeftlinge: Hochkommissar sichert gewissenhafte Pruefung zu." This is a meeting of Gollancz, ${ }^{101}$ the publisher from London, Victor Gollancz, a Jew, who is head of the Jewish Gesellschaft fuer Menschendienste, the Jewish organization for human services human rights group might be a translation. Theodor Vogel, ${ }^{102}$ they have here. Carlo Schmid, begruendet Antrag der SPD, he got Professor Carlo Schmid, he was SPD leader. Then you had Bishop...

JJM He's dead now too, isn't he.

100 Die Neue Zeitung wurde von Oktober 1945 bis Januar 1955 von der amerikanischen Besatzungsbehörde bzw. später der Hohen Kommission herausgegeben und sollte unter anderem die Entnazifizierungspolitik gegenüber der deutschen Bevölkerung stützen. Die Artikel wurden größtenteils von deutschen Autoren bzw. Redakteuren verfasst.

101 Victor Gollancz (1893-1967) war ein britischer Verleger und Publizist jüdischer Herkunft. Er setzte sich für die Verständigung mit Deutschland nach dem Zweiten Weltkrieg ein und gründete 1948 die Jewish Society for Human Service. Diese agierte als Hilfsorganisation vor allem in Israel, wo sie nicht nur hilfsbedürftige Juden, sondern auch Palästinenser und Araber unterstützte.

102 Theodor Vogel (1901-1977) war ein deutscher Unternehmer und Freimaurer. 
BF He's dead. Yes. He died some years ago. He wrote a very good biography. ${ }^{103}$ I don't think he dealt with this question. I don't remember. I read it, but I don't remember it.

JJM I used to know him quite well.

BF And the Bishop of Augsburg ${ }^{104}$ came along. I've got another one here also referring to the Carlo Schmid group. I think you ought to xerox all of these.

JJM I don't remember any threats ever being made to me.

BF There is no referece [sic] to any threats, but these are important delegations of non-Nazis. You were naming, you know, Schlabrendorff and others. These were, you know, "decent Germans." These were people who came...

JJM Importuning me on this business. But the people that... I knew Inge Scholl and I knew what a nice $|8|$ little girl she was. She was 23 or 24 when I was over there, and she'd been through all this ordeal, told us all about it. She used to come around the house, and then she sat down and wrote this thing absolutely unbeknownst to Ellen McCloy, ${ }^{105}$ and it's quite an eloquent thing. ${ }^{106}$ But Puppi Sarre who, as I say, saved herself on the way to Ploetzensee to be hanged in that damned room there, and she was begging Mrs. McCloy to use her influence with me - let's cut this bloodshed out Mr. McCloy, as she said. And I don't want to have anything vindictive left in me.

BF Well, I would say if you want to address yourself to the issue, you know, which has been raised, the issue raised is what were Mr. McCloy's motivations.

JJM They said they were political. Christ, I didn't ever have anything political ever cross my mind. I wouldn't know whether they were Democrats or Republicans.

BF Let me put on the tape, because she's going to have to pull all these strands together some of the thoughts... First of all, I thought you'd be amused - I was going through some of my papers (I didn't go through all of them) and I found a letter I received from

103 Carlo Schmid, Erinnerungen, Bern/München/Wien 1979.

104 Vermutlich ist Joseph Freundorfer (1894-1963) gemeint, der von 1949 bis 1963 Bischof von Augsburg war.

105 Ellen Zinsser McCloy (ca. 1898-1986) war die Ehefrau von John J. McCloy. Sie engagierte sich aktiv für gemeinnützige Zwecke und Hilfsorganisationen.

106 Wahrscheinlich meint McCloy damit das Buch Die weiße Rose, das Inge Scholl 1952 erstmals publizierte. 
Telford Taylor in July 1949 from the Department of the Army in Washington. He was then writing a report on the Nuremberg trials. He was then a general in the army. And he says in a letter to me attaching an introduction to you: "I enclose a letter for you to Mr. McCloy (I don't have that letter. I have it someplace else, I suppose) whom I think you will like very much.” Telford Taylor said I would like you very much. So you were in his good graces too, at least in July of ' 49.

JJM Yes. Later on, he got pretty excited about that.

BF Yes, we ought to deal with what excited him, because if you're going to write a serious book, and I assume that is the intention here, you have to confront, you know, the questions. I've pulled out some papers that I thought might be helpful, and if you agree, unless you have some other thoughts, I will just outline what I think the issue is on that and what my own observations are based upon my recollection as well as upon my examination of the record, because I think you $|9|$ are getting on a bit in years, they tell me, or something like that.

JJM Well, I'm 89 years old, yes.

BF Okay, you're entitled, you're entitled, you know. Okay. I think the issue was first raised by William Manchester. ${ }^{107}$

JJM He's the one that called me political. That's what sent me up the wall.

BF His allegation...

JJM And nobody in the government ever suggested anything we should do in regard to any of those cases. Acheson ${ }^{108}$ was the Secretary of State then, and he said, use your own God-given judgment, Jack, because nobody is going to tell you what you ought to do about those things. We're sorry that you have to make these decisions, but, he said, you've got to get down on your knees and make up, choose who's going to live and who's going to die and whose liberties are to be taken away. We're not going to help you.

107 Gemeint ist der amerikanische Historiker William Manchester (1922-2004), der McCloy in seinem Buch The Arms of Krupp wegen der von ihm vorgenommenen Begnadigungen scharf angegriffen hatte. William Manchester, The Arms of Krupp. 1587-1968, Boston, Mass., 1968.

108 Dean Acheson (1893-1971) war von 1949 bis 1953 Außenminister der Vereinigten Staaten. In dieser Funktion beteiligte er sich am Aufbau der westlichen Allianz als Gegenentwurf zur Sowjetunion und anderen kommunistischen Staaten während des Kalten Kriegs. 
BF Well let me answer then Manchester's allegation which is repeated elsewhere and which becomes the charge - that in fact you were lenient to some of the convicted war criminals because you were trying to win the political allegiance of Germany, of the reinforced new Germany, and therefore, in order to gain their political good will on the side of the United States and to have them join NATO and join in the Korean War and all that...

JJM That never crossed my mind.

BF Okay. That was the motivation why you released these industrialists and other big Nazis, that is the charge which should be answered and laid to rest. Because if you just beat around the bush and so on, the charge is still there. And I dealt with that in my book LESS THAN SLAVES. I tried to check the record, to find out how do you see what is really in a man's mind besides from my personal impression. I mean, I used to see you then quite regularly, and I had my own impression as to the sincerity of your motivation, which I never doubted. I never doubted it for a moment. I mean, I didn't agree $|10|$ with the specific acts of clemency. I think there were some mistakes made.

JJM I agree with that. I think there were some mistakes.

BF But then everybody is entitled to make mistakes. I never had any personal feeling - my God, you're a villain or something of that kind. I wouldn't have done it quite that way, or perhaps would have made mistakes of my own. Anyway, I set out to find how do you test a man's motive, how do you prove a man's motive. The first thing I did is I went to all the documents that I could find, and I found some very interesting ones. I found first of all the basic document - Staff Announcement No. 117 of July 18, 1950. This was the announcement issued by the Office of the U.S. High Commissioner for Germany, signed by you, dealing with the establishment of the Advisory Board on Clemency for War Criminals. That was the Peck Board ${ }^{109}$ which you set up. So I said to myself, what instructions did you give them? If you had instructed them - "now look, if you find any important political leader, don't hang him." You know, that would have been a whitewash. But what did you, in fact, say? You said, and I quote

109 Unter Leitung von David W. Peck überprüfte das von McCloy eingesetzte Begnadigungsgremium die verhängten Strafen und legte am 28. August 1950 den sogenannten Peck-Bericht vor. Siehe dazu Schwartz, Die Begnadigung deutscher Kriegsverbrecher, 390-393. 
here, among other things, "The Board shall not review the decisions of such tribunals on questions of law or fact." That was out. They were going to accept the decisions on the law and on the facts ... "The Board may consider disparities among sentences for comparable offenses and such other facts as tend to show that the sentence imposed on the defendant was excessive." The second instruction was to compare the sentences to see whether they were equal. This is an equitable approach. "The board may consider the physical condition and family situation of the particular defendant and other pertinent facts tending to warrant mitigation of his sentence." So you said, facts that would warrant mitigation would be his family situation or his physical condition - perfectly humanitarian approaches. "The Board in its discretion may permit counsel for any defendant to appear before it and shall determine the form and manner of the presentation made on behalf of any defendant." Based on that, that is about the gist of it.

JJM There was also something about newly discovered evidence.

|11| BF Now wait a minute, now this is one of things which ran into trouble. I...

JJM How could I hang somebody if I had evidence...

BF Wait a minute. Let me tell you what the problem was. I found a document on that too. I wrote to the Clemency Board. I was in Nuremberg at the time, and they were meeting in Munich. And I said, look, you know, clemency is being considered down there. I'm here. I was executive counsel at the trials. I was chief prosecutor against the Einsatzgruppen. I'm about the only one left in Germany who knew anything about the trials. So if you have any questions and you would like to ask me anything. I'm at your service. That was about the gist of my letter. They wrote back and said, well thank you very much, but we're not listening to the prosecution. We're just... I want to find that letter. I had it. Oh yes, here it is.

JJM I don't think I remember that.

BF "The Clemency Board has requested me to acknowledge your letter of 1 August. They wish to extend their thanks for your kind offer of assistance in connection with petitions for clemency submitted by Nuremberg War Criminals. The Board has been hearing only counsel of petitioners and other persons acting by or in behalf of petitioners. At this point the Board has familiarized itself with all available records and all petitions submitted. Nevertheless should the occasion arise, the Board will certainly take 
advantage of your kind offer." Thanking you and so on. Goodbye. So, they were only hearing from one side. Well, that was alright. That was their instruction. Because if you want to worry about a prisoner's health and his family condition, that is not an issue about which you need to hear from the prosecution. If you are accepting the record on the facts and on the law, there is no need to hear from the prosecution. At the time when I wrote to them, I was unaware of the instructions which they had. I was unaware of it until I researched that many years later. And I must say when I got that I said, boy, some proceeding. They listen to just one side. That's what irked Telford Taylor later, and I'll come to that.

|12 Anyway, so the first piece of evidence that I found indicated to me from your instruction that your approach to it was a purely humanitarian one, not a legal one, because you accepted the law and you accepted the facts. You were prepared to mitigate disparities in sentences between different defendants. You were prepared to take into account family circumstances, sickness and health and age of the particular defendants, as far as I can see a perfectly laudable and understandable approach that speaks for you. Then I found something which I thought was decisive, and nobody else in the world found this. I finally tracked down the Peck Report and the Peck recommendations. Peck ${ }^{110}$ didn't have it. Moran ${ }^{111}$ didn't have it. The other guy, one of them was dead, the State Department guy.

JJM Conrad Snow. ${ }^{112}$

RB [sic $]^{113}$ He didn't have it either. Nobody had it. I checked the archives of the State Department. They didn't have it. I checked the National Archives. They didn't have it. I checked with you. You didn't have

110 David W. Peck (1902-1990) war ein amerikanischer Jurist und Präsident der Ersten Berufungskammer des Obersten Gerichtshofs des Staates New York. Peck wurde 1950 zum Vorsitzenden des Advisory Board on Clemency (auch Peck-Panel) ernannt, das die Urteile der Nürnberger Nachfolgeprozesse für die 104 noch inhaftierten Landsberger Häftlinge einer Revision unterzog und Empfehlungen für die Begnadigungsgesuche der verurteilten Kriegsverbrecher erarbeitete.

111 Frederick A. Moran (1913-2013) war ein amerikanischer Jurist und Mitglied des Advisory Board on Clemency for War Criminals.

112 Conrad Snow (1889-1975) war ein amerikanischer Jurist, Rechtsberater des Außenministeriums und Mitglied des Peck-Panels.

113 Hier liegt wahrscheinlich ein Tippfehler vor, aus dem Gespräch heraus ist die Antwort Benjamin B. Ferencz zuzuordnen. 
it. I checked with Shep Stone. ${ }^{114}$ He didn't have it. Nobody had it. And then by pure chance, some buddy of mine in the State Department happened to be in the same office which Conrad Snow had been in, and he found a copy in Conrad Snow's old file cabinet. He found a carbon copy of the complete report including their recommendations, and that's the only one that I have ever been able to track down anywhere. It was of course marked "Secret" at the time, but nobody had it. By now, I've put it in the National Archives, so it's available. What I did then ...

JJM What was the gist of it?

BF That's just the point. I took their specific recommendations and I made a table. I took every single defendant. I took the Clemency Board's recommendations and I took your final decision on it. And when I began that, I had no advance inkling of where that was going to take me. I was going to test to see what were McCloy's intentions. Now, it was clear to me that if McCloy wanted to whitewash these defendants, he had an easy out. First of all, he should have appointed a less objective Clemency Board. These guys were pretty objective fellows, you know. |13| You could have appointed a number of patsies, which you didn't do. Secondly, you could have accepted all their recommendations and said, fine, this was a Clemency Board. They've done it and so and so. That's it. Much to my surprise... I mean I'm not really surprised. I wasn't surprised really, but some people were surprised. I found that in very many cases, you were more severe than the Clemency Board.

JJM I knew that I had been in some cases.

BF You were in many cases more severe. And I've got it broken down case by case, defendant by defendant, showing the Nuremberg sentence, the Clemency Board recommendation and your final decision. For example, case number one, the Medical Case. The first one: a guy by the name of Fischer ${ }^{115}$ was given life by Nuremberg; the Clemency Board recommended 10 years; you gave

114 Shepard Stone (1925-1990) war ein Journalist und von 1949 bis 1952 für den amerikanischen Hohen Kommissar in Deutschland John J. McCloy stellvertretender, später leitender Direktor für öffentliche Angelegenheiten und Informationswesen.

115 Fritz Fischer (1912-2003) war Chirurg und SS-Sturmbannführer. Während des Zweiten Weltkriegs unternahm er Experimente an inhaftierten Frauen im Konzentrationslager Ravensbrück, weshalb er im Nürnberger Ärzteprozess zu lebenslanger Haft verurteilt wurde. 1951 wurde die Strafe auf 15 Jahre Haft herabgesetzt und bereits 1954 wurde Fischer aus dem Gefängnis Landsberg entlassen. 
him 15. The second one: Genzken ${ }^{116}$ got life by the Nuremberg sentence; fifteen recommended by the Clemency Board; you gave him twenty. Handloser, ${ }^{117}$ one of the principal defendants, was given life by the Nuremberg Tribunal; the Clemency Board recommended ten; you gave him twenty. Now ...

JJM Who was that?

BF Handloser, he was one of the medical men, one of the doctors who engaged in medical experiments. So that says to me, now look, if this guy is looking to whitewash criminals and looking to make political goodwill in Germany, that is a hell of a way to do it. The Clemency Board recommends ten years, and he says give them 20. Of course, 20 was less than life, depending on the age, you know. But, even so. It goes to the point of what was your intention. Now even more so, I was the chief prosecutor in the Einsatzgruppen case. We had 13 death sentences in that case. You know, I had brought up all the Nuremberg statistics. They thought I was the greatest because I had more people sentenced to death. I didn't consider that a great honor, frankly. I mean, I'm not that type. But on the statistical chart, I was it. So you had my boys, you know. Now, Blobel, sentenced to death by Nuremberg, Peck Tribunal - death, McCloy says hang him. Braune, ${ }^{118}$ hang him. Naumann, hang him. Ohlendorf, hang him. McCloy final...

|14| JJM Now let us talk about Ohlendorf. I had this tremendous pressure on me on Ohlendorf. I don't know why. He had a lot of influence, apparently.

BF I'll tell you why. So, I see that you do two things here. One, you're tougher than your Clemency Board, and two, even more important, you confirmed death sentences in a number of cases - Pohl,

116 Karl Genzken (1885-1957) war Chef des Sanitätswesens sowie Generalleutnant der Waffen-SS. Für die Beteiligung an Menschenversuchen in Konzentrationslagern wurde er im Nürnberger Ärzteprozess zu lebenslanger Haft verurteilt, die 1951 auf 20 Jahre Haft herabgesetzt wurde. 1954 erfolgte die vorzeitige Entlassung.

117 Siegfried Handloser (1885-1954) war Internist und ab 1942 Chef des Wehrmachtssanitätswesens. Im Nürnberger Ärzteprozess wurde er zu lebenslanger Haft verurteilt, 1951 erfolgte die Haftreduktion auf 20 Jahre. Aus gesundheitlichen Gründen wurde Handloser schließlich 1953 entlassen.

118 Werner Braune (1909-1951) war Jurist und während des Zweiten Weltkriegs als SS-Obersturmbannführer Leiter des Sonderkommandos 11b der Einsatzgruppe D, das unter anderem für das Massaker von Simferopol verantwortlich war. Braune wurde im Nürnberger Einsatzgruppenprozess zum Tode verurteilt und 1951 hingerichtet. 
Blobel, Braune, Naumann, Ohlendorf. Now, if you were seeking goodwill in Germany, and if you are approached by all these decent Germans, SPD leaders and so on, and they say, for God sake, humanitarian reasons, don't execute, you have a very good out. You can say, alright, I won't execute for humanitarian reasons.

Tape one

side two

If in fact you were trying to grant clemency in order to gain good will in Germany, that was no way to get it. On the contrary, this was sure as hell going to antagonize all the friends of Ohlendorf, and all of the friends of all the others who were sentenced to hang. So, that told me very clearly your motivation, leaving aside, you know, specific cases right or wrong. But your motivation could not have been political, unless you are a total idiot which nobody says you are. I haven't heard that from anybody, you know. If I combined the three things, the instructions you gave to the board, the Clemency Board, the Peck Panel, plus your being tougher on many of the cases than the Peck recommendations, plus your carrying out the executions in five cases, this seems to me absolutely persuasive that you could not have been politically motivated. Nobody who was politically motivated would take such measures. He would have done it quite differently. If you had come to me and said, look, I want to earn Germany's goodwill, what should I do? I would have said fine, appoint a group of sympathetic people to a panel, have them lower the sentences, and you say, well, I have to accept these sentences. When the people come like SPD people and church people and all the other German political leaders who were themselves victims of the Nazis and they say, go easy on him, I say, well, I accept your recommendations. You've got to build up the future of Germany. That would be the approach. But you did the opposite. You did the $|15|$ opposite. Anyway, I sent this all to my friend Telford Taylor, and I said, Telford, I've checked it out. This was in 1978. I say, finally what appears to be the full text of the Peck Clemency Board's recommendations reached me. It's yours with my compliments, and I give it to him. I made a statistical chart showing the comparison. It's also attached and so on, and I go on. "The chart indicates that apart from the commutation of some death sentences in the Einsatz case, McCloy was generally harsher that [sic] his own clemency advisors. If, in fact, McCloy's sole motivation was the appeasement of Germany, it would have been much easier for him to just rely on Peck. This is not to 
suggest that I disagree with your statement that McCloy's action must have been a source of comfort to the industrialists, but simply that I remain unconvinced that his action was politically motivated." I wrote this in 1978. I didn't send you a copy. It wasn't written for your benefit. It was written for Taylor's benefit, and I said I've arranged that one copy of the full report goes into the National Archives. That's where it is. So, that was and is my opinion, and I've given you the basis for that opinion. There was some guy ... [...] $]^{119}$

BF There must have been somebody in the legal division, you know, who made recommendations.

|16| JJM We suggest so and so...

BF Yes, sure, sure. Because .... now let me deal more specifically with some of the complaints which are justified in my opinion. It has been voiced in many ways and it will come up again. It's no sense trying to avoid it and so on. And I'm trying to make the case the best I can, and I apologize for the fact that in my book, I only put it in footnotes. And the reason I put it in footnotes... I had put it first in the text, you know, and spelled this out a bit, because I thought it would be interesting. Telford, who wrote the introduction to the book, said, look, if you get off on this McCloy tangent, that is going to be the whole focus of the book. Nobody is going to care at all about the negotiations with the German companies. And he said, you're shifting the focus of your book. And I thought that was correct, so I said, well I think that is correct. What I'll do is I'll put it in the footnotes so that any scholar who is really seriously interested will find it. There I made the reference and the citations to these documents which I then put into the National Archives, and I said where they can be found in the National Archives so that a serious person would find them, and the record would be clear, I think, on that point, by any serious person.

Now, let me touch for a few minutes on what I think were legitimate complaints, and that came as a result of some confusion. There was an article... Let me deal with what Telford Taylor raised, because he wanted it published, and there is no secret about it. As I indicated to you, he was a great admirer of yours, and I'm sure he still is, even though he disagrees with some of your views and some of your statements. Some of them are not quite accurate, you know, based upon my research. He wrote

119 Es folgt im Gespräch eine kurze Unterhaltung über die Mitglieder des Peck-Panels. 
to Mrs. Roosevelt. ${ }^{120}$ She had written to you at some point in connection, it is before the executions, and I guess the gist of her letter was that - don't do it, or why did you do it. I'm not sure which because I don't have her letter. But you replied, and in your reply, you made several statements which were not quite accurate, and somehow Telford Taylor got a copy of that or it was published. It was published in the INFORMATION BULLETIN. He wanted to reply, and he wrote to Mrs. Roosevelt and he said, look, several statements have been made $|17|$ here which are not correct, and they impugn the integrity of the court, of General Clay, and of the Chief Prosecutor, who was Taylor, and therefore I want to set the record straight. He sent a copy of that to be published in the HICOG Bulletin; which they never published. You had your staff boys there. They were protecting the boss, so they never published it. What he said specifically was this. I have his letter here. He says there were numerous inaccuracies in your letter to her "damaging to the Nuremberg proceedings, to the judges who sat on the trials, to General Clay, and also to me. Mr. McCloy states at the outset of his letter - I inherited these cases from General Clay who for one reason or another had been unable to dispose of them finally." And he quotes your letter. Now, Taylor points out that that is only partly true, and that is correct. Taylor was right. There were some defendants whom Clay hadn't reviewed, but most of them he had reviewed. Those that he hadn't reviewed filed appeals.

JJM How do you account for the fact that he came to me?

BF On the few cases. Clay was concerned about the few, and he apologized to you and he said to you, I'm sorry to stick you with these few cases. I wish I could have cleaned this whole mess up.

JJM So he was only talking about a few cases.

BF Only talking about a few. See, he didn't stick you with all of them. He had reviewed most of them, and Taylor who knew that, he figured it out. The statement is $871 / 2$ percent incorrect.

JJM I can remember very distinctly ...

BF Sure, no question about that.

JJM I thought that Clay was saying to me, look, I've got this whole damn mess and I apologize to you. I'm proud...

120 Eleanor Roosevelt (1884-1962) war eine UN-Diplomatin und engagierte sich darüber hinaus für humanitäre Zwecke. Von 1933 bis 1945 war sie als Ehefrau von Franklin D. Roosevelt amerikanische First Lady. 
BF But he was only apologizing for one out of 12 cases. Eleven of the 12 cases he had reviewed, and as you know Lucius Clay, he wasn't just rubber stamping. He had a good legal staff checking it out, including John Raymond, who you may remember was a colonel, and $\mathrm{Al}$ Rockwell, ${ }^{121}$ and $|18|$ these were good guys. They went over their records. They made their recommendations to Clay. Clay went over it, and just as you did, he didn't rubber stamp it. He went over it, and 11 of the 12 he confirmed. So, Taylor's point, which was I think a correct point, was if you want to review, you don't have to review the 11 which have already been reviewed. Now apparently this escaped you in this process. You knew you got stuck with some, so you figured you might as well review them all since you were going about it.

JJM I remember thinking I had to review them all.

BF Right. Okay. That's one gripe which may be made - that there was no legal justification or requirement for a review of cases that have already been reviewed and had been reviewed, you know, not only by the court, but they had appealed to the Supreme Court of the United States. Every legal avenue had been explored and had gone to Clay.

JJM They were still going on when I was there.

BF Those were the ones that you were stuck with, the ones which were still pending. Clay said, look, I can't act on those. They're before the Supreme Court, so I can't act on those. I've got to stick them with my successor. That's the ones he was apologizing for. Now, the next one...

JJM That's a nuance I didn't know until this minute.

BF Okay, see. We're going to try to get it on the record. What you use and what you don't use is up to you or up to her, whoever is going to do the writing, but there is no sense, it seems to me, to pussyfoot around and try to bypass these issues, because somebody will come with a rebuttal and make these points. If you were not aware of them at the time or now, you are just vulnerable.

The next point, and this is a serious one which occurs again and again. You had the impression, which I must say is widespread, it's a myth which is difficult to kill, that Alfried Krupp was standing in for his father. Sometimes you were not concerned, you didn't know whether it was his uncle or his father or whatever, but

121 Alvin Rockwell (1908-1979) war ein amerikanischer Jurist und nach dem Zweiten Weltkrieg als stellvertretender Direktor der Rechtsabteilung bei OMGUS tätig. 
he was $|19|$ standing in for Gustav Krupp. ${ }^{122}$ You remembered Gustav's name. Well, the implication of that, which incidently was repeated by Guido Goldman ${ }^{123}$ in his report justifying why they shouldn't protest naming this scholarship fund in your honor, Guido Goldman repeats it too. The contention is that Alfried Krupp was just standing in for his father. Well if that is so, that means that Telford Taylor as the chief of counsel at Nuremberg was deliberately trying a guy not for his own crimes, but for the crimes of his father. The prosecution was prosecuting an innocent person. The judges were punishing a guy who was only a stand-in for someone else who committed the crimes. Well, this is a pretty insulting allegation. I mean, pretty widespread. And Taylor went through the roof, because Alfried Krupp was convicted for the crimes of Alfried Krupp, period. There was no relevance of anything done by his father, and although he seemed to be a very nice and gentle soul, and he may have been, but the fact is, and this was documented in spades throughout the Nuremberg record, he was the sole owner of that company during the time, and he not only was the sole owner, he sat in as the director and the chairman of the meetings when they decided what to do with these slave laborers, and to send them back to Buchenwald to be killed instead of being liberated and so on. So Alfried Krupp was guilty as found by the court unanimously, and these were judges from I don't know - Oklahoma and Colorado and so on. They didn't come with any preconceived notions. They were

122 Der deutsche Industrielle und Aufsichtsratsvorsitzende der Friedrich Krupp AG Gustav Krupp von Bohlen und Halbach (1870-1950) wurde aufgrund der engen Beziehungen zwischen dem Unternehmen und dem nationalsozialistischen Regime vor dem Internationalen Militärtribunal (IMT) in Nürnberg angeklagt. Das Verfahren gegen ihn wurde jedoch aus gesundheitlichen Gründen eingestellt. Sein Sohn Alfried Krupp von Bohlen und Halbach (1907-1967) trat 1938 in den Vorstand der Friedrich Krupp AG ein. Im März 1943 folgte die Ernennung zum Vorsitzenden des Direktoriums und zum Ende desselben Jahres wurde Alfried Krupp Alleininhaber des Unternehmens. Nach dem Zweiten Weltkrieg wurde er im Zuge der Nürnberger Nachfolgeprozesse angeklagt, zu zwölf Jahren Haft verurteilt und sein gesamtes Vermögen eingezogen. Im Januar 1951 erfolgte die Begnadigung und vorzeitige Haftentlassung durch McCloy. 1953 übernahm Alfried Krupp erneut die Leitung der Friedrich Krupp AG.

123 Guido Goldman $\left({ }^{\star} 1938\right)$ ist ein amerikanischer Politikwissenschaftler. Er gründete 1969 das Minda de Gunzburg Center for European Studies an der Harvard-Universität, das er bis 1994 leitete. 
not anti-industrialist or pro-communist or anything of the kind. These were American appellate judges, and the prosecution laid the evidence before them, and Alfried Krupp was found guilty. Now, the Clemency Board never really went into the records of the case, and the myth existed because there was this problem with his father. They wanted to indict both Krupps in the IMT trial, in Jackson's ${ }^{124}$ trial, and then they decided two of them would be too many. The French or somebody raised objections to it, and then they decided only to indict only [sic] the old man, but then they discovered that he was senile, totally senile. So the young one was spared by the father's senility in the first trial and then picked up in the second trial and convicted only of his own crimes. Anyway, so Krupp is where everybody was screaming - aha, you see, that $|20|$ proves that McCloy is only interested in saving industrialists, and he even says, the man is not guilty. He condemns the prosecution for trying an innocent man for the crimes of his father. That's the way...

JJM Jackson thought that too.

BF Everybody thought that. That's what you wrote.

AG May I ask you a question? In the Peck Panel report, it says something to the effect that there wasn't enough specific evidence linking the various Krupp defendants to the particular crimes they committed.

BF Those were acquitted. The Krupp defendants who were not linked were acquitted. Anybody who was not convicted on the weight of the evidence beyond a reasonable doubt ... That was our standard, to convict them beyond a reasonable doubt. If they were not found guilty beyond a reasonable doubt, they were acquitted. And Krupp defendants were acquitted. And besides, it wasn't the Peck Panel's to review, and they didn't review the evidence. They were instructed not to review the evidence, and they never did review the evidence.

JJM Who instructed them not to review the evidence.

BF You did, in your instructions to them. You said you have to accept the law and facts as found, and not only didn't they review the evidence, they wouldn't even hear from the prosecution on anything. So Taylor says, what kind of a review proceeding is that?

124 Robert H. Jackson (1892-1954) war ein amerikanischer Jurist. Ab 1941 wirkte er als Richter am Supreme Court und 1946 als Hauptankläger der Vereinigten Staaten beim IMT. 
The public had the impression there was a general review, and then when somebody is released, it is a repudiation of the court and the prosecution as well, and the United States government as well. So that is where they moved in on you. And I think that is the truth. There was a misunderstanding on your part as to the nature of the conviction of Alfried Krupp, and that reflected itself in your subsequent...

JJM Oh yes, I thought they were doing him dirt.

BF Because you hadn't read the record. No one expected you to read the record. The record is this high. The Peck Panel hadn't read the record $|21|$ because they were instructed not to read the record. They were told to accept the facts, and they didn't want to hear from the prosecution. If somebody came in and said, alright, Krupp is a sick man, fine. They don't have to hear from the prosecution about that. Someone comes in and says, Krupp is innocent, and they say, oh yes, he is innocent, and therefore we will release him. That is another matter, because that wasn't called for, and that wasn't your instruction. Anyway, so that is the thing that is still hanging, and I think what is hanging, or should be addressed are the errors of fact that were made. The errors of judgment are matters of judgment. If you say that Ohlendorf should not have been hanged because he was a gentleman or he should be hanged because he was a dog, I mean that is your judgment. And you know ...

JJM I know you pressed very hard for Ohlendorf's hanging. I remember talking to you about Ohlendorf a great deal.

BF Well Ohlendorf killed 90,000 people.

JJM Well I got the impression that he was...

BF You know, and he bragged about it, and he would do it again, and he told me he would do it again. I went down to the death house and spoke to him afterwards, and he said he would do it again. Of course he would do it again - he was absolutely sure he was right, and most of the defendants in the Einsatzgruppen [trial] were sure they were right. So...

JJM Well you convinced me on Ohlendorf. I was beaten over the head by a whole lot of people on Ohlendorf.

BF Well if I convinced you it was only in response to a question from you, because I found in my files also some correspondence. The Jewish organizations were after me to get after you before the decision was to be handed down, and I said, no, I won't do it. I said, I was there dealing with the restitution problems. If you asked me any questions in connection with the war crimes busi- 
ness, I would answer them as best I could, but I would not intervene to try to influence your judgment on a moral issue. This was your decision and I wouldn't intervene on $|22|$ that. So, you must have asked me what I thought, or you may have asked me some questions about Ohlendorf. You did ask me a couple of times about a few specific people, and I don't remember specifically now one by one. But I remember one of them, I came away and I said, Jesus, you had gotten some kind letters about some guy who was an awful dog. The other defendants had told me "he's the biggest bloodhound of all," and you didn't execute him. I don't object to that. I didn't ask for the death penalties. I didn't come in saying, I want blood. That's not my way. But, you made mistakes, okay? Alright. That's normal. You know, you're not God. I suppose God makes mistakes too, otherwise you wouldn't have an Auschwitz. So, but to the issue of your political motivation, there is no doubt in my mind that the record will sustain the fact that there could not have been any political motivation in your action. To the issue of whether it denigrated the impact of the trials, it did. It's a public relations fact. It weakened the stand that the United States government had previously taken. Now, the Nuremberg trials haven't gone anywhere in the history of the development of international law. I wrote a two-volume book called AN INTERNATIONAL CRIMINAL COURT: THE SEARCH FOR WORLD PEACE or something like that in which I traced the evolution of these concepts of international criminal law and what we were trying to do at Nuremberg. We were trying to make crimes against humanity, this type of genocide, a crime, which was a punishable offense, for which the heads of state and those who were directly responsible would be held accountable. Nuremberg was a step forward in that direction, but Nuremberg has almost been repudiated by the United States. The United States no longer supports the concept of an international criminal court. They haven't said so explicitly, but in all their action, United Nations and elsewhere, they take a very negative and halting position. Now anything which undermines Nuremberg, that step forward as we saw it in the prosecution, of course is something which we regret, you know. And the public relations impact had to be... You know the public doesn't know the details. You had forgotten your own instructions to the Clemency Board, and you were the man in charge, so what can you expect of $|23|$ the public? They saw this as a repudiation of the court as being a victor's court, which it wasn't. We tried to be... 
JJM I got it from a lot of places, the vindictiveness of that court against...

BF Ex post facto and vindictiveness is the big charge, and it's not true.

JJM And they were all against Alfried. They had their place lined up with and their prosecution room was lined up with Raemaekers's cartoons. ${ }^{125}$ The fellows came to me and told me, he said, they're all trying to tie it into the Kaiser. These were Americans.

BF Well...

JJM And I said, they've all got a scun [sic]. I'm not going to talk to them. I tried to talk to you because I thought you knew more about the individuals than anybody else that I could possibly talk to. But I got the strongest... right from the horse's mouth that they were all laying for Alfried, so I just felt that I was being a ...

BF Kind and just man, okay. But the record is there, and well, I think all you can do is, you know, state the record. I stated part of the record against Krupp in my book LESS THAN SLAVES. So if you take another look at that and I cited all the documents, not all, but I cited enough, you know. Have you read that book?

AG It's right over there.

BF That's good because I can look for the citation. I didn't bring one along. But the record is there. This guy is no innocent lamb by a long shot. Now whether he should be given 20 years or ten years or five years, I don't know. That depends.

JJM Well how long did he spend in jail?

BF He didn't spend very long. I think it was about five or six years, maybe seven. The sentence said it was seven years.

JJM Seven years, that's quite a long time.

|24| BF Okay, you can say look...

JJM I got to know the fellow later on...

BF I'm sure he was nice. You know, Ohlendorf was a charming fellow. He really was. The father of five children.

JJM I talked to his fiance.

BF Ohlendorf's fiance? He had a wife and five children.

JJM She came around to see me.

BF That must have been somebody else, his wife maybe.

JJM I don't know. A woman came around to see me.

BF It may have been his wife.

125 Louis Raemaekers (1869-1956) war ein niederländischer Cartoonist, der während des Ersten Weltkriegs mit seinen gegen das Deutsche Reich gerichteten Cartoons internationale Bekanntheit erlangte. 
JJM Pleaded with me.

BF He was a charming fellow. He had two doctorates, no he only had one doctorate degree. Some of the others, Rasch ${ }^{126}$ had two doctorate degrees, a degree in law and economics...

JJM Look, I don't want to put this Krupp business out of perspective. I don't think it is that important. I'm not going to try ...

BF Of course you have other things...

JJM I mean that isn't as important as what I would like to leave behind me. I'd like to be able to distill, and not because I've made a mistake. I'm ready to admit a mistake, but I really was soaked with this damn thing. I never went through such an ordeal in my life. I had to get down on my knees with the chaplain, and all that sort of business. But it was a ... it upset my family and upset me. I didn't have the adjustment, the philosophical adjustment I guess that I should have had at that point. However, and I don't want to distort it in terms of history. I would like to put my emphasis, or my thoughts and my thinking now along with what I would consider a more constructive step rather than to go into all this. I could write another book on Krupp. But I don't want to deflect from what I'm trying to do in terms of getting and $|25|$ distilling out of my experience some guidelines for the future so that we'll have a better form of decision-making process than we now have. Ours is not adequate in my judgment to meet the problems that I can see com$[\ldots]^{127}|27|[\ldots]$ ing down the road to confront us that are really quite hazardous.

BF Well, I just wrote a book. This is now Volume VII of ... I wrote six volumes dealing with the problems of world peace. Two volumes were called DEFINING INTERNATIONAL AGGRESSION: THE SEARCH FOR WORLD PEACE, the next two were INTERNATIONAL CRIMINAL COURT, also something about the search for world peace, and the third one was THE ENFORCEMENT OF INTERNATIONAL LAW. And now I wrote a short one, which

126 Otto Rasch (1891-1948) war Jurist und als SS-Brigadeführer Befehlshaber der Einsatzgruppe $\mathrm{C}$, die unter anderem für das Massaker von Babi Jar verantwortlich war. Er wurde im Nürnberger Einsatzgruppenprozess angeklagt, schied aus gesundheitlichen Gründen jedoch aus dem Verfahren aus.

127 Es folgt eine Gesprächspassage über die McCloy-Zorin-Vereinbarung von 1961, die zwischen der Sowjetunion und den Vereinigten Staaten ausgehandelt wurde und als Grundlage für weitere Verhandlungen über (nukleare) Abrüstung und die Vermeidung von Krieg dienen sollte. 
consolidates these six volumes. The six volumes were... I collected all the documents and all the historical background, Elihu Root's ${ }^{128}$ statements and all involving all this. And in my latest one, which I just gave to Norton \& Company about a week ago, I deal with the question of what you need for a peaceful world, and I deal with the McCloy-Zorin. ${ }^{129}$ I reproduce your documents, your whole correspondence in my book on enforcement of international law. I took the position then, I said, this is as far as human kind has gone toward a rational approach to problems of world peace - the McCloy-Zorin agreement which was confirmed by the General Assembly of the United Nations and then repudiated by the Soviets and in fact repudiated by the United States.

JJM Well de facto. We never actually repudiated it.

BF That's correct. But, you know, I followed up on the correspondence that you had with the guy from Colorado - Matteson, ${ }^{130}$ or whatever his name is, who had been the staff member on that. And I wrote to him and I had correspondence with him. You gave me a letter and you authorized me to be in touch with him, and I wrote to him and I said, what was really going on there? Was all this propaganda on both sides? And he said, in effect, yes, it was. He said, because if we had accepted general and complete disarmament, it would have been opening up our society to Russian surveillance and so on. We were never going to do that, and they would have had to do the same. They were never going to do that. So I said, what the heck were you guys doing?

128 Elihu Root (1845-1937) war ein amerikanischer Jurist und Politiker. Zwischen 1899 und 1904 wirkte er als Kriegsminister und von 1905 bis 1909 als Außenminister der Vereinigten Staaten. Er setzte sich für die Lösung internationaler Konflikte durch Schlichtung ein und erhielt dafür 1912 den Friedensnobelpreis. Nach dem Ersten Weltkrieg war er an der Ausarbeitung eines Statuts für den Ständigen Internationalen Gerichtshof in Den Haag beteiligt.

129 Valerian Zorin (1902-1986) war sowjetischer Diplomat und von 1960 bis 1962 Vertreter der Sowjetunion bei den Vereinten Nationen.

130 Robert E. Matteson (1914-1994) war während des Zweiten Weltkriegs Leiter einer US-Spionageabwehr-Einheit der 80. Infanteriedivision und wurde für die Gefangennahme Ernst Kaltenbrunners ausgezeichnet. Von 1953 bis 1972 arbeitete er in verschiedenen Positionen für die Regierung der Vereinigten Staaten, unter anderem war Matteson von 1955 bis 1958 Mitglied des Abrüstungsstabs und von 1962 bis 1967 in der Behörde für Rüstungskontrolle und Abrüstung tätig. Als Spezialist für atomare Abrüstung und Nachrichtendienste war er auch am amerikanisch-sowjetischen Austausch um McCloy und Zorin beteiligt. 
|28| JJM I know exactly what we were doing. Because I was running it and I said, let's try these people out. Maybe they've been thinking further than we have.

BF Right, you were the boss. Well there were two things, you said. One, we're going to sound them out. But what's the use to sound them out if you're not prepared to accept it if they go along? And the second one was to try to get their consent to a more limited treaty, put pressure on them to get a more realizable object. Now, in my last book, I deal with this question. I would be very happy if you would deal with it too in yours, because you know, the more people deal with it, the better it is from my judgment. And I had found the first time this was discussed was at the League of Nations with Litvinov ${ }^{131}$ who was the Soviet Ambassador at the League and who became a foreign minister, Maxim Litvinov. He was a very popular guy in Geneva and he was a very intelligent guy. And the question came up at one point in the League of Nations early days in which it was proposed in connection with the definition of aggression that there be an international court to determine who is the aggressor. And he said, look, we are the only socialist/communist society in the world. If you ask us to submit ourselves to a court of arbitrament, as you call it, which is Elihu Root's words too, when everybody in the world is against us... The United States tried to overthrow us by a counter-revolution and we haven't forgotten it.

$[\ldots]^{132}|30|[\ldots]$

BF But here, I'm saying, pick up McCloy-Zorin again. It was a very positive step forward and make the argument that the world has changed so that even if it was not acceptable in 1961 or whatever the date was, perhaps now it is acceptable. Enough time has gone by. The principles were sound, of complete disarmament and impartial arbitrament, verification by impartial agencies. These are the essential ingredients. So that if you can pick up on where you left it off, I think that would be a very positive and useful contribution.

JJM Well I would rather do that than retry the damn Krupp business.

131 Maxim Litvinov (1876-1951) war sowjetischer Diplomat und von 1930 bis 1939 Außenminister der Sowjetunion.

132 In diesem Gesprächsabschnitt diskutieren Ferencz und McCloy über nukleare Gefahren und Überlegungen zu transnationalen Abkommen nach dem Vorbild der McCloy-Zorin-Vereinbarung im Rahmen der UN. 
BF Of course, you shouldn't try the Krupp case. I mean, Krupp, you know, I would say, look, I would cite the two documents that I've given you to show you that there was no political motivation, and you could say the others, you were not as familiar with the facts as perhaps you might have been, but so perhaps some people would have had a different judgment, but that's it, goodbye. Goodbye. The same with Auschwitz. You've got to deal with the Auschwitz bombing too. ${ }^{133}$ You know you can't ignore these things, because people say you skipped them. You ran away from them. The Auschwitz bombing, look, your primary consideration was to win the war, then deal with the other problems. You didn't know the details. You couldn't know the details. You didn't know they would be constructive or $|31|$ destructive, and so in your judgment that was it. And that's the truth.

JJM I didn't have any decision of the Auschwitz bombing.

BF And besides, it wasn't your decision.

JJM It wasn't my decision. They said, what do you think? When I said, look, they've been around, and this is the soldiers. I was the fellow dealing with the Joint Chiefs of Staff, and I said, they tell me that in the first place, it's too deep a penetration. They're going to lose so many planes.

BF They were flying over Auschwitz at the time.

JJM Yes, I know that. I knew that. I knew that perfectly well, that they were going past the thing. But the idea was to bomb a rail line. Nothing is less productive to bomb a rail line. That night, you can put it in ...

BF In the morning, sure.

JJM Put it together. And then Sam Rosenman ${ }^{134}$ who was the Jewish representative in the White House, we consulted him on every-

1331981 veröffentlichte der britische Historiker Martin Gilbert das Buch Auschwitz and the Allies, das eine Diskussion über die Rolle von McCloy während des Zweiten Weltkriegs auslöste. Dabei ging es darum, dass er im August 1944 in seiner damaligen Funktion als stellvertretender Kriegsminister die Bitte jüdischer Organisationen, die Bahnlinien nach Auschwitz zu bombardieren, mit militärischen Argumenten abgelehnt hatte. Siehe Stuart G. Erdheim, Could the Allies Have Bombed Auschwitz-Birkenau?, in: Holocaust and Genocide Studies 11 (1997), H. 2, 129-170; Rondall Rice, Bombing Auschwitz: US 15th Air Force and the Military Aspects of a Possible Attack, in: War in History 6 (1999), H. 2, 205-229; Michael J. Neufeld/Michael Berenbaum (Hg.), The Bombing of Auschwitz. Should the Allies Have Attempted It?, New York 2000.

134 Samuel Rosenman (1896-1973) war amerikanischer Jurist und von 1943 bis 1946 Rechtsberater des Weißen Hauses. 
thing, anything to do with the Jews. And he was a hell of a good man, and a hell of a good draftsman. He and Harry Hopkins ${ }^{135}$ are the people that I dealt with in the White House. The Boss, the President ${ }^{136}$ was very much opposed to the idea of bombing Auschwitz. (They always called him the Boss.) And they called me once, said he's been over here. And they called me in and - tell us what you know about it. The Boss is opposed to it. He said they are due for extermination anyway. I think it is only going to be exacerbating. It's going to make it worse. The Boss is not in favor of it. You find out what the logistics are. And I told them what they were, and I said, we've been down there a couple of times, I find, bombing over there, but I said, in the first place, they don't think there is any kudos in bombing a line of communications there.

BF Sure, bomb the crematoria.

JJM Yes, but the idea was to bomb the line of communications which you could restore in two $|32|$ hours, and he said, when I got through talking, and Sam popped up and says, have McCloy write it, take the Boss off the hook. It was typical - have McCloy do it.

BF That's their solution - pass the burden to you.

JJM That's right. And I said, well, I'd say the same thing. Well you say it, said Sam. And that's how I happened to say it. But they weren't in favor of it. Nobody was.

BF Well the British were concealing the whole thing, playing games with it too. That's been researched pretty well, a fellow by the name of Martin Gilbert ${ }^{137}$ who was the official biographer for Churchill. ${ }^{138}$

135 Harry Hopkins (1890-1946) war ein amerikanischer Politiker und persönlicher Berater von Präsident Roosevelt.

136 Gemeint ist Franklin D. Roosevelt (1882-1945), der von 1933 bis 1945 als 32. Präsident der Vereinigten Staaten von Amerika amtierte. Obgleich die Vereinigten Staaten zu Beginn des Zweiten Weltkriegs ihre Neutralität erklärt hatten, traten sie in Roosevelts dritter Amtszeit nach dem japanischen Überraschungsangriff auf Pearl Harbor am 7. Dezember 1941 in den Krieg ein.

137 Martin Gilbert (1936-2015) war ein britischer Historiker. Er führte unter anderem die von Randolph Churchill begonnene mehrbändige Churchill-Biografie und -Edition nach dessen Tod fort.

138 Winston Churchill (1874-1965) war von 1940 bis 1945 sowie von 1951 bis 1955 Premierminister von Großbritannien. Zu seiner Haltung zur Bombardierung des Konzentrationslagers Auschwitz siehe Martin Gilbert, Auschwitz und die Alliierten, München 1982. 
JJM I know that he talked to, I know the President talked to the British about it. And he said. They're against it and so am I, said the President.

BF I think I would have been against it too, you know, frankly.

JJM Well he said, I think it will only stir them up more.

BF Well, look, I know the scene in Auschwitz. I didn't know it then, but I know it now. And in retrospect, the idea of bombing the rail lines, you're quite right, would have been absurd, because rail lines are immediately replaceable. I was an old infantry soldier, you know, in Germany all during the war. The idea of bombing the crematoria ... God, you can just see American planes bombing and killing all the inmates. What an outcry - Americans are bombing the inmates, you know. You can't hit it with the precision that the Israelis knocked out the Iraqui [sic] nuclear reactor. If you could do that, okay.

JJM Yes, sure.

BF But I was in the anti-aircraft, and we shot down more American planes than German planes, you know. With all due respect to the U.S. army, which you were in charge of.

JJM Yes.

|33| BF When I landed in Normandy Beach, the water was supposed to be up to here $<$ points to chest $>$, for me it was up to here $<$ points to forehead $>$.

JJM We didn't have that logistic figured out.

BF So I wouldn't rely on the American army to go bombing, pinpoint bombing Auschwitz. You know.

JJM So that's how it happened.

BF Here we are laughing like hell about the bombing of Auschwitz.

JJM That's how it happened, because I... look, said Sam. Look, Harry, get Jack to take this, get the Boss off the hook.

BF Right, right, right. But you see, these are issues that you have to touch on in any case, because they are live issues. One thing I think you should touch on from your own point of view and as well as from a fair presentation, is your role in connection with the restitution program. Part of it I've given here, but after you left as High Commissioner, but during your time as High Commissioner (get this down on the tape) you were perfect, you were absolutely perfect. You did everything you possibly could to help restore property to the Nazi victims and particularly heirless property, which I was responsible for. Just for the record, I was then the Director General of the Jewish Restitution Successor 
Organization which was responsible for recovering the heirless property of the Jews who had been killed. And we had a lot to do with military government, and we had the German court system to go through, and then we finally had the Court of Restitution Appeals ${ }^{139}$ which is a military government appointed court, and we had a lot of dealings with the legal department and all kinds of regulations and so on. And I can honestly say that I went to you dozens of times with problems, and I do not recall a single time when I went away other than being completely satisfied with the way you handled it. I think that is something which you don't remember any more.

JJM No, I just remember that was my general principle.

$[\ldots]^{140}|34|[\ldots]$

BF Everytime I went to him [General Clay] with a problem, he was also very responsive and very helpful. So these are things which are worth recording, because that was also a historical achievement, that never before had there been a program of this dimension to compensate the survivors of persecution by a government, and not only the theft of hundreds of thousands of pieces of property of all kinds, businesses, houses, everything they owned, jewelry, but also the program to compensate the survivors for their individual suffering, for time spent in a concentration camp, for the injury to their health, to the loss of their professions. We finally worked all this out. Your intervention with Adenauer to have them accept liability... ${ }^{141}$

JJM Adenauer, I did that time and time again.

BF I know that.

1391950 wurde als oberste Revisionsinstanz in Rückerstattungssachen auf dem Gebiet der amerikanischen Besatzungsszone der Court of Restitution Appeals (CORA) mit Sitz in Nürnberg eingerichtet. Siehe zum Aufbau der Rückerstattungsgerichtsbarkeit Walter Schwarz, Rückerstattung nach den Gesetzen der Alliierten Mächte, München 1974 (Die Wiedergutmachung nationalsozialistischen Unrechts durch die Bundesrepublik Deutschland, hg. v. Bundesminister der Finanzen in Zusammenarbeit mit Walter Schwarz, Bd. 1).

140 Es folgt ein kurzer Verweis von Ferencz auf Forschungsliteratur zu Restitutionsprogrammen.

141 McCloy wies Adenauer regelmäßig auf die große politische und moralische Bedeutung der Wiedergutmachungsfrage für die Bundesrepublik hin, wobei er es im außenpolitischen Interesse der Vereinigten Staaten vermied, unmittelbaren Druck auszuüben. Siehe zusammenfassend Goschler, Schuld und Schulden, $164 \mathrm{f}$. 
JJM Because I had my connections with Adenauer.

BF So, your intervention with Adenauer was very important. That has not been given adequate recognition anywhere, as far as I know.

JJM I haven't seen it anywhere.

BF I know the field.

JJM And I used to go to see Abs, ${ }^{142}$ remember, Abs and his friend up in Cologne, Oppenheimer, ${ }^{143}$ the banker up there.

BF And Pferdmenges ${ }^{144}$ and Oppenheimer, yes, the banker.

|35| JJM And several times I got them to importune Adenauer after I had talked to Adenauer and they upped the ante again.

BF And I remember one occasion I was in The Hague. We were negotiating this reparations agreement between Israel and Germany and the Claims Conference which represented the Jewish organizations outside of Israel. And you had come home from church. You must have been in church with Adenauer because you called me up. It was early in the morning. I said, who's waking me up. It's Sunday morning. And you said, you just came from church, and you just wanted to let me know that (because we were in the middle of negotiating all these different things) Adenauer had agreed to up the ante on something, to accept the liability of the Reich from one billion to two billion Marks.

JJM I know it was a big sum.

BF Something like that. It was a big sum. It was in the billions. I figured, well, okay, to wake me up for a couple billion, okay. But I remember that, and it was a touching occasion for me. Now, you don't remember any of these, and I wouldn't expect you to remember them. But these have never been recorded anywhere, and they are reflective of the very important role that you played

142 Hermann Josef Abs (1901-1994) war ein führender deutscher Bankier und wirkte während der Zeit des Nationalsozialismus an der sogenannten Arisierung jüdischen Vermögens mit, gleichzeitig verkehrte er in Widerstandskreisen. In der jungen Bundesrepublik war er am Abschluss des Londoner Schuldenabkommens 1953 beteiligt. Zudem nahm er in verschiedenen Positionen lange eine führende Rolle in der Deutschen Bank ein und war Mitglied zahlreicher Aufsichtsräte deutscher Unternehmen.

143 Hier ist entweder Waldemar von Oppenheim (1894-1954) oder Friedrich Carl von Oppenheim (1900-1978) gemeint. Beide waren Bankiers und geschäftsführende Teilhaber der Privatbank Sal. Oppenheim jr.

144 Robert Pferdmenges (1880-1962) war Bankier, Gesellschafter des Kölner Bankhauses Sal. Oppenheimer jr. und von 1950 bis 1962 für die CDU Abgeordneter des Bundestags. 
in a very significant new area of the evolutionary development of international principles of compensation as well as a humanitarian approach, and particularly in the Jewish questions, which ties in with Auschwitz. These go hand in hand. You can't at one time say you're an anti-Semite because you wouldn't bomb Auschwitz, and then on the other hand, you know, have that kind of a record.

AG Do you remember specific instances where you asked Mr. McCloy for things, or specific meetings?

BF Yes. There was one which I recounted when we were at the Harvard Club ${ }^{145}$ which I think is worth recounting. It's one of my favorite stories. When this whole restitution program was set up, the Jewish organizations didn't expect anything to come of it. I was then at Nuremberg. They invited me to come to Paris and asked me if I would take over the job of trying to organize the |36| whole problem of getting restitution for the Nazi victims. And they said, we really don't expect anything to come of it, but we feel we have a moral obligation to try, and they said, besides, we don't have any money, you know. So, I said, well why not? And I went to see General Clay, and I said, look, the military government law has a provision in it that the heirless Jewish property can be collected and, instead of letting it escheat to the German state which was responsible for the crime, which would be immoral, that property will go to Jewish charitable organizations and will be used then to help the survivors rehabilitate themselves. And that provision was written into the military government Restitution Law 59. ${ }^{146}$ And I said, the Jewish organizations have asked me to take that on. And he said, great, good idea. He said, Benny, that's good. You do that. And I said, I'm happy to do that. There's only one trouble. They have no money. And he said, well, I don't know how you're going

145 Der Harvard Club of New York ist ein privater Club in Midtown Manhattan. Die Mitgliedschaft ist weitgehend auf Dozenten und Alumni der Harvard-Universität in Cambridge, Massachusetts, beschränkt.

146 Am 10. November 1947 regelte die amerikanische Militärregierung durch das Militärregierungsgesetz Nr. 59 die Rückerstattung wiederauffindbaren jüdischen Eigentums. Diesem Gesetz waren intensive Verhandlungen mit amerikanischen jüdischen Organisationen, dem Stuttgarter Länderrat sowie im Alliierten Kontrollrat vorausgegangen. Siehe dazu v. a. Schwarz, Rückerstattung nach den Gesetzen der Alliierten Mächte, 12-54; Lillteicher, Raub, Recht und Restitution, 53-61; Goschler, Schuld und Schulden, 103-108. 
to do it. I said, how about giving me an allocation from occupation funds.

JJM Yes, I remember that.

BF And he said, well, you can't do that, because it's quadripartite. And he said, (those were the quadripartite days) the Russians will never agree. The French will never agree. I said, well, I'll tell you what. Supposing you give me a loan out of occupation funds, and then when I get restitution and I sell the houses and the businesses and so on, I'll pay you back. He said, can I do that legally? I said, well I just happen to have a memorandum here that says that you can. He said, okay, you go down to Bennett, ${ }^{147}$ or whoever was the finance man, and you tell him I said it was okay. So I went down and I said, I just came from the General and he says it's okay. We're going to set up this program, and he wants me to get it through in a hurry, so I'm going to need a big allocation. He said, how much do you want? I said, one million Marks will start us off, which was a lot of money. So he said, okay, if the General said it's okay. In fact, the General hadn't said how much. However, it was reasonable under the circumstances, at least in my judgment. So I got the million Marks and off I went. And we set up this big program, and we claimed 163,000 pieces of property. Then $|37|$ the money ran out, and you were in. So, I came to see you and I said, look, the money has run out, and we haven't yet gotten rolling on getting these properties back. It's a long process. We need some additional money. And you said, well, can I do that? And I said, why sure, I just happen to have a legal memorandum here saying you can do it, and you said, well if you repay it, okay. And I signed some papers, you know, and I got the second million. Then, time went on and we spent that. By that time money was coming in. But there was an urgent need for that money, because the DPs were moving out of the camps of Germany and going to Israel, and there was no housing for them. They were being housed in US army surplus pyramidal tents which were about the size of this room, and they had 15 people living in the tents on army cots, one next to each other. I'd been to Israel and seen those conditions. And so we decided to spend the money. We couldn't transfer it at the time - the Marks were blocked. There was lumber in Bavaria, and we bought and built prefabricated houses and we sent those to

147 Jack Bennett war ab 1946 Leiter des Finanzwesens des OMGUS und Sonderberater von Lucius D. Clay. 
Israel to be used as housing for these DPs who were coming out of the camps. ${ }^{148}$ And then the money ran out, so I figured why I just got to get more money. I just can't stop. So I came to see you, and you said, well, I said, look, we need this money now. We just don't have any money left to repay. I can't hold up these shipments. We were shipping these houses to Israel, people in these hot tents, no sanitation, the heat beats down on them, the rain and the cold and so on. I'll pay it back later when I get a little surplus. We just can't interrupt this. And you said okay, and I got another million. So I had three million Marks. Then one day I saw my chance. When you gave Krupp back all of his assets, I came to see you. And I said, Mr. McCloy, you've just given back to a convicted war criminal about three billion Marks in assets. I owe you three million. If you insist, I'll pay it back, but it's got to come out of the pockets of the victims, and I don't think it's fair to ask the victims to pay back the expenses of what it took to get back part of what was stolen from them. And you said, can I do it, and I said, I happen to have a legal memorandum here that says you can. And you said, "the debt is cancelled." And I think that is a lovely story which has never been told, never been printed. If you want to write something $|38|$ about, in a selling book, of a human-interest story, you may quote me. It's an accurate story, and it reflects, as well as anything else, perhaps better than anything else, the humanism in the approach to these problems and the significance of what it $[\ldots]^{149}|39|[\ldots]$ meant to the people.

BF You're not bragging about yourself, I'm telling you a story about what happened, a typical type of incident. There were others, you know, you had one general down in Stuttgart, I think. His aunt had acquired some Jewish property and ...

JJM I remember something about that.

BF We claimed it. We claimed it. And he was raising hell. How dare I, you know, and he got on me on the phone and was chewing me out, you know. I used to be a sergeant in the infantry in the war days. I didn't care very much for high ranking officers, I must admit, although later they promoted me. They gave me a rank of

148 Vgl. dazu Bentwich, The United Restitution Organisation 1948-1968, 15.

149 Auf einer Seite folgt ein Gesprächsteil über Hermann Abs sowie dessen Haltung in den Verhandlungen zum Londoner Schuldenabkommen. Zudem bedauern Ferencz und McCloy, dass viele Bekannte aus dieser Zeit inzwischen nicht mehr leben. 
a general when I was a civilian working for the War Department. Anyway, so this guy got a hold of me, and he was chewing me out - how dare I claim his aunt's got this property and how dare I suggest that, you know, that it's got to be restituted. And I said, look, Mister, we've got this law and I'm carrying out the law. And if she acquired Jewish property, she gives it back. She gets back what she gave for it, and then we're even. But it was sold under duress, and a duress transaction is revocable as soon as the duress is removed. And those are principles not only of military government law, they are principles of equity and law all over the world. And I'm going to carry out the law. And he raised hell. And he raised hell with you...

JJM I remember something like that.

$[\ldots]^{150}|40|[\ldots]$

BF I'll give you another story, since you want stories. I told you this at the Harvard Club too, and you had forgotten it, which is understandable.

We had gotten back the paintings which had been stolen by the Nazis. They had a whole list of Jewish artists that they considered were unworthy to be reproduced. One of them was Max Liebermann ${ }^{151}$ who was a very modernistic German artist. He died during the Nazi period, and they came to get his wife to take her off to a concentration camp. She committed suicide on the way down, because they had come to pick her up, so it was a sad family story with that. But we recovered the paintings, and I gave one of them to you as a gift. Yes, and I inscribed on the back of it, you know, to Mr. McCloy...

JJM Yes. I do remember it.

BF And I put that on the back of the painting, and the inscription was so fancy that people had said that they would turn it around the other way just to see the inscription and hide the painting.

JJM What's happened to it?

BF I figured out that it could be a sandwich sign, something that you have to hang in the middle so people can look at both sides

150 Das Gespräch zu dem genannten Fall wird mit inhaltlicher Wiederholung des bereits Gesagten fortgeführt.

151 Max Liebermann (1847-1935) war ein deutscher Maler und Grafiker und zählt zu den bedeutendsten Vertretern des Impressionismus. Aufgrund seiner jüdischen Herkunft und seiner als »entartete Kunst« betrachteten Werke wurde er ab 1933 von den Nationalsozialisten mit einem Berufs- und Arbeitsverbot belegt. 
of it. Anyway, you have such a painting as an expression of some appreciation from the survivors of Nazi persecution for some of your endeavors as High Commissioner. If you can dig that up somewhere, you may find that [it] has an inscription on the back there of something.

|41| JJM I remember something about that now. Anyway, you come on this bookwriting a little late in the day.

$[\ldots]^{152}$

(present politics, Elihu Root, how much to talk about Krupp)

JJM How about this newly discovered evidence business. Where did that come up?

BF I'll tell you my honest opinion. It's a joke. I'll tell you why it's a joke. In the Einsatzgruppen case, I found in Berlin, not I but one of my research people, all these loose-leaf folders which gave their daily reports of how many Jews they killed each day. And I ran down to Nuremberg to Telford Taylor with that, and I said look what we've just found. I said "we." |42| I took the credit, but it was the other guy who found them. He found them in Gestapo headquarters. And I said, look, we know how many people were killed each day, who was the commander, which unit, we have the complete description. We've got to prosecute these guys. All we have to do is pluck out these names and arrest them, see if we can find them. Telford said, we can't do it. We don't have any staff anymore. I said, what do you mean, you don't have any staff. You've got to try these guys. This is a cinch. He said, you want to do it, you can do it. So I said, okay, I'll do it. So, he stuck me with that case, and all 22 defendants were convicted, with 13 sentenced to death.

Tape two

side two

It was the record for a Nuremberg trial. After three days, I said, the prosecution rests. I gave the defendants all my documents a month in advance. I said, prepare your defense. Then they came, and if the document said, March 1, 1941, we killed 2,416 Jews, 14,000 women, children and gypsies and whatever else, they said, oh, yeah, that's my name. I was the commander of that unit. But on March 1, that was my anniversary. I was home with my wife,

152 Es folgt eine Sequenz zu aktuellen politischen Themen, Rückerinnerungen an die Restitutionsbemühungen sowie an die politischen Entwicklungen nach der McCloyZorin-Vereinbarung. 
you know. We were at home in Berlin. I didn't know about that. If I had known about it... Not me. And for every single point, they cooked up an alibi. And they came in with affidavits, newly discovered evidence, from the Buergermeister - oh yeah, he was at the wedding, you know, at the so and so, and he was there and 16 witnesses. And it was all baloney. Well I got so mad ... We had a big investigative department. I called in the head of the unit, and I said, look, I want you to go out to the home of each one of these defendants. (We put them together by that time.) You begin on the top of the roof, in the chimney, and you end up under the basement floor. You strip that house down and bring me every piece of evidence you can find, every document, every letter, everything you can find. And they did, and then of course, when he was supposed to be home celebrating his wedding celebration, he was sending a letter to his wife saying dear wife, boy did I have a day today. You should see the Jews that I killed today, you know. And so, we had all the rebuttal. So when |43| I got through after three days, they went for about six months presenting all this evidence that they weren't there, you know, all these alibis. That took me another three months to rebut on the basis of the evidence that we found. So the newly discovered evidence which they gave you, without letting the prosecution even look at it, I wouldn't give two cents for that evidence, you know.

JJM But that was part of the thing that was to be taken into account.

BF Not according to your instructions to them.

JJM No it is not, but it turns up.

BF Yes, it turns up. They came to you, and they said oh yes, look it here, and they gave you all that baloney. Newly discovered... let me take a look at that newly discovered evidence, and give me a crack at the rebuttal, then you make up your mind, not before.

JJM Well it was... I wondered where that had come from, because that was...

BF They came, of course they came.

JJM I used it as an argument.

BF Sure, they said it was a mistake. They said look, I wasn't really there. Now I've got evidence, look here.

JJM Yes, but what I used it for ... I said, look, you can't say that I should execute this man when I've got newly discovered evidence that he's innocent.

BF Yes, but did you ever get the prosecution to take a look at that evidence? What kind of a procedure is that? 
JJM No, but it's down there that that was one of the things that I had to take into account.

BF Well you shouldn't have. You shouldn't have, because newly discovered evidence without being subjected to cross examination is not very valuable evidence, is it? So that is what made Taylor annoyed, you know. McCloy was treating |44| this as a review proceeding. This isn't a review proceeding.

JJM Yes, but included amongst the things that I had to take into account was newly discovered evidence.

BF You didn't have to take anything into account. That was up to you.

JJM But that is part of the... That's down in black and white in the Landsberg business.

BF Yes, but that's not so. That's...

JJM Then I went around to see these fellows in jail. There were a lot of people, Heusinger ${ }^{153}$ and a number of people said, look...

BF Go to meet them. They're nice people.

JJM You ought to meet them. Go to see them, talk to them.

BF Ohlendorf is charming. I'm sure he never harmed a cat or a dog.

JJM I went in and talked to them and I found that some of them wouldn't talk to me, turned their back on me.

BF Really.

JJM Yes, and I didn't pay any more attention to them, but then there were others I sat down and I talked to them. I said, well look, it was this town there that you were supposed to have executed this reprisal, and they said, he said, yes, I remember that. And he was quite contrite about it. He said, I have no defense to that. He said, I was... it got out of hand and I was guilty on that. He was... There were two or three fellows there...

BF I only met one of all the defendants who was really contrite about it. And he said, look, we did terrible things and now we have to pay the price. And he at least had the decency to try to commit suicide, and he was the one who got the least clemency - Walter Klingelhoefer. ${ }^{154}$

153 Adolf Heusinger (1897-1982) war während des Zweiten Weltkriegs Generalleutnant der Wehrmacht. Er war über den Attentatsplan des 20. Juli 1944 informiert, jedoch nicht daran beteiligt. Nach dem Krieg wurde er bis 1948 von den Alliierten interniert und trat wiederholt als Zeuge während der Nürnberger Prozesse auf.

154 Wahrscheinlich meint Ferencz Waldemar Klingelhöfer. 
JJM They mentioned Warlimont. ${ }^{155}$

|45| BF General Warlimont, yes.

JJM But he was a pretty high up sort of fellow.

BF They were all pretty high up. We didn't take any small fish. The small fish we threw into the pond.

JJM I increased him...

BF We had 22 defendants. There were 3,000 guys who for two years did nothing else everyday but kill Jews, for two years, every day. And somedays they were pretty good, like in Babi Yar they killed 33,000 Jews in two days. ${ }^{156}$ That's a pretty good operation - 33,000 people, line them up and machine gun them in a ditch, you know.

JJM They killed them with machine guns.

BF Had them dig their own grave and machine gun them, but 33,000 people. You know how many you've got to kill, just ...

JJM Where did they kill them, in prisons around?

BF No they took them out into the woods and had them dig their own graves. This happened to be a ravine. They didn't have to do much digging. And then they just lined them up on the edge of the ravine and machine gunned them, throw the bodies in. That's all - push them in, you know. And that was it. So, but 33,000, you know, in two days, and it happened to be the Jewish high holidays on top of it, you know. The man who did that, the man who was in charge was a fellow by the name of Doctor Doctor Rasch. I've forgotten his first name.

JJM What happened to him?

BF We hanged him by the neck for a while. He was one of those executed. But... No, Rasch died. He died in prison. We never got to execute him. He had an epileptic stroke, and we brought

155 Walter Warlimont (1894-1976) war deutscher Offizier und diente ab 1938 als Stellvertreter der Leitung im Wehrmachtführungsamt. Er war an hochrangigen Entscheidungen wie dem Überfall auf die Sowjetunion beteiligt und wurde im Nürnberger Prozess gegen das Oberkommando der Wehrmacht zu lebenslanger Haft verurteilt. 1951 wurde das Urteil in 18 Jahre Haft umgewandelt, 1954 erfolgte die vorzeitige Entlassung.

156 Am 29. und 30. September 1941 ermordeten Einheiten der Einsatzgruppe C unter Beteiligung der Ordnungspolizei, der Geheimen Feldpolizei, der ukrainischen Miliz und der Wehrmacht in Babi Jar, einer Schlucht in der Nähe von Kiew, über 33000 jüdische Frauen, Männer und Kinder. Siehe Dieter Pohl, Die Einsatzgruppe C 1941/1942, in: Klein (Hg.), Die Einsatzgruppen in der besetzten Sowjetunion 1941/42, 71-87; Hartmut Rüss, Kiev/Babij Jar 1941, in: Gerd R. Ueberschär (Hg.), Orte des Grauens. Verbrechen im Zweiten Weltkrieg, Darmstadt 2003, 102-113. 
him in for trial and then we severed him, and then he died. But I remember first meeting him. I didn't know what a doctor doctor was. He had two doctor degrees, two doctorates, mind you, and a $[\ldots]^{157}$ bloodhound like you never saw, you know. Any way ...

[|1|] LUNCH WITH MR. BENJAMIN FERENCZ

rev'd 9/13/84

April 24, 1984

Tape three

side one at La Gouloue ${ }^{158}$

$[\ldots]^{159}|5|[\ldots]$

JJM What was the significance of my administration in Germany that was the centerpiece, probably, of one phase of my life. Another one was the ending of the Japanese war, which I would like to talk to you about at some point. What do you think? Sum it up. What was the McCloy administration in Germany that was significant.

BF Several things were significant. First of all it was reestablishing a relationship between Germany and the United States. (Now you had better get your tape out for this, because I'll give you some wisdom.) The only way to have peace is to make your enemies your friends, and Mr. McCloy did more in that direction than any other American. How is that? That will be a terrific quote. These gems I just pour off, you know.

JJM Clay did a great deal on that.

BF Clay did too, but Clay was different. They admired Clay. They liked Clay, but Clay was $|6|$ tough. You were there with the healing process. Clay made it clear to them that they had been defeated by the United States and they had nothing more to say. You tried to make them our friends.

It was a great thing, and you did something else, in connection with the restitution program. You tried to point out to them that

157 In der Fortführung des Gesprächs werden die McCloy-Zorin-Vereinbarung und McCloys Selbst- und Fremdwahrnehmung bezüglich seiner Zugehörigkeit zum Establishment thematisiert.

158 Gemeint ist das Restaurant La Goulue an der Upper East Side in New York.

159 Das zum Mittagessen verlagerte Gespräch beginnt mit einer Sequenz über Winston Churchill, aktuelle politische Herausforderungen der internationalen Politik sowie zur McCloy-Zorin-Vereinbarung. 
they could never be accepted in the family of nations unless they were ready to do justice to their victims, and you taught them. You initiated this program which continues to this very day, which has made a tremendous difference in the lives of hundreds of thousands of people who had given up on Germany.[... $]^{160}$

JJM That was one I'd forgotten about, but that was a big feature. That restitution program was very...

BF It was massive, you know, it was massive. There were millions of claims filed. There were about five million claims filed for various types of damage, and the total cost to the German government was about 70 billion Marks at the last time I saw statistics. If it is continuing, it will probably be closer to 100 billion Marks before they are through.

JJM Is that right.

BF And this is the first time in the history of mankind, as a result of massive persecution of peoples, a program of individual compensation and restitution was inaugurated. And for that the world can thank Mr. McCloy, to a large extent. How about that, another quote.

JJM That's a little extravagant.

BF These are great things. It was exciting times.

JJM I remember so well talking to you at the time I was going through that turmoil of spirit.

BF That's very difficult. You know, I went through a similar turmoil. As the chief prosecutor, I was expected to recommend sentences, and I couldn't. I couldn't. It seemed to me - how could you recommend sentences of people who had murdered over one million human beings by machine $|7|$ gunning them into a ditch. The things are so disparate that all I could ask for that they, in their judgment, make it clear that this type of crime can never be committed again. Somewhere I said, if these men be immune, then law has lost its meaning, and man must live in fear. But they have to condemn the crime because I didn't see that hanging a few people more or less would make any difference. It seemed a little inconsistent to be urging respect for human life, which was the thrust of my case, and at the same time saying - hang them, hang them. That didn't sit well with me. So I just didn't, and I said

160 An dieser Stelle schweift das Gespräch kurz ab. 
to the judge, and the judge, Michael Musmanno, ${ }^{161}$ he was the chief judge, a devout Catholic, and a big kibitzer ... You know, he liked to joke around a lot, and I was very annoyed, although as you hear, I am also a kibitzer. But in that courtroom, I was very serious. You know, the book LESS THAN SLAVES, if you've read it, you know my wife always asked, when did you start to cry. Musmanno would always be making jokes, and I thought that was no place for jokes. I mean, this was a serious business, you know. At the end of the trial, I thought, gee, this judge, I don't know what he's going to do. He went into a monastery with a priest for a week and came out, and as he sat in the courtroom listening to the sentences, he began. Ohlendorf was number one. "For the crimes which you have been convicted, I sentence you to death by hanging." Boom, boom, boom, down the list he went, chopped them all down - death by hanging, bang, death by hanging. And he had taken it very seriously, and that was his conscience. His conscience was different from mine. He was a devout Catholic. I was, I'll tell you. I was shocked.

161 Michael Musmanno (1897-1968) war ein amerikanischer Jurist. Als Richter war er an drei der Nürnberger Nachfolgeprozesse beteiligt (Fälle II, IV und IX). Im Einsatzgruppenprozess übernahm er den Vorsitz. 
3. Die Organisation der Restitution:

JRSO, URO, JCC 



\section{Dokument 15}

Benjamin B. Ferencz an Andy Logan ${ }^{1}$

Ohne Ortsangabe, 18. Mai 1951

Maschinenschriftlicher Brief, 2 Seiten; handschriftliche Korrekturen und Ergänzungen

$R G 12.001 .03 * 02$

18 May 1951

Mr. [sic] Andy Logan

The New Yorker

25 West, 43rd Street

New York 18, N.Y.

Dear Andy:

“The New Yorker is sending me another bill" I thought when your recent letter arrived. A most pleasant surprise indeed to discover your newsy [sic] missive. The joys of yesteryear have passed from Nuerberg [sic] and on this barren isle it is still a comfort to know that those who have been here abandoned have not quite been forgotten. Like Lo the poor Indian, last of the Mohicans, ${ }^{2}$ little chief Benny holds the fort of our once stalwart tribe. Only my faithful squaw and my papoosei [sic] brighten the days of this lost man on any totem pole.

To make merry with the saga of restitution will take considerable talent. Since I may not have the pleasure of seeing you as soon as you apparently anticipate, let me give you a brief outline so that you may determine whether your employers would really be interested.

The tale begins with the simple thought that the Herrenvolk ought return what was acquired by duress. Where the victim lost not only his property but his family and his life who was to put the bee on the boy with the loot? To prevent the culprits reaping an added benefit from successful extermination the humanitarian idea was born that an independent organization (as successor to the victims) would be authorized to demand restitution of the heirless or unclaimed Jewish properties which had passed into German hands after

1 Andy Logan (1920-2000) arbeitete seit 1942 als Journalistin für das Magazin The New Yorker und berichtete unter anderem über die Nürnberger Prozesse.

2 Anspielung auf den 1826 erstmals erschienenen historischen Roman von James Fenimore Cooper The Last of the Mohicans, der sprichwörtlich für den letzten Vertreter einer Gruppe oder Idee wurde. 
Uncle Adolf began implementing the fate of the Chosen People. The proceeds so derived were to be used for the relief and rehabilitation of those who had survived. Oh, noble thought!

Appropriate laws were passed by Military Government ${ }^{3}$ and the world's principal Jewish bodies established the JRSO \{Jewish Restitution Successor Organization\}, a New York corporation, to represent them in this historic effort. It soon appeared that those supermen who had been occupying homes of the Untermenschen for the past ten or fifteen years were most reluctant to make a change. The opposition to the idea of restitution increased daily and was particularly directed against this "foreign organization" which purported to speak for the dead. The German courts which were required to determine hich $\{$ each case on heirless \{its\} legal merits and upon the evidence adduced, presented a series of long and difficult obstacles. The German press and public officials increasingly raised their voices against this unjust enrichment of the foreign Jews, and powerful protective societies were formed by the persons liable to make restitution.

Finding the going rough this director general wanted out. My scheme was a simple one I would give the claims to the new \{ $\}$ democratic\{"\} German state governments and they in turn would give us a fair and prompt payment. $|2|$ The responsibility for drawn out wrangling with the Buergerschaft would then be in their hands and if it took them 10 years tant pis. After a year of Jessup-\#\#\{G̊R̊O̊ํYKo̊ $\}$-like negotiation ${ }^{4}$ the State of Hesse capitulated to the tune of 25 million DM. The other states gave 25 million promises but no money. We are keeping the pressure on, and hope has not been abandoned that some day soon we will bring them to their knees. ${ }^{5}$

Thus we have offered to take half $\{$ the time value in order that we might get out of this burdensome business. Yet currency laws prevent the effective

3 Ferencz bezieht sich auf das am 10. November 1947 erlassene amerikanische Militärregierungsgesetz Nr. 59.

4 Von März bis Juni 1951 versuchten sich Vertreter der vier alliierten Mächte in 74 Sitzungen vergeblich auf eine Agenda für ein Außenministertreffen zu verständigen. Die US-Delegation wurde von Philip C. Jessup, die sowjetische Delegation von Andrjej Gromyko geleitet. Siehe Hermann-Josef Rupieper, Der besetzte Verbündete. Die amerikanische Deutschlandpolitik 1949-1955, Opladen 1991, 236.

5 1951/1952 vereinbarte die JRSO Globalabkommen mit den vier Ländern der ehemaligen US-Zone (Bremen, Hessen, Württemberg-Baden und Bayern) und Westberlin, mit denen ihre restlichen Forderungen auf erbenloses jüdisches Eigentum für rund 48 Millionen DM pauschal abgelöst wurden. Siehe Kagan/Weismann, Report on the Operations, 8-10; Goschler, Wiedergutmachung, 175-180; Winstel, Verhandelte Gerechtigkeit, 237-267; Schreiber, New Jewish Communities in Germany after World War II, $181 \mathrm{f}$. 
use of the Deutschmarks received. They can legally be sold for dollars but only half their official value. On the other hand the Federal Republic is about to enact a law designed to equalize the burdens of the war. ${ }^{6}$ This they propose to do partly by taxing restituted properties of the extent of about $50 \%$ of the value. This would mean that the JRSO would have lost about three halfs, which is without even taking off my shoes I can commute as being not a very good business. Furthermore the expenses connected with recovering the stolen loot will have to be borne by the victims since you must realize the occupation costs imposed on the Germans must be kept to a minimum. We have begged for permission to spend the recovered funds on pre-fabricated houses or medical equipment which ${ }_{i}$ could ${ }_{1}^{7}$ be sent to Israel where Germany's victims dwell in tents on barren plains. This has been refused since the German economy (where you may purchase without limitation mink coats, caviar, imported champaign [sic] and every other luxury) must be protected.

These are some of the delightful torments which prevent me from leaving Germany. As long as there is any hope I refuse to surrender, because what is happening here is terribly wrong and everyone is too busy to notice. The battle has now reached such a pitch that it cannot go on much longer and one of these days this last warrior will be repatriated.

Mrs. Kagan ${ }^{8}$ and the kiddies have sought refuge in the States. They can be found at 6202 Grand Central Park Way, Forest Hills, N. Y. and I am sure they would welcome a call from you. Other gossip I leave to them, to Gertrude or to the back of a Christmas card.

The news from home is received like water in the desert and I hope that this volume (which is not to be taken as precedent) will encourage you to drop us a line from time to time.

Our fond affection extends to you, Charly, the kiddies and all our mutual friends.

\section{BENJAMIN B. FERENCZ}

6 Das Gesetz über den Lastenausgleich vom 14. August 1952 gewährte Deutschen, die Vermögensverluste durch den Zweiten Weltkrieg und seine Folgen erlitten hatten, darunter vor allem Bombengeschädigten, Flüchtlingen und Vertriebenen, einen finanziellen Ausgleich. Dieser wurde durch Vermögensabgaben auf die erhaltenen deutschen Vermögenswerte finanziert. Siehe dazu vor allem Michael L. Hughes, Shouldering the Burdens of Defeat. West Germany and the Reconstruction of Social Justice, Chapel Hill, N.C./London 1999; Lutz Wiegand, Der Lastenausgleich in der Bundesrepublik Deutschland 1949 bis 1985, Frankfurt a. M. u. a. 1992; Paul Erker (Hg.), Rechnung für Hitlers Krieg. Aspekte und Probleme des Lastenausgleichs, Heidelberg 2004.

7 Maschinenschriftliche Einfügung neben dem Text.

8 Gemeint ist die erste Ehefrau Saul Kagans, Elizabeth Koblenzer (gest. 1967). 


\section{Dokument 16}

Benjamin B. Ferencz an Telford Taylor

Ohne Ortsangabe, 28. Juni 1953

Maschinenschriftlicher Brief, 1 Seite

$R G 12.001 .03 * 02$

\section{Dear Telford:}

June 28, 1953

A mass of books should be leaving here within the next few days to provide you with enough reading for the next few years. Ach du liber [sic] - your home will be crawling with German generals! The memoirs etc. are still being collected by the local bookshop.

Several months ago I looked up Frau General Adam ${ }^{9}$ at the Brauhaus address you gave me. I thought I might see the old lady and in my most charming and persuasive manner convince her to depart with the old man's notes. This was to be done by asking her to show me the manuscript, grabbing it and running like hell. Probably divining that such a subtle approach was forthcoming, she moved. I traced her to 21 Alpspitzstrasse, Garmish [sic], ${ }^{10}$ but she was at the moment hiding out with relatives in Munich. Not knowing how important you considered the matter I temporarily abandoned the \#\# chase. I'll try to drop in on her next time I'm down thataway. If the $\mathrm{mm}^{11}$ is really important let me know and I'll take my bloodhounds and strongarm boys along.

My distinguished Bavarian children are beginning to fear a loyalty investigation of their foreign connections. It is indeed time that I returned to the States and started to work for a living. I was beginning to hope that your footloose businessman was about to acquire a new deputy but your silence on that score leads to the conclusion that the prospect vanished with the winters

9 Gemeint ist wahrscheinlich Isabella Adam (ca. 1885-1970), die Ehefrau des Wehrmachtsgenerals Wilhelm Adam (1877-1949), der Ende 1938 aus dem Dienst ausschied. Bei den von Ferencz gesuchten Notizen handelt es sich vermutlich um Wilhelm Adams Memoiren, die sich mit Hitlers Aufstieg seit dem Ende des Ersten Weltkriegs, der Wehrmachtsorganisation und Kriegsvorbereitungen beschäftigen. Das Manuskript befindet sich heute im Archiv des Instituts für Zeitgeschichte in München.

10 Garmisch-Partenkirchen.

11 Manuscript. 
snow. Should you discover other similar possibilities, please let me know as the temptation to depart Deutschland would be substantially reinforced by the \#\#\# knowledge that gainful employment would be promptly available elsewhere. So far the offers have been singularly lacking so I have had to confine my efforts to raking in the millions for sundry charities.

I see by the papers that you have won the Bridges case ${ }^{12}$ - for which my sincere congratulations to client and counsel. Since acquittal in such cases is seldom a bar to further prosecution these days, I presume you will have a career in defending the West Coast man until they finally succeed in evicting him. All the best!

Gertrude and Kinder join in sending fond regards to you, Mary and the Taylor tots.

Yours, ${ }^{13}$

\section{Dokument 17}

Benjamin B. Ferencz an Saul Kagan ${ }^{14}$

Ohne Ortsangabe, 3. Juli 1955

Maschinenschriftlicher Brief, 2 Seiten

$R G 12.001 .03 * 06$

12 Telford Taylor verteidigte ein Jahrzehnt lang Hunderte Opfer der von Senator Joseph McCarthy angeheizten antikommunistischen Kampagne in den Vereinigten Staaten, darunter auch Harry Bridges, den Funktionär der International Longshoreman's and Warehouseman's Union. Dieser war angeklagt worden, weil er bei seiner Einbürgerung seine frühere Mitgliedschaft in der Kommunistischen Partei unterschlagen habe. Taylor konnte den Prozess 1953 für seinen Mandanten gewinnen. Siehe Patrick Maguire, Telford Taylor, in: Independent, 24. Mai 1998, 16.; Luther A. Huston, Supreme Court Frees Bridges Under Statute of Limitations, in: The New York Times, 16. Juni 1953, 1.

13 Unterschrift fehlt auf archivalischer Kopie.

14 Saul Kagan (1922-2013) floh 1940 aus Wilna in die Vereinigten Staaten und kehrte als US-Soldat nach Europa zurück. Nach Kriegsende wurde er zum Leiter der OMGUS Financial Investigation Division ernannt, bevor er ab 1948 für die JRSO tätig wurde, u. a. als geschäftsführender Sekretär. Ab 1951 war er zudem geschäftsführender Direktor der JCC, deren Gründungsdirektorium er angehörte. In diesen Funktionen war er (mit zeitweiliger Unterbrechung) über mehrere Jahrzehnte an der Aushandlung und Umsetzung diverser Entschädigungs- und Restitutionsabkommen für Holocaustüberlebende beteiligt. 
Confidential 3 July 1955

Dear Saul:

Many thanks for your handwritten letter of June 25 giving me the various time schedules. Unfortunately, things are not working out as I had hoped and I am therefore in somewhat of a quandry [sic].

As I told you when you were here, just before his departure Boukstein ${ }^{15}$ offered that I go to work for him at a wage which was unspecified, but which was indicated as being in the neighborhood of $\$ 12,000$. He also spoke of an eventual partnership. (Others have reported him as willing to offer an immediate partnership.) I told Boukstein that I would make up my mind one way or the other only after my next visit to the States at which time I would again recanvass the field, talk to my friends, and reach a definite decision. I anticipated that, as in the past, there would be some business which could require my presence in NY around Sept. Your letter indicates that mid-November is a more appropriate date as far as the work is concerned.

The matter has become precipitous with this damned logistics problem. There is every reason to believe that within 30 days the dear US army will withdraw all of its furniture, including stove, frig. etc. To refurnish the place in any livable fashion would cost at least several thousand dollar [sic] and would cause Gertrude considerable time and trouble. If we are then to leave within a few months, it will all have been in vain. The cost of transporting such furniture to the States would be more than the junk is worth. The only alternatives seem to be to give up the idea of returning soon or else to send the family back to the States as soon as the furniture is removed.

I had not given Boukstein a definite answer, because I wanted to learn more about the present situation among lawyers in NY. I wanted in particular to talk to Taylor about a possible association which we had once discussed about 2 years ago and which had been put aside because of my other commitments and the fact that Taylors own practice was rather limited. I also wanted particularly to talk to Leavitt ${ }^{16}$ about the whole thing since he was the one primarily responsible for my getting involved in URO at all.

15 Maurice Boukstein (1905-1980) war amerikanischer Jurist, der sich in diversen jüdischen Organisationen engagierte und unter anderem für die JCC, die JRSO, die Jewish Agency und die Zionistische Weltorganization arbeitete. Gemeinsam mit Leo Guzik leitete er die Anwaltskanzlei Guzik \& Boukstein in New York.

16 Moses Leavitt (1894-1964) koordinierte über viele Jahre als stellvertretender Vorsitzender des JDC Hilfsprogramme in Europa während und nach dem Zweiten Weltkrieg und engagierte sich vielfältig für jüdische Belange. Als Schatzmeister der JCC 
The URO is still pretty much of a mess and no quick panacea is possible. We've made very substantial improvements in the past year and a half and I still have a number of uncompleted plans designed to push the organization into better shape. (Don't tell Kagan but I hope that by the end of 1955 we will have more than doubled the annual income for claimants and will have at the same time substantially reduced the deficit requirements. I hope to see better than $\$ 15$ million for the claimants as compared to the $\$ 7$ million in 1954. $)^{17} \mathrm{I}$ have been troubled about the problem of who would be my successor. You can either bring in a new man which I think would be bad since without the background he would be under a tremendous handicap for a very long time, or those who are now here could take over the responsibilities. The choice of candidates are May, ${ }^{18}$ Schoenfeldt, ${ }^{19}$ Katzenstein,${ }^{20}$ Weis, ${ }^{21}$

war Leavitt 1952 in Wassenaar an den Verhandlungen des Entschädigungsabkommens mit der Bundesrepublik beteiligt.

17 Wahrscheinlich handelt es sich bei dieser Einfügung um ein Versehen der Sekretärin von Ferencz. Da Ferencz seine Briefe für gewöhnlich diktierte und sich keine Unterschrift unter diesem Brief findet, ist davon auszugehen, dass es sich um einen Entwurf handelt, der vor dem Versand nochmals überarbeitet wurde.

18 Kurt May (1896-1992) war ein deutsch-jüdischer Jurist. 1933 emigrierte er nach Palästina, kehrte jedoch nach Ende des Zweiten Weltkriegs nach Europa zurück. Von 1948 bis 1953 leitete May die Rechtsberatungsstelle der JRSO und wurde $1952 \mathrm{zu}$ Ferencz' Stellvertreter bei der URO ernannt. Nach dessen Weggang aus Deutschland übernahm May die Leitung der URO. In diesen Positionen übte May großen Einfluss auf Gesetzgebungsprozesse der Wiedergutmachung aus und setzte sich für die Erleichterung von Restitutions- und Schadenersatzansprüchen ein.

19 Herbert Schönfeldt (1895-1956) war ein deutsch-jüdischer Rechtsanwalt. Nach der Emigration in die Vereinigten Staaten 1939 kehrte er mit dem American War Crimes Investigation Team nach Deutschland zurück und war von 1946 bis 1948 an den Vorbereitungen für die amerikanischen Kriegsverbrecherprozesse beteiligt. Anschließend arbeitete Schönfeldt von 1948 bis 1956 als Rechtsanwalt für die JRSO und wechselte von dort aus zur JCC, als deren Vertreter er Verhandlungen mit der deutschen Bundesregierung führte und das BEG von 1956 mitinitiierte.

20 Ernst Katzenstein (1898-1989) war als Rechtsanwalt in Hameln tätig. Nachdem ihm die Nationalsozialisten 1933 aufgrund seiner jüdischen Herkunft die Zulassung als Anwalt entzogen, emigrierte er ins britische Mandatsgebiet Palästina und setzte seine Tätigkeit als Rechtsanwalt dort bis 1949 fort. Nach dem Zweiten Weltkrieg engagierte er sich in Wiedergutmachungs- und Rückerstattungsangelegenheiten und war von 1949 bis 1955 Direktor der JRSO und anschließend ab 1956 Direktor der JCC Deutschland sowie Leiter des Frankfurter URO-Büros.

21 Der Rechtsanwalt George Weis (1898-1978/1979) emigrierte 1939 aus Deutschland nach Großbritannien und war als Rechtsberater, u. a. für jüdische Organisationen wie das Jewish Relief Unit, tätig. Von 1948 bis 1956 besetzte er verschiedene Posten bei 
Rosenthal ${ }^{22}$ or any others you can think of. Reichmann ${ }^{23}$ and Goldschmidt ${ }^{24}$ would also be prepared I suppose. Whether they possess the creative imagination, the organizational talent, and the necessary management skill are matters which you can judge about as well as I.

[|2|] I hate to be in the position of talking about or for myself, particularly when it has to be in the form of a letter, but I do have some thoughts on the subject which might be mutually beneficial. I think there is plenty of legal talent in the URO, but I am not sure that any of the potential candidates would want or be able to successfully cope with the personal management and budgetary problems which have taken up so much of my time in the past. They would probably welcome being relieved of any such headaches since it would ensure continued harmonious working relationships rather than competition and friction among them. The job of budget and management direction can, if necessary, be done by a periodic review twice a year, each such review lasting a few weeks. General contact with the major events can be maintained by way of correspondence. In short, if the Conference feels that

der JRSO, zuletzt als Direktor der Berliner Geschäftsstelle. Ab 1956 lebte er in Österreich und war weiterhin im Bereich der Rückerstattungs- und Wiedergutmachungsangelegenheiten tätig.

22 Karl Rosenthal (1879-1970) war ein deutsch-jüdischer Jurist. Nach dem Novemberpogrom 1938 musste er seine Kanzlei schließen und emigrierte über die Schweiz in die Vereinigten Staaten. 1949 kehrte er nach Würzburg zurück und vertrat jüdische Mandanten in Rückerstattungsverfahren, bis er 1953 nach Amerika zurückging.

23 Hans Reichmann (1900-1964) war ein deutsch-jüdischer Jurist. Ab 1927 wirkte er als Syndikus für den Centralverein deutscher Staatsbürger jüdischen Glaubens und setzte sich in dieser Funktion auch dafür ein, der nationalsozialistischen Propaganda mit eigener Aufklärungsliteratur zu begegnen. Nach dem Novemberpogrom 1938 wurde er im Konzentrationslager Sachsenhausen inhaftiert und nur unter der Auflage entlassen, sofort zu emigrieren. Kurze Zeit später siedelte er nach Großbritannien über. Dort wirkte er unter anderem von 1947 bis 1964 als Generalsekretär des URO-Büros in London und war von 1955 bis 1964 als Präsidiumsmitglied des Council of Jews from Germany - dem internationalen Dachverband jüdischer Emigranten aus Deutschland und den deutschsprachigen Gebieten Zentraleuropas - führender Vertreter der Interessen deutscher Juden in Wiedergutmachungsangelegenheiten.

24 Fritz Goldschmidt (1893-1968) war ein deutsch-jüdischer Rechtsanwalt. In den 1930er Jahren setzte er sich gegen die Berufsverbote für jüdische Ärzte ein. Nach seiner Emigration 1939 arbeitete er in Großbritannien zunächst für das Jewish Refugee Committee. Von 1948 bis 1968 war er Rechtssachverständiger für die URO in London sowie deren Büroleiter. Als Vertreter des Council of Jews from Germany war Goldschmidt 1952 an den Verhandlungen der JCC mit der Bundesrepublik in Wassenaar beteiligt. 
there is any value in maintaining a continuity of management control, and if the Conference or URO is prepared to work out some reasonable retained basis I would be pleased to continue that function from the States even if it involved coming to Europe twice a year for a few weeks in order to keep the reins in hand. I need not add that I would welcome such an arrangement since I would then not have to be completely dependent upon any other employer. I would not make such a suggestion unless I were completely convinced that the organizations would also "get their money's worth".

I would be very grateful if you could let me have your own reaction to this whole problem. It may be useful for you to discuss it with Leavitt to whom you may show this letter if you wish. If my suggestion appears feasible, I would probably want to ship the family home at once, and I would follow at a convenient time, probably mid-November as you suggest, to work out the details as well as to finalize an arrangement with Boukstein, Taylor, or perhaps someone else. If my suggestion does not attract anyone then I would probably try to "rough it" here with the family until November and make up my mind as to whether I'm coming or going after I go over the matter in the States.

Sorry to be bothering you with all this, Saul, but unfortunately I don't see any other way out at the moment. Many thanks in advance for your patience, consideration and friendship.

With best regards from all to all, ${ }^{25}$

\title{
Dokument 18
}

Benjamin B. Ferencz an Freunde $e^{26}$

New York, 16. April 1956

Maschinenschriftlicher Brief, 2 Seiten

$R G 12.001 .03^{\star} 06$

\author{
UNITED RESTITUTION ORGANIZATION \\ 50 West 77 th Street \\ New York 24, NY
}

25 Unterschrift fehlt auf archivalischer Kopie.

26 Die Empfänger konnten nicht ermittelt werden. 
Dear Friends:

16th April 1956

By this time, you may reasonably have reached the conclusion that I departed not for New York but for another world, and this is indeed another world. Being a careful planner, I arranged my trip so that I would arrive in New York in the midst of a budding spring. On board ship those who were still on their feet received notice that there was a blizzard raging on the East Coast, which fact was apparent from the peculiar gyrations of the liner. We arrived in New York to find the place blanketed in about 14 inches of snow. Almost all roads were impassable and the hope of proceeding directly to our new home was shattered.

Most of our packing crates could be unloaded within a matter of days. The balance had gone astray somewhere in Bremerhaven and was coming on another freighter.

The first night we spent at my sister's home on couches, floors and any convenient receptacles.

The next day Gertrude and I proceeded to our new home. It was of course impossible to get near it, but with the help of a friendly neighbor (whose friendship exceeding the normal bounds in America consisted of lending me a shovel) I managed within a few hours to reach the door. There I discovered that the contractors who were to build two rooms and a bath in the attic, had been forced by the weather to stop in the middle, so that we were confronted instead by a gaping mess.

In the office the situation was slightly worse, but on a smaller scale. There I faced one dirty room, unfurnished except for the loads of books and files which were dumped on the floor within a few days. Mrs. Lehner arrived amidst her own confusion which practically paralleled mine, and this is the first letter I have had a chance to dictate since I arrived.

There was much work to be done which cried for immediate attention at the JRSO, the Claims Conference, the URO and Guzik \& Boukstein. Most of it is still crying. I am slowly but slowly getting adjusted to life in America. I have joined the ranks of faithful commuters, spending about three hours a day in transit. All the busy executives rush home to their gardens in midafternoon in order to dig and ditch. Their main concern seems to be the lawn and whether it is appropriate to add lime or manure. All living rooms are elaborately and expensively decorated, and the owners do most of their living in the basement. As in England, each commuter carries a black umbrella as an identifying badge and listens to the radio eagerly each morning for the wrong weather report. This is now my life.

Gertrude has been frantically trying to buy furniture in order that we might have a place to sit. The system in America is very simple: you cannot 
enter an acceptable furniture shop without a card from a dealer introducing you. This alone automatically doubles the price. Then you must wait two to three months for delivery in order to impress you with the notion that your chair is being made exclusively for you and is greatly in demand. This doubles the price again. Furthermore, before furniture can be really acceptable it must be imported from a Scandinavian country, otherwise the decorators have a fit and tell you that the design is archaic. This doubles the price again. We are thinking about moving out into the liftvan which transported our household effects from Germany and which [|2|] is built more solidly than our house.

Hot pastrami here is wonderful and you poor Europeans probably don't even know what I am talking about. Despite the tribulations referred to Gertrude, I and the children are delighted to be home. The neighbors are most friendly and there is a feeling of being where we belong. We hope we survive. In a few days I will probably even be able to settle down to serious work. Until then please bear with me. We haven't had time to do much thinking but if we did, we would think fondly of all our friends abroad to all of whom we send our warmest regards.

Affectionately,

BENJAMIN B. FERENCZ

\section{Dokument 19}

Benjamin B. Ferencz an Martin Sobotker ${ }^{27}$

Ohne Ortsangabe, 22. Januar, 1957

Maschinenschriftlicher Brief, 2 Seiten; Kopfzeile auf Seite 2 (»Mr. Sabotker Congregation Habonim ${ }^{28}$ New York, N. Y. January 22, 1957 «)

$R G 12.001 .04^{\star} 01$

27 Martin Sobotker (1899-1977) war ein deutsch-jüdischer Jurist und als Verbandsfunktionär in jüdischen (Jugend-)Organisationen aktiv. 1939 emigrierte Sobotker in die Vereinigten Staaten, wo er unter anderem von 1946 bis 1967 als Verwaltungsdirektor der Synagogengemeinde Habonim in New York tätig war.

28 Die Congregation Habonim ist eine jüdische Gemeinde in New York, die 1939 von deutsch-jüdischen Immigranten gegründet wurde. 
Mr. Sabotker [sic]

Congregation Habonim

200 West 72nd Street

New York, N. Y.

Dear Mr. Sabotker:

As requested by you I am pleased to submit this brief summary and outline of the address I had the pleasure of giving at the Mizpah Temple on the 18th:

On January 18, 1957, Mr. Benjamin B. Ferencz, addressed the Mizpah Temple on the subject of "The World Situation, the Jews and Germany". Mr. Ferencz was formerly Executive Counsel at the Nuernberg War Crimes Trials and then Director General of the Jewish Restitution Successor Organization. He served as Counsel to the Israel-German Reparations Negotiations in The Hague and then as Director for Germany of the Conference on Jewish Material Claims against Germany. After almost 10 years in Germany serving Jewish interests, last April Mr. Ferencz returned to the United States where he resumed his law practice in New York City.

In his address, Mr. Ferencz stated that he wanted to give the Congregation "something to think about". As he scanned the political scene in Russia, Poland and Hungary he invited particular attention to the plight of the Jews in those countries. He described incidents in the exodus of the refugees from Hungary to indicate that despite the common suffering and the common persecution anti-semitism persisted. This reminded him of the demonstration of overt anti-semitism he witnessed during the war among the inmates of a Concentration Camp at the time of their liberation by the American Army. "Suffering alone" said Mr. Ferencz "teaches people nothing, Mitmenschgefuehl [sic] and tolerance must be developed by other means".

In surveying the political situation in the Middle-East Mr. Ferencz carefully analyzed the Eisenhower Doctrine. ${ }^{29}$ He raised a number of questions indicating that the Eisenhower Doctrine may not be adequate to cope

29 Mit der Eisenhower-Doktrin vom 5. Januar 1957 sicherte der amerikanische Präsident Eisenhower den Ländern des Nahen Ostens finanzielle und militärische Unterstützung für den Widerstand gegen sowjetische Einflussnahme oder Aggressionen zu. 
with some of the imminent problems facing Jews in that area. He referred to types of aggression, $|2|$ such as psychological and economic, which he indicated are more immediate threats than the fear of overt armed intervention by International Communism. He described the plight of the Jews in Egypt who now are being deported and expropriated in a manner reminiscent of the early days of Adolf Hitler. He emphasized the fact that inadequate attention had been paid to the problems faced by the Jews in Egypt in [sic] the major problems of absorption which the State of Israel has before it. "How long", he asked, "will the world stand by without taking effective action while the inhabitants of a tiny nation must live in constant fear and insecurity?".

After his many years in Germany, Mr. Ferencz spoke with real authority about the situation in that country. He described the condition of the Jewish Communities and the attitude of the Germans toward the Jews. He examined the question of American Foreign Policy in Germany and called it "one of the major speculations of our time." "Russia," he said, "will not surrender the Eastern Part of Germany without receiving its price". He noted that Russia can offer reunification, trade and neutrality to Germany, whereas the West has already given Germany everything it wanted. "No one can foretell now", said Mr. Ferencz, "whether Germany will be part of a Cordon Sanitaire, a Third Force or a Satellite of either East or West."

At the conclusion of his address, Mr. Ferencz again scanned the world horizon and the part of the Jews in particular, thereby giving the Congregation very much to think about.

I would appreciate receiving from you a copy of your Bulletin on this matter. Let me again convey my appreciation for the opportunity of addressing the Congregation.

SINCERELY YOURS,

BENJAMIN B. FERENCZ 


\section{Dokument 20}

Benjamin B. Ferencz an Eugene Kaufmann ${ }^{30}$

Ohne Ortsangabe, 8. Januar 1958

Maschinenschriftlicher Brief, 2 Seiten

$R G 12.001 .03 * 03$

January 8,1958

Dear Eugene:

I am writing with reference to your recent phone call requesting a confession of my past deeds for your own nefarious purposes.

I am a graduate of the Harvard Law School and a member of the New York Bar. From 1946 to 1948 I was Executive Counsel in the office of the Chief of Counsel for War Crimes in Nuremberg, where I also served as Chief Prosecutor in the War Crimes trial against SS-General Ohlendorf and 23 other defendants charged with the murder of over one million Jews. These defendants were the leaders of special extermination squads operating in Poland and Russia and having as their assignment the elimination of the Jews and any other possible sources of opposition to the Nazi regime. Although all of the defendants were convicted, and 13 were sentenced to death, with the remainder receiving long prison terms, subsequent clemency action eventually released most of the defendants. Four were actually hanged, including Ohlendorf who admitted murdering 90,000 Jews.

At the end of 1948, I took over the job of trying to recover heirless Jewish property in the U.S. zone of Germany pursuant to Military Government law. As Director-General of the Jewish Restitution Successor Organization, over 100 million marks (\$25 Million) were retrieved and used for the benefit of the survivors of Nazi persecution. Under the U.S. Military Government law, over 250 million dollars worth of confiscated real estate or businesses were restored to the former owners or their heirs.

In 1952, I served as one of the counsels to the [The] Hague Delegation conducting reparations negotiations between the State of Israel and the

30 Der Richter Eugene Kaufmann (1909-1964) flüchtete vor den Nationalsozialisten in die Vereinigten Staaten und wurde 1945 leitender Direktor der Zweigstelle der Hebrew Immigrant Aid Society (HIAS) in Baltimore. Die Hilfsorganisation HIAS wurde 1881 gegründet, um jüdische Migranten auf ihrem Weg in die Vereinigten Staaten und vor Ort zu unterstützen. Darüber hinaus half Kaufmann jüdischen Flüchtlingen in Baltimore bei der Aufnahme von Entschädigungsklagen. 
German government, as well as the Conference on Jewish Material Claims Against Germany. Following these negotiations which ended in Germany's agreement to pay to Israel $\$ 715$ million in goods over a period of 10 to 12 years, and to the Claims Conference over \$ 107 million to be used for relief outside of Israel, ${ }^{31}$ I became the Director for Germany of the Claims Conference. The primary object of this assignment was to see to it that Germany enacted legislation providing compensation to the individual victims for their personal losses and sufferings in addition to the global amounts paid to the Conference and to the State of Israel.

|2| In addition, I became the Director of Operations of the United Restitution Organization which received Conference support to aid needy victims in presenting their claims against the German government. As you know, the URO now has a staff of over 1,000 people in 13 different countries and has already paid out to its clients over $\$ 100$ million.

In 1956, I resigned from the various positions and returned to private law practice in New York. Since I am a counsel to the URO and other Jewish organizations, I do not handle individual restitution or indemnification claims but specialize in international matters.

Can it be that at age 37 my future is behind me?

With warm regards, Cordially yours,

Benjamin B. Ferencz

Dr. Eugene Kaufmann

Executi\#ve Director

Hias of Baltimore, Inc.

319 West Monument Street

Baltimore 1, Md.

BBF: js

31 Siehe dazu die Einleitung, $30 \mathrm{f}$. 


\title{
Dokument 21
}

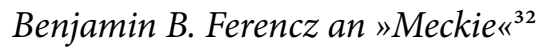

New Rochelle, N. Y., 8. Februar 1975

Maschinenschriftlicher Brief, 2 Seiten; gedruckter Briefkopf auf Seite 1

$R G 12.008 .03$

\author{
Benjamin B. Ferencz \\ 14 BAYBERRY LANE \\ New Rochelle, New York \\ $\star * *$
}

(914) NE 2-3717

8 Feb. 1975

Dear Meckie:

If you could have heard our squeals of joy when the post-man handed us a letter from you it would have made your heart sing. That, of course, was before we opened the envelope.

In any case I was happy to see that you were well enough to give me hell. The fact that the hell was completely unjustified at least gave me the satisfaction of knowing that you can always turn to your old friends to get something of your chest.

At the outset let me just set the record straight so that we can get on to more interesting things. Dr. Kurt May, who was one of the recipients of your love letter of 28 Jan., has absolutely nothing to do with the JRSO or JRSO files. It is only by chance that he even has any idea of what the thinking is on the subject. On my assurance that this is certainly so I hope you will consider a note to the poor man suggesting that you may have jumped on his grey head much too hard and much too soon.

My own official involvement with the JRSO ended in 1956. Since that time they have occasionally called for my unpaid advice on particularly difficult problems. 'Before’ May $\left.{ }_{\uparrow} 1974\right\}$ I was at a non-JRSO meeting attended by Kagan and Boukstein and the question of finally closing the JRSO Berlin office came up. Since they knew I would be in Berlin I was asked to visit the office and indicate when it could be closed and what files were worth preserving. I

32 Diese Person konnte nicht ermittelt werden. 
did that, \& on May 17th 1974 ; sent them a memo outlining the various types of files and suggestions for terminating the staff and closing the office in 1975. In not one word did I indicate where the files should go.

I happened to be in Berlin again in July 1974 on a delicate mission trying to contact East Germans. At that time, at Saul's request I met Aryeh Segall ${ }^{33}$ of the Central Archives for the History of the Jewish People who was surveying the files and who was later joined by a Colonel Pomrenze ${ }^{34}$ who had for many years been the archivist for the U.S. Army. Ever since I was a Sergeant in the army, I have been very allergic to Colonels. Nevertheless I must confess that both gentlemen made an excellent impression upon me regarding their professional competence and their sincere interest in general Jewish welfare. Segall particularly stressed that there were more Jewish scholars in Israel ready and eager to work on holocaust problems than anywhere else in the world. Like all good archivists he too was consumed with a passion for hoarding all documents in sight.

|2| The following week Segall came to the Claims Conference meeting in Geneva and by that time he had prepared a comprehensive outline of the files and a recommendation that they be shipped to Jerusalem for storage, preparation for further research, and security microfilming of those having important archival value. The matter was considered further while in Geneva and it was left that the JRSO Board of Directors would, in consultation with the JTC, ${ }^{35}$ have to decide the matter and appropriate funds as required. That was the end of my connection with the whole subject.

From a copy of a letter which Saul wrote to Oscar Joseph ${ }^{36}$ I deduce that the subject has been completely discussed with the JRSO Board, which

33 Aryeh Segall war stellvertretender, später leitender Direktor der Central Archives for the History of the Jewish People in Jerusalem. Seit den 1970er Jahren war er mit der Überführung von Akten der jüdischen Organisationen, die sich um die Rückerstattung jüdischen Eigentums in Deutschland bemühten, in das Jerusalemer Archiv betraut.

34 Seymour Pomrenze (1915-2011) war ein jüdischer Archivar aus den Vereinigten Staaten. Als erster Direktor des Offenbach Archival Depot war er seit 1945 mit der Restitution jüdischer Kulturgüter befasst. In den 1970er Jahren beriet Pomrenze die Central Archives for the History of the Jewish People bezüglich jüdischer Archive außerhalb Israels.

35 Die Jewish Trust Corporation (JTC) wurde 1950 gegründet, um in der britischen Besatzungszone erbenloses jüdisches Vermögen zu erfassen und zurückzufordern oder Entschädigungen zu erwirken.

36 Henry Oscar Joseph $\left({ }^{\star} 1901\right)$ war ein britischer Bankier. Von 1945 bis 1957 war er Schatzmeister des Central British Fund for Jewish Relief and Rehabilitation (auch 
includes the Council of Jews from Germany. ${ }^{37}$ As far as I know the N. Y. JRSO files are still fairly intact and there is no early plan to send them anywhere. These are, in my judgement, by far the most interesting ones.

You will see from the foregoing that I was rather sad to read in your letter that you feel very bitter about being by-passed by your friends whom you feel should have thought that they might be treading on your toes in Locarno if they didn't also consult with you. I must confess that such a thought never crossed my own mind, and it is perhaps because I still entertain the hope that you occupy yourself with more joyous and constructive pursuits.

Poor Katzenstein is also "Not Guilty". He simply carries out policies laid down by the $U\{J\} R\{S\} O$ Board, and the choice between $\mathrm{LBI}^{38}$ or Jerusalem or anyplace else is surely not something about which he would want to get himself agitated.

In any case you will be happy to know that I DO have something to say about the disposition of the URO files and I can assure you that the Leo Baeck Institute will, along with others, be given ample opportunity to be considered for that blessing.

When I'm not busy defending myself from friends I try to establish peace throughout the world. My 2 Volume work on the definition of aggression and the search for peace ${ }^{39}$ is now at the printers. My so-called children are fine - which by today's standards means that they are neither in hospitals nor in jails. Robin has a Master in Mathematics and is selling insurance but may go to the Peace Corps this month. Don is getting his teacher's license soon and expects to marry a girl who already has a nice son. Nina was married and divorced and lives in Oregon where there are trees. Gertrude stays home and puts up with me, which is a full-time occupation.

Central British Fund for German Jewry, CBF) und anschließend dessen Vorsitzender. Ab 1950 war Joseph zudem Schatzmeister der Jewish Trust Corporation und ab 1953 im Direktorium der JCC tätig.

37 Der Council of Jews from Germany wurde 1945 als Dachverband von Organisationen gegründet, die Juden aus Deutschland und aus anderen deutschsprachigen Ländern Zentraleuropas in den Ländern repräsentierten, in denen sie sich nach ihrer Emigration niedergelassen hatten. In der unmittelbaren Nachkriegszeit war der Council of Jews from Germany vor allem mit Fragen der Restitution befasst und 1952 an der Gründung der JCC beteiligt.

38 Das Leo Baeck Institut (LBI) erforscht und dokumentiert seit 1955 als außeruniversitäre Forschungseinrichtung die Geschichte des deutschsprachigen Judentums.

Ferencz, Defining International Aggression. 
And I would be happy to have a personal letter telling me all about you, and Lise and I̊rmo̊ to all of whom I send my warmest greetings. Gertrude sends love.

$\{$ Ben $\}$

\section{Dokument 22}

Benjamin B. Ferencz an Eran Laor ${ }^{40}$

Ohne Ortsangabe, 13. August 1983

Maschinenschriftlicher Brief, 3 Seiten

$R G 12.009 .02$

[In einem Antwortschreiben berichtet Ferencz rückblickend über die Gründung der URO und seine Motive für ein weiteres Engagement in der neugegründeten Bundesrepublik. Er stellt den Zusammenhang mit den 1948 abgeschlossenen Prozessen gegen die Leiter der Einsatzgruppen heraus und beschreibt Rechtsrahmen, Organisation, Personal und Praxis der URO in den frühen 1950er Jahren.]

Dr. Eric [sic] Laor

Brennerstr. 9

Jerusalem

Dear Eric,

I trust you arrived home safely and well and that the weather in Israel was better than it was in Germany. I have not forgotten my promise to send you a few lines about the origins of the restitution programs and the URO. Since I am relying largely on memory, I hope the following recollections will prove helpful.

Under pressure from American Jewish organizations, the U.S. gov't agreed to enact restitution laws to restore confiscated assets in Germany. The other occupying powers were less than enthusiastic, particularly about

40 Eran Laor (1900-1990) wurde als Erich Landstein in der Slowakei geboren und emigrierte 1934 ins britische Mandatsgebiet Palästina. Er arbeitete in verschiedenen Positionen für die Jewish Agency und die israelische Regierung und war zudem Vorstandsmitglied der URO. 
appointing a Jewish organization to succeed to the heirless or unclaimed Jewish property. When consensus proved impossible, the US unilaterally enacted such a law for the US zone of occupation. US Military Gov't Law No. 59 was enacted at the end of 1947 and provided that property taken from Nazi victims should be reclaimed. A Jewish organization was to be designated to claim the heirless property. The JRSO, created in NY by the AJDC ${ }^{41}$ and the Jewish Agency, in cooperation with such other organizations as the American Jewish Committee, the World Jewish Congress, the $\mathrm{CBF}^{42}$ etc. was designated by the US to become the Jewish Restitution Successor Organization. That was in August 1948 and the deadline for the filing of all claims was to expire on Dec. 311948.

At that time I was finishing my job as Chief Prosecutor for the United States \#n the Nuremberg trial against the SS Einsatzgruppen which had murdered over a million Jews. The trial had generated a lot of publicity and someone got the idea that I might be the right guy to try to recover the stolen property of murdered Jews. Joe Schwartz, ${ }^{43}$ head of the AJDC, invited me to Paris where he persuaded me to accept the job of Director-General of the JRSO. < The title I invented myself! > That was Aug. 1948, and, as far as I know, I was the first employee hired exclusively for restitution. It was estimated that the job might take up to 2 years.

I proceeded, with money borrowed from Military Gov't <and never repaid - but that's another story $>^{44}$ to employ over 300 people and claim over 163,000 pieces of property by Dec. 1948. Within the next few years, similar laws were enacted for the British and French Zones, as well as Berlin, and

41 Das American Jewish Joint Distribution Committee (AJDC; kurz: Joint Distribution Committee, JDC) ist eine bis heute weltweit arbeitende jüdische Hilfsorganisation, die 1914 zur Unterstützung der Juden in Palästina gegründet wurde.

42 Der Central British Fund for German Jewry (CBF) wurde 1933 als Hilfsorganisation für verfolgte deutsche Juden gegründet. 1939 erfolgte die Umbennenung in Central Council for Jewish Refugees, 1944 dann zu Central British Fund for Jewish Relief and Rehabilitation und einige Jahre später wurde die Organisation zum Central British Fund for World Jewish Relief (kurz World Jewish Relief). Nach dem Zweiten Weltkrieg organisierte und finanzierte der CBF auch das Jewish Committee for Relief Abroad, das jüdische Überlebende der nationalsozialistischen Verfolgung in Europa unterstützte.

43 Joseph J. Schwartz (1899-1975) war zunächst Rabbiner und Orientwissenschaftler, bevor er von 1940 bis 1949 Direktor für Europaangelegenheiten des JDC wurde. Anschließend war er für jüdische Hilfsorganisationen wie den United Jewish Appeal tätig.

44 Siehe dazu Dokument 14. 
former German Jews began to seek help in claiming the return of their former properties.

[|2|] A group of former German lawyers who had taken refuge in England formed a co-ordinating Committee and, with the help of various associations of German Jews (Irgun, ${ }^{45}$ American Federat [sic] on Ass. of Jewish Refugees) ${ }^{46}$ established a United Restitution Office, which received modest support from the AJDC, the Jewish Agency and the CBF. As far as I can recall, this was also at the end of 1948 and the URO, led by Reichmann, Goldschmidt and Kurt Alexander ${ }^{47}$ (with Norman Bentwhich ${ }^{48}$ as Chairman) began to assist former German Jews who had restitution claims.

The United Restitution Office wished to establish offices in Germany, but General Lucious [sic] Clay, the US Military Governor refused to grant the necessary permission since he felt that the JRSO could do the job. I therefore

45 Die Irgun ole merkaz Eropa (Organisation der Einwanderer aus Zentraleuropa) wurde 1932 in Tel Aviv unter dem Namen Hit'ahdut ole Germanya (Vereinigung der Immigranten aus Deutschland) gegründet. Zwischen 1938 und 1942 trug sie den Namen Hit'ahdut ole Germanya we-Austria (Vereinigung der Einwanderer aus Deutschland und Österreich). Die Organisation widmete sich der kulturellen und sozialen Eingliederung der Einwanderer aus dem deutschsprachigen Raum. Gegen Ende des Zweiten Weltkriegs beschäftigte sie sich verstärkt mit Fragen der Restitution. 1945 war sie an der Gründung des Council of Jews from Germany beteiligt. Heute trägt die Organisation den Namen Irgun yoz'e merkaz Eropa (Vereinigung [der Israelis] mitteleuropäischer Herkunft).

46 Wahrscheinlich ist hier sowohl die American Federation of Jews from Central Europe als auch die Association of Jewish Refugees from Germany gemeint. Die American Federation of Jews from Central Europe wurde 1939 gegründet und widmete sich der Unterstützung deutschsprachiger jüdischer Einwanderer in den Vereinigten Staaten. Die Association of Jewish Refugees from Germany wurde 1941 gegründet und übernahm ähnliche Aufgaben in Großbritannien. Die beiden Organisationen gründeten gemeinsam mit der Organisation der Einwanderer aus Zentraleuropa 1945 den Council of Jews from Germany, der 1948 maßgeblich an der Gründung der URO beteiligt war.

47 Kurt Alexander (1892-1962) war von 1922 bis 1938 als Rechtsanwalt in Krefeld tätig. 1939 emigrierte er nach Großbritannien und arbeitete dort für verschiedene jüdische Organisationen, bevor er 1948 Mitgründer und Direktor des Londoner URO-Büros wurde. Anschließend leitete Alexander von 1949 bis 1962 das URO-Büro in New York.

48 Norman Bentwich (1883-1971) war ein britisch-jüdischer Jurist und arbeitete nach seinem Einsatz an der palästinensischen Front während des Ersten Weltkriegs für die britische Mandatsbehörde in Palästina. 1932 wurde er Professor an der Hebräischen Universität Jerusalem und war für verschiedene jüdische Organisationen tätig. Von 1948 bis $1971 \mathrm{saß}$ er im Vorstand der URO. 
created the Legal Aid Dept. of the JRSO, that functioned as a fairly autonomous arm, in cooperation with the URO to assist private restitution claimants. Kurt May was engaged to be the head of the LAD of the JRSO, which operated in fact as the Frankfurt Branch of the URO but under JRSO responsibility. That must have been in 1949. URO London managed, some time thereafter, to establish small offices in the British and French zone and to work in cooperation with the JRSO office in Berlin, which was headed by Dr. Bental, again as an extension of the Legal Aid Department (LAD) but for all practical purposes as a URO office. URO offices, created in cooperation with local agencies, were also established in Israel and other countries, which funneled the claims into the German offices for transmittal to the official restitution agencies, in consideration of a contingent fee (initially $2 \%$ ) that was supposed to cover all costs.

The programs for the restitution of confiscated real estate or businesses transferred under duress by German Jews was in progress when laws providing slight indemnification for personal injuries to DP's and other Nazi victims were enacted, first in the US zone and then in other areas. ${ }^{49}$ Since such indemnification laws were totally inadequate, Jewish organizations everywhere were clamoring for improvements. The negotiation of improved indemnification laws began in The Hague and agreement was reached in Sept. 1952 for the enactment of a very comprehensive program to compensate Nazi survivors for a very wide range of personal and economic losses. It was obvious to all of us who were involved in the negotiations that it would be necessary to have a very large apparatus to cope with all of the authorized claims and that Jewish claimants would require a much greater measure of assistance than was then available through the United Restitution Office of London.

The BEG went into effect toward the end of $1953 .{ }^{50}$ The Claims Conference, which had been the negotiating partner together with the State of Israel

49 Im August 1949 beschloss der Stuttgarter Länderrat das Entschädigungsgesetz der US-Zone (USEG), das rückwirkend zum 26. April 1949 in Bayern, Württemberg-Baden, Hessen und Bremen in Kraft trat. Auch in den Ländern der britischen und französischen Besatzungszonen wurden verschiedene Entschädigungsgesetze erlassen. Dadurch ergab sich insgesamt eine zersplitterte Rechtslage, die erst 1953 durch das Bundesergänzungsgesetz vereinheitlich wurde. Siehe Hockerts, Wiedergutmachung in Deutschland, 167-214, hier 175 f.; Goschler, Schuld und Schulden, 92-95.

50 Gemeint ist das Bundesergänzungsgesetz von 1953. Es wurde als erstes einheitliches, bundesweites Entschädigungsgesetz beschlossen und regelte in 113 Paragrafen die zu entschädigenden Personengruppen, Schadensbestände und Verfahrensvorschriften. 1956 wurde es durch das BEG ersetzt. Siehe Goschler, Schuld und Schulden, 181-203. 
in the Hague agreements ${ }^{51}$ with the Federal Rep. of Germany, had established an office in Bonn to lobby for the enactment of the required legislation. I was, in addition to my JRSO duties, designated as the Claims Conference Director for Germany (no extra pay, just extra work and titles) and being the "man of confidence" on the scene, I was asked to also establish an expanded network to help needy Nazi victims with their new indemnification claims.

|3| You may be interested to know that Moses Leavitt (also known as "Moe" Leavitt, or more appropriately as "No" Leavitt) as Claims Conference treasurer and Executive of the JDC, strongly urged that a completely independent organization be established to help the indemnification claimants. The United Restitution Office did not inspire his confidence and he was prepared to scuttle the URO by withdrawing JDC support. I, being a more peaceable type, did not agree that there should be a confrontation with the German lawyers of the URO and make good use of its trained staff.

To make a long story short - in April 1954, an agreement was reached between the Coordinating Committee of the United Restitution Office in London and the Claims Conference (Nahum Goldmann, ${ }^{52}$ Leavitt and Saul Kagan) according to which the URO was to be re-organized and reincorporated. ${ }^{53}$ The new United Restitution Organization (URO) would have a Board of Directors of all members of whom, in fact 6 would be controlled by the Conference. In addition, the Conference would designate (me) as the new Director of Operations and I would be responsible for running the offices and the finances. To make sure that the position of the "old boys" was protected, it was specifically agreed that service contracts would be offered to Reichmann (who was to be the General Secretary) Goldschmidt (Legal Adviser) and Kurt May, who was to be the Deputy Director of Operations. On 16 Nov. 1954, the United Restitution Organization Ltd. was formed in London as the successor to the former United Restitution Office. It carried out the understandings reached with the Claims Conference earlier that year.

51 Alternative Bezeichnung für das Luxemburger Abkommen von 1952 nach dem Ort der Verhandlungen.

52 Nahum Goldmann (1895-1982) war ein zionistischer Politiker. Ab 1926 leitete er die Zionistische Vereinigung für Deutschland. Nach seiner Emigration aus Deutschland 1933 war er in verschiedenen internationalen jüdischen Organisationen aktiv, etwa der Jewish Agency. 1936 war er an der Gründung des Jüdischen Weltkongresses beteiligt, dem er von 1949 bis 1977 als Präsident vorstand. In dieser Funktion begann er 1951 die Gespräche über Reparationszahlungen mit Konrad Adenauer, die 1952 in das Luxemburger Abkommen mündeten.

53 Siehe Einleitung, 32. 
As you know, the early antagonisms and distrust evaporated over the years so that the Claims Conference controls were relaxed, the advances received to expand the URO were repaid to the Conference, most of the original participants (Leavitt, Goldmann, Bentwich, Reichmann, Brotman, ${ }^{54}$ Goldschmidt, etc. etc.) have passed on to a more sublime atmosphere, and the rest of us live happily ever after.

What was accomplished was much more than any of us ever dreamed would be possible and it has taken very much longer than any of us thought would be the case. By and large, not a bad job. You can be proud to be associated with such a noble undertaking!

Stay well. We still need you.

Warm regards, ${ }^{55}$

Best to Helen.

54 Adolph G. Brotman (1896-1970) wirkte von 1933 bis 1966 als Sekretär des Board of Deputies of British Jews und gehörte seit ihrer Gründung 1948 der Leitung der URO an.

55 Unterschrift fehlt auf archivalischer Kopie. 
4. Entschädigung jüdischer Zwangsarbeiter durch die deutsche Industrie 



\section{Dokument 23}

Benjamin B. Ferencz an Hans Reichmann

Ohne Ortsangabe, 25. Februar 1954

Maschinenschriftlicher Brief, 1 Seite

$R G 12.004 .12 * 02$

\{new file || Cases against German firms. ?/200\}

February 25, 1954

Dr. Reichmann

United Restitution Office

8, Fairfax Mansions

London, N.W. 3

Dear Dr. Reichmann:

Dr. May and I had a longer talk yesterday with Dr. Ormond ${ }^{1}$ concerning assistance required in the further presentation of the case against the I. G. Farben Company. Dr. May has read the brief for the company which is being submitted in appealing the lower court's decision. ${ }^{2}$ It is his view, which I fully share, that the Jewish claimants are at an unfair disadnantage since the I. G. Farben Company has arraid [sic] a large battery of excellent lawyers against Ormond who stands alone on the other side. He reached the conclusion that in order to safeguard Jewish interests, it will be necessary to jump in quickly in order to counterbalance this disadvantage. Ormond says that there are approximately two thousand claimants involved.

It seems to me that there are three kinds of assistance we might conceivably render. One is to make available the services of one or more lawyers who

1 Henry Ormond (1901-1973) war ein deutsch-jüdischer Jurist. 1939 floh er über die Schweiz nach Großbritannien, wo er die britische Staatsbürgerschaft erhielt. Als Mitglied der britischen Armee kehrte er ins besetzte Deutschland zurück, war Mitbegründer des Nachrichtenmagazins Der Spiegel und betätigte sich ab 1950 als Rechtsanwalt. In dieser Funktion arbeitete er vor allem im Bereich von Entschädigungs- und Rückerstattungsverfahren und vertrat unter anderem Norbert Wollheim gegen die I. G. Farben sowie 15 Nebenkläger im Frankfurter Auschwitz-Prozess.

2 In der Entscheidung des Landgerichts Frankfurt am Main im Fall Wollheim gegen I. G. Farben vom 10. Juni 1953 hatte dieses den Entschädigungsanspruch Wollheims erstinstanzlich anerkannt. Siehe dazu Ferencz, Lohn des Grauens, 63 f.; Benz, Der Wollheim-Prozeß, 303-326. 
would work with Ormond in preparing the briefs and arguments. Second, we can make available the use of URO offices and lawyers abroad in helping to obtain and examine witnesses. Third, we can provide funds for ex[p]e̊rit legal opinions and other materials essential for presenting the case properly.

To decide whether any or all of these devices is appropriate is practically a full-time job, and my thinking therefore is that Dr. Goldschmidt might deal with the question and give us the benefit of his views. You will recall that when I raised the matter in London at the board meeting it was decided that Dr. Goldschmidt would prepare a memorandum examining the whole complex of claims against industrial concerns and making a recommendation. I have asked Dr. May to be in touch with Dr. Goldschmidt and give him the details and the materials which he will need before being able to form a judgement. I also promised Dr. Ormond \#\#\# answer to his request by the first week of March.

With best regards,

Cordially yours,

BENJAMIN B. FERENCZ

cc: Dr. Goldschmidt

Dr. May

\section{Dokument 24}

Benjamin B. Ferencz an Saul Kagan

Frankfurt am Main, 15. November 1954

Maschinenschriftlicher Brief, 2 Seiten; gedruckter Briefkopf mit maschinenschriftlichen Einfügungen auf Seite 1

$R G 12.004 .12^{*} 02$

CONFERENCE ON JEWISH MATERIAL CLAIMS AGAINST GERMANY OFFICE FOR GERMANY

¡Frankfurt/Main,'

'Friedrichstrasse 29.'
'Cable: Restitution Ffm.'

'Tel: 70831.' 
15 November 1954.

Mr. Saul Kagan

JRSO - New York

Letter \#2042, U-1200. ${ }^{3}$

\section{Dear Saul:}

On 13 November there was a meeting in my office concerning claims against the I. G. Farben Company. The meeting was attended by Dr. Schmidt, ${ }^{4}$ I. G. Farben liquidator, Dr. Samson, ${ }^{5}$ Chief legal advisor of I. G., Dr. Mueller who was brought along as their secretary, Dr. Ormond, the lawyer representing Wollheim ${ }^{6}$ in the case against Farben, Dr. May, Dr. Schoenfeldt and myself.

Without going into the details the position put forward by the Farben representatives was that they could not acknowledge any legal liability, that whatever sum they would be prepared to pay would be only for labor in Monowitz (one of the Auschwitz camps built by Farben), and that they wanted to pay a fixed sum. Schmidt expressed unhappiness about the argument in our brief to the effect that all companies employing slave laborers had acted improperly, and he felt that these arguments had weakened the chances for settlement.

3 Die Raute steht an dieser Stelle als Nummernzeichen.

4 Walter Schmidt (1889-1961) war Rechtsanwalt und vertrat Friedrich Flick im sogenannten Flick-Prozess (Fall V) der Nürnberger Nachfolgeprozesse. Zudem war er für die Liquidation von I. G. Farben zuständig. Wie Schmidt waren einige Verteidiger aus den Nürnberger Prozessen in den Folgejahren weiterhin für deutsche Firmen bzw. Industrielle tätig und vertraten diese unter anderem gegen Schadenersatzforderungen ehemaliger Zwangsarbeiter. Siehe dazu Hubert Seliger, Politische Anwälte? Die Verteidiger der Nürnberger Prozesse, Baden-Baden 2016, $427 \mathrm{f}$.

5 Der Jurist Benvenuto Samson (1887-1983) vertrat die I. G. Farben im Prozess gegen Norbert Wollheim.

6 Norbert Wollheim (1913-1998) war ein deutscher Jude, der 1943 in das Konzentrationslager Buna/Monowitz deportiert wurde. Dort musste er für den I. G.-Farben-Konzern Zwangsarbeit leisten. Nach der Befreiung setzte er sich für den Wiederaufbau jüdischen Lebens in Deutschland ein und war Mitbegründer des Zentralrats der Juden in Deutschland. 1951 verklagte er I. G. Farben in einem Musterprozess erfolgreich auf Entschädigung. In zweiter Instanz führte das Urteil zu einem außergerichtlichen Vergleich mit der JCC, durch den mehrere tausend ehemalige Zwangsarbeiter der I. G. Farben Entschädigungsleistungen erhielten. 
Schoenfeldt made some introductory remarks during the course of which he casually mentioned that we had also brought Kuester ${ }^{7}$ in as one of our lawyers on the case.

I divided our discussion into three parts:

1. Establishing the correct partner for concluding an agreement. I stated that the partner would be the Claims Conference which had been accepted by the Bund and explained the relationship of the various organizations to the Claims Conference. I made it clear that we did not purport to speak for all potential claimants in the world and that individuals might still come forward against Farben despite any agreement we might reach. Nevertheless, I assured them that if we did reach agreement the Conference would not lend its support to any such private claimants outside the terms of the agreement. I explained also that I had sounded out some of the Conference leaders who were inclined to accept the heavy responsibility involved if it appeared that the Farben company would be ready to make a reasonable settlement. It was clear that the Conference would be accepted by Farben as the appropriate partner in concluding any agreement.

2. The second question concerned the technique to be followed in dealing with the claims. I explained the procedure and practices of the Pensions Advisory Board which would serve as our model. This would mean the establishment of a joint committee with possibly three representatives, one representing Farben, one representing the Conference and one mutually agreed upon, which would receive the claims, check them for accuracy against the available records and decide upon the payment. Claimants will be limited to the victims themselves, widows or widowers, minor children and parents. The general outline of this procedure seemed to be acceptable although some modifications will undoubtedly be necessary should an agreement be reached. [|2|] 3. The third question concerned the amount of payment. Schmidt felt that the figures that I had mentioned at the last meeting of possibly 10,000 claimants involving a total Farben liability of DM 100,000,000 were much too high and had served to frighten them off. I replied that since then we had made a more careful examination including a quick survey of the available documents from which it appeared that about 38,000 Jews had been employed at Monowitz at one time or another, and that about 7,000 (including

7 Otto Küster (1907-1989) war ein deutscher Rechtsanwalt und von 1945 bis 1954 Staatsbeauftragter für Wiedergutmachung in Württemberg-Baden bzw. Baden-Württemberg. Er wurde schließlich entlassen, da er aus Sicht des Finanzministeriums das Entschädigungsgesetz zu häufig zugunsten der Verfolgten interpretiert habe. Anschließend war Küster als Rechtsanwalt tätig und vertrat u. a. Norbert Wollheim bei seiner Klage gegen I. G. Farben. 
some non-Jews) had been liberated. These records were available at Arolsen ${ }^{8}$ which also had the roster of inmates of the Auschwitz hospital during a oneyear period. I had also received a report from Israel, based upon discussion I had there with Mr. Schlomai, who was personally in Monowitz and is leader of an organization of former DPs, to the effect that he estimated the number of Jewish claimants against Farben to be 4,000, which would be increased to 8,000 if the heirs were included. As a result of these various computations I stated that I had reached the conclusion that the number of claims could be reasonably estimated at 6,000 . Dr. Schmidt also felt that this estimate was reasonable, despite the fact that only 2,000 had thus far approved.

I suggested that each claimant receive $500 \mathrm{DM}$ for each month of labor of Monowitz and we take as an average estimate twenty months per person, making the total per person about DM 10,000. This would mean a total liability for Farben of DM $60,000,000.0$. In addition I suggested that a hardship. fund of $10 \%$ be set aside to deal with cases which, experience showed, could not be brought within the framework of any general rules but which would probably require some extra compensation. This would mean a total bill of DM 66,000,000. Schmidt replied that he had only counted on spending DM 20,000,000 and that the figure of 66 million was high. He felt strongly that DM 500 per month was too much to give since this was in the nature of an extra donation by Farben. He pointed out that the Farben employees had been fired by the Allies, and they were not seeking compensation for their unemployment. Farben had only paid for 18 months and at a rate of ten to one. Also having in mind the compensation of $150 \mathrm{DM}$ per month being paid for incarceration under the Federal Indemnification $\mathrm{Law}^{9}$ he concluded that DM 250.per month would be an appropriate sum. This would thereby bring the total obligation down to 33 million DM.

8 Gemeint ist der Internationale Suchdienst/International Tracing Service in Bad Arolsen (ITS). Dort lagern über 30 Millionen Dokumente zur Geschichte des Nationalsozialismus sowie den Nachkriegsjahren. Ein Schwerpunkt liegt dabei auf Dokumenten, die die Verfolgungspraxis und das Schicksal der Opfer des Nationalsozialismus dokumentieren. Siehe dazu Suzanne Brown-Fleming, Nazi Persecution and Postwar Repercussions. The International Tracing Service and Holocaust Research, Lanham, Md., 2016; Jennifer Rodgers, From the >Archive of Horrors to the sShop of Window Democracy<. The International Tracing Service 1942-2013, Diss., University of Pennsylvania 2014 sowie für weitere Informationen die Webseite des ITS, <https://www. its-arolsen.org/> (19. Dezember 2018).

9 Das BEG gewährte anerkannten Verfolgten des Nationalsozialismus als Haftentschädigung für Konzentrationslagerhaft fünf DM pro Tag, was 150 DM pro Monat entsprach. Daneben bestanden gegebenenfalls Ansprüche für Gesundheitsschäden etc. 
I argued that in many cases the claimant would not be able to prove the full period of employment and therefore a settlement would have to be made at a lesser amount. We could not enter into an arrangement which might give large numbers of claimants totally trivial sums since we could then be subjected to the accusation of having sold out their interests for a trifle. I suggested that we might give consideration to a plan according to which Farben's maximum liability would be fixed and, should there be any surplus, the balance would go back to the company. Schmidt seemed to like the idea, but Ormond and Schoenfeldt were opposed, pointing out that this might encourage the Farben representative on the commission to be very exacting in his requirements before acknowledging the validity of a claim.

We adjourned with Schmidt's promise to take up the matter again with his board and to let us know their views at an early date. All agreed that some progress had been made.

Cordially yours,

\{Ben $\}$

BENJAMIN B. FERENCZ

BBF.le

Dictated but not read

cc: Dr. Reichmann, Dr. Kreutzberger

Mr. Schlomai, Dr. Robinson ${ }^{10}$

Mr. Jacobson, Herr Ormond, HS, KM. ${ }^{11}$

\section{Dokument 25}

Benjamin B. Ferencz an Henry Ormond

Frankfurt am Main, 25. Januar 1956

Maschinenschriftlicher Brief, 2 Seiten; gedruckter Briefkopf mit maschinenschriftlichen Einfügungen auf Seite 1, Kopfzeile auf Seite 2 (»Mr. Ormond 25th January 1956«)

$R G 12.004 .12^{*} 04$

10 Nehemia Robinson.

11 Wahrscheinlich Hans Seidenberg und Kurt May. 
CONFERENCE ON JEWISH MATERIAL CLAIMS AGAINST GERMANY OFFICE FOR GERMANY

'Frankfurt/Main'

¡Friedrichstrasse 29!

\section{CONFIDENTIAL}

25th January 1956

U-1200.

Henry Ormond Esq.

Frankfurt/Main

Schillerstr. 30 .

Dear Mr. Ormond:

I am writing to confirm our discussion of today dealing with the proposed settlement with the IG Farben Company. After briefly reexamining the agreement drafted by Dr. Kuester I proposed that the appropriate parties to the agreement would be the IG Farben Company and Mr. Wollheim. The agreement itself could make reference to the amount of money to be paid to Mr. Wollheim in settlement of his claim and part of the consideration for his agreeing to the settlement would be the establishment of a special trust fund by the I.G. Farben Company to meet the claims of other similar claimants in accordance with rules to be worked out and agreed upon with the Claims Conference. The Claims Conference would probably be prepared to enter into an exchange of letters with the Farben Company in which the terms of the overall agreement would be stipulated. This exchange of letters might also be referred to in the formal court settlement of the Wollheim claim. The Conference would, furthermore, probably be prepared to sanction such a settlement by publicly endorsing it as being appropriate and by refusal to assist anyone seeking to undermine the agreement.

As for the settlement itself, I envisaged the establishment of a trust fund by the Farben Company.: The fund would consist of two parts: one part available for distribution to claimants and the second part to be held in resereve for defending suits brought against the Farben Company and making whatever payments might be decreed by the German courts. No payments could be made unless there was a court decree. The trust fund would consonsist

12 Die folgenden Überlegungen beziehen sich auf die Gründung der Compensation Treuhand GmbH (CT), die mit der Auszahlung der Leistungen der deutschen Industrie an ehemalige jüdische Zwangsarbeiter beauftragt wurde. Siehe dazu die Dokumente $51,54,67,70,73,74,76,77,79$. 
of three sections: the main office being in Frankfurt under the control of a group of perhaps five trustees, designated with the concurrence of the Claims Conference and the Farben Company. These trustees would supervise a small staff which I envisage would consist of one or two persons plus secretarial help. This staff would be responsible for preparing the files for the consideration of the trustees.

In addition to the Frankfurt office there would be two branches of the trustfund: one in Israel and one in New York. Each one of these branches would function under the supervision of a local advisory committee of perhaps three people and would consist of probably one employee and one secretary. The local branches would receive the claims locally, try to prepare the files and make their recommendations for transmittal to the main office in Frankfurt. The main office would have responsibility for the final decision, having due regard to the recommendation made by the local office. The main office would also deal with cases coming from areas other than Israel and New York. A majority of the trustees would constitute a quorum, and a majority of these present would have authority to decide. We also considered the possibility of setting up a three-men appeal board componsed of persons designated by the Frankfurt, the Israel and the New York offices, but it was agreed that this matter might be left in abeyance until there was some more experience.

As concerns the persons who would be eligible for payment from the trust, it was agreed that basically the funds were intended for such persons who had themselves been employed as laborers for the I. G. Farben Company at the Monowitz plants in Auschwitz. It was also agreed that labor for at least one month between the period of 1 October 1942 and 18 January 1945, the dates during which Jews were employed there, would be a prerequisite for consideration. In addition to the group of former inmates, widows that have not remarried, minor children and parents of persons who worked for the Farben Company wound be eligible for some compensation from a hardship funnd, to be created out of the amounts available for distribution. Widows would be eligible even though the husband died after the $|2|$ employment by the Farben Company.

We discussed a payment plan and a system of priorities and agreed that it would be advisable to have a first instalment of $3,000 \mathrm{DM}$ go to all persons who had worked for Farben. A second instalment of up to $2000 \mathrm{DM}$ would be payable for those who had worked for the Farben Company in Auschwitz for more than six months and would be payable only after the filing deadline has expired and it can be determined whether funds are available. The next order of priority would be payments to those who are eligible under the hardship fund, and such dependents would receive up to $3,000 \mathrm{DM}$. We 
considered limiting these payments to such persons as could establish that they were in finnancial need, but this matter was not clear when you left, and it is my feeling that, if the funds are available, we should try to give all such dependents 3,000 DM without regard to their present financial condition. The next priority would go back to those who had worked for the Farben Company for more than six months, and whatever funds would be available out of the total trust would then be distributed equally among these claimants as a supplementary payment.

We also agreed that it would be necessary to have some small hardship fund available to the trustees to be used within their unlimited discretion to discharge claims which, in their unanimous opinion, should equitably be met. The existence of such funds would have to be kept confidential.

Any funds not consumed in the defense of claims against Farben would go into the general trust fund for distribution. It would therefore be in the interest of the claimants themselves to limit the number of collateral attacks against Farben.

This memorandum can serve as the basis for a redrafting of the contract and the preparation of new "Richtlinien".

Cordially yours,

$\{$ Ben $\}$

BENJAMIN B. FERENCZ

cc: Mr. Ormond (5)

Mr. Kagan (3)

Mr. May

Dr. Rosenthal

Mr. Jacobson

Dr. Schoenfeldt

Dr. Robinson

Dr. Goldmann

Mr. Schlomai 


\section{Dokument 26}

Benjamin B. Ferencz an Kent $R .{ }^{13}$

Ohne Ortsangabe, 16. November 1956

Maschinenschriftlicher Brief, 2 Seiten

$R G 12.004 .12^{*} 14$

$\mathrm{BBF} / \mathrm{IB}$

Mr. Kent R.

November 16, 1956

33 Illinois Avenue

LONG BEACH, L.I., N. Y.

DeAr Mr. R.:

Thank you For your LetTer of November 12, DeAling With the PROBLEM OF RECEIVING A COMPENSATION FOR NAZI VICTIMS. YOUR LETTER RAISES A NUMBER OF QUESTIONS WHICH SHOULD BE KEPT DISTINCT AND SEPARATE. YOU REFER TO COMPENSATION FOR THE MURDER OF YOUR PARENTS AND MOTHER-IN-LAW IN A GERMAN CONCENTRATION CAMP. YOU ALSO REFER TO POSSIBLE CLAIMS against THE IG-FARbeN COMPANY AND RAISE OBJECTIONS TO THE RETURN OF VESTED GERMAN assets. Although I haVe the fUllest UNDERSTANDING AND SYMPATHY FOR YOUR FEELING OF FRUSTRATION AND OUTRAGE CONCERNING THE UNPUNISHED AND UNCOMPENSATED EVILS WHICH WERE PART OF THE NAZI ReICH, I AM AFRAID THAT THESE PROBlems CANNOT BE MET BY STRIKING OUT BLINDLY IN ALL DIRECTIONS AT THE SAME TIME.

The extent to which the Federal Republic of Germany was PREPARED TO GRANT COMPENSATION TO NAZI VICTIMS IS CONTAINED IN the existing Restitution and indemnification laws. Although a VERY SIZABLE PROGRAM HAS BEEN UNDERTAKEN BY VIRTUE OF THIS LEGISLATION, YOU HAVE BEEN ADVISED THAT NO COMPENSATION IS PROVIDED FOR THE TYPE OF LOSSES TO WHICH YOU REFER. COMPENSATION FOR LOSS OF LIFE IS PAYABLE ONLY TO THE SURVIVING WIDOW, MINOR CHILDREN OR ORPHANED GRAND-CHILDREN AND DEPENDENT RELATIVES. AlTHOUGH THIS

13 Da die Person Ferencz als Verfolgter des nationalsozialistischen Regimes kontaktierte, wurde der Name von den Herausgebern anonymisiert. 
MAY BE REgarded AS INADEQUATE, IT IS AS FAR AS THE Federal RePUbliC FEELS IT CAN GO.

A test Case is PENDing against the IG-Farben COMPANy in AN ATTEMPT TO OBTAIN FROM THEM COMPENSATION FOR ALL OF THE SLAVE LABORERS WHO WERE EMPLOYED AT THE IG-FARBEN PLANT ADJACENT TO THE AUSCHWitz CONCENTRATION CAMP. IN ADDition, NEgotiations ARE IN PROgRess FOR A SETTLEMENT With THE FARbEN COMPANy ON BEHALF OF ALL SUCH NAZI VICTIMS.

The PROBlem OF THE RETURN OF VESTED GERMAN ASSETS AND THE problem of the general ANillin- [SIC] AND Film Corporation are MATTERS WHICH ARE BEING DEALT WITH BY THE CONGRESS AND THE Department of Justice. ${ }^{14}$ The CONgressional hearings have BeEN PUblished By THE SUB-COMMitTeE OF THE COMMitTEe OF THE JUdiCiary of the United States Senate and the 84Th Congress and the RECORD OF ALL THE ARGUMENTS MADE, |2| BOTH PRO AND CON, IS AVAILABLE TO THE PUBLIC. IF YOU WISH TO TAKE A STAND IN OPPOSITION TO ANY IMPENDING LEGISLATION, THE CORRECT PROCEDURE IS FOR YOU TO ADDRESS YOUR OBSERVATIONS TO YOUR CONGRESSIONAL REPRESENTATIVES.

Although I WOUld BE PLEASEd TO BE OF EVERY POSSIBle ASSISTANCE IN OBTAINING GREATER AND MORE SATISFACTORY INDEMNIFICATION FOR NAZI VICTIMS, I AM AFRAID I DO NOT DETECT IN YOUR CORRESPONDENCE a pRactical proposal for that END. SHOUld you Wish to Discuss THE MATTER FURTHER WITH ME, I AM AT YOUR DISPOSAL, EITHER AT THE URO-OfFice, Where I SERVE as General Counsel or at my private law office, 150 Broadway, New York, Tele phone Hannover 2-7600.

SINCERELY YOURS,

Benjamin B. FerencZ

COUNSEL

14 Zur Auseinandersetzung um beschlagnahmtes deutsches Auslandsvermögen siehe Kreikamp, Deutsches Vermögen in den Vereinigten Staaten. 


\section{Dokument 27}

Benjamin B. Ferencz an Hendrik van Dam ${ }^{15}$

Ohne Ortsangabe, 4. Dezember 1957

Maschinenschriftlicher Brief, 1 Seite

$R G 12.004 .02 * 01$

December 4, 1957

Dear Henry [sic]:

There has been a lot of activity recently with regard to claims of slave laborers against German industrial concerns. One of the problems has been to find lawyers in Germany who would be prepared to handle such claims on a contingent fee basis. Lawyers are necessary in whatever areas the firms are located.

Dr. Katzenstein has been of assistance in this and he contacted an attorney who works for the JRSO in Berlin by the name of Karlheinze [sic] Schildbach. ${ }^{16}$ In Berlin we have claims against Brabag and Telefunken, as well as AEG.

A committee has been established here in New York to handle the claims against AEG and Dr. Gringauz ${ }^{17}$ is chairman of the committee. He has been in touch with you and is sending you the names of all possible claimants who have surrendered powers of attorney to him. We are, therefore, treating you as the German attorney prepared to handle the AEG claims.

Please let me know if this meets with your approval and give me the benefit of any suggestions you may have on this whole problem.

15 Hendrik van Dam (1906-1973) war ein deutsch-jüdischer Jurist. Er emigrierte 1933 in die Schweiz und gelangte später über die Niederlande nach Großbritannien. 1945 arbeitete er im Auftrag des britischen Kontrollrats an der Reorganisation des deutschen Gerichtswesens. Von 1946 bis 1950 war er Justiziar der Jewish Relief Unit in Germany und Abteilungsleiter für Hamburg und Bremen. Von 1950 bis 1973 war er Generalsekretär des Zentralrats der Juden in Deutschland.

16 Karl-Heinz Schildbach (1924-2012) arbeitete als Rechtsanwalt für die JCC sowie die JRSO und vertrat ehemalige Zwangsarbeiter in Entschädigungsprozessen gegen deutsche Firmen.

17 Samuel Gringauz (ca. 1900-1975) war Mitarbeiter des URO-Büros in New York. Der Jurist stammte aus Litauen, überlebte den Holocaust und engagierte sich im DP-Lager Landsberg in der jüdischen Selbsthilfe sowie im Führungsgremium des Komitees der befreiten Juden in der amerikanischen Zone in Deutschland, bevor er in die Vereinigten Staaten emigrierte. 
With warm regards.

Cordially yours,

Benjamin B. Ferencz

Dr. Henry van Dam

Zentralrat der Juden in Deutschland

Fischerstr. 49

Duesseldorf, Germany

$\mathrm{BBF}:$ js

\title{
Dokument 28
}

Benjamin B. Ferencz an die leitenden Funktionäre der Claims Conference ${ }^{18}$ New York, 4. Juni 1958

Maschinenschriftlicher Brief, 5 Seiten, mit Anhang, 3 Seiten; Brief mit gedrucktem Briefkopf mit maschinenschriftlich eingefügtem Datum auf Seite 1, Anhang mit separater Paginierung

$R G 12.004 .01^{\star} 02$

[Ferencz berichtet über den Stand der Verhandlungen zur Zwangsarbeiterentschädigung mit verschiedenen westdeutschen Unternehmen nach Abschluss des Vergleichs mit I. G. Farben im Jahr 1957. Vor dem Hintergrund möglicher Verjährungsfristen informiert er über kurzfristig angestrengte Testklagen gegen einige größere Firmen vor westdeutschen Gerichten. In der angefügten Übersicht fasst Ferencz neun Fallkonstellationen zusammen.]

$\{1958$ Slave Labor General $\}$

\author{
Benjamin B. Ferencz \\ Attorney and Counselor at LaW \\ 21 EAST 40TH StREET \\ New York 16, N. Y.
}

Benjamin B. Ferencz

***

Nathan Eisner
Murray Hill 3-6120

'June 4, 1958| Cable: Benferen New York

18 Die einzelnen Empfänger konnten nicht ermittelt werden. 
To

The Senior Officers of the Claims Conference

\section{SLAVE LABOR CLAIMS AGAINST GERMAN FIRMS}

\section{Gentlemen:}

The following memorandum summarizes the present status with regard to the entire question of slave labor claims against various German firms. As will be seen, the Conference has started various activities and now that the Farben settlement has been concluded a decision must be reached on to what, if anything, the Conference wishes to do further on this matter.

The agreement between the Claims Conference and the I.G. Farben company was signed in February 1957 and received publicity throughout the world. Shortly thereafter a number of persons wrote to the Claims Conference and other Jewish organizations requesting assistance in pressing their claims against other German firms. They reasoned that their claims were as justified as were those of the Auschwitz inmates who worked for the Farben company and that they were entitled to the same measure of assistance as the Conference had given to Mr. Wollheim. They also noted that without such assistance they would be unable to obtain any compensation from the German firms involved.

I raised the problem with the URO and suggested that it assist its clients with such claims. The URO, however, refused to do so since such claims did not fall under the existing indemnification or restitution laws and legal action in the regular German courts would be required. Recognizing the difficulties involved in such lawsuits and the doubtful outcome, the URO concluded that it could not handle the cases.

The matter was discussed with Dr. Goldmann ${ }^{19}$ and Mr. Kagan who felt that there was a moral obligation on the part of the Claims Conference to do something. Attempts were made to find private lawyers who would handle those cases on a contingent fee basis. Several lawyers in Germany were approached, including Dr. Ormond who handled the Wollheim case, Dr. Walter Schwarz ${ }^{20}$ of Berlin, and Dr. Kuester of Stuttgart, all of whom refused

19 Hier und auch im Weiteren ist, wenn nicht anders vermerkt, Nahum Goldmann gemeint.

20 (Carl) Walter Schwarz (1906-1988) war ein deutsch-jüdischer Rechtsanwalt, der nach seiner Rückkehr aus der Emigration in Palästina/Israel ab 1950 zunächst im Auftrag der Jewish Agency, anschließend als selbstständiger Rechtsanwalt (1952-1968) in der Bundesrepublik auf dem Gebiet der Wiedergutmachung, vor allem im Bereich 
noting that the amount of work involved would be considerable and the successful |2| outcome far from certain.

In the meanwhile there arose the acute danger that the statute of limitations for such suits would expire at the end of 1957 and persons who might otherwise have a claim would lose their rights by default if no means could be found to help them. ${ }^{21}$ The matter was again discussed with the Conference and in informal committee composed of Mr. Kagan, Nehemiah Robinson, Norbert Wollheim and myself exchanged views on what should be done with regard to several of the problems which called for immediate solution. These included finding and financing lawyers for the claimants, trying to obtain the right of paupers for the claimants in the German courts, determining the theory behind such lawsuits - whether for unjust enrichment, pain and suffering or maltreatment, problems involving security for court costs and methods of notifying the claimants throughout the world of their rights.

In October of 1957 I arranged to have dinner in Frankfurt with the Secretary of the German Chamber of Commerce (Bundesverband der Deutschen Industrie - BDI $)^{22}$ in an attempt to eliminate their opposition to the I. G. Farben settlement which could still be revoked. I used the occasion to urge the BDI to support a similar settlement involving other German firms. I argued that unfavorable litigation would be avoided and that general goodwill would be earned at a relatively minor cost if a settlement could be reached. The Secretary, Dr. Veith, ${ }^{23}$ was interested, and promised to discuss it with the Legal Department of the Chamber of Commerce and let me know the outcome. In due course he requested further details about the number of claimants, the companies involved and the estimated cost of settlement. On instructions of the Senior Officers I replied that further study on our part would be required.

On November 15, 1957 the Conference representative in Germany as well as the head of the URO wrote that they deemed it "completely out

der Rückerstattung, arbeitete. 1974 veröffentlichte er den ersten Band einer siebenbändigen Reihe zur Geschichte der Wiedergutmachung in der Bundesrepublik Deutschland.

211957 beschloss der Deutsche Bundestag das Gesetz über den Aufruf der Gläubiger der I. G. Farbenindustrie Aktiengesellschaft in Abwicklung, wonach alle nach dem 31. Dezember 1957 eingereichten Forderungen von Gläubigern gegen I. G. Farben verjährt sein würden.

22 Hier scheint bei Ferencz ein Übertragungsfehler vorzuliegen. Der Bundesverband der Deutschen Industrie ist im Englischen die Federation of German Industries.

23 Werner Veith war als Rechtsanwalt für den Bundesverband der Deutschen Industrie tätig und vertrat diesen bei den Verhandlungen um das BEG. 
of the question" for any agreement to be reached with the companies to extend the claiming period, and thereby give the organizations greater time for negotiating. They therefore recommended that the Conference not get involved and noted, further, that Conference involvement might jeopardize the Farben agreement and encounter opposition from the German Chamber of Commerce. Nevertheless, in the face of pressures from New York, they said that if lawyers could be found in the United States who would completely prepare all of the cases and the proof required they would try to find lawyers in Germany who would handle the lawsuits if the Conference agreed to pay the regular German fees amounting to several hundred marks or more, depending upon the size of each individual lawsuit.

Despite the unfavorable recommendation from Germany, the Senior Officers decided to proceed cautiously. It was felt that it would be hard to $|3|$ justify doing nothing for these claimants particularly when a successful outcome for the Farben group was imminent. A nominal "Committee of Former Jewish Slave Laborers in Germany" was therefore established. Conference office space at 25 Ann Street was made available for the purpose of centralizing claims and correspondence on this matter which might be received by any Jewish organization and a post office box was opened in order to provide the claimants with an address, even if anonymous, to which to turn. At the same time publicity was issued by the Yiddish press calling upon former slave laborers to notify the Committee if they felt they had a claim against any German firms. It was further decided that one or more "test cases" would be started against German firms where it appeared that there might be substantial numbers of claimants and where liability might be proved.

After considerable last-minute effort, a young lawyer working for the JRSO in Berlin, Dr. Schildbach, was retained to submit test cases against five companies (Telefunken, Siemens, Rheinmetal-Borzig [sic], Brabag and AEG) with offices in Berlin. A German lawyer, Dr. Loehnis, ${ }^{24}$ working for the URO in Frankfurt, was retained to handle the "test cases" against Krupp, Holzmann and Heinkel. The former head of the URO office in Munich, Dr. Wolf, ${ }^{25}$ who had resigned to go into private practice was retained to handle the case against the Moll firm in Munich. It was understood by all the attorneys in Germany that their fees would be contingent on successful conclusion of their individual cases and would be regulated by the official

24 Rudolf Löhnis arbeitete für die URO in Frankfurt a. M. und vertrat einige ehemalige Zwangsarbeiter in ihren Klagen auf Entschädigung.

25 Hans Wolf leitete das URO-Büro in München und übernahm anschließend als niedergelassener Rechtsanwalt Entschädigungsklagen gegen deutsche Firmen. 
German scales. In addition, however, the Committee acting for the Conference, agreed to pay for the court costs and all disbursements. The preparatory work in the United States was done on an ad hoc basis by various former slave laborers, some of whom are employed with the URO in New York, who were recruited for this purpose. No fees were provided for persons working outside of Germany.

In addition, a few private lawyers, notably Mr. Mattern ${ }^{26}$ of New York with about 70 claims against Krupp, and Dr. Werner ${ }^{27}$ of Duesseldorf with 116 claims against Telefunken, started separate test actions.

Contrary to the predictions from Germany, both the Krupp company and the Telefunken company agreed, at least for a limited number of claimants, whose names were given to them before December 31, 1957, not to plead the statute of limitations for six months ending on June 30, 1958. The Krupp attorney has advised Mr. Mattern and his German correspondent, Dr. Meyer of Essen, that although a settlement cannot be recommended, a further extension of the statute of limitations will probably be granted. The class suit started by Dr. Werner against the Telefunken company was recently dismissed on the grounds that the suit was not submitted in proper form by December 31, 1957. |4| Dr. Werner feels that the grounds given by the court are wrong and that an appeal will be successful, but among the 116 cases he represents only 25 have shown a willingness to pay the DM 800 each which an appeal would cost. Both private attorneys have indicated that without financial backing they are not inclined to deal with these matters further.

In my discussions with the Conference attorneys in Germany they gave me to understand that despite the denials of liability the attorneys for Krupp, Telefunken and Brabag might be prepared to settle the claims out of court.

At the end of March 1958, acting on instructions of the Senior Officers, I met with the head of the Legal Department of the German Chamber of Commerce, Dr. Froehlich, as soon as it became apparent that the I. G. Farben settlement would not be revoked. At my suggestion, he subsequently convened a meeting with representatives of Krupp, AEG, Telefunken and Brabag and discussed with them the possibility of a bulk settlement. My proposal

26 Wahrscheinlich ist der Rechtsanwalt Theodore Mattern (1909-2003) gemeint. Mattern wurde 1909 als Theodor Matfus in Österreich geboren. Als Jude sah er sich 1938 zur Emigration in die Vereinigten Staaten gezwungen. Ab den 1950er Jahren widmete er sich verstärkt Fragen der Restitution.

27 Der deutsch-jüdische Rechtsanwalt Alfred Werner war für die URO und die JCC tätig. Unter anderem vertrat er Norbert Wollheim in dessen Entschädigungsklage gegen I. G. Farben i. L. 
was that German industrial firms contribute to a trust fund to be payable to former slave laborers along the lines of the Farben agreement. Dr. Froehlich wrote me on the 21st May that it was his impression that they considered my proposals with interest but for various reasons, particularly technical ones, they did not regard such a settlement as being feasible and noted also that the circumstances differed from those applicable in the Auschwitz area. Nevertheless, he felt that during my next visit to Germany in the fall it might be well for me to meet with the firms involved in order to personally give them my proposals for a solution of the problem and he offered to arrange such a meeting. I have not yet replied to his letter.

It seems clear to me that the door is deliberately being left open to further negotiations. If the Conference does nothing more than what it has already done or started, there is little or no hope of obtaining any compensation for the former forced laborers. If the Conference decides to support these Nazi victims, it will have to be done in a comprehensive manner or it will be meaningless and useless. At this time, we do not even know the approximate number of claimants involved, although we do have indications that less than a dozen firms would be involved in the settlement and that a few thousand claimants would have to be satisfied.

In order to prepare the settlement properly the facts concerning each firm from which a payment is desired would have to be ascertained and documented. I know from my experience as one of the prosecutors against Krupp, for example, that the Nuremberg trials contained a wealth of documentation against the Krupp firm ${ }^{28}$ which has not been touched or mentioned in any of the pending actions. The firm must know that the ugly truth regarding their handling of concentration camp labor will be disclosed and forced $|5|$ into the courts for a judicial determination. The surviving victims, thousands of whom have already been alerted, must be organized so that their claims can be properly evaluated and met and the mass of material already available must be assembled and worked on with that end in mind. Competent personnel in Israel, Germany and New York, working in cooperation with the Jewish organizations, must be entrusted and charged with responsibility for getting the job done in a serious and businesslike way.

If the Conference will demonstrate a determined effort to bring about the settlement of these claims, there is, in my opinion, reason to hope that,

28 Von Dezember 1947 bis Juli 1948 wurde der Krupp-Prozess als Fall X der Nürnberger Nachfolgeprozesse verhandelt. Siehe Kim C. Priemel, Der Sonderweg vor Gericht. Angewandte Geschichte im Nürnberger Krupp-Prozess, in: Historische Zeitschrift 294 (2012), H. 2, 391-426; Weinke, Die Nürnberger Prozesse, 88-91. 
as in the case of the Farben company, an acceptable solution can eventually be reached.

Sincerely,

$\{$ Ben $\}$

Benjamin B. Ferencz

BBF: js

[|1|]

\section{Krupp}

$$
\text { Summary of Claims Against German Firms }{ }^{29}
$$

$\{$ General June 4, 58\}

The Committee of Former Forced Laborers has in its files about 300 unassorted letters of persons claiming to have worked for the Krupp company as slave laborers. About 60 persons whose regular indemnification claims are handled by the URO have also indicated that they worked for the Krupp company. Mr. Mattern, a New York attorney working together with Dr. Meyers [sic] of Essen, has about 70 clients with such claims and has started a lawsuit against the Krupp company.

The Krupp attorneys have agreed to extend the claiming period to June 30, 1958 as concerns 30 claimants whose names were sent to them before December 31, 1957. Although they originally indicated a willingness to settle, the latest letter from the Krupp attorney says that he cannot recommend settlement and Mr. Mattern has indicated that he is not prepared to proceed. The correspondent for the New York Committee has been Dr. Loehnis of Frankfurt.

2. Telefunken

At least 100 cases have been received and sorted by the New York Committee but there may be substantially greater numbers among the unsorted mail. Dr. Werner of Duesseldorf represents 116 clients and his class suit was recently dismissed by the Berlin District Court for failing to file specific claims on time. Whether an appeal will be lodged is doubtful. The company agreed to extend the claiming period to June 30, 1958 for seven claimants submitted by the New York Committee. The indications were that they were inclined to settle the case. The Committee is represented by Dr. Schildbach of Berlin. The Telefunken company is represented by Dr. Buchwald and Dr. Ludwig.

29 Vgl. hierzu im Einzelnen Ferencz, Lohn des Grauens, 100-193; Goschler, Schuld und Schulden, 246-253; Borggräfe, Zwangsarbeiterentschädigung, 60-67. 


\section{Brabag}

There are about 90 known claimants against the Brabag company in Berlin. Dr. Wehle ${ }^{30}$ of the URO New York has been active with regard to these claims for a long period of time and they are now being handled by Dr. Schildbach in Berlin. Four test cases were started and hearings are expected on June 16, 1958. The attitude of the company has not been unfavorable, but they have argued that they lack sufficient funds to make a settlement. The company is represented by Dr. Voigt, Dr. Wurzner and attorney Sieburg.

$|2| 4$. $\underline{\mathrm{AEG}}$

There are about 100 known claimants and the matter in New York is being handled by Dr. Gringauz. Dr. van Dam submitted a number of claims against the company in Germany but upon their refusal to pay he dropped the matter. The attorney who represented him, Dr. Bar-Guttman [sic ${ }^{31}$ requested and received DM 300 from the Conference for his disbursements. (He originally asked for DM 600). The matter is now being handled by Dr. Schildbach. The attitude of the company has been negative.

\section{MOLL}

There are about 125 known claimants and the total maximum estimate is 500. The matter is handled by Dr. Gershwin of URO, New York and Dr. Wolf of Munich working in cooperation with Dr. Pick ${ }^{32}$ of URO Munich. There were three test cases started by Dr. Pick at the Landgericht in Munich and the company has refused to negotiate.

\section{Holzmann}

There are about 90 known claimants. The matter is handled in New York by Mr. Wollheim and in Germany by Dr. Loehnis. Two cases were submitted to the labor court in Frankfurt and one was submitted by attorney Dr. Auerbach in Frankfurt. There are other cases apparently submitted by Ruth Klein

30 Kurt Wehle (1907-1995) war Mitarbeiter im URO-Büro in New York und unterstützte von dort die Entschädigungsklagen gegen die deutsche Industrie. Darüber hinaus war er Präsident der Society for the History of Czechoslovak Jews.

31 Möglicherweise ist Martin Gur-Guttmann gemeint, der als Rechtsanwalt in Frankfurt tätig war und die Klagen ehemaliger jüdischer Zwangsarbeiter gegen AEG betreute.

32 Fritz Pick (1887-1974) war ein deutsch-jüdischer Rechtsanwalt. 1939 floh er in die Niederlande, wo er nach dem deutschen Einmarsch 1940 ins Konzentrationslager Westerbork und von dort aus nach Bergen-Belsen deportiert wurde. 1944 gelangte er durch einen Gefangenenaustausch ins britische Mandatsgebiet Palästina. Nachdem er als Rechtsberater die Gründung der URO begleitet hatte, leitete er von 1954 bis 1966 das URO-Büro München. Danach kehrte er als Berater der URO nach Israel zurück. 
in Frankfurt and Dr. Borchardt ${ }^{33}$ of New York has also sent two cases to Dr. Loehnis. The company's attitude has been negative.

7. Heinkel

There are about 90 known cases. The matter in New York is handled by a Mr. Ingeborg and in Germany it is now handled by Dr. Loehnis. It was originally handled by the firm of Stellweg \& Ostertag of Stuttgart, but they declined to file an action. Dr. Loehnis was to start an action in the labor court. 8. Siemens

There are about 70 known claims and the matter is being handled in Germany by Dr. Schildbach.

9. Rhein-Metal [sic] Borsig

There are 12 claimants known to Department $\mathrm{C}$ of the URO and represented by Dr. Wehle. In Germany Dr. Schildbach is handling $|3|$ the matter. One test case was started and the firm's attitude was negative. The court is definitely hostile. The attorneys for the defendant are Drs. Schmidt and Muller of Berlin.

The files at the Ann Street office have not been properly sorted or arranged. I estimate that there are about 2,000 letters which will have to be re-examined and classified. Some of them are duplicate inquiries and some of them contain lists of names submitted by private attorneys.

June 4, 1958

\section{Dokument 29}

Benjamin B. Ferencz an Saul Kagan

New York, 9. Juni 1958

Maschinenschriftlicher Brief, 1 Seite; gedruckter Briefkopf mit maschinenschriftlich eingefügtem Datum

$R G 12.004 .01^{\star} 01$

33 Wahrscheinlich ist Frederick (Fritz) Borchardt (1901-1956) gemeint. Borchardt war ein deutsch-jüdischer Industriekaufmann, der 1937 in die Vereinigten Staaten emigrierte und sich dort in verschiedenen jüdischen Hilfsorganisationen sowie der jüdischen Gemeinde Habonim engagierte. Darüber hinaus war er Vizepräsident der JRSO und Gutachter der JCC. 
Benjamin B. Ferencz

Attorney and Counselor at LaW

21 East 40Th STREet

New York 16, N. Y.

\author{
Benjamin B. Ferencz \\ Murray Hill 3-6120 \\ Nathan EISNeR \\ 'June 9, 1958; Cable: Benferen New York
}

Dear Saul:

$\{$ copy $\}$

I have before me at the moment a number of inquiries from attorneys here and abroad asking my advice on how to proceed on the cases against Krupp, AEG, Rheinmetal [sic] and Telefunken. The letter from the Bundesverbandes [sic] der Deutschen Industrie, suggesting that I meet again with them and with various German firms, still waits for my reply. I have described to you the present status of the activities of the Committee of Former Slave Laborers and the need for immediate corrective action. I initiated some of the remedial steps today. The lengthy memorandum I prepared last week ${ }^{35}$ presents the current status of the cases against the different companies, and what I think must be done to bring the matter to a successful conclusion.

During the recent meetings with the Senior Officers, I was understandably admonished that if payment is to be made for services rendered, it should be arranged in advance. I do not know if the Conference will desire my endeavors on behalf of the slave laborers to be continued, but in order to avoid any future misunderstandings, please permit me to deal with the matter now. I sincerely regret that I cannot at this time afford to exert any further efforts in this area on a gratuitous basis. If retained, I would, therefore, require compensation on the standards generally prevailing in the legal profession for similar services.

Since it certainly is not my desire or intention to charge more than what is customarily deemed to be reasonable, I will accept whatever fee a group of three informed attorneys selected by the Conference would regard as appropriate.

34 Möglicherweise handelt es sich bei diesen handschriftlichen Einfügungen um Notizen der Archivare.

35 Siehe Dokument 28. 
It would give me a great deal of personal satisfaction to meet the challenge and reach a settlement for the slave laborers. If I did not hope that I might be successful I would not be interested in doing anything further in this matter. I trust, therefore, that the Senior Officers will recognize the fairness of my proposal and will favor me with their confidence.

Sincerely,

Benjamin B. Ferencz

Mr. Saul Kagan

Claims Conference

3 East 54th Street

New York 22, N. Y.

BBF: js

\section{Dokument 30}

Benjamin B. Ferencz an Drexel A. Sprecher ${ }^{36}$

Ohne Ortsangabe, 20. Juni 1958

Maschinenschriftlicher Brief, 2 Seiten

$R G 12.004 .14^{\star} 01$

June 20, 1958

Dear Drex,

You have undoubtedly read in the papers about the recent settlement with the I. G. Farben company according to which they agreed to pay (and have already paid) DM 30 million to be distributed among the concentration camp inmates

36 Drexel A. Sprecher (1913-2006) arbeitete nach seinem Abschluss an der Harvard Law School ab 1938 als Jurist für das US Government Labor Board. Nach dem Zweiten Weltkrieg war er amerikanischer Ankläger im Nürnberger Hauptkriegsverbrecherprozess sowie in mehreren Nürnberger Nachfolgeprozessen. Zudem leitete er die Editionsarbeiten für die 15-bändige sogenannte Green Series, die die Nachfolgeprozesse dokumentierte (Nuernberg Military Tribunals, Trials of War Criminals, 15 Bde.). 
who worked for them in the Auschwitz area. The agreement went into effect on 1 April and now that the first target has been hit, I am turning my sights on some other of our former Nuernberg friends. I am going for a gentleman called Alfried Felix Alwyn von Bohlen und Halbach, more commonly known to us intimates as "Alfie the Drip".

The plan simply is to start one or more cases in a German court seeking to hold Alfie and the firm liable for personal injuries, pain and suffering or other damages inflicted upon concentration camp inmates laboring for them. This endeavor is designed to be the key opening the way to an overall settlement on behalf of all similarly situated concentration camp inmates. In order to impress our friend with the seriousness of our intent, it is necessary to build up a strong case against him. For this purpose, I will require as a starting point our old Nuernberg documents.

In trying to locate the prosecution document books on this point in either English or preferably German, or both, I contacted Cel Goetz ${ }^{37}$ who told me that she had had them but they unfortunately went up in flames a few years ago when her mother's home burned down. Herb Goldenberg ${ }^{38}$ left them behind in Nuernberg and Joe Kaufman ${ }^{39}$ has since that time discarded his copies in disgust. My next thought was to turn to the fountain of all wisdom or, at least, documents, to wit, your goodself.

Do you have, or do you know where I can obtain the materials I need to build my bonfire? I shall cover the New York Public Library and Columbia University here and will also write to Rags. Any suggestions from your side would be gratefully received. I just don't have enough brains to know that we have lost the war and I'm getting ready to hoist the flag and sound the bugle. [|2|] I haven't had any Washington business for a long time but hope that you will find some excuse to come to New York and visit with us. Gertrude joins in sending warm regards to you and the family.

Cordially yours,

Benjamin B. Ferencz

37 Cecelia Goetz (1917-2004) arbeitete als erste Anklägerin für die Anklagebehörde der Nürnberger Nachfolgeprozesse und war an den Prozessen gegen Flick (Fall V) und Krupp (Fall X) beteiligt. Bei letzterem hielt sie die Eröffnungsrede für die Anklage.

38 Herbert Goldenberg $\left({ }^{\star} 1916\right)$ war Jurist und Mitglied der Anklagebehörde für den Fall X der Nürnberger Nachfolgeprozesse (Krupp-Prozess).

39 Joseph Kaufman (1899-1981) war Jurist und gehörte der Anklagebehörde der Nürnberger Nachfolgeprozesse an. Er war an den Vorbereitungen für den Pohl-Prozess (Fall IV) beteiligt sowie Ankläger im Krupp-Prozess (Fall X). 
Drexel A. Sprecher, Esq.

Oaklyn Drive, RFD 3

Bethesda, Md.

BBF: js

\section{Dokument 31}

Benjamin B. Ferencz an Jacob Blaustein ${ }^{40}$

Ohne Ortsangabe, 12. September 1958

Maschinenschriftlicher Brief, 1 Seite

$R G 12.004 .14^{*} 01$

September 12, 1958

$\{$ Krupp $\}$

Mr. Jacob Blaustein

Senior Vice-President

Conference on Jewish Material Claims Against Germany

P.O.B. 238

Baltimore, Md.

Dear Mr. Blaustein:

In June I wrote to Saul stating that if the Conference desired my services with regard to slave labor claims I would require compensation on the standards generally prevailing in the legal profession. I agreed to accept whatever fee would be regarded as appropriate by a group of three informed attorneys selecte̊ ${ }^{41}$ by the Conference, with whom I assumed the matter would be discussed in my preseenñceę. ${ }^{42}$

40 Jacob Blaustein (1892-1970) wurde als Mitgründer der American Oil Company zum amerikanischen Großindustriellen und war von 1949 bis 1954 Präsident des American Jewish Committee sowie Vizepräsident der JCC.

41 Das Wort ist im Dokument zum Teil abgeschnitten.

42 Das Wort ist im Dokument zum Teil abgeschnitten. 
I was informed that in view of other retainers from the URO and the Conference, a fee of $\$ 5,000$ per annum was offered for dealing with the claims against Krupp and more than half a dozen other firms. I continued to do the work because there was an urgent need for immediate action and I did not want the Conference to have to consider the matter under pressure, but my silence should not be misinterpreted as indicating satisfaction and I feel obliged, therefore, to let you know my views.

I appreciate the expression of confidence and am grateful for the friendship shown by you and the other officers, the sincerity of whose intention is beyond question. I have reflected upon the offer and recognize that there are honest differences arising from different points of view. I sincerely regret that I cannot at this time afford to donate my efforts without regard to the financial aspects and it is my considered opinion that the obligation to my family and my profession makes it inadvisable for me to accept the Conference's proposal as it now stands.

If my original suggestion is not acceptable, perhaps it can be reviewed at a later date when the amount and nature of the work is clearer. I would also agree to the terms given to Mr. Ormond in connection with the I. G. Farben matter. You will recall that he served as attorney for claimants and received from the Conference his disbursements and a reasonable fee which was credited toward a subsequent contingent fee. I will, of course, continue to cooperate fully with you until such time as the Conference may reconsider its previous proposal, and as I know the meetings in London will be occupied with more urgent and important matters, may I suggest that after we are all back in the States we sit together and try to reach a mutually satisfactory arrangement.

Sincerely yours,

Benjamin B. Ferencz

BBF: js 


\title{
Dokument 32
}

Benjamin B. Ferencz an Ernst Katzenstein

New York, 22. März 1960

Maschinenschriftlicher Brief, 1 Seite; gedruckter Briefkopf mit maschinenschriftlicher Einfügung

$R G 12.004 .19^{*} 03$

$\left\{\right.$ copy for Siemens file ${ }^{43}$

\author{
Benjamin B. Ferencz \\ Attorney and Counselor at LaW \\ 21 EAST 40TH STREET \\ New York 16, N.Y.
}

Benjamin B. Ferencz

$* * *$

Nathan EISNer
Murray Hill 3-6120

$|34.38|^{44}$ CABle: Benferen New YorK

March 22, 1960

Dr. Ernst Katzenstein

JRSO

Grueneburgweg 119

Frankfurt/Main, Germany

Dear Ernst:

Saul Kagan and I have discussed your letter of March 16 concerning Mr. Langbein's ${ }^{45}$ proposals. It is very unfortunate that Dr. Knoll is so little informed about Krupp's wartime activities and her denial that Krupp had a factory

43 Im Original ist das Wort Siemens eingekringelt.

44 Wahrscheinlich Aktenverweis des Absenders.

45 Hermann Langbein (1912-1995) war ein österreichischer Kommunist. Nach dem sogenannten Anschluss Österreichs flüchtete er nach Spanien und schloss sich den Internationalen Brigaden an. Nach deren Niederlage gelangte er 1939 nach Frankreich, wurde interniert und 1941 an die deutsche Polizei ausgeliefert. Es folgte die Inhaftierung im Konzentrationslager Dachau, von wo aus er 1942 nach Auschwitz deportiert wurde. Dort arbeitete Langbein als Schreiber u. a. für SS-Ärzte und gründete mit anderen Häftlingen die Widerstandsorganisation "Kampfgruppe Auschwitz«. 
in Auschwitz played right into Langbein's hands. A careful analysis of the documents, however, will disclose that Krupp never really succeeded in getting his production going in Auschwitz and that the total number of people he employed there was very limited. Without referring back to the documents themselves, my present recollection is that there may have been perhaps 125 Jews working there and the number of survivors can at best be very few. It was for this reason that we gave no publicity to the fact that Krupp operated in Auschwitz for the name "Auschwitz" itself would invite thousands of claimants who would have to be disappointed.

I think that if these facts were explained to Langbein, he would also recognize the inadvisability of publicizing Krupp's connection with Auschwitz. Dr. Stein ${ }^{46}$ has all of the details about the Auschwitz operation and they were contained in a recent letter of Dr. Bergmann.

The information sheet on the Krupp case indicates that racial Jews as well as confessing Jews ${ }^{47}$ will be covered by the agreement. I do not, however, feel that we should give Langbein any assurance on this point since we would have great difficulty in rebutting any allegation of Jewishness arising from Poland's non-confessing Jews connected with this group. ${ }^{48}$

As far as his proposal for joint negotiations with Siemens is concerned, I think it should be clear that we cannot accept his invitation. You may simply tell him that we are not in negotiation with Siemens ${ }^{49}$ that our plans are still very uncertain, and that we therefore cannot bind ourselves to a partnership

1954 war er Mitbegründer des Internationalen Auschwitz-Kommittees (IAK) und fungierte 1964 als Zeuge im Frankfurter Auschwitz-Prozess. Siehe dazu Stengel, Hermann Langbein.

46 Max Stein (1901-1964) war ein deutsch-jüdischer Jurist. Nachdem er 1933 mit einem Berufsverbot belegt worden war, emigrierte er ins britische Mandatsgebiet Palästina. Nach einer Ausbildung zum Wirtschaftsprüfer arbeitete er für das israelische Finanz- und Justizministerium. Von 1958 bis 1962 war er Rechtsberater der JCC. Anschließend befasste er sich mit der Durchsetzung von Entschädigungsansprüchen ehemaliger Zwangsarbeiter gegen deutsche Industrieunternehmen.

47 Siehe dazu die Erläuterungen in der Einleitung, $33 \mathrm{f}$.

48 Da die JCC nur bekennende Juden vertrat, entstanden bei Entschädigungsfragen immer wieder Konflikte, weil der Kreis derer, die von den Nationalsozialisten als Juden verfolgt worden waren, auch Personen umfasste, die sich nicht zum Judentum bekannten. Konkret ging es hier um die mit der JCC konkurrierenden Ansprüche derjenigen nicht-bekennenden polnischen Juden, die durch das von Hermann Langbein geleitete Internationale Auschwitz-Komitee vertreten wurden. Siehe dazu Goschler, Streit um Almosen, 184; Stengel, Hermann Langbein, 232-237.

Das Wort ist im Original eingekringelt. 
which may not prove to be in the best interests of those ifor' whose welfare we are primarily concerned.

With warm regards,

Cordially yours,

Benjamin B. Ferencz

cc. Dr. Robinson; ${ }^{50}$ Dr. Stein;

Mr. Kagan

\section{Dokument 33}

Benjamin B. Ferencz an Alfred L. Goldberger ${ }^{51}$

Ohne Ortsangabe, 22. März 1960

Maschinenschriftlicher Brief, 2 Seiten; Kopfzeile auf Seite 2 ("Alfred L. Goldberger, Esq. March 22, 1960«)

$R G 12.004 .14^{*} 03$

$34.38^{52}$

March 22, 1960

Alfred L. Goldberger, Esq.

90 State Street

Albany 7, N.Y.

\section{Re: Estate of Charlotte W. ${ }^{53}$}

Dear Mr. Goldberger:

Thank you for your letter of March 21 in the above captioned matter.

50 Nehemia Robinson.

$51 \mathrm{Zu}$ dieser Person konnten keine biografischen Informationen ermittelt werden.

52 An dieser Stelle sowie in weiteren folgenden Dokumenten handelt es sich wahrscheinlich um einen Aktenverweis des Absenders.

53 Da es sich bei dieser Person um eine Verfolgte des nationalsozialistischen Regimes handelte, wurde der Name von den Herausgebern anonymisiert. 
I was equally surprised to discover that we are related and, indeed, my uncle, Ben, had phoned me and spoken to me about this matter a few weeks ago.

The terms of the settlement agreement with Krupp state that claims of heirs would only be considered "when the concentration camp prisoner registered the claim himself". Although there is no further clarification in the text of the agreement, I know from my negotiations in the matter that this was intended to exclude any persons who died before the agreement was reached. The agreement was signed on 23 December, 1959 and I note that Mrs. W. died on October 20, 1959.

You will recognize, therefore, that technically her estate should be excluded. Nevertheless, I would suggest that you write for the application mentioned in my letter of January 18 and submit it. The total amount payable cannot exceed 5,000 DM (about $\$ 1,200$ ) but there may be a certain measure of flexibility possible on the part of the trustees who are distributing the funds. I am one of the trustees and I am also counsel to the URO. In view of the brief period of time between her death and the signing of the agreement and the fact that she had submitted various $|2|$ claims to the URO it may be possible to do something for the estate if there are funds available after all the living claimants have been satisfied. I cannot hold out much promise, but it seems certainly worthwhile for you to complete the simple application form and submit it or to have it done by the URO so that the matter may be given consideration when distribution begins. This will not be possible before a year from now and once your application is submitted, I think you will have discharged your obligation to the estate to safeguard their interests by every possible means.

The next time you are in New York do give me a ring.

Cordially yours,

Benjamin B. Ferencz

BBF: js 


\section{Dokument 34}

Benjamin B. Ferencz an Mary S. ${ }^{54}$

Ohne Ortsangabe, 25. April 1960

Maschinenschriftlicher Brief, 1 Seite

$R G 12.004 .01^{\star} 04$

April 25, 1960

Mrs. Mary S.

3936 Dolfield Avenue

Baltimore 15, Md.

Dear Mrs. S.:

I have your letter of 12 April sent to my former address advising me that you and 500 other women were employed as slave laborers in an ammunition factory in Oedern-Flossenburg [sic $]^{55}$ and that the company for which you worked was Agricola G.m.b.H. which you say belongs to Auto-Union, Dusseldorf [sic].

The Conference on Jewish Material Claims Against Germany and the URO have been very active in trying to obtain compensation for former slave laborers wherever possible. Since the number of persons who have thus far appeared to claim compensation against this particular company is very limited, no negotiations with this company have yet been instituted.

Your name will, however, be registered with the Claims Conference and if it should appear at a subsequent date that any action on your behalf can be

54 Da die Person Ferencz als Verfolgte des nationalsozialistischen Regimes kontaktierte, wurde ihr Name von den Herausgebern anonymisiert.

55 Bei der Deutschen Kühl- und Kraftmaschinen GmbH Scharfenstein in Oederan, einem Tochterunternehmen der Auto-Union AG Chemnitz, produzierten 500 jüdische Zwangsarbeiterinnen aus dem dortigen Außenlager des Konzentrationslagers Flossenbürg Munition. Seit Oktober 1944 trug dieses Unternehmen den Tarnnamen Agricola GmbH, Scharfenstein, Werk S. Oederan. Siehe Ulrich Fritz, Oederan, in: Wolfgang Benz/Barbara Distel (Hg.), Der Ort des Terrors. Geschichte der nationalsozialistischen Konzentrationslager, Bd. 4: Flossenbürg, Mauthausen, Ravensbrück, München 2006, 219-223. 
successfully undertaken, you may be sure that it will be done and you will be notified when further information is required.

Sincerely yours,

Benjamin B. Ferencz

cc. Mr. Saul Kagan

BBF: js

\section{Dokument 35}

Benjamin B. Ferencz an Ernst Katzenstein

New York, 29. April 1960

Maschinenschriftlicher Brief, 2 Seiten

$R G 12.004^{*} 11$

Dr. Ernst Katzenstein

April 29, 1960

JRSO

Grueneburgweg 119

Frankfurt/Main, Germany

\section{$\underline{\text { Re: HOLZMANN }}$}

Dear Ernst:

Saul and I, with URO help, have been trying to figure out the potential number of claimants against the Holzmann company. Our conclusions based on discussions with a substantial number of claimants and a study of a number of affidavits indicates that Holzmann employed Jewish slave laborers in at least eight different locations and that we may anticipate at least 2,000 claimants. As of April 20, 643 claimants had been registered against Holzmann in the Claims Conference office in New York. The following is a brief outline of the camps and the number of employees: 
1. The Dachau area: This includes (a) Kaufering (Lager 1, 2, 4, and 11); ${ }^{56}$ (b) Landsberg (Lager 3, 4, 7, and 8); ${ }^{57}$ (c) Mildorf [sic] ${ }^{58}$ and (d) Uting $\left[\right.$ sic] ${ }^{59}$ (Lager 10). The testimony indicates that there were at least 150 Jewish women working for Holzmann in that area and in addition there were anywhere from 700 to 2,000 Jewish men. The Moll company worked in the same area doing similar construction work and groups of laborers were taken from the different Dachau Lagers with varying regularity to work for the different construction companies.

2. Workers were employed at Gutenbrunn-Posen ${ }^{60}$ which included workers from the nearby camps at Nekla and Wrzesnia. ${ }^{61}$ Our conclusion is that a few hundred people must be assumed to have survived the Gutenbrunn area activities.

3. Reval-Estonia. ${ }^{62}$ Here we have a fairly clear picture that there were about 125 women working for Holzmann in that area.

$|2|$ 4. Waldenburg (Schmiedberg $[$ sic $]):^{63}$ The indications are that there were 500 men employed in that area.

5. We know that there was a $\mathrm{ZAL}^{64}$ in Zesmania-Lithuania ${ }^{65}$ in operation from the end of 1941 to the beginning of 1943 and that originally 500 men and women were employed there by Holzmann and the figure was later increased to 1,200.

6. Jaworzno: There were about 1,200 persons employed there from April 1943 to January 1945.

7. Other camps about which there is still insufficient information include Wuertemberg [sic $]^{66}$ on [sic] der Elbe (Camp Roxen, Zell-

56 Gemeint sind Außenlager des Konzentrationslagers Dachau, die unter dem Namen Kommando Kaufering zusammengefasst wurden und ab 1944 in der Nähe von Landsberg am Lech und der Gemeinde Kaufering errichtet worden waren. Mit insgesamt elf Lagern bildeten sie den größten Außenlagerkomplex des Konzentrationslagers Dachau.

57 Wahrscheinlich sind weitere Lager des Komplexes Kaufering/Landsberg gemeint.

58 Wahrscheinlich ist Mühldorf gemeint. Die Lagergruppe Mühldorf gehörte neben dem Lagerkomplex um Kaufering und Landsberg am Lech zu den größten Außenkommandos des Konzentrationslagers Dachau.

59 Gemeint ist das Außenlager Utting am Ammersee, das Teil des Lagerkomplexes Kaufering/Landsberg war.

60 Gemeint ist das Zwangsarbeitslager Posen-Gutenbrunn.

61 Gemeint ist das Zwangsarbeitslager Września.

62 Gemeint ist das Zwangsarbeitslager Tallinn.

63 Gemeint ist Schmiedeberg (heute Kowary, Polen).

64 Zwangsarbeitslager.

65 Wahrscheinlich ist das Lager von Žiežmariai in Litauen gemeint.

66 Wahrscheinlich bezieht sich Ferencz hier auf die Stadt Wittenberge. 
wolle Fabrik, near Potsdam) and camps at Markstadt, ${ }^{67}$ Reichenbach and Funfteichen [sic], ${ }^{68}$ near Breslau, where all the big construction companies had activities going for which they drew upon local concentration camp inmates.

From all of this you can see that it would be most unwise to approach Dr. Kesselheim $^{69}$ with a request for payment for only 1,000 people. On the other hand, if we come in with too high a figure now we may scare him off completely. Under the circumstances, the best thing for us to do is to stall. We do not wish anything to interfere with the negotiations with AEG or Telefunken.

In the next meeting with Dr. Kesselheim you can simply indicate to him that we are still trying to obtain an accurate picture of the number of survivors who worked for Holzmann. You may also indicate to him that we have a number of areas where it appears that Holzmann employed slave labor and you may give him the list, but not the figure contained therein. You may ask him for his information concerning the number of employees and the time and duration of the employment. You may impress upon him the fact that we are very conscientious and studious in this matter and therefore further detailed research and discussion with survivors is essential before we can fix even an approximate figure. In the meanwhile, we can continue to exchange information with them.

This should give them enough to do for a while and explain why we are not pressing for an immediate or early settlement. In the meanwhile, we should continue to try to improve our information and when the AEG agreement is settled (Halevai!) ${ }^{70}$ we can deal with the Holzmann matter on the basis of the facts then known.

With warm regards, Cordially yours,

Benjamin B. Ferencz

cc. Dr. Muller/Gringauz

cc. Mr. Saul Kagan

67 Gemeint ist das Zwangsarbeitslager Markstädt (heute Jelcz-Laskowice, Polen).

68 Gemeint ist das Außenlager Fünfteichen des Konzentrationslagers Groß-Rosen.

69 Walter Kesselheim war Vorstandsmitglied der Philipp Holzmann AG.

70 Der ursprünglich aramäische Ausdruck halevai hat im modernen Hebräisch die Bedeutung von »schön wär's«. 


\section{Dokument 36}

Benjamin B. Ferencz an Ernst Katzenstein

Ohne Ortsangabe, 11. Mai 1960

Maschinenschriftlicher Brief, 1 Seite

RG $12.004^{\star} 11$

May 11, 1960

Dr. Ernst Katzenstein

JRSO

Grüneburgweg 119

Frankfurt/Main, Germany

re: HOLZMANN

Dear Ernst:

Your letter of May 6 re Holzmann came as no surprise. I even admired the fact that they didn't miss a trick and made every possible argument why they shouldn't pay.

I am very skeptical about their arguments that they didn't pay the SS for the use of the forced labor. We went into this point in some detail in our prosecutions of various industrialists at Nuremberg and my recollection is that we had clear evidence that no German industrial firm was forced to use slave labor. They could obtain such labor only on their own request and requisition and, as far as I know, the industrial firms were required to pay the SS for each day of labor and they received a certain discount if the firm itself was required to provide the food. I would, therefore, very much like to see these Cost-Plus contracts to which Dr. Kesselheim or Dr. Bernet ${ }^{71}$ referred.

I have noted that the records of the main office were destroyed but I always marvelled at Nuremberg how these destroyed documents could suddenly reappear when they were useful for the defense. The SS kept records of the receipts, the tax authorities had records of the payments made, and the local firms as well as the central offices kept detailed records on all these matters. Dr. Stein should be alerted to this and see what he can find in the

71 Otto Bernet war Rechtsanwalt und vertrat die Philipp Holzmann AG bei Gerichtsverfahren zu Entschädigungsklagen ehemaliger Zwangsarbeiter. 
various document centers. He should direct his attention particularly to the records of the Dachau camp and camps in the Reval area.

With warm regards,

Cordially yours,

Benjamin B. Ferencz

cc. Dr. Nehemiah Robinson

Mr. Saul Kagan

BBF: js

\section{Dokument 37}

Benjamin B. Ferencz an Ernst Katzenstein

New York, 11. Mai 1960

Maschinenschriftlicher Brief, 3 Seiten; gedruckter Briefkopf mit maschinenschriftlicher Einfügung auf Seite 1, Kopfzeile aufjeder folgenden Seite (gedruckt: "TAYLOR, SCOLL, FERENCZ \& SIMON")

$R G 12.004 .20 * 04$

[Ferencz geht auf verschiedene Aspekte eines möglichen Abkommens mit AEG-Telefunken ein. Er verweist auf die Spezifika dieses Falls, insbesondere den geringen Kenntnisstand über die Beschäftigung von Zwangsarbeitern. Abschließend rät er nachdrücklich zu einem zügigen Abschluss mit einem moderaten Forderungsvolumen.]

\section{TAYlor, SColl, Ferencz \& Simon COUNSElors at LaW}

Telford TAylor

DAVID E. SCOLL

Benjamin B. Ferencz

KenNeth Simon
400 Madison Avenue

$|34.31 \& 39|$

New York 17, N. Y.

Murray Hill 8-8990

Cable Address: Lantalaw 
May 11, 1960

Dr. Ernst Katzenstein

JRSO

Grueneburgweg 119

Frankfurt/Main, Germany

$\{\stackrel{8}{c} \mathrm{c}$ in AEG file $\}$

\section{$\underline{\text { Re: AEG and TELEFUNKEN }}$}

\section{Dear Ernst:}

I am writing in supplement to Saul Kagan's letter of May 4, dealing with the problem of a possible AEG-Telefunken settlement.

Let me say at the outset that I was rather amused to read Dr. Stein's report of April 21 on his discussion with Messrs. Hellenbroich ${ }^{72}$ and LeCoque. The attempt of their part to exclude persons from behind the Iron Curtain, to allege that they were compelled to employ prisoners, that they treated the people decently and were only protecting them, that they saved lives thereby, that their companies were no longer in existence having been taken by the Russians, and that we should really settle with other companies first, were the refrains of an old familiar song. I wiped away my tears and remembered the good old days in Nuremberg. But I suppose I am just a hardboiled cynic or perhaps it's because I have hanging on the wall before me a picture of a much-admired judge - Oliver Wendell Holmes - whose caution to ascertain "by bathing everything in cynical acid" has much impressed me. ${ }^{73}$

I am very much concerned about our own ignorance regarding AEG and Telefunken. In the Farben and Krupp cases we had the benefit of the enormous research done at Nuremberg. That is not the case here. Our estimates contain many gaps and we may be vulnerable to surprises. Dr. Stein's list of 314 sites occupied by Telefunken is impressive but actually tells us very little, if anything, about the employment of Jewish concentration camp labor. The

72 Der Anwalt Hellenbroich war Rechtsberater der AEG und vertrat diese in Verhandlungen mit der JCC. Siehe dazu auch Ferencz, Lohn des Grauens, 148-151.

73 Oliver Wendell Holmes (1841-1935) war ein amerikanischer Jurist und 1902 bis 1932 Richter am Supreme Court. Er avancierte zu einem der meistzitierten Juristen der Vereinigten Staaten und zur Symbolfigur für amerikanische Progressivisten. Das vollständige Zitat lautet: »You see how the vague circumference of the notion of duty shrinks and at the same time grows more precise when we wash it with cynical acid and expel everything except the object of our study, the operations of the law «, vgl. Oliver Wendell Holmes, The Path of Law, in: Harvard Law Review 10 (1897), H. 8, 457-478, hier 462 . 
figures given by the AEG representatives are simply unreliable. I have spoken to many survivors $|2|$ here and I am convinced that the figures contained in Dr. Stein's letter in April 21 as given to him by AEG are vastly understated.

Nevertheless, Saul ${ }^{74}$ and I both feel that a settlement for both AEG and Telefunken of between 7 and 10 million DM would be reasonable. Since we do not know and cannot know in advance the precise number of claimants who may be eligible for payment, I feel that we cannot undertake to pay approximately 5,000 DM to each. We may find that it will be necessary to revise our approach completely and to pay only "according to the urgency of need". It would be important, therefore, in any discussion with Dr. Boden ${ }^{75}$ to keep the door open for this possibility. In other words, if you should reach a point where you are discussing the Claims Conference obligations, make sure that you retain sufficient flexibility to permit a distribution along lines other than those accepted in the I. G. Farben and Krupp agreements.

There are various ways in which this can be formulated. You may say that if the number of eligible claimants does not exceed 2,000 then payments of $5,000 \mathrm{DM}$ per person are envisaged, but if the number of claimants exceeds 2,500 then the Claims Conference shall be authorized to distribute the funds to the eligible claimants according to the urgency of their need as determined by the Conference. You will recognize that this is the formula taken from the Hague Agreements ${ }^{76}$ and if it was good enough for the German government it should be good enough for the AEG.

It will also be more difficult here to give them a "save harmless" clause. ${ }^{77}$ This is particularly true in view of the fact that private lawyers, such as Dr. Werner, already have an accumulation of cases and are in the highest courts. If we make a settlement and Werner is not satisfied, what is really to

74 Saul Kagan.

75 Hans Boden (1893-1970) war ab 1929 Aufsichtsratsmitglied der AEG. Nach Stationen als Leiter der Finanzabteilung und stellvertretender Vorstandsvorsitzender wurde er 1956 Vorstandsvorsitzender der AEG und übte dieses Amt bis 1961 aus. In dieser Funktion verhandelte er mit der JCC über Entschädigungszahlungen an jüdische Zwangsarbeiter. Anschließend war Boden bis 1963 Präsident der Internationalen Handelskammer und Aufsichtsratsmitglied verschiedener Unternehmen.

76 Im Protokoll Nr. 2, das zu dem am 10. September 1952 in Luxemburg unterzeichneten Abkommen zwischen der Bundesrepublik, Israel und der JCC gehörte, wurde festgelegt, dass von der Globalentschädigung in Höhe von 500 Millionen DM ein Betrag von 50 Millionen DM für die Forderungen nicht-bekennender Juden verwendet werden sollte. Siehe Goschler, Schuld und Schulden, 286.

77 Die deutschen Industrieunternehmen forderten von der JCC, im Gegenzug für ihre Entschädigungsleistungen zugunsten ehemaliger jüdischer Zwangsarbeiter von allen künftigen Ansprüchen und Klagen freigestellt zu werden. 
prevent him from pursuing the matter to judgment and perhaps enforcing a greater liability? It may be that all we can guarantee is that we will not support any further claimants and that we will encourage all to accept the terms of our settlement. We may also give them a statement of satisfaction on our part which they can use as they see fit, but it would be very dangerous for us to accept a limited payment and an unlimited liability.

|3| Saul and I both feel that you can advise Dr. Wieczorek ${ }^{78}$ in general terms about the present status of our discussions, but I think it would not be advisable for him to suggest to his clients that we are approaching an amicable settlement as such advice at this stage would be premature.

With warm regards, Cordially yours,

Benjamin B. Ferencz

cc. Dr. Max Stein

Mr. Saul Kagan

BBF: js

\section{Dokument 38}

Benjamin B. Ferencz an Manfred Saalheimer ${ }^{79}$

Ohne Ortsangabe, 6. Juni 1960

Maschinenschriftlicher Brief, 1 Seite

RG $12.004 .01{ }^{*} 04$

78 Bernhard Wieczorek arbeitete als Rechtsanwalt im Auftrag der JCC in den Revisionsverfahren gegen Rheinmetall vor dem Bundesgerichtshof (siehe Kapitel 4, Fußnote 115).

79 Manfred Saalheimer (1906-1967) war ein deutsch-jüdischer Rechtsanwalt und in jüdischen Verbänden, etwa der Reichsvertretung der deutschen Juden, aktiv. 1933 wurde er von den Nationalsozialisten mit einem Berufsverbot belegt. Während des Novemberpogroms wurde er festgenommen und im Konzentrationslager Buchenwald inhaftiert. 1939 konnte er nach Großbritannien emigrieren. Ein Jahr später siedelte er nach Kanada über. Dort leitete er von 1954 bis 1967 das Büro der URO in Montreal. 
June 6, 1960

Dr. M. Saalheimer

URO

493 Sherbrooke St. West

Montreal, Canada

Dear Dr. Saalheimer:

With reference to the claim of Erzsebet W. against Christian Dierig of Langenbielau, ${ }^{80} \mathrm{I}$ don't believe it is possible for us to do anything at this time. I have never heard of the company and have no idea as to whether they even exist in West Germany. It certainly is not worth the URO's while to conduct any investigation for only one claim, particularly when there is not the slightest indication that if the company were approached it would agree to pay anything.

I would suggest therefore that the lady be advised to simply forget about it and we will put her name and the name of the company on file just in case there should be any later change in the situation.

With warm regards,

Cordially yours,

Benjamin B. Ferencz

b.c. Mr. Kagan

\section{Dokument 39}

Benjamin B. Ferencz an Ernst Katzenstein

Ohne Ortsangabe, 17. November 1960

Maschinenschriftlicher Brief, 2 Seiten; Kopfzeile auf Seite 2 ("November 17, 1960 Dr. Ernst Katzenstein Re: Rheinmetall «)

$R G 12.004 .18^{\star} 04$

80 Das 1805 gegründete Unternehmen Dierig war vor und nach 1945 einer der größten deutschen Textilkonzerne. Seit 1945 leitete Christian Gottfried Dierig (1923-2016) das Unternehmen, das nach dem Verlust seines im schlesischen Langenbielau (heute Bielawa) gelegenen Hauptwerks seinen Stammsitz nach Augsburg verlagerte. 
November 17, 1960

Dr. Ernst Katzenstein

JRSO

Grüneburgweg 119

Frankfurt/Main, Germany

Re: RHEINMETALL

Dear Ernst:

When I was in Berlin on 24th October, I reviewed the Rheinmetall situation with Dr. Schildbach. He expected the decision of the Kammergericht Berlin on the 30th November and although we have sent him additional supporting evidence it seems clear that the decision will be negative. We will then have to file a notice of appeal to the Bundesgericht within the next thirty days. This will give us a little more time during which to prepare the appeal, but we will need a new lawyer admitted to the Bundesgericht (which will cost - don't mention the word - money). I have no doubt that the lawyer would succeed in obtaining some delay, but all of this delay is getting us nowhere.

While I was in Berlin I asked Schildbach to inquire further about the real owners of Rheinmetall and he reported that it was owned by the Allgemeine Berg und Hutterwerke [sic], A.G., Salzgitter which, in turn, is owned by the Bund. ${ }^{81}$ If that is so, we would be well advised to find out who in the Bund deals with this matter and try to get them to agree to a suspension of the case. I can see no particular advantage in accumulating negative decisions against us.

I would suggest, therefore, that you inquire in Bonn to find out more about this and see what can be done to obtain a suspension on the grounds that we look forward to an amicable settlement of the problem.

I have examined the Annual Report of Rheinmetall, Berlin, A.G. and I find several points of interest. The company seems $|2|$ to be prosperous and growing in value. As of 31 December, 1959 they had put aside a reserve of about $\$ 2$ million for uncertain obligations. I would be pleased to relieve them of the uncertainty. They have also acknowledged debts incurred before 1945

81 Das Rüstungsunternehmen Rheinmetall-Borsig war während des Nationalsozialismus Teil des Konzerns Reichswerke »Hermann Göring«. Ab 1949 befand es sich im Besitz des Bundes. 1956 wurde das Unternehmen privatisiert und von der Röchlingschen Eisen- und Stahlwerke GmbH übernommen. In diesem Prozess ging die überschuldete Borsig AG an das staatseigene Unternehmen Aktiengesellschaft für Bergund Hüttenbetriebe, das 1961 in Salzgitter AG umbenannt wurde. Die Rheinmetall Berlin AG blieb bis 2004 als Holding im Besitz der Röchling-Gruppe. 
in an amount of over $\$ 1$ million which is included in the above-mentioned reserve. We will probably settle for less.

The Deputy Chairman of the Aufsichtsrat is an old pal of mine, Rechtsanwalt Otto Kranzbuhler [sic], ${ }^{82}$ defender par excellence of notorious war criminals. (It seems that those who worked for the defense in Nuremberg fared much better than those engaged for the prosecution).

It would be useful for us to obtain some better indication of the total number of claimants who have thus far registered, and I trust that Dr. Stein or Dr. Lowenthal ${ }^{83}$ will arrange to get this information to us quickly.

It may be that because of the Bund's connection with the company we have no hope for a successful settlement. The sooner we find out the better off we'll be. From the Annual Report I would guess that the company operates fairly independently, and the Bund should not object to a modest settlement if the members of the board can be persuaded that it should be done. Direktor Caesar ${ }^{84}$ of Düsseldorf is Chairman of the Board and we should all start thinking of the correct approach if we are going to talk settlement to him or to Kranzbuhler.

Any suggestions are welcome but let's first find out if we cannot postpone the thing via your intervention in Bonn.

With warm regards, Cordially yours,

Benjamin B. Ferencz

cc. Mr. Saul Kagan

82 Otto Kranzbühler (1907-2004) war ein deutscher Jurist und während des Zweiten Weltkriegs ab 1943 als Marinerichter tätig. Vor dem Internationalen Militärtribunal gegen die Hauptkriegsverbrecher in Nürnberg verteidigte er Karl Dönitz. Auch in den Nürnberger Nachfolgeprozessen war er als Verteidiger für verschiedene Angeklagte tätig. Anschließend arbeitete er als Rechtsanwalt für deutsche Industrieunternehmen und gehörte ab 1956 dem Aufsichtsrat der Rheinmetall AG an.

83 Ernst Gottfried Lowenthal (1904-1994) war ein deutsch-jüdischer Journalist und politischer Funktionär. Ab 1929 war er als Referent des Centralvereins deutscher Staatsbürger jüdischen Glaubens tätig. 1939 emigrierte er nach Großbritannien und engagierte sich dort für die Belange jüdischer Flüchtlinge. Nach seiner Rückkehr nach Deutschland war er im Bereich der Restitution tätig. 1953 bis 1962 arbeitete er für die JCC und leitete die CT.

84 Otto Paul Caesar war von 1956 bis 1971 Vorstandsvorsitzender der Rheinmetall AG. 


\section{Dokument 40}

Benjamin B. Ferencz an Ernst Katzenstein

Ohne Ortsangabe, 11. Januar 1961

Maschinenschriftlicher Brief, 1 Seite

$R G 12.004 .18^{*} 05$

\section{$\underline{\text { Personal \& Confidential }}$}

Dr. Ernst Katzenstein

January 11, 1961

JRSO

Gruneburgweg [sic] 119

Frankfurt/Main, Germany

re: RHEINMETALL

Dear Ernst:

With further reference to your letter of January 5th, I have discussed the Rheinmetall problems with Saul ${ }^{85}$ and we both feel that before we can do anything further on this we must have some better indication of the total number of claimants. I am quite confident that you are not eager to start negotiations with Roechling ${ }^{86}$ without even knowing approximately how many claimants we purport to present.

We do know that there were 1,200 female prisoners taken from Sommerada [sic] ${ }^{87}$ which was a Kommado [sic] of Buchenwald to work for Rheinmetall. The camp was established on 20 September 1944 and the inmates were taken from Gelsenkirchen.$^{88}$ The two test cases of Judith B. and Irene R. have had a tough time in the Berlin District Court where the claims have been rejected and this rejection is, I anticipate, about to be confirmed by the Kammergericht. Although we do not want to collect negative decisions for their own sake, nevertheless, we still entertain the hope that we will be able to effect some settlement with other companies such as Siemens and the

85 Saul Kagan.

86 Die Familie Röchling erwarb 1956 die Mehrheitsbeteiligung an der damaligen Rheinmetall-Borsig AG. Vgl. dazu auch Ferencz, Lohn des Grauens, 182.

87 Siehe zu den Recherchen zum Lager Sömmerda Ferencz, Lohn des Grauens, 191. Vgl. auch Irmgard Seidel, Sömmerda, in: Benz/Distel (Hg.), Der Ort des Terrors, Bd. 3: Sachsenhausen und Buchenwald, München 2006, 575-577.

88 Satz auf der rechten Marginalie angestrichen. 
very fact that these issues are being contested in the courts may be useful in supporting our other endeavors. ${ }^{89}$

In short, we must be patient and proceed step by step. It is discouraging along the way and a bit frightening, but occasionally at the end of the rocky and perilous road one finds a pot of gold which makes all effort and indignation worthwhile. ${ }^{90}$

With warm regards,

Cordially yours,

Benjamin B. Ferencz

cc. Mr. S. Kagan

Dr. May

Dr. Stein

\section{Dokument 41}

Benjamin B. Ferencz an Ernst Katzenstein

Ohne Ortsangabe, 24. August 1961

Maschinenschriftlicher Brief, 2 Seiten; Kopfzeile auf Seite 2 (»August 24, 1961 Dr. Ernst Katzenstein Re: Krupp“)

RG $12.004 .14^{*} 04$

$\{\mathrm{K}\}$

August 24, 1961

Dr. Ernst Katzenstein

JRSO

Gruneburgweg [sic] 119

Frankfurt/Main, Germany

89 Satz teilweise eingekreist.

90 Satz auf der rechten Marginalie angestrichen. 
Dear Ernst:

I have been belaboring our poor friend, Saul, ${ }^{91}$ about our delays in making payment to those Krupp claimants who are obviously entitled to compensation. My study of the files there and Stein's subsequent reports indicated clearly that there are at least 500 cases where the claimants are obviously entitled. This is particularly true of the Hungarian girls who worked in Essen, ${ }^{92}$ where one look at the files shows their age, place of birth, their movement from one camp to the other as a group and their ITS record, all proving conclusively that the claim is legitimate. The only excuse we have for not paying is that we have not yet set up the necessary bureaucratic machinery.

What must be done in each case is:

(1) The case must be "approved." This can be done, I hope, quickly by a committee of three (I thought two would have been adequate for the clear cases);

(2) The claimant (or his attorney if one has been designated) must be notified that his case has been approved and he must be asked to submit a waiver ${ }^{93}$ together with instructions as to where payment is to be made;

(3) A check for 3,000 DM must be sent to him and he must be advised that the balance will be paid when we know how much more there will be available.

All of the foregoing has been approved in principle, but it lacks implementation. I recognize that everything takes $|2|$ time and that everything must be done properly, but I hope that when you return from your vacation you will have so such renewed vigor and strength that this program can be launched

91 Saul Kagan.

92 Von August 1944 bis März 1945 bestand in Essen das Außenlager Humboldtstraße des Konzentrationslagers Buchenwald. Die dort festgehaltenen 520 ungarischen Jüdinnen wurden in der Gussstahlfabrik der Friedrich Krupp AG zur Zwangsarbeit eingesetzt. Siehe Ulrich Herbert, Von Auschwitz nach Essen. Die Geschichte des KZ-Außenlagers Humboldtstraße, in: Dachauer Hefte 2 (1986), 13-34; Michael Zimmermann, Essen (Humboldtstraße), in: Benz/Distel (Hg.): Der Ort des Terrors, Bd. 3, 436-439.

93 Die Entschädigungsleistungen der deutschen Industrieunternehmen kamen allesamt als außergerichtliche Vergleiche zustande. Die Unternehmen bezeichneten diese als freiwillige Leistungen, mit denen keine Schuldanerkenntnis verbunden war, und verlangten im Gegenzug für die Leistungen den Verzicht auf künftige Forderungen und Klagen. Siehe dazu Goschler, Schuld und Schulden, $252 \mathrm{f}$. 
like a rocket. Since all of the generals are now away gathering their strength, I am sending a copy of this to Elkan ${ }^{94}$ who I believe is the only one left, in the hope that he can begin to take whatever preparatory steps are possible.

With warm regards,

Cordially yours,

Benjamin B. Ferencz

cc. Dr. May

Dr. Elkan

Mr. Kagan

\section{Dokument 42}

Benjamin B. Ferencz an Ernst Katzenstein

Ohne Ortsangabe, 30. Juli 1962

Maschinenschriftlicher Brief, 1 Seite

$R G 12.005 .01^{\star} 01$

July 30,1962

Dr. Ernst Katzenstein

JRSO

Gruneburgweg [sic] 119

Frankfurt/Main

Dear Ernst:

I have your letter of July 26th suggesting the employment of additional staff to serve as screeners of the slave labor claims. Frankly, I have my doubts whether additional screening personnel, even if they could be found, would substantially alter the situation.

94 Wahrscheinlich handelt es sich um Frederick (Fritz) W. Elkan (ca. 1897-1981), einen deutschen Juden, der nach seiner Inhaftierung durch die Nationalsozialisten nach Großbritannien floh. Nach dem Zweiten Weltkrieg war Elkan im Bereich der Restitution tätig und arbeitete als Rechnungsprüfer für die JRSO, die JCC und die CT. 
Stein and I did a lot of screening together, and where the case is simple it is a fairly quick procedure. Either the documents in the file meet the criteria established to validate the claim or they do not. It takes only a minute to answer the question once the file has been properly assembled and after the question has been answered, it is purely a clerical job to write up the reason for the decision.

The time-consuming operation consists in collecting the documentation and the clerical work involved in transmitting and assembling forms and other papers, as well as trying to decide the cases where the documents are clear. The former can be done with clerical help and the latter requires a personal interview by people who are experienced in the interrogation of claimants or who are personally familiar with the facts.

I don't think, therefore, that adding lawyers to the staff will do anything other than create an empire of people who will react in an inconsistent way to the claims and give rise to the need for other lawyers to serve as arbiters. (Mr. Parkinson wrote a famous treatise on this subject). ${ }^{95}$

I realize that all of this may seem rather overwhelming to Dr. Eran ${ }^{96}$ at this point, but as he settles down to the work, I am confident that he will be able to manage it himself and we have never objected to the addition of clerical staff wherever required.

With warm regards,

Cordially yours

cc. Dr. May

Mr. Kagan (2)

95 Ferencz verweist hier auf das Parkinsonsche Gesetz. Cyril Northcote Parkinson (1909-1993) hatte in Bezug auf Verwaltungstätigkeiten und Bürokratiewachstum in ironischer Weise postuliert, dass sich die zu erledigende Arbeit in dem gleichen Maß ausdehne, wie Zeit zu ihrer Erledigung zur Verfügung stehe. Siehe Cyril Northcote Parkinson, Parkinson's Law, and Other Studies in Administration, Boston, Mass., 1957.

96 Dr. Avraham Eran. 


\section{Dokument 43}

Benjamin B. Ferencz

Ohne Ortsangabe, 7. November 1962

Maschinenschriftliches Memorandum, 1 Seite

$R G 12.004 .08^{\star} 02$

\section{Report of Benjamin B. Ferencz - 7 November, 1962}

Slave Labor - Dynamit Noble [sic]

When we learned that Mr. Flick, who was one of the defendants at Nuremberg, had acquired control of Dynamit-Noble [sic], we planned to have him approached via Mr. Krupp. We had discussed the possibility of having Mr. Blaustein talk to Mr. Beitz ${ }^{97}$ in order to solicit Krupp's assistance. Katzenstein and I had prepared a memorandum for Mr. Blaustein, but we decided to cancel those plans after I had discussed the matter with Eric Warburg. ${ }^{98}$ Warburg felt that an approach via Krupp would be wrong. He offered instead to intervene on our behalf with Dynamit Noble [sic] and he said he knew the key people there very well.

On October 9th Katzenstein wrote to Warburg, giving him an outline of the claim and Warburg arranged some introductions for Katzenstein. Katzenstein has asked to meet with a member of the Board and is now trying to arrange an appointment.

97 Berthold Beitz (1913-2013) war seit 1953 Generalbevollmächtigter von Alfried Krupp von Bohlen und Halbach. Nach dessen Tod 1967 wurde Krupps Vermögen in die Alfried Krupp von Bohlen und Halbach-Stiftung überführt und Beitz zum Vorsitzenden des Stiftungskuratoriums bestimmt. 1973 wurde er von der Gedenkstätte Yad Vashem als »Gerechter unter den Völkern« geehrt, da er während des Zweiten Weltkriegs als Leiter der Karpaten Öl AG in Boryslaw jüdische Männer und Frauen als »kriegswichtige Facharbeiter « vor der Deportation bewahrt hatte.

98 Eric Warburg (1900-1990) war ein deutsch-jüdischer Bankier und zunächst Teilhaber im Familienbankhaus M.M. Warburg. 1938 emigrierte er in die Vereinigten Staaten, wo er gemeinsam mit seinem Vater Max M. Warburg 1945 das Bankhaus neu gründete. 1956 kehrte er nach Westdeutschland zurück, beteiligte sich dort am Wiederaufbau jüdischer Institutionen und Organisationen und unterstützte die Entschädigungsverhandlungen mit Alfried Krupp und Berthold Beitz. 


\section{Dokument 44}

Benjamin B. Ferencz an Ernst Katzenstein

Ohne Ortsangabe, 10. Januar 1963

Maschinenschriftlicher Brief, 2 Seiten; Kopfzeile auf Seite 2 (»January 10, 1963 Dr. Katzenstein ")

RG $12.004 .14^{*} 06$

Dr. Ernst Katzenstein

January 10, 1963

JRSO

$\{$ Krupp $\}$

Gruneburgweg [sic] 119

Frankfurt/Main

Dear Ernst:

I have your letter of January 2nd enclosing the letter from Dr. HannemannStrauss to Dr. Eran with a number of questions about the Krupp case. It should be made clear to Mr. Strauss that the funds at our disposal from Krupp compel us to adopt as restrictive a policy as possible when acknowledging the validity of claims. ${ }^{99}$ This principle will determine the answers to most of the questions she posed. In short -

1. Work in the hospital by women is in my opinion not eligible for compensation. The same applies to work by women in the tailor shop and the kitchen.

2. Medical personnel used outside the camp, kitchen personnel and other service personnel are not eligible.

3. Workers employed by other companies are not eligible unless they can show that they worked exclusively on the Krupp factory; women serving those workers in the kitchen are not eligible.

4. Women employed as textile workers, etc. in Langenbielau-Reichenbach $^{100}$ are not eligible. Those who worked in the Vidia-Stahlwerk $[\text { sic }]^{101}$ are eligible and have already been approved.

99 Das Abkommen mit Krupp sah sehr restriktive Kriterien für die Anerkennung von Leistungen vor. Siehe dazu Ferencz, Lohn des Grauens, 130-138.

100 Gemeint sind die Dierig-Textilwerke in Langenbielau (heute Bielawa) im Kreis Reichenbach (Schlesien).

101 Gemeint ist die Widia-Fabrik in Essen, in der das gleichnamige Hartmetall hergestellt wurde. 
I realize that we are making distinctions which are morally indefensible in many cases since I assume that the suffering endured by the people doing various functions was comparable, but we must draw a line somewhere simply because we have not been able to get more money. We can therefore only accept those who were either employed in the Krupp factory or can show that they were assigned exclusively to do construction work on the Krupp factory including laying the foundation for the factory.

|2| If we must seek a rational basis, we can with reasonable conscience maintain that construction work was harder than any other and for that reason we have included them.

I would suggest that you have Dr. Eran send you a copy of Mr. Gutter's ${ }^{102}$ letter to Dr. Strauss of 18 th December which may have crossed in the mail with hers and which goes into considerable detail about the facts in the various camps.

With warm regards,

Cordially yours,

Benjamin B. Ferencz

BBF: js

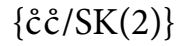

\section{Dokument 45}

Benjamin B. Ferencz an Jacob Blaustein

Ohne Ortsangabe, 13. September 1963

Maschinenschriftlicher Brief, 1 Seite

$R G 12.004 .14^{\star} 06$

102 Simon Gutter $\left({ }^{*} 1918\right)$ war ein deutscher Jude, der 1938 in die Niederlande emigrierte. Nach der Besetzung der Niederlande durch die Deutschen wurde er inhaftiert und über das Konzentrationslager Sachsenhausen nach Auschwitz-Monowitz deportiert. Aufgrund seiner persönlichen Kenntnisse des Lagers war er nach dem Krieg als Mitarbeiter der JCC in New York, unterstützt durch einige andere Überlebende des Konzentrationslagers Monowitz, mit der Prüfung eingegangener Entschädigungsanträge betraut. 
Mr. Jacob Blaustein

September 13, 1963

American Trading Corp

American Building

Baltimore \& South Streets

Baltimore, Md.

Dear Mr. Blaustein:

I understand from Saul Kagan that you are planning to see Mr. McCloy soon with reference to our attempt to obtain some additional compensation from Mr. Krupp. In this regard, you may want to remind Mr. McCloy that Krupp has not yet disposed of his enormous steel holdings at Rheinhausen. ${ }^{103}$ As I recall it, the sale of this empire was a specific condition imposed by Mr. McCloy at the time Krupp was released from Landsburg [sic] Prison ${ }^{104}$ and had his entire fortune restored to him. I believe Mr. McCloy was quite unhappy about Mr. Krupp's failure to live up to his personal, written undertaking, and a reminder on this point may be appropriate should Mr. Krupp or Mr. Beitz suggest that the Conference is bound by the original agreement and Krupp will consider nothing else.

I was pleased to learn from Mr. Snyder that you have made a good recovery and send you my best wishes for the New Year and warm regards.

Cordially yours,

Benjamin B. Ferencz

cc. Mr. Saul Kagan (2)

BBF: js

bc. Dr. Ernst Katzenstein - Confidential and Personal

\section{Dokument 46}

Benjamin B. Ferencz an Ernst Katzenstein

Ohne Ortsangabe, 25. Oktober 1963

Maschinenschriftlicher Brief, 1 Seite

RG 12.004.08*03

103 Vgl. hierzu auch Ferencz, Lohn des Grauens, 105 und $113 \mathrm{f}$.

104 Gemeint ist die Justizvollzugsanstalt Landsberg. 
October 25, 1963

Dr. Ernst Katzenstein

JRSO

Gruneburgweg [sic] 119

Frankfurt/Main

Dear Ernst:

Eric Warburg has arrived here and has called me for additional documentary proof to show Flick's connection to Dynamit-Nobel. ${ }^{105}$

Eric made a point that he had through his own independent research "although it was not his job" ascertained that Flick was a member of the Board of Dynamit-Nobel in 1942 and he was put up for re-election in 1943. Eric wanted to know whether we had any documentary proof to show that Flick was in fact re-elected in 1943 or thereafter in order to tie him in with some personal responsibility. He was under the impression that the Nuremberg archives must have been full of this sort of stuff.

Fischer's ${ }^{106}$ efforts in Munich did not seem very productive and, frankly, I don't know where else we can turn at the moment to get some quick answers. I would suggest that you give this problem back to Fischer and also that you take it up informally with I. G. Farben because they must have some old records which should show the connection between the two companies or at least who sat on the boards.

I'll stall Eric here, try to meet with him here and have him arrange for the three of us to meet with von Schlabrendorff after he and I are both in Germany.

With warm regards,

Cordially yours,

Benjamin B. Ferencz

cc. Mr. S. Kagan (2)

105 Das Wort ist im Original eingekringelt.

106 Es könnte Bruno Fischer (vgl. Dokument 63) gemeint sein. 


\section{Dokument 47}

Benjamin B. Ferencz an Ernst Katzenstein

Ohne Ortsangabe, 6. November 1963

Maschinenschriftlicher Brief, 1 Seite

$R G 12.004 .08^{\star} 03$

November 6, 1963

Dr. Ernst Katzenstein

JRSO

Gruneburgweg [sic] 119

Frankfurt/Main

Re: Dynamit-Nobel

Dear Ernst:

Saul Kagan, Mr. Weisman [sic] ${ }^{107}$ and I met yesterday with Eric Warburg and Hans Meyer ${ }^{108}$ in New York. Our topic was primarily Dynamit-Nobel. Eric repeated what I had already indicated to you in my letter of October 25th. ${ }^{109}$ We will provide him with additional affidavits from here which will describe the conditions in the camps and I will try again to send Henry Sachs ${ }^{110}$ to Washington to see what he can find there in our effort to tie in Mr. Flick to the activities of Dynamit-Nobel in 1943.

107 Ernest (Ernst) H. Weismann (1901-1989) war ein jüdischer Jurist aus Deutschland. Bis 1933 war er als Richter tätig. 1933 emigrierte er nach Frankreich und 1942 von dort aus in die Vereinigten Staaten. Ab 1954 arbeitete er als Rechnungsprüfer für die JCC.

108 Hans J. Meyer (1891-1968) war ein deutsch-jüdischer Bankier und Diplomat. Nach dem Ersten Weltkrieg war er im Finanzministerium tätig und in dieser Funktion mit Reparationsfragen befasst. 1926 wechselte er in das Bankhaus M. M. Warburg \& Co., für das er ab 1930 in Amsterdam arbeitete. Nach seiner Emigration in die Vereinigten Staaten 1941 war er im Office of Strategic Services tätig. Danach wirkte er in verschiedenen jüdischen Organisationen, darunter der American Federation of Jews from Central Europe und dem JDC.

109 Siehe Dokument 46.

110 Henry B. Sachs (1899-1960) übernahm Recherchetätigkeiten in Archiven, um Beweismaterialien für die Prozesse gegen die deutsche Industrie zu sammeln. Der Kontakt zwischen ihm und Ferencz stammte aus der Zeit der Nürnberger Prozesse, als Sachs bereits für das Berliner Büro des OCCWC tätig gewesen war. 
Of course, I tried to make the argument that the obligation to compensate slave laborers is a liability of the company and even if Flick was not personally in charge of those activities at the time they occurred, he is, as the present owner, together with the other owners, still responsible to make payment. Eric insisted that all of this must be handled delicately and that my pushing was not the appropriate approach.

He indicated that the main opposition comes from the manager and the legal counsel of the company, a Mr. Fischer. Flick and Buehle are not really opposed but they are having difficulties with the management. Saul suggests that it would be a good idea for us to check the Nazi Party affiliation of Mr. Fischer at the Berlin Document Center. Dr. Tuch ${ }^{111}$ still has access there and the details about Mr. Fischer's name, date of birth, etc. can probably be obtained from a registry of the German firms or by a discreet phone call to the company.

Eric Warburg will be back in Hamburg on the 17th November and we agreed that I would call him on the 18th. We will then decide whether it is useful for us to see von Schlabrendorff together.

I'll see you soon after you get this letter. With warm regards,

Cordially yours,

Benjamin B. Ferencz

cc. Mr. S. Kagan (2)

\section{Dokument 48}

Benjamin B. Ferencz an Ernst Katzenstein

Ohne Ortsangabe, 30. Januar 1964

Maschinenschriftlicher Brief, 2 Seiten; Kopfzeile aufSeite 2 (»January 30, 1964")

$R G 12.004 .14^{*} 07$

111 Hans Tuch (1888-1980) war ein deutsch-jüdischer Jurist. 1938 emigrierte er nach Großbritannien, kehrte 1949 nach Deutschland zurück und arbeitete bis 1965 als Direktor des JRSO-Büros in Berlin. Daneben war er auch für die JTC tätig. 
January 30, 1964

Dr. Ernst Katzenstein

JRSO

Gruneburgweg [sic] 119

Frankfurt/Main

Dear Ernst:

Thank you for sending me a copy of Dr. Goldmann's prompt reply to Mr. Beitz. I consider Beitz' letter one of the most arrogant and disgusting documents I have ever read.

In his letter, Mr. Beitz suggests that Krupp was improperly convicted at Nuremberg and therefore he is entitled to some kind of restitution. In reply to our reference to bitterness on the part of the victims, he laments about the bitterness they all feel about the Nuremberg trials.

The incident to which he refers suggests that a great injustice was done since Krupp was convicted for the murder of 400 persons who are still alive. ${ }^{112}$ The Judgement of the Tribunal described the strenuous efforts undertaken by Krupp and his leading officials to have the Hungarian girls, who worked as his slaves, sent back to Buchenwald since it was not planned to have these inmates remain alive and thus be liberated by the advancing American troops. A few girls escaped from the train taking them to their destined death and told the story to the court. The Tribunal concluded that "nothing further has been discovered about the fate of the young Hungarian Jewesses of the Krupp firm" (Judgment, p. 1429). ${ }^{113}$ The Judgment spoke the truth. It was only years later that I discovered how the plan to murder all these girls went astray. When they arrived at Buchenwald the camp was so crowded that the Kommandant refused to accept them and sent them on to Bergen-Belsen in the belief that the job could be done better there. Before they could be killed, many of them

112 Die Verurteilung Alfried Krupps in Nürnberg 1948 beruhte unter anderem auf der Annahme der amerikanischen Richter, dass die im Essener Krupp-Walzwerk beschäftigten ungarischen jüdischen Zwangsarbeiterinnen alle ums Leben gekommen seien. Als aber die Anträge auf Entschädigung aus dem Abkommen der JCC mit Krupp eingingen, waren darunter auch 400 der tot geglaubten Jüdinnen aus Ungarn, worauf sein Generalbevollmächtigter Berthold Beitz einen sehr kritischen Brief an die JCC schrieb. Siehe Joachim Käppner, Berthold Beitz. Die Biographie, Berlin 2010, 207-220.

113 Nuernberg Military Tribunals, Trials of War Criminals, Bd. 9, 1429. 
were liberated. Now Mr. Beitz wants credit for this, and he argues that because the attempted murder did not succeed in its entirety Krupp is entitled at least to moral restitution in the eyes of the world. (The classic example of the boy who murdered his parents and then pleaded for leniency because he was an orphan!)

|2| The reasons why Mr. Krupp was convicted at Nuremberg are explained in detail in 121 pages of the Judgment published in Volume IX "Trials of War Criminals Before the Nuremberg Military Tribunals" available from the U.S. Government Printing Office. ${ }^{114}$ (This is the Green Series which I left in Dr. May's office). It is a catalog of incredible bestialities perpetrated on a vast scale of plunder and spoliation, of illegal use of prisoners of war, and of proof beyond any reasonable doubt of the individual criminal responsibility of each and every convicted defendant. Knowing the truth as I do, I cannot share the bitterness of the Krupp leaders about what happened to Mr. Krupp. Ås I compare the status of his impoverished victims today with his own status as one of the richest and most powerful men in the world, I can find plenty of room for bitterness but only on the side of the former slaves.

It is perhaps fortunate, therefore, that the reply to Beitz has come from Mr. Goldmann who is not burdened with a knowledge of the details. His statement that the Claims Conference is not responsible for what happened in Nuremberg is more defensive than the facts warrant. I know what happened in Nuremberg and am quite prepared to defend it. But, as you see, I am much too emotional about the whole thing. Occasionally, in this cynical breast the spark of justice flames, only to be put out by reading such correspondence as has here been exchanged.

We can re-examine the whole question in depth when we all meet in Brussels. Meanwhile, I would suggest that no further action be taken.

With warm regards,

Cordially yours,

Benjamin B. Ferencz

cc. Mr. S. Kagan (2)

114 Vgl. ebd., 1327-1499. 


\section{Dokument 49}

Benjamin B. Ferencz an Ernst Katzenstein

Ohne Ortsangabe, 28. April 1964

Maschinenschriftlicher Brief, 2 Seiten; Kopfzeile auf Seite 2 (»April 28, 1964«)

$R G 12.004 .18^{*} 08$

April 28, 1964

Dr. Ernst Katzenstein

JRSO

Gruneburgweg [sic] 119

Frankfurt/Main

Re: RHEINMETALL

Dear Ernst:

The negative decision of the $\mathrm{BGH}^{115}$ comes as no great surprise. I am of course not much impressed by the reasoning of the court which I think is exceedingly shallow and even erroneous in its dictum that the labor was assigned within the framework of the state-controlled armaments industry. Nevertheless, I agree with your conclusion that we should not seek an appeal to the constitutional court.

We can, however, try to use some of the court's argumentation for other useful purposes. The court made a special point of the fact that the claim was rejected as being unfounded at this time. It follows, therefore, that the claim could be validly asserted at some later date. The whole issue is merely

115 Gemeint ist die Entscheidung des Bundesgerichtshofs vom 17. März 1964, die Revision gegen die Urteile des Berliner Kammergerichts abzuweisen. Dieses hatte die Klagen zweier aus der Tschechoslowakei stammender ehemaliger Zwangsarbeiterinnen, die inzwischen die US-amerikanische Staatsbürgerschaft besaßen, gegen Rheinmetall auf Vergütung ihrer Dienste, Entschädigung und Schmerzensgeld »als zur Zeit unbegründet « abgelehnt, da eine Prüfung der Ansprüche bis zu einer endgültigen Reparationsregelung mit dem Heimatstaat, entsprechend dem Londoner Schuldenabkommen, hätte zurückgestellt werden müssen. Siehe: Bundesgerichtshof, VI ZR 186/61, [Abweisung der Revision gegen das Urteil des 10. Zivilsenats des Kammergerichts in Berlin vom 12. Juli 1961 über die Zulässigkeit der Geltendmachung von Schadensersatzanspruch], Karlsruhe, 17. März 1964 sowie Bundesgerichtshof, VI ZR 187/61, [Abweisung der Revision gegen das Urteil des 10. Zivilsenats des Kammergerichts in Berlin vom 12. Juli 1961 über die Zulässigkeit der Geltendmachung von Schadensersatzanspruch], Karlsruhe, 17. März 1964; Ferencz, Lohn des Grauens, 169. 
postponed, and the possible liability of the German firms remains together with the possibility that interest on their liability will be accumulating from the time the liability arose. If we are now to move toward an overall settlement with the Bund of German Industry, ${ }^{116}$ we can point out that this type of claim remains as a potential threat to German firms. I don't suppose that even cautious accountants are putting aside any great reserves to meet this contingent liability; yet, according to the German Supreme Court, this type of claim can be asserted at a later date. I can hardly imagine that the statute of limitations would run as long as the Supreme Court says an international treaty prevents the claimant from asserting his claim.

If we took an assignment from all of the claimants who had turned to the Claims Conference for assistance, we could even perpetuate the claim in a form which would survive the death of the potential original claimants.

These are arguments which I think we can make when we talk about an overall settlement on behalf of all German firms. If we can persuade the "Spiegel" to write its story to the effect $|2|$ that the Stuttgart Court holds the German firms liable ${ }^{117}$ and the BGH postpones the imposition of that liability which results in a continuing cloud over the German firms, it might strengthen our hand. I think it is worthwhile for you to call the "Spiegel" writer and try to have a chat with him in order to induce him to point up the moral responsibilities as well as the legal risks. We must show the German companies that this is an issue which will not be laid to rest. Only by so doing can we see any results.

With warm regards, Cordially yours,

Benjamin B. Ferencz

cc. Mr. S. Kagan (2)

\section{Dokument 50}

Benjamin B. Ferencz an Ernst Katzenstein

Ohne Ortsangabe, 6. Mai 1964

Maschinenschriftlicher Brief, 1 Seite

RG 12.004.10

116 Gemeint ist der BDI.

117 Gemeint ist die Entscheidung des Stuttgarter Landgerichts im Fall Bartl gegen Heinkel vom 11. März 1964. Siehe Ferencz, Lohn des Grauens, 169. 
May 6, 1964

\author{
Dr. Ernst Katzenstein \\ JRSO \\ Gruneburgweg [sic] 119 \\ Frankfurt/Main
}

\title{
Re: Heinkel and Rheinmetall
}

\section{Dear Ernst:}

The decision of the OLG ${ }^{118}$ Stuttgart in the case of Bartl v. Heinkel ${ }^{119}$ was really exciting. I managed to obtain a copy of the 38-page decision here, and am much impressed with the wisdom and courage of the court. The reasoning that a 30-year statute of limitations applies is most helpful on a difficult problem which we have never succeeded in resolving internally in the past.

In the light of the Stuttgart decision, of course I agree with your letter of April 28th that we now have a much stronger case against Rheinmetall. The powers of attorney which you requested should be on their way to you since the claimants were asked to come into the URO to sign the powers and I asked Mr. Gutter to mail them off to you directly in order to save time.

The Stuttgart decision also substantially strengthens our hand in any approach toward the BDI. ${ }^{120} \mathrm{I}$ hope that we can begin to move in that direc-

\section{Oberlandesgericht.}

119 Edmund Bartl klagte ab 1959 (siehe dazu auch die Dokumente 51 und 70) in mehreren Instanzen gegen die Ernst Heinkel AG, von der er Schmerzensgeld wegen körperlicher Misshandlung und Lohnausgleichszahlungen für seinen Einsatz als Zwangsarbeiter forderte. Das OLG Stuttgart entschied 1964, dass Bartl zwar ein Ausgleich des entgangenen Arbeitsentgelts zustehe, wies die Schmerzensgeldforderungen aber zurück. Der Bundesgerichtshof wies allerdings 1967 die Ansprüche Bartls letztinstanzlich ab, da diese verjährt seien, und erlegte ihm zudem die Prozesskosten auf. Schließlich scheiterte Bartl auch vor dem Europäischen Gerichtshof für Menschenrechte und vor dem Bundesverfassungsgericht. Siehe dazu Ferencz, Lohn des Grauens, 218-220; Borggräfe, Zwangsarbeiterentschädigung, $61 \mathrm{f}$.

120 Bereits 1957 hatte Ferencz Kontakt zum BDI aufgenommen, um die Chancen einer Generallösung für die Entschädigungsforderungen der JCC zugunsten ehemaliger jüdischer Zwangsarbeiter auszuloten, war damit jedoch erfolglos geblieben. Siehe Borggräfe, Zwangsarbeiterentschädigung, 49. 
tion as soon as the Dynamit-Nobel payment is received. ${ }^{121}$ I would appreciate being kept closely informed.

With warm regards,

Cordially yours,

Benjamin B. Ferencz

BBF: js

cc. Mr. Kagan (2)

\section{Dokument 51}

Benjamin B. Ferencz an Ernst Katzenstein

Ohne Ortsangabe, 15. Mai 1964

Maschinenschriftlicher Brief, 1 Seite

$R G 12.005 .01^{\star} 03$

May 15, 1964

$\{$ S. L. General\}

Dr. Ernst Katzenstein

JRSO

Gruneburgweg [sic] 119

Frankfurt

Dear Ernst:

I have read with interest the copy of the Spiegel article on slave labor ${ }^{122}$ which was attached to your letter of May 11th. I noticed that they attached a chart

121 Die Zahlung von Dynamit-Nobel blieb aus. Siehe dazu die Einleitung, 58f. sowie Ferencz, Lohn des Grauens, 203-212.

122 Ferencz verweist hier auf den Artikel Anonymus, Entschädigung. Sklaven des Reiches, in: Der Spiegel, 13. Mai 1964, 59-61. Der Artikel thematisiert die Klage von Edmund Bartl, der im Konzentrationslager Oranienburg inhaftiert war und zur Zwangsarbeit in den Heinkel-Werken Oranienburg eingesetzt wurde. Zum Verlauf der Klagen siehe Kapitel 4, Fußnote 119. 
which presumably shows the number of Jewish slave laborers who worked for various firms. I gather that this chart consists of the breakdown prepared by Mr. Holstein of the claims submitted to Compensation Treuhand. ${ }^{123}$ As published, it is very misleading since it would indicate that the 50 or so companies listed employed only 18,999 Jews. The fact is that hundreds of thousands of concentration camp inmates were employed by German industry and the figures indicate only a small fraction which represents those who have turned to Compensation Treuhand.

This error by the Spiegel should give us an opportunity to get a correction published and perhaps put in some good words for our cause. I would suggest, therefore, that you write to the Editor for publication, asking him to please correct the impression which may have been created, that German industry employed only about 19,000 Jews. Hundreds of thousands were employed, and the numbers given represent only those survivors who have come forward with claims, none of which have been paid. The German industry has thus far refused to recognize either its legal or moral obligation to these unfortunate people and their failure to respond sympathetically can only be detrimental to Germany's reputation throughout the world.

The article itself might serve as a good basis for introducing the topic for re-discussion with the BDI and I would suggest that you send some copies to Eric Warburg and ask him whether he feels this would be an appropriate entree for him to take up the matter again with Dr. Berg. ${ }^{124}$

With warm regards,

Cordially yours,

Benjamin B. Ferencz

cc. Mr. S. Kagan (2)

Dictated but not read.

123 Zur Umsetzung der Abkommen der JCC mit deutschen Firmen, die im Zweiten Weltkrieg jüdische Zwangsarbeiter beschäftigt hatten, gründete diese die Compensation Treuhand (CT) als gemeinnützige Gesellschaft mit Sitz in Frankfurt am Main. Seit Anfang der 1960er Jahre übernahm die CT die Prüfung und Bewilligung individueller Ansprüche jüdischer Geschädigter. Siehe dazu Ferencz, Lohn des Grauens, $78 \mathrm{f}$.

124 Vermutlich Fritz Berg (1901-1979), der von 1949 bis 1971 Präsident des BDI war. 


\section{Dokument 52}

Benjamin B. Ferencz an Ernst Katzenstein

Ohne Ortsangabe, 16. Juni 1964

Maschinenschriftlicher Brief, 2 Seiten; Kopfzeile auf Seite 2 (»June 16, 1964«)

$R G 12.004 .08^{\star} 04$

June 16, 1964

Dr. Ernst Katzenstein

JRSO

Gruneburgweg [sic] 119

Frankfurt/Main, Germany

Dear Ernst:

Hans Meyer, Saul Kagan and I had a luncheon meeting with von Schlabrendorff yesterday. He again raised the points referred to in your report of May 22nd but concluded that the only remaining objections related to the Claims Conference's power of attorney from the claimants and an assurance that the Claims Conference would still be around to carry out its guarantees. He explained that the first point would not have been raised by them, but it was raised by a representative of a Jewish organization who had told them that they should not settle since the Claims Conference was not authorized to speak for its claimants. Von Schlabrendorff did not disclose who that person was, and we did not press him but I think it might be interesting if you had a chat with Dr. van Dam on this subject to see whether he has any ideas. Since my suspicion moves in his direction, tact is recommended or if you feel that no good can come of it you may want to do nothing at all. I am just curious to know who our "friends" are.

We concluded that we would try to obtain McCloy's signature on the letter, draft of which is attached, in order to meet the point of establishing the Conference's right to speak for the claimants and the value of the Claims Conference guarantee for future years. Since von Schlabrendorff indicated that Mr. Flick was eager to wind up any claims that might exist against him with reference to other companies, we agreed to send von Schlabrendorff a letter indicating our general willingness in principle to make such settlements once Dynamit Nobel is concluded. A copy of that draft letter is also attached.

We all agreed that no approach should be made to the BDI until Dynamit 
Nobel is finished and thereafter we are in favor of such settlement, but it depends upon timing in relationship $|2|$ to the BEG or other matters.

Von Schlabrendorff had some very kind words for you and your great skill as a negotiator and in the face of such flattery even I managed to remain polite.

I will let you know when the McCloy letter is signed and the next step will have to take place on July 22nd in Germany.

With warm regards,

Cordially yours,

Benjamin B. Ferencz

BBF: js

Encl.

cc. Mr. S. Kagan (2)

\section{Dokument 53}

Benjamin B. Ferencz an Ernst Katzenstein

Ohne Ortsangabe, 18. Dezember 1964

Maschinenschriftlicher Brief, 2 Seiten; Kopfzeile auf Seite 2 (»December 18, 1964«)

RG $12.004 .08^{\star} 04$

December 18, 1964

Mr. Ernst Katzenstein

$\{\# \# \#$

JRSO

Gruneburgweg [sic] 119

Frankfurt/Main

Re: DYNAMIT-NOBEL

Dear Ernst:

Since I have not been very successful in evading my responsibilities, I am afraid that I've had to do some of the Dynamit-Nobel work myself. I have completely reviewed the entire file and have prepared various summaries which I hope will make it easier for us to continue and conclude our negotiations. 
Enclosed please find a summary history of the Dynamit-Nobel negotiations. This consists of a brief extract of the important correspondence. The conclusion which flows from a study of that correspondence is that Dynamit-Nobel has at one time or another made every conceivable argument against their liability for payment. They have argued the statute of limitations; the London Debt Agreement; ${ }^{125}$ that they didn't employ Jews; that labor was forced upon them; that it was all done by Verwert-Chemie ${ }^{126}$ which was $50 \%$ owned by the Reich; that I. G. Farben has already paid for these claims and that the Claims Conference has no authority to act. Despite all these arguments, von Schlabrendorff, as attorney for Dynamit-Nobel, drafted an agreement to pay from 5 to 8 million DM. This was finally watered down to an agreement to pay 5 million DM which you signed and which Mr. Flick reportedly agreed to, but which was never accepted by the Board of Directors. ${ }^{127}$

They now assert that the Bund agreed to meet $50 \%$ of all claims against Verwert-Chemie. I think you should ask Eric ${ }^{128}$ to try to get that agreement for us.

The present principal stumbling block presented is the demand that we prove that Verwert-Chemie was owned by Dynamit-Nobel and that Verwert-Chemie requisitioned concentration camp inmates as labor. I believe we have that proof.

Document NI-4185 (referred to in Vol. VI of the Green Series on the Nuremberg Trials ${ }^{129}$ and mentioned in my letter to you of December 30, 1963) is a report of the Arbeitseinsatzfuhrer [sic] of $|2|$ Buchenwald dated January 6, 1945. It shows the use of concentration camp inmates for the armaments program in December, 1944. It lists the companies using KZ

125 Art. 5, Abs. 2 des Londoner Schuldenabkommens von 1953, das die kommerziellen Vor- und Nachkriegsschulden der Bundesrepublik regelte, stellte unter anderem die Prüfung der Ansprüche ehemaliger Zwangsarbeiter aus dem Ausland bis zum Abschluss eines Friedensvertrags zurück. Siehe dazu Goschler, Schuld und Schulden, 152-159 sowie Einleitung, 56.

126 Gemeint ist die Gesellschaft m.b.H. zur Verwertung chemischer Erzeugnisse (kurz: Verwertchemie), die im Zweiten Weltkrieg Fabriken zur Sprengstoffherstellung betrieb.

127 Siehe zu den jahrelangen Verhandlungen mit Flick, die schließlich ergebnislos endeten, Ferencz, Lohn des Grauens, 196-212.

128 Wahrscheinlich Eric Warburg.

129 Partial Translation of Document NI-4185 Prosecution Exhibit 142: Extracts from the Report for December 1944 of the Chief of Labor Allocation, Buchenwald Concentration Camp, 6. January 1945, in: Nuernberg Military Tribunals, Trials of War Criminals, Bd. 6, 759-767. 
labor, the number of man-days worked in the month and the total number of man-hours. It shows that women were employed by "Nobel Allendorf" for 23,065 working days and 219,118 hours. It shows that women were employed by Verwert-Chemie Hessische-Lichtenau [sic] for 16,453 working days and 172,757 hours. The summary of requisitions (Forderungsnachweise) for December shows under the heading of "Privat betriebe" [sic], Fabrik Allendorf $\mathrm{GmbH}$ employed women at $4 \mathrm{RM}$ for 23,917 hours 'days!, total 92,068 RM; Fabrik Hessische-Lichtenau employed women at 4 RM for 16,543 days, total number 65,812 RM.

This document properly analyzed is clear proof that labor was requisitioned by the companies mentioned in the document. It shows that Fabrik Allendorf GmbH was synonymous with Nobel Allendorf and that Fabrik Hessische-Lichtenau was synonymous with Verwert-Chemie HessischeLichtenau. Both Allendorf and Lichtenau were listed as private companies by the Buchenwald camp. The argument, therefore, that these companies were Reich-owned and were therefore treated differently from other private companies in that labor was assigned to them, is clearly refuted by the documentary evidence.

The document itself was given to von Schlabrendorff by you as part of the collection of Fischer documents on February 12, 1964. I am, nevertheless, sending you an additional copy and marking the important points.

The attached letter to Henry Sachs will show you that we are now trying to present a more comprehensive memorandum on the relationship of Verwert-Chemie to Dynamit-Nobel and the Reich.

I have some more summary materials which I will be sending along shortly but this is enough to give you something to think about until the balance comes in.

With warm regards,

Cordially yours,

Benjamin B. Ferencz

cc. Mr. H. Sachs

Mr. S. Kagan

BBF: js

Encl. 


\section{Dokument 54}

Benjamin B. Ferencz an Hans Seidenberg ${ }^{130}$

Ohne Ortsangabe, 21. Januar 1965

Maschinenschriftlicher Brief, 2 Seiten; Kopfzeile auf der Seite 2 (»January 21, 1965 Dr. Seidenberg")

$R G 12.004 .18^{\star} 09$

January 21, 1965

\section{CONFIDENTIAL}

Dr. Seidenberg

Compensation Treuhand $\mathrm{GmbH}$

Staufenstrasse 29A

Frankfurt/Main

Re: RHEINMETALL

Dear Seidenberg:

I have just had a visit from the Mayor of Springfield, Massachusetts, ${ }^{131}$ in connection with a Rheinmetall problem which is of great interest to us.

It appears that the U.S. Department of Defense is about to close the Springfield Armory, which was founded by George Washington, and at the same time transfer about $\$ 50$ million in orders from Springfield to the Rheinmetall company. The Mayor was very interested in obtaining whatever information he could to show the Nazi background of Rheinmetall and its directors. I gave him an outline of our negotiations with Rheinmetall and of their refusal thus far to negotiate any settlement on behalf of the former slave laborers. Both the World Jewish Congress and the B'nai B'rith here have indicated a keen interest in protesting against any substantial U.S. orders going to Rheinmetall as long as the slave labor complex is unsettled.

My files do not contain the Nazi Party records of the Rheinmetall directors. We usually made such a check at the Berlin Document Center via Dr. Tuch of the JRSO before beginning negotiations, and perhaps you can find

130 Hans Seidenberg war Jurist und als Nachfolger Ernst Lowenthals Geschäftsführer der CT. 131 Charles Ryan $\left.{ }^{\star}{ }^{\star} 1928\right)$ war von 1962 bis 1967 Bürgermeister der Stadt Springfield, Mass., wo sich die lange Zeit größte Waffenfabrik der Vereinigten Staaten befand. Er kämpfte vergeblich gegen die 1964 von Verteidigungsminister Robert McNamara beschlossene Schließung der Fabrik. 
that information in the files kept by the late Dr. Stein or by Dr. Katzenstein. In any case, it would be most useful if we could have such a check made and I am attaching a list of some of the directors which the Mayor of Springfield left with me.

Our objective will be to resume talks with Rheimmetall in order to persuade them that the United States might be reluctant to place orders with a company which continues to ignore the slave labor claims.

|2| Since the matter is being pursued at the Pentagon within the next few days, I would be grateful if you could give this your immediate attention and advise me promptly.

With warm regards, Cordially yours,

Benjamin B. Ferencz

BBF: js

Encl.

cc. Dr. Katzenstein

Dr. May

Dr. Rosenthal

Mr. Kagan

\section{Dokument 55}

Benjamin B. Ferencz

Ohne Ortsangabe, 1. Februar 1965

Maschinenschriftliches Memorandum, 1 Seite

$R G 12.004 .18^{*} 09$

February 1, 1965

\section{CONFIDENTIAL}

Memorandum for the Record

Re: RHEINMETALL 
Mayor Ryan of Springfield, Mass. called today to advise me that although he had been in Washington all of last week, the Secretary of Defense, McNamara ${ }^{132}$ had been ill in hospital and they had been unable to meet. He plans to see the Secretary of Defense as soon as the latter is well again.

The Mayor discussed the Springfield problem with several of the Congressmen and others concerned and felt optimistic about the possibility of recapturing the business for Springfield. He made no reference to the political aspects of a possible deal with Rheinmetall. He said he refrained from doing so because he understood that Rheinmetall and Colt ${ }^{133}$ had worked out some arrangement and if we were to direct our fi $\{r\}$ e at Rheinmetall, Colt would simply step forward and cloak the fact that Rheinmetall was the real party in interest.

I advised the Mayor of my intention to informally alert the Assistant Secretary, Vance, ${ }^{134}$ to the political ramifications of a possible deal with Rheinmetall. We agreed that no public protest would be made regarding the planned order being given to the German company until the matter had developed further. He promised to call me again in about a week's time and hoped that he would be able to see the Secretary of Defense in the interim.

Benjamin B. Ferencz

cc. Dr. Seidenberg

Dr. Katzenstein

Dr. May

Dr. Rosenthal

Mr. Kagan

132 Robert McNamara (1916-2009) war von 1961 bis 1968 Verteidigungsminister der Vereinigten Staaten. Während dieser Zeit trat er für die Ausweitung des Engagements im Vietnamkrieg ein, was er zum Ende seiner Amtszeit als Fehler bezeichnete. Zudem war er für die Planung amerikanischer Rüstungsprojekte zuständig und daher in den Konflikt über den im Memorandum thematisierten möglichen Rüstungsauftrag an Rheinmetall involviert.

133 Gemeint ist der amerikanische Waffenhersteller Colt Industries.

134 Cyrus R. Vance (1917-2002) war von 1964 bis 1967 stellvertretender Verteidigungsminister und von 1977 bis 1980 Außenminister der Vereinigten Staaten. 


\section{Dokument 56}

Benjamin B. Ferencz an Ernst Katzenstein

Ohne Ortsangabe, 2. Februar 1965

Maschinenschriftlicher Brief, 2 Seiten; Kopfzeile aufSeite 2 (»February 2, 1965«)

$R G 12.004 .18^{\star} 09$

February 2, 1965

\section{PERSONAL AND CONFIDENTIAL}

Dr. Ernst Katzenstein

c/o Hotel Harzburger Hof

3388 Bad Harzburg

Germany

Dear Ernst:

While you have, I hope, been basking in the sunshine and recuperating your strength, we have been trying to generate enough problems to exhaust you promptly upon your return.

One of the problems is Rheinmetall. You may have gathered from some earlier letters that a sudden spark of life was injected into the smouldering ashes of this case by the knowledge that the United States Department of the Army was considering giving a substantial order to Rheinmetall. The fact that this would be done at the expense of American employees in the oldest arsenal in the United States gives us added political ammunition. The situation is rather a delicate one. We cannot do anything which would look like an attack on German industry by Jewish organizations at a time when we are asking the German government for improvements in the indemnification laws. On the other hand, I feel that if we can quietly let Rheinmetall know that the settlement of the slave labor problem would be welcomed in the United Statess since failure to do so might be a source of embarrassment to the U.S. government, then perhaps Rheinmetall may change its tune.

I am now trying through personal contacts to talk to the Assistant Secretary of Defense ${ }^{135}$ in an effort to have him advise the German Ministry. 
of Defense through their normal procurement channels that the United States would welcome a settlement of the slave labor problem. I think it is important, therefore, that we resume contact on your side. Dr. Tuch's suggestion may be a good one, that the Rheinmetall Board member, Prof. Leo Brandt, ${ }^{136}$ who has the reputation apparently of being a philosemite, be contacted. If you can get copies of his articles in the Allgemeine Wochenzeitung ${ }^{137}$ you may use that as a spring-board for arranging a personal meeting with Prof. Brandt, and then discuss the problem with him. You could tell him $|2|$ truthfully that 'if' the American claimants were to know that Rheinmetall refused to pay anything on behalf of their small claims and at the same time the U.S. government was considering a very substantial order to Rheinmetall, it may reasonably be anticipated that sharp protests would flow quickly to Senator Javits ${ }^{138}$ and many other Senators and Congressmen. It would also almost certainly be picked up by the press, and the chances of Rheinmetall getting the business would at the very least be substantially diminished. You can convey the hope, therefore, that a settlement will still be possible since such a settlement would not only be humanitarian but would avoid any possible embarrassment to either Rheinmetall or the Pentagon.

We are continuing to gently probe the situnation here and trying to keepp. out any press reference to the entire matter. I will try to arrange it so that you may be able to tell Rheinmetall that the Pentagon has indicated its sympathy in favor of a settlement and perhaps the Pentagon would even give such instructions to the Army people in Germany.

You will recall that there were about 1,000 claimants, that we were asking for 5 million DM and would probably accept 4 million DM, that all negotiations had been refused, that the Federal Supreme Court had ruled the claims barred at this time because of the London Debt Settlement Agreement, and that the case is being appealed to the Supreme Constitutional Court because

136 Leo Brandt (1908-1971) arbeitete ab 1932 als Ingenieur bei Telefunken. Nach dem Krieg wurde er Politiker und war ab 1953 als Staatssekretär im Wirtschafts- und Verkehrsministerium Nordrhein-Westfalens tätig. Zudem war er Aufsichtsratsmitglied von Rheinmetall.

137 Siehe Leo Brandt, Über den Anteil jüdischer Persönlichkeiten an der Entwicklung der deutschen Elektroindustrie. Einige Bemerkungen, in: Allgemeine Wochenzeitung der Juden in Deutschland 15 (1960), H. 6, 49, 51; Leo Brandt, Zur Erinnerung an Leo Löwenstein, in: Allgemeine Wochenzeitung der Juden in Deutschland 15 (1960), H. $25,49,64$.

138 Jacob K. Javits (1904-1986) war ein amerikanischer Politiker der Republikanischen Partei und von 1957 bis 1981 Senator für den Staat New York. 
of the conflict with the Stuttgart decision in favor of the slave laborer claim against Heinkel.

I am enclosing a copy of the memorandum I gave the Mayor of Springfield, Mass. in preparation for his visit to the Pentagon, as well as a memorandum showing the present status of his efforts. As this is highly confidential, I am not sending copies to the other members of the Board and I would therefore appreciate it if you would inform Dr. Seidenberg and the other members for me. You may let them have copies if you think it should be done.

With warm regards,

Cordially yours,

Benjamin B. Ferencz

BBF: js

Encl.

cc. Mr. Kagan

\section{Dokument 57}

Benjamin B. Ferencz an Ernst Katzenstein

Ohne Ortsangabe, 15. März 1965

Maschinenschriftlicher Brief, 2 Seiten; handschriftliche Unterstreichungen, maschinenschriftliche Einfügung auf Seite 2 oben mit einer anderen Schreibmaschine (»Mr. Crowley's phone number: State Dept., Republic 7-5600 X.4734. Call him April 1st if not heard in interim. Mr. Maurer's X. is 5906.")

$R G 12.004 .18^{\star} 09$

March 15, 1965

Dr. Ernst Katzenstein

CONFIDENTIAL

JRSO

Gruneburgweg [sic] 119

Frankfurt/Main

Re: RHEINMETALL 
Dear Ernst:

I have your letter of March 8th reporting on your discouraging discussions with Dr. Brandt ${ }^{139}$ with reference to Rheinmetall. The arguments advised by Dr. Brandt are not particularly surprising. In almost every case, we have encountered the arguments that the company was not really responsible, that it was the Bund to whom we should turn for redress and that the company or its present owners were really helpful to the Jews. If they were really so sympathetic, then they should continue that sympathy now and recognize some moral obligation to provide token compensation to the survivors of the company whose assets they now possess and whose liabilities were undoubtedly taken over by them when the company was acquired.

Unless my memory fails me, there was some testimony by the late Mr. Roechling ${ }^{140}$ to the effect that in some of his companies he had refused to accept slave labor and this was used during the Nuremberg Trials to prove that some companies were able to reject slave labor. At least in the Rheinmetall case, therefore, we should not encounter the argument that labor was imposed upon the company.

During the last few days I was in Washington to follow up on my discussions there as reported to you in my confidential letter of February 25th. The Deputy Secretary of Defense, Mr. Vance, had been in touch with Mr. William Tyler, ${ }^{141}$ the Under Secretary of State for European Affairs. Mr. Vance suggested that I talk to Mr. Tyler, which I did, and Mr. Tyler set up a meeting for me with an old friend, Mr. Ely Maurer, ${ }^{142}$ who is the Assistant Legal Adviser for Military \& Economic Affairs, and his assistant, Mr. Kent, and a Mr. Crowley who is apparently much concerned with German economic affairs. We had a chance to review the entire situation.

\section{Leo Brandt.}

140 Vermutlich Hermann Röchling (1872-1955), der als Inhaber des Eisen- und Stahlimperiums der Röchlings ab 1939 auch Wehrwirtschaftsführer sowie Mitglied in verschiedenen nationalsozialistischen Industrievereinigungen war. Vom französischen Militärgericht in Rastatt wurde er 1949 zu zehn Jahren Haft verurteilt, aber bereits 1951 entlassen. Alternativ könnte sich Ferencz auch auf dessen Neffen, den Teilhaber der Röchling'schen Eisen- und Stahlwerke Völklingen Ernst Röchling (1888-1964) beziehen. Dieser war 1946 von den Amerikanern in Nürnberg inhaftiert und ebenfalls 1949 in Rastatt zu fünf Jahren Gefängnis verurteilt worden.

141 William Tyler (1910-2003) war von 1962 bis 1965 Assistant Secretary of State for European Affairs im Außenministerium der Vereinigten Staaten.

142 Ely Maurer (1913-1997) war ein jüdischer Jurist. Nach dem Zweiten Weltkrieg wurde er Rechtsberater im US-Außenministerium und galt als Experte für die Restitution von während des Zweiten Weltkriegs geraubten Kunstwerken und Besitztümern. 
Following my visit to Washington on February 24th, the State Department had requested a report about Rheinmetall from its embassy in Bonn. The U.S. Embassy had sent in a report which $|2|$ had apparently indicated that Rheinmetall was owned by Krupp. I have a strong suspicion that whatever genius dispatched that report from Bonn must have had his head under water in the Rhine and was probably mixing up Rheinmetall with Rheinhausen. I conveyed these impressions to the U.S. governmental representatives in Washington.

The State Department representatives were quick to recognize that if the Pentagon were to give an order to a German company managed by former Nazis (and we have the Nazi Party records), which company had absolutely refused to make even token compensation to the former concentration camp inmates who had worked as slaves for that company, there might be sharp political repercussions in the United States. This would be enhanced by the fact that the principal claimants in the test case (B. and R.) ${ }^{143}$ were now U.S. citizens who had been exploited by the company while they were 12 -year old girls. Mr. Kent particularly recognized that this would make a tremendous story in the American press and Mr. Crowley was much concerned that its repercussions might rock all kinds of other commitments between the United States and Germany with reference to military procurement. I smiled sweetly.

I suggested that the matter be dealt with on a low level and low-pitched approach. It was my view, and I think they shared it, that informal inquiries with the company or its procurement agents should be undertaken in which the U.S. indicates that the failure to make a settlement might prove a source of U.S. embarrassment. It is of course possible that the State Department was so frightened that they will simply refuse to do any business at all with Rheinmetall. If that is so, then we will have to derive only the subsidiary benefit of pointing out to other companies, with which we may negotiate, the consequences of the failure to reach an amicable understanding.

The way the matter was left was that Mr. Tyler and Mr. Vance wounld again consider the problem and they would again be in touch with the U. S. Embassy. in Bonn. After a few weeks they thought they might have some word for me and if I did not hear from them within about two weeks I would contact Mr. Crowley who was charged with primary responsibility.

In the meanwhile, you will presumably see Mr. Ceaser [sic] ${ }^{144}$ and $\mathrm{Mr}$. Blume $^{145}$ to let them know that this matter is not quite as dormant as they might wish. I will be in Frankfurt in connection with the URO Budget

143 Die Personen wurden anonymisiert.

144 Gemeint ist wohl Otto Paul Caesar.

145 Ernst Blume war Ingenieur und Vorstandsmitglied der Rheinmetall AG. Zu seiner Rolle bei den Entschädigungsverhandlungen siehe Ferencz, Lohn des Grauens, 171. 
Committee meetings and if you think it preferable for me to join you at any further discussions with Rheinmetall I would of course be pleased to do so.

I would appreciate your duplicating copies of this letter for Dr. Seidenberg and other members of the Board, if you believe it useful.

With warm regards,

Cordially yours, ${ }^{146}$

c̊c̊. Mr. Kagan

\section{Dokument 58}

Benjamin B. Ferencz an Ernst Katzenstein

Ohne Ortsangabe, 8. September 1965

Maschinenschriftlicher Brief, 1 Seite; handschriftliche Unterstreichungen

$R G 12.004 .18^{\star} 09$

September 8, 1965

Dr. Ernst Katzenstein

CONFIDENTIAL

JRSO

Gruneburgweg [sic] 119

Frankfurt/Main

Dear Ernst:

I was sorry to see from your letter of August 25th that as early as July 21st Rheinmetall told us to go jump in the lake. I have no intention of following their kind advice.

I have written to the State Department as per the attached. In fairness to Ministerialdirektor Dr. Bode ${ }^{147}$ of the Ministry of Defense, I think you should be in touch with him as we had promised and tell him about the reply received from the company. You should ask him for his advice and whether he has any further suggestions which might be helpful to the slave laborers.

146 Unterschrift fehlt auf archivalischer Kopie.

147 Günter Bode war Ministerialdirektor im Bundesministerium der Verteidigung und für die Rüstungswirtschaft zuständig. 
If Dr. Bode has no suggestion and if the Defense Department has not yet made up its mind, it seems to me we have nothing to lose by releasing the information to the press. What I have in mind is to collect all of the material and present it to a friend of mine, Jack Raymond, ${ }^{148}$ who has been covering the Pentagon for the New York Times. I believe I can also induce the B'nai B'rith to protest to the Defense Department and to issue a general press release on the subject. They will also follow up on it to make sure that Rheinmetall gets no order from the United States.

I have not had an opportunity to discuss this with Saul, ${ }^{149}$ but I am writing now to make sure that we are all proceeding in the same direction. Please let me know whatever you learn from Dr. Bode and I will inform you as soon as I hear from the State Department. I would also welcome the reactions and suggestions which you and Saul may have regarding further action.

With warm regards,

Cordially yours,

Benjamin B. Ferencz

cc. Mr. Kagan

P.S.: B'nai B'rith will very shortly be releasing for widespread public distribution a general report on the reaction of German industry to the slave labor claims. This is by way of attracting public interest to the problem.

\section{Dokument 59}

Benjamin B. Ferencz an Saul Kagan

Ohne Ortsangabe, 22. November 1965

Maschinenschriftlicher Brief, 1 Seite

RG 12.004.18*09

148 Jack Raymond (geb. Israel Rosenblatt; 1918-2007) berichtete als Journalist sowohl von den Kriegsschauplätzen des Zweiten Weltkriegs als auch anschließend als Korrespondent von The New York Times über die Entwicklungen in Nachkriegsdeutschland sowie in Ost- und Südosteuropa. Ab 1957 widmete er sich für ein Jahrzehnt der Berichterstattung über Militärangelegenheiten.

149 Saul Kagan. 
November 22, 1965

\author{
Mr. Saul Kagan \\ Claims Conference \\ 3 East 54th Street \\ New York 22, N. Y.
}

Dear Saul:

I was in Washington from November 17th to the 19th and as planned took various steps to advance the Rheinmetall matter.

The B'nai B'rith Slave Labor Survey was issued. Copy attached.

I met with Jack Raymond of the New York Times and was joined by Bernard Simon, ${ }^{150}$ the public relations man of B'nai B'rith. Raymond felt that a good story could be made of the fact that for eight years there had been quiet efforts made to induce Rheinmetall to pay but to no avail, and now a public protest is made to the U.S. as a last resort to stop the U.S. purchase of Rheinmetall guns.

I made it clear that the Conference had to be left out. He agreed but said it was impossible to leave me out of the story as it had to hang on somebody. I then urged him to substitute B'nai B'rith but he could 'only' tie them in if B'nai B'rith issued a public protest since the B'nai B'rith Survey alone was not newsworthy.

A letter was prepared from B'nai B'rith to Secretary of State Rusk ${ }^{151}$ but we all agreed that we should talk to Amb. Knappstein ${ }^{152}$ first. Phil Klutznick, ${ }^{153}$

150 Bernard Simon (1920-2010) war von 1956 bis 1979 Leiter der Presseabteilung von B'nai B'rith. Er berichtete nach Reisen in Staaten des Warschauer Pakts über die Situation der osteuropäischen Juden, insbesondere in der Sowjetunion, und unterstützte damit deren Emigrationsbestrebungen.

151 David Dean Rusk (1909-1994) diente von 1961 bis 1969 unter den Präsidenten Kennedy und Johnson als Außenminister der Vereinigten Staaten. Anschließend lehrte er bis 1970 als Professor für Internationales Recht an der University of Georgia.

152 Karl Heinrich Knappstein (1906-1989) war ein deutscher Politiker, Diplomat und von 1962 bis 1969 Botschafter der Bundesrepublik in Washington. Während des Zweiten Weltkriegs hatte er als Journalist gearbeitet. Nach Kriegsende war er Gründungsmitglied der CDU in Hessen. Von 1951 bis 1956 leitete Knappstein das deutsche Generalkonsulat in Chicago. Nach Tätigkeiten als Botschafter in Madrid und im Auswärtigen Amt war er von 1960 bis 1962 Beobachter der Bundesrepublik bei den Vereinten Nationen.

153 Philip M. Klutznick (1907-1999) war ein amerikanischer Politiker und jüdischer Verbandsfunktionär. Von 1953 bis 1959 wirkte er als Präsident der amerikanischen 
President William Wexler, ${ }^{154}$ Exec.V. P. Jay Kaufman ${ }^{155}$ and I met with Knappstein. The Ambassador promised to take it up in Bonn next week when he returns to brief and pick up Chancellor Erhard ${ }^{156}$ for his U.S. visit. I then asked Raymond to hold the story until after Knappstein's return.

I am sending Knappstein an aide memoire, copy attached, and will try to contact him in Bonn. I'll do what I can in Germany of course and will pick it up again upon my return.

Warm regards,

Cordially yours,

Benjamin B. Ferencz

cc. Dr. Katzenstein

Dr. May

Dr. Rosenthal

Dr. Seidenberg

BBF: js Encl.

\section{Dokument 6o}

Benjamin B. Ferencz an Ernst Katzenstein

New York, 7. Februar 1966

Sektion von B’nai B’rith und 1977 bis 1979 als Präsident des Jüdischen Weltkongresses. Daneben betätigte er sich als Geschäftsmann im Immobilienbereich und hatte verschiedene Regierungsposten inne, etwa den des amerikanischen Vertreters im Wirtschafts- und Sozialrat der Vereinten Nationen von 1961 bis 1962 oder den des Handelsministers von 1980 bis 1981 .

154 William A. Wexler (1913-2000) war ein jüdischer Verbandsfunktionär. Er wirkte ab 1951 für fünf Jahre als Vorstandsmitglied des United Jewish Appeal. Anschließend leitete er bis 1963 die Israel Bond Organization und war von 1965 bis 1971 Präsident von B'nai B'rith.

155 Der Rabbiner Jay Kaufman (1918-1971) war ab 1965 Vizepräsident von B’nai B'rith. Zuvor hatte er ab 1948 für die Union of American Hebrew Congregations gearbeitet, deren stellvertretender Vorsitzender er 1957 wurde.

156 Der Ökonom und Politiker Ludwig Erhard (1897-1977) war von 1949 bis 1963 Wirtschaftsminister und von 1963 bis 1966 zweiter Kanzler der Bundesrepublik. 
Maschinenschriftlicher Brief, 2 Seiten; handschriftliche Unterstreichungen, gedruckter Briefkopf mit maschinenschriftlich eingefügtem Datum auf Seite 1, Kopfzeile auf Seite 2 (gedruckt: "TAYLOR, SCOLL, FERENCZ \& SIMON«, maschinenschriftlich: »February 7, 1966«)

$R G 12.004 .08^{\star} 06^{157}$

\section{TAylor, Scoll, Ferencz \& Simon}

\{extra D.N. file\}

Counselors at LaW

Telford TAYlor

DAVID E. SCOLL

Benjamin B. Ferencz

KenNeth Simon
|February 7, 1966!
Pan Am Building 200 Park Avenue New YoRK, N. Y. 10017

***

MO 1-0934

Cable Address: Lantalaw

CONFIDENTIAL

Dr. E. Katzenstein

JRSO

Gruneburgweg [sic] 119

Frankfurt

Re: RHEINMETALL

Dear Ernst:

The past several days have been very hectic here. As I indicated in my letter to Saul Kagan on November 22nd, I had taken various steps to publicize Rheinmetall's refusal to pay its slave laborers. During the week I met with Pres. Wexler and Exec. Vice President Rabbi Kaufman of B'nai B'rith and arranged to have them cable Secretary Rusk and Secretary McNamara in opposition to the proposed army purchase from Rheinmetall.

I had a long meeting in my office on February 3rd with Mayor Ryan of Springfield, Mass. and several of his assistants and arranged to have him cable the President, objecting to the purchase and assuring the President that better guns could be manufactured here.

I was again in touch with my old friend, Jack Raymond of the New York Times, who covers the Pentagon and arranged to give him the exclusive story.

157 Dieses Dokument ist doppelt überliefert. Die Dublette findet sich in RG 12.004.18^10, dort ohne Briefkopf und ohne die handschriftlichen Unterstreichungen. 
I asked him to leave out the Claims Conference and to make no reference to me in order that the impetus might seem to come from other sources. $\mathrm{He}$ agreed to hold the story and timed it to appear in the New York Times on Sunday, February 6 th. ${ }^{158}$ It appeared on the front page and a copy of the article is attached. I had also been in touch with the influential Christian Science Monitor $^{159}$ and their article is also attached. The New York Times' story was picked up by all the press services and received widespread press and radio coverage all across the country.

In taking this action, I had several things in mind. I felt that it would not be appropriate for Rheinmetall to refuse any settlement and to have the Jewish organizations accept their defiance without response. I also felt that it might be useful in connection with our Dynamit-Nobel and other efforts to demonstrate that the slave labor question could be front page news in the United States and that other companies could anticipate similar $|2|$ treatment if they refused to settle. Of course, I took personal delight in striking back where I felt strongly that a great injustice was being done to Nazi victims. I intend to follow up by seeking the assistance of Senators Javits and Kennedy, ${ }^{160}$ and others, to make sure that the purchase from Rheinmetall does not go through.

I think you will have to follow up on your side in order that we may try to derive some constructive benefit from the action taken here. Specifically, this means contacting Warburg and/or von Schlabrendorff of Dynamit-Nobel, and telling them truthfully that the Jewish organizations are being asked which other companies have thus far failed to pay and that we are getting very tired of their lame excuses. I again repeat my own conviction that until we start to kick Mr. Flick I do not believe Dynamit-Nobel will move. After dictating the above, I received your letter of February 4th reporting that Dynamit-Nobel is still stalling. I again urge that we take a firmer stand now. that we have the good argument that the U.S. press is insisting upon an answer and we will have no choice but to tell them the whole truth. Saul has been fully informed and will try to get Hans Meyer to call Eric.

158 Jack Raymond, Pentagon Scored on Gun Purchase. B'nai B'rith Protests Plan to Buy from German Plant That Used Slave Labor, in: The New York Times, 6. Februar 1966, 1.

159 Christian Science Monitor ist eine in den Vereinigten Staaten erscheinende Tageszeitung.

160 Robert F. Kennedy (1925-1968) war ab 1960 Justizminister in der Regierung seines Bruders, John F. Kennedy, und wurde 1964 für New York in den Senat gewählt. Am 6. Juni 1968, während des Wahlkampfs um das Amt des 37. Präsidenten der Vereinigten Staaten, starb Robert Kennedy an den Folgen eines Attentats. 
It might also be well for you to advise Ministerialrat Direktor Bode of the Ministry of Defense of the action taken here simply for the purpose of keeping him informed since he had tried to be helpful.

I will keep you further advised and know you will do the same.

With warm regards,

Cordially yours,

Benjamin B. Ferencz

BBF: js

Encl.

cc. Dr. May

Dr. Seidenberg

Dr. Kagan (2)

\section{Dokument 61}

Benjamin B. Ferencz an Philip M. Klutznick

Ohne Ortsangabe, 23. Februar 1966

Maschinenschriftlicher Brief, 2 Seiten; Kopfzeile aufSeite 2 (»February 23, 1966»)

RG $12.004 .18^{\star} 10$

February 23, 1966

Mr. Philip M. Klutznick

401 North Michigan Avenue

Chicago, Ill.

My Dear Phil:

Bill Wexler has shown me your exchange with Julius Klein. ${ }^{161}$ I am grateful to you for your prompt and, as always, precise rejoinder to Congressman Farb-

161 Julius Klein (1901-1984) war ein amerikanisch-jüdischer Journalist und General. Nach dem Zweiten Weltkrieg gründete er eine PR-Firma, die in den 1950er und 1960er Jahren für deutsche Firmen wie Rheinmetall arbeitete, um deren öffentliches Bild nach 
stein, ${ }^{162}$ and particularly for your kind observations about me personally. Mindful of the many more important matters which consume your time, I have tried to spare you the Rheinmetall problems. Obviously, you cannot escape, and I am confident that Bill will soon burden you with much of the past correspondence. Allow me, therefore, to elaborate on a few points.

A public relations man blowing his own horn is the customary practice of that trade, and I am sure you can distinguish sweet music from hot air. Julius Klein specifically accuses me of "stirring up the Rheinmetall controversy by unethical means, choosing to side-step the true facts in the case." I can only imagine that he has in mind my letting it be known to all concerned that failure to settle the legitimate claims of the Jewish slave laborers would surely produce a public outcry. This was a very sore point with the Nazi managing directors of Rheinmetall who denounced it as "blackmail." They would have desired to spit in the Jewish face and have me go away quietly, and they fiercely resented my assurance that I was not so inclined.

Julius says that Mr. Ferencz "encouraged the labor unions there (Springfield, Mass.) to make protests to our government against Rheinmetall, which failed". This is plain madness. I have never had anything whatsoever to do with any labor unions in Massachusetts.

Klein says I have "also misrepresented the facts" to Bill Wexler and to you and had you call on Ambassador Knappstein to make protests. I need not comment on the Knappstein visit whose origins you know, but I can again assure you that every statement I have made about Rheinmetall can be fully documented. $|2|$ There is no essential difference between this case and the others where settlements were reached.

The foulest blow of all is Julius Klein's assertion that "Mr. Ferencz is attempting to pursue these alleged claims against Rheinmetall for a legal fee from his clients". I appreciate your suggesting that it would be my right to take as my clients the persecuted, just as it is his right to represent their persecutors. It may come as a surprise, but you should know that I have never in my life taken any fee from any concentration camp victim. For many years the Claims Conference has favored me with a modest retainer for services

dem Krieg in den Vereinigten Staaten zu verbessen. Er besaß darüber hinaus gute Kontakte zur deutschen Regierung. Zu den Vorwürfen Kleins gegenüber Ferencz siehe Hofmann, Benjamin Ferencz, $177 \mathrm{f}$.

162 Leonard Farbstein (1902-1993) war ein amerikanischer Politiker der Demokratischen Partei. Von 1932 bis 1956 war er gewähltes Mitglied der New York State Assembly und anschließend bis 1971 Abgeordneter im Repräsentantenhaus der Vereinigten Staaten. 
which include protecting the interests of Jewish slave laborers. I have acted for the Rheinmetall claimants with no possibility, expectation or desire for any personal gain from them as a consequence of those endeavors.

There is a great deal of satisfaction in fighting for what I deeply believe to be right. The libelous attacks by which Julius Klein now seeks to tarnish my reputation will not diminish my efforts and I am indeed heartene̊d\#\# by your friendship and support.

With warm regards,

Sincerely yours,

Benjamin B. Ferencz

cc. Dr. William A. Wexler

Rabbi Jay Kaufman

bc. Mr. Bernard Simon! ${ }^{163}$

\section{Dokument 62}

Benjamin B. Ferencz an die Redaktion Der Spiegel

New York, 8. März 1966

Maschinenschriftlicher Brief, 4 Seiten; handschriftliche Streichungen, Korrekturen und Unterstreichungen, gedruckter Briefkopf mit maschinenschriftlich eingefügtem Datum auf Seite 1, Kopfzeile auf jeder folgenden Seite (gedruckt: »TAYLOR, SCOLL, FERENCZ \& SIMON«, maschinenschriftlich: »March 8, 1966«) $R G 12.004 .18^{\star} 10$

[Ferencz fordert von der Redaktion des westdeutschen Nachrichtenmagazins Der Spiegel den Abdruck einer Richtigstellung zu einem im März 1966 dort veröffentlichten Artikel. Hierbei wird vor allem die in der amerikanischen Öffentlichkeit geführte Debatte über eine Waffenbestellung des US-Verteidigungsministeriums bei Rheinmetall sowie das Verhalten des Konzerns in der Zwangsarbeiterfrage thematisiert. Ferencz weist dabei nachdrücklich medial formulierte Behauptungen über seine Rolle zurück.]

163 Mit anderer Schreibmaschine eingefügt. 


\section{Taylor, Scoll, Ferencz \& Simon \\ Counselors at LaW}

Telford Taylor

David E. Scoll

Benjamin B. Ferencz

Kenneth Simon
|March 8, 1966|

\author{
Pan Am Building \\ 200 Park Avenue \\ New York, N. Y. 10017 \\ MO 1-0934 \\ Cable Address: Lantalaw
}

An die

Redaktion DER SPIEGEL

2 Hamburg 1

Pressehaus, Speersort 1.

Federal Republic of Germany

Sehr geehrte Herren!

Auf Grund des Paragraph 7 des Pressegesetzes ersuche ich Sie, in Ihrer nächstmöglichen Ausgabe die folgende Berichtigung zu Ihrem am 7. Maerz aufS. 52-54 erschienenen Artikel, betitelt „Wiedergutmachung, Rheinmetall, Schuesse gegen Wunderwaffe "164 zu veroeffentlichen.

Es ist unwahr, dass ich „nach eigenem Bekunden“ etwa tausend amerikanische Buerger, die, „obwohl sie Wiedergutmachungszahlungen nach dem Bonner Entschaedigungsgesetz erhalten - weitere Zuwendungen von Rheinmetall verlangen", vertrete. Wahr ist, dass das Bundesentschaedigungsgesetz keinerlei Entschaedigung fuer geleistete Arbeit, ungerechtfertigte Bereicherung, unerlaubte Handlung oder Schmerzensgeld vorsieht.

Es ist unwahr, dass ich von irgendeinem der frueheren Zwangsarbeiter eine Vollmacht fuer deren Vertretung habe. Ich habe niemals ein Honorar gefordert oder von irgendeinem Konzentrationslagerhaeftling jemals ein solches akzeptiert.

|2| Wahr ist, dass ich die Opfer in dem Sinne repraesentiere, dass ich fuer ihre legalen und moralischen Rechte kaempfe, eine Aufgabe, die ich auch weiterhin erfuellen werde.

164 Ferencz bezieht sich auf den Artikel Anonymus, Rheinmetall. Schüsse gegen Wunderwaffe, in: Der Spiegel 7. März 1966, 52-54. Seine Gegendarstellung wurde jedoch anscheinend nicht abgedruckt. 
Unwwahr ist, dass ich die Kongress-Abgeordneten Celler ${ }^{165}$ und Bingham ${ }^{166}$ „gewann ... gegen Rheinmetall zu agieren".

Wahr ist, dass ich weder direkt noch indirekt Kontakt mit den Abgeordneten gehabt habe und deren Aktion offensichtlich aus eigener Ueberzeugung, der Gerechtigkeit zu dienen, herrührt.

Unwahr ist, dass $\{$,$\} die Jewish Claims Conference oft nicht einmal in der$ Lage war, die Namen der Zwangsarbeiter, geeschweige denn Ort und Zeit der Beschäftigung zu nennen".

Wahr ist, dass die Claims Conference eine vollstaendige Liste hat, die die Namen von nahezu 1000 Personen, die fuer Rheinmetall arbeiteten, enthaelt, sowohl als auch Angaben ueber Zeit und Ort ihrer Beschaeftigung, und die die Claims Conference um Hilfe angingen. Haette Rheinmetall sich willens gezeigt, die Angelegenheit zu bereinigen, waere diese Liste der Firma sofort vorgelegt worden.

Unwwahr ist, dass McNamara „versprach ... bei Rheinmetall 2500 Maschinen-Kanonen vom Typ HS 820 sowie zehn Millionen Schuss Munition zu kaufen - vorausgesetzt, der amerikanische Senat stimme zu."

|3| Wahr ist, dass am 28. Februar 1966 das State Department in einem offiziellen \{Brief\} feststellte, dass "das Verteidigungsministerium noch technische Versuche unternimmt und noch keine endgueltige Entscheidung getroffen hat, diese Kanone zu kaufen".

Ihr Artikel verzerrt durrch irrefuehrende Darstellung, Andeutungen und Weglassungen das wahre Bild der Versuche der Sklavenarbeiter, eine Entschaedigung zu erhalten. So erwaehnen Sie nicht die wichtige Entscheidung des Bundesgerichts vom 17. Maerz 1964, ${ }^{167}$ dass Rheinmetall Berlin AG, vertreten durch ihren Vorstand, Gerichtsassessor a.D. Dr. Otto Paul Caesar und Dipl. Ing. Ernst Blume, beide in Düsseldorf, „eingeräumt hat, dass in ihrem Werk Sömmerda Haeftlinge aus dem dortigen Konzentrationslager, insbesondere juedische Frauen beschäftigt worden sind“.

Das Oberlandesgericht in Stuttgart, in einer Entscheidung vom 19. Mai 1965 betreffend den ähnlichen Fall eines deutschen Sklavenarbeiters betonte, dass eine Geschaeftsleitung, die koerperlich gebrechliche Sklavenarbeiter

165 Emanuel Celler (1888-1981) war von 1923 bis 1973 demokratischer Abgeordneter aus New York im Repräsentantenhaus und setzte sich besonders für Bürgerrechte und die Liberalisierung der Einwanderungsbestimmungen ein, u. a. um nach dem Zweiten Weltkrieg die Emigration oftmals jüdischer DPs aus Europa zu ermöglichen. 166 Jonathan B. Bingham (1914-1986) praktizierte zunächst als Jurist in New York, bevor er in die Politik wechselte. Er war von 1965 bis 1983 demokratischer Abgeordneter im Repräsentantenhaus.

167 Siehe Kapitel 4, Fußnote 119. 
verwendete, „verpflichtet“ war, „deren Los im Rahmen des Möglichen zu erleichtern und alle unnötigen Erschwerungen zu verhindern. Diese selbstverständliche Menschenpflicht gegenüber den in ihre Obhut gegebenen Häftlinge [sic] ist nicht nur eine moralische, sondern auch eine rechtliche Pflicht.“ (Bartl gegen Heinkel, 10 U 8/1965)

|4| Niemand behauptet, dass die gegenwaertigen Besitzer der Rheinmetallaktien persoenlich fuer die Vergehen, die im Namen der Gesellschaft begangen wurden, verantwortlich sind. Der Kern unserer Beschwerde ist, dass wer immer Namen und Kapital einer Gesellschaft uebernimmt, die Sklavenarbeiter ausgebeutet hat, sowohl die legale wie die moralische Verpflichtung hat, diese frueheren Sklavenarbeiter fuer die geleistete Arbeit und die durchgemachten Leiden, ftter die Rheinmetall verantwortlich war, zu entschaedigen. Wer diesem Grundsatz nicht zustimmt, demonstriert eine Missachtung fuer Menschenrechte und sollte nicht \#\#\# dafuer auch nicht noch von denjenigen belohnt werden, die an Arbeitsrecht und Menschenwuerde glauben.

Mit vorzueglicher Hochachtung,

\{Benjamin B. Ferencz

\section{Dokument 63}

Benjamin B. Ferencz an Ernst Katzenstein

Ohne Ortsangabe, 15. März 1966

Maschinenschriftlicher Brief, 1 Seite

$R G 12.004 .18^{\star} 10$

March 15, 1966

Dr. Ernst Katzenstein

JRSO

Gruneburgweg [sic] 119

Frankfurt

Dear Ernst:

The Rheinmetall battle is raging nicely. The company keeps issuing statements that the present owners had nothing to do with the former company. It would 
be important therefore for us to double-check the documentary evidence available to show the relationship of the present company to the slave-using companies. Dr. Seidenberg and Dr. Fischer ${ }^{168}$ may be able to check on the documentary side and perhaps Brinckmann Wirt ${ }^{169}$ or other banking friends can check on the commercial side.

The company also insists that I am acting as "a lawyer interested in business and not as the representative of the Claims Conference". I add this information only for your amusement. There is no need to correct their impression since it is one of the more obvious lies they are disseminating.

They also state, however, that their attitude in refusing any payment on either legal or moral grounds "has been backed up by numerous highly regarded American, Israeli and German personalities". You might inquire of the Israel Mission whether anyone on their side has to their knowledge indicated that the slave labor claims of the Israeli citizens for whom we have been fighting, are not well founded when applied to the Rheinmetall company. It would also be helpful if we could ascertain whether in fact Israel has acquired arms from Rheinmetall, as the Spiegel article states and has been stated by the company. ${ }^{170}$

You are very quiet on this whole matter. I hope the roar of the guns does not intimidate you.

Warm regards.

Cordially yours,

Benjamin B. Ferencz

cc. Dr. Seidenberg; Mr. Kagan

168 Bruno Fischer $\left({ }^{\star} 1900\right)$ war seit 1956 als Anwalt für die URO tätig. Er leistete wichtige Beiträge zur Erforschung der Geschichte der Juden in Rumänien und anderen Satellitenstaaten des Deutschen Reichs während des Zweiten Weltkriegs und veröffentlichte eine mehrbändige Dokumentensammlung zu diesem Thema.

169 Rudolf Brinckmann (1889-1974) und J. J. Paul Wirtz (1881-1946) waren Bankiers und übernahmen 1938 die Leitung des Bankhauses M. M. Warburg, seit 1941 Brinckmann, Wirtz \& Co., nachdem die Bankiersfamilie Warburg emigrieren musste. Ab 1949 war Eric Warburg wieder in das Geschäft der Bank involviert, 1969 erfolgte dann die Umfirmierung in M. M. Warburg-Brinckmann, Wirtz \& Co.

170 Anonymus, Rheinmetall. Schüsse gegen Wunderwaffe. 


\section{Dokument 64}

Benjamin B. Ferencz an Ernst Katzenstein

Ohne Ortsangabe, 29. März 1966

Maschinenschriftlicher Brief, 2 Seiten; handschriftliche Unterstreichungen, Kopfzeile auf Seite 2 (»March 29, 1966")

$R G 12.004 .18^{\star} 10$

|P.S. I regret that through inadverte̊nce, this letter was not mailed until today, the 31st March. BBFI

March 29, 1966

Dr. Ernst Katzenstein

CONFIDENTIAL

JRSO

Gruneburgweg [sic] 119

Frankfurt

Dear Ernst:

On March 28th I had a meeting in the State Department in connection with the Rheinmetall matter. The persons present were Mr. Hugh Gownley, Internal Security Officer of the Office of the Secretary of Defense, Mr. Ely Maurer and Mr. Crowley of the State Department. These are the key "working officials" in the United States government who deal with the Rheinmetall problem, and we spent almost two hours together reviewing every facet of the matter.

The U.S. government understands that the allegations of Julius Klein are not to be taken seriously. They also believe that the Rheinmetall company of Düsseldorf is at least morally responsible to compensate the former slave laborers in Sömmerda. They know that some of the Rheinmetall directors were former Nazis and they also recognize that the demands on behalf of the slave laborers are being put forward by responsible Jewish organizations. I pointed out to them specifically that although I was acting for the Claims Conference on all slave labor matters, neither the Conference nor I wanted to appear in the public eye for the simple reason that we did not wish to be accused of a general attack on German industry, which was not our purposes nor did we wish to stimulate such an attack by other Jewish forces which we might not be able to control.

The Pentagon would like to buy the gun. Most of its shortcomings have been corrected and it is already a much better weapon than any- 
thing now in use by the U.S. Army. Both the State Department and the Defense Department are very mindful of the moral implications involved in doing business with a company which has repudiated justified claims of its slave laborers. I have the distinct impression that they would not like to do business with Rheinmetall if no payment is made. They recognize that major Jewish organizations as well as many important Congressmen would protest and that the U.S. Government would be substantially embarrassed. Their only way out of the dilemma, therefore, is to have Rheinmetall settle its slave labor claims.

|2| On the other hand, neither the Defense Department nor the State Department feels that they should be directly involved as an intermediary. between the two parties in the dispute. If settlement is reached they would of course be delighted. If no settlement is possible, the Pentagon will explore in greater depth alternate methods of acquiring a suitable weapon. The alternatives are already being probed and the Defense Department believes that Rheinmetall must be aware that such alternatives are being considered. I think this should be made clear to Rheinmetall if the opportunity arises.

There are many technical questions involved, such as whether Rheinmetall Düsseldorf is the exclusive producer of some of the machine-gun parts or whether other complete units can be manufactured by the Hispano Suiza subsidiaries in England and Holland. Apparently, Rheinmetall, Düsseldorf is the sole manufacturer for some of the types of ammunition to be used by the gun, even if it is obtained from other sources. It will also take at least two years before the gun can be used even if the blue-prints were turned over tomorrow. There are technicalities of obtaining rights to produce spare parts in the United States and all of this is still pending. The slave labor issue has already caused a delay in the planned conclusion of the deal and many things are now being held up until the political situation is clear.

The men with whom I spoke stated that something was going on between the Department of Defense and the German Ministry of Defense, but they did not choose to be explicit or were themselves a bit in the dark. The general conclusion reached was that we would remain in close contact and would for the time being do nothing to further provoke the issue in the public eye.

I think the only thing for us to do now is to sit tight and wait for an approach from Rheinmetall. If they come forward, we'll deal with it on the merits. I will have to be in Germany beginning around May 8th for the URO meetings and by that time you should be back from Israel. If they come forward with a decent offer, perhaps we can wind up the deal around that time.

The B'nai B'rith has resolved to continue to maintain its interest in this problem and may be relied upon to do whatever is required. I am asking them to do donothing until the situation clarifies itself. 
With warm regards,

Cordially yours,

Benjamin B. Ferencz

cc. Dr. W. Wexler; Rabbi Jay Kaufman;

Dr. Seidenberg; Mr. Kagan

\section{Dokument 65}

Benjamin B. Ferencz an Ernst Katzenstein

Ohne Ortsangabe, 4. April 1966

Maschinenschriftlicher Brief, 2 Seiten; Kopfzeile auf Seite 2 (»April 4, 1966«)

$R G 12.004 .18^{\star} 10$

April 4, 1966

Dr. Ernst Katzenstein

CONFIDENTIAL

JRSO

Gruneburgweg [sic] 119

Frankfurt/Main

Dear Ernst:

On April 1st, the Executive Vice President of B'nai B'rith, Rabbi Jay Kaufman and I had a meeting with the German Ambassador Knappstein who was joined by Dr. von Stackelberg ${ }^{171}$ and Dr. Müller-Dethard. ${ }^{172}$ The meeting lasted almost an hour and a half, and the sole purpose was to discuss Rheinmetall.

The Ambassador had not been convinced that the company had any obligation to pay. He was unable to grasp why the Röchlings, who had been

171 Wahrscheinlich ist der deutsche Diplomat Herbert Freiherr von Stackelberg (19111975) gemeint, der verschiedene Posten im Auswärtigen Dienst der Bundesrepublik inne hatte. In der zweiten Hälfte der 1960er Jahre war er Gesandter an der Botschaft der Bundesrepublik in Washington.

172 Helmut Müller-Dethard (1917-1986) war ab 1951 im Auswärtigen Dienst der Bundesrepublik tätig und arbeitete in den 1960er Jahren in der Botschaft in Washington. 
very decent, should now be under any obligation to pay for what happened in Sömmerda with which they had in no way been connected and which was still operating under Polish administration. ${ }^{173}$ The concept of corporate liability was difficult for him to understand.

I tried to persuade him, as you will see from the attached copy of my confirming letter to him. I think he was persuaded when I left, but such things usually wear off quickly. His legal assistants who were with him seemed to be convinced.

It also came out during the discussion that he had not been authorized to transmit the 2 Million mark offer. It was my impression that this offer was to come from the company to you and that the German government, just like the U.S. government, wanted to avoid anything which looked like negotiation on their part. I told them that we would treat as confidential the mention of the 2 Million mark figure by him. This means that you can make no reference to it should you be approached by the company.

|2| When that happens, you can repeat our request for 3,000 marks for an estimated 1,000 claimants. If they pay 5 Million DM, we will give them the same type of guarantee we have given the other companies. If they will accept an open-end obligation for 5,000 DM per person, we can also accept that. We could also accept 4 Million marks without a guarantee clause, just as was done in the AEG case. If there is anything left over after paying 5,000 DM to each claimant, we would of course agree to reimburse the remainder to the company. Our accounts can also be audited by any recognized auditing firm.

The United States government has been kept fully informed. The Pentagon will withhold any action for a reasonable period of time in order to give the parties a chance to negotiate. If we have not heard from Rheinmetall by April 13th I am to advise the U.S. State Department.

I know you are in Greece and I hope you are having a good time, but this will be waiting for you when you return. In the meanwhile, I presume Dr. Seidenberg can act for you and that he will contact me at once if there is any approach from the Rheinmetall side.

Warm regards,

Cordially yours,

Benjamin B. Ferencz

173 Das Rheinmetall-Werk Sömmerda in Thüringen wurde 1952 von der Sowjetischen Kontrollkommission an die DDR zurückgegeben und anschließend in einen volkseigenen Betrieb umgewandelt. 
cc. Dr. Seidenberg

Mr. Kagan (1)

On April 1, I also met with Bill Landfer, Ed Crowley and Ely Maurer who are handling this problem for the State Dept. ${ }_{1}^{174}$

\section{Dokument 66}

Benjamin B. Ferencz an Ernst Katzenstein

Ohne Ortsangabe, 27. Mai 1966

Maschinenschriftlicher Brief, 3 Seiten; Kopfzeile ab Seite 2 (»May 27, 1966«)

$R G 12.004 .08^{*} 06$

[Ferencz geht auf jüngste Entwicklungen in den Verhandlungen mit Vertretern des Flick-Konzerns ein. Hierbei kritisiert er vor allem die von Flicks Rechtsanwalt Fabian von Schlabrendorff verfolgte Verzögerungstaktik. Er rät schließlich, die bislang vertraulich geführten Verhandlungen in die Öffentlichkeit zu tragen, um so den Druck auf Flick zu erhöhen.]

\section{May 27, 1966}

Dr. Ernst Katzenstein

JRSO

Gruneburgweg [sic] 119

Frankfurt

Dear Ernst:

Contrary to your expectations, your letter of May 24th regarding DYNAMIT NOBEL does not please me but disgusts me. Never in my life have I seen such unmitigated and unjustified procrastination on the part of a person of good reputation as we have witnessed in the waltz we have been having with Dr. von Schlabrendorff.

For over four years we have been trying to obtain compensation from the convicted Nazi criminal and multi-millionaire owner of a company which was one of the major abusers of Jewish slave labor. The matter is aggravated and not ameliorated by the fact that several verbal agreements were reached.

$174 \mathrm{Zu}$ anderem Zeitpunkt oder mit anderer Schreibmaschine geschriebene Einfügung. 
Indeed, von Schlabrendorff originally proposed to pay between 5 and 8 Million DM as early as December 1962 . He was at that time acting as attorney for the company and personally drafted the agreement. One would expect that an attorney so acting would not then be disavowed by his own client. In April 1964, he drafted another agreement, this time to pay 5 Million DM and ratification was expected by May 1, 1964. This agreement was signed by you and confirmed by the Claims Conference, yet the company never concluded the deal.

Von Schlabrendorff has repeatedly asked for all kinds of documents which we have given him. On February 12, 1964 he received a complete batch of documents more than adequate to justify whatever payment they purportedly contemplated. On March 1, 1966 I sent you a comprehensive memorandum of the case with reference to the documents proving all essential ingredients. On March 17th you sent von Schlabrendorff an 8-page comprehensive letter setting forth all of the arguments and facts which would justify the immediate fulfillment on their part of the agreement which he had offered.

|2| We were given the most absurd excuses for the stalling which was taking place. I do not speak of the repeated illnesses on the part of various participants, but I do have in mind the repeated searches for new documents, new expert opinions, new members of the board of directors, new trips to Washington and similar non-persuasive excuses. Von Schlabrendorff's most recent request in my opinion belongs in the same category.

I again repeat what I have been saying for years. I simply do not believe that this company will do anything until and unless it is persuaded that we will act forcefully and publicly against it. Their admission that the Rheinmetall matter has prompted their approach to you is further confirmation of my thesis. I am prepared to assemble a "White Paper" showing the entire history of our negotiation with this company. It is a story which will disclose that a convicted major war criminal who has in recent years given away millions to German charities has thus far refused to pay the slightest compensation to his former Jewish victims. Flick's personal support of Himmler and personal demonstrable knowledge of what went on would make a delightful story in itself and I am sure that when that story is publicized Dynamit-Nobel could not possibly sell anything in the United States. I would present the facts to such Jewish organizations as would be prepared to disseminate the information. I have repeatedly been asked - "Who's Next?" and have replied "Dynamit Nobel". I have told this to the State Department as well.

I think it is high time for us to put a stop to the cat and mouse game which Mr. von Schlabrendorff is to my mind again resuming. I think he should be told in no uncertain terms that he has had time enough and plenty to reach a conclusion on this issue and that there has been so much interest generated 
in the United States that you can no longer sit on the kettle which is about to explode. You may tell him politely that we have given him all of the documents we have available and they should suffice for all purposes. You may tell him if you think it useful that I am the villain and that I can no longer be restrained.

I would suggest that you call a meeting immediately with von Schlabrendorff and Eric Warburg and ask for a clear and prompt reply. If the answer is not prompt fulfillment of their earlier agreement, I would suggest you tell him quite honestly that we have lost faith in the sincerity of their intention or their ability $|3|$ to carry out that intention and that we are left no choice but to give the facts to the claimants and thereby the public.

I have not cleared these views with Saul but express merely my own opinion. I will do nothing further until I hear from you.

Warm regards,

Cordially yours,

Benjamin B. Ferencz

BBF: js

cc. Mr. Saul Kagan

Miss Marga Cohen

\section{Dokument 67}

Benjamin B. Ferencz an Felix L. ${ }^{175}$

Ohne Ortsangabe, 11. Juli 1966

Maschinenschriftlicher Brief, 2 Seiten

$R G 12.004 .19^{\star} 09$

July 11, 1966

Mr. Felix L.

251 West 87th Street

New York, N. Y.

175 Der Name wurde von den Herausgebern anonymisiert. 


\section{Dear Felix:}

I have obtained additional information regarding the claims of your wife Felicia as a former slave laborer of the Siemens company. I have noted that she was employed between the fall of 1943 and the spring of 1944 in Gera-Tils. ${ }^{176}$ Of course I have tried to find out whether it would be possible to include her among the beneficiaries of the Siemens agreement. I have, however, regretfully been forced to come to the conclusion that she cannot be favorably considered for a number of reasons.

The agreement with Siemens specifically provides that the money can only he paid out to those claimants who, among other things, are able to prove that:

(1) They were persecuted because they were Jews, and

(2) They worked for Siemens while they were inmates of a concentration camp.

It appears that your wife does not meet either of these two requirements. Gera is not listed as a concentration camp but only as a Zwangsarbeiterlager which is not eligible under the agreement. It would therefore not be possible to include her. All payments made by Compensation Treuhand will be subjected to a strict audit to be made by the Siemens company which must be given access to every file.

As I told you when you first mentioned this case to me, some time ago, all of the money received from Siemens will be paid out to the Jewish concentration camp inmates who qualify. The failure to grant one or another case cannot result in the enrichment of Siemens since we know already that more claimants will be approved than there are funds available to pay out the amount originally hoped for. The inability to grant your wife's claim will therefore result in money going instead to Jewish concentration camp inmates who probably were required to endure even greater hardships than those who were than in a forced labor camp only.

|2| I hope you will recognize that the conclusion reached is a just one and that it is the only one possible under the circumstances.

With all good wishes to you and Mrs. L.

176 Gemeint ist das in der Panzerkaserne in Tinz (einem Stadtteil von Gera) eingerichtete Zwangsarbeiterlager. Die dort untergebrachten Zwangsarbeiterinnen waren für Siemens-Halske tätig. Zu den Verhandlungen mit Siemens siehe Ferencz, Lohn des Grauens, 153-164. Vgl. auch Carola Sachse, Zwangsarbeit jüdischer und nichtjüdischer Frauen und Männer bei der Firma Siemens 1940 bis 1945, in: Internationale wissenschaftliche Korrespondenz zur Geschichte der deutschen Arbeiterbewegung 27 (1991), H. 1, 1-12; Wilfried Feldenkirchen, Siemens. 1918-1945, München 1995, 159-169. 
Sincerely yours,

Benjamin B. Ferencz

BBF: js

cc. Dr. Seidenberg

bc. Mr. Kagan

Mr. Gutter

\section{Dokument 68}

Benjamin B. Ferencz an Ernst Katzenstein

Ohne Ortsangabe, 13. Februar 1967

Maschinenschriftlicher Brief, 2 Seiten

RG $12.004 .08^{*} 07$

February 13, 1967

Dr. Ernst Katzenstein

CONFIDENTIAL

JRSO

Gruneburgweg [sic] 119

Frankfurt

Dear Ernst:

Never in my life have I heard of such unmitigated gall as was contained in your letter of February 7th reporting on Dynamit-Nobel's most recent manouver. According to Schlabrendorff (about whose integrity and intelligence I for one have come to have the most serious doubts), Nobel agrees to pay its former slaves but won't put the obligation in legal form since it has no money. $\mathrm{He}$ suggests we see him on August 23, 1967.

My own answer to him would be that on March 30th (or some other proximate and specific date) I am simply going to release the entire story to the press. He may do whatever he likes. We will do nothing more than state the absolute truth and all of the truth. I would then proceed to prepare all the materials and do exactly as promised. 
If they do nothing, as they well might, we will at least have stopped covering up what to my mind is scandalous behavior.

I am going to suggest to Saul that he meet with Schlabrendorff next week. I do not wish to be present at such a meeting. Saul can than tell him that B'nai B'rith has been aware of the facts for some time and has been constantly pressing for authorization to release the story. He may inform him that the General Counsel to B'nai B'rith is not convinced that it would be in the Jewish interest to withhold any of the facts and is not inclined to protect the interest of Dynamit-Nobel. If they want to pay after they have been blasted - just as was done by Rheinmetall - that will always be possible. If they never want to pay, we can't force them to do so under German law at this time, but there are many Jewish organizations which will not cease to try to obtain what they believe to be the most modest sign of justice.

|2| Now I am very mindful that responsible Jewish leaders, for whose judgment I have the greatest respect, may take a different view. I am aware of the counter-arguments about not making demands against any Germans when they are having general budgetary problems and the mood is not particularly sympathetic to any further indemnification. Since I have in this matter acted in the name of the Claims Conference, I am of course willing to abide by whatever conclusion the responsible officers of the Claims Conference may reach.

But I want no mistake about my own feeling and recommendation. I am not recommending any threats, any extortion or any blackmail, but simply. that we make the truth available to the press. It is the story of a company, largely owned by a convicted war criminal who is now a multi-millionaire, refusing to honor a contract drawn up by his own counsel two or three years ago to grant modest compensation to former slaves, on the grounds that the company has no money. I would be pleased to undertake the responsibility of seeing that the true story is told, and I am reasonably confident that I could count on the continued cooperation of B'nai B'rith.

I shall do nothing until further advised by Saul.

Warm regards.

Cordially yours,

Benjamin B. Ferencz

BBF: js

cc. Mr. S. Kagan

Miss Cohen 


\section{Dokument 69}

Benjamin B. Ferencz an Kurt Wehle

Ohne Ortsangabe, 17. Juli 1967

Maschinenschriftlicher Brief, 1 Seite

$R G 12.004 .05 * 08$

i $<$ Schildbach's letter said that he was becoming an employee of the Justice Dept. and therefore the claimants would have to look to someone else - possibly the URO - for further assistance. $>_{1}^{177}$

July 17, 1967

Mr. Kurt Wehle

32-34 265th Street

Floral Park, N. Y. 11004

Dear Wehle:

$\{\text { Brabag }\}^{178}$

It was good to hear from you in your letter of the 14th and I trust that you and yours are well.

The slave labor situation is rather dormant at the moment. We are hoping for onne settlement with the Dynamit-Nobel ${ }^{179}$ company and, after that, possibly an overall agreement with the German Association of Manufacturers. ${ }^{180}$ Both of these, however, are exceedingly uncertain.

As far as the courts are concerned, the German Supreme Court has held that claims of foreign nationals cannot be determined until there is a final peace settlement with Germany (London Debt Settlement Agreement). ${ }^{181}$ A recent Supreme Court decision in the Heinkel case held that claims of German nationals are barred by the statute of limitations. ${ }^{182}$ The Supreme Court therefore says that either you are too late or you are too early. Under the

177 Die Anmerkung wurde mit einer anderen Schreibmaschine eingefügt.

178 Das Wort ist im Original eingekringelt.

179 Im Original ist »the Dynamit-« eingekringelt.

180 BDI.

181 Hier bezieht sich Ferencz auf Art. 5, Abs. 2 des Londoner Schuldenabkommens (Abkommen über deutsche Auslandsschulden, London, 27. Februar 1953). Siehe dazu auch die Einleitung, 56.

182 Siehe zum Fall Bartl gegen Heinkel die Dokumente 50 und 51. 
circumstances, we can hardly hope for any favorable action from the German courts although the issue has now been thrown into the Federal Constitution Court on the ground that there is unequal treatment of various groups.

As far as Brabag ${ }^{183}$ is concerned, I think the only thing for the claimants to do is nothing. They are in no different position than the slave laborers of hundreds of other German companies. If something can be done to help them I will do it, but this does not require any action on their part. If a settlement becomes a reality the claimants will be appropriately notified.

I am returning Dr. Schildbach's letter.

With all good wishes,

Cordially yours,

Benjamin B. Ferencz

cc.

Dr. Katzenstein

Dr. Seidenberg

b.c. Mr. Kagan (2)

\section{Dokument 70}

Benjamin B. Ferencz an Ernst Katzenstein

Ohne Ortsangabe, 14. August 1967

Maschinenschriftlicher Brief, 1 Seite

RG 12.004.10

August 14, 1967

$\{$ Heinkel\}

Dr. Ernst Katzenstein

JRSO

Gruneburgweg [sic] 119

Frankfurt

183 Das Wort ist im Original eingekringelt. 
Dear Ernst:

The letter from Dr. Bartl attached to yours of August 10th was a very sad document. Not only has the German Supreme Court assisted by the Finance Ministry beaten this poor slave laborer into the legal dust, but they now threaten to bankrupt him with court costs which he cannot bear. ${ }^{184}$

Dr. Bartl's request for a contribution of only 1,000 marks towards his costs of 23,000 DM seemed to me to be very modest. The only agency in the world which has taken up the fight for slave laborers has been the Claims Conference and Dr. Bartl singlehandedly carried on an important aspect of that fight. I think it would be a very fine gesture for the Claims Conference to meet his request. If necessary, it can come out of the Compensation Treuhand fund. I recommend therefore that the payment be made and that Dr. Bartl be thanked for his courageous battle and be encouraged to carry on as long as he can.

I plan to write up the decision of the BGH for the American Journal of Comparative Law. ${ }^{185}$ I don't think that I can refrain indefinitely from publicising the fact that one of Hitler's principal armament manufacturers, on an immoral technicality like the statute of limitations, defeated a poor slave laborer and then tried to bleed him further out of all of his assets.

Warm regards,

Cordially yours,

Benjamin B. Ferencz

BBF: js

cc. Mr. Seidenberg

Mr. S. Kagan (2)

184 Siehe zum Fall Bartl gegen Heinkel die Dokumente 50 und 51.

185 Benjamin B. Ferencz, West Germany: Supreme Court Bars Claims of Forced Laborers Against German Industrial Concerns, in: The American Journal of Comparative Law 15 (1966-1967), H. 3, 561-566. 


\title{
Dokument 71
}

Benjamin B. Ferencz an Saul Kagan

Ohne Ortsangabe, 17. September 1969

Maschinenschriftlicher Brief, 2 Seiten

$R G 12.004 .08^{\star} 09$

September 17, 1969

\author{
Mr. Saul Kagan \\ 85 Midland Avenue \\ Tarrytown, New York
}

\section{Dear Saul:}

I have just come from a meeting with Mr. McCloy which lasted the good part of an hour. After exchanging some personal pleasantries, Mr. McCloy again gave me a description of his last meeting with the Flick people. He wanted to know what more he might do to further the matter.

I told him that we had tried everything except a direct approach to Mr. Flick. Although Flick was now 86 years old, recent reports had indicated that he was still in control of Dynamit-Nobel. I reviewed for Mr. McCloy the history of our negotiations and the facts concerning the use of slave labor as well as the present legal status of such claims. I explained what had happened in connection with the Rheinmetall matter and that if no settlement was made we might be faced with the unpleasant alternative of making all of the facts public. I indicated that a boycott of purchase of Mercedes cars, which could affect both Flick and Abs, was not out of the question and it might still be possible to have Senator Javits and Congressman Celler raise some protest against the U.S. government doing business with Dynamit-Nobel.

Mr. McCloy did not seem distressed at any of these alternatives, but was inclined to doubt whether much public interest could today be generated in the matter.

We considered at some length what might go into a letter from Mr. McCloy to Mr. Flick and agreed that such a letter should contain no recriminations or threats but rather an appeal on humanitarian grounds. I told him that by a strange coincidence I just happened to have such a letter with me for his consideration. He smiled as he read it through carefully. He agreed that it contained all of the essential material which he would require and $|2|$ that he would "play with it for a while" and send out the letter to Flick as suggested. 
He also wanted to know whether he should send copies to anyone else and I suggested that copies go to von Schlabrendorff, Eric Warburg, Mr. Abs and Prof. Kronstein, ${ }^{186}$ all of whom had indicated a willingness to be helpful. Mr. McCloy agreed to do so and I left with him another copy of my memorandum of July 8th, containing the addresses. Mr. McCloy promised to send me a draft of the revised letter and I, of course, urged him to make all changes which he felt might be useful.

It was a thoroughly pleasant meeting, and, as in all of my encounters with Mr. McCloy, I found him most cooperative and eager to be of service.

I am enclosing a copy of the draft I left with Mr. McCloy.

Warm regards,

Cordially yours,

Benjamin B. Ferencz

BBF: js

Encl.

cc. Mr. Jacob Blaustein

Dr. Ernst Katzenstein

\section{Dokument 72}

Benjamin B. Ferencz an Tuviah Friedmann ${ }^{187}$

Ohne Ortsangabe, 11. November 1970

Maschinenschriftlicher Brief, 2 Seiten; gedruckte Kopfzeile auf jeder Seite (nur für Seite 1 wiedergegeben), auf Seite 2 zusätzliche maschinenschriftliche Kopfzeile (»Mr. Tuwiah Friedmann Vorsitzender 11/11/70«)

$R G 12.005 .01 * 09$

186 Der Jurist Heinrich Kronstein (1897-1972) emigrierte, von den nationalsozialistischen Berufsverboten für Juden betroffen, im Dezember 1935 in die Vereinigten Staaten. Dort arbeitete er für das Justizministerium und studierte parallel erneut Rechtswissenschaft. Anfang der 1940er Jahre erhielt Kronstein mit der amerikanischen Staatsbürgerschaft auch die Zulassung als Anwalt. 1946 wurde er auf eine Professur an der Georgetown University in Washington berufen. Von 1951 bis 1965 lehrte er zudem an der Universität Frankfurt am Main.

187 Tuviah Friedman(n) (auch Tobias Friedman, Tuwiah Fridman oder Towia Frydman; 1922-2011) war ein jüdischer Publizist. Im polnischen Radom geboren, überlebte 
Taylor, Scoll, Ferencz \& Simon

Nov. 11, 1970

Mr. Tuwiah Friedmann

Vorsitzender

Institute of Documentation in Israel

P.O. Box 49300

Haifa, Israel

Dear Mr. Friedmann:

Please pardon the delayed reply to your letter of 18 October, but I have been out of the country. Let me clarify some of the questions you raised.

Neither Dr. Katzenstein nor I have the slightest interest in serving as paid representatives for any slave labor claimants. What we have done and tried to do in this area has been on behalf of the Claims Conference and has been supported by the leading Jewish organizations of the world. After twenty years of experience and intensive effort, we have reached the conclusion that nothing more can be achieved at this time.

If you will study the decision of the German courts, you will find that despite many test cases which we fought through the highest courts, the conclusion was reached that there is no legal obligation on the part of the German firms to pay their former slave laborers. (There is no use in you and I agreeing that such decisions are outrageous. The decisions are there. They are binding and they are final.) The German firms refuse to recognize any moral obligation despite years of pressure from us and from highly placed German and American sources.

Let me assure you that we are not withholding the names of any firms because of any obligation to protect them. The major firms which we contacted employed concentration camp inmates and which included the construction firms Phillip Holzman[n], and Moll, ${ }^{188}$ both of which are still

er das dort eingerichtete Ghetto sowie die Inhaftierung in deutschen Arbeitslagern. 1944 konnte er fliehen und widmete sich nach dem Krieg dem Aufspüren von untergetauchten Nationalsozialisten, wobei er insbesondere mit Simon Wiesenthal zusammenarbeitete. 1952 emigrierte er nach Israel und setzte dort, zunächst als Mitarbeiter von Yad Vashem, seine Tätigkeit fort. 1957 begründete er das Institute of Documentation in Israel for the Investigation of Nazi War Crimes, das sich gleichfalls dem Aufspüren von nationalsozialistischen Verbrechern widmete.

$188 \mathrm{Zu}$ den ergebnislosen Bemühungen der JCC um eine Entschädigungsvereinbarung für jüdische Zwangsarbeiter mit den deutschen Bauunternehmen Philipp Holzmann AG und Leonhard Moll siehe Ferencz, Lohn des Grauens, 222-224. 
active, the aircraft industry firms of Messerschmidt [sic], and Heinkel, ${ }^{189}$ the firms of BRABAG ${ }^{190}$ and Buessing, ${ }^{191}$ Continental Gummi, and WMF which does business around the world. We also had long discussions with the Bund der Deutsche [sic] Industrie. ${ }^{192}$ We got absolutely nowhere. We are still trying to persuade one company to conclude an agreement which was negotiated years ago, but so far, we have had no success despite the fact that the company is $|2|$ controlled by a major war criminal who is making millions selling his products everywhere. ${ }^{193}$

Our sole concern is the welfare of the former slave laborers. We do not wish their hopes to be aroused in vain that they will be able to receive additional compensation from German companies. We would be delighted to have you prove us wrong, but until you have some much firmer basis than a few vague discussions with a few polite people, we are convinced that you are harming those you intend to help, if you let your optimism interfere with reality, and you let them believe you have a reasonable hope of getting money for them.

I expressed these views to Dr. Eberstein $\{$ Te̊icichfơůße̊ri $\}$ when he called me and he seemed to share my conclusion.

With every good wish,

Cordially yours,

Benjamin B. Ferencz

c.c. Dr. Katzenstein

Dr. Seidenberg

Mr. Kagan

BBF: rkl

189 Zur Rolle der JCC bei den vergeblichen Bemühungen um eine Entschädigungsregelung für jüdische Zwangsarbeiter mit den Flugzeugunternehmen Messerschmitt und Heinkel siehe Ferencz, Lohn des Grauens, 216-220.

$190 \mathrm{Zu}$ den vergeblichen Bemühungen um eine Entschädigungsregelung für jüdische Zwangsarbeiter mit der Braunkohle-Benzin AG (BRABAG) siehe Ferencz, Lohn des Grauens, 220-222.

191 Zur Auseinandersetzung um die Entschädigung von jüdischen Zwangsarbeitern mit dem Fahrzeughersteller Büssing siehe Ferencz, Lohn des Grauens, 214-216.

192 Gemeint ist der BDI.

193 Gemeint sind die Verhandlungen mit Friedrich Flick. Siehe dazu die Dokumente 43, $46,47,53,60$ und 66 . 


\section{Dokument 73}

Benjamin B. Ferencz an Hans Seidenberg

Ohne Ortsangabe, 25. Januar 1971

Maschinenschriftlicher Brief, 1 Seite; gedruckter Briefkopf

$R G 12.004 .02 * 06$

Taylor, Scoll, Ferencz \& Simon

Dr. H. Seidenberg

January 25, 1971.

Compensation Treuhand G.M.B.H.

$\{\mathrm{AEG}\}$

6 Frankfurt/Main

Wiesenau 55-1

West Germany

Dear Seidenberg:

Thank you for your letter of the 8th dealing with the case of Mrs. H. ${ }^{194} \mathrm{I}$ understand that the lady who is now in Tel Aviv is suspected of having deceived the German authorities by obtaining compensation as a concentration camp inmate, whereas it now seems that she actually managed to escape to Russia. We believed the same story and paid her DM2,000 in reliance on two witnesses to whom we have also apparently made payments for which they did not qualify under the terms which we laid down for distribution of the AEG ${ }^{195}$ Fund. ${ }^{196}$

I must confess that I'm really not as unhappy about it as you seem to be. We acted in good faith and did the best we could. If some poor Jewish woman who had to flee to Russia managed to get $\$ 500$ out of us by pretending that she was in Hell No. 1, which qualified for payment, whereas she was actually in Hell No. 2, which doesn't qualify - well, I'm not inclined to make her life miserable any more. I know perhaps better than anyone how arbitrary were the rules under which we had to operate, and we never pretended that we were meting out absolute justice.

The AEG case is closed. Our conscience is clear, and my inclination is to let the lady rest in peace.

194 Der Name wurde von den Herausgebern anonymisiert.

195 Das Wort ist im Original eingekringelt.

$196 \mathrm{Zu}$ den Verteilungskriterien bei der Umsetzung des Entschädigungsabkommens mit AEG durch die CT siehe Ferencz, Lohn des Grauens, 152. 
With warm regards, ${ }^{197}$

c.c. Dr. Katzenstein

P.S. What's happening with the medical claims? ${ }^{\text {198 }}$ The NYANA ${ }^{199}$ (whose cases you said were all well prepared) is getting very impatient - and they don't even have a Dan Lack! ${ }^{200}$

BBF: rkl

\section{Dokument 74}

Benjamin B. Ferencz an Hans Seidenberg

Ohne Ortsangabe, 13. Februar 1976

Maschinenschriftlicher Brief, 1 Seite

$R G 12.005 .01^{\star} 15$

Dr. Hans Seidenberg: Frankfurt

13 February 1976

Dear Seidenberg:

Thank you for your letter of the 6th warning that Compensation Treuhand is going pleite. I have only a slight modification to make. Compensation Treuhand is not going pleite - it IS pleite!

You note that the total assets of C.T. is DM 100,000 plus DM 6,908. (You will notice that I am not even counting the pfennigs.) You will have to pay the URO, you say, for the expenses during the second half of 1975, and that presumably will absorb the DM 6,908. The Claims Conference advanced to C.T. in 1957 and 1958, an amount of $\$ 33,432.02$, which at the then prevailing rate of exchange was just DM 100,000. On Feb. 6th, the same day you were sending

197 Unterschrift fehlt auf archivalischer Kopie.

198 Siehe dazu die Dokumente 132-147.

199 NYANA steht für die New York Association for New Americans, die 1949 für die Unterstützung jüdischer Immigranten im Raum New York gegründet wurde.

200 Daniel Lack war Rechtsberater des JDC in Genf und arbeitete zudem jahrzehntelang für den Jüdischen Weltkongress. 
me your happy news, Dr. Weisman [sic] was reminding Dr. Sherman ${ }^{201}$ and the new Comptroller of the Claims Conference about the outstanding debt of DM 100,000. Since the debts exceed the assets you will recognize, as a former accountant, that Compensation Treuhand is about as rich as the City of New York, which means that it is not only pleite but is in fact bankrupt!

But don't worry. We in New York are accustomed to such a condition. I believe Israelis have similar feelings. We don't admit that we are bankrupt, we just declare a moratorium on old debts. My advice to the Claims Conference was simple: "Forget it!" The matter is now under advisement. I may have similar advice for the URO. In any case the problem has not escaped my attention. I don't think it can be resolved until I appear on the scene in Frankfurt and at that time we can all decide what to do with the money which we don't have.

With warm regards, ${ }^{202}$

P.S. Please share this with Katzenstein and May.

\section{Dokument 75}

Benjamin B. Ferencz an Heinz Gerling ${ }^{203}$

Ohne Ortsangabe, 26. Januar 1982

Maschinenschriftlicher Brief, 1 Seite

$R G 12.004 .09^{\star} 16$

201 Wahrscheinlich A. Joshua Sherman (1934-2013), der als ausgebildeter Jurist und promovierter Historiker unter anderem als Stiftungstreuhänder, Berater im Bankenwesen und Autor tätig war. Von 1975 bis 1978 war er Geschäftsführer der Memorial Foundation for Jewish Culture.

202 Unterschrift fehlt auf archivalischer Kopie.

203 Heinz Gerling (1904-2002) war in den 1920er Jahren als Verbandsfunktionär in verschiedenen zionistischen Organisationen aktiv. 1933 verließ er Deutschland und emigrierte ins britische Mandatsgebiet Palästina. Dort wirkte er als Direktor der Vereinigung der Immigranten aus Deutschland (hebr. Hit'ahdut ole Germanya), die 1942 in Organisation der Einwanderer aus Zentraleuropa (hebr. Irgun ole merkaz Eropa) umbenannt wurde, und war Mitglied des Council of Jews from Germany. Von 1949 bis 1952 war Gerling stellvertretender Abteilungsleiter für Restitution bei der Jewish Agency. Zwischen 1953 und 1970 arbeitete er in leitender Stellung beim Rechnungshof Israels. 1955 war er an der Gründung des Leo Baeck Instituts (LBI) beteiligt und wirkte im Anschluss im Beirat des LBI Jerusalem. 
January 26,1982

Dr. Hans [sic] Gerling

Leo Baeck Institute

33 Bustanai St.

Jerusalem 93229

Dear Dr. Gerling:

Your letter of the 20th regarding the appropriateness of accepting a grant from the "Flick Foundation"204 touches moral and emotional problems more than legal ones.

The fact that Friedrich Flick was a convicted major war criminal who died unrepentant and without providing any compensation to his victims has been well established in the Nuremberg trial against him and my book Less Than Slaves (German title "Lohn des Grauens"). Criminal guilt is certainly not inherited; it ends with the criminal's death. Yet I do feel that responsibility for compensating the victims remains a corporate liability, despite any subsequent cloaking of the corporate form.

There can, of course, be no discharge of that liability by small grants to charitable or scientific organizations associated with former Nazi victims. I am quite confident that the Leo Baeck Institute, in accepting Funds from the "Flick Foundation" was neither authorized nor did it intend to grant anything by way of pardon or release from the continuing obligation of Flick companies or their successors to compensate those who were victimized by them.

Apparently the direct recipient of the research grant feels uncomfortable about accepting funds from so tainted a source. That seems to me to be a purely emotional reaction - which I can understand and respect even though I would not share it. I would not presume to comment on such a sensitive point of personal morality.

With every good wish, ${ }^{205}$

204 Eine Flick-Stiftung existiert erst seit 2001 unter dem Namen F. C. Flick Stiftung gegen Fremdenfeindlichkeit, Rassismus und Intoleranz und wurde von Friedrich Christian Flick ( $\left.{ }^{\star} 1944\right)$, dem Enkel von Friedrich Flick, gegründet. Im Rahmen der Recherchen für diese Edition war es nicht möglich herauszufinden, ob es sich bei den erwähnten Mitteln um eine private Spende oder um eine Initiative der Friedrich Flick KG handelte.

205 Unterschrift fehlt auf archivalischer Kopie. 


\section{Dokument 76}

Benjamin B. Ferencz an Ernst Katzenstein

Ohne Ortsangabe, 5. März 1986

Maschinenschriftlicher Brief, 2 Seiten

$R G 12.004 .09 * 20$

March 5, 1986

Dr. Ernst Katzenstein: Frankfurt

Re: Dynamit-Nobel

Dear Ernst:

Saul and I have, of course, been discussing the content of your letters and phone conversations and he will see you soon with the details. But I wanted to jot down some of my comments so that in the invariable rush during his meetings in Germany the points do not get lost. Your letter of 4 Feb. outlined most of the immediate problems so let me address that first. ${ }^{206}$

You list the $\mathrm{D} / \mathrm{N}$ camps and show how many claimants we had from each camp as of 17.10.1967. The total was 3,495 from the 8 camps. Saul will take to Germany a copy of a letter dated 14 Jan. 1972 that indicates that complete lists are available regarding the entry and exit from some of the camps and partial lists are available for others. My guess is that we will be able to put together lists tolling at least 5,000 names of persons who worked for D/N. How many we can still trace remains to be seen.

Both Saul and I felt that it would be desirable to pay each entitled claimant at least DM 2,500. The DM 5 million available means that only 2,000 claimants can be covered at that rate. My own feeling is that we should therefore pay out ONLY to persons whose names appear on our lists - at least initially. If there are fewer than 2,000 certified claimants then, of course, other proof should be considered. We should pay out nothing until we have set a deadline, all claims have been received and checked against the lists. If there are more than 2,000 certified claims, the amount payable to each will have to be reduced

206 Nach dem Verkauf der Dynamit Nobel AG durch Friedrich Karl Flick an die Deutsche Bank zahlte diese 1986 fünf Millionen DM an die JCC für ehemalige jüdische Zwangsarbeiter. Siehe Goschler, Schuld und Schulden, 351. Zur Verteilung dieser Summe durch die CT siehe ausführlich Borggräfe, Zwangsarbeiterentschädigung, 171-173. 
pro-rata. (We can always try to get additional funds if the amounts available prove to be totally inadequate.)

If this approach is accepted, there are consequences that follow:

Testing the validity of the claim becomes much simpler.

The questionnaire become[s] much simpler. We do not have to ask the claimant whether he submitted claims at an earlier "Aufruf" (See Para. 2 of your 4 Feb. letter).

The press release is affected. I am inclined to state in the release the name of the specific camps where we have lists and inform the claimants that priority will be given to those whose names appear on them. This may eliminate many of those who might otherwise simply try to "take a chance" by filing an unjustified claim. I would give claimants a month filing period. If we find that the response is inadequate, we can extend it for another month or two.

I agree (your Para. 7) that those from the East must be included. ${ }^{207}$ But I don't think we can or should make distinctions or priorities, at least regarding the listed persons, regarding age or need. Efforts should be made in advance to be sure that the money reaches the intended beneficiary free of tax and at the maximum rate of exchange. Our experience with the Hungarian national bank was good and they had an office in Frankfurt where we could make such arrangements.

|2| I agree with your Para. 8 that there should be no appellate procedure. If the claimant is not on the list, the claim is to be put aside. Paymentes are to be made by crossed-check payable only to the name of the person on the list (or new name if there is proof of marriage or legal name change). Proof of identity will be essential.

I agree with your Par. [sic] 9 that no heirs can be considered. If there are funds left over after all the listed claimants have been paid, we can consider hardship cases.

The most immediate problem in my judgment is to get our hands on as many lists as possible. The sources should be: ITS (If they refuse to cooperate we should scream like hell and go over the heads of the bureaucrats!), the scholars who have been writing on the subject, ${ }^{208}$ our own archives both in

207 Ferencz bezieht sich hier auf jüdische Verfolgte des Nationalsozialismus, die seit den 1970er Jahren zunehmend nach Israel, Westeuropa oder in die Vereinigten Staaten ausreisen konnten und bisher keine Entschädigungszahlungen erhalten hatten. Siehe dazu ausführlicher Kapitel 8, Fußnote 50.

208 Die zeithistorische Erforschung der Zwangsarbeit bei Dynamit Nobel im Zweiten Weltkrieg setzte damals gerade erst ein. Siehe vor allem Bernd Klewitz, Die Arbeitssklaven der Dynamit Nobel. Ausgebeutet und vergessen. Sklavenarbeiter und KZ- 
Frankfurt and in Yad Washem [sic], and Dynamit-Nobel itself. Until that is done, I don't think we can issue any "Aufruf" but should simply issue a press release serving as a report to possible claimants and their lawyers telling them that the CC is engaged in completing its search for complete lists of inmates who worked in the specific locations. That press release may also serve to stimulate additional names and lists from persons who have information to share. Such an interim report or press release may take some of the pressure off for immediate payout.

I have also indicated to Saul that I don't think there is any need to expand the Board of Compensation Treuhand. This is likely to be a one-shot deal and those who are experienced with how such problems were solved in the past are most qualified to act on this one or any new one that may come along. I do not mean to exclude anyone who can make a significant substantive contribution, but I see no need to simply add bodies.

I would appreciate it if you would circulate these views to May, Wolff, ${ }^{209}$ and Rom so that you can be in a better poosition to deal with these complicated problems. Sorry I can't be there to help you.

Warm regards to all, ${ }^{210}$

CC: S. Kagan

\section{Dokument 77}

Benjamin B. Ferencz an Werner Wolff

New Rochelle, N. Y., 9. Februar 1987

Maschinenschriftlicher Brief, 2 Seiten

RG 12.004.21*02

Häftlinge in Europas größten Rüstungswerken im 2. Weltkrieg, Schalksmühle 1986; Friederike Littmann, Vom Notstand eines Haupttäters. Zwangsarbeit im Flick-Konzern, in: 1999. Zeitschrift für Sozialgeschichte des 20. und 21. Jahrhunderts 1 (1986), H. 1, 4-43.

209 Der Anwalt Werner Wolff war langjähriger Mitarbeiter der URO. Er leitete etwa das URO-Büro in Köln und wechselte von dort 1965 als Rechnungsprüfer in die Zentralstelle der URO nach Frankfurt am Main.

210 Unterschrift fehlt auf archivalischer Kopie. 
\{Comp. Treuhand ${ }^{211}$ Gl\#\# L\#\#\# General Legal File\}

BENJAMIN B. FERENCZ

Counsellor at Law

Adjunct Professor

Pace Law School
14 Bayberry Lane

New Rochelle, N. Y. 10804

(914) 632-3717

February 9, 1987

Dr. W. Wolff: URO Frankfurt

Dear Wolff:

With reference to your letter of Feb. 5, I'm sorry but I can't think of any English equivalent of "Nimm es nicht auf die leichte Schulter." The best I can do is: "It's no laughing matter!" Needless to say, I take everything from you very seriously - even if I think you worry too much and should more often Nimm es auf die leichte Schulter [sic].

Twenty years ago, when Compensation Treuhand was first established, we had similar problems. As I recall it, the establishment of a charitable organization required that there be enough paid-in capital to fulfill the functions of the organization. The Claims Conference, as the parent body, paid in the necessary sum (which I believe was DM 20,000) and once the organization had other income which was more than adequate to meet the requirements, the DM 20,000 was withdrawn and repaid to the CC. And so it went merrily along and Compensation Treuhand paid out all of its fund receipts from German companies to the entitled beneficiaries, repaid the CC for all of its advances and even left a few thousand marks with which we were all going to celebrate and have a party. I was happy, and proud. But we never got the party!

Of course, I know nothing about the new Bilanzrichtliniengesetz. ${ }^{212}$ Nor do I want to know. I now leave that to Kagan. I did not understand why the URO, rather than the CC, should have put up any money for the recent re-activation of Compensation Treuhand. ${ }^{213}$ Nor did I find much sense in the

211 Compensation Treuhand.

212 Durch das Bilanzrichtliniengesetz vom 19. Dezember 1985 wurden in der Bundesrepublik Richtlinien der Europäischen Gemeinschaft zur Rechnungslegung von Kapitalgesellschaften und Personenunternehmungen in innerstaatliches Recht überführt, wodurch inbesondere die Publizitätspflichten erhöht wurden.

213 Die CT war nach Abwicklung der in den 1960er Jahren ausgehandelten Abkommen mit deutschen Industrieunternehmen zur Entschädigung jüdischer Zwangsarbeiter stillgelegt worden. Aufgrund des Dynamit-Nobel-Abkommens reaktivierte die JCC die CT im Januar 1986 wieder. Siehe Borggräfe, Zwangsarbeiterentschädigung, 172. 
proposed arrangement whereby the CC would pay interest to the URO for the URO loan to Compensation Treuhand. As I understand it, both you and Katzenstein now appear as the founders of the company with a paid in capital of DM 15,000 each, which money was in fact put up by the URO so that you each personally owe the URO the return of that amount. Obviously, the whole thing is a very round-about arrangement (translation in German: Meshugga!) and of course I agree that it should be put straight.

Clearly there has to be a Buchprufer [sic], and clearly we have to comply with the law. Clearly we are obliged to use all funds received for the sole benefit of the beneficiaries, after deducting reasonable administrative costs. Your proposal to [|2|] assign your shares to the CC so that you get out from being caught in the middle seems to me to be eminently sensible. I still do not see why the URO should be in any way involved. The URO should get its "loan" repaid by the CC and the CC should have an acknowledgment by the CT Board Members that they are acting only as agents of the CC. That, in my judgment, would be the correct position and I see no good reason why we can't so $[\mathrm{sic}]^{214}$ just that.

The CC may, of course, object to laying out DM30,000 because it's short of cash. I'm not clear whether the new law prohibits CT from "lending" $\mathrm{DM} 30,000$ to the $\mathrm{CC}$ from the accumulated interest already received from the DM 5 million paid by Dynamit-Nobel, so that the cash flow problem is resolved that way. I must leave that decision to our able lawyers in Frankfurt. Whatever procedure you think can best achieve the purposes set forth above is fine as far as I'm concerned.

Warm regards, ${ }^{215}$

P.S. Yesterday and today I spoke to Saul on the phone and he is doing very well. He is cheerful and even tells jokes! I have refrained from talking business with him but at his speedy rate of recovery there is danger that I will not succeed for very long.

P.P.S. Following our phone conversation recently, I have studied my calendar and find that although a URO meeting between June 21 and July 15 would be preferable, the dates you suggested of August 2 and 3 would be tolerable. Please let me know as soon as you can.

\section{$\{$ S.K. $\}$}

214 Hier liegt ein offensichtlicher Tippfehler vor. Es muss »do« lauten.

215 Unterschrift fehlt auf archivalischer Kopie. 


\section{Dokument 78}

Benjamin B. Ferencz an Saul Kagan

New Rochelle, N. Y., 14. März 1988

Maschinenschriftlicher Brief, 1 Seite; handschriftliche Ergänzung am unteren Seitenrand

$R G 12.004 .07^{\star} 01$

\section{BENJAMIN B. FERENCZ}

Counsellor at Law

Adjunct Professor

Pace Law School
14 Bayberry Lane

New Rochelle, N. Y. 10804

(914) 632-3717

March 14, 1988

\section{Saul Kagan NY}

Dear Saul:

A big mazeltov for having reached an agreement with Daimler-Benz! ${ }^{216}$ Without your initiative and intervention the Jewish victims of Nazi persecution would have been DM 10 million poorer. You have earned your Claims Conference salary forever!

As I indicated on the phone, the sooner the deal is wrapped up and the fewer formalities the better. The presence of Reuter ${ }^{217}$ and Gentz ${ }^{218}$ in the key positions of the company is particularly opportune.

I therefore suggest a simple exchange of letters which sets forth the terms of the understanding reached. A draft is attached. A more formal contract might imply that we have sold the rights of the former Daimler-Benz slaves for

216 Das Wort Daimler ist im Original eingekringelt. Am 13. Juni 1988 erklärte das Unternehmen Daimler-Benz sich bereit, 20 Millionen DM als »humanitäre Geste« zugunsten ehemals bei diesem Unternehmen beschäftigter Zwangsarbeiter an soziale und karitative Hilfsorganisationen zu zahlen, wovon 10 Millionen DM an die CC gingen. Siehe Barbara Hopmann u. a., Zwangsarbeit bei Daimler-Benz, Stuttgart 22017, 466, 470 f.; Borggräfe, Zwangsarbeiterentschädigung, $180 \mathrm{f}$.

217 Der studierte Jurist Edzard Reuter $\left({ }^{*} 1928\right)$ arbeitete seit 1964 bei der Daimler-Benz AG. 1973 wurde er stellvertretendes und ab 1976 ordentliches Mitglied des Vorstands. Zwischen 1987 und 1995 war er Vorstandsvorsitzender des Unternehmens.

218 Manfred Gentz $\left({ }^{*} 1942\right)$ war Jurist und seit 1970 bei der Daimler-Benz AG tätig. Ab 1983 bis zu seiner Pensionierung 2004 arbeitete er für den Vorstand, u. a. als ordentliches Vorstandsmitglied. 
a mess of porridge. Their offer and our acceptance of their conditions is more palatable, and very few will insist that we should have rejected the money.

Publicity will be a delicate matter. I don't think the Claims Conference can or should make a big thing of it. Daimler-Benz will have to be careful too - but that is their problem. I'm sure their publicity department will not want to emphasize their use of $\mathrm{KZ}$ inmates as slaves. Four our part, I think it will be enough to issue a release to the effect that Daimler-Benz made a contribution to the CC for the stated uses and the CC accepted the money and agreed to distribute it in accordance with the conditions of the grant. Anything more is likely to evoke a flood of requests for money or outrage that you didn't get more. The usual.

I'm happy. You did a good job!

Warm felicitations, $\{$ Ben $\}$

$[\ldots]^{219}$

\section{Dokument 79}

Benjamin B. Ferencz an Karl Brozik ${ }^{220}$

New Rochelle, N. Y., 28. Juli 1990

Maschinenschriftlicher Brief, 1 Seite

$R G 12.004 .21^{\star} 04$

BENJAMIN B. FERENCZ

Counsellor at Law

Adjunct Professor

Pace Law School
14 Bayberry Lane

New Rochelle, N. Y. 10804

(914) 632-3717

219 Im Original folgt eine kurze handschriftliche, aber zum Teil unleserliche Notiz vom 25. März 1988 zu einem Telefongespräch mit Saul Kagan über Manfred Gentz.

220 Karl Brozik (vorm. Abeles; 1926-2004) war in einer deutschsprachigen, jüdischen Familie in der Tschechoslowakei aufgewachsen. Als einziger seiner Familie überlebte er das sogenannte Ghetto Litzmannstadt und mehrere Konzentrationslager. Nach dem Krieg studierte er in Prag Rechtswissenschaft und arbeitete zwischenzeitlich für das Außenhandelsministerium. 1968 flüchtete er nach Deutschland, wo er ab 1972 als Anwalt für die URO und JCC tätig war, deren Frankfurter Büro er leitete. Ab 1987 war Brozik Repräsentant der JCC in Deutschland sowie Geschäftsführer der CT. 
July 28, 1990

Dr. Karl Brozik, Geschaftsfuhrer [sic]

Compensation Treuhand

Wiesenau 52, 6000 Frankfurt/Main 1

Dear Dr. Brozik:

Thank you again for your courtesies during our recent meetings in Israel and Frankfurt.

Upon my return home, I re-read your minutes of the Board meeting of July 7, in Jerusalem. It is with some hesitancy that I suggest a minor correction - particularly since you read the sentence to me in Frankfurt and I made no objection. I refer to point 1 . on page 2 of your Protokoll. Since it might be misunderstood, I felt that I should drop you a line about it - even at the risk of being considered personal or petty on an unimportant matter.

You say that "after thorough debate" it was a Board decision that I step down as Chairman and Board Member. To the uninformed, that might sound as though I had been voted out of office for some reason. As you know, it was not a Board decision but it was MY decision. In fact, I had communicated my desire to the Claims Conference many months ago.

Having been involved with Compensation Treuhand since the day it was formed, it was not an easy decision for me to decide to leave. But I do feel that it's work is now essentially over and there are other priorities which have a greater demand upon my time. My decision was not prompted by any disagreement with any of my colleagues with whom I have enjoyed working these many years.

May I therefore extend to you and all members of the Compensation Treuhand Board, especially to my successor as Chairman, Saul Kagan, my deep appreciation for your friendship and cooperation in the successful pursuit of goals which have been very dear to my heart. To all of you, I send my warm greetings and very best wishes.

Sincerely,

$\{$ Ben $\}$

PS: You may simply add this to your "Protokoll."

CC: S. Kagan 

5. Entschädigung für Opfer medizinischer Humanexperimente 



\title{
Dokument 80
}

Benjamin B. Ferencz an David Apter ${ }^{1}$

New York, 15. April 1957

Maschinenschriftlicher Brief, 1 Seite; gedruckter Briefkopf

$R G 12.012 .02 * 02$

\author{
Benjamin B. Ferencz \\ Attorney and Counselor at LaW \\ 60 EAST 42ND STREET \\ New York 17. N. Y. \\ Murray Hill 7-2393
}

Mr. David Apter

Director, Washington Office

Edward Gottlieb \& Associates Ltd.

1145 19th Street, N.W.

Washington 6, D.C.

Dear Mr. Apter:

I was recently approached by Miss Caroline Woolsey Ferriday, ${ }^{2}$ who is chairman of the Friends of ADIR, Inc. (Association nationale des anciennes deportees et internees de la Resistance) with a problem which may be related to the return of vested assets. For the last several years the ADIR has been

1 Zu dieser Person konnten keine biografischen Informationen ermittelt werden.

2 Caroline Woolsey Ferriday (1902-1990) stammte aus einer wohlhabenden amerikanischen Familie und war zunächst Schauspielerin am Broadway. Als Freiwillige arbeitete sie ab Mitte der 1930er Jahre im französischen Konsulat in New York, beobachtete die politischen Entwicklungen in Europa und sympathisierte mit der französischen Résistance. Nach dem Krieg unterstützte Ferriday ADIR, eine Organisation für Frauen aus der Résistance, die die Haft in Konzentrationslagern überlebt hatten. Als Ferriday durch diese Kontakte auf das Schicksal polnischer Frauen aufmerksam wurde, die im Konzentrationslager Ravensbrück für pseudo-medizinische Versuche missbraucht worden waren, die sogenannten Ravensbrueck Lapins, initiierte sie eine Kampagne, um Entschädigungsleistungen von der Bundesrepublik für die Frauen zu erwirken. Ihr Name ist im Original eingekringelt. 
trying to obtain pensions from the German government for a limited number of persons who were victims of Nazi medical experiments. It is estimated that the total number of such victims is about 600 . Many of them are stateless and many of them are nationals of countries allied with the United States.

In March, 1951, the United Nations passed a resolution calling on the German authorities to make the fullest possible reparation to these unfortunate persons. ${ }^{3}$ As a result of this intervention the German government did agree to provide some compensation but the total amount payable to the very few persons who have qualified have been limited to between $\$ 250$ minimum and about $\$ 6,000$ maximum. ${ }^{4}$

The victims of these experiments reading in the press about the large pensions being paid to returning Nazi war criminals felt that they too would be entitled to receive a reasonable pension for the remainder of their lives. These pleas have fallen on deaf ears as far as the German government is concerned. They have repeatedly refused to do anything further for this particular group.

The ADIR have proposed to Senator Watkins ${ }^{5}$ that the German assets in the United States be used to pay the pensions of these victims. The Senator had replied that insofar as the victims were not American citizens, he did not feel that the Congress could intervene in the manner suggested.

The thought occurred to me that we might use the example of these victims of Nazi medical experiments to establish that Germany has not been quite as generous in their compensation programs as she would have the American public believe. Insofar as Germany has relied on the Paris Reparations Agreement ${ }^{6}$ to deny compensation to the medical experiment victims

3 Im März 1951 beschloss das Sozialkomitee der Vereinten Nationen einen Entschädigungsfonds für Opfer medizinischer Versuche, der von der International Refugee Organisation (IRO) verwaltet wurde. Siehe dazu Weindling, Nazi Medicine and the Nuremberg Trials, $336 \mathrm{f}$.

4 Ein Kabinettsbeschluss der Bundesregierung vom 26. Juli 1951 sah Hilfen für überlebende Opfer von Menschenversuchen in besonderen Notfällen vor. Siehe Bundespresseamt, Mitteilung des Presse- und Informationsamtes der Bundesregierung, Nr. 651/51, 26. Juli 1951. Vgl. dazu ausführlich Baumann, Menschenversuche und Wiedergutmachung, 57-61.

5 Vermutlich ist der republikanische Politiker Arthur V. Watkins (1886-1973) gemeint, der von 1947 bis 1959 den Bundesstaat Utah im Senat der Vereinigten Staaten vertrat.

6 Im Pariser Reparationsabkommen vom 14. Januar 1946 wurde die Aufteilung der aus dem Zweiten Weltkrieg resultierenden Reparationsansprüche gegen das Deutsche Reich geregelt, wobei die völkerrechtlichen Ansprüche von Staaten dominierten. Die 
it is further indication that the Reparations Agreement is simply a tool being used by Germany for her own convenience.

I hope you will be able to make use of these arguments somewhere and that it may also contribute towards the German government's consideration of its position with regard to the Friends of ADIR.

Sincerely yours,

BENJAMIN B. FERENCZ

BBFel

\section{Dokument 81}

Benjamin B. Ferencz an Caroline Ferriday

Ohne Ortsangabe, 30. April 1957

Maschinenschriftlicher Brief, 3 Seiten; Kopfzeile ab Seite 2 (»April 30, 1957«)

$R G 12.012 .02 * 02$

[Ferencz berichtet über seine im Auftrag von ADIR durchgeführten Sondierungen zur Entschädigung von in Osteuropa lebenden Opfern medizinischer Experimente während des Nationalsozialismus durch die Bundesrepublik. Dabei beschreibt er Konsultationen mit Mitarbeitern der Vereinten Nationen sowie vertrauliche Gespräche mit US-amerikanischen Public-Relations-Beratern im Dienste der Bundesregierung.]

Miss Caroline Ferriday, Chairman

April 30, 1957

Friends of A.D.I.R., Inc.

47 East 50th St.

New York 22, N.Y.

individuellen, ausländischen Opfer von Krieg und Verfolgung blieben unberücksichtigt. Die einzige Ausnahme bildete der Anspruch auf in Deutschland aufgefundenes ungemünztes Gold, der staatenlosen, nichtrepatriierbaren Flüchtlingen zuerkannt wurde und 30 Millionen US-Dollar einbrachte. Siehe Goschler, Schuld und Schulden, $54-56$. 
Dear Miss Ferriday:

On April 29th, I met Mr. Tardu ${ }^{7}$ at the United Nations and discussed our problem with him. We then saw Mr. Schwelb ${ }^{8}$ together and had occasion to review the entire situation thoroughly and systematically. As you know, both gentlemen are sympathetic to our cause, but they feel that their position inhibits them from taking the initiative in any significant way.

We discussed the possibility of putting the question of medical experiment victims on the agenda of the Economic and Social Council. This had been considered by the Human Rights Commission before, but there had not been sufficient support in favor of it since some felt that it might prove embarrassing to the German government. Mr. Schwelb advised that unless the United States Delegation was in favor of it, there would be practically no prospect for success and he suggested we take it up with the American Delegation. I will discuss this possibility with the State Department the next time I am in the Capitol.

Mr. Tardu advised me confidentially that on April 25th, he had sent a reminder to the German government, informing them that the United Nations had not received any recent report on Germany's payment due to the medical experiment victims. This was the third note which had been sent and no reply had been received to the past two. I suspect that Mr. Tardu's transmission was stimulated by the fact that on the same day he had to cancel an appointment which we had made for April 26th, and he felt that he simply had to report something. The impression certainly exists with the Human Rights Commission that Germany does not want to pay, which conclusion is unfortunate from a German point of view and I believe that it might even be

7 Der französische Jurist Maxime E. Tardu $\left({ }^{\star} 1925\right)$ arbeitete seit den 1950er Jahren in verschiedenen Positionen und Kommissionen der Vereinten Nationen und befasste sich vor allem mit der Fragen der Menschenrechte. Als Leiter der Forschungsabteilung des UN Centre for Human Rights und Professor für Rechtswissenschaft an den Universitäten Grenoble und Paris betätigte er sich auch wissenschaftlich auf diesem Feld.

8 Egon Schwelb (1899-1979) war ein jüdischer Jurist aus der Tschechoslowakei. 1939 floh er vor den Nationalsozialisten nach Großbritannien. Nach dem Zweiten Weltkrieg war er zwischen 1945 und 1947 in der UN-Kommission für Kriegsverbrechen in London tätig und daher mit den medizinischen Verbrechen während des Nationalsozialismus vertraut. Er unterstützte frühe Entschädigungsbestrebungen der Überlebenden dieser Versuche. Ab 1947 bis zu seiner Pensionierung 1962 war er stellvertretender Direktor der Abteilung für Menschenrechtsfragen der Vereinten Nationen. Zudem setzte er sich wissenschaftlich mit Fragen des internationalen Strafrechts und der Menschenrechte auseinander. 
erroneous, since the amount involved is relatively innsignificant. The excuse that has been given for not reporting to the U.N., has been that it was not possible to dissent the claims of medical experiment victims from the large mass of other claims under the German indemnification law.

I explained to Mr. Schwelb and Mr. Tardu that the German statistical difficulties could in no way justify the fact that victims of medical $|2|$ experiments who were neither stateless persons nor political refugees and who could not show financial hardship, were excluded from compensation under the new German law. ${ }^{9}$ After much discussion, Mr. Schwelb agreed that if I would give him a memorandum setting forth the facts and the arguments and relating them to the 1951 U.N. resolution, he would arrange to transmit that memorandum to the German government via the United Nations. He insisted however, that in addition to stating the legal and moral arguments for more appropriate compensation, the memorandum would have to give specific illustrations, showing that Germany was not complying with the spirit of the U.N. resolution. This would not require that the names of the persons be disclosed but would serve to show that there is a real problem.

The A.D.I.R. office in Paris prepared a list of persons receiving compensation under the U.N. resolution and that list could be used to discover a few cases of persons who are not eligible for payment under the German law and who have already spent the funds they may have received. I would suggest that you write to our friends in Paris and solicit their cooperation in trying to find persons who are not eligible for pension payments, since they could not show specific physical disability, statelessness, political persecution or need. I would use such cases as illustrations in the memorandum I plan to submit on behalf of A.D.I.R. Although Mr. Schwelb was not optimistic in general, he did agree to go over a draft of the memorandum with me before submission, so that we could include whatever might be helpful and exclude anything which he felt might not serve our interest.

I had lunch with Mr. Roy Blumenthal, ${ }^{10}$ who is the principal partner in the public relations firm of Roy, Bernard and Company. They represent

9 Nach dem BEG von 1956 konnten anerkannte Verfolgte des Nationalsozialismus, die die Wohnsitzanforderungen erfüllten und zu mindestens 25 Prozent erwerbsunfähig waren, für die Folgen medizinischer Versuche entschädigt werden. Siehe Baumann, Menschenversuche und Wiedergutmachung, 61 f.; Goschler, Schuld und Schulden, 256, 283.

10 Roy Blumenthal (1908/1909-1975) war Miteigentümer des New Yorker Public-Relations-Unternehmens Roy Bernhard Company, das sich im Auftrag des Presse- und Informationsamts der Bundesregierung in den 1950er Jahren um eine positive Außendarstellung der Bundesrepublik Deutschland in den Vereinigten Staaten bemühte. 
the German government in the United States and in many other countries. I discussed the A.D.I.R. problem with him and tried to convey to him my feeling that Germany's behavior vis-a-vis the medical experiment victims was not enhancing German public relations; whereas for a very small sum the Federal Republic might gain a considerable amount of prestige and good will. He was inclined to share my views and suggested that I set up a meeting with him and Mr. Carl von Mutius, who is the Information Officer of the Office of the Permanent Observer of Germany, to the United Nations. I had met Mr. von Mutius at a cocktail party in Mr. Blumenthal's home a few days ago and of course did not miss the opportunity to put in some good words for the friends of Friends [sic] of A.D.I.R. He had indicated his general sympathy and had invited me to call him for further assistance if necessary, so that the combination seemed to work out quite well. I am arranging a luncheon on Monday May 6th, for Mr. Blumenthal and representatives of the German UN O̊b̊o̊rervers to explore the matter further.

I would appreciate your assistance in connection with the specific cases |3| needed for my memorandum and I will then go to work in preparing the necessary documents. If you have any questions, please phone me.

With kind regards,

Cordially yours

Benjamin B. Ferencz

BBF: CB

\section{Dokument 82}

Benjamin B. Ferencz an Caroline Ferriday

Ohne Ortsangabe, 7. August 1957

Maschinenschriftlicher Brief, 1 Seite

$R G 12.012 .02 * 02$

August 7, 1957

Miss Caroline Ferriday

Bethlehem,

Connecticut. 
Dear Miss Ferriday:

I have made all of the necessary corrections to the various letters and memoranda and they are on their way. I took the liberty of having your signature forged to a letter of transmittal to the German Embassy in Washington, three copies of which are attached hereto. I will also send a new memorandum to the United Nations simply giving them the information they asked for with regard to the cases listed and unless I hear from you to the contrary will also have your signature put on the letter of transmittal copies of which I will, of course, send you.

I am sending you ten copies of the memorandum under separate cover and will hold the additional copies here for your instructions.

I am enclosing my bill for $\$ 500$ as the final payment under our original agreement of April 17, 1957 plus disbursements to date of $\$ 138.06$.

I must confess that I feel a bit unhappy about leaving this problem in its present state. Although I think we have made considerable progress since April 17, or at least done all that was possible, I am afraid much still remains to be done. As you know, the original retainer was to cover only a three-month period and the decision is up to you whether or not you wish to take any further steps on behalf of A.D.I.R. These are difficult matters to write about and it would probably be worthwhile for you to come to town some day so that we may discuss the matter at lunch together.

I will be leaving for Europe on August 25 and will probably be gone for about four to six weeks. It would, therefore, be well if we could have our talk soon and we can then decide upon any matters which are still outstanding.

Cordially yours,

Benjamin B. Ferencz

BBF: js

Enc. ${ }^{11}$

11 Enclosure. 


\section{Dokument 83}

Benjamin B. Ferencz

Ohne Ortsangabe, 7. April 1959

Maschinenschriftliches Memorandum, 3 Seiten

$R G 12.012 .02 * 01$

[Ferencz gibt einen Überblick über den Stand der Bemühungen um eine erweiterte Entschädigungslösung für in Osteuropa lebende Opfer medizinischer Experimente während des Nationalsozialismus. Er geht vor allem auf die Rolle der amerikanischen Öffentlichkeit sowie auf das Kalkül der Bundesregierung ein. Schließlich bringt sich Ferencz am Ende selbst als Vermittler für Verhandlungen ins Spiel.]

April 7, 1959

Memorandum: Compensation for Victims of Nazi Medical Experiments

From: Benjamin B. Ferencz

The significant achievement of Mr. Norman Cousins is drawing U.S. public attention to the plight of Nazi experiment victims, the presence of the Ravensbruck [sic] "Lapins" in the United States, ${ }^{12}$ and the Federal Republic's recent offer to make some payment to the victims has created new hope that fair compensation may yet be obtained for them. ${ }^{13}$ A number of coordinated steps are now required if maximum advantage is to be derived from the current opportunities.

In the first instance it is necessary that public support in and from the U.S. be maintained and further stimulated. This can be done by additional

12 Norman Cousins (1915-1990), der Herausgeber der New Yorker Wochenschrift Saturday Review, leitete seit 1958 das sogenannte Cousins Committee, das in den Vereinigten Staaten eine Public-Relations-Kampagne zugunsten von Opfern medizinischer Experimente organisierte. Im Rahmen des Ravensbrueck Lapins Project organisierte Cousins den Besuch von 29 betroffenen polnischen Frauen in den Vereinigten Staaten, wo sie über ihr Schicksal berichteten. Siehe Baumann, Menschenversuche und Wiedergutmachung, 112-123.

13 Im Februar 1959 hatte die deutsche Botschaft in Washington angekündigt, dass die polnischen Frauen, die durch medizinische Versuche geschädigt worden waren und sich in den Vereinigten Staaten aufhielten, jeweils 1.000 Dollar für ihre Heilbehandlung erhalten sollten. Siehe Baumann, Menschenversuche und Wiedergutmachung, 118. 
press releases, representations at the German Embassy in Washington and, in particular, further discussions with the German Press and Information Office which may be expected to be sympathetic and cooperative. I suggest that at this time whatever speeches are prepared take a moderate line. A hårish or very critical approach is likely to find little U.S. governmental favor. Denunciation which is not backed by a real public outcry is soon recognized as unsupported rhetoric. The silk glove must precede the mailed fist.

A more positive approach of praise for Germany's recognition of the principle that the experiment victims are entitled to payment, coupled with the firm declaration that of course the sum now offered can only be a beginning if the Cabinet's fine resolution of "effective aid"14 is finally to be carried out is, in my view, more likely to be effective. The subtle suggestion that if Germany fails to fulfill these justified hopes there will be a strong American public reaction will suffice to convey the point. The important thing which impresses the officials in Bonn is that the matter is being actively discussed in the United States.

At the same time steps must be taken in Bonn to raise the issue anew and to create a receptive atmosphere. The new developments in the U.S., the new offer and the current negotiations between Germany and the former occupied countries concerning additional indemnification rights provide increased justification for the renewed demands. ${ }^{15}$ The Press Office of the Bund will probably favor an amicable settlement as will the Foreign Office. $|2|$ The Ministry of the Interior is often sympathetic on these questions and the Office of the Chancellor can probably now be induced to offer general support if a personal and direct approach is made. Representatives of the SPD can probably be persuaded to take a positive stand and the Indemnification Committee of the parliament should be approached in support of a more liberal interpretation of the Cabinet resolution. Finally, the matter must be discussed with the Finance Ministry which is directly in charge and an attempt must be made to convene the Inter-Ministerial Council for a new look at the entire problem, in a forum in which the Finance Ministry will not have the majority voice.

14 Der Kabinettsbeschluss von 1951 hatte von "wirksamer Hilfe« gesprochen. Siehe Baumann, Menschenversuche und Wiedergutmachung, 57.

15 Seit Ende der 1950er Jahre verhandelte die Bundesrepublik mit elf westeuropäischen Staaten über globale Entschädigungsleistungen für Opfer des Nationalsozialismus aus diesen Ländern. Siehe dazu Goschler, Schuld und Schulden, 233-247; Hans Günter Hockerts/Claudia Moisel/Tobias Winstel (Hg.), Grenzen der Wiedergutmachung. Die Entschädigung für NS-Verfolgte in West- und Osteuropa 1945-2000, Göttingen 2006. 
All of these endeavors can only be effective if at the same time a new and feasible proposal is put forward. After the idea has been accepted by the German representatives that additional benefits should be granted, the form of the benefits must be agreed upon. I do not believe that the repeatedly rejected proposal for pensions for all the medical experiment victims will be accepted, although it may be submitted again as a starting position. Alternative suggestions must be available. One such proposal might be to request a lump sum to be administered by a joint trust in accordance with mutually acceptable rules. Under this plan the German government could limit the extent of its obligation while obtaining maximum propaganda benefits from a dramatic form of payment. Distribution of the trust funds would create legal, financial and administrative problems but with the help of the Nuremberg War Crimes records and United States documentation these problems could be overcome and there would undoubtedly be substantial advantages to the victims.

Another possibility might be to accept one-time grants from which annuities could be purchased for a stated number of individual victims of groups of victims classified according to the nature of their original injuries, personal hardship or their present physical condition. At Nuremberg we established that the Nazis conducted over a dozen different types of medical experiments in numerous concentration camps. ${ }^{16}$ Today, we can deduce the approximate number of survivors in the various categories. This information is absolutely essential for any closed-end agreement.

The negotiation and conclusion of a satisfactory agreement together with the preparation of whatever new legislation is necessary demands precise knowledge of the factual situation. The number of alternate proposals is infinite and would have to be varied, depending upon the mood in Bonn and the extent to which they can be persuaded to render really effective aid.

I would suggest that the most useful role I could play in helping to bring about a settlement would be that of a mediator seeking to find a common $|3|$ meeting ground between the differing points of view. In an explosive situation I would try to guide the parties toward a solution which would be in the best interest of all concerned. Many of the reasons advanced for refusing to make the requested payments cannot withstand the critical rebuttal of informed opinion and if an atmosphere of conciliation can be induced in Bonn I am hopeful that substantial progress can be made.

16 Als Fall I der Nürnberger Nachfolgeprozesse wurde vom 9. Dezember 1946 bis zum 20. August 1947 der Ärzteprozess verhandelt. Angeklagt waren neben 20 ehemals in Konzentrationslagern tätigen Ärzten auch ein Jurist sowie zwei Verwaltungsfachleute. Siehe Paul Weindling, Der Nürnberger Ärzte-Prozess. Entstehungsgeschichte, Verlauf, Nachwirkungen, in: Priemel/Stiller (Hg.), NMT, 158-193. 
It would give me a great deal of satisfaction to be able to bring to a happy conclusion these endeavors into which so much effort has already been poured and which for the first time now seem to show real promise of success.

\section{Dokument 84}

Benjamin B. Ferencz an Norman Cousins

Ohne Ortsangabe, 24. April 1959

Maschinenschriftlicher Brief, 3 Seiten

RG $12.012 .02 * 01$

[Ferencz berichtet über die jüngsten Verhandlungen zur Entschädigung für osteuropäische Opfer medizinischer Humanexperimente mit Vertretern der Bundesregierung in Bonn. Im Mittelpunkt stehen Konsultationen mit Beamten der verschiedenen Bundesministerien sowie deren juristische Argumentationslinien. Schließlich wird eine Intensivierung der Bemühungen empfohlen.]

Mr. B. B. Ferencz

April 24, 1959

Mr. Norman Cousins

25 West 45 Street

New York 36, N.Y.

Dear Norman:

I learnt from Prof. Boèhn [sic $]^{17}$ that at yesterday's meeting it was felt that payments to medical experiments victims resident in Poland would prejudice Germany's position vis-à-vis the iron curtain countries and therefore could not be made. ${ }^{18}$ More specifically, Germany has thus far refused to make any indemnification payments to any Nazi victims behind the iron curtain and

17 Der Jurist und Nationalökonom Franz Böhm (1895-1977) war von 1946 bis 1962 Professor für Bürgerliches, Handels- und Wirtschaftsrecht an der Universität Frankfurt. 1952 leitete Böhm zusammen mit Otto Küster die deutsche Delegation bei den Verhandlungen mit Israel und der JCC in Wassenaar. 1953 bis 1965 war er für die CDU Abgeordneter im Bundestag, wo er von 1955 bis 1965 auch als stellvertretender Vorsitzender des Ausschusses für Wiedergutmachung amtierte.

18 Zum Kontext dieses Gesprächs siehe Baumann, Menschenversuche und Wiedergutmachung, $120 \mathrm{f}$. 
once the dike is broken, they argue that the position could not be maintained particularly since Germany is about to make new reparations agreements for Nazi victims to the eleven Western European countries. The Professor quickly added that he had been more successful on some of the other points on the agenda and I was so disgusted that I did not care to probe into the details. I thanked him for his efforts and his courtesy, told him that I would have to report the facts as I saw them and let the matter drop. I may get a more detailed report from Herr Frenzel ${ }^{19}$ later in the day.

About three hours before yesterday's meeting I again contacted Mr. Born and asked him to be sure to inform Herr Globke ${ }^{20}$ of the message received from Minister $\mathrm{Krapf}^{21}$ and to see that the position of the Foreign Office is also considered at the meeting. Born said that he could not contact Herr Globke without clearance from his superior, Dr. Berger, ${ }^{22}$ and that he was not even aware that there was going to be such a meeting or that the medical victims

19 Alfred Frenzel (1999-1968) war ein sozialdemokratischer Politiker und von 1953 bis 1960 Abgeordneter im Bundestag. 1958 bis 1960 leitete er den Ausschuss für Wiedergutmachung des Bundestags.

20 Hans Globke (1898-1973) arbeitete seit 1929 als Verwaltungsjurist im preußischen Innenministerium und 1933 bis 1945 im Reichsinnenministerium. Seit 1949 war er am Aufbau des Bundeskanzleramts beteiligt, das er 1953 bis 1963 als Staatssekretär leitete. Seine Rolle als Kommentator der Nürnberger Gesetze und Autor anderer diskriminierender Rechtsvorschriften während des Nationalsozialismus führte nach 1945 immer wieder zu kontroversen Diskussionen. Siehe dazu Klaus Gotto (Hg.), Der Staatssekretär Adenauers. Persönlichkeit und politisches Wirken Hans Globkes, Stuttgart 1980; Jürgen Bevers, Der Mann hinter Adenauer. Hans Globkes Aufstieg vom NS-Juristen zur Grauen Eminenz der Bonner Republik, Berlin 2009; Erik Lommatzsch, Hans Globke (1898-1973). Beamter im Dritten Reich und Staatssekretär Adenauers, Frankfurt a. M./New York 2009; Klaus Bästlein, Der Fall Globke. Propaganda und Justiz in Ost und West, Berlin 2018.

21 Franz Krapf (1911-2004) arbeitete seit 1938 im diplomatischen Dienst des Auswärtigen Amts des Deutschen Reichs. Seit 1950 setzte er seine Laufbahn in der Bundesrepublik fort und war von 1951 bis 1976 für das Auswärtige Amt auf verschiedenen internationalen Posten tätig. Von 1958 bis 1961 war er Gesandter und Vertreter des Botschafters der Bundesrepublik in Washington. Nach seinem Tod wurde er wegen seiner NSDAP- und SS-Mitgliedschaften zum Ausgangspunkt einer vergangenheitspolitischen Kontroverse um das Auswärtige Amt.

22 Vermutlich ist Hans Berger (1909-1985) gemeint, der nach verschiedenen Richterposten 1953/1954 im Bundesinnenministerium die Abteilung für Verfassung und Staatsrecht leitete und anschließend von 1954 bis 1959 Leiter der Rechtsabteilung des Auswärtigen Amts war. Von dort aus wechselte er als Botschafter in die bundesdeutsche Botschaft in Kopenhagen. 
would be on the agenda. I assured him that I had arranged it and that some action was urgently required in order to support our friends at the meeting. He stuttered and stammered that the notice was very short, that he would have to confirm the facts and I gathered that he was trembling in his boots at the prospect of having to do something.

As the Foreign Office was not officially represented at the meeting and as I suspected that Mr. Born had done nothing but talked to himself and his secretary, I arranged this morning to see Born's superior, Dr. Berger. I told Berger of the outcome of yesterday's meeting, about which he was naturally uninformed and that I felt a serious mistake was being made for which the Foreign Office would have to bear the consequences. I showed him $|2|$ that a payment to the medical experiment victims could not be prejudicial since this particular group had already been accepted as a special category deserving of the United Nations support ${ }^{23}$ and which had been recognized as a separate category by Germany itself in the cabinet decision. In neither the United Nations intervention nor the cabinet decision was it stated that persons behind the iron curtain were to be excluded and therefore the arguments advanced that this group could not be treated differently were absolutely spurious. Nor could I accept the argument that if Polish nationals now in the U.S. were paid it would open the door to other persons who could by simply crossing the border assert a claim which would otherwise not be recognized. I drew his attention to the fact that there were only seventy-five other cases in Poland, and even if all the medical experiment victims in the iron curtain countries did take a trip to Germany the total number would be so small that the fear could only be characterized as ridiculous.

Dr. Berger gave me a big speech about how his heart was bleeding for all these unfortunate people and I could just see the imaginary crocodile tears running down his sleeve. He said he was most moved by the unfortunate circumstances rather than by my argument that it did not pay financially or politically to incite strong American public reaction against Germany on an issue of this kind.

Without boring you with all the details, the conclusion reached was that he will have to verify what had actually happened at yesterday's meeting and then see what could still be done.

23 Die Menschenrechtskommission der Vereinten Nationen setzte sich seit Anfang der 1950er Jahre kontinuierlich für die Interessen der überlebenden Opfer der Menschenversuche ein. Siehe etwa Anonymus, Nazi Experimentation Victims Are Helped by United Nations, in: United Nations Bulletin, 15. März 1952, 270 f.; sowie Baumann, Menschenversuche und Wiedergutmachung, $105 \mathrm{f}$. und 111. 
I suggested that I might want to use his superior, State Secretary Knappstein and added that this had been suggested by Minister Krapf, and I would therefore not like to leave Bonn without following through.

Berger said that it was a very good idea and that I should also try to see Herr Globke, but, of course, in neither case should I mention that he made the suggestion.

I tried to see both of the gentlemen, but unfortunately Globke is leaving the country this afternoon, and it was suggested that I see Janz ${ }^{24}$ whom I wanted to see anyway since I know him well enough to be able to count on his support, but he is only going to be back in his office on Monday, April 27th and I will have to arrange to see him thereafter. Knappstein was not available today, $|3|$ but his secretary said that he would get a report from Berger as soon as he was able to meet with him.

I therefore cabled you as follows:

"ALL DECISIONS NEGATIVE BUT AM CONTINUING PRESSURE HIGHER LEVELS AWAIT TODAYS REPORT"

I will be in touch with Janz next week and also with Knappstein and also tried to arrange to see him and/or Globke before I return. I think you should advise Minister Krapf of these developments and if you agree I would like to send him a personal note, saying that I did my best to find a solution which would avoid unpleasant recriminations, but the final decision is up to the German government.

I do not anticipate that anything much will happen here during the next week, but if there is any development I will let you know at once, and look forward to your further advice.

With kindest regards,

Cordially yours,

\section{B.B. FERENCZ}

P.S. You might be amused to know that after yesterday's meeting Blessin ${ }^{25}$ jokingly told me that I was getting a reputation as a Communist sympathizer

24 Friedrich Janz (1898-1964) arbeitete von 1927 bis 1945 im Auswärtigen Dienst des Deutschen Reichs. Nach Stationen im badischen Finanzministerium und in der badischen Staatskanzlei war er von 1953 bis 1959 Ministerialdirektor im Bundeskanzleramt, anschließend wechselte er als Leiter der Rechtsabteilung ins Auswärtige Amt.

25 Georg Blessin (gest. 1968) war Ministerialrat in der für Restitution zuständigen Abteilung des Bundesfinanzministeriums und Verfasser eines Kommentars zum BEG. 
because of my intervention on behalf of people behind the iron curtain and he further suggested that I keep hands off. I told him that my job was about finished when I submitted my report and that from thereon in [sic] it was a problem of the German Foreign Office and political groups in the U.S.

\section{Dokument 85}

Benjamin B. Ferencz an Caroline Ferriday

Ohne Ortsangabe, 15. Oktober 1959

Maschinenschriftlicher Brief, 1 Seite

$R G 12.012 .02^{*} 03$

October 15,1959

$\#^{26} 39$

Miss Caroline Ferriday

875 Park Avenue

New York 21, N.Y.

Dear Caroline:

Thank you for sending me the latest article on the Lapins. I put it to good use in Bonn. Although I am no longer "retained," I must confess that I could not refrain from taking some steps on behalf of the medical experiment victims. The Inter-ministerial Committee will be meeting again shortly in order to reexamine the entire position. I would guess that their meeting will take place some time after the 20th, and the date had not yet been fixed when I was in Bonn on 8 October. The few U. S. cases (I think that 7 were rejected and 5 were classified as doubtful) will be restudied at that time. The objections against paying persons in Poland on the grounds that they could not be medically examined have disappeared and I anticipate that payments to persons residing in Poland will be effected. This is still on the basis of the old Cabinet decision and no one in Bonn seems to be giving any thought to the possibility of paying pensions.

You should know that very recently the Cabinet, as a special measure, approved a payment of 5,000 DM each to 150 persons from the "Wapniaka"

26 Die Raute steht an dieser Stelle als Nummernzeichen. 
[sic] Camp, ${ }^{27}$ whose health had been damaged when they ate poisoned food set for them by the SS. ${ }^{28}$ The persons are now resident in Israel and have not qualified for compensation under the general rules, nevertheless, the Cabinet was prepared to approve the one-time payment to them and the payment will probably be made globally via the Israel Ministry of Finance to one representative of the group. The group has expressed dissatisfaction with the amount offered and is also clamoring for pensions, but I don't think they have the slightest hope. The precedent is important for you since these cases are very closely related to the medical experiment cases and it indicates the Cabinet's readiness to deal with such problems globally and outside the framework of the existing legislation.

Of course, I put in a good word wherever I could, and if you keep hammering at the gates (who could stop you?) I feel that something constructive must come of it.

With kind regards,

Cordially yours,

Benjamin B. Ferencz

\section{Dokument 86}

Benjamin B. Ferencz an Norman Cousins

New York, 13. Juli 1960

Maschinenschriftlicher Brief, 4 Seiten; gedruckter Briefkopf auf Seite 1, Kopfzeile auf jeder folgenden Seite (»July 13, 1960 Mr. Norman Cousins")

$R G 12.012 .02 * 04$

[Ferencz berichtet über die jüngst von ihm in Europa geführten Verhandlungen zur Entschädigung für in Osteuropa lebende Opfer medizinischer Experimente. Er thematisiert politische Verhandlungen in Bonn, vorbereitende Gespräche mit Vertretern des Roten Kreuzes in Genf sowie Konsultationen mit Aktivisten von ADIR in Paris. Schließlich empfiehlt er eine Fortsetzung der Bemühungen.]

27 Gemeint ist das Konzentrationslager in Wapniarka südlich von Odessa, das im Zweiten Weltkrieg zu Rumänien gehörte.

28 Nach einem Kabinettsbeschluss vom 1. August 1959 erhielten die in Israel ansässigen Überlebenden des rumänischen Konzentrationslagers Wapniarka, die an den Folgen eines Nahrungsexperiments mit einer giftigen Futtererbse litten, eine Entschädigung von 5.000 DM. Siehe Baumann, Menschenversuche und Wiedergutmachung, $150 \mathrm{f}$. 


\section{Taylor, Scoll, Ferencz \& Simon \\ Counselors at LaW}

Telford Taylor

David E. SCOLL

Benjamin B. Ferencz

Kenneth Simon

Mr. Norman Cousins, Editor

Saturday Review

25 West 45th Street

New York 36, N. Y.
400 Madison Avenue

New York 17, N. Y.

Murray Hill 8-8990

Cable Address: Lantalaw

July 13,1960

\section{Dear Norman:}

The hasty reports which I dispatched from Germany have already given you a pretty rough idea of our most recent attempts to obtain adequate compensation for the victims of Nazi medical experiments.

As you know, the Finance Ministry had in the past successfully insisted that no payments could be made to Nazi victims resident behind the Iron Curtain for there were no diplomatic relations with those countries and reparations had already been paid. The German parliament, on motion of the Social Democratic Party, had unanimously resolved however that adequate compensation be provided for the 29 Ravensbruck [sic] Lapins ${ }^{29}$ who had visited the United States under the auspices of your Committee. The Indemnification and Budget committees of the Parliament were to be advised of the action taken by the government in response to the resolution. When I arrived in Germany on June 12th, I was shocked to learn that the only action contemplated by the government was an offer of free medical care in Germany to the Lapins and that this proposal advanced by the Finance Ministry had already met with the approval of the leading representatives of the Indemnification committee.

29 Deutscher Bundestag, [Entschließungsantrag der SPD-Fraktion zur Entschädigung weiblicher Mitglieder der polnischen Widerstandsbewegung], Stenografischer Bericht der 112. Sitzung, Bonn, 5. Mai 1960, 6359; siehe dazu und zum Folgenden Baumann, Menschenversuche und Wiedergutmachung, 132 und $135 \mathrm{f}$. 
Our objective was to present a plan which would not only satisfy the legitimate demands of the victims but to persuade the responsible German authorities to accept our proposal. The German Congress ${ }^{30}$ acts in these matters through its Finance and Indemnification committees and the government acts through its Finance Ministry and its Foreign Office. I met with and spoke repeatedly to representatives of all the appropriate Congressional committees and ministries in line with our previous decision and urged upon all of them the prompt payment of pensions of about $|2| \$ 150.00$ per month to at least the 30 Ravensbruck Lapins who had been in the United States. We obtained the entire support of the Vice-President of the Bundestag, Carlo Schmid and Berlin's Senator of the Interior, Dr. Lipschitz ${ }^{31}$ both of whom spoke, wrote or cabled other representatives urging acceptance of our proposals.

By July 1st, when the parliament adjourned for the summer recess, I was able to cable you that the government and Congressional committees had reached a new agreement, according to which the medical experiment victims now resident in Poland would receive cash compensation in the form of a pension which would be payable in zlotys and/or a one-time capital grant of 25,000 DM..$^{32}$ The funds necessary to make those payments would be transferred by the German government to the International Committee of the Red Cross which would be charged with responsibility for administering the fund. The details were to be worked out with the International Committee of the Red Cross during the parliamentary recess. This was a great step forward from the previous German position.

As soon as I was convinced that the German government was ready to move in the direction indicated, I took steps to alert the International Committee of the Red Cross to the problem in order to safeguard our interests until final payment is made. I contacted Mr. Jerome J. Jacobson, ${ }^{33}$ an able American attorney practicing in Geneva and a close friend of Mr. Rodger [sic]

30 Gemeint ist der Deutsche Bundestag.

31 Joachim Lipschitz (1918-1961) war ein sozialdemokratischer Politiker. 1951 wurde er Mitglied des Berliner Abgeordnetenhauses und wirkte ab 1955 als Innensenator von Berlin.

32 Durch einen Kabinettsbeschluss vom 22. Juni 1960 wurde bestimmt, dass allen überlebenden Opfern von medizinischen Experimenten aus Staaten des Warschauer Pakts finanzielle Beihilfen zu gewähren seien. Da keine diplomatischen Beziehungen zwischen der Bundesrepublik und diesen Staaten bestanden, sollten die Zahlungen über das Internationale Rote Kreuz in Genf als neutraler Hilfsorganisation abgewickelt werden. Siehe Baumann, Menschenversuche und Wiedergutmachung, 132.

33 Jerome J. Jacobson (1911-1995) arbeitete als Rechtsberater für das JDC und das American Jewish Committee, wo er auch mit Restitutionsfragen betraut war. 
Gallopin, ${ }^{34}$ the Director of the International Committee of the Red Cross. I explained the entire situation to him and he, in turn, immediately alerted the I.C.R.C. to the need for them to insist that the fund be adequate to satisfy the victims. It was specifically pointed out to him and thereby to them that the acceptance of an inadequate fund would merely result in substituting the I.C.R.C. for the German government as the target of justified world-wide complaints. It was also urged upon them that they act in concert with the representatives of the victims in order to assure a smooth and satisfactory distribution of the fund.

The day after my intervention at Geneva via Mr. Jacobson, the I.C.R.C. was approached by the representative of the Federal Republic of Germany. A meeting was fixed in Geneva for Monday, July 11th between Dr. Born, whom I had seen at the German Foreign Office, together with a representative of the Finance Ministry and the German permanent delegate at Geneva, and the representatives of the I.C.R.C. I persuaded Mr. Jacobson to meet me in Paris on $|3|$ July 5 th, where we again reviewed the situation, this time in greater detail, and he returned to Geneva to meet with the other representatives of the I.C.R.C. and to prepare the stage for the German meeting. I will, of course, be kept informed of everything that transpires.

In Paris I met with Caroline Ferriday and together we saw Mme. PostelVinay $^{35}$ of A.D.I.R. and Mr. Serge Wourgaft ${ }^{36}$ of the World Veterans Federation. ${ }^{37}$ Mme. Postel-Vinay was pleased about the developments in Germany but most distressed about the victims in France. Despite all of the reports that

34 Der Jurist Roger Gallopin (1909-1986) war seit 193640 Jahre lang für das Internationale Komitee des Roten Kreuzes (IKRK) tätig. 1942 übernahm er die Abteilung für Gefangene, Internierte und Zivilisten. Ab 1946 leitete er den operativen Bereich des IKRK, bevor er von 1950 bis 1969 den Posten des Generaldirektors ausübte.

35 Anise Postel-Vinay $\left({ }^{\star} 1922\right)$ war Mitglied der Résistance und überlebte die Inhaftierung im Konzentrationslager Ravensbrück. Nach Kriegsende war sie an der Gründung der Organisation ADIR beteiligt, die sich für medizinische Unterstützung der befreiten französischen Frauen der Résistance sowie Entschädigungszahlungen an Überlebende der nationalsozialistischen Menschenversuche in Ravensbrück einsetzte. In den 1950er und 1960er Jahren wirkte Postel-Vinay als Generalsekretärin der Organisation.

36 Serge Wourgaft $\left({ }^{\star} 1917\right)$ wurde 1943 als Mitglied der Résistance verhaftet und 1945 aus dem Konzentrationslager Buchenwald befreit. Er begann 1957 für die World Veterans Federation zu arbeiten, wirkte zwischen 1976 und 1997 als Generalsekretär, von 1997 bis 2000 als Präsident und ist bis heute Ehrenpräsident der Organisation.

37 Die World Veterans Federation wurde 1950 von französischen und amerikanischen ehemaligen Soldaten initiiert, um alle nationalen Veteranenverbände zu vereinen. Sie setzt sich für die Interessen von Veteranen und Kriegsopfern sowie ihrer Familien ein. 
we had received here about 7 million DM being payable for the French Lapins out of the 400 million DM German reparations fund, ${ }^{38}$ it now appeared that there had been no separate earmarking of this amount or any amount for the Lapins, and there was therefore an acute danger that those resident in France would receive nothing. She was particularly unhappy since she felt that the 400 million-figure had only been reached because of the intervention of Mlle. De Gaulle, ${ }^{39}$ which intervention had been brought about by A.D.I.R. prompted by the needs of the Lapins. Now the German funds would go into a common pot for all Nazi victims resident in France and the medical experiment victims would have the greater difficulty in receiving any special consideration. (I specifically referred to this danger in my letter to you of April 22, 1959 from Bonn and was therefore doubly disturbed that my early warning had gone unheeded and the foreboding realized). I suggested to Mme. Postel-Vinay that she draw the attention of the French authorities to the equities involved and I hope that (if it is forcefully done) she will be successful in obtaining adequate recognition of the needs of the French Lapins.

Mr. Wourgaft, too, was rather unhappy at what he considered to be a clever German maneuver. The World Veterans were interested in the principle of adequate compensation for all medical experiment victims regardless of residence. I pointed out to him that by virtue of the completed or pending treaties with 11 countries, ${ }^{40}$ Germany would discharge its obligations to all of the nationals concerned and the World Veterans would therefore be in a difficult position to criticize Germany on behalf of any local nationals when their own government had given Germany a general release in return for a specific payment. Now Germany was agreeing to pay to $|4|$ Lapins behind the

38 Gemeint ist das Globalabkommen mit Frankreich vom 15. Juli 1960 für Verfolgte des Nationalsozialismus französischer Nationalität in Höhe von 400 Millionen DM. Siehe dazu Claudia Moisel, Pragmatischer Formelkompromiss: Das deutsch-französische Globalabkommen von 1960, in: Hockerts/Moisel/Winstel (Hg.), Grenzen der Wiedergutmachung, 242-284.

39 Geneviève de Gaulle-Anthonioz (1920-2002) war eine Nichte von Charles de Gaulle (1890-1970), der 1959 bis 1969 als Präsident Frankreichs wirkte, und ebenfalls in der Résistance aktiv. Sie wurde 1943 festgenommen und im Konzentrationslager Ravensbrück inhaftiert. Als Präsidentin von ADIR setzte sie sich später dafür ein, dass osteuropäische Frauen, die ebenfalls in Ravensbrück inhaftiert gewesen waren, Entschädigungszahlungen erhielten.

40 Zwischen 1959 und 1964 vereinbarte die Bundesrepublik bilaterale Abkommen mit elf westeuropäischen Staaten, worin sie sich zu globalen Entschädigungsleistungen in Höhe von 876 Millionen DM verpflichtete. Siehe Goschler, Schuld und Schulden, 240-247; Hockerts/Moisel/Winstel (Hg.), Grenzen der Wiedergutmachung. 
Iron Curtain too, so that the problem would be solved on a world-wide basis. I suggested that the World Veterans could nevertheless continue to play a useful role by remaining constantly alert to the need for adequate compensation and that we might call upon them at a later date if it appeared that the German government would try to limit the size of the payments to be made. I am quite sure that this is exactly what the Germans will try to do and the need continues therefore to remain constantly vigilant until the final payment to each victim is made.

We've come a very long way from our position of last year. We are on the threshold of what I hope will prove to be a satisfactory conclusion of this vexing problem. A little more patience and a little more persistence should see the end of the matter.

With warm regards,

Cordially yours,

Benjamin B. Ferencz

cc. Miss Caroline Ferriday

Mrs. Jeanne Benonson [sic $]^{41}$

Donald Wilson, Esq. ${ }^{42}$

BBF: js

\section{Dokument 87}

Benjamin B. Ferencz an Norman Cousins

Ohne Ortsangabe, 18. Juli 1960

Maschinenschriftlicher Brief, 3 Seiten; Kopfzeile auf Seite 2 (»July 18, 1960 Mr. Norman Cousins")

$R G 12.012 .02^{*} 04$

[Ferencz informiert über den Fortgang der Verhandlungen in der Entschädigungsfrage für die in Osteuropa lebenden Opfer medizinischer Experimente. Im Mittelpunkt stehen dabei die Verhandlungen zwischen Bundesregierung

41 Jeanne Benenson war die geschäftsführende Direktorin des sogenannten Cousins Committee.

42 Der Anwalt H. Donald Wilson war Mitglied im sogenannten Cousins Committee. 
und Internationalem Roten Kreuz über die praktische Ausgestaltung des Abkommens. Ferencz kritisiert insbesondere die geplante nochmalige medizinische Untersuchung der Betroffenen.]

Mr. Norman Cousins, Editor

July 18,1960

Saturday Review

25 West 45th Street

New York 36, N. Y.

\section{Dear Norman:}

I have just received confirmation from Geneva that the meeting of July 11th between representatives of the German government and the International Committee of the Red Cross has taken place. I wrote about this in my letter of July 13th, but I have now received all of the details. ${ }^{43}$

The meeting lasted two days. The German government was represented by Dr. Born of the Foreign Office, Dr. Zorn of the Finance Ministry and Mr. Deerfelder [sic] ${ }^{44}$ Germany's permanent delegate to Geneva. The International Committee of the Red Cross was represented by Mr. Gallopin, Mr. Monnier and Mr. Beck.

The Germans offered to place a maximum fund of 5 million DM (about $\$ 1,200,000)$ in the hands of the I.C.R.C. to cover the claims of medical experiment victims in Poland and Hungary. They requested the I.C.R.C. to make grants in line with what the Germans themselves had been doing and therefore the maximum should not exceed 25,000 DM in any individual case. The Germans indicated that whereas in the past they had only considered claims from persons in need, they were now prepared that all claimants from Poland and Hungary should be treated as needy, and their present economic circumstances would not have to be examined and would present no bar to

$43 \mathrm{Zu}$ den Verhandlungen über die Umsetzung des Kabinettsbeschlusses vom 22. Juni 1960 siehe Baumann, Menschenversuche und Wiedergutmachung, 141-149.

44 Der Jurist und Diplomat Rudolf Thierfelder (1905-1997) hatte vor dem Zweiten Weltkrieg als Staatsanwalt gearbeitet. Während des Kriegsdiensts in der Wehrmacht war er in Paris an der Ausformulierungen von Richtlinien zur Geiselerschießung beteiligt. Nach Kriegsende trat er in den Auswärtigen Dienst ein. Von 1956 bis 1961 war er bundesdeutscher Generalkonsul in Genf. Im Anschluss bekleidete er das Amt des deutschen Botschafters in der Türkei. 
payment. The claims are not to be paid as a matter of right, but on the basis of equity, and the payments will be ex gratia payments.

The payment of annuities was considered, but the I.C.R.C. itself was opposed to them since it was afraid of getting involved in indefinite financial and administrative responsibilities and they could not anticipate what future problems $|2|$ might arise from the governments involved. They therefore favored lump sum payments and this was of course also the view favored by the German government. (If we still insist on pensions we will have to propose an acceptable new procedure.)

The I.C.R.C. also felt that they should have some official contact in Poland and Hungary and intends, therefore, to send someone to both countries for discussions with the Red Cross organizations of those countries. Both the Germans and the I.C.R.C. have been alerted to the possibility and desirability of favorable transfer rates and have agreed that these advantages were to be kept in mind.

The Board of the I.C.R.C. is scheduled to meet this week in order to formally deal with the German request. It is anticipated that the Board will approve in principle, and that Mr. Gallopin will then proceed to Bonn in order to examine all the files. When they have a clear factual picture they will make contact in Poland and Hungary. Mr. Gallopin is now considering the creation of a mixed medical commission to review the individual claims and to make recommendations. He is thinking of an I.C.R.C. doctor who would be Swiss, a German doctor, a Polish doctor and, in the case of Hungary, a Hungarian. An Allied doctor, either French, British or American may be added.

Mr. Jacobson was also asked by the I.C.R.C. to make informal contact with you in order to ascertain how you regarded these developments.

The Germans anticipate that as a result of an announcement concerning the new arrangements, many additional claims will be received from countries behind the Iron Curtain.

These developments present a number of problems for policy consideration. I personally regard the suggestion of a mixed medical commission as an undesirable one. If the Germans have paid a limited sum from which they still expect to receive return payments, the presence of a German doctor on the medical commission may be harmful. Furthermore, most of the cases in the German files have already been examined by competent medical authorities and have already been found to $|3|$ justify maximum payments. Further reexamination of these claims is neither necessary nor useful and serves as an needless source of delay. I also regard the official contact with the Polish and Hungarian Red Cross as not being particularly desirable. These agencies must be under the strong influence of their local governments and the claimants may be better served by an independent group unfettered by such limitations. 
It would be highly desirable if on the strength of the powers of attorney which you already have, you could continue to act as the sole representative for the Polish group. I am quite confident that in so doing you would substantially increase the benefits which those claimants might be expected to receive.

These are all matters which we will have to discuss during our meeting on July 19th.

With kind regards,

Cordially yours,

Benjamin B. Ferencz

cc. Miss Caroline Ferriday

\{6 Rue Chauveau La Garde Paris $\}$

Mrs. Jean Benenson

Donald Wilson, Esq.

BBF: js

\section{Dokument 88}

Benjamin B. Ferencz an Norman Cousins

Ohne Ortsangabe, 26. Januar 1961

Maschinenschriftlicher Brief, 3 Seiten; Kopfzeile ab Seite 2 (»January 26, 1961 Mr. Norman Cousins «)

RG $12.012 .02^{*} 05$

[Ferencz schildert den Fortgang der Bemühungen in der Entschädigungsfrage für die Opfer von medizinischen Experimenten in Osteuropa. Er erläutert ausführlich die ersten Beratungen mit Vertretern der polnischen Regierung. Dabei thematisiert er vor allem Fragen nach der Höhe der Entschädigungsleistungen sowie der künftigen Auszahlungspraxis.]

Mr. Norman Cousins

January 26, 1961

Editor

Saturday Review

25 West 45th Street

New York 36, N.Y. 


\section{Dear Norman:}

Yesterday Caroline Ferriday and I had a long meeting in my office with Dr. Dobrosielski, ${ }^{45}$ Counselor of the Polish Embassy in Washington. He confirmed that the International Committee of the Red Cross was in contact with the Polish Red Cross and that the German government was offering to pay the Lapins between 3,000 and 25,000 DM, depending upon the severity of the injuries. This was the first "official" confirmation of the magnitude of the offer which I reported to you on November 4th after my return from Europe. Dr. Dobrosielski stated that the Polish government wished to express its appreciation to you and your Committee for all of your assistance and now a point has been reached where the Polish Red Cross can continue to negotiate directly with the International Committee of the Red Cross.

We advised Dr. Dobrosielski that we considered the offered payment to be inadequate and could not recommend acceptance. We gave him the reasons for it and he took copious notes. I explained to him that it was the German strategy to bypass the Norman Cousins Committee by going directly to the national Red Crosses which probably would be ready to accept any German offer. He confirmed that this had in fact been done and that he, too, was under the impression that no one thus far had raised the point that the amount offered was inadequate. I informed him that in case of the Hungarians there had, according to my reports, already been a clear acceptance, simply because there was no outside group to advise or act for the claimants.

|2| Dr. Dobrosielski was quickly persuaded that the amount offered by the German government was insufficient and should not be accepted. We were all mindful of the responsibility involved in rejecting any offer. We agreed, however, that he would advise the Polish government and the Polish Red Cross that no offer was to be accepted without the concurrence of the Norman Cousins Committee. I feel that this concession from him was all that we could ask for and again it may have saved the day at the last moment.

He further agreed that he would support my recommendation that a joint committee be established of representatives of the German government, the International Committee of the Red Cross, the Polish Red Cross and the victims represented by the Norman Cousins Committee, for the purpose of discussing all these problems together and trying to dispose of the cases

45 Marian Dobrosielski $\left({ }^{\star} 1923\right)$ war ein polnischer Diplomat, Politiker und Professor für Philosophie. Von 1958 bis 1964 wirkte er als Botschaftsrat an der polnischen Botschaft in Washington. Zwischen 1969 und 1972 war er Botschafter in London und 1978 bis 1981 stellvertretender polnischer Außenminister. 
expeditiously. Even if this recommendation were not accepted in Warsaw he made it clear that he would ask the Polish Red Cross to keep him closely advised of all progress and he, in turn, would keep us informed.

On our part, we agreed to nothing further for the time being but await future developments. If an official offer is made public which is not acceptable, we will consider it and if we decide to reject it we will do so publicly, giving our reasons for it. Dr. Dobrosielski felt that further intervention by the American Congress would be most helpful but I advised him that all matters of public relations would have to be left to your decision.

In response to my inquiry, Dr. Dobrosielski stated that the rate of transfer to the Lapins would be at the highest rate available. This was between 70 to 75 zlotys to the dollar, under the PKO. ${ }^{46} \mathrm{He}$ also stated that he felt $99 \%$ sure that there would be no taxation by the Polish government on these funds and he explained that he had not given any written confirmation because he felt that the matters were now being negotiated directly between the Polish Red Cross and the International Committee of the Red Cross, and therefore there was no need to confirm these facts to us. Once we have gotten the ball back into our territory, therefore, it will be necessary for us to follow up on this again and obtain written confirmation.

|3| I feel it was a very important meeting (thanks to Caroline's prodding) and we have established another vital link. I gave Dr. Dobrosielski copies of my letter of December 2nd to Dr. Maunoir ${ }^{47}$ in which I outlined all of the arguments for increased payments as well as a copy of my letter of December 9th to Ambassador Knappstein in which I stated exactly what we wanted. These documents will go to Poland by diplomatic pouch and will give us further assurance that the German government will not succeed in bypassing us, as now seems to be their intention.

With kind regards,

Cordially yours,

Benjamin B. Ferencz

BBF: js

Encl.

46 Powszechna Kasa Oszczędności (Allgemeine Sparkasse).

47 Jean-Pierre Maunoir arbeitete in verschiedenen Positionen für das Internationale Komitee des Roten Kreuzes in Genf, darunter als Mitglied des Direktorats. Er war zudem in die Verhandlungen um Entschädigung der Häftlinge von Ravensbrück involviert. 
cc. Miss C. Ferriday

Mrs. J. Benenson

Don Wilson, Esq.

\section{Dokument 89}

Benjamin B. Ferencz an Norman Cousins

Ohne Ortsangabe, 10. April 1961

Maschinenschriftlicher Brief, 2 Seiten; Kopfzeile auf Seite 2 (»April 10, 1961 Mr. Norman Cousins")

$R G 12.012 .02^{\star} 05$

Mr. Norman Cousins

April 10, 1961

Editor, Saturday Review

25 West 45th Street

New York 36, N.Y.

Dear Norman:

After my letter of April 7th to you was dispatched, I received a phone call from Ambassador Knappstein. The Ambassador advised me that he had just received a cable from Bonn in response to the cable he had transmitted just a day or two before. Bonn advised him that they accepted the terms of the counter-proposal according to which each victim of medical experiments would receive a minimum of $25,000 \mathrm{DM}(\$ 6,250)$ and a maximum of $40,000 \mathrm{DM}(\$ 10,000)$. The matter was still to be treated as confidential until such time as the German government together with the International Committee of the Red Cross would issue an appropriate press release.

Of course, the agreement must still be drawn up and signed and the techniques for payment worked out in detail. I hope to be able to do this while I am in Bonn and trust that it will not be necessary for me to proceed to Geneva as suggested by the International Committee of the Red Cross. If all goes well, we should be able to finally complete the entire matter by the time I return from Europe in about two or three weeks. We will probably have a few more minor crises between now and then but I am hopeful that these, too, will be overcome successfully. 
I am sending photostatic copies of the powers of attorney given to you by each girl to Geneva as requested by M. Maunoir in the attached copy letter. I would appreciate your signing the attached substitution authorizing me to act in your stead in order that the formal requirements set by the International |2| Committee of the Red Cross may be met. I have followed the form so ably set by Don Wilson.

The next report you receive from me will be from Europe.

With warm regards,

Cordially yours,

Benjamin B. Ferencz

BBF: js

Enc.

cc. Miss C. Ferriday

Mrs. J. Benenson

Don Wilson, Esq.

\section{Dokument 90}

Benjamin B. Ferencz an Marian Dobrosielski

Ohne Ortsangabe, 1. Mai 1961

Maschinenschriftlicher Brief, 2 Seiten; Kopfzeile auf Seite 2 (»May 1, 1961 Dr. Marian Dobrosielski «)

$R G 12.012 .02 * 05$

May 1, 1961

Dr. Marian Dobrosielski

Polish Embassy

Washington, D.C.

Dear Dr. Dobrosielski:

I have just returned from visits to Bonn and Geneva in connection with our attempts to obtain compensation for the victims of Nazi medical experiments now living in Poland. 
I am pleased to confirm to you what had already been indicated in my letter of April 10th, that each victim will now receive between 25,000 DM and 40,000 DM, depending upon the degree of physical disability. ${ }^{48}$

Although the International Committee of the Red Cross has received verbal confirmation that the most favorable rate of exchange would be applied and that these payments would not be subject to any taxation, the written confirmation of this understanding has not yet been received. I have learned that the rate of exchange which is applied for the transmittal of dollars to Poland to be used for relief purposes, equals 72 zloty to the dollar. M. Maunoir of the International Committee of the Red Cross will request these same benefits for the medical experiment victims. It is anticipated that payments will be made by the German government to the International Committee of the Red Cross which will make its transmittal from Switzerland via the PKO Bank.

It shall also be requested that your government consent to $20 \%$ of the funds being used for the purchase of goods from abroad. This should enable the victim to acquire machines, tools, or other equipment which may not otherwise readily be available to them.

I am confident that you will recognize the importance and desirability of giving to the victims of Nazi atrocities $|2|$ the maximum benefits possible. I take the liberty, therefore, of urging you to convey to your government the desirability of promptly confirming in writing that those requested benefits will be granted.

May I again express my appreciation as well as the appreciation of Norman Cousins and his Committee for all of your cooperation and assistance. We trust that this endeavor on our part to assist victims of persecution, regardless of nationality or residence, will be a small contribution toward cordial relations between all the countries concerned.

Sincerely yours,

Benjamin B. Ferencz

BBF: js

48 Als Ergebnis der Verhandlungen zwischen der Bundesregierung und dem IKRK wurden die Geschädigten in vier Kategorien eingeteilt, die abgestuft zwischen 25.000 und 40.000 DM erhalten sollten. Siehe Baumann, Menschenversuche und Wiedergutmachung, 143. 
cc. M. J. P. Maunoir

Mr. Norman Cousins

Miss C. Ferriday

Mrs. J. Benenson

Don Wilson, Esq.

\section{Dokument 91}

Benjamin B. Ferencz an Karl Heinrich Knappstein

Ohne Ortsangabe, 7. Juni 1961

Maschinenschriftlicher Brief, 2 Seiten; Kopfzeile auf Seite 2 (»June 7, 1961 Hon. ${ }^{49}$ Ambassador K. H. Knappstein ")

$R G 12.012 .02^{\star} 05$

Hon. Ambassador K. H. Knappstein

June 7, 1961

Permanent Observer of the Federal Republic

of Germany to the United Nations

460 Park Avenue

New York 22, N. Y.

Dear Dr. Knappstein:

I called your office after I returned from a recent visit to Bonn and Geneva. By this time you undoubtedly know that an agreement has been reached between the International Committee of the Red Cross and your government, according to which each of the medical experiment victims now resident behind the Iron Curtain will receive between 25,000 DM and 40,000 DM. Since I have not yet seen a copy of the official exchange of letters on the subject, and no payments have yet been made, it would be a bit premature now for me to start expressing appreciation on behalf of the beneficiaries, but I did want to let you know that I was very mindful of your support and very grateful for all that you and the Embassy in Washington have done to bring about a solution in this difficult matter.

You undoubtedly recall our correspondence and discussion concerning allegations, presumably made by representatives of the Finance Ministry

49 Honorable. 
with regard to the motives of Norman Cousins and his Committee. These allegations were subsequently denied by the Finance Ministry and we agreed not to press the matter further. In this connection, however, I have recently come into possession of a document which I thought might be of interest to you. It is Vorlagenummer 7/60 of the Finance Ministry File No. VI A/4 $0147227 / 6011 /$ A - AF $0418^{50}$ - 27/60 dated Bonn, 25 May, 1960. 60 copies of the 13-page memorandum were prepared and I think you should obtain a copy for your files $|2|$ if you do not already have it. On pages 9 and 10 it says that, "the conduct of Mr. Norman Cousins and the so-called 'Cousins Committee' founded by him must lead to the presumption that this group is not interested in support to the Polish women but in a political defamation of the Federal Republic."

You may have noticed an Associated Press release dated June 1st which appeared in the World Telegram and other papers. Norman Cousins, who happened to be in Moscow on a State Department mission, took advantage of his presence there to issue a release stating that the West German government had agreed to pay from $\$ 5,000$ to $\$ 10,000$ compensation to the Polish women who served as guinea pigs in the Nazi medical experiments. At the same time, Mr. Cousins drew attention to the fact that the East German Communist government had refused to take any responsibility for the women. I think this action on his part is clear evidence, if any should be required, that the accusations of the Finance Ministry are totally unfounded. I am confident that the compensation agreement will not merely assist the deserving beneficiaries but will also enhance the prestige of your government throughout the world.

With renewed appreciation and kind regards,

Sincerely yours,

Benjamin B. Ferencz

BBF: js

cc. Mr. Norman Cousins

Miss C. Ferriday

Mrs. Jeanne Benenson

Don Wilson, Esq.

50 Die letzte Ziffer ist im Originaldokument verwaschen und daher kaum lesbar. 


\section{Dokument 92}

Benjamin B. Ferencz an Norman Cousins

New York, 8. September 1961

Maschinenschriftlicher Brief, 2 Seiten; gedruckter Briefkopf auf Seite 1, Kopfzeile auf Seite 2 (gedruckt: "TAYLOR, SCOLL, FERENCZ \& SIMON «, maschinenschriftlich: $»$ Mr. Norman Cousins ")

$R G 12.012 .02 * 05$

\section{Taylor, Scoll, Ferencz \& Simon COUNSElors at LaW}

Telford TAylor

David E. SCOLL

Benjamin B. Ferencz

KenNeth Simon

Mr. Norman Cousins

Editor, Saturday Review

25 West 45th Street

New York 36, N. Y.

\author{
400 Madison Avenue \\ New York 17, N. Y. \\ $* * *$ \\ Murray Hill 8-8990 \\ Cable Address: Lantalaw
}

Dear Norman:

September 8, 1961

I am very pleased to attach hereto photostatic copies of the correspondence just received from the International Committee of the Red Cross.

You will note that the Polish victims of medical experiments will shortly receive a total of $2,545,000 \mathrm{DM}$ which is $\$ 636,250.26$ of the claimants will receive the maximum of $\$ 10,000,25$ will receive $\$ 8,750,16$ will receive $\$ 7,500$ and 6 will receive the minimum of $\$ 6,250$.

You will also notion that there is a right of appeal if there are valid reasons why these conclusions are inequitable.

My impression is that the handling of the cases has been fair. In some cases, like that of Stefania L., I think the file will have to be reconsidered on the basis of the new evidence submitted after the Commission had examined the case.

I am enclosing further a copy of a letter sent by special delivery today to the Lapins Committee in Poland on your behalf and after consultation with Mary Harvey and Caroline Ferriday. 
I have also, on your behalf, advised Dr. Dobrosielski in Washington and Ambassador Knappstein in New York. Both of them were enormously pleased. I indicated to them that they would receive some more formal expression of appreciation at the appropriate time. Dr. Dobrosielski requested copies of $[|2|]$ the correspondence which I have sent to him as per the attached covering note. He again urged me very strongly to visit Poland and I indicated to him that if some useful purpose could be served thereby on behalf of the Lapins and if it could conveniently be connected with one of my regular business trips I would try to do so. I am planning to be in Europe during the latter part of October and unless the girls are all paid out and happy by then it would in fact please me to be able to tidy up the package and finish off the job completely. This would mean stopping in Bonn to see that all arrangements for transmittal of funds are flowing smoothly and to express your appreciation to Dr. Born and other members of the Foreign Office who have been helpful, going on to Geneva to thank M. Maunoir and the Red Cross and to set up the procedure for appeals which I have no doubt will follow in some cases and then go to Poland for a few days to see that payments will in fact be made at the very preferential rate we have agreed upon. Upon my return I would then render a final report to you and your committee and be very pleased to mark the case "closed."

We're not quite through yet but we've come a very long way and I hope you are as pleased as I am.

With warm regards,

Cordially yours,

Benjamin B. Ferencz

cc. Miss C. Ferriday

Mrs. J. Benenson

Don Wilson, Esq.

BBF: js

Encl. 


\section{Dokument 93}

Benjamin B. Ferencz an Norman Cousins

New York, 29. September 1961

Maschinenschriftlicher Brief, 2 Seiten; gedruckter Briefkopf auf Seite 1, Kopfzeile auf Seite 2 (gedruckt: "TAYLOR, SCOLL, FERENCZ \& SIMON ", maschinenschriftlich: $»$ Mr. Norman Cousins September 29, $1961 «)$

$R G 12.012 .02 * 05$

\section{Taylor, Scoll, Ferencz \& Simon \\ COUNSElors at LaW}

Telford TAylor

David E. SCOLL

Benjamin B. Ferencz

KenNeth Simon

Mr. Norman Cousins

Editor, Saturday Review

25 West 45th Street

New York 36, N. Y.
400 Madison Avenue

New York 17, N. Y.

Murray Hill 8-8990

$* * *$

Cable Address: Lantalaw

September 29, 1961

\section{Dear Norman:}

Yesterday I had a very long luncheon meeting with Dr. Dobrosielski. He wanted to know about the attitude of the International Committee of the Red Cross which had prompted our recent exchange of correspondence and he also had some problems with regard to the keeping of the funds in foreign accounts. On my part, I wanted some clarification about the attitude of the Polish Red Cross and possibly other agencies in Poland.

From my exchange of letters with M. Maunoir, I had concluded personally that the Polish Red Cross (and possibly ZWOBID [sic]) ${ }^{51}$ wanted to be the first to notify the girls about the receipt of payment. There would obviously be a certain amount of prestige connected with it and there may also have been

51 Związek Bojowników o Wolność i Demokrację (Verband der Kämpfer für Freiheit und Demokratie; ZBoWiD) war die offizielle Kriegsveteranenvereinigung in der Volksrepublik Polen. 
some Polish interest in playing down the effect of American intervention on behalf of the victims. I expressed my concern in these points to Dr. Dobrosielski and reassured him that there were not propaganda motives in our actions and that our only concern was the welfare of the victims. He needed no persuasion, but the situation may look different from Warsaw.

Dr. Dobrosielski was concerned about the right the girls would have of keeping the compensation payments in foreign currency accounts outside of Poland. He felt that he and I had discussed an arrangement whereby only $20 \%$ of the proceeds would be used in that manner and he felt that it might not be in the interests of his government if all of the funds were $|2|$ kept out of the country. He had no objection to the holding of the proceeds in foreign currency accounts within Poland. He also noted that they were offering the girls a rate of exchange of 72 zlotys to the dollar and that this was really very fair and they could buy with it whatever they wished. He also explained that $\$ 10,000$ converted at 72 zlotys to the dollar would give the girls 720,000 zlotys or the equivalent of what a university professor might earn in 20 years' time. It was therefore a very sizeable fortune. He urged me to use my influence with the Lapins in order that the funds might be kept in Poland.

I replied that his suggestions seemed reasonable and under the circumstance I would be surprised if more than $20 \%$ of the girls requested that the funds be kept outside of Poland. I said that I would explain the facts to the girls when the time arose.

I agree with Dr. Dobrosielski that in connection with my forthcoming European trip I would go to Warsaw and meet with the Polish Red Cross in an attempt to wind up the matter and settle all outstanding problems. I would be the guest of the Polish Red Cross during the time I was in the country.

I am planning to leave here some time between the 15th and 20th October. I will go to Bonn and Geneva before going to Warsaw and I expect to be in Poland between the 5th and the 10th of November. With victory so close we must be sure that there are no last-minute slips. I will of course convey your greetings and gratitude (or concern) to the interested parties in Germany, Geneva and Warsaw and if you have any special messages to anyone, please let me know.

With warm regards,

Cordially yours,

Benjamin B. Ferencz

cc. Miss C. Ferriday

Mrs. J. Benenson

Don Wilson, Esq. 


\section{Dokument 94}

Benjamin B. Ferencz an Caroline Ferriday

Ohne Ortsangabe, 8. Januar 1962

Maschinenschriftlicher Brief, 1 Seite

$R G 12.012 .02 * 06$

Miss Caroline Ferriday

January 8, 1962

875 Park Avenue

New York, N. Y.

Dear Caroline:

Your report on the Lapins ${ }^{52}$ is a very moving story. I would have liked to know more about how you got involved in the first place and how and where the whole thing really started. Perhaps it's a task for a historian but I do feel that the complete story should be told some time and I fear that "Voix et Visages"53 will not have the space to do the job justice.

Since I am only asked to comment on any "boo-boos" (which of course is spelled correctly) I would like to suggest that the spots on page 6, 7, 14 and 16 which I have marked with a question mark, be somewhat tempered. You will note that in all of these spots your affection for the Germans is showing. After all, the Germans have paid and if we continue to call them names even after they have taken the painful step of reaching into their pockets, some of them may be encouraged to believe that they have wasted their efforts and should not have done so in the first place. In truth, it should also be said that the opposition came from a small nucleus which successfully blocked action for a long time, but we did have many friends, as subsequent events showed, and to talk about "the Germans" without any distinction is perhaps unfair.

I am sure your article will make interesting and inspiring reading.

With warm regards,

Yours $^{54}$

Encl.

52 Caroline Ferriday, Les «Amis de l'A.D.I.R.» d'Amerique obtiennent des indemnités substantielles pour 136 cobayes (Hongrois et Polonais), in: Voix et Visages (Januar/ Februar 1962), H. 82, 5-8.

53 Gemeint ist die Monatszeitschrift Voix et Visages. Bulletin mensuel de l'ADIR.

54 Unterschrift fehlt auf archivalischer Kopie. 


\section{Dokument 95}

Benjamin B. Ferencz an Ernst Katzenstein

Ohne Ortsangabe, 28. März 1968

Maschinenschriftlicher Brief, 1 Seite

RG $12.012 .02 * 07$

March 28, 1968

Dr. Ernst Katzenstein

\{ADIR file\}

JRSO

Gruneburgweg [sic] 119

Frankfurt/Main

Dear Ernst:

I was delighted to see from your letter of March 23 that the Finance Ministry is crying about how much it costs them to pay the medical victims from the East. It serves them right! I had proposed a global settlement to them on behalf of about 50 girls from Poland. Blessin told the Cabinet that I was trying to enrich myself and was a dupe of the communists and so they by-passed me (I was working gratuitously for the girls) and decided to use the International Red Cross. Now the International Red Cross pays no attention to what the Finance Ministry wants and it has already cost them 10 times as much as it would have cost had they accepted my plan - Hoorah! The next time the Finance Ministry tells you their troubles, you can tell them that's what they can expect if they don't accept my terms.

Warm regards,

Cordially yours,

Benjamin B. Ferencz

BBF: js

cc. Mr. S. Kagan 


\section{Dokument 96}

Benjamin B. Ferencz an Karl Baum ${ }^{55}$

Ohne Ortsangabe, 5. März 1970

Maschinenschriftlicher Brief, 2 Seiten

RG $12.012 .02 * 07$

March 5, 1970

\{“ADIR" file\}

Mr. Karl Baum

Council of Jews from Czechoslovakia ${ }^{56}$

30 Craven Street

Strand, London, W.C.2.

Dear Mr. Baum:

Herman Edelsberg ${ }^{57}$ has sent me a copy of his letter to you of February 20 and some of the correspondence regarding the Czech recipients of Tusex coupons ${ }^{58}$

55 Karl Baum (1907-1991) war ein jüdischer Journalist und Verbandsfunktionär. Aufgewachsen in der Tschechoslowakei arbeitete er dort zunächst für verschiedene deutschsprachige Zeitungen. 1938 floh er vor den Nationalsozialisten nach Großbritannien. Nach dem Krieg war er von London aus weiterhin für verschiedene Zeitungen tätig und engagierte sich in jüdischen Organisationen. 1968 war er Gründungsvorsitzender des International Council of Jews from Czechoslovakia.

56 Der International Council of Jews from Czechoslovakia wurde 1968 mit dem Ziel gegründet, jüdische Auswanderer aus der Tschechoslowakei bei ihrer Eingliederung in Israel oder westlichen Staaten zu unterstützen. Zahlreiche Aktivitäten richteten sich jedoch schnell auf die Verbesserung der Situation der Juden in der Tschechoslowakei, darunter auch die Unterstützung in Entschädigungsverfahren.

57 Herman Edelsberg (ca. 1909-1986) arbeitete viele Jahre für B’nai B’rith. In den 1950er und 1960er Jahren war er Direktor des Washingtoner Büros der Anti-Defamation League. Anschließend wirkte er von 1967 bis 1977 als Direktor des Internationalen Rats von B'nai B'rith.

58 Tusex-Gutscheine konnten gegen Fremdwährung (z. B. US-Dollar) erworben werden und dienten in der Tschechoslowakei zum Einkauf in Geschäften, in denen sonst nur mit Devisen bezahlt werden konnte. Außerdem war es möglich, diese gegen tschechische Kronen einzutauschen. 
as well as the agreement between Germany and Czechoslovakia to compensate Czech victims of Nazi Medical experiments. ${ }^{59}$

I was the attorney who negotiated the basic agreement between Germany and the International Committee of the Red Cross on behalf of the Polish Catholic women who had been victims of experiments in Ravensbruck [sic]. Claimants from other countries, notably Hungary and Czechoslovakia, then appealed to the International Committee of the Red Cross for similar treatment, and, as a result, subsequent agreements were reached which would provide some compensation to them. ${ }^{60}$

The agreement between Czechoslovakia and Germany of 30 October, 1969 follows the line of the agreement with Yugoslavia. ${ }^{61}$ You will note from the agreement that a fixed sum (71/2 Million DM) was paid to Czechoslovakia in exchange for which the Czechs undertook to satisfy the claims of Czech nationals for compensation for injuries resulting from medical experiments. The agreement contains no specific criteria to be applied and the German government is to be held harmless against any such claims by Czech nationals. In order to deal with possible claims via the International Red Cross (presumably by those who were no longer under the control of the Czech government) the German government reserved an amount of up to $500,000 \mathrm{DM}$ which they would use to satisfy such claims, and the amount involved as well as expenses would be deducted from the payments to Czechoslovakia. The IRC has an elaborate procedure for the screening of applications and further medical examinations to verify that the injuries were caused by medical experimentation rather than mere persecution.

|2| What this all adds up to is that if there are any Czech nationals outside of Czechoslovakia who can prove that they were victims of Nazi medical experiments they should immediately submit a claim to the International Committee of the Red Cross in Geneva (it should have been done about 10 years ago). If their claim is justified, presumably the IRC will recommend

59 Am 30. Oktober 1969 wurde ein Globalabkommen zwischen der Bundesrepublik und der Tschechoslowakei zur Entschädigung von Opfern medizinischer Experimente abgeschlossen. Als Gesamtsumme der Entschädigungszahlungen wurden 7,5 Millionen DM festgelegt. Siehe Baumann, Menschenversuche und Wiedergutmachung, 161.

60 Globalabkommen für Opfer medizinischer Experimente wurden mit Jugoslawien (1961/1963), der ČSSR (1969), Ungarn (1971) und Polen (1972) abgeschlossen.

611961 schloss die Bundesrepublik mit Jugoslawien ein Abkommen über eine Globalsumme von 1,75 Millionen DM, die 1963 auf 7,5 Millionen DM erhöht wurde. Siehe Baumann, Menschenversuche und Wiedergutmachung, 159-161. 
to the German government that payment be made out of the one-half Million DM reserve indicated above.

With every good wish,

Cordially yours,

Benjamin B. Ferencz

BBF: js

cc. Herman Edelsberg, Esq.

\section{Dokument 97}

Benjamin B. Ferencz an John Mendelsohn ${ }^{62}$

Ohne Ortsangabe, 13. September 1983

Maschinenschriftlicher Brief, 1 Seite

$R G 12.012 .02^{*} 01$

Mr. John Mendelsohn

Sept. 13, 1983

Military Archives Division

National Archives

Washington DC

Dear John:

Miss Caroline Ferriday informed me that the records which she had concerning medical experiments performed on Polish women at Ravensbruck [sic] were sent to you for inclusion in the National Archives. The story of how compensation was finally obtained for some of the victims has never been fully written and I trust that the Ferriday files will help to write the final

62 Der Historiker und Archivar John Mendelsohn (1928-1986) war in den National Archives für die War Crimes Records zuständig und darüber hinaus Herausgeber mehrerer Dokumentensammlungen zum Holocaust (John Mendelsohn/Donald S. Detwiler (Hg.), The Holocaust. Selected Documents, 18 Bde., New York 1982) und den Nürnberger Nachfolgeprozessen. 
chapter of what was released by the prosecution in the Nuremberg trial in The Medical Case.

Part of the record of the compensation story was hidden in my basement. I have now gone through my own files and have extracted the correspondence and other material that may help to make the picture more complete. I hope I will be forgiven for sending you the attached box of files without prior clearance. I am confident that you will find these records to be a significant supplement to what you have already received.

The attached correspondence, going back to 1957, will fill in some of the details of the negotiations with the German government and the International Committee of the Red Cross as well as various Polish authorities. Some general reports and printed material (articles in magazines, books and newspapers) should also be of interest.

I would be grateful if you would acknowledge receipt and I would be pleased to hear that these records will also be included as part of the National Archives.

With warm regards,

Cordially, ${ }^{63}$

CC: Caroline Ferriday

Encl. About 1 yard of records

63 Unterschrift fehlt auf archivalischer Kopie. 

6. Restitution für B'nai B'rith in Deutschland und den Vereinigten Staaten 



\section{Dokument 98}

Benjamin B. Ferencz an Maurice Bisgyer ${ }^{1}$

Berlin, 25. März 1958

Maschinenschriftlicher Brief, 2 Seiten

$R G 12.003 .01 * 04$

Berlin

25 March 1958

Maurice Bisgyer

Executive Vice President

B'nai B'rith

1640 Rhode Island Avenue

Washington D.C.

Dear Maurice:

I have just come from a meeting with Mayor Brandt ${ }^{2}$ and [had] the unhappy duty of telling him politely what the B'nai B'rith must think about Berlin. The gist of my song was that 21 years ago the Germans in Berlin confiscated all the B'nai B'rith assets in a ruthless way, yet today despite all declarations about restitution the sad truth is that the lodge has received not one cent for any of the furnishings, bank accounts or securities and the buildings in Berlin stand as useless ruins. To top it all, Berlin has the colossal affrontry [sic] to demand through its Special Property section that the lodge pay 3 Million DM to the Bund for the "improvements" they made by converting it from a lodge building to a film building which today apparently no one needs.

I told him that of the over 2,000 former Berlin B'nai B'rith members less than 25 remain here and we were all prepared to believe that Berlin was ready to help recreate the lodges when its Senate approved the notarized contract which was signed when I was here last for the sale of the Kleiststrasse building. Then we were told that the building would have to be acquired because the superhighway would soon intersect it. Now we were told that the plans for the

1 Maurice Bisgyer (1897-1973) war von 1937 bis 1964 Verwaltungsdirektor und Vizepräsident von B'nai B'rith. Zuvor war er u. a. Direktor der Jewish Education Alliance in Baltimore sowie des Jewish Community Center in Washington.

2 Der sozialdemokratische Politiker Willy Brandt (1913-1992) war von 1957 bis 1966 regierender Bürgermeister von Berlin und von 1969 bis 1974 der vierte Bundeskanzler der Bundesrepublik. 
highway had been changed in order to avoid the necessity of purchase and that only part of the building would have to be torn down at some unknown future date, perhaps after the unification of Berlin. The fact that the fate of the building was unknown made it the more difficult for us to find a buyer, and the liability for all these damages morally rests with Berlin.

Nevertheless we were prepared to extend the hand of friendship and reopen the lodge in line with the wishes of the Chancellor, ${ }^{3}$ the Presschief [sic] and others who looked toward a happier future, but what would he say at the installation, and what would Heuss ${ }^{4}$ say, to the B'nai B'rith members throughout the world who must also be told that Berlin has not paid a penny but makes counterclaims of outlandish size.

I appealed to him to see beyond the paragraphs of the law and the narrow confines of a property purchase, but to view the problem in its entirety and to take the necessary steps to reach a just solution.

The Mayor was silent for a while and then murmured that he would have to call some of his people together and impress upon them that this was more than a financial and economic problem and they would have to understand the political implications. He said he had only heard about the counterclaim from his personal assistant Dr. Siewert with whom Dr. Tuch and I had thoroughly discussed the problem yesterday. He suggested |2| that I discuss it with Berlin's representative in Bonn, Dr. Klein, who had been present when I saw the mayor in New York. Since the Bund is really the party presenting the counterclaim the Mayor thought it would be well to discuss it with the Finance Ministry and he promised his assistance. I will be in Bonn 2 days from now and will certainly take the matter up there.

As for the sale itself I have the feeling that the Mayor is personally embarrassed. He will certainly try to do something, but having been previously burned in my predictions I think we must now await his next move.

I met yesterday with the Main Property Office of Berlin, where Dr. Schluroff, the man who had signed the contract for Berlin, and who had exchanged congratulations with me the last time I left his office was also visibly embarrassed. He apologized but noted that parliamentary committees are often very powerful and sometimes block the Senate in the U.S. as well. He told me of other parties who might be willing to use the building and assured us of his efforts to find some prospective tenant in order to meet the objections raised by the Property Committee of the Parliament.

3 Gemeint ist Konrad Adenauer.

4 Theodor Heuss (1884-1963) war Journalist und liberaler Politiker. 1949 wurde Heuss zum ersten Bundespräsidenten der Bundesrepublik gewählt und übte das Amt bis 1959 aus. 
Dr. Tuch and I visited the Orania $[\mathrm{sic}],{ }^{5}$ a non-profit cultural group partly sponsored by the city, and which has expressed a keen desire to obtain the building. Their architects are about to submit a detailed plan showing how much it would cost to convert the building to their needs and plans for adjoining buildings to be erected. This is expected shortly, and until it is ready, I fear the plans are rather vague. We also met with the Volksbank which would finance the venture but found that the matter is still in its early stages and nothing definite can be said at this point.

I have been trying for the past two days to see the head of the Parliamentary Committee and although I spoke to him briefly on the phone, he has managed to avoid a meeting. I may have to leave Berlin without seeing him, but my views will certainly be transmitted to him by the Mayor and the Mayor's assistant.

Another film group is to view the building tomorrow, but it's too early to say what will come of the inspection.

I have extracted from the Berlin files whatever material we will need to support our global settlement talks in Bonn and will now carry the ball there.

Please pardon the typing, as I am knocking this out myself as the fastest if not the nicest way to get the message to you.

I paid my respects to Shoyer ${ }^{6}$ by meeting with him and had a long chat on the phone with Dr. Ehrlich. ${ }^{7}$ They told me that the installation date ${ }^{8}$ is being tentatively set for the 20th of April (Hitler's birthday) but it may be postponed

5 Gemeint ist die Berliner Gesellschaft Urania, die sich der Vermittlung wissenschaftlicher Erkenntnisse und kultureller Themen widmet.

6 Wahrscheinlich ist Adolf Schoyer (1872-1961), ein deutsch-jüdischer Industrieller, gemeint. Schoyer war von 1931 bis zu seiner Emigration 1938 im Vorstand der Jüdischen Gemeinde Berlin aktiv und Mitglied der B’nai-B'rith-Loge Jehuda Halevi. Im britischen Exil war er 1941 Mitgründer der Association of Jewish Refugees, als deren Vorsitzender er wirkte. Zudem war er an der Gründung des Council of Jews from Germany und der Section 1943 des B'nai B'rith beteiligt. Nach Kriegsende kehrte er als Vertreter des Council of Jews from Germany nach Westberlin zurück, wo er 1946 einen neuen B'nai-B'rith-Bruderkreis formierte.

7 Ernst Ludwig Ehrlich (1921-2007) war ein deutsch-jüdischer Judaist, Historiker und Religionsphilosoph. Nach einem Jahr Zwangsarbeit konnte er 1943 in die Schweiz fliehen. Nach dem Ende des Zweiten Weltkriegs lehrte er ab 1955 Judaistik in Frankfurt am Main, Zürich, Basel, Bern und Berlin. Zudem engagierte er sich für den christlich-jüdischen Dialog. Von 1961 bis 1994 wirkte er als Direktor für Kontinentaleuropa von B'nai B'rith.

8 Wahrscheinlich ist hier die Wiedergründung der B'nai-B'rith-Loge Deutschland gemeint, die schließlich 1959 erfolgte, nachdem sie im April 1937 von den Nationalsozialisten aufgelöst worden war. 
for two weeks. I wished them all well. Somebody will still have to tell the Mayor when and where to appear.

If Hannah Sinauer' can retype this so that it's legible it will add to the many blessings she has bestowed upon mankind.

With warm regards,

Benjamin B. Ferencz

\title{
Dokument 99
}

Benjamin B. Ferencz an Willy Brandt

New York, 6. Juli 1959

Maschinenschriftlicher Brief, 1 Seite; gedruckter Briefkopf mit maschinenschriftlicher Einfügung

$R G 12.003 .01{ }^{*} 06$

\author{
Benjamin B. Ferencz \\ Attorney and Counselor at Law \\ 21 EAst 40Th STREeT \\ New York 16, N.Y.
}

Benjamin B. Ferencz $* * *$

Nathan Eisner

The Hon. Willy Brandt

Der Regierende Bürgermeister

Rudolph-Wilde Platz

Berlin Schöneberg, Germany

9 Hannah Sinauer (geb. Rothschild; 1918-2001) emigrierte 1938 aus Deutschland in die Vereinigten Staaten. 1948 begann sie für B'nai B'rith zu arbeiten und war Chefsekretärin sowie Assistentin des Präsidenten der Sektion der Vereinigten Staaten. Nach ihrer Pensionierung arbeitete sie ehrenamtlich im Archiv der Organisation in Washington, D.C. 
Dear Mayor Brandt:

Mr. Philip Klutznick, the past President of B'nai B'rith and now Chairman of the International Council of B'nai B'rith will be visiting Berlin for a few days beginning August 2, 1959. He is returning from the International B'nai B'rith Convention which was recently concluded in Israel and is now touring various countries of Europe in order to gain his own impression of local conditions.

I know that you are fully aware of the significance of B'nai B'rith throughout the world and of the important role it plays in Jewish affairs. I had the pleasure of informing Mr. Klutznick of the fine cooperation received from you and other friends in Berlin in connection with the B'nai B'rith problems there and although there still seem to be some difficulties remaining, I know that Mr. Klutznick is looking forward to meeting you in order that he may convey to you personally the appreciation of the B'nai B'rith for all of your assistance.

You will find Mr. Klutznick an outstanding man of keen intellect and great personal charm and I am very pleased, therefore, to send you this letter of introduction.

With best regards,

Sincerely yours,

Benjamin B. Ferencz

BBF: js

\section{Dokument 100}

Benjamin B. Ferencz an Philip M. Klutznick

Ohne Ortsangabe, 11. Dezember 1962

Maschinenschriftlicher Brief, 2 Seiten; Kopfzeile auf Seite 2 ("Amb. Klutznick

December 11, 1962«)

$R G 12.003 .01^{\star} 09$

$\underline{\text { Personal }}$

Ambassador Philip M. Klutznick

December 11, 1962

United States Mission to the U.N. 
799 United Nations Plaza

New York 17, N. Y.

Dear Phil:

On December 6th Maurice Bisgyer and I met with Ambassador Knappstein and since you were the subject of some of the discussions I thought you might like to hear about it.

We were there to urge Germany to pay the second installment of 5 million DM due under the agreement with B'nai B'rith. ${ }^{10}$ The money was due "in principle" by March 31, 1962 and there is very real danger that Germany will rely on the small print in the contract to argue that nothing more need to be paid since they have reached the ceiling of $11 / 2$ billion DM fixed by them and the Allies for the discharge of such obligations. ${ }^{11}$ In fact, they are nowhere near spending $11 / 2$ billion for those claims which the Allies listed and had in mind when the $11 / 2$ billion DM ceiling was set, so it is just another German attempt at chiselling if they can get away with it.

Ambassador Knappstein spoke very warmly of you and there is no doubt that you earned his respect and admiration during the time he was at the U.N. We did not miss the opportunity of pointing out that you were the one who brought about the original settlement of 10 million DM, announced it at the Triennial in Jerusalem and also announced, as reported in the New York Times, that the second instalment was due on March 31, 1962. Knappstein seemed much distressed that Germany might now appear to be trying to evade its obligation. He promised to be in touch with his government in support of full payment. He also indicated that he would write a personal note to his Minister about it and I have no doubt that your name will appear in that note.

10 Auf Grundlage des 1957 erlassenen Bundesrückerstattungsgesetzes, das die Geldverbindlichkeiten des Deutschen Reichs und gleichgestellter Rechtsträger regelte, vereinbarte die international verbreitete und in den Vereinigten Staaten beheimatete jüdische Organisation B'nai B’rith 1959 mit der Bundesrepublik ein Globalabkommen über 10 Millionen DM. Siehe die Unterlagen im USHMM, BBF Collection, RG 12.003.01*06 sowie 12.003.01^07.

11 Der Überleitungsvertrag von 1952 zwischen der Bundesrepublik und den drei westlichen Alliierten hatte für die rückerstattungsrechtlichen Verbindlichkeiten der BRD eine Obergrenze von 1,5 Milliarden DM festgelegt. Siehe Lillteicher, Raub, Recht und Restitution, Göttingen 2007, v.a. 309-402; Goschler, Schuld und Schulden, $210-212$. 
|2| Although you have unfortunately physically removed yourself from the B'nai B'rith stage, I thought it might warm the cockles of your heart to know that even in absentia your spirit still serves the Jewish weal. I need not tell you that you are missed and I particularly feel the absence of the close relationship we enjoyed when you still had time for some of the less important things.

With warm regards as always, Yours, ${ }^{12}$

BBF: js

\section{Dokument 101}

Benjamin B. Ferencz an Jay Kaufman

Ohne Ortsangabe, 7. April 1966

Maschinenschriftlicher Brief, 2 Seiten; Kopfzeile auf Seite 2 (»April 7, 1966«)

$R G 12.003 .01^{\star} 13$

April 7, 1966

Rabbi Jay Kaufman

Executive Vice President

B'nai B'rith

1640 Rhode Island Ave. NW

Washington 6, D.C.

Dear Jay:

Ministerialdirektor Ernst Feaux de la Croix ${ }^{13}$ who is in charge of all restitution and indemnification matters for the German Ministry of Finance, will be visiting the United States beginning around April 13th. He will be

12 Unterschrift fehlt auf archivalischer Kopie.

13 Ernst Féaux de la Croix (1906-1995) arbeitete von 1934 bis 1945 in der völkerrechtlichen Abteilung des Reichsjustizministeriums und war von 1949 bis 1971 im Bundesjustizministerium in leitender Position zuständig für die »Liquidation der Kriegsfolgen«, wozu auch Restitutions- und Entschädigungsangelegenheiten gezählt wurden. 
accompanied by his wife and Dr. and Mrs. Martin Hirsch. ${ }^{14}$ Dr. Hirsch is a member of the German parliament and was in charge of the indemnification Committee of the parliament for several years.

Both Feaux and Hirsch are in the United States as guests of the Claims Conference. The purpose of their visit is to learn at first hand what some of the problems look like from this side of the ocean and to answer questions from various refugee groups concerning the further implementation of the restitution legislation.

I have known both of the gentlemen for many years and I will be spending considerable time with them while they are here in New York. According to the present indications, they should be leaving for Washington around Saturday, April 16th or 17th, and will remain in Washington until Tuesday, April 19th. Since both of these gentlemen have been very helpful to B'nai B'rith, it seemed appropriate to me that B'nai B'rith would extend to them the deserved courtesy of playing host to them during part of their visit in the American capital.

Seymour Rubin, ${ }^{15}$ Esq. of Surrey, Karasik, Gould \& Greene, Woodward Building, Washington, Phone RE. 7-0866, is arranging a luncheon for them on Monday, April 18th. He is acting for the Claims Conference in so doing and it has been agreed that you would be invited to that luncheon together with such other member[s] $|2|$ of the B'nai B'rith as you deem appropriate. Officials of the State Department will also be invited, as well as some other representative[s] of Jewish organizations with offices in Washington.

It would be appropriate for B'nai B'rith to arrange a tour of the capital and certainly of the B'nai B'rith building for the distinguished visitors. Joe Sklover's ${ }^{16}$ able secretary, Edith Yaeger would be a most suitable guide for them since she could explain everything to them in their native tongue. I am sure that Hannah Sinauer could do the same, and either of these ladies would be pleased to escape their daily chores for such a new assignment. A souvenir from B'nai B'rith to the ladies, Mrs. Hirsch and Mrs. Feaux de la Croix would of course be a nice gesture.

14 Der Jurist und SPD-Politiker Martin Hirsch (1913-1992) war von 1954 bis 1961 Mitglied des Bayerischen Landtags. Anschließend war er bis 1971 Abgeordneter im Bundestag, wo er 1961 bis 1965 als Vorsitzender des Ausschusses für Wiedergutmachung fungierte. 1971 bis 1981 war er Richter am Bundesverfassungsgericht.

15 Seymour Rubin (1914-2003) arbeitete als Rechtsanwalt unter anderem für das Außenministerium der Vereinigten Staaten sowie für die JRSO. Zudem lehrte er als Professor für Internationales Recht in Washington und wirkte als geschäftsführender Direktor der American Society of International Law.

16 Joseph Sklover war Mitarbeiter von B'nai B'rith. 
I am sending a copy of this letter to Mr. Rubin with a request that he be in touch with you in order that the details may be arranged.

With warm regards,

Cordially yours,

Benjamin B. Ferencz

cc. Seymour J. Rubin, Esq.

Mr. Saul Kagan

Mr. Ernst Weismann

BBF: js

\section{Dokument 102}

Benjamin B. Ferencz an William A. Wexler

New York, 28. Dezember 1970

Maschinenschriftlicher Brief, 4 Seiten; gedruckter Briefkopf auf Seite 1 $R G 12.011 .05^{\star} 10$

[Ferencz berichtet über die soeben abgeschlossene Gesetzgebung zu kriegsbedingten Entschädigungsansprüchen von in den Vereinigten Staaten ansässigen gemeinnützigen bzw. religiösen Organisationen, deren Einrichtungen in Europa während des Zweiten Weltkriegs durch das Deutsche Reich enteignet wurden. Er beschreibt die umfangreiche wie langjährige politische Lobbyarbeit in Washington und hebt die durchgesetzten Entschädigungsansprüche für B’nai B'rith hervor.]

Taylor, Ferencz \& Simon

COUNSElors at LAW

Telford TAYlor

OF COUNSEL

Benjamin B. Ferencz

Kenneth Simon
LiNCOLN BUILDING

60 East 42ND Street

New York, N. Y. 10017

$\star * *$

MO 1-0934 
December 28, 1970.

Dr. William Wexler \{- sent to P.O.B. 735 Savannah, Ga. 31402\}

President

B'nai B'rith

1640 Rhode Island Ave.

Washington, D. C. 20036

Dear Bill:

Thank you very much for your thoughtful words of congratulation on the War Claims Amendment. ${ }^{17}$ Since there was opposition until the moment the President signed the Bill, I refrained from responding until the Bill became Law. Now that it is final, I can heave a sigh of relief and I dare to write.

I know that these have been difficult times for you, and I have not wanted to add to your concerns by detailing every round of the unbelievable battles we were forced to wage. Now that they are over, a more comprehensive report may be in order.

When the present War Claims Law was enacted in $1962,{ }^{18}$ I detected the injustice which had been slipped in providing that privately owned profit-making companies with less than 1,000 employees would receive priority payment in full, while non-profit agencies like B'nai B'rith might receive only partial payment. I soon learned how that injustice had been engineered, and although I was determined to try to change it, my hands had to remain tied until the time was ripe.

First there was the problem of the B'nai B'rith claims itself. I had the precedent established by the highest Court that the Supreme Lodge did not own the property of the lodge abroad (in Yugoslavia) and therefore was not eligible to claim under the American War Claim Law. It was necessary to devise a theory which would enable us to by-pass the normal civil law and apply principles of equity based on the precedents I had established in Germany. As you will

17 United States Congress, Public Law No. 91-571, An Act to Amend Section 213 (a) of the War Claims Act of 1948 With Respect to Claims of Certain Non-Profit Organizations and Certain Claims of Individuals, Washington, D. C., 24. Dezember 1970. Durch dieses Gesetz wurde die Entschädigungsquote für karitative Organisationen nach dem War Claims Act von 1962 erheblich verbessert.

18 Der 1962 in den Vereinigten Staaten beschlossene War Claims Act regelte die Entschädigung amerikanischer Individuen und Unternehmen für aus dem Zweiten Weltkrieg in Feindstaaten resultierende Verluste. Siehe dazu Domke, The War Claims Act of 1962. 
recall, we were finally successful in overcoming the Yugoslavia precedent. Until we succeeded in obtaining a judgment for B'nai B'rith, there was no basis for trying to amend the priorities in the war claims legislation.

|2| We appealed against the inadequacy of the original judgment in favor of B'nai B'rith and succeeded in having it nearly doubled to close to $\$ 11 / 2$ million. Then we had to wait and see whether the claim would be paid in full as had been promised. It soon appeared that because large sums had been drained off out of the vested German assets, there would not be enough to satisfy everyone. The large corporations had consumed the vast bulk of the fund and only about $62 \%$ could be paid out. All the small claimants (up to $\$ 10,000$ ) and all the so-called "small business" claimants, had been paid in full, but unless the Law was changed, the large corporations would still get $83 \pitchfork$ out of every remaining dollar, wealthy individuals would get about $9 \$$, and the non-profit agencies would get only $8 \notin$.

To correct the inequitable system of priorities and to protect B'nai B'rith's award, I drafted an amendment to the Law in Feb. 1966. It provided that the non-profit agencies shouldn't be treated worse than business and should be paid next. Dave Brody ${ }^{19}$ had the Bill introduced by Senator Javits and Kenned $y^{20}$ joined as a sponsor.

For years the Bill lay pigeon-holed in the Judiciary Committee while the small business lobby tried to clean out the remaining fund by attaching hidden riders to other bills in order to get $150 \%$ interest on top of the $100 \%$ they had already received. These attempts were defeated by the narrowest of margins, and it became obvious that if we didn't do something more effective, there would soon be no money left.

It appeared that there were 29 Churches and Charities which would be the beneficiaries of the law I had drafted. I urged them to meet together and organize for united action. A Coordinating Council was formed and I agreed to represent them. Since I didn't want my personal interest to deter anyone from joining the group, the fee was fixed at whatever they thought was fair. Many of the largest claimants chose to remain outside the group and go for a free ride completely. The modest fee set by the council was much lower than the $10 \%$ referred to in the law. I didn't feel it would be equitable for B'nai B'rith to pay more than the newcomers. I therefore advised Rabbi Kaufman that the B'nai B'rith fee would be cut to the lowest level.

19 David A. Brody (ca. 1916-2004) war als Lobbyist für jüdische Interessen in Washington tätig und vertrat fast 40 Jahre lang die Anti-Defamation League des B'nai B'rith im Kongress.

20 Edward M. Kennedy (1932-2009) war ein amerikanischer Jurist und Politiker der Demokratischen Partei. Von 1962 bis 2009 war er Senator für Massachusetts. 
The story of how the Bill was moved through the Congress would require a recital of miracles. Dave Brody had persuaded Congressman Sam Friedel ${ }^{21}$ to introduce the Bill in the House, and we decided to make that our fixed battleground. Delegations representing Catholics, Jews and Protestants, and now purporting to speak for " 68 million Americans of all faiths", marched on Washington. Hearings were finally set and hold and the House was unanimously convinced that the Bill was fair. They went even further. They $|3|$ said that after Churches and Charities, those individuals who had only received $\$ 10,000$ plus $62 \%$ should come next, and the large corporations should come last.

We knew that Senator Dirksen ${ }^{22}$ had given instructions to keep the Bill frozen in the Judiciary Committee. When he died, his responsibilities were taken over by Senator Hruska, ${ }^{23}$ who was equally opposed. Senator Javits was no longer on the Judiciary Committee and Senator Kennedy had only lent his name. We finally managed to awaken Kennedy's interest and he began to press for hearings. We were now dependent upon the Chairman, Senator Eastland, ${ }^{24}$ who thought to kill the idea by designating a special sub-committee consisting of himself, Senator Hruska and Senator McClellan, ${ }^{25}$ all potential opponents. Again, the delegations marched and telegrams and letters flew. By now the corporations were out in force. Some of the largest American companies represented by prominent Washington law firms and lobbyists began to make their weight felt in opposition. All kinds of legal and constitutional objections were raised and referred to every conceivable governmental agency for opinion and delay. As fast as obstacles came up they

21 Samuel N. Friedel (1898-1979) war ein amerikanischer Politiker der Demokratischen Partei. Von 1953 bis 1971 war er Abgeordneter im Repräsentantenhaus der Vereinigten Staaten.

22 Der amerikanische Politiker Everett McKinley Dirksen (1896-1969) war von 1933 bis 1948 Abgeordneter im Repräsentantenhaus für die Republikanische Partei. 1950 wurde er für den Bundesstaat Illinois in den Senat gewählt, wo er ab 1959 als Franktionsvorsitzender der Republikaner wirkte. Er übte das Amt bis zu seinem Tod aus.

23 Roman L. Hruska (1904-1999) war 1953 zunächst für ein Jahr Abgeordneter der Republikanischen Partei im Repräsentantenhaus und wurde anschließend für den Bundesstaat Nebraska in den Senat gewählt. Er blieb bis zu seinem Eintritt in den Ruhestand 1976 als Senator im Amt.

24 Der Demokrat James O. Eastland (1904-1986) vertrat bereits 1941 einen vakant gewordenen Posten im Senat. Ein Jahr später wurde er selbst gewählt und war von 1943 bis 1978 Senator für Mississippi.

25 John L. McClellan (1896-1977) war von 1935 bis 1939 Abgeordneter der Demokratischen Partei im Repräsentantenhaus. Von 1943 bis zu seinem Tod vertrat er den Bundesstaat Arkansas im Senat. 
were knocked down, and hearings were finally held. By vote of 9 to 1 , the Judiciary Committee reported the bill favorably, but only after a considerable amount of persuasion both in Washington and in the home states of many of the principal Senators involved.

Senator Hruska would only accept a compromise according to which the non-profit groups would come next in line and then individuals and corporations, but only up to $\$ 35,000$ with the residue if any divided among the larger individual and corporate claimants. In the meanwhile, time was running out. By continuous nagging, and the combined political skills of Kennedy, Scott ${ }^{26}$ and Javits, the Senate finally passed the bill.

Because the Senate had changed the text, the Bill had to go back again to the House. There was no time for a Conference Committee to act. It had to be unanimously accepted in the form approved by the Senate. Any one vote against it would mean its demise. This time combinations of Representatives had to be set up to block even a single negative vote. Harley Staggers, ${ }^{27}$ Chairman of the House Committee, Congressman Friedel, now a lame duck, and the House Speaker McCormack ${ }^{28}$ now had to become the principal players. In a last-minute flurry of excitement the objectors were silenced, the revised Bill was unanimously voted by the House and was passed to the President on December 14th.

|4| With the Congress in recess on Dec. 23rd and the President having until midnight Dec. 25th to act, if he failed to sign the Bill it would die of a pocket veto. On the $23 \mathrm{rd}$ one of the principal corporate opponents solicited a telegram from the largest single Church claimant, the United Presbyterian Church, which had remained aloof from the Coordinating Council. The telegram stated that they did not support the Bill! It could only have been intended to block the President's signature. Again we laid down a barrage of defensive telegrams including one from the President of B'nai B'rith (thank you!). On Dec. 24th President Nixon ${ }^{29}$ signed the Bill into Law.

26 Wahrscheinlich ist der republikanische Politiker Hugh D. Scott (1900-1994) gemeint, der von 1959 bis 1977 für den Staat Pennsylvania im Senat saß und zuvor von 1941 bis 1945 sowie 1948 bis 1959 Abgeordneter im Repräsentantenhaus gewesen war.

27 Harley O. Staggers (1907-1991) vertrat die Demokraten von 1949 bis 1981 im Repräsentantenhaus.

28 John W. McCormack (1891-1980) war von 1928 bis 1971 Abgeordneter der demokratischen Partei im Repräsentantenhaus und von 1962 bis 1971 Sprecher des Hauses.

29 Richard Nixon (1913-1994) war von 1969 bis 1974 der 37. Präsident der Vereinigten Staaten. Er wurde 1947 Abgeordneter im Repräsentantenhaus und 1950 zum Senator gewählt. Unter der Präsidentschaft Eisenhowers amtierte er 1953 bis 1961 als Vizepräsident. 
I have sketched the bare outlines of what happened. The details of the staff meetings, reports prepared, speeches drafted, pleading, cajoling, threatening, nagging and everything else required to move the legislative mountain would make this an even longer story. Fortunately, we were blessed by a crew of volunteers who were as effective as they were devoted. On the B'nai B'rith side, in addition to Dave Brody, whose participation has been sketched above, Rabbi Kaufman, Herman Edelsberg, Maurice Weinstein, ${ }^{30}$ and the loyal secretaries Edith Miller ${ }^{31}$ and Hannah Sinauer all pitched in. My report to the Coordinating Council, which is attached, lists others. Your own support, as evidenced by your encouragement and your telegram published in the hearings before the Senate and your appeal to the White House, is not to be minimized.

Now all we have to do is to collect the money. Nothing comes automatically, but I am now confident that the B'nai B'rith will receive additional amounts of over half a million dollars as a result of the new law. About two-third of that should come fairly soon, and I will then get to work trying to squeeze out the remainder, which must be pried loose from the Department of Justice where it is tied up by pending litigation.

It will be a happy New Year for me finally to have disposed of a challenge which is now about nine years old. It completes a program of restitution to B'nai B'rith which I outlined for Phil Klutznick almost fifteen years ago. Forgive me for having sent you such a long "megilla" but I do so in the hope that it will also mean a happier New Year for you and for B'nai B'rith as well.

With warm regards,

Sincerely

Benjamin B. Ferencz

c.c. Rabbi Kaufman

Bernie Simon

Joe Sklover

30 Maurice Weinstein (1915-1995) war Rechtsanwalt und engagierte sich für den Ausbau von Erwachsenenbildungsprogrammen bei B'nai B'rith. Zudem wirkte er zeitweise als Vorsitzender des Internationalen Rats von B'nai B'rith.

31 Edith Miller arbeitete als Sekretärin für Jay Kaufman. 
7. Entschädigungsverhandlungen mit der DDR 



\section{Dokument 103}

Benjamin B. Ferencz an Ernst Katzenstein

Ohne Ortsangabe, 2. Januar 1973

Maschinenschriftlicher Brief, 1 Seite

$R G 12.006 .01^{\star} 01$

Dr. Ernst Katzenstein

January 2, 1973

Wiesenau 53

Frankfurt/Main

Germany

Dear Ernst:

In connection with the DDR syndrome, I think the time has come for the Claims Conference to take some soundings at the State Department.

The Jewish organizations have a legitimate interest in seeking to obtain compensation from Eastern Germany on behalf of the Nazi victims from that area who have not been adequately compensated under any of the existing laws. Since the State Department is undoubtedly getting ready to recognize the DDR ${ }^{1}$ it would be good to know whether all the private property owners whose assets in the DDR were lost are also remaining silent or whether some representations have already been made and what, if anything, is the preliminary feeling in the Department about what can or should be done.

Based upon such feelers perhaps a decision can be reached regarding the most suitable next steps. I would suppose that the legitimate question to be put to the Jewish organizations (which means to you) is: "What do you want?" Have you given it any thought?

With warm regards,

\{Ben\}

BENJAMIN B. FERENCZ

BBF: aa

c.c.: Saul Kagan

$\{$ Jan 15$\}$

1 Im Zuge der Entspannungspolitik der 1970er Jahre erkannten die Vereinigten Staaten die DDR 1974 völkerrechtlich an und nahmen diplomatische Beziehungen zu ihr auf. 


\section{Dokument 104}

Benjamin B. Ferencz an Charles Kapralik ${ }^{2}$

Ohne Ortsangabe, 18. Februar 1973

Maschinenschriftlicher Brief, 1 Seite

$R G 12.006 .01 * 01$

18 February 1973

Dr. Charles Kapralik - London

Dear Charles - alias Dr. Kapralik, alias Kopralik,

I send you my apologies for all spelling errors, committed either by me, when I type these letters at home, or by a new secretary who replaced my faithful English slave of 13 years, and who unfortunately lacks the efficiency of Miss Michel. But a rose by any other name would be equally loved. You will have noted that to save myself from accusations as well as boredom I merely dictate my long letters, but I am not so foolish as to read them.

Besides I think you are a trouble-maker. You had to ask Katzenstein about collecting from the DDR, and now I have about 2,000 pages of memoranda on my desk. Sorry I could not join you in Frankfurt. It seems like old times, and I would have enjoyed seeing many old friends discussing old problems. Oi do I feel old!

The DDR problem will be fun, and I am delighted to see that you are leading the charge. It may turn out to be the Light Brigade, but nothing ventured nothing in the pot. I did not mean to equate you with Wiesenthal, ${ }^{3}$

2 Charles (Carl) Kapralik (1895-1993) war ein jüdischer Verbandsfunktionär. Nach dem Studium der Rechtswissenschaft arbeitete er als Finanzfachmann in Wien. 1938/1939 leitete er die Finanzabteilung der dortigen jüdischen Gemeinde. 1939 floh er nach Großbritannien und arbeitete für verschiedene jüdische Organisationen wie den Central British Fund for Jewish Relief and Rehabilitation. Nach Kriegsende befasste er sich mit der Rückerstattung jüdischen Eigentums. 1950 war er Mitgründer der JTC, deren Generalsekretär er bis 1969 blieb. Zudem gehörte er den Vorständen mehrerer (jüdischer) Flüchtlings- und Opferorganisationen an. Kapralik publizierte zudem mehrere Bücher zur Rückerstattungspraxis und zur JTC.

3 Simon Wiesenthal (1908-2005) war Publizist und Überlebender mehrerer Konzentrationslager. 1947 war er Mitgründer des Zentrums Jüdische Historische Dokumentation in Linz, das sich der Dokumentation der nationalsozialistischen Verbrechen und 
but he was quickly quoted in the press as insisting that East Germany assume the obligations to the Austrians which the Federal Republic rejected. ${ }^{4}$ I think you will share his hope, but I agree that a lump sum is the only thing which seems even remotely probable.

I now try to avoid going into "Fun City" 5 as much as possible and am following in your footsteps. I am trying to write a book on the slave labor problems and at the same time am producing various scholarly articles on esoteric legal problems for learned journals. I therefore leave it to Katzenstein and his whirlwind mimeo machine to transmit copies of such wisdom or garbage as he considers useful.

You probably have seen a copy of my report on the views of the State Dept. I'm sure that is only the beginning of a long journey.

With all the best wishes to you and Mrs. Kapralik, Cordially, ${ }^{6}$

\section{Dokument 105}

Benjamin B. Ferencz

Ohne Ortsangabe, 7. März 1973

Maschinenschriftliche Aktennotiz, 1 Seite; handschriftliche Ergänzungen und Korrekturen

$R G 12.006 .01^{\star} 01$

der Suche nach den Tätern widmete. Nach der Schließung der Linzer Einrichtung 1954 gründete er 1961 das Dokumentationszentrum des Bundes Jüdischer Verfolgter des Naziregimes in Wien, von wo aus er seine Tätigkeiten fortführte. Zu Wiesenthal siehe Tom Segev, Simon Wiesenthal. Die Biographie, München 2010.

4 Siehe beispielsweise Anonymus, Mit Israel auf einer Linie. Auch die DDR müßte zu den Zahlungen für Kriegsgeschädigte einen Beitrag leisten, in: Sudetenpost. Offizielles Organ der Sudetendeutschen Landsmannschaft in Österreich, 19. Januar 1973, 1.

5 Damit ist das in der Nähe von New Rochelle (dem Wohnort von Ferencz) gelegene New York gemeint, das in den 1960er und 1970er Jahren unter diesem Namen bekannt war.

6 Unterschrift fehlt auf archivalischer Kopie. 
File Note of phone conversation with Mr. James Sutterlin, ${ }^{7}$ State Dept. Director of Office of German affairs, Phone (202) 632-1484

\{Sent. Helen C̊ole̊man. (\#\#\# J̊. Letzki)\}

I told him that the Jewish organizations in the Claims Conference were meeting on March 9, and I wanted to bring him up to date as well as learn whether there had been any change since our last meeting. I told him that Goldmann had met in Bonn with Brandt and Egon Bahrs as well as other party leaders, primarily to discuss shortcomings in the Federal Law but that the DDR problem had also been mentioned. The Germans were pleased that Jewish claims should be brought against the DDR. They did not offer to help but suggested that France would be a suitable intermediary and that Goldmann might best appear in his capacity as WJC. ${ }^{9}$

I asked Sutterlin whether he had any view on Goldmanns affiliation when presenting such claims. He felt that international claims such as global indemnity had best be presented in an international capacity whereas property claims relating to any specific nationality had best be presented by an organization from that specific nation.

I promised to advise him as soon as a position had been formulated regarding the nature and extent of claims to be put forward.

He told me that Goldmanns son \{Guido (they met at Harvard - took lecture \#\#\# together!)\} had seen him and stated that Goldmann was planning to take the matter up with Washington. He did not seem to fully grasp the nature of the Claims Conference organization or the different roles played by Goldmann. He stressed that whatever claims were presented should also deal with non-Jews. I agreed and indicated that past experience showed that non-Jews represented about $10 \%$ of the Jewish claims.

7 James S. Sutterlin (1922-2017) war von 1946 bis 1974 für das Außenministerium der Vereinigten Staaten tätig. Von 1969 bis 1973 wirkte er als Direktor der für Deutschland zuständigen Abteilung. Ab 1974 arbeitete er über ein Jahrzehnt für das Sekretariat der Vereinten Nationen.

8 Der sozialdemokratische Politiker Egon Bahr (1922-2015) wurde 1960 Leiter des Presse- und Informationsamts des Landes Berlin. 1966 wechselte er als Ministerialdirektor ins Auswärtige Amt und wurde anschließend 1969 Staatssekretär im Bundeskanzleramt. Von 1972 bis 1974 war er Bundesbevollmächtigter für Berlin und als Bundesminister für besondere Aufgaben der ständige Berater von Bundeskanzler Willy Brandt in Fragen der Ost- und Deutschlandpolitik.

9 World Jewish Congress. 
On present status he said the British and French had agreed upon a test with the DDR. Both were somewhat different, but the question of claims was left open, in that the options to come forward with claims at a later date and the nature of the claims was protected. As expected the DDR had reacted negatively regarding the assertion of any pre-war claims. They were less negative on postwar nationalization claims. Discussion on both however will be taken up later with all NATO countries. I can see the texts of the British and French agreements when I am in D. C. The U.S. text has not been put forward yet and it may be some months during which the position can be further clarified. No call up of new registrations was agreed upon yet for fear of arousing undue hopes. It may be done later. It appears that the property claims will be very substantial.

He has assigned a legal specialist to deal with these problems. He is David Small, a young and very able lawyer, just reassigned from Berlin. As soon as he and his family have settled down he'll call me for a briefing. ---

\section{Dokument 106}

Benjamin B. Ferencz an Ernst Katzenstein

Ohne Ortsangabe, 9. März 1973

Maschinenschriftlicher Brief, 2 Seiten

$R G 12.006 .01 * 01$

9 March 1973

Dr. Ernst Katzenstein - Frankfurt

Dear Ernst:

I am writing to give you the conclusions of the meeting which took place in New York today to deal with the DDR problem. Saul, Arnulf, ${ }^{10}$ and I had a preliminary discussion with Goldmann, and this was followed by the gathering of about 20 representatives of 14 member organizations.

10 Arnulf M. Pins (1926-1978) emigrierte 1936 von Deutschland ins britische Mandatsgebiet Palästina und 1938 weiter in die Vereinigten Staaten, wo er für diverse jüdische Organisationen und als Pädagogikdozent arbeitete. Von 1972 bis 1974 war er Mitarbeiter der JCC. Anschließend arbeitete er in Israel u. a. als stellvertretender Direktor des JDC Israel, als JDC-Direktor für den Mittleren Osten und für MALBEN, die Einrichtung des JDC zur Unterstützung kranker und älterer Einwanderer. 
Goldmann briefly reviewed his discussions in Bonn and his hesitation about accepting the responsibility for pursuing the DDR claims. He explained that he would first have to sound out Honneker [sic $]^{11}$ before reaching a final decision regarding his own involvement as well as the form of organizational involvement. He recognized that the Conference had a more experienced team, but it had been recommended that he appear as representative of the World Jewish Congress, which some felt would arouse less hostility. He had asked the French government to arrange the meeting with Honneker, and they were sounding it out informally first.

Goldmann had discussed the problem with Sapir ${ }^{12}$ who would handle it himself for the time being. There was no indication of anyone taking up our suggestion that Rosenne ${ }^{13}$ be involved. Goldmann's confidence in Ortar was not overwhelming. Goldmann referred to an Israel[i] demand of $\$ 500,000$ \{milillioํon\}. I would guess that this is a translation of $11 / 2$ billion DM. The Israel situation was still vague. ${ }^{14}$

Arrangements had been made by Goldmann to see Sutterlin at the State Dept. next week, but even though the arrangements had been made by Guido, Goldmann was not sure whether he would stick to it. We are urging him to do so.

A few representatives present asked some questions, a few more asserted their organizational jurisdiction and insisted on closer consultation, and the general consensus was that we would keep in touch. The official conclusion is that the matter is simply under advisement. Information should continue

11 Erich Honecker (1912-1994) war von 1971 bis 1989 Erster Sekretär des Zentralkomitees (ZK) der SED und ab 1976 zudem Staatsratsvorsitzender der DDR.

12 Pinhas Sapir (ursprünglich Koslowski; 1909-1975) emigrierte 1929 aus Polen ins britische Mandatsgebiet Palästina, wo er sich politisch engagierte und Mitglied der Hagana wurde. Nach der Staatsgründung Israels arbeitete er in leitenden Funktionen zunächst für das Verteidigungs- und später für das Handelsministerium. Ab 1955 bekleidete er verschiedene Ministerposten, darunter den des Finanzministers von 1963 bis 1968 sowie von 1969 bis 1974. Von 1974 bis 1975 war er Vorsitzender der Jewish Agency und der Zionistischen Weltorganisation.

13 Der israelische Jurist und Diplomat Shabtai Rosenne (1917-2010) arbeitete nach der Staatsgründung Israels als Rechtsberater des Außenministeriums. Von 1967 bis 1971 war er Stellvertreter des Ständigen Vertreters Israels bei den Vereinten Nationen in New York und von 1971 bis 1974 der Ständige Vertreter Israels bei den Vereinten Nationen in Genf. Rosenne war zudem von 1962 bis 1971 Mitglied der UN-Völkerrechtskommission.

14 Dies bezieht sich auf die symbolische Forderung nach dem »fehlenden Drittel«, das heißt einem entsprechenden Anteil der DDR an der 1951 von Israel und der JCC an die Bundesrepublik gestellten Entschädigungsforderung. Siehe Goschler, Schuld und Schulden, $403 \mathrm{f}$. 
to be gathered. The idea of asking for additional compensation for $|2|$ incarceration was characterized by Goldmann as an excellent idea, but he said that new ideas might also be forthcoming after further study. The whole situation will be reviewed again at another Conference meeting in either May, or more likely in July in Geneva.

Saul and I both made presentations of the facts and the alternatives to impress and confuse the representatives present. We did.

Those present were authorized and indeed urged to continue to give publicity to the fact that East Germany had an obligation to compensate former Nazi victims for personal and property losses.

It now seems likely that I will continue to be involved in this question as some kind of Special Counsel to the Claims Conference, much as was done in connection with the slave labor claims, and the two responsibilities will be merged.

That is the gist of the whole meeting which lasted less than 2 hours. It means that you are to continue doing what you have been doing anyway. Everyone was duly appreciative of the important role you have been playing. (No cash value.)

With warm regards,

Benjamin B. Ferencz

cc: S. K.

\section{Dokument 107}

Benjamin B. Ferencz an Siegfried Roth ${ }^{15}$

Ohne Ortsangabe, 18. Juni 1973

Maschinenschriftlicher Brief, 2 Seiten

$R G 12.006 .01^{\star} 01$

15 Siegfried (später Stephen) Roth (1915-1995) war ein Jurist und zionistischer Funktionär aus Ungarn. Roth engagierte sich in der Zionistischen Organisation Ungarns, in deren Vorstand er 1940 eintrat. Während des Zweiten Weltkriegs gehörte er zu den Gründern des Hilfs- und Rettungskomitees, das versuchte, Juden vor der Deportation zu bewahren. 1946 war er Gründungsdirektor der ungarischen Sektion des Jüdischen Weltkongresses, emigrierte kurze Zeit später nach Großbritannien und leitete von 1947 bis 1980 die europäische Sektion des Jüdischen Weltkongresses. Bis 1966 war er zugleich Generalsekretär der britischen Sektion. In diesen Funktionen war er an den 
June 18, 1973

Dr. Sigmund [sic] Roth

World Jewish Congress

55 Cavendish Street

London W.1, ENGLAND

\section{Dear Sigi:}

It is anticipated that the Security Council will very shortly move to admit the two Germanys into the United Nations. ${ }^{16}$ It may be appropriate at that time for members of the Council to make some remarks which may be helpful in connection with our plans to try to obtain compensation for Nazi victims from East Germany. Saul Kagan has spoken to Dr. Goldmann, who has agreed that such efforts should be made.

What we have in mind is simply some observations welcoming the movement toward conciliation but noting at the same time that true reconciliation requires that the victims of Nazi persecution throughout the world receive tangible evidence that the new governments of Germany recognize the obligation to compensate the victims for the injuries resulting from Nazi crimes and confiscations. What has been done by West Germany has been impressive, but a great deal more needs to be done - particularly by the East. Such corrective action would be welcomed and indeed required before the desired feelings of mutual respect can be achieved.

That is the general direction desired, and it will of course be adapted to the local requirements. Please coordinate whatever action is taken with all the Claims Conference member organizations in England, and particularly with Lord Janner. ${ }^{17}$ We would also appreciate it if you would contact Dr. Kaplan ${ }^{18}$ in Paris (whose current address I do not have) and advise him

Entschädigungsverhandlungen für jüdische Opfer des Nationalsozialismus beteiligt. 1966 wurde Roth Leiter des Institute of Jewish Affairs in London.

161973 wurden beide deutsche Staaten in die Vereinten Nationen aufgenommen.

17 Greville Janner (1928-2015) war neben seinen Tätigkeiten als Rechtsanwalt und Politiker im britischen Parlament in mehreren jüdischen Organisationen wie dem Board of Deputies of British Jews, dem Commonwealth Jewish Council and Trust und dem Jüdischen Weltkongress aktiv.

18 Armand Kaplan (ca. 1920-1984) war ab 1950 Generalsekretär der französischen Sektion des Jüdischen Weltkongresses und ab 1969 parallel Direktor für internationale Angelegenheiten. Er übte die Ämter bis zu seiner Pensionierung 1980 aus und setzte sich insbesondere für den Aufbau von Verbindungen zu jüdischen Gemeinden in Osteuropa ein. 
of the steps being taken and see him to do the same in Paris, in coordination with the interested French Jewish groups. I am sending a copy of this to Dr. Meyrowitz, ${ }^{19}$ with a request for his assistance and cooperation.

|2| We will do what can be done with the U.S. Government, and the B'nai B'rith will also try to move some of the non-permanent members of the Security Council. Please keep us and Dr. Katzenstein informed. You may write to my home address: 14 Bayberry Lane, New Rochelle, N. Y. 10804.

With warm regards,

BENJAMIN B. FERENCZ

BBF: LK

$\mathrm{CC}^{20}$

\section{Dokument 108}

Benjamin B. Ferencz an Ernst Katzenstein

New York, 10. September 1973

Maschinenschriftlicher Brief, 2 Seiten; gedruckter Briefkopf auf Seite 1, Kopfzeile auf Seite 2 (»Dr. Ernst Katzenstein September 10, 1973«)

$R G 12.006 .01{ }^{\star} 01$

\section{TAylor, Ferencz \& Simon \\ COUNSElors at LaW}

Telford TAYlor

OF COUNSEL

Benjamin B. Ferencz

KenNeth Simon
LiNCOLN BUILDING

60 EAST 42ND STREET

New York, N. Y. 10017

$* * *$

MO 1-0934

19 Henri Meyrowitz war ein französischer Jurist, Verfasser zahlreicher Publikationen zum Kriegsrecht und arbeitete unter anderem für die französische Zweigstelle der JTC.

20 Hier folgen die Adressen von Henri Meyrowitz, Ernst Katzenstein, Saul Kagan, Arnulf Pins, Herman Edelsberg und William Korey. 
Dr. Ernst Katzenstein

September 10, 1973

URO 119 Gruneburgweg [sic]

Frankfurt/Main

Germany

\section{Dear Ernst:}

I'm sorry you had to interrupt your vacation in Flims ${ }^{21}$ but after a week of pleasant loafing I'm sure your restless spirit was eager to soar anyway, so if I were to shed crocodile tears it would probably only be adding to your own. I hope you have the good sense to get back there, or reasonable facsimile, as long as the weather is good.

Saul and I are "tummelling" like crazy on the DDR business. We continue to nag the State Department and the U.S. Mission at the U.N. and have organized all the Jewish non-governmental organizations to nag all the governments they can reach, in order to obtain statements at the General Assembly opening on September 18th reminding the DDR of their unfulfilled obligations to the Nazi victims. To what extent we'll be successful remains to be seen. There has been complete silence from Roth and Riegner ${ }^{22}$ so I have no idea about what if anything is happening to give us some support from the other side of the ocean.

We are now considering an approach to the DDR Foreign Minister while he is here, in order to try to encourage or set up a meeting of Honecker with Nahum (preferably in the middle of his vacation) and to give him some idea of what it's all about.

The U.S. is now giving serious consideration to announcing that all American citizens who had property in the present DDR territory should file a report indicating the value of the assets. The information so obtained

21 Flims ist eine Gemeinde in der Schweiz.

22 Der deutsch-jüdische Verbandsfunktionär Gerhart Riegner (1911-2001) musste sein Studium der Rechtswissenschaft 1933 aufgrund der repressiven Politik der Nationalsozialisten in Paris und Genf fortsetzen. In Genf arbeitete er ab 1936 für die dortige Geschäftsstelle des Jüdischen Weltkongresses, zu deren Leiter er 1939 aufstieg. In dieser Funktion setzte er sich für Hilfsmaßnahmen für die verfolgten europäischen Juden ein. Bereits 1942 informierte er britische und amerikanische Stellen im sogenannten Riegner-Telegramm über das Vorhaben der Nationalsozialisten, alle Juden unter ihrer Herrschaft zu ermorden. Von 1948 bis 1983 war Riegner erst Mitglied, dann Generalsekretär des Exekutivausschusses des Jüdischen Weltkongresses und darüber hinaus Mitglied in verschiedenen internationalen Organisationen. 
would then serve as the basis for negotiations with the DDR for a settlement of those claims. It is not yet clear whether the registration would be restricted to those who were U.S. nationals at the time the property was lost or whether those who acquired American citizenship since that time would also be asked to register. I am inclined to think that, since the old Americans have already registered and settled their claims, that any new registration would apply only to new Americans. This, however, gives rise to a problem regarding which I need your help.

|2| As I recall it, the Lastenausgleich Office in Bad Homburg took the position that if a foreign national had a claim under his domestic law then he would be excluded from receiving any payments under the German equalization law, or at least that there would be a set-off and a postponement until the claim under the domestic law was settled. ${ }^{23}$ If that is so, then we face the danger that once the United States announces registration of claims by those who previously were not entitled to claim, i.e. the new Americans, then the LAG Office will stop all action on any LAG claims pending in Germany. Since the registration will only serve to give a financial basis for the negotiations between the U.S.A. and the DDR, and it will by no means indicate what, if any, payment will eventually be forthcoming, it occurs to me that we may be doing the Jewish claimants a big disservice if we were to insist upon the new registration.

What is necessary is to inquire at the LAG Office for an authoritative indication of what their reaction would be if the U.S. registration as indicated were to take place. If you can let us know it may be very important in connection with our recommendation for action by the U.S.

With warm regards,

\{Ben\}

BBF: aa

c.c. Saul Kagan (2)

23 Zum Lastenausgleichsgesetz siehe Kapitel 3, Fußnote 6. 


\section{Dokument 109}

Benjamin B. Ferencz

Ohne Ortsangabe, 21. November 1973

Aktennotiz, 2 Seiten; handschriftliche Ergänzungen auf Seite 2

$R G 12.006 .01{ }^{*} 01$

21 Nov. 1973

File Note: Subject DDR

By chance I was joined at the dining room table in the U.N. cafeteria by Dr. Gunter Görner ${ }^{24}$ Deputy Director Legal and Treaties Dept. Ministry of Foreign Affairs DDR and his deputy Mr. H. Meissner. They are in N. Y. for the 28th Gen. Ass. ${ }^{25}$ session and living at Hotel Tuscany (?).

We started a conversation. Meissner remained silent. I introduced myself and we managed to have a fairly thorough discussion of the entire DDR problem. $\{11 / 2$ hours $\}$

Gorner [sic] referred to the Potsdam agreement ${ }^{26}$ which they had carried out much more than West Germany, that the Soviets had, appropriately, he added, taken a heavy toll from the DDR for many years, they had ceded territories and it was their understanding that their agreements covered all of their obligations including personal damages, and that it was West Germany which would have to be responsible for any claims coming from the west. He referred to the claims for property losses coming in from many countries and

24 Der Völkerrechtler Gunter Görner $\left({ }^{*} 1939\right)$ arbeitete von 1963 bis 1990 im Ministerium für Auswärtige Angelegenheiten der DDR als Abteilungsleiter für Rechts- und Vertragswesen. Nachdem die DDR 1973 in die Vereinten Nationen aufgenommen worden war, beteiligte sich Görner an der Verhandlung internationaler Abkommen im Rechtsausschuss der Vereinten Nationen.

25 General Assembly.

26 Das zum Abschluss der Berliner Konferenz der drei alliierten Siegermächte, den Vereinigten Staaten, Großbritannien und der Sowjetunion, am 2. August 1945 verkündete Potsdamer Abkommen bestimmte als Teil der beschlossenen Maßnahmen zum weiteren Vorgehen gegenüber dem besiegten Deutschen Reich Grundsätze, nach denen Reparationszahlungen für die erlittenen Kriegszerstörungen geleistet werden sollten. Dabei wurde Deutschland reparationspolitisch in einen westlichen und östlichen Kreis geteilt, wobei die Sowjetische Besatzungszone für die Forderungen der Sowjetunion aufzukommen hatte, die zugleich aus ihrem Anteil auch die Forderungen Polens erfüllen sollte. Siehe André Steiner, Von Plan zu Plan. Eine Wirtschaftsgeschichte der DDR, Berlin 2007, 25. 
the extreme hesitation of the DDR to do anything in that area until the total volumes and basis would be clear. He seemed to doubt my assumption that they would eventually have to pay for the property claims of Ford and other large corporations. He was knowledgeable, friendly and pleasant. A young man of about 30 years of age. A bachelor, restricted to the 25 mile limit around N. Y. until diplomatic relations are established. He is from Thuringia.

I made the legal arguments and the public relations arguments. To his statement that the DDR could only deal with governments I recited the Claims Conference - Bund example which had worked out very well from every point of view. I chided him about their fear to even meet and hear the Conference position and told him that all we wanted from Winzer ${ }^{27}$ was to set up a meeting between Goldmann and Honecker. I assured him that the Conference was discreet and reasonable. He stressed that any public pressure would be counter-productive. I replied that detente could not be achieved without the DDR doing something in this area and that it would be impossible for them to receive favored nations treatment or US credits without coming to terms with the Jews in the US. He said that credits had to be repaid and they really didn't want much from the US.

As we left he made a point of the fact that our chance meeting was purely informal and that he had expressed his own private views and that nothing was to be used. I agreed. To my reminder that despite the merit of whatever arguments he could [|2|] make it was still in the interest of the DDR to do something for the Nazi victims in the west I seemed to detect a nodding agreement. I urged him to report back to his superiors about our conversation.

$\{27$ Nov. 73$\}$

\{I met Görner + Meissner at UN. I was w/ Katzenstein. They told me Görner had reported to his superior. No response. I gave Görner copy [sic] of my articles on

1. Comp\#\# Def. of Aggression ${ }^{28}$

2. Compensating Victims of the Crimes of $\mathrm{War}^{29}$

27 Der DDR-Politiker Otto Winzer (1902-1975) war ab 1947 Mitglied des Parteivorstands, später des ZK, der SED. 1956 wurde er stellvertretender Minister für Auswärtige Angelegenheiten. Von 1965 bis 1975 war er Außenminister der DDR.

28 Damit könnte gemeint sein: Benjamin B. Ferencz, Defining Aggression: Where it Stands and Where it's Going, in: American Journal of International Law 66 (1972), H. 3, 491-508.

29 Benjamin B. Ferencz, Compensating Victims of the Crimes of War, in: The Virginia Journal of International Law 12 (1972), H. 3, 343-353. 
3. West German Decision having slave labor claims + Adenauers Bekentnis [sic] zur Wiedergutmachung. ${ }^{30}$

I said I'd contact him again after Dec. 2 to consider whether meeting w/ current or the new Permanent Rep. ${ }^{31}$ Florin ${ }^{32}$ should be \#\#\#.

I had the impression that NY can't move w/o instructions from Berlin + the present policy is to look away whenever possible.\}

\title{
Dokument 110
}

Benjamin B. Ferencz an Nahum Goldmann

Ohne Ortsangabe, 4. Dezember 1973

Maschinenschriftliches Memorandum, 2 Seiten; maschinenschriftliche Unterstreichungen

$R G 12.006 .01^{\star} 01$

\section{CONFIDENTIAL: To DR. NAHUM GOLDMANN}

\author{
MEMORANDUM
}

\section{Magnitude and Basis of Claims Conference Demands Against the DDR}

Should it be possible to discuss Jewish claims with DDR representatives the following should be considered:

It should be noted that indemnification for personal injuries to Nazi victims is fundamentally a moral and political obligation which has nothing to do with war reparations as settled in the Potsdam agreement.

30 Damit könnte gemeint sein: Benjamin B. Ferencz, Restitution to Nazi Victims: A Milestone in International Morality, in: Harry Schneiderman (Hg.), Two Generations in Perspective. Notable Events and Trends 1896-1956, New York 1957, 300-310.

31 Representative.

32 Der Politiker Peter Florin (1921-2014) war seit der Gründung der DDR in verschiedenen Positionen für das ZK der SED sowie das Außenministerium tätig. Von 1973 bis 1981 wirkte er als ständiger Vertreter bei den Vereinten Nationen und wurde anschließend Vorsitzender der UNESCO-Kommission der DDR. 1969 bis 1989 war er stellvertretender Außenminister der DDR. 
1. A Global Sum to the Claims Conference as Partial Reimbursement for The Cost of Absorbing Concentration Camp Survivors in Countries Outside of Israel.

It was recognized in The Hague that the Jewish organizations, and Israel, had expended enormous sums to absorb the victims of the camps. It was specifically agreed by all parties that the Bund, having received only a portion of the Reich territory and assets, would pay only two-thirds of the recognized debt. ${ }^{33}$ Accordingly, the Claims Conference received 450 million DM. The remaining share of 225 million DM is unpaid. (Consideration of the Israel share of 1.5 billion DM should await a more favorable political climate.)

The funds received by the Claims Conference would be used for the relief and rehabilitation of Jewish Nazi victims outside of Israel.

2. A Global Sum as Compensation for Heirless Property and Unclaimed Individual, Communal and Organizational Property.

Only a very small fraction of former Jewish property in the DDR has been returned or is used by Jews or newly reestablished Jewish communities. The value of the property retained for the benefit of the DDR can only be estimated, but it would surely amount to several hundred million DM.

\section{Direct Compensation by the DDR to Individual Victims of Persecution.}

No one contemplates a massive claims program along the lines enacted by the Federal Republic. What is called for, however, is a gesture by the DDR to show that in declaring itself to be the legitimate successor to a portion of the Reich, it is willing to assume an obligation to do something for Hitler's victims. One of the simplest, most direct, and most needy steps would be to pay a specific turn for each month of recognized deprivation of liberty. The Federal Republic, and its courts have de- $[|2|]$ clared that the 5 DM per day now paid by the Bund is only a partial payment. (The Bund also pays for

33 Die israelische Regierung begründete ihre Reparationsforderung an Deutschland in Höhe von 1,5 Milliarden US-Dollar mit den Verlusten des jüdischen Volks durch deutsche Hand sowie den Eingliederungskosten für etwa 500000 Einwanderer aus früher vom Deutschen Reich besetzten Ländern. Zwei Drittel dieser Forderungen wurden an die Bundesrepublik adressiert. Siehe Goschler, Schuld und Schulden, 160, 163 und $171 \mathrm{f}$. Zu den Verhandlungen in Wassenaar zwischen Israel, der JCC und der Bundesrepublik und dem daraus resultierenden Luxemburger Abkommen von 1952 siehe ebd., 159-175; Sagi, Wiedergutmachung für Israel; Jelinek, Deutschland und Israel 1945-1965, v. a. 161-250; Hansen, Aus dem Schatten der Katastrophe, 155-366; Diner, Rituelle Distanz. 
damage to health caused by persecution.) The amount is totally inadequate by every standard. The amount of $5 \mathrm{DM}$ per day should at least be equalled by the DDR.

Payment to individuals on humanitarian grounds would not violate any socialist doctrine and should not create insurmountable political problems even if some of the beneficiaries now reside in Israel. If the additional payment is made to all those, Jews and non-Jews alike, whose claims have been recognized by the Bund, the administration would be easy, and the cost could be precisely predicted at about 2.5 billion DM. If, in order to avoid problems with other Eastern countries, payment is to be made only to Jewish claimants (in recognition that they were the worst treated as the principal and primary objects of Nazi extermination), the cost to the DDR would be less.

\section{Conclusion:}

The cost of the 3 items above is less than 3 billion DM. Payments can be spread over a number of years. (As in The Hague, trade arrangements rather than cash could be considered, if necessary.) Any settlement with the Claims Conference would be without prejudice to individual property restitution claims, or any settlements with Western Governments regarding nationalized corporate or individual property or bondholder claims.

$\mathrm{BBF} / 12 / 4 / 73$

\section{Dokument 111}

Benjamin B. Ferencz an Ernst Katzenstein

Ohne Ortsangabe, 2. Februar 1974

Maschinenschriftlicher Brief, 1 Seite

$R G 12.006 .01^{\star} 02$

2 February 1974

Dr. Ernst Katzenstein: Frankfurt

Dear Ernst:

This is just to bring you up to date on what has not been happening in connection with our "claims" against the DDR. You will recall that with the outbreak 
of the Middle-East hostilities ${ }^{34}$ it was decided to defer any further action on this subject until the time might appear to be more opportune. With that nice excuse both Saul and I were happy to do nothing.

Now we are beginning to stir again. A few days ago I sent Mr. Florin, the new DDR permanent representative at the UN, a copy of my latest article on aggression, with an inscribed extra copy for their representative on the Sixth Committee $^{35}$ whom you met while you were here. I also noted that I would like to see him soon on a matter which would be of interest. I will wait awhile [sic] and then try to approach him for a meeting.

I have been in touch with Dr. Hermann as per copy attached. I would suggest that you try to get copies of the article in Die Zeit. Unfortunately, my copy is so bad that I can not have it duplicated. I have had no word regarding my draft reply to the Foreign Minister of Canada, or my suggested intervention in the DDR via the International League for the Rights of Man. I hope to take these up soon, and I have also requested the U.S. Dept. of Commerce for a list of firms doing business with the DDR so that we may consider whether a useful approach can be made in that direction. I am also in touch with the U.S. Government authorities who are already having their hands full with the DDR generated problems in Berlin and elsewhere.

Otherwise all is quiet on the East German Front.

With warm regards,

CC: Kagan,

Pins

\section{Dokument 112}

Benjamin B. Ferencz

Ohne Ortsangabe, 18. Juni 1974

Maschinenschriftliches Memorandum, 1 Seite

RG $12.006 .01{ }^{*} 02$

34 Im Oktober 1973 griff eine von Ägypten und Syrien angeführte Koalition arabischer Staaten Israel an. Die Kämpfe werden als Jom-Kippur-Krieg oder auch vierter arabisch-israelischer Krieg bezeichnet.

35 Das Sixth Committee ist der Hauptausschuss der Generalversammlung der Vereinten Nationen zur Erörterung rechtlicher Fragen. 
18 June 1974

File Memo: Claims Against the DDR

From: Benjamin B. Ferencz

On 18 June 1974 I had lunch at the Harvard Club with Gerhard Haensel, ${ }^{36}$ First Secretary of the DDR Mission to the U.N. The meeting lasted 2 hours and took place in response to my invitation to discuss the attitude of the Jewish community in the USA with reference to the DDR. He understood that I was acting on behalf of the Claims Conference and we agreed that the meeting was informal and unofficial. The atmosphere was friendly but cautious.

Mr. Haensel stated that he was fully informed regarding my informal meetings with Dr. Gunter Görner, who represented the DDR at the meetings of the U.N.s Third (Legal) Committee last fall. I repeated the gist of my argument that there was both a legal and a moral basis to except the DDR to provide compensation to Nazi victims now resident in the West, and that there was an even more impelling political imperative, as part of the overall desire for detente, that some gesture of conciliation be made. I described the extreme sensitivity of the Jewish community on this issue.

Mr. Haensel explained that the DDR mission was limited to dealing with U. N. problems and was under instructions not to concern itself with any other American issues. He offered that as an explanation why there had been no response to Saul Kagan's personal letter addressed to Foreign Minister Winzer when he was in New York. In fact Haensel said he knew nothing about that letter. He also seemed surprised to learn that Senator Javits had written to Mr. Kissinger ${ }^{37}$ opposing any recognition of the DDR by the U.S. until the Jewish claims question was settled.

I explained that Dr. Goldmann was not inclined to address any official communication to Mr. Honecker until he knew that it would not generate the type of confrontation we were seeking to avoid. In response to my question about what steps were now recommended to move out of the present impasse the thought was expressed that the Claims Conference might address a letter to the Foreign Ministry requesting that a meeting take place with the appropriate official to consider this matter. I suggested that Mr. Haensel might render a service to his government if he were to inform them of the seriousness and significance of the problem as seen from the United States.

36 Gerhard Haensel war Sekretär der ständigen Vertretung der DDR bei den Vereinten Nationen und dort u. a. Mitglied des Informationskomitees.

37 Der amerikanische Politiker und Professor für Politikwissenschaft Henry Kissinger ( $\left.{ }^{\star} 1923\right)$ war von 1969 bis 1973 Sicherheitsberater des Präsidenten Richard Nixon und 1973 bis 1977 Außenminister der Vereinigten Staaten. 
Mr. Haensel understood that I would report our conversation to the Claims Conference meeting in July. We agreed to remain in contact.

\section{Dokument 113}

Benjamin B. Ferencz

Ohne Ortsangabe, 21. Mai 1975

Maschinenschriftliches Memorandum, 3 Seiten

$R G 12.006 .01 * 03$

[Ferencz erläutert den Fortgang der Verhandlungen mit Vertretern der DDR über mögliche Restitutions- und Entschädigungszahlungen. Im Fokus des Berichts steht ein Treffen mit hochrangigen Vertretern des Komitees der Antifaschistischen Widerstandskämpfer in Ostberlin, bei dem verschiedene Rechtsstandpunkte ausgetauscht wurden. Zudem berichtet Ferencz über ein Anschlussgespräch in der amerikanischen Botschaft in Ostberlin.]

\section{Memorandum}

\section{CONFIDENTIAL}

Re: $\quad$ GDR

On 20 May 1975 at 3:30 pm I met with Ludwig Einicke, ${ }^{38}$ Mitglied des Präsidiums des Komitees der Antifaschistischen Widerstandskämpfer ${ }^{39}$ in his office at Unter den Linden 12, phone (0372)2000236. I had cabled that I was coming and as agreed with the State Department in Washington the appointment was confirmed by the US Embassy in East-Berlin a few days before my arrival. The meeting was a follow-up of my report of December 16, 1974. The primary purpose was to encourage a meeting between Dr. Nahum Goldmann and Eric [sic] Honecker and to keep alive the subject dealt with in December. The meeting lasted one hour and 20 minutes and was cordial throughout.

38 Ludwig Einicke (1904-1975) war ab 1962 Präsidiumsmitglied des KdAW und nach seinem Übergang in den Ruhestand 1969 weiterhin als politischer Mitarbeiter für die Organisation tätig. Zuvor hatte er als Journalist sowie Leiter verschiedener Ministeriumsabteilungen und Institute in der DDR gearbeitet.

39 Das Komitee der Antifaschistischen Widerstandskämpfer (KdAW) war der Nachfolger der 1953 aufgelösten Vereinigung der Verfolgten des Naziregimes (VVN). Es war eng mit der SED verbunden und vor allem auf dem Gebiet der Traditionspflege des kommunistischen Widerstands tätig. 
After some initial pleasantries about the recent celebrations in the GDR to commemorate the "liberation" 4030 years ago, I informed Mr. Einicke about [the] development since our December meeting. Their proposal that they would consider only American claims and would meet only with American nationals had encountered severe opposition from the Jewish side. Dr. Goldmann, as President of the Claims Conference, felt that such a discrimination was both politically and morally unjustified and unacceptable. These views had been communicated to the State Dept. which had urged that negotiations not be broken off. Goldmann felt that the only way to overcome the impasse was to take it up to a higher level. He therefore wished to meet personally with Honecker, who had twice indicated an inclination toward such a meeting by his observations to the late Joseph Wulf ${ }^{41}$ and some recent remarks to Ambassador Cooper ${ }^{42}$ who had reported on Honecker's initiative in that direction. Nonetheless efforts to finalize such a meeting via the GDR Ambassadors in Berne and Paris had been unproductive. I stated that Goldmann would probably be available any time in June and asked Einicke for his suggestions on what could be done to expedite a meeting between Goldmann and Honecker.

Einicke's initial reaction was to suggest that the US government make an official request on behalf of Goldmann as a US-citizen, but this was quickly dropped when I observed that GDR's refusal to deal with this problem on a government-to-private-organization-level had been one of the major stumbling blocks during the Hartman-Suss ${ }^{43}$ talks and was therefore not

40 Gemeint sind die Feierlichkeiten zum 30. Jahrestag des Endes des Zweiten Weltkriegs. Der 8. Mai 1945 diente in der DDR als zentraler erinnerungspolitischer Bezugspunkt.

41 Der jüdische Historiker Joseph Wulf (1912-1974) überlebte die Inhaftierung in Auschwitz und war im Anschluss Mitgründer der Jüdischen Historischen Kommission in Krakau, die nationalsozialistische Verbrechen dokumentierte. In seinen Arbeiten beschäftigte er sich mit der Geschichte des Nationalsozialismus und dem Holocaust. Siehe Klaus Kempter, Joseph Wulf. Ein Historikerschicksal in Deutschland, Göttingen/Bristol, Conn., ${ }^{2} 2014$.

42 John S. Cooper (1901-1991) war ein amerikanischer Politiker der Republikanischen Partei und von 1946 bis 1973 mit kurzen Unterbrechungen Abgeordneter des Senats. Anschließend wirkte er von 1974 bis 1976 als Botschafter der Vereinigten Staaten bei der DDR.

43 Ferencz bezieht sich auf die Gespräche zwischen Arthur A. Hartman und dem Unterhändler der DDR, Herbert Süß, die am 4. September 1974 zur Aufnahme diplomatischer Beziehungen zwischen den Vereinigten Staaten und der DDR führten. Vgl. Stefan Meining, Im Schatten der Vergangenheit. Ostdeutsch-jüdisch-amerikanische Beziehungen (1974-1989), in: Heiner Timmermann (Hg.), Diktaturen in Europa im 20. Jahrhundert - der Fall DDR, Berlin 1996, 695-720, hier 699. 
likely to be favored by either government. He then suggested that Goldmann send a personal letter to Honecker in his capacity not as a government official but in his organizational capacity as First Secretary of the SED and, making reference to the favorable indications received via Wulf and Ambassador Cooper, suggest a personal discussion, rather than a negotiation, to consider the problems. Einicke felt that there would be a favourable reply, but in response to my question conceded that he had no specific basis for his assumption. My request whether his Committee could take the initiative in suggesting a meeting to Honecker was answered in the negative. He said they could comment if asked, and in that case he would recommend a meeting. We agreed that I would pass this advice on to Goldmann with a favorable recommendation.

|2| We reviewed various possible scenarios should further progress appear to be possible. He repeated what he had told me in December - that the Committee was ready to meet with a Jewish delegation outside of Germany, and would consider the questions raised sympathetically and with a serious intent to reach some understanding, but according to their instructions the Committee could only meet with an American delegation and could only consider claims of American nationals. I asked whether American claims could be considered only as a beginning or whether that was to be the end. He replied that no other claims had yet been raised on an organization-toorganization level and if such claims would be raised in that form they might have to deal with them. I had the impression that his response was improvised. He was reluctant to concede that the GDR policies were influenced by either Arab or US pressures.

I asked whether it would be possible to find some formula which would be sufficiently vague so as to allow each side free to consider the payment to be acceptable within their respective frames of reference. There was no clear response.

We talked about the size and nature of possible claims. I indicated that even American claims alone could easily exceed the GDR's capacity or willingness to pay. I noted that one American agency alone had spent over 100 million dollars in providing relief and rehabilitation to Nazi victims, and such "absorption costs" had been accepted by the Federal Republic as a sound basis for payments to Israel and the Claims Conference. If we added heirless property and Jewish organizational property claims, as well as the unpaid portion of DM225 mio [sic] which the FRG withheld from its payment to the Claims Conference the bill would swell accordingly.

I told Einicke that I had discussed the GDR capacity to pay with the US Dept. of Commerce which had given me a memorandum of comparative figures between the GDR and the FRG. The US felt a substantial increase 
in trade would be possible and that the GDR could find a US market for its machine tools and optical goods among others. Should Most Favored Nations treatment become available at some future date that would provide a major stimulus, but that possibility was dependent upon US good-will and was not unrelated to human rights considerations.

I again reminded him that when the Conference had negotiated with the Federal Republic that country was in a worse financial position than the GDR today. The agreement had taken into account, since an arrangement was made whereby goods were shipped for over 10 years, and in fact it had proved to be a very good thing for the FRG not only politically but economically as well.

In response to my question whether his Committee had yet given any consideration to the nature and size of an acceptable claim he replied that they had not. Since the Committee itself was without any means all they could do would be to consider whatever claims was submitted and then refer it to other departments of the government for advice or action.

|3| Before we parted I told him that I felt his Ambassador in Washington was making a serious public relations mistake in giving American Jewish leaders the impression that he was not prepared to receive a Jewish delegation. Einicke expressed the view that the action of Ambassador Siebers [sic] ${ }^{44}$ was a further reflection of the GDR policy not to allow the question of Nazi victims claims to be considered on any governmental level. In that context I indicated that a refusal by Honecker to meet with Goldmann would invite an explosion and Einicke again reiterated the importance of making a distinction between an approach to Honecker as a government official and the recommended approach to him in his capacity as an organizational man.

All of this, in my view, is a reflection of the GDR attempt to rewrite the history of Germany by treating the Eastern part as a liberated victim of the "Fascists" in the West, and for that reason they refuse to acknowledge any governmental connection between the Third Reich and the new socialist GDR.

Immediately after my meeting with Einicke I went to the US Embassy in East Berlin and reported in full to Brendon Grove, ${ }^{45}$ the Chargé d'Affairs

44 Der Ökonom Rolf Sieber $\left({ }^{\star} 1929\right)$ war nach verschiedenen wissenschaftlichen Positionen an der Hochschule für Ökonomie in Berlin von 1974 bis 1978 Botschafter der DDR in den Vereinigten Staaten und Kanada. Nach seiner Rückkehr in die DDR wirkte er als Rektor der Hochschule für Ökonomie Berlin.

45 Der amerikanische Diplomat Brandon Grove (1929-2016) war zwischen 1974 und 1980 in der neu eröffneten US-Botschaft in Ostberlin tätig. Anschließend wirkte er als Generalkonsul in Jerusalem, als Botschafter in Zaire (Kongo) und ab 1988 als Direktor des Foreign Service Institute, der Ausbildungsstätte der Vereinigten Staaten für Laufbahnen im diplomatischen Dienst. 
and William Nenno, ${ }^{46}$ the Second Secretary. Grove expressed the view that we had taken the correct step and seemed intrigued by the distinction between Honecker as party man and Honecker as a member of the Government Politbureau [sic]. They agreed to recommend to the US Ambassador Cooper that he urge GDR Ambassador Siebers, who was visiting Berlin, and whom he would see shortly, to meet with a Jewish delegation and, if possible, for Ambassador Cooper, to encourage a meeting between Goldmann and Honecker.

Frankfurt, May 21, 1975

$\mathrm{BBF} / \mathrm{ik}$

Benjamin B. Ferencz

\section{Dokument 114}

Benjamin B. Ferencz

Ohne Ortsangabe, 11. Dezember 1975

Maschinenschriftliches Memorandum, 1 Seite; handschriftliche Korrekturen $R G 12.006 .01^{\star} 03$

File Memo: Re: GDR

\{Confidential\}

Dec. 11, 1975

Kagan reported that he had spoken to Goldmann along the lines of my letter of $5 \mathrm{Dec}$. and that we had the green light to start protests at the State Dept. He also sent a memo dated Dec. 10 transmitting a message from Max Melamed of the WJC ${ }^{47}$ that he had received a letter dated Dec. 4 from Armand Kaplan of the WJC Paris advising that a high level GDR trade delegation was about to visit Washington and requesting that Kagan be advised so that the claims question could be raised.

I phoned James Treichel, ${ }^{48}$ Commerce Dept. Eastern European Affairs Div. (202) 967-2645 with whom I had discussed the problems earlier (Apr.

46 William Nenno (gest. 2008) war Diplomat und am Aufbau der ersten US-Botschaft in der DDR beteiligt.

47 World Jewish Congress.

48 James A. Treichel (1937-2014) arbeitete zunächst für das Handelsministerium und von 1966 bis 1982 für das Außenministerium der Vereinigten Staaten. Dort war er u. a. mit Fragen des Handels mit Staaten aus dem sowjetischen Einflussbereich betraut. 
1975). (First I called Melamed and had him read me Kaplan's letter). Treichel had been transferred to State Dept. Soviet Trade desk. Donald Hasfurther ${ }^{49}$ now handles GDR at Commerce.

I called John Kornblum ${ }^{50}$ at State. (202) 632-0665. He was out but his asst. ${ }^{51}$ John Ward was fully informed. He advised that GDR Deputy Minister of Foreign Trade, Gerhard Beil, ${ }^{52}$ had been in Washington on an "unofficial visit", and had met with Hartman. ${ }^{53}$ Kornblum, but not Ward, had been present but Ward had Kornblums report. The exchange was general and Beil intended to meet several US banks and manufacturers in the hope of stimulating trade. Hartman expressed to Beil that progress in other areas was dependent upon progress re the claims including Nazi victims claims. Mr. Geyer ${ }^{54}$ of GDR Foreign Affairs desk at the GDR Embassy in D. C. replied that the Anti-Fascist Committee chairman Funke ${ }^{55}$ was going to be in touch with me about it.

I told Ward that I had heard nothing from the Committee after Einicke's death and that Einicke had even retracted what he had told me at our last meeting in East Berlin, and that the Jewish organizations were rather fed up and determined to start pounding on some tables. I had called in the hope

49 Donald J. Hasfurther war Mitarbeiter des US-Handelsministeriums und dort für die Staaten des Warschauer Pakts zuständig.

50 John C. Kornblum $\left({ }^{\star} 1943\right)$ war ab 1964 im diplomatischen Dienst der Vereinigten Staaten tätig. 1973 bis 1975 war er Mitglied des politischen Planungsstabs im Außenministerium und leitete anschließend die Abteilung für europäische regionalpolitische Angelegenheiten. Nach zahlreichen Tätigkeiten im Außenministerium, an europäischen Vertretungen der Vereinigten Staaten und bei der NATO war Kornblum 1997 bis 2001 Botschafter in Deutschland.

51 Assistent.

52 Der Politiker und Ökonom Gerhard Beil (1926-2010) war ab 1961 im Ministerium für Außenhandel der DDR tätig. Von 1969 bis 1976 übte er das Amt des Staatssekretärs und anschließend des stellvertretenden Ministers aus. 1986 bis 1990 war er Minister für Außenhandel.

53 Vermutlich Arthur A. Hartman (1926-2015), der seit 1948 im Außenministerium der Vereinigten Staaten arbeitete. Im Zuge seiner diplomatischen Karriere war er von 1974 bis 1977 Leiter des Europareferats. Anschließend wurde er Botschafter der Vereinigten Staaten in Frankreich und ab 1981 in der Sowjetunion.

54 Hans-Martin Geyer ( ${ }^{\star}$ ca. 1922) war ein politischer Funktionär und Diplomat der DDR. Ab 1963 leitete er die außereuropäische Abteilung (Amerika) im Ministerium für Auswärtige Angelegenheiten.

55 Otto Funke (1915-1997) war ab 1974 Vorsitzender der Zentralleitung des KdAW. Er gehörte als Abgeordneter seit den 1950er Jahren der Volkskammer der DDR und ab 1963 auch dem Zentralkomittee der SED an. 
of intercepting the mission in order that we would be able to make both negative and positive recommendations. The negative ones, such as no trade and no $\mathrm{MFN}^{56}$ treatment without a claims settlement, and the positive ones by exploring the possibilities for receiving goods as part of the settlement. I noted that we had done the same with the Fed. Rep. when they were in worse economic condition [s] than the GDR and that it had all worked out very well, particularly for German industry, by priming the pump and opening new markets. Ward was obviously taking notes and had many questions.

Ward noted that the GDR mission had left on Dec. 8th, that Hartman had done all he could, that Ambassador Cooper had met with Honecker in a long meeting and had also noted US eagerness for progress on claims (to which Honecker had not replied) and that Hartman was in Europe. I agreed to hold off action until after Hartman's return and to call Ward again at the beginning of 1976 (early Jan.) to try to review facts and set up meetings if necessary. Kagan says Goldmann may be planning a Washington visit at that time and we can explore advisability of his joining any meeting.

CC: EK, SK

$\{\mathrm{BBF}\}$

\section{Dokument 115}

Benjamin B. Ferencz an Ernst Katzenstein

Ohne Ortsangabe, 28. September 1976

Maschinenschriftlicher Brief, 2 Seiten

$R G 12.006 .01{ }^{*} 04$

28 Sept. 1976

Dear Ernst:

We were delighted to hear from you and even more so from Hilda via your kind letter from Buhlerhohe [sic]. If Hilda can send such nice notes with such a clear hand and mind, she's obviously doing better than I am and there is every reason to expect that she will soon be back to enjoying life as heretofore. Let us hope so, for both of you, and that was included among our New Year's wishes.

56 Most favored nations. 
Knowing that you had more important things on your mind I have deliberately refrained from writing to you on some of the business matters which have been transpiring here. Since your worst anxieties seem to be over you can no longer escape.

There has been a lot of excitement on the DDR problem. The U.S. Foreign Claims Commission and the State Dept. tried to get the Congress to enact come [sic] routine enabling legislation which would allow the commission to begin to predetermine the property claims. The draft law said nothing about Jewish claims. I raised hell. My point was that the U.S. should not seem to be concerned only with the large US corporate losses which is the truth as far as the Executive Branch is concerned. I testified at the Congressional Hearings and urged the US to be mindful and supportive of claims for heirless property, reimbursement to welfare agencies of rehabilitation and resettlement costs, a supplementary payment for incarceration, etc. Leave it to me! The sponsors of the bill were of course furious.

I finally made a deal with the State Dept. according to which the Dept. would support the Claims Conference efforts for a separate arrangement with the DDR and if that failed then the State Dept. would negotiate the items on the gov't to gov't negotiations $\mathrm{re}^{57}$ Claims Settlement. The understanding was to be incorporated into the record of the Committee hearings. I made such a fuss that I don't think the Congress will act at all until after the election.

The State Dept. instructed Ambassador Cooper to talk to Honecker and tell him how important it was to settle all the claims. The Ambassador reported back that he felt a symbolic settlement would be possible. He urged that I come to Berlin to talk to the Anti-Fascist Committee. Today a cable arrived from Funke to the Claims Conference asking that a representative come to Berlin soon to negotiate. I have drafted a reply from the C.C. giving him the dates I will be in Germany for the URO meeting and asking the $|2|$ Committee to confirm. I have suggested that the meeting would be exploratory only. I hope the Claims Conference can make up its mind before then just what we expect or want from the GDR. Perhaps we can get some clearer picture when Nahum is here next week.

Unfortunately Saul has, as you know, also had his mind on other and more pressing problems. ${ }^{58}$ The situation is a mess. I need not tell you that I am convinced that Saul personally has not profited in any way from whatever dealings caused the bank to be taken over. Since the bank no longer exists Saul's job has also gone down the drain. The Holding Co. still exists as a shell without assets. Whether the shareholders are willing to put some more money

57 Regarding.

58 Siehe dazu Dokument 158. 
into the pot to try to salvage some of the bank's assets is doubtful. It is also uncertain whether or not those shareholders whose investments have been wiped out will try to find a scapegoat. In short Saul is available and indeed rather desperately in need of new employment. The cloud over the bank does not make it easy. Various alternatives are being probed but it is still too early to know the outcome.

I'm OK and usually buried in writing. I have a few more chapters finished of "Less Than Slaves" and I hope to get it off my neck by the end of the year at the earliest. The family is relatively OK too. No complaints.

Keep well and renewed good wishes for the coming year.

With warm regards, ${ }^{59}$

\section{Dokument 116}

Benjamin B. Ferencz

Ohne Ortsangabe, 3. Dezember 1976

Maschinenschriftliches Memorandum, 4 Seiten; Kopfzeile ab Seite 2 (»GDR File Memo«)

$R G 12.006 .01{ }^{*} 04$

[Für die eigenen Akten dokumentiert Ferencz seine Aktivitäten in den Verhandlungen mit der Regierung der DDR. Neben einer präzisen Erfassung von Treffen mit verschiedenen Vertretern der DDR thematisiert er den Vorschlag einer einmaligen Sonderzahlung in Höhe von einer Million US-Dollar durch das Komitee der Antifaschistischen Widerstandskämpfer an die JCC. Abschließend begründet er die Zurückweisung des Geldes durch die JCC.]

B.B. Ferencz

Dec. 3rd, 1976

File Memo: Subject: Claims Against the GDR

19. Nov. 1976. On arriving in Berlin I phoned the US Embassy (0372) 2202741, and spoke to William Nenno. I learned that the Chargé Brendon Grove had been replaced by Saul Polansky. ${ }^{60}$ They had heard from the Department and

59 Unterschrift fehlt auf archivalischer Kopie.

60 Gemeint ist Sol Polansky (1926-2016), der seit 1952 für das Außenministerium der Vereinigten Staaten arbeitete. Zwischen 1976 und 1979 war er Stellvertreter des amerikanischen Botschafters in Ostberlin. Anschließend wirkte er in der Botschaft 
had been discussing my visit that morning. I told them of the Funke cables and the phone call from the GDR Embassy in Washington asking for the Claims Conference bank account number. I asked if they knew anything new. They said no. We agreed that I would report to the Embassy as soon as the meeting with the anti-fascist committee (AFC) was over.

22. Nov. 1976, 10 A. M. I met at the office of the AFC with AFC Chairman Otto Funke, Rudolf Helmer ${ }^{61}$ and Max Friedman [sic $]^{62}$ both of whom I had met before. A photographer took some photos as soon as I sat down. I suggested that publicity would be inappropriate. I was assured that it was simply "for the archives". Funke placed before him a fancy folder with gold engraving and ribbons. He ceremoniously read forth a "Declaration" saying that the AFC was paying one million US dollars to benefit needy Nazi victims who were citizens of the United States. He then read another statement in which it was stated that the GDR did not recognize any legal or moral claims of Nazi victims and no such claims could be discussed. He then handed me the fancy folder with the "Declaration".

I tried to engage them in an exchange on the claims issue but to no avail. I then thanked them for the spirit in which the million dollars was offered. I noted that as a donation it was a respectable sum but in the context of Jewish claims such an amount was not significant. I referred to Adenauer's first offer of DM 20 million which was ignored by the Jews and to West Germany's payment of over DM50 billion by way of indemnification payments thus far out of what would probably be about a total of DM 100 billion before the last pension payment was completed. I noted that although the Claims Conference did not expect the GDR to match the Federal Republic it was hoped that the GDR would recognize the Jewish view regarding both a legal and moral obligation of the GDR as a successor to the assets of the Reich.

in Wien. 1983 wurde er zum Botschafter ernannt und vertrat die Vereinigten Staaten u. a. in Bulgarien.

61 Rudolf Helmer (1914-2007) arbeitete ab 1950 im Ministerium für Auswärtige Angelegenheiten der DDR. 1954 bis 1956 war er als Botschaftsrat in Polen und anschließend für zwei Jahre als Botschafter in Ungarn tätig. Seit 1976 war Helmer Mitglied des Präsidiums und Sekretär der Zentralleitung des KdAW.

62 Gemeint ist vermutlich Max Friedemann (1905-1986), ein deutsch-jüdischer Kommunist, der 1946 nach Ostdeutschland zurückkehrte, nachdem er zuvor im Spanischen Bürgerkrieg und in der Résistance gekämpft hatte. In der DDR war er Leiter des Stahl- und Walzwerks Riesa und gehörte seit 1953 dem KdAW an. Zwischen 1953 und 1958 war er als stellvertretender Minister und Staatssekretär im Ministerium für Bergbau und Hüttenwesen tätig und anschließend bis 1965 Handelsrat der DDR in China. 
Funke made it clear that he was under strict instruction not to discuss claims or any aspect of the claims problem. As far as the AFC was concerned that subject was closed. Cognac was served (I chose soda water) and I was invited to pay a visit to the Sachsenhausen concentration camp in which I had expressed an interest during my last meeting at the AFC. A car and driver was waiting and flowers had been procured so that I could lay a wreath on the memorial to those who had perished in the camp. I explained that I had promised to visit the U.S. Embassy first and it was agreed that the driver would take me there first. The meeting was cordial and correct and it was made clear that I would have to report to the Jewish organizations on whose behalf I had appeared.

|2| 22. Nov. 1976: 11:30 A. M. I met the new Chargé d'Affairs Saul Polansky and gave him a copy of the "Declaration" which he was to transmit to Washington. From his office I called Katzenstein in Frankfurt and reported. I asked him to relay the information to Goldmann in Paris. I also obtained Goldmann's phone number and tried to reach him from the US Embassy. There was no answer.

12 P. M. I proceeded to Sachsenhausen with Herr Helmer and Friedman. It's about an hour's drive away. I visited the camp, laid the wreath and tried without success to obtain some information for my new book "Less than Slaves" since Sachsenhausen was the main office of the SS for the allocation of concentration camp inmates to German firms. I was told that the records had been destroyed when Sachsenhausen was liberated.

2 P.M. I had lunch with Helmer and Friedman. They wanted to know the name of the bank to which a remittance could be made to the Claims Conference. They had difficulty understanding that the American system is not the same as the more efficient German method of transfer from one bank account directly to the account number of the recipient. I promised to provide the information within a day or two and indicated that I might need that much time to procure a reaction from the Jewish organizations to the proposed transfer. They declined to consider a transfer to the Claims Conference account in the Federal Republic.

4 P.M. I called Katzenstein and asked him to phone New York to report on the situation and obtain the requested information. I promised to call back at 10 A.M. the next morning. I also spoke to Kurt May in Frankfurt, to whom I had also spoken in the morning. He expressed congratulations at the breakthrough.

5 P. M. I again phoned Goldmann in Paris (00331) 2562299. He was out. I dictated the "Declaration" to his secretary Hella and promised to call back in two hours. I indicated my feeling to accept the million dollars since it was specifically stated to have nothing to do with Jewish claims against the GDR. 
I felt that it might be a useful precedent to open the way to other requests for humanitarian gestures on behalf of Jews from France, Holland, etc. and that the Claims Conference could continue to pursue the claims via U.S. legislation and intervention exactly as before.

7 P. M. I reached Goldmann at his home in Paris. Katzenstein had already gotten through to him. He indicated immediately that he was absolutely against accepting the million dollars. He said it didn't mean anything, particularly to Jews in America. He felt that the acceptance would make it possible for the GDR to state that they had paid Jewish claims and the issue was settled. I explained that by its terms it was clear that the payment was not for claims $|3|$ and the acceptance was not a release. He said it didn't matter. I suggested that Goldmann discuss the question with other members of the Claims Conference Board. He said he could only do that in January but was not sure of the precise date. I said that I would try to stop the remittance until after the Board could consider the problem and Goldmann agreed that it would be better not to do anything which would offend the AFC. I stated that I did not know whether I could succeed in stopping the transfer since the AFC seemed very eager to carry out their instructions quickly.

23. Nov. 1976: 10 A. M. I phoned Katzenstein who had obtained the name of the Claims Conference bank in New York, Manufacturers Hannover Trust Co. Branch at 52nd St. Ave. of the Americas, Account No. 115-0-06840. I discussed the situation and he could think of nothing better than my idea to simply inform the AFC of the response and to request delay in the transmittal. 10:30 A.M. I phoned an acquaintance at the GDR Foreign Office (GG) ${ }^{63}$ He informed me that Neues Deutschland ${ }^{64}$ had carried a very brief notice ${ }^{65}$ that a payment had been made by the AFC to me as a representative of Jewish organizations in the US and that I had expressed appreciation. No mention had been made of the amount. (I arranged to see him the next |later that ${ }_{1}^{166}$ day on personal matters, connected with my book on world peace, and to leave with him a copy of my latest article on the definition of aggression.)

3 P. M. I met with Rudolf Helmer of the AFC. I told him that I had spoken to the President of the Claims Conference and it appeared most likely that the money, if sent, would be returned. I asked him to withhold any transfer, if possible, until the Jewish organizations could meet to discuss the problem

63 Wahrscheinlich Gunter Görner.

64 Die Tageszeitung Neues Deutschland war von 1946 bis 1989 das Zentralorgan der SED.

65 Siehe Anonymus, Unterstützung für Verfolgte des Naziregimes in den USA, in: Neues Deutschland, 23. November 1976, 2.

66 Maschinenschriftliche Einfügung über den durchgestrichenen Worten. 
in January. He asked for the name of the bank, which I had promised and I gave it to him. He said he would pass on the information and the request. I explained in general terms the nature and magnitude of Jewish claims which would indicated why there had been such a negative reaction to the million dollars. Helmer made some counterarguments but it was in the nature of a personal reaction rather than any official response on the claims issue. The atmosphere had turned cool.

(4 P.M. I met with GG at the Foreign Office.)

5 P. M. I reported to the US Embassy. Polansky called in the Press attaché (Public affairs officer Edward Alexander). ${ }^{67}$ The story in Neues Deutschland had been picked up by all the wire services and various reporters including the Associated Press and the Washington Post had been searching for me. We agreed that I would remain incommunicado. We prepared some background information for the press based on the understandings when the GDR was recognized by the US and prior press releases. The amount was not to be mentioned and my whereabouts was not to be disclosed.

|4| 24. Nov. 1976: The German radio carried the news of the payment by the GDR. The press was quoted as saying that Goldmann had rejected the payment as not to be taken seriously. (See $N^{68}$ statement of Nov. 23) Galinski, ${ }^{69}$ Berlin's Gemeinde head was quoted as saying that it was a good first step which he hoped would follow the pattern set by the Federal Republic.

12 noon: I met with Galinski in the Gemeindehaus and informed him fully. He was annoyed at not having been given the picture in advance. The press and TV people were besieging his office and he had been widely quoted, and misquoted, in the German papers. We agreed that he was not to mention that I had been there or disclose my whereabouts to the press.

25 Nov. 1976: I proceeded to Frankfurt. Discussed the problem with Katzenstein, May, Eric Laor and later with Saul Kagan, who arrived on the

67 Edward Alexander $\left({ }^{*} 1920\right)$ war ein amerikanischer Journalist und 1959 bis 1964 beim Rundfunk im amerikanischen Sektor (RIAS) in Westberlin tätig. In den 1970er Jahren wirkte er als Berater für Public Affairs und Pressesprecher an verschiedenen Botschaften der Vereinigten Staaten.

68 Wahrscheinlich Nahum Goldmann.

69 Heinz Galinski (1912-1992) war ein deutsch-jüdischer Verbandsfunktionär. Er überlebte verschiedene Arbeits-, Konzentrations- und Vernichtungslager, kehrte 1945 nach Berlin zurück und engagierte sich für den Wiederaufbau der dortigen jüdischen Gemeinde. Zudem setzte er sich für Entschädigungsleistungen für Verfolgte des Nationalsozialismus ein. Von 1949 bis 1992 war er Vorsitzender der Jüdischen Gemeinde Berlin und 1954 bis 1963 sowie 1988 bis 1992 Vorsitzender des Zentralrats der Juden in Deutschland. 
27th, and Herb Katzki ${ }^{70}$ of JDC. There was almost unanimous feeling that the money would have to be rejected. Katzki and I were not so sure.

29 Nov. 1976: Word was received via Joshua Sherman in New York that one million dollars had been deposited into the Claims Conference account. He wanted instructions.

30 Nov. 1976: Kagan and I, in consultation with Katzenstein, Laor and May, drafted a letter to the AFC explaining why the money had to be returned. Kagan was in touch with Goldmann by phone to arrange to meet with him in Paris, on Dec. 3rd.

1 Dec. 1976: I informed US Embassy in East Berlin of status. Polansky had nothing new to report. The US had received no indication from the GDR and had made no move but continued, as before, to remain aloof on the Jewish claims problem.

2 Dec. 1976: I returned to New York and informed Sherman as well as Steve Schwebel ${ }^{71}$ of the State Department of the status. I wanted to know from Schwebel whether the US knew in advance what the GDR intended. I also wanted to know why the US had entered into a deal with the GDR's minister Beil to allow GDR ships to load U.S. grain in U.S. harbors, when Sect. Hartman had previously indicated to the Jewish organizations that no trade benefits would be granted to the GDR until the claims issue was settled. Schwebel was cautious and said he would pass on the questions. My own feeling from my talks in Germany and the US is that the US knew in advance what was intended and deliberately refrained from notifying the Jewish organizations.

\section{Dokument 117}

Benjamin B. Ferencz an Shabtai Rosenne

Ohne Ortsangabe, 9. September 1977

Maschinenschriftlicher Brief, 1 Seite

$R G 12.006 .01{ }^{\star} 05$

70 Herbert Katzki (1907-1997) arbeitete seit den 1930er Jahren in verschiedenen Funktionen für das JDC. Seit dem Ende der 1960er Jahre war er Vizepräsident der Hilfsorganisation.

71 Stephen M. Schwebel $\left({ }^{\star} 1929\right)$ war von 1974 bis 1981 stellvertretender Rechtsberater im US-Außenministerium und von 1977 bis 1981 Mitglied der UN-Völkerrechtskommission. Anschließend wurde er Richter am Internationalen Gerichtshof und wirkte 1997 bis 2000 auch als dessen Präsident. 
Ambassador Shabtai Rosenne

Ministry for Foreign Affairs

Jerusalem, Israel

Dear Shabtai:

Thank you very much for your letter of the 18th and your kind offer to be of assistance in connection with the GDR claims.

We have just had word via the U.S. Embassy in East Berlin that Herr Honecker felt there was some misunderstanding when one million dollars was handed over to the Claims Conference only to be returned. He has suggested that we resume contact with the Anti-Fascist Committee and try to straighten it out.

I have written to the Committee suggesting a meeting during the week beginning October 17th. We have no idea of course what their response will be.

If somehow it could be recognized in international law that a successor state is responsible for the wrongs of the predecessor government that would be certainly help our argument. How that recognition can be brought about and how it can be used to induce the GDR to make compensation to the Jews is the problem. I'm sure the Jewish organizations would welcome anything which would serve the common goal. I am not quite so sure that, given the present U.N. environment, a statement by Israel would be the most effective way of proceeding.

You will be able to judge the situation better than I. You may want to give some thought to the possibility of having some other government, such as Holland or Sweden, or whoever else may have been supporting such a position at the International Law Commission, take the lead at the U.N. I could ask Steven Schwebel for suggestions. Please give me a ring when you get to New York and we can then agree on tactics.

I look forward to seeing you. With all good wishes to you and your wife for the coming year.

Cordially, ${ }^{72}$

72 Unterschrift fehlt auf archivalischer Kopie. 


\section{Dokument 118}

Benjamin B. Ferencz

Ohne Ortsangabe, 26. Oktober 1977

Maschinenschriftliches Memorandum, 3 Seiten; maschinenschriftliche Unterstreichungen

$R G 12.006 .01^{\star} 05$

[Für die eigenen Akten dokumentiert Ferencz den Fortgang der Gespräche mit Vertretern der DDR in Ostberlin. Dabei steht die angestrebte Wiederaufnahme der Verhandlungen nach der Zurückweisung der Millionen-Zahlung durch die JCC im November 1976 im Zentrum. Er geht insbesondere auf die Interessen und Motive der beteiligten Akteure ein.]

\section{FILE MEMORANDUM}

October 26, 1977

$\mathrm{BBF} / \mathrm{ik}$

From: $\quad$ Benjamin B. Ferencz

Subject: $\quad$ Meeting with Otto Funke, Chairman

Committee of Anti-Fascist Resistance Fighters (AFC)

and his Assistant Mr. Friedemann.

Time: $\quad$ October 24, 1977, 10:00 a.m. to 11:05 a.m.

Place: $\quad$ Office of the AFC, Unter den Linden 12, Berlin, GDR

I was cordially received by the members of the AFC, both of whom I had met before. As we sat down to coffee and cognac, which was promptly served, I jested that if they had sent a check for $\$ 100$ million instead of $\$ 1$ million following our last meeting in November 1976, it would probably not have been necessary for me to be there again. Mr. Funke responded that I had called for a meeting and he was sorry that it took so long for them to send a reply but the mail between the US and the GDR was slow.

I explained I would not have come again, if I had not felt that I might suggest something which could be of mutual benefit to both, the GDR and the Nazi victims. My purpose, I said, was not to negotiate on any subject but merely to arrange a subsequent meeting between representatives of the AFC and the Jewish Organizations and, if possible, to lay the ground work for such a meeting.

I explained in detail what had happened on the Jewish side after my meeting with the AFC on November 22, 1976 and why it had been necessary to return the $\$ 1$ million, which the AFC sent to the Claims Conference in New York. The money was so limited in amount and so restricted in purpose 
that it could not be put to effective use without creating disproportionate problems. The public would never have been able to understand that the money was intended as a humanitarian gesture unrelated to Jewish claims since the contacts between the Claims Conference and the AFC were created for the sole purpose of dealing with claims and nothing else. I indicated that there would have been no public response from the Jewish side, had the fact of a payment not first appeared in "Neues Deutschland", which stimulated vigorous enquiries by the international press.

I pointed out that in directing that the money be returned Dr. Goldmann had specifically stated: "wir wollen die Leute nicht brüskieren" and it was not intended to be a rebuff to the GDR. Dr. Goldmann's action had been ratified at the Claims Conference meeting in Amsterdam on June 21, 1977. I gave Mr. Funke a copy of the resolution adopted by the Claims Conference which urged that negotiations be continued.

|2| I noted that I had been at the United Nation when the GDR Foreign Minister, Oskar Fischer, ${ }^{73}$ had reported to the General Assembly. I was impressed by his emphasis on the need for "Entspannung" - détente - and "wirtschaftliche Zusammenarbeit" - economic cooperation; and those desirable objectives encouraged me to ask for another meeting with the AFC. It seemed to me that it might be possible to reach some accomodation with the Jewish Organizations along the lines of the settlement made between the Claims Conference and the Federal Republic, whereby payment was made in the form of goods delivered over a period of years. Trade between the GDR and the US was presently inhibited by the unwillingness of the United States to grant Most Favored Nation (MFN) treatment to the GDR. It was conceivable to me that the US Congress might be willing to make an exception for goods imported into the United States in order to provide revenues for the benefit of Nazi victims. That would open the US-market for GDR products, would stimulate trade and might prove to be of long range benefit to the GDR.

I sketched the scenario for a possible joint meeting which I thought might be held in Switzerland or another neutral country. It might be anticipated that each side would send four or five representatives, the Jewish Organizations would set forth the magnitude and types of Jewish losses, the AFC would indicate the counter arguments, and hopefully the parties could negotiate and

73 Oskar Fischer $\left({ }^{\star} 1923\right)$ war von 1975 bis 1990 Minister für Auswärtige Angelegenheiten der DDR. Zuvor wirkte er von 1955 bis 1959 als Botschafter in Bulgarien und seit 1965 als stellvertretender Außenminister. Ab 1971 war er zudem Mitglied des ZK der SED und ab 1976 Abgeordneter der Volkskammer. 
agree upon a final sum and the time and form of payments. I concluded by asking whether he thought such a meeting would be possible.

Funke replied that my letter, calling for a meeting, had spoken of a misunderstanding. He assured me that there was no misunderstanding on their part. The AFC had made its position clear at our last meeting. They were not prepared to discuss Jewish "claims" or Jewish "demands". If the Claims Conference felt it had to return the $\$ 1$ million which had been sent to the Claims Conference to help needy Nazi victims in the United States, the Conference was ignoring the humanitarian rights of the possible recipients. Despite Dr. Goldmann's express desire not to offend the GDR, the return of the money was seen as a clear rebuff to the GDR.

As far as any trade deals were concerned Mr. Funke pointed out that such matters were not the concern of the AFC. It was a matter for the GDR-government. If the Jewish Organizations wanted to meet with the AFC, there was no need to go to a neutral country and such a meeting could be arranged to discuss subjects of mutual interest on behalf of Nazi victims but not to discuss any Jewish "claims".

I asked if we could arrange a meeting simply to discuss "Entspannung". His reply made it clear that as far as the AFC was concerned that banner could not be used as a cloak under which claims could be discussed. He repeated several times that the GDR did not consider itself morally or legally responsible for anything done by the Hitler-Regime and therefore any liability related to such crimes could not be discussed.

I reminded Funke that when the GDR was recognized by the United States in 1973 it had been specifically agreed between our two governments that there would be negotiations between the Claims Conference and the AFC with the view toward a settlement of the claims of Nazi victims. He interrupted to correct me by pointing out that the agreement had only referred to "Gespräche" or "talks" between the two organizations and nothing more. He said that "Gespräche" had taken place repeatedly and therefore $|3|$ the GDR obligation was fulfilled. I pressed the point that the US must have understood "talks" to mean "negotiations" and not merely conversations. $\mathrm{He}$ replied that that was not the GDR understanding. "Talks" meant "talks" and the GDR had not agreed and was not required to alter its fundamental policy position regarding responsibility for Nazi crimes.

When I spoke about the need to establish good relations, and the connection between a settlement of the Jewish question and American attitudes toward the GDR, Mr. Funke replied that the GDR was patient and could wait for relations to improve through normal contacts over the years.

I indicated that I expected a settlement to be reached between the GDR and the US which would provide compensation for US commercial properties 
nationalized by the GDR, and how unfortunate it would be if the Nazi victims were excluded from any such compensation. Funke replied that he did not share my assumptions and he doubted whether any payment would be made by the GDR, but that was a matter for the government and not for the AFC.

In response to my specific question whether there would by any possibility or purpose in a meeting between the two groups along the lines I had indicated, his reply was clearly negative. Both, he and Hr. Friedemann, who simply took notes during the meeting, added that they would be pleased to see me personally at any time but not to discuss Jewish claims. I indicated that I might like to re-visit the Buchenwald concentration camp, which I had last seen as an American soldier with the liberating US-army. They said they would be delighted to arrange such a meeting if I would simply give them a few weeks' notice and they would obtain the visa and provide an escort for me. I said I might consider it in connection with my next visit to the German Federal Republic.

The atmosphere of the meeting was cordial, but in substance it was like biting on granite.

\section{Dokument 119}

Benjamin B. Ferencz

New York, 20. Oktober 1978

Maschinenschriftliches Memorandum, 3 Seiten; maschinenschriftliche Unterstreichungen, gedruckter Briefkopf mit maschinenschriftlichen Einfügungen auf Seite 1, Kopfzeile auf jeder folgenden Seite (»October 20, 1978«)

$R G 12.006 .01^{*} 06$

[Ferencz berichtet über Konsultationen mit Vertretern des Außen- und des Handelsministeriums der Vereinigten Staaten bezüglich der Forderungen gegenüber der DDR. Dabei stehen wirtschafts- und handelspolitische Interessen der DDR-Regierung im Mittelpunkt. Abschließend wird über ein Treffen von JCC-Vertretern und dem neuen Botschafter der DDR in den Vereinigten Staaten berichtet.]

Conference On Jewish Material Claims Against Germany, Inc.

15 East 26th Street, New York, N. Y. 10010 .

Cables: "Mecultfund" New York · Tel: 679-4074 


\section{'MEMORANDUM}

To: $\quad$ |Files'

From: 'BBenjamin B. Ferencz' New York, |October 20, 1978|

Re: $\quad$ Meetings in Washington on

October 12, $1978 \mathrm{re}^{74}$ German Democratic

Republic (GDR)!

\section{CONFIDENTIAL}

Met with Steve Schwebel, Assistant Legal Adviser, State Department. Following our conversation of about two weeks ago, he had prepared a long memorandum to Congressman Bingham re the freezing of payments by the Federal Republic of Germany (FRG) under the Equalization of Burdens Law. The memorandum, which was to be given to the West German Ambassador, ended with the suggestion that Bingham might have to consider new legislation to correct the inequity. Bingham planned to meet FRG Ambassador von Stadden $[\mathrm{sic}]^{75}$ on October 13th. It was also intended that Assistant Secretary of State George S. Vest ${ }^{76}$ would meet with von Stadden thereafter and again request action to lift the freeze. I indicated that all those efforts would be without success and urged that more effective measures be contemplated.

Met with Victor Gray, GDR desk, State. Reviewed situation.

Meeting at Department of Commerce with Rick Chidester, new chief, and Suzanne Porter of East-West Trade. Both were supportive of any plan to increase trade and to grant Most Favored Nations (MFN) to GDR. Commerce Department report of September 20, 1978 shows increased GDR trade with U.S., and first-half 1978 imports from GDR of $\$ 21$ million as against exports of $\$ 71$ million. GDR must earn more dollars to keep balance. Present duties average about $25 \%$ to $30 \%$, almost all of which would be saved by GDR if the goods could come in under "Column 2" goods, which received MFN

74 Regarding.

75 Der westdeutsche Diplomat Berndt von Staden (1919-2014) arbeitete für die Europäische Wirtschaftsgemeinschaft in Brüssel und für das Auswärtige Amt. Von 1963 bis 1968 war er als Botschaftsrat in Washington tätig und von 1973 bis 1979 deutscher Botschafter in den Vereinigten Staaten.

76 George S. Vest $\left({ }^{\star} 1918\right)$ war ein amerikanischer Diplomat. Von 1977 bis 1981 leitete er das Europareferat im Außenministerium der Vereinigten Staaten. Anschließend wurde er Botschafter bei der Europäischen Gemeinschaft und 1985 Generaldirektor des Auswärtigen Dienstes. 
exemptions, rather than the present "Column 1" goods which are fully taxable. Commerce has estimated that with MFN the GDR could increase its exports to the U.S. by $250 \%$. Porter promised to send me a copy of the study on which that figure was based. It appeared in a Congressional report which was out of print.

I explored the idea that if GDR exports to U.S. could be increased, as projected, to a per annum rate of about $\$ 100$ million, then the shift from Column 1 to Column 2 would not only multiply the exports to the U.S. but it would also save the GDR about $25 \%$ of the duty or about $\$ 25$ million per annum. Commerce would pro-|2|bably support such a move if at least the $\$ 25$ million per annum saved by the GDR would go to Nazi victims for a number of years, and Commerce would also support a plan which required the GDR to turn over to the Claims Conference not only the amount saved in duties but also some part of the additional dollar earnings. All talks were to be regarded as informal and non-binding preliminary exchanges of view.

Meeting in office of Congressman Bingham and new GDR Ambassador Horst Grunert. ${ }^{77}$ Present: Rabbi Israel Miller, ${ }^{78}$ Bingham's aide Roger Majak, ${ }^{79}$ Grunert's aide, Second Secretary Rainer Weidenbeck, and BBF. Meeting lasted almost one and a half hours. Friendly and open throughout. Our previous information that a new proposal was forthcoming was apparently a misunderstanding. Grunert repeated all the standard arguments the GDR was not identical with the Nazi Reich, it had paid its reparations obligations and there was neither a legal nor a moral obligation to do more. The GDR was not prepared to negotiate regarding MFN since that was purely a matter within U.S. control, and if MFN was not granted this year it would be granted later. In any case, the GDR could survive without it. He was opposed to any linkage between free trade and political objectives. He repeatedly noted the steps taken by the GDR to eradicate Nazism and anti-Semitism and did not think that a money payment was a suitable means for improving relations.

77 Horst Grunert (1928-2005) arbeitete seit 1951 beim Ministerium für Auswärtige Angelegenheiten der DDR. 1974 wurde er zum stellvertretenden Minister für Auswärtige Angelegenheiten ernannt. Von 1978 bis 1983 war er Botschafter in den Vereinigten Staaten und Kanada.

78 Der Rabbiner Israel Miller (1918-2002) engagierte sich in verschiedenen jüdischen Organisationen. Von 1982 bis zu seinem Tod war er Präsident der JCC und in dieser Funktion an Verhandlungen über die Rückgabe jüdischen Eigentums und Entschädigungszahlungen mit der DDR beteiligt.

79 Roger Majak ( $\left.{ }^{\star} 1941\right)$ leitete den Mitarbeiterstab Jonathan Binghams von 1969 bis 1974. Anschließend war er bis 1985 Stabsdirektor im Unterausschuss für internationale Wirtschaftspolitik im US-Außenministerium. 
His presentation was forthright and couched in assurances of a desire for friendship and better relations.

Rabbi Miller stressed the moral considerations and the need to reconstruct Jewish communal life. BBF challenged the GDR's legal assumptions and reviewed the history of past restitution actions. He noted the symbolic nature of a global payment of $\$ 100$ million which the Jewish organizations expected. He urged consideration of the economic benefits which might flow to the GDR from even a provisional grant of MFN status and how a Jewish claims settlement would serve the common goals of detente and improved trade. Congressman Bingham noted that without improved relations MFN might be a long time in coming.

The discussions seemed to have some impact on the Ambassador. $\mathrm{He}$ requested a copy of the study showing the anticipated increase in trade which would follow a grant of MFN status and advised BBF when in Berlin to remit his greetings to his friends Funke and Helmer, of the Anti-Fascist Committee, but not to enter into any substantive negotiations at this time. He asked that $\mathrm{BBF}$ be in touch with him after his return from Europe in November. He also asked Rabbi Miller to explain the structure of Jewish organizational life in the U.S., and Miller promised to meet with him later for that purpose. For the first time, direct line of contact seems to have been established between the GDR Embassy and the Claims Conference representatives.

|3| IM: ${ }^{80}$ The Ambassador appeared to have been well briefed both in terms of the subject of our discussion and in his own firm unyielding attitude. It was only at the conclusion of the meeting that he showed any flexibility and a readiness to continue our meetings. We told him at the outset that we would not publicize our contact with him; at some point we must consider going public if our discussions lead us in a circle or to a dead end.

BBF: fz

cc: Dr. Nahum Goldmann

Mr. Saul Kagan

Dr. Ernst Katzenstein

Mr. Philip M. Klutznick

Dr. William Korey ${ }^{81}$

80 Israel Miller.

81 William Korey (1922-2009) war Historiker, Menschenrechtsaktivist und Lobbyist. Ab 1960 leitete er das UN-Büro von B'nai B'rith und setzte sich für die Rechte von Juden in der Sowjetunion sowie für die Ratifizierung der UN-Genozidkonvention durch die Vereinigten Staaten ein. 
Dr. Edith Kosterlitz

Rabbi Israel Miller

Dr. Ernest H. Weismann

\section{Dokument 120}

Benjamin B. Ferencz

Ohne Ortsangabe, 22. September 1981

Maschinenschriftliches Protokoll, 3 Seiten; maschinenschriftliche Unterstreichungen

$R G 12.006 .01{ }^{*} 09$

[Ferencz dokumentiert eine offizielle Zusammenkunft mit dem Minister für Auswärtige Angelegenheiten der DDR Oskar Fischer in New York im Herbst 1981. Er berichtet detailliert über die verschiedenen in der Gesprächsrunde artikulierten Standpunkte der anwesenden Vertreter der JCC und der DDR.]

Minutes of Meeting with East German Foreign Minister, September 22, 1981

Present: $\quad$ Oscar [sic] Fischer, Minister for Foreign Affairs, GDR Ambassador Horst Grunert, GDR Ambassador to the United States

One interpreter and one other who took notes.

For the Claims Conference: Rabbi Israel Miller, Saul Kagan and Benjamin B. Ferencz

Place: $\quad$ The GDR Mission to the U.N. 58 Park Avenue, New York, N. Y. Time: $\quad 3$ p.m. to 4 p.m.

As had been previously agreed in a preliminary meeting between Rabbi Miller, Kagan and Ferencz, Rabbi Miller opened the substantive discussions after greetings had been exchanged with the customary compliments on both sides. He briefly sketched the moral nature of the Jewish claims against the GDR and noted that the Reagan Administration, whose views were expressed by Assistant Secretary Eagelberger [sic], ${ }^{82}$ was even stronger in support of

82 Der amerikanische Politiker und Diplomat Lawrence S. Eagleburger (1930-2011) begann 1957 im Auswärtigen Dienst der Vereinigten Staaten zu arbeiten, wo er verschiedene Positionen durchlief: 1977 bis 1980 war er Botschafter der Vereinigten Staaten in Jugoslawien und von 1981 bis Anfang 1982 fungierte er als Assistent Se- 
Jewish claims than had been previous administrations. He made 3 specific requests:

1. that during his forthcoming visit to Berlin, Ferencz be received by an official of the GDR with sufficient authority to deal with the problem;

2. that a meeting be arranged between Eric [sic] Honecker and Nahum Goldmann, and

3. that an appropriate gesture be made by the GDR that would help to reconstruct the Jewish community life that had been destroyed by Hitler. $\mathrm{He}$ hoped that Jewish patience would be rewarded.

Minister Fischer replied by repeating the traditional arguments that the GDR had neither a moral nor a legal obligation. Not moral since they were themselves persecuted by the Nazis and not legal since they had discharged their reparation obligations under the Yalta and Potsdam agreements. He did not see any real difficulty in having Mr. Ferencz meet with someone from the government just as he had met regularly with Fishcer's [sic] friends Funke and Helmer of the Anti-Fascist Committee. A meeting between Goldmann and Honecker was something that would have to be considered in Berlin, and he would take up the suggestion further but could make no commitment. As far as gestures were concerned, he considered the fact that the GDR was ready to meet with Jewish representatives was itself a gesture of their concern for Jewish problems. He explained how much was being done in the GDR to combat anti-semitism and prevent the rebirth of Nazism. A monetary gesture in the amount of $\$ 1,000,000$ (one million dollars) had been made by the Anti-Fascist Committee in November 1976 but it had been rejected.

|2| Saul Kagan went on to explain the reasons behind the Jewish sensitivity on this particular issue. He noted that when the Federal Republic had resolved the problem it had been done by payments spread over a number of years. $\mathrm{He}$ indicated that an amount of $\$ 100$ million, by goods, if necessary, and spread over a long term would be a gesture that would not be rejected by the world Jewish community. He noted the good will that would be created not merely in the United States and in Jewish circles but in non-Jewish circles and other parts of the world as well.

Mr. Ferencz supplemented his statement by stating that the cost to the Federal German Republic would be over 80 billion marks and that even in the FRG's final Hardship Fund, which Kagan would administer, the payment was for DM 400 million. In such a context the figure of $\$ 100$ million was really only a gesture. The FRG had paid the Claims Conference, as representative

cretary of State for European Affairs. Anschließend war Eagleburger Staatssekretär, stellvertretender Außenminister und von 1992 bis 1993 kurzzeitig Außenminister der Vereinigten Staaten. 
of Jewry outside of Israel, a sum of DM 450 million over a period of 10 years, but in so doing they had specifically noted that they would pay only twothirds of the bill for the cost of absorbing Nazi victims. The remaining one-third, or DM 225 million was expected to be paid by East Germany. The Jewish successor organizations have received over DM 300 million from heirless and unclaimed Jewish property in the western zones and sectors of Berlin. The heirless property in the East was still in the possession of the GDR, which so far paid nothing. These two items alone would more than cover the token $\$ 100$ million. He felt that a political decision had to be made whether goodwill with the Jewish community was desired, and if so what price they would be willing to pay and how could that be justified. The possibility of shipping goods was designed to make it easier for the GDR and open the way for exporting to the U.S. without the penalty of exclusion. He hoped that he could meet with governmental officials in order to explain them in greater detail exactly how Jewish claims were computed and how they were justified.

Minister Fischer replied that his desire to improve relations was not quantified by any specific amount. It was a matter of principle. Other Ministries might deal with problems of finance and trade.

Rabbi Miller raised the question whether the GDR would find it easier to deal with the Jewish claims problem if the Claims Conference turned the negotiating responsibility over to the U.S. Government, which was handling the traditional American claims anyway.

The Foreign Minister replied that the claims negotiations that were being carried on with a number of countries entailed various bi-lateral obligations and would be dealt with in due course. He could not answer off hand whether there would be any advantage in combining Jewish claims and leaving the negotiations exclusively to the U.S. officials. He promised to consider it.

|3| The meeting was most cordial, with tea, coffee and cakes served and a pleasant atmosphere throughout. Minister Fischer extended an invitation for Mr. Ferencz to call his office when he was next in Berlin and promised that if he was in town and could arrange it, they would take tea or coffee together. Ferencz promised to call.

\section{B.B. Ferencz}

$\{\mathrm{BA} \#\}$

BFG $9 / 22 / 81$

P.S. I informed Bruce Clark at the State Department concerning this meeting. 


\section{Dokument 121}

Benjamin B. Ferencz

New York, 26. Januar 1982

Maschinenschriftliches Memorandum, 1 Seite; gedruckter Briefkopfmit maschinenschriftlichen Einfügungen

$R G 12.006 .01^{\star} 10$

Conference On Jewish Material Claims Against Germany, Inc.

15 East 26th Street, New York, N. Y. 10010 .

Cables: "Mecultfund" New York · Tel: 679-4074

'MEMORANDUM!

ICONONFIDENTEIIAL'

To: $\quad$ ¡File!

New York, 'January 26, 1982!

From: $\mid$ B. Ferenczi

Re: $\quad$ 'Meeting on Jan. 22, 1982 with Ambassador Horst Grunert|

The meeting took place at the Harvard Club and was attended by Rabbi Israel Miller, Saul Kagan and B. B. Ferencz. It came about as a result of an initiative by Rabbi Miller who expected to meet Grunert in Washington, but that didn't work out and the Ambassador said that he would be available to meet in New York.

In the course of a very pleasant luncheon at which Jewish claims against the GDR were reviewed, the Ambassador stated that there had been a change in the GDR position. They were now prepared to settle Jewish claims, but they lacked foreign exchange to meet the Jewish demand. They had come back to consideration of the possibility of sending goods to the U.S. if they could do so without the exorbitant duties now applied to some of their exports. $\mathrm{He}$ recognized that in the current political climate it would not be feasible to grant general MFN treatment to the GDR, but he wondered whether limited exemptions could be obtained in connection with goods shipped to fulfill an indemnification payment on behalf of Nazi victims. He mentioned, by way of illustration that one large importer of porcelain (Lipschitz?) was being charged an $80 \%$ duty, which severely restricted the possibility of selling the products.

Kagan reviewed the needs of Nazi victims in the U.S. and Rabbi Miller noted that the GDR suggestion would have to be carefully and discretely discussed before any response could be given. 
It was agreed that the Conference would make whatever soundings it considered necessary and that it might then be advisable to have another meeting with the Ambassador and some people from the GDR trade mission to explore the matter further. It was suggested that a private room at the Harvard Club might be a suitable location for the meeting. The next move is up to the Conference.

Benjamin B. Ferencz

\section{Dokument 122}

Benjamin B. Ferencz

New York, 30. September 1983

Maschinenschriftliches Memorandum, 2 Seiten; gedruckter Briefkopf mit maschinenschriftlichen Einfügungen auf Seite 1, Stempel auf Seite 1, obere rechte Ecke (»CONFIDENTIAL«)

$R G 12.006 .01^{*} 11$

$\{$ MR. Ferencz $\}$

Conference On Jewish Material Claims Against Germany, Inc.

15 East 26th Street, New York, N. Y. 10010 .

Cables: "Mecultfund" New York · Tel: 679-4074

\section{'MEMORANDUM!}

To: $\quad$ |Files'

From: ‘Benjamin Ferencz'

New York, |'Өetober 3 \{Sept 30/83\} 1983!

Re: $\quad$ 'Meeting at the State Department - September 30th'

Present: Thomas Niles, ${ }^{83}$ Deputy Assistant Secretary for European Affairs, State Department, Allan Thompson (formerly Counsellor at the US Embassy in E. Berlin) Jeff Gallub, GDR Desk, and Keith McCormick (who is also on

83 Thomas Niles $\left({ }^{\star} 1939\right)$ begann 1962 seine Tätigkeit im diplomatischen Dienst der Vereinigten Staaten. 1981 bis 1985 war er Deputy Assistant Secretary for European Affairs. Anschließend wirkte Niles als amerikanischer Botschafter zunächst bei der Europäischen Union und zwischen 1989 und 1991 in Kanada. 
the GDR Desk under Gallub), Mary Beth West, Assistant Legal Adviser for European Affairs, Susanne Lotarski ${ }^{84}$ of Commerce Department. For the Claims Conference: Saul Kagan, B.B. Ferencz

Purpose of the meeting was to report to the Department on the meeting with GDR Foreign Minister Fischer ${ }^{85}$ in New York and to get clearance for the proposed outline of an agreement which Fischer had requested.

Kagan and Ferencz reported and the outline that had been prepared by Ferencz was reviewed. Minor modifications in form were suggested, the US being concerned that it not appear as an official US governmental draft.

Niles was the most positive. He stated that in spite of the generally strained atmosphere, the US government continues to deal with bilateral issues such as arms limitations, etc. He therefore feels that the claim matters with the GDR should be pursued although he thought that it may take considerable time before these matters will be settled.

Thompson, who had accompanied Ambassador Ridgeway [sic] ${ }^{86}$ when she was in Washington, was surprised that so few Congressmen had even heard of the proposed settlement. Kagan explained that confidentiality was being enforced until such time as more positive action was imminent.

Ms. West expressed some concern about the possibility of assuring preferential tariff to the GDR list of goods without complying with the formal requirements of the Trade Act of 1974. Dr. Lotarski acknowledged that Commerce was aware of the problem and was considering it. Kagan stressed that this matter should be presented not as a trade matter but as a means of satisfying the Foreign Claims Settlement Commission (FCSC) ${ }^{87}$ claims and the Jewish claims with tariff concessions for a specified list of goods as the method for their payments.

84 Susanne S. Lotarski (1942-2017) war von 1973 bis 2005 Mitarbeiterin des US-Handelsministeriums, unter anderem als Direktorin der Osteuropaabteilung und zuletzt Deputy Assistant Secretary. Zudem war sie interessiert am amerikanisch-polnischen Austausch und Vizepräsidentin des Polish Institute of Arts and Sciences.

85 Oskar Fischer.

86 Rozanne L. Ridgway ( $\left.{ }^{\star} 1935\right)$ war von 1983 bis 1985 amerikanische Botschafterin bei der DDR. Zuvor war sie u. a. als Botschafterin in Finnland tätig. Von 1985 bis 1989 wirkte sie als Assistant Secretary of State for European and Canadian Affairs.

87 Die Foreign Claims Settlement Commission wurde 1954 als unabhängige Behörde im Justizministerium der Vereinigten Staaten gegründet. In der Nachfolge der War Claims Commission und der International Claims Commission urteilt sie über und vertritt die Forderungen amerikanischer Bürger gegenüber ausländischen Regierungen. 
There was a brief discussion about the possibility of separate but parallel agreements between the GDR and the US concerning Foreign Claims Settlement Commission claims and the GDR, and between the GDR and CC concerning Jewish claims. It was agreed that it is premature to deal with this question.

The conclusion reached was that the State Department as represented by Mr. Niles, understands and agrees that the CC is proposing a settlement which offers the GDR what is in effect MFN treatment for a specific list of goods $|2|$ and that the proceeds of the GDR exports, over the current base figure of the $\$ 40$ million, are to be split in even dollar amounts between the FCSC and the CC. Mr. Thompson wanted to know if the CC \$100 million was a negotiable figure and he was assured by BBF that it was not. It was understood that the ratios of payout of the dollars earned by the GDR might have to be adjusted to provide the GDR with some "sweetener" but that at this stage it would be best to stick with the division as contained in the BBF draft.

The revised outline is attached. It will be handed to Minister Fischer at the United Nations on Monday, October 3rd.

BBF

\section{Dokument 123}

Benjamin B. Ferencz

Ohne Ortsangabe, 3. Oktober 1983

Maschinenschriftliches Memorandum, 1 Seite

$R G 12.006 .01 * 11$

File memo:

From B.B. Ferencz

Oct. 3, 1983

Meeting with GDR Foreign Minister Oskar Fischer

I met Minister Fischer at the entrance to the General Assembly Hall at the UN and handed him a copy of our letter of Oct. 3rd containing an outline of a possible agreement on Jewish claims. In the large manila envelope I included a copy of Lohn des Grauens, the German edition of Less Than Slaves, which I inscribed to Fischer with wishes for world peace. 
We chatted a while and I mentioned that I had been to Washington where the text of the outline had been discussed. He nodded his appreciation. He asked me when I was coming to Berlin again and I responded that I had no such plans at this time but if it were necessary to expedite matters, I could become available at any time. He asked that I let him know in advance should I have occasion to be in Berlin.

After his speech to the General Assembly a long line of Ministers and Ambassadors formed to congratulate him. He had referred to nuclear war hazards being provoked by the US by its arms race, actions in Latin America etc. and praised the Soviet Union for its declarations on the non-first use of nuclear arms, its proposed treaty on the non-use of force, its proposals at Geneva etc. and also expressed GDR's concern about maintaining the independence of states that had been assured in the Helsinki and prior agreements on the division of European borders. He wanted Israel to go back to its 1967 borders and that Middle East problems be settled by a conference which would include the USSR and the PLO. ${ }^{88} \mathrm{He}$ also spoke about the need for "patient negotiations" < Geduldige Verhandlungen>, "ęcoononomic-cooperation", "common interests" and the "continuation of political dialogue" $<$ Fortsetzung politische dialogue $>$ [sic]. He ended with a peroration: "All the problems are soluble; what is needed is peace." $<$ He spoke in German $>$ The tone seemed a bit milder than it had been $\mathrm{O}\{\mathrm{i}\} \mathrm{n}$ 1982. I will receive the full text later.

After the speech I joined the line to congratulate him and later met him in the washroom where we kibittzed [sic] further. I said that he was a man who came with clean hands (as he scrubbed at the basin) and he explained that since he had been a communist since the age of 13 and had fought for his ideals, he always had clean hands. I told him I appreciated his comments about the need for patient dialogue and economic cooperation and we could reach agreement quickly on those points, I told him that I too was concerned with world peace, and I wished him a safe journey home.

\section{Dokument 124}

Benjamin B. Ferencz

Ohne Ortsangabe, 23. September 1985

Maschinenschriftliches Memorandum, 1 Seite

$R G 12.006 .01^{\star} 13$

88 Palestine Liberation Organization. 
$\{\mathrm{BF} \# \#$ \# copy $\}$

CONFIDENTIAL FILE MEMO

From: B. B. Ferencz

Re: Luncheon Meeting at La Petite Marmite, Sept. 23, 1985

Present: Assistant Secretary of State for European and Canadian Affairs, Rozanne Ridgway

For the Claims Conference: Rabbi Israel Miller, Saul Kagan, B. B. Ferencz

Rabbi Miller reported on the meeting of Sept. 20th with GDR Foreign Minister Fischer ${ }^{89}<$ See file memo>

Roz reported on her new duties and the difficulties of keeping pace with the Secretary. She feared that Congress would not be willing - in the current protectionist mood - to approve MFN (or its equivalent) for a sufficient volume and variety of GDR goods to make it possible for the GDR to meet its claims obligations within a reasonable period of time. She spoke of $\$ 100$ million for the CC and a similar sum for the FCSC claims. She mentioned that it might take the GDR 20 years to earn that amount from an improved trade deal and the GDR would simply have to recognize that it was necessary for them to make a current cash investment to settle the claims in order to reap good-will and the economic rewards in future years. \{Mr. Ferencz expressed doubt that they would be willing to do so.\}

She also mentioned that the entire arrangement would have to be cleared with the Defense Department, where Richard Perle ${ }^{90}$ was a strong opponent of any concessions to Eastern states. Rabbi Miller indicated that he would be able to talk to Mr. Perle and hoped to be able to soften his opposition as regards the proposed settlement.

Mr. Kagan referred to his phone conversations with Mr. Furth [sic $]^{91}$

89 Oskar Fischer.

90 Der Politiker Richard Perle $\left({ }^{\star} 1941\right)$ arbeitete von 1981 bis 1987 für das Verteidigungsministerium der Vereinigten Staaten im Bereich der internationalen Sicherheitspolitik. Anschließend wurde er Mitglied, später Vorsitzender des Defense Policy Board, einem Beratungsgremium des Pentagons.

91 Leon Fuerth $\left({ }^{\star} 1939\right)$ war nach Tätigkeiten im diplomatischen Dienst der Vereinigten Staaten seit den 1980er Jahren Mitarbeiter und Berater von Al Gore. Als Gore 1993 Vizepräsident wurde, blieb Fuerth weiterhin sein Berater für nationale Sicherheit und Waffenkontrolle. Nach Gores Wahlniederlage im Jahr 2000 begann Fuerth als Professor für Internationale Beziehungen an der George Washington University in Washington, D.C., zu unterrichten. 
of Senator Gore's ${ }^{92}$ office who was proposing legislation to block all bank credits to the GDR. Roz replied that US banks were the ones who took the initiative to be able to grant such credits since foreign banks had taken all of the business. It was agreed that Kagan would proceed to Washington to meet with Mr. Furth and try to persuade him to drop the idea. He would also talk to the Dept. of Commerce and try to get a clearer picture about the anticipated volume of GDR trade in the prevailing political climate.

Roz indicated that the responsibilities of Tom Niles would be taken over by James Woessner ${ }^{93}$ but she hoped that she would be able to arrange for the claims problems to be dealt with by her former Berlin aide, Mr. Wilkinson ${ }^{94}$ who had moved to Washington with her.

The luncheon was warm and cordial. GDR/

\section{Dokument 125}

Benjamin B. Ferencz

Ohne Ortsangabe, 17. Juni 1986

Maschinenschriftliches Memorandum, 2 Seiten; Kopfzeile auf Seite 2 (»Confidential memo on June 17, 1986 meeting, continued «)

$R G 12.006 .01^{*} 14$

File Memo: CONFIDENTIAL

$\{$ M. B. Ferencz $\}$

From: B. B. Ferencz

Subject: Meeting at the State Dept. on 17 June, 1986 re GDR Claims

92 Der demokratische Politiker Albert A. »Al« Gore jr. ( $\left.{ }^{\star} 1948\right)$ war von 1977 bis 1985 Abgeordneter des Repräsentantenhauses und anschließend bis 1993 Senator. Von 1993 bis 2001 wirkte er als Vizepräsident unter Bill Clinton. 2000 unterlag er bei den Präsidentschaftswahlen gegen den Republikaner George W. Bush.

93 Wahrscheinlich ist William M. Woessner (1931-2016) gemeint, der drei Jahrzehnte im diplomatischen Dienst der Vereinigten Staaten tätig war, Ende 1985 von einer Entsendung an die Botschaft der Bundesrepublik Deutschland zurückkehrte und Stellvertreter von Rozanne Ridgway im Außenministerium wurde.

94 James Wilkinson (1927-2010) arbeitete seit 1962 im diplomatischen Dienst der Vereinigten Staaten, zuletzt unter Rozanne Ridgway. 
Present: $\quad$ For the State Dept.: Roz Ridgway, Asst. Sect. ${ }^{95}$ for European and Canadian Affairs; Harry Gilmore, ${ }^{96}$ Director of Off. ${ }^{97}$ of Central European Affairs; Jim Lane, GDR Desk Officer; Wayne Merry ${ }^{98}$ For the Claims Conference: Rabbi Israel Miller, Saul Kagan, B. B. Ferencz

After some personal introductory remarks, Rabbi Miller explained that he wanted to touch base with the Dept. before the scheduled meeting of the Claims Conference in Israel in July. The conversation which followed was completely candid and friendly and only the main conclusions will be noted herein.

"Roz" acknowledged that there was still opposition being expressed by Michael Smith of the Office of the Special Trade Rep. ${ }^{99}$ But that was not new; what was of current concern was the deterioration of relations between the US and the GDR that was brought about by recent actions of the GDR by seeking to impose travel and documentation restrains on Allied diplomats crossing the East Berlin border, and more particularly by the fact that the GDR was suspected of having failed to prevent the attack on a West Berlin Discotheque that resulted in the killing of several Americans and the wounding of many others. ${ }^{100}$ The attack was believed to have been made by Libyans with the assistance of the Libyan mission in East Berlin - despite the fact that the US had warned the GDR that such an attack might be made. Under the circumstances it would not be possible to get anything through the Congress that might favor the GDR and even the State Dept. would not support such

95 Assistant Secretary.

96 Der Diplomat Harry Gilmore (1937-2015) war 36 Jahre im diplomatischen Dienst der Vereinigten Staaten tätig, u. a. in Jugoslawien, Russland und Ungarn. Von 1985 bis 1987 war er Direktor des Büros für Zentraleuropäische Angelegenheiten, anschließend erlebte Gilmore als amerikanischer Vertreter in Westberlin 1989 den Mauerfall.

97 Office.

98 E. Wayne Merry arbeitete als politischer Berater und Diplomat im Auswärtigen Dienst der Vereinigten Staaten, wobei er sich auf Osteuropa und vor allem Russland spezialisierte. Von 1980 bis 1983 und von 1991 bis 1994 war er an der amerikanischen Botschaft in Moskau tätig. Ab 1995 wirkte er im Pentagon als Regional Director for Russia, Ukraine and Eurasia.

99 Representative. Gemeint ist das Büro des außerordentlichen Handelsbeauftragten, das 1963 gegründet wurde.

100 In der Nacht vom 4. zum 5. Juni 1985 wurde ein Bombenattentat auf die bei US-amerikanischen Soldaten beliebte Diskothek La Belle in Berlin-Friedenau verübt, für das vermutlich die damalige libysche Regierung verantwortlich war. Drei Menschen starben, Hunderte wurden verletzt. 
an effort at this time. Secretary Shultz ${ }^{101}$ was even inclined to cut off all connections with the GDR, and there was strong Allied unity on turning off the relationship. She felt that GDR Ambassador Herder ${ }^{102}$ recognized the need for the GDR to improve its relationship with the West if the GDR hoped to acquire needed technology for modernization, but the position was now in suspense.

Regarding the settlement of US (Foreign Claims Commission) claims there had been little change. A new meeting was scheduled to take place in Berlin on July 1st and 2nd, but the best that was hoped for would be the preparation of a draft with a great many items left unresolved and bracketed.

The lists of products that had been submitted by the GDR was being examined by the Dept. of Commerce and had been divided into 4 categories: A- Those that were politically "sensitive" since they would compete with US products and would not be acceptable for import into the US, B- Those of lesser sensitivity, C and D, those that were not "sensitive" and would probably be acceptable. There was still no indication of the dollar volume that might be expected in each category, but it was clear that the increased volume resulting from reduced tariffs would not be nearly as high as the parties had previously hoped or expected. It would therefore be necessary for the GDR to advance cash toward a settlement or to add a significant number of new items to the list of proposed GDR exports to the US.

[|2|] To Kagan's inquiry about assistance to the GDR or guidance in the types of products that might still be saleable in the US, Lane suggested that the US was now importing about $\$ 200$ million worth of rifles, of which the GDR had only about $10 \%$, but there was no indication of any readiness at this time to lend any special assistance to the GDR. It would be at least a month or two before there would be any indication of what the dollar volume of potential GDR exports to the US might be.

Sect. Ridgway indicated that further substantial progress would depend upon "a political call on both sides." Pending a rapprochement on a higher level, the only thing that could be done to move the process forward would

101 Der republikanische Politiker George P. Shultz $\left({ }^{*} 1920\right)$ wurde 1982 von Ronald Reagan zum Außenminister der Vereinigten Staaten ernannt und übte das Amt bis 1989 aus. Zuvor hatte er verschiedene Posten in Ministerien und in der Wirtschaft durchlaufen. So war Shultz u. a. Arbeits- und Finanzminister unter Präsident Nixon und Präsident der Bechtel Corporation.

102 Gerhard Herder $\left({ }^{\star} 1928\right)$ war seit 1983 Botschafter der DDR in den Vereinigten Staaten und Kanada. Zuvor hatte er - seit 1962 im Ministerium für Auswärtige Angelegenheiten tätig - die DDR unter anderem als Botschafter im Libanon und als ständiger Vertreter bei den Vereinten Nationen in Genf repräsentiert. 
be to continue the "in-house" preparations that were in fact taking place: screening the lists and drafting a settlement of the US claims. A preliminary draft of an agreement between the Claims Conference and the GDR had been prepared by Ambassador Herder and Mr. Ferencz pursuant to an authorization by GDA Foreign Minister Fischer ${ }^{103}$ but the gaps in that agreement could hardly be filled in until the dollar amounts expected from the lists of goods could be more accurately appraised. She had no objection to the Claims Conference informing Herder why there was now an impasse and to urge him to begin adding items to the list of products.

Rabbi Miller indicated that the Claims Conference would again try to meet Minister Fischer when he attends the meeting of the UN General Assembly later this year. No objection was raised and the indication was that the Conference could pass the same message along to the Minister.

The Sect. indicated that she would be on vacation during August and it was agreed that the parties would remain in touch after the summer.

\section{Dokument 126}

Benjamin B. Ferencz

Ohne Ortsangabe, 21. September 1987

Maschinenschriftliches Memorandum, 3 Seiten

RG $12.006 .01^{\star} 15$

[Für die eigenen Akten dokumentiert Ferencz ein erneutes Treffen mit dem Minister für Auswärtige Angelegenheiten der DDR Oskar Fischer in New York im Herbst 1987. Er erläutert die unverändert gegenläufigen Standpunkte der Vertreter der JCC sowie der Regierung der DDR in Fragen der Restitution und Entschädigung. Dabei hebt er vor allem handelspolitische Aspekte hervor.]

\section{CONFIDENTIAL FILE MEMO RE CLAIMS AGAINST THE GDR}

Luncheon Meeting at Princeton Club ${ }^{104}$ in NY, Sept. 21, 1987

103 Oskar Fischer.

104 Der Princeton Club of New York ist ein privater Club in Midtown Manhattan. Die Mitgliedschaft ist weitgehend auf Dozenten und Alumni der Princeton University, New Jersey, beschränkt. 
PRESENT: For the GDR: Foreign Minister Oskar Fischer, GDR Ambassador Gerhard Herder, Chef de Cabinet Manfred Niklas ${ }^{105}$ and Interpreter Herr Simon.

For the Claims Conference: Rabbi Israel Miller, Saul Kagan and B. B. Ferencz.

Through a misunderstanding, the GDR group had gone to the Harvard Club where they had been waiting for about 10 minutes before being picked up there by Mr. Ferencz and walked to the Princeton Club around the corner. They took the error and delay with good humor.

The atmosphere was friendly and sociable over (mostly non-alcoholic) drinks before lunch. Rabbi Miller expressed his profound appreciation for the extraordinary hospitality shown by the GDR and its highest officials to Dr. and Mrs. Miller and to Mr. and Mrs. Kagan while they were the invited guests of the GDR from June 22 to 26 . He noted that the GDR could be proud of having risen from the ashes of World War II. The friendly banter covered such matters as disarmament, peace, German re-unification etc.

Rabbi Miller mentioned that he had been very moved by his visit to the former concentration camp at Buchenwald. He stressed the importance which he attached to the placement of commemorative plaques - in Yiddish and Hebrew - at the Buchenwald Memorial Monument. Mr. Fischer replied that he did not anticipate any problems in meeting Rabbi Miller's request, but he noted that the monument came under the jurisdiction of another Ministry. He promised to remind that Ministry of the need to take care of the request.

The substantive discussion began with Dr. Miller's noting that many problems still remained before a settlement of Jewish claims could be reached. He conveyed appreciation for the gesture of good will manifested by Mr. Honecker's willingness to give the Claims Conference $\$ 5$ million. He explained that there had not yet been a Claims Conference response to that offer since it had to be considered within the context of an overall agreement. The offer had been discussed with other Jewish leaders but had not been publicized lest it invoke criticism as being inadequate, and it might be misunderstood if it was not seen as part of a more comprehensive package.

He had also approached various members of Congress, but it was difficult to speak with them in concrete terms until and unless it was clear exactly what the GDR was offering. What was required now was a clear acceptance of the Claims Conference [|2|] request for $\$ 100$ million. We are on the threshold of a

105 Manfred Niklas ( $\left.{ }^{\star} 1940\right)$ war Leiter des Ministerbüros im Ministerium für Auswärtige Angelegenheiten der DDR. 
major political breakthrough but the absence of the acceptance of the specific sum requested was a major stumbling block.

Mr. Fischer replied that he understood and respected the reluctance to publicize the $\$ 5$ million offer, but he was not sure that he understood the broader thrust of Rabbi Miller's statement. He noted that it had always been accepted that the payments to the Claims Conference would have to come out of the proceeds of increased exports from the GDR to the US. As he put it, "We expect the payments to come from the sale of goods and to use part of the proceeds until we reach your sum." He asked whether that basis was now being changed.

Mr. Fischer made the point that the GDR was hopeful that the claims issue could be resolved with the present US administration or it might require another $21 / 2$ to 3 years before a new administration could move on it. If the old basis (the linkage between trade and payments) remained intact, the US should respond more promptly to the list of potential exports that had been provided to the State Dept. some time ago.

Dr. Miller assured the Foreign Minister that the Claims Conference had not changed its position and was not insisting upon additional payments at this time. But it was important to have a clean confirmation from the GDR that the $\$ 100$ million figure was acceptable.

Mr. Fischer expressed appreciation that there was no change in the position and promised that Dr. Miller would receive an answer as soon as Mr. Fischer returned home to East Germany.

Dr. Miller noted that Deputy Secretary of State Whitehead ${ }^{106}$ planned to visit the GDR around the end of October and it would be well if the GDR response could be ready before that time. He assured the Foreign Minister that the Claims Conference also wished to conclude the Jewish agreement during the Reagan administration, if possible. Mr. Fischer repeated that the GDR position would be clarified by that time.

Dr. Miller then took from his pocket a letter he had received from Secretary of State Shultz, which he asked the translator to read aloud in German. The letter (dated Sept. 9, 1987) indicated that Rabbi Miller had urged the Secretary to meet with Mr. Fischer and that the Department was firm in its support of a settlement with the East Germans. Mr. Fischer seemed pleased and acknowledged that a meeting with the Secretary had been fixed.

Mr. Kagan drew attention to the fact that the time was not particularly favorable for any new made agreements. The Congress was in a protectionist mood, wohnåt did not relate to the GDR but to other trade problems faced \#\#\#

106 John C. Whitehead (1922-2015) war zwischen 1985 und 1989 Vizeaußenminister der Vereinigten Staaten. Zuvor hatte er viele Jahre leitend bei Goldman Sachs gearbeitet. 
the US. The Claims Conference had always viewed the settlement with the GDR as [|3|] primarily a matter of humanitarian consideration which should not be deterred by other difficulties.

Mr. Fischer again reverted to the lists of goods which the GDR had provided to the US but which was still awaiting some favorable response. He indicated that he might raise the question of the delayed response with Secretary of State Shultz when they met in a few days time.

BBF/GDR87

\section{Dokument 127}

Benjamin B. Ferencz an Gerhard Herder

New Rochelle, N. Y., 12. Dezember 1987

Maschinenschriftlicher Brief, 1 Seite; gedruckter Briefkopf mit maschinenschriftlich eingefügtem Datum

$R G 12.006 .01^{\star} 15$

Benjamin B. Ferencz

Counsellor at Law

'Dec. 12, 1987'

14 Bayberry Lane, New Rochelle N. Y. 10804

914 632-3717

Ambassador Gerhard Herder and Mrs. Herder

The Ambassador of the German Democratic Republic

1717 Massachusetts Ave. N.W.

Washington DC 20036

Dear Ambassador and Mrs. Herder:

I am beginning to believe that Santa Claus exists and he lives in Dresden. Once again I am delighted to thank you, in my own name, in the name of my wife, my children and grandchildren, for your thoughtful - and delicious - gift. We shall all share it with pleasure and think of you while we get fat.

I do not know what I can send in return to match your gift. I am enclosing a small brochure which announces that my next book on world peace is on the way. I shall surely subject you to a copy as soon as it appears. (You are not obliged to read it.) 
You will also notice from the attached news story that I have been very busy trying to save the world from extinction. I am glad that I have the help of General Secretary Gorbachev. ${ }^{107}$ As a great expert on disarmament, I am sure that you share my satisfaction that at last the super-powers are moving in the right direction. Let us hope that the world will come to its senses before it is too late. I am really quite optimistic - as you will see from my last book "A Common Sense Guide to World Peace." I am also grateful that your government also recognizes the need for a more peaceful world order.

So let me simply wish you and your family a very happy holiday season at home and let us join together to do whatever we can to make it a more peaceful and just world in the future.

Sincerely,

$\{$ Ben $\}$

\section{Dokument 128}

Benjamin B. Ferencz an Saul Kagan

New Rochelle, N. Y., 1. September 1988

Maschinenschriftlicher Brief, 2 Seiten

$R G 12.006 .01^{\star} 16$

Counsellor at Law

Adjunct Professor

Pace Law School

\section{BENJAMIN B. FERENCZ}

\author{
14 Bayberry Lane \\ New Rochelle, N.Y. 10804 \\ (914) 632-3717
}

September 1, 1988

Saul Kagan: Claims Conference

107 Michail Sergejewitsch Gorbatschow $\left({ }^{\star} 1931\right)$ war von 1985 bis 1991 Generalsekretär des Zentralkomitees der Kommunistischen Partei der Sowjetunion (KPdSU). Von März 1990 bis Dezember 1991 hatte er zudem das Amt des Staatspräsidenten der Sowjetunion inne. Sein politisches Handeln ist eng mit den Schlagworten Transparenz (Glasnost) und Umgestaltung (Perestroika) verbunden. Die damit einhergehenden Reformen führten zur Auflösung der Sowjetunion, ermöglichten die deutsche Wiedervereinigung und das Ende des Kalten Kriegs. 


\section{CONFIDENTIAL}

\section{Dear Saul:}

The official GDR Foreign Affairs Bulletin of 15 July 1988 reported "a statement of the GDR Foreign Ministry Spokesman recently published which says that the GDR is ready to extend humanitarian aid to needy Jewish victims in other countries." ${ }^{108}$ I think that may offer an opening for the next discussion with Oskar Fischer. Please share my thoughts with Rabbi Miller.

We will no doubt be called upon to explain why - despite GDR compliance with U.S. demands for export lists - there has been no progress on the U.S. side in moving toward the tripartite settlement (Jewish claims, US claims, and Trade Agreement) that has been the subject of negotiation for years. Dr. Miller will have to acknowledge the failure of the State Department plan and try to explain it.

The blame will have to be shared by the GDR. We may note its reluctance and delayed response to Jewish overtures; its refusal to accept a commitment to pay the sum of $\$ 100$ million - which created doubts about GDR's sincerity; its insistence upon a linkage between payment and trade concessions - which made it appear that they wanted the U.S. to pay their obligations; its argument that they lacked sufficient dollars lost persuasiveness as GDR reserves continued to grow; GDR's persistent rejection of either legal or moral responsibility remained an unconvincing irritant.

Under such circumstances, the State Dept. position, which was the product of strong intervention by Dr. Miller, was always a vulnerable one. It lacked Congressional support since Dr. Miller recognized (and repeatedly made clear) that it would be futile for him to approach leading members of Congress without a firm commitment from the GDR to pay the relatively modest sum requested by the Claims Conference. With many members of the Administration ideologically opposed to anything resembling concessions to a Socialist state, they forced a showdown in which the State Dept. plan was rejected.

|2| Where do we go from here? We all recognize that nothing can be expected during the remaining tenure of this administration. Dr. Miller has indicated a willingness to go directly to the Congress - providing there is a clear commitment by the GDR to pay $\$ 100$ million over a number of years. The State Dept. - regardless of who wins the elections - will probably continue its support. But the other branches of a new administration would have to be won over, and if the Republicans prevail, we may very well encounter the same opposition. Without administration support, or a radical change in the 
GDR position, Congressional support sufficient to enact necessary legislation will - I fear - be very difficult to come by.

The thought occurred to me therefore, that we should take Fischer by his officially published word. What did he mean when he announced that the GDR was "ready to extend humanitarian aid to needy Jewish victims"? Was he thinking of another "gift" of $\$ 1$ million or $\$ 5$ million, or $\$ 10$ million - which would again evoke world wide scorn as "throwing a dog a bone"? Let him clarify his statement in specific detail - how much, when and to whom and under what conditions and procedures. Or was it propaganda?

We may note that after committing over DM 100 billion (over $\$ 55$ billion) the West Germans created a Hardship Fund of DM 400 million (over \$200 million) for "needy Jewish victims." ${ }^{109}$ Those needs have still not been satisfied by a long shot. There are literally many thousands of Nazi survivors who receive no pensions, whose indemnification was inadequate and who are still in great need. Institutions that assist Jewish Nazi victims are desperately in need of funds. Is the GDR serious in its public declaration of willingness to help?

We may note that the attempted eradication of anti-semitism in the GDR is very praiseworthy; that remembrance ceremonies on occasions of great Jewish persecution, the maintenance of cemeteries or the rebuilding of synagogues and welcoming Jewish visitors from abroad is much appreciated. But it does very little to improve the lot of the survivors. Nor are they helped by the fact that reparations were paid to the USSR under the Potsdam agreement. 50 years after Crystalnacht [sic] and 40 years after the formation of the GDR as an independent state it is time for the GDR to do something more constructive for those whose lives were shattered by German (East and West) persecution.

The Claims Conference is the representative Jewish body to deal with the issue of Jewish claims. It has refrained-from any criticism of the GDR and has through patient dialogue (as recommended by Oskar Fischer) sought to

109 Am 25. Juli 1980 verabschiedete das Bundeskabinett die vom Bundesfinanzministerium ausgearbeiteten Richtlinien, nach denen als »Abschlussgeste« bis zu 400 Millionen DM an die JCC sowie 40 Millionen DM an den Zentralrat gezahlt werden sollten. Am 3. Oktober 1980 wurden die Richtlinien für die Vergabe von Mitteln an jüdische Verfolgte zur Abgeltung von weiteren Härten in Einzelfällen im Rahmen der sogenannten Wiedergutmachung im Bundesanzeiger veröffentlicht. Die Gelder waren zur Entschädigung jüdischer Verfolgter des Nationalsozialismus vorgesehen, die nach 1965 aus den Staaten des Warschauer Pakts emigriert waren. Die Umsetzung des sogenannten Post-65-Härtefonds wurde damit der JCC übertragen. Siehe Hermann-Josef Brodesser u.a., Wiedergutmachung und Kriegsfolgenliquidation. Geschichte Regelungen - Zahlungen, München 2000, 122 f.; Goschler, Schuld und Schulden, 342. 
improve relations. So far, it has nothing concrete to show after almost 15 years of quiet diplomacy. What course should it now follow, what help can it get from the GDR and what message should it give to the Jewish people?

\{Warm greetings,

Ben\}

\section{Dokument 129}

Benjamin B. Ferencz an Israel Miller

New Rochelle, N. Y., 5. April 1990

Maschinenschriftlicher Brief, 2 Seiten

$R G 12.006 .01 * 18$

Counsellor at Law

Adjunct Professor

Pace Law School

\section{BENJAMIN B. FERENCZ}

14 Bayberry Lane

New Rochelle, N. Y. 10804

(914) 632-3717

April 5, 1990

Rabbi Dr. Israel Miller

President

Conference on Jewish Material Claims Against Germany

15 East 26 St.

New York NY 10010

Dear Israel:

A recent statement issued by the Israel Executive of the World Jewish Congress on the subject of German Unification has just come to my attention. It contains one paragraph which raises problems within your competence which I feel merit your attention and action.

The paragraph states: "Negotiations concerning material claims to families of Holocaust victims from East Germany should be finalized. Heirless private and community property which belonged to Jews and was either confiscated or destroyed should be given consideration."

The fact is that no negotiations have ever been carried on regarding claims to families of Holocaust victims. To suggest that they should now be entitled 
to file claims would introduce a new category of claims with major impact. The reference to heirless property and communal property omits any mention of unclaimed property - which is most likely to be the most important category for which restitution is to be sought. The further omission of properties which were neither "confiscated or destroyed" but were sold under duress might be misinterpreted as a waiver of such claims. The statement "should be taken into consideration" is so vague as to be almost frivolous. In short, the undoubtedly well-intentioned statement can lead to serious confusion.

These shortcomings could easily have been avoided if the statement was cleared with you in advance which obviously would have been the correct organizational procedure in any case.

[|2|] I understand that the World Jewish Congress is planning a meeting at Wannsee in Berlin in early May. It would of course be an opportune time to support what you and the Claims Conference have been doing in the claims field. May I therefore suggest that you request the $\mathrm{WJC}^{110}$ representatives to issue the following statement.

"The World Jewish Congress, as an original member of the Conference on Jewish Material Claims against Germany, fully supports all efforts by the Claims Conference and its President Rabbi Dr. Israel Miller to obtain as quickly as possible a fair measure of compensation from the German Democratic Republic for the surviving victims of Nazi persecution."

I don't think that more is called for at this time. As you know, the subject is a complicated one and you have correctly proceeded after consultation with the Claims Conference Board and the Government of Israel. Raising false hopes is as unkind to the surviving victims as it is detrimental to the Jewish organizations trying to help them. The Claims Conference has been the accepted Jewish organization to speak with one voice on this very serious subject and it should continue that way if we are to fulfill our responsibilities to those who survived Hitler's Holocaust.

With best wishes for Pesach,

Shalom, ${ }^{111}$

CC: Saul Kagan

110 World Jewish Congress.

111 Unterschrift fehlt auf archivalischer Kopie. 


\section{Dokument 130}

Benjamin B. Ferencz

Ohne Ortsangabe, 5. Juni 1990

Maschinenschriftliches Memorandum, 1 Seite; handschriftliche Unterstreichungen, handschriftliche Einfügung am oberen Seitenrand (vierzeilig, unleserlich, da verblasst)

$R G 12.007 .01^{\star} 15$

$\operatorname{gdr} / 90$

June 5,1990

Memorandum: Thoughts re Jewish Claims against the GDR

The new non-communist government of the GDR has apologized for Nazi crimes against the Jews and indicated a desire to make material amends. ${ }^{12}$ What should be requested?

It appears likely that the GDR will merge with the FRG by early 1991. An impoverished GDR will hardly make significant commitments without FRG concurrence. The FRG part of the equation must be taken into account. Experience has shown that pressing Jewish claims into a strict German legal mold took over 40 years and produced a morass of inequity. We should move away from a legal approach to a social approach. Whatever is requested should be clear, justifiable and capable of quick administration.

BOTTOM LINE: Ask for DM 5 billion ( $\$ 3$ billion) payable over ten years.

Justification: Consider what the FRG has done and what remains undone. Official FRG reports show that about DM 83 billion has already been paid for Nazi victims (non-Jews included,) that another 37 billion will still be paid out by the year 2030, making the total cost about DM 120 billion. The Jewish claim, to cover gaps in FRG laws and missing GDR components, amount to less than $5 \%$ of the total. A claim for DM 10 billion could also be justified. Consider the following 4 items only:

1- Global Claims under The Hague Agreement: gave DM 3 billion to Israel and 450 million for the Claims Conference. In 1952, the FRG admitted that it was paying only $2 / 3 \mathrm{rds}$ of a recognized obligation. The remaining $1 / 3 \mathrm{rd}$, attributable to the GDR share, amounts to DM 1,725 billion. Adding interest at $4 \%$ per annum, increases the amount by another $152 \%$ to DM 4,347 billion.

112 Siehe Volkskammer, Antrag aller Fraktionen der Volkskammer der Deutschen Demokratischen Republik zu einer gemeinsamen Erklärung, Berlin, 12. April 1990. 
2- Jewish successor organizations recovered over DM 300 million in the West. The GDR portion of heirless and unclaimed individual, community and organizational property can modestly be estimated at DM 100 million. Adding 4\% interest, as above, brings the amount over DM 235 million.

3- The indemnification law alone will cost the FRG DM95 billion. There is no doubt that it has produced many inequities. $5 \%$ more, to alleviate injustices and cover claims attributable to the GDR, would amount over DM 4,75 billion.

4- Inequities also exist regarding other types of claims, including hardship payments. The FRG estimate for such claims is about DM 13 billion. 5\% to eliminate the inequities and cover the GDR portion would cost DM650 million.

The total for the 4 items, with limited interest as stated, is DM 10 billion. The request for only half of that is modest; spread over 10 years it should be acceptable.

\section{Dokument 131}

Benjamin B. Ferencz

Ohne Ortsangabe, 7. September 1990

Maschinenschriftliche Aktennotiz, 1 Seite

$R G 12.006 .01^{\star} 18$

File Note GDR Sept. 7/1990

Gerda Feigan [sic] ${ }^{113}$ called at about 10 AM. Very upset. Said she was "scared to death." There was a phone call for Kagan at 9:15. A voice spoke in good English and when she said she understood German, another voice came on and said in German:

"Tell that damned Jew that if he comes to Germany we will slit his throat." <"Den [sic] gurgle [sic] runterziehen">

I suggested she tell Saul and tell him that I advise him to notify the police so that they can try to trace the call and take appropriate action. \{Done.\}

113 Gemeint ist wahrscheinlich Gerta Feigin $\left({ }^{\star} 1928\right)$, eine aus Lettland stammende Anwältin, die bis 1998 leitende Mitarbeiterin der JCC im Bereich des Post-65-Härtefonds war. 
I later called Saul who said he had spoken to Miller who has contact via his nephew or son with the National Jewish Community Relations Council which knows the police officers who handle such matters. He said he would report it.

I advised Saul not to go to Germany. Not merely because of the threat but because it would be counterproductive. He had so antagonized them that they would not listen to his demands and the demands themselves were so clear that Brozik should be able to handle it. After some discussion he said he would stay home if Miller so advised. I asked if I could talk to Miller about it. He said Yes.

I called Miller and told him my view. He said he would talk to Saul.

Later that afternoon Saul confirmed that he had cancelled his trip. 


\section{Ausbau der bundesdeutschen Entschädigung für jüdische Opfer des Nationalsozialismus}





\section{Dokument 132}

Benjamin B. Ferencz an Philip Soskis ${ }^{1}$

New York, 9. November 1965

Maschinenschriftlicher Brief, 2 Seiten; gedruckter Briefkopf mit maschinenschriftlich eingefügtem Datum auf Seite 1, Kopfzeile auf Seite 2 (gedruckt: "TAYLOR, SCOLL, FERENCZ \& SIMON")

$R G 12.012 .01{ }^{*} 01$

\section{Taylor, Scoll, Ferencz \& Simon COUNSElors at LaW}

Telford TAYlor

DAVID E. SCOLL

Benjamin B. Ferencz

KenNeth Simon
|November 9, 1965'
Pan Am Building 200 Park Avenue NeW YoRK, N. Y. 10017
$* * *$
MO 1-0930
Cable AdDress: Lantalaw

Mr. Philip Soskis

Executive Director

NYANA $^{2}$

15 Park Row

New York 18, N. Y.

1 Philip Soskis (1910-1989) war von 1952 bis 1975 geschäftsführender Direktor von NYANA. Zuvor war er u. a. beim United Service for New Americans tätig. Darüber hinaus engagierte er sich in verschiedenen sozialen Organisationen.

2 Die New York Association for New Americans (NYANA) wurde 1949 als Zweig der Organisation United Service for New Americans (USNA) gegründet. USNA widmete sich der Unterstützung von Überlebenden des Holocaust bei ihrer Übersiedlung in die Vereinigten Staaten. NYANA übernahm diese Aufgaben für New York, wo die meisten Einwanderer ankamen. Während sich USNA 1954 mit HIAS zusammenschloss, blieb NYANA eigenständig. Zu den umfangreichen Angeboten der Organisation zählten neben Unterstützung bei der Wohnungssuche, Sprachunterricht und juristischer Beratung auch medizinische und psychologische Hilfe. Seit den 1950er Jahren richteten sich die Hilfsangebote von NYANA auch an jüdische Flüchtlinge, die nicht vom Holocaust betroffen waren, etwa an Juden aus Ägypten. In den 1970er Jahren unterstützte NYANA zahlreiche Emigranten aus der Sowjetunion und wandte sich zugleich auch an nichtjüdische Flüchtlinge, die nach Amerika gelangt waren. 
Dear Mr. Soskis:

Pursuant to our conversation of today, I am pleased to confirm that I would be willing to represent NYANA in connection with its claims against the Federal Republic of Germany for reimbursement of medical expenses incurred by NYANA in aiding victims of Nazi persecution.

I would agree to take whatever steps are legally possible to negotiate a satisfactory settlement with the German government. This would include the assembly in suitable form of supporting documentary and legal materials, the preparation of legal argumentation and such representations here and abroad with the German Consulate, the German Embassy and the appropriate German Ministries as may appear to be useful or necessary. Your office would be called upon solely to provide such materials as are exclusively in your possessions and which may be essential in support of our case.

Since this claim by NYANA has already been carefully considered by the competent German authorities and has been rejected as not meeting the requirements of the existing indemnification law, an early or easy settlement of this matter does not appear likely. It is impossible to predict how long it will take or even what precise steps will finally be required to obtain a reversal of the German position. I can assure you, however, that everything which can reasonably be done will be done and of course no agreement with the German authorities will be concluded without the prior approval of your office.

|2| My fee for these services would be a one-time retainer of $\$ 5,000$. Expenses would also have to be reimbursed but these would not exceed $\$ 1,000$ per annum without your prior consent. In addition, there would be a contingent fee of $20 \%$ of the first $\$ 300,000$ recovered for NYANA and $15 \%$ of any amounts recovered in excess of $\$ 300,000$.

Since I believe strongly that the claim of NYANA is morally justified, I am hopeful that the German government can eventually be persuaded to recognize the merit of the demands which will be made. If you and your Board agree to retain my services on the basis indicated above, I would appreciate your signifying your consent by signing and returning one copy of this letter.

I look forward to being of service.

Sincerely yours,

Benjamin B. Ferencz

BBF: js

Encl.

Agreed:

\{Philip Soskis\} 


\section{Dokument 133}

Benjamin B. Ferencz an James P. Rice

New York, 22. April 1966

Maschinenschriftlicher Brief, 2 Seiten; gedruckter Briefkopf mit maschinenschriftlich eingefügtem Datum auf Seite 1, Kopfzeile auf Seite 2 (gedruckt: »TAYLOR, SCOLL, FERENCZ \& SIMON «, maschinenschriftlich: AApril 22, 1966«) $R G 12.012 .01^{\star} 01$

\section{Taylor, Scoll, Ferencz \& Simon COUNSElors at LAW}

TElford TAYLOR

David E. SCOLL

Benjamin B. Ferencz

Kenneth Simon
|April 22, 1966|

PAN-Am BuILding

200 Park Avenue

New York, N. Y. 10017

***

MO 1-0934

Cable Address: Lantalaw

Mr. James P. Rice

Executive Director

United Hias Service, Inc. ${ }^{4}$

200 Park Avenue South

New York, N. Y.

3 James P. Rice (1913-1997) bekleidete von 1957 bis 1966 den Posten des geschäftsführenden Direktors von HIAS. Zuvor hatte er seit 1945 für das JDC gearbeitet und dessen Hilfsprogramm für jüdische DPs in Italien, Frankreich, Österreich und der Schweiz betreut. Von 1966 bis 1979 war er Vizepräsident der Jewish Federation of Metropolitan Chicago.

4 Die Organisation United HIAS Service, Inc. entstand 1954 aus dem Zusammenschluss der Hebrew Immigrant Aid Society (HIAS), der Organisation United Service for New Americans (USNA) sowie dem Migration Department des JDC. HIAS war 1881 gegründet worden, um die oftmals mittellosen jüdischen Einwanderer aus dem östlichen Europa zu unterstützen. In den 1930er und 1940er Jahren suchte sie auch die Emigration und Flucht von Juden aus dem nationalsozialistischen Machtbereich zu befördern. Nach Kriegsende waren Hilfsleistungen für jüdische DPs und deren Neuansiedlung ein wichtiges Arbeitsfeld. Mit der Fusion zum United HIAS Service entstand in den 1950er Jahren eine internationale Hilfsorganisation, die die Migration und Integration jüdischer Flüchtlinge weltweit unterstützt. Seit Mitte der 1970er Jahre richtet sich ihr Angebot auch an nichtjüdische Flüchtlinge. 
Dear Mr. Rice:

This will confirm the understanding reached during the course of our meeting in my office on April 21, 1966, together with Edward Benton, Esq., Thomas Baer, Esq. and Mr. Harry Friedman.

It is agreed that I will represent the United Hias Service in connection with an attempt to obtain compensation from the Federal Republic of Germany for the medical expenses incurred by the United Hias Service and its affiliated agencies on behalf of victims of Nazi persecution. I would agree to take whatever steps are legally possible to negotiate a satisfactory settlement with the German government. This would include the assembly in suitable form of supporting documentary and legal materials, the preparation of legal argumentation and such representations here and abroad with the German Consulate, the German Embassy and the appropriate German ministries as may appear to be useful or necessary. Your office would be called upon solely to provide such materials as are exclusively in your possession and which may be essential in support of our case. No agreement with the German authorities would be concluded without the prior approval of your office.

My fee for these services would be a one-time retainer of $\$ 5,000$, payable quarterly. Expenses would also have to be reimbursed but these would not exceed $\$ 1,000$ per annum without your prior consent. In addition, there would be a contingent fee of $20 \%$ of the first $\$ 300,000$ recovered for the United Hias Service and its affiliated agencies, and $15 \%$ of any amount recovered in excess of $\$ 300,000$. These terms are the same as those agreed to by the New York Association for New Americans (NYANA).

|2| I would appreciate your signifying your consent by signing and returning one copy of this letter.

I look forward to being of service.

Sincerely yours,

\{Benjamin B. Ferencz\}

Benjamin B. Ferencz

Agreed:

\{James P. Rice\}

BBF: js

cc. Mr. Harry M. Friedman, Comptroller 


\section{Dokument 134}

Benjamin B. Ferencz an Philip Soskis und James P. Rice

Ohne Ortsangabe, 24. Mai 1966

Maschinenschriftlicher Brief, 4 Seiten; Kopfzeile auf jeder Seite (nur für Seite 1 wiedergegeben)

$R G 12.012 .01^{\star} 01$

[Ferencz fasst Sondierungsgespräche und Recherchen zu Bemühungen um die Übernahme medizinischer Versorgungskosten für Verfolge des Nationalsozialismus durch die Bundesrepublik zusammen. An zwei Fallbeispielen beschreibt er die uneinheitliche Erstattungspraxis des Bayerischen Landesentschädigungsamts. Zudem berichtet er von einem Treffen mit Vertretern einer israelischen Krankenkasse, die sich ebenfalls um die Erstattung von Kosten medizinischer Behandlungen von Holocaustüberlebenden bemühen.]

May 24, 1966

Mr. Philip Soskis

Executive Director

NYANA

15 Park Row

New York, N. Y. 10038
Mr. James P. Rice

Executive Director

United Hias Service, Inc.

200 Park Ave. South

New York, N. Y.

Dear Phil, dear Jimmy:

Having returned to my desk, I am writing now to summarize the various steps taken in Germany in connection with our attempt to obtain compensation for medical costs incurred on behalf of Nazi victims.

On May 3rd, I convened a meeting in Munich attended by Dr. May, Director of the United Restitution Organization, Dr. Selowsky, ${ }^{5}$ Director of the URO Munich office and Dr. Gruenbaum and Dr. von Bubner [sic], ${ }^{6}$ attorneys on the URO Munich staff. The primary purpose of the meeting was to ascertain more specifically how it had come about that the Munich Indemnification Agency was continuing to pay a few medical expense claims even where it appeared that the individual had not incurred the expense

5 Es handelt sich vermutlich um Ludwig Selowsky, der in den 1950er Jahren für die URO in Frankfurt am Main tätig war und in den 1960er Jahren das Büro der URO in München leitete.

6 Wahrscheinlich ist Ulrich von Bubna gemeint, der als Rechtsanwalt für die URO tätig war. 
himself but that the bills had been paid by a charitable organization. The law did not allow such payments so I was particularly curious to see whether we could not find any bridgehead over which we might be able to advance with the HIAS and NYANA claims.

I had referred to this problem briefly in my report to Phil on December 15, 1965, but in the interim he had drawn my attention to two new cases where HIAS was a partial beneficiary, and I wanted to see what we could learn from those cases without of course jeopardizing any of the rights of the individual claimants.

It appeared that many years ago and before the new and restrictive law was enacted, ${ }^{7}$ the Indemnification agency in Munich, then led by a sympathetic person, had agreed with the URO that where a claimant presented original bills and showed that he had assigned the benefits in whole or in part to the welfare agency which had actually incurred the expense, the Munich authorities would pay the claim on equitable grounds. This had involved the $|2|$ claim of the Jewish charitable hospital Ethania $[\text { sic }]^{8}$ of Davos, Switzerland, and was known as the "Ethania Settlement". The Bavarian authorities had accordingly continued to treat all similar cases as coming under the Ethania banner. They did not understand the difference between Ethania and any other organization and since there were very few such cases, no one had bothered to change the prevailing practice.

I asked that the two cases which Phil had drawn to my attention be specifically checked. This presented rather a delicate problem since they were represented by other attorneys with whom URO's relationship was not particularly cordial, and the files are only accessible to those holding the power of attorney. Nevertheless, we managed to obtain access to the records on a confidential basis and learned that in the case of Hanka B. ${ }^{9}$ no reference had been made to any activity by NYANA although an organization by the name of Altro Health and Rehabilitation Services ${ }^{10}$ had intervened in the case.

7 Gemeint ist das am 14. September 1965 erlassene BEG-Schlussgesetz, die letzte Novellierung des BEG. Siehe dazu zusammenfassend Hockerts, Wiedergutmachung in Deutschland, 187 f.; Goschler, Schuld und Schulden, 273-284.

8 Gemeint ist das 1919 gegründete jüdische Sanatorium Etania in Davos, wo nach 1945 ehemalige Konzentrationslagerhäftlinge gepflegt wurden.

9 Die Person wurde anonymisiert.

10 Altro Health and Rehabilitation Services wurde 1913 unter dem Namen Committee for the Care of Jewish Tuberculous gegründet. Die Umbenennung erfolgte 1951. Die Einrichtung betrieb zunächst medizinische Rehabilitationsprogramme für Tuberkulosekranke. Seit den 1950er Jahren kamen die medizinische Nachsorge bei Herzleiden und psychischen Erkrankungen hinzu. Altro Health and Rehabilitation Services war 
In the case of Jacob G., ${ }^{11}$ it appeared that the claimant suffered from t. b. ${ }^{12}$ caused by persecution. The claimant was hospitalized at Montefiore Hospital and the bills were paid by NYANA. On October 29, 1963 NYANA sent the bills to the New York restitution attorney, Mr. Alberti. In December 1965 Mr. Alberti submitted the bills to Munich for payment. It was always clear from the record that the amount had been paid by NYANA and not by the claimant directly, nevertheless, payment of the claim was made in an amount of DM 8,416.- on January 16, 1966 via Mr. Alberti's Munich correspondent attorney, RA. ${ }^{13}$ Levinson.

The Munich authorities were under the impression that NYANA serves as a sort of supplementary medical insurance plan, similar to the Blue Shield or the Blue Cross. The Munich Indemnification Agency has no idea about the function of NYANA nor did it feel called upon to make further inquiry. The authorities were clear, however, that the money was to go to NYANA on the basis of a letter from NYANA dated September 29, 1963, which was part of the file. (I would appreciate a copy of that letter.) The case therefore came under the above-mentioned Ethania Settlement.

The value of my Munich investigation, therefore, was to demonstrate that the Germans are not being consistent and that some German agencies are in fact creating precedents which we would like all German indemnification agencies to follow. Unfortunately, the Munich agency only deals with claims of persons who had been resident in the Munich area. This means in effect those who were $|3|$ in D. P. camps of Bavaria. I have asked that close watch be kept on such cases and that they be reported to me since I feel that somewhere in the negotiations with the Germans such cases can be used to weaken the German position by showing their inconsistent handling of the same matter in different areas. I do not wish to publicize the Munich practice now as I would not do anything which might tend to close the door through which a few cases are now slipping.

On May 4th I proceeded to Berlin where I spoke to RA. Kroll, ${ }^{14}$ (a leader of B'nai B'rith Berlin Lodge) who represents the KUPOT HOLIM. ${ }^{15} \mathrm{He}$ and

eine Einrichtung der United Jewish Appeal - Federation of New York, von der auch NYANA wesentlich subventioniert wurde.

11 Die Person wurde anonymisiert.

12 Tuberculosis.

13 Rechtsanwalt.

14 Siegfried Kroll war Rechtsanwalt und in der Berliner B'nai-B'rith-Loge sowie in der Berliner jüdischen Gemeinde aktiv.

15 Der hebräische Ausdruck Kupot ḩolim bedeutet »Krankenkassen«. Wahrscheinlich ist die Kupat holim klalit (Allgemeine Krankenkasse) gemeint. Die Krankenkasse der 
his assessor, Mr. Reuter, advised me that on May 11th they were meeting with the subcommittee of the German parliament dealing with medical expenses and at that meeting in Hannover they hoped to settle the KUPOT HOLIM case. The sub-committee represents Bavaria, Berlin, North Rhine-Westphalia, Hamburg and Baden-Wurttemberg. We briefly reviewed the statutes of the organization. He again promised to let me have them and also promised to advise me promptly of the outcome of the May 11th meeting. I, in turn, agreed that I would continue to do nothing which might rock the KUPOT HOLIM boat. The next day I received a complete set of the statutes which are about 100 pages long and contain hundreds of articles regarding the organization and functioning of this particular "Krankenkasse".

I studied the statutes carefully and the following facts emerged: The statutes were enacted in 1958. In accordance with para. 108 on p. 41, the "Krankenkasse" was not responsible to provide medical aid in cases where its member was injured by an act which would be a violation of the criminal law. Medical care could be provided on condition, however, that the member paid the fee which the organization would establish. (I am translating this into English from a German translation of the Hebrew). It was on the basis of this paragraph that the German authorities felt they might be able to grant the KUPOT HOLIM claim.

In my further discussions and correspondence with RA. Kroll and Reuter, it became clear that although the KUPOT HOLIM had no direct claim under the prevailing law, the Germans were prepared to consider a settlement. They had originally rejected any such settlement in 1964 on the grounds that the KUPOT HOLIM was not entitled to claim under the law since the rights belonged only to the individual persecutee and he could not assign those rights. On the basis of the above-quoted paragraph 108, however, of the KUPOT HOLIM statutes, it appeared that the KUPOT HOLIM might ask its members to pay the fees of the organization for having been treated for injuries sustained during the German persecution. The consequence would be that the individual member $|4|$ of KUPOT HOLIM would then be entitled to present a bill to the German authorities for the amount he had been required to pay to KUPOT HOLIM for the medical care.

The KUPOT HOLIM has about 25,000 members who sustained injuries at German hands. If each one of these members were to assert only two claims per year for reimbursement of the medical costs the German indemnification

israelischen Gewerkschaft wurde 1911 im osmanischen Palästina gegründet, nahm seit der israelischen Staatsgründung eine zentrale Stellung in der Entwicklung des Gesundheitssystems ein und bot den zahlreichen Neueinwanderern nach dem Zweiten Weltkrieg medizinische Versorgung. 
authorities would have to deal with at least 50,000 individual claims. It was primarily to avoid this administrative burden that the German authorities indicated their willingness to make a global settlement of the KUPOT HOLIM matter. They also wanted to assure that KUPOT HOLIM would continue to take care of the future medical needs of Nazi victims.

You will notice of course that the KUPOT HOLIM facts are distinguishable from the facts pertaining to NYANA and HIAS. On the other hand, knowing the details of the KUPOT HOLIM pattern, we are in a better position to present a claim where the distinctions, if any, will not justify contrary handling of the claims arising from the United States.

I arranged to inquire discreetly with the German authorities as to the outcome of the May 11th meeting, I learned that the Germans had refused to recognize any expenses incurred before the 1958 statutes were enacted. They did, however, offer to pay 10 Million DM ( $\$ 2,5$ Million) to KUPOT HOLIM in contrast to the 30 or 40 Million previously mentioned by the claimant. The matter is now under advisement by KUPOT HOLIM. I have had no direct word yet from RA. Kroll as to their reaction.

In my view we are still best advised to wait quietly until the KUPOT HOLIM agreement has been brought to a conclusion. The statute which the Germans used as a justification for their action was a rather flimsy straw and I am hopeful that we will in due course manage to find \{at least\} equally strong support for the HIAS-NYANA position.

I am hopeful that once I have cleared the debris from my desk, we will be able to sit together to review the position and to initiate whatever additional steps seem indicated to prepare the case for eventual submission.

I was pleased to be able to report to the cooperating agencies of the United Hias Service during the Washington meeting on May 17th. I am enclosing a draft of an information sheet which you may want to send out to your cooperating agencies in order that the information which is available to them may be assembled and consolidated for further action.

With warm regards, Cordially yours,

Benjamin B. Ferencz

BBF: js 


\section{Dokument 135}

Benjamin B. Ferencz an Charles Kapralik

Ohne Ortsangabe, 2. März 1967

Maschinenschriftlicher Brief, 2 Seiten

$R G 12.012 .01 * 02$

Dr. Charles Kapralik

Jewish Trust Corporation for Germany Ltd.

Woburn House

Upper Woburn Place

London, W.C.1.

Dear Charles:

I was very pleased to see from your letter of February 24th that the $\mathrm{CBF}^{16}$ may be interested in retaining my services. You know that obtaining money from Germany for Jewish Charity is my favorite sport. Let me, however, give you some more of the details so that you can make your decision based upon a clearer view of the problem.

As you undoubtedly know, the German Indemnification Law provides that individuals who have sustained damage to health may have a claim for reimbursement of the medical expenses incurred by them as a result of their persecution. In many cases, the expense was not incurred by the individual persecutee directly but was paid for by some Jewish charitable organization. Under these circumstances the German government has generally refused to reimburse the individual since the German view was that the individual had not incurred any expense or any legal obligation to repay the charitable agency which they view as a gratuitous volunteer.

Some time ago, I was approached by some Jewish charities in the U.S. and asked whether they might be able to obtain reimbursement for the medical expenses incurred by them on behalf of Nazi victims. ${ }^{17}$ I advised them of the status of the law, and also indicated to them my own conviction that the German interpretation was unjust in that the wrong-doer was seeking to pass the burden to the shonoulders of Jewish charity which had never intended the

16 Central British Fund for German Jewry.

17 Siehe dazu die Dokumente 132-134. 
German government to be the beneficiary of their benevolence. There were certain indications in the legislative history which supported my feeling that it might be possible to reverse the German position. I asked them, however, to send their own representatives to Germany to discuss the problem in detail with Dr. Katzenstein and other experts on the scene, before any conclusion on their part was reached. They did so and then returned and asked me to represent them, which I agreed to do. At this time, therefore, I do represent all of the principal Jewish charitable agencies in the U.S. who were engaged in the problem of giving $|2|$ assistance to German refugees.

It was my advice to the Jewish organizations here that this problem was too speculative to justify any major expenditure of funds in its pursuit. We did, however, agree upon a modest fee plus a contingent fee on a sliding scale in the event the matter was successfully concluded. In the meantime there have been certain legal developments which have encouraged me to believe that a settlement of this matter should be possible. A settlement of one group of similar claims from Israel is now imminent.

I believe it would be in the interest of all parties if the matter could be settled globally and therefore the addition of the CBF to the ranks would, in my view, be helpful to all.

If after the matter has been considered further the CBF should conclude that they would wish to retain me for this purpose, nothing would please me more than to be able to join forces with you again for a common cause.

With warm regards,

Cordially yours,

Benjamin B. Ferencz

BBF: js

\{copy for Saul Kagan, Montreal\}

\section{Dokument 136}

Benjamin B. Ferencz an Ernst Katzenstein

Ohne Ortsangabe, 27. Dezember 1967

Maschinenschriftlicher Brief, 3 Seiten

$R G 12.012 .01^{\star} 03$

[Ferencz berichtet von den Diskussionen mit Vertretern der bundesrepublikanischen Entschädigungsbehörden über die Kostenübernahme für die medizinische 
Versorgung von Verfolgten des Nationalsozialismus. Im Mittelpunkt steht eine kritische Auseinandersetzung mit den Argumenten, die gegen eine Ausdehnung der staatlichen Kostenübernahme aufseiten der sogenannten Wiedergutmachungsbehörden formuliert wurden. Zudem werden die anstehenden Schritte in dieser Angelegenheit erwogen.]

December 27, 1967

Dr. Ernst Katzenstein

JRSO

Gruneburgweg [sic] 119

Frankfurt

Dear Ernst:

Many thanks indeed for your fine and comprehensive memo of December 20th containing the miserable news regarding NYANA. You may be sure that the unreasonableness of the German officials in failing to recognize the validity of my arguments in no way detracts from my gratitude for all of your help.

I would be more discouraged if Dr. Hirschberg ${ }^{18}$ had supported his opposition to the proposed settlement by arguments which were more persuasive. It seems to me that his negative attitude is buttressed only by points which are either factually wrong or erroneous in conception. He assumed that the Kupot Holim settlement ${ }^{19}$ prompted my submission on behalf of other organizations. It would be irrelevant at best, and it is quite wrong in fact since, as you know, we were planning the claim long before I heard of Kupot Holim. He says it is irrelevant since the indemnification agency will pay the individual even if he didn't incur the expense. That's very generous but it's neither the law nor the practice. He reasons that there was some kind of legal obligation on the part of the individual to refer to the expense of organizations on his behalf at the time the original health claim was submitted. Unfortunately, there is no question in the health claim regarding such expenses by charitable organizations and the insertion of such information would have been pure surplusage. He thinks it is too late for such claims now, although the law specifically provides that

18 Eventuell Ernst Hirschberg (1903-1974), ein jüdischer Rechtsanwalt, der 1938 aus Deutschland emigrieren musste. 1950 kehrte er nach Hamburg zurück und war bis 1971 in leitender Position im Hamburger Amt für Wiedergutmachung tätig.

19 Siehe dazu Dokument 134. 
there shall be no limitation, and the possibility of asserting such claims only became clear after the Bundestag Committee debated the provision in the Schlussgesetz ${ }^{20}$ which opened the door for Kupot Holim and others. In fact and law, the individual can receive reimbursement from the indemnification authorities at any time he pays a legitimate medical bill, no matter how old that bill may be, and Hirschberg's argument that a claim should have been presented at some distant and uncertain time in the past is simply unfounded. He rejects the $|2|$ well-reasoned decisions of the Swiss Supreme Court and the OLG in Dusseldorf [sic] and asserts the peculiar notion that the charitable organizations were fulfilling a legal duty, or that the money they spent was not their own but belonged to the contributors who had a claim for refund from the organizations.

There is some shaft of light, for Dr. Hirschberg concedes that if the organization spent its own money and paid the medical bills because the health claim took too long, then the situation might be quite different. In fact, that is just what happened. The organizations spent only money over which they had an absolute right to $\{$ of $\}$ disposition and spent it on Nazi victims only because the German government at that time was either unable or unwilling to meet what it subsequently and correctly recognized to be its obligations. Dr. Hirschberg ignores the fact that in very many cases the organizations made the payments only after the individual had specifically agreed to reimburse the agency and in all American cases the organizations had undertaken a legal guarantee that the persecutee could not become a public charge. He also forgets that the Kupot Holim settlement covered payments for past expenses and was wrong in saying that the settlement had nothing to do with the Laender which in fact specifically agreed to it and agreed to make specific payments to Kupot Holim from their indemnification accounts.

Despite all of Dr. Hirschberg's negative argumentation, I still can detect some acknowledgment that where it can be shown that a specific sum was paid for medical care related to a recognized Nazi-caused damage-to-health to a specific individual then the conclusion might be otherwise. In fact, that's all we are asking for. Indeed, the immediate issue is whether there should be a global settlement, and the second question of "how much, and how do you prove the damage" will only arise later.

Reg. ${ }^{21}$ Director Hennings' suggestion that the welfare organizations supply each individual with the specific bills is surely not \{ån\} administratively desirable situation from either the German or the Jewish point of view, and if

20 Siehe dazu Kapitel 8, Fußnote 7.

21 Regierungs(direktor). 
the administrative expenses could be avoided without causing any increased cost to the Germans on the substantive claim he should not insist upon doing it the hard way. His observations that Kupot Holim was a one-time exception because they are the largest Kranekenkasse in Israel is not very persuasive. Malben ${ }^{22}$ spends even more, and the law does not allow for favoring one group over another.

|3| I recognize that I need not direct these arguments to you but rather to those who raised them - but you will forgive me since I have no one else to talk to. Since both Hamburg and Bremen are only liable for less than $1 \%$ each of the Kupot Holim payments, I hope that their voices will be given equivalent weight. Much more important will be Kaizik ${ }^{23}$ in Munich and Fritz in Berlin, who are the two remaining members of the sub-committee. Then of course come the other states who are not on the sub-committee and perhaps we can find some support there.

You will see from my attached letter on B'nai B'rith that I have fortunately been excused from joining Dr. Wexler for his January visit to Frankfurt. Nevertheless, I am still faced with the problem of whether to come to Germany in February in connection with both the sub-committee and full referenten [sic] conference meetings. Despite my real pleasure at seeing you and Hilda and other Frankfurt friends, I have no desire whatsoever to visit Frankfurt in February. Nevertheless, the JDC-NYANA claim is sufficiently important as to receive every attention which may be helpful. I am therefore willing to be on hand to lobby with the committee members before their meeting, and to let them know that I will be on hand after their meeting in order to impress upon them the seriousness of the matter and the fact that neither it nor I will go away until it is settled. Should they absolutely refuse a global settlement I will then have to lay the foundation for the submission of individual claims. I can hardly imagine that I would say that we will simply let the matter drop.

If I am deluding myself into believing that my presence may be important or helpful, I would be grateful for your candid advice telling me to stay home.

221949 wurde MALBEN (Akronym für Mosedot le-tippul be-olim nehshalim; dt. Einrichtungen zur Pflege armer, kranker und benachteiligter Einwanderer) vom JDC als Betreuungseinrichtung für alte, kranke und gebrechliche jüdische Einwanderer in Israel gegründet. Bis 1968 unterstützte diese Organisation, die ihre finanziellen Mittel vor allem vom United Jewish Appeal erhielt, etwa 250000 Immigranten, darunter zahlreiche Holocaustüberlebende.

23 Heinrich Kaizik $\left({ }^{*} 1909\right)$ war als Ministerialrat in leitender Stellung im Bayerischen Finanzministerium tätig und dort mit Fragen der Entschädigung befasst. 
If you or Schem ${ }^{24}$ should feel that some good might come of my presence then it's simply a matter of letting me know when to arrive in order to be able to do whatever needs to be done.

With warm regards,

Cordially yours,

Benjamin B. Ferencz

BBF: js

Encl.

Dictated but not read.

\section{Dokument 137}

Benjamin B. Ferencz an diverse Empfänger ${ }^{25}$

New York, 7. Juni 1968

Maschinenschriftlicher Brief, 2 Seiten; gedruckter Briefkopf mit maschinenschriftlich eingefügtem Datum auf Seite 1, Kopfzeile auf Seite 2 (gedruckt: "TAYLOR, SCOLL, FERENCZ \& SIMON«)

$R G 12.012 .01{ }^{*} 04$

\section{TAylor, Scoll, Ferencz \& Simon Counselors at LaW}

Telford TAYlor

DAVID E. SCOLL

Benjamin B. Ferencz

KenNeTh Simon
Pan Am Building 200 Park Avenue

IJune 7, 1968! NeW YoRK, N. Y. 10017

MO 1-0934

Cable Address: Lantalaw

24 Peter Schem $\left({ }^{\star} 1913\right)$ war von 1947 bis 1952 Leiter des Wiedergutmachungsdezernats des Regierungspräsidenten in Hildesheim. Anschließend wechselte er ins niedersächsische Innenministerium, wo er zunächst als Referent und von 1957 bis 1971 als Referatsleiter für Wiedergutmachungsangelegenheiten wirkte.

25 Die Empfänger konnten nicht ermittelt werden. 
Gentlemen:

Upon my return from Europe I found the attached report from Dan Lack, the Legal Adviser to the JDC, describing our joint efforts in Germany from May 14-17, 1968. Since his description was so comprehensive and precise (as well as complimentary) I have decided simply to add to it a brief report of further developments after Mr. Lack left Germany, together with my own evaluation of the present status.

The presence of Mr. Lack was most helpful, not merely for the benefit of his opinions, but also as a demonstration to the German officials that we were most serious in our determination. Mr. Lack had recently returned from Israel in connection with this problem and had brought with him an impressive mass of files and cases which were frequently flourished to embellish our discussion.

On May 23rd, I had tea at the home of Mr. Martin Hirsch in Berlin. Mr. Hirsch is a member of Parliament and was the one most responsible for the amendment of the $\operatorname{law}^{26}$ which made it possible for the Kupot Holim settlement to be concluded. He is a leading member of the SPD and most influential in all indemnification matters. He is a personal friend with whom the medical expense problem has frequently been discussed in the past.

I reviewed the problem with him again and reported on the present status. He and Mrs. Hirsch were planning to be in Israel from June 1-15, and I offered to arrange to have him see the Malben institutions during the course of that visit. He said he would welcome such an opportunity. (I contacted Mr. Lack who immediately took steps to make the necessary arrangements with Mr. Harold Trobe ${ }^{27}$ the JDC Director in Israel).

Dr. Hirsch also suggested that we try to obtain some support from the labor union leader, Ludwig Rosenberg ${ }^{28}$ who had written to the Laender

261965 wurde das BEG letztmalig novelliert. Um den Willen des Bundestags zu dokumentieren, dass dieses Gesetz künftig nicht mehr verändert werde solle, erhielt es den Zusatz »Schlussgesetz«. Siehe dazu Goschler, Schuld und Schulden, 273-284.

27 Harold Trobe (1914-1996) war seit 1966 Direktor von MALBEN und des JDC in Israel. Zuvor hatte er ab 1944 für das JDC in Europa gearbeitet und zunächst von Portugal aus jüdische Flüchtlinge aus dem deutschen Herrschaftsbereich unterstützt. Nach Kriegsende war er bis 1956 für das JDC in der Tschechoslowakei, Österreich und Italien tätig. Im Anschluss wirkte er als HIAS-Direktor für Frankreich und Südamerika.

28 Der jüdische Gewerkschafter und Sozialdemokrat Ludwig Rosenberg (1903-1977) emigrierte 1933 nach London, wo er u. a. als Journalist arbeitete. Nach dem Krieg war 
and the Finance Ministry in support of the Kupot Holim settlement on moral grounds. I felt that this suggestion might effectively be taken up by an approach to Mro. Rosenberg via the Jewish Labor Committee, which I presume has had some contacts with him. I will ask Mr. Haber ${ }^{29}$ for the help of the JDC in this connection.

|2| I also discussed with Mr. Hirsch the possibility of again "clarifying" the law to assure payment of medical expense disbursements to welfare agencies. The German government itself may have to take the initiative soon to bring about certain modifications in order to protect its own position. It is anticipated that there will be an adverse decision by the German Supreme Court on a question which would involve a substantial additional cost to the German authorities. Although the present law was intended to be the final law and only clarifying amendments would be considered, we both felt that such amendments would probably be required, and at that time it might still be opportune to bring in the charitable agencies.

My own conclusion as a result of our discussion with most of the important Laender officials is that a global settlement of the medical expense claims will be difficult but not impossible to achieve. It will be necessary for us to present more specific evidence before any progress is made since no settlement will be possible until the German authorities can gauge with reasonable accuracy the impact of our action if they refuse to settle.

Dan Lack is collecting individual cases from the JDC files to show how much was spent for a particular individual, and we will have to submit that information with a showing of what happened to that individual's claim for damage to health and his claim for medical expense reimbursement. Similar files will be necessary to show the situation in New York and other parts of the U.S. I have already requested Mr. Soskis to begin assembling such files from the NYANA records and this letter requests some information from the United Hias Service. On my return to New York I paused in Montreal and

er am Wiederaufbau der westdeutschen Gewerkschaften beteiligt und hatte diverse leitende Gewerkschaftsposten inne.

29 Der Wirtschaftswissenschaftler Samuel L. Haber (1903-1984) war von 1967 bis 1975 zweiter Vorsitzender und Geschäftsführer des JDC. Zuvor hatte er von 1947 bis 1954 als Direktor des JDC in Deutschland gearbeitet und anschließend Programme der Hilfsorganisation in Marokko organisiert. Von 1958 bis 1964 war er stellvertretender Generaldirektor des JDC in Europa und 1964 bis 1967 Stellvertreter des zweiten Vorsitzenden. 
reported to Saul Hayes ${ }^{30}$ of the Canadian Jewish Congress, who will renew his efforts to obtain more specific information regarding the situation in Canada.

I have verbally reported to Consul General Curtius ${ }^{31}$ in New York about the present status and we are assured of his continued interest and support.

We must now await the outcome of the July 1 meetings and take appropriate action once the results are known.

Sincerely yours,

Benjamin B. Ferencz

BBF: js

Encl.

\section{Dokument 138}

Benjamin B. Ferencz an Samuel L. Haber, Philip Soskis, Gaynor I. Jacobson ${ }^{32}$ und Charles Kapralik

New York, 19. November 1968

Maschinenschriftlicher Brief, 2 Seiten; gedruckter Briefkopf mit maschinenschriftlich eingefügtem Datum auf Seite 1

$R G 12.012 .01^{\star} 04$

30 Saul Hayes (1906-1980) war ein jüdischer Verbandsfunktionär aus Kanada. Seit 1942 übte er das Amt des geschäftsführenden Direktors und von 1959 bis 1974 das des Vizepräsidenten des Canadian Jewish Congress aus. Zunächst als Anwalt tätig, war Hayes 1938 als Direktor zu den United Jewish Relief Agencies of Canada gewechselt. Auch nach seiner Pensionierung 1974 engagierte er sich in verschiedenen kanadisch-jüdischen Verbänden.

31 Klaus Curtius $\left({ }^{*} 1906\right)$ war Diplomat und in der zweiten Hälfte der 1960er Jahre Generalkonsul der Bundesrepublik in New York.

32 Gaynor I. Jacobson (1912-1999) war von 1966 bis 1968 geschäftsführender Direktor von United HIAS Service. Er hatte von 1944 bis 1950 für das JDC in Europa gearbeitet. Von 1953 bis 1954 sowie von 1961 bis 1966 leitete er die Aktivitäten der HIAS in Europa und Nordamerika. Dazwischen hatte er die Leitung der HIAS in Lateinamerika inne. Von 1968 bis 1981 war er geschäftsführender Vizepräsident der HIAS. 
TAYlor, Ferencz \& Simon

Counselors at LaW

Telford TAYlor

OF COUNSEL

Benjamin B. Ferencz

Kenneth Simon
LiNCOLN BUILDING

60 EAST 42ND STREET

'November 19, 1968'

New York, N. Y. 10017

MO 1-0934

To:

Mr. Samuel Haber, Executive Vice-Chairman, A.J.D.C.

Mr. Philip Soskis, Executive Director, NYANA

$\{(2$ copies $)\}$ Mr. Gaynor Jacobson, Executive Director, United Hias Service Mr. Charles Kapralik, Secretary, Central British Fund.

Gentleman:

The attached file notes contain the details of my recent visit to Germany. Let me summarize the main points:

The German states finally agreed upon the text of an 8-page letter rejecting our proposed global settlement of claims for reimbursement of medical expenditures for Nazi victims. The reasons given are not completely persuasive, but the German view will not be altered by further argumentation since there is no legal way of compelling them to do more than what the law requires.

It is my considered opinion, which is unanimously shared by the most experienced and highly regarded experts in this field, that there is only one course left for the Jewish organizations. We must now proceed to assert claims on a case-by-case basis.

The German rejection contained the acknowledgement that payment would be made wherever the persecutee confirmed that he was indebted to the welfare agency for the medical assistance provided to him. Without such a declaration or other legal proof of indebtedness neither the persecutee nor the agency can receive any reimbursement from the German states. This being so, it becomes advisable for the Jewish agencies now to seek to obtain such statements of obligation from the persecutee and at the same time to obtain authorization to file a claim in the individual's name and to receive and apply the proceeds to discharge his debt. The details of how this can be worked out are set forth in the report. Drafts of the forms to be used will be sent to you soon for further consideration.

Efforts will be continued to bring about a package settlement of the claims of MALBEN in Israel and it is conceivable that the German authorities 
themselves will later propose bulk settlements if they see that the Jewish organizations are assembling substantial numbers of claims.

|2| Before any further steps are taken, we should meet to review the entire situation. I will phone your office within the next few days to try to fix a time and place convenient to all.

Sincerely,

$\{$ Ben $\}$

Benjamin B. Ferencz

BBF: js

Encl.

cc. Daniel Lack, Esq.

\section{Dokument 139}

Benjamin B. Ferencz an Ernst Katzenstein

Ohne Ortsangabe, 5. Februar 1970

Maschinenschriftlicher Brief, 2 Seiten

$R G 12.012 .01^{\star} 07$

February 5, 1970

Dr. Ernst Katzenstein

JRSO

Gruneburgweg [sic] 119

Frankfurt

Dear Ernst:

You have seen from the exchange of correspondence between Dan Lack and Dr. Seidenberg that the speedy processing of Malben claims is running into serious obstacles. One of the main hurdles seems to be the requirement that the Israel Medical Board approve the reasonableness of the amount spent and its relation to the Nazi-caused injury.

We know that the German's behavior with reference to the payment of 
the medical expenses of Jewish organizations has been abominable. The amount which can be substantiated on a case by case basis is only a tiny fraction of the total spent and even if the German authorities paid in full the amount claimed on a case by case the German government would still be enormously enriched and will have succeeded in having Jewish charity pay for the damages which the Germans caused. I feel that Dr. Schem and probably Dr. Oberlauter are aware of this. I don't know whether they would approve of the further minimizing of the payment by the bureaucratic insistence upon absolute compliance with every regulation. What we are dealing with here is not the demand of an individual claimant based upon the bill of a private doctor but the itemized requests of a world famous Jewish charitable agency which established whole hospitals for the exclusive care of the tubercular patients coming out of the concentration camps. It is almost an insult to put them on the same level and when the net effect of so doing is to almost destroy the claim completely I think the German authorities are going much too far.

I think it would be most helpful if you would discuss this problem with Oberlauter and request that he advise his officials to accept the claims of Malben without requiring further certification by the Medical Board. The books of Malben are of course open for inspection by anyone he may care to send to Israel for that purpose so that he may be sure that everything stated is $|2|$ authentic. I don't know if any other officials will be involved but if so, it may also be necessary or advisable to go over the question with Dr. Schem.

I am sorry to have to trouble you with this, but I don't think we ought to jump through every hoop and over every hurdle without at least making an effort to find a more sensible solution.

With warm regards, Cordially yours,

Benjamin B. Ferencz

BBF: js

cc. Dr. Seidenberg

Dan Lack, Esq.

Mr. K. May 


\section{Dokument 140}

Benjamin B. Ferencz an Daniel Lack

Ohne Ortsangabe, 22. Februar 1971

Maschinenschriftlicher Brief, 1 Seite

$R G 12.012 .01 * 08$

Feb. 22, 1971

Mr. Daniel Lack

AJDC

75 rue de Lyon

Geneva, Switzerland

Dear Dan:

I was glad to see from your letter of the 15th that following your phone conversation with Seidenberg you had the impression that he was on the right rails. I often have the impulse to add some tar and feathers and make sure the train is leaving town! When it comes to putting on the brakes, Seidenberg is really great. You may have noticed his letter to von Bubna of the 9th agreeing that nothing would be done in Munich until he settled the daily rate question in Mainz - which both of us had the impression he had settled months ago.

You will see my views from the attached letter. The only man we can really rely on for intelligent action is Katzenstein. Now we've got to wait and see what he can do. I won't be in Germany until the end of April and aside from nagging by mail, I'm really helpless from here.

Just to make sure you don't get too carried away by your own exhortation about any settlement price, let me dilute my usual cheerful note by pouring a little vinegar into your wine. I have no doubt that Munich, as well as every other agency, will argue that the amounts actually expended were not within the range of what the Germans consider to be a "reasonable" expenditure. They are only required to pay what they consider to be "angemessen" according to their standards. The problem will, I hope, not be as acute for Israel as I'm sure it will be for N.Y. Furthermore, they will surely argue that not all of the expenditures were for persecution-caused injuries. The inmates of an institution also used toothpaste - which is not subject of compensation, etc. All of this is a bargaining technique to lower the price. And it can hardly be resisted. That's why as shrewd a man as von Bubna talks about a settlement for 
a lesser figure. I also gave him hell, but that was just to put some more starch in him. He knows whereof he speaks.

We'll soon see. Till then have fun - with other matters. Warm regards.

Cordially ${ }^{33}$

c.c. Dr. E. Katzenstein

BBF: rkl/Encl.

\section{Dokument 141}

Benjamin B. Ferencz an Daniel Lack

Ohne Ortsangabe, 6. Dezember 1971

Maschinenschriftlicher Brief, 1 Seite

$R G 12.012 .01{ }^{*} 08$

6th Dec. 1971

Daniel Lack Esq.

American Joint Distribution Committee

75 Rue de Lyon

1211 Geneva 13, Switzerland

Dear Dan:

Thank you for your letter of 2 nd December dealing with the Z. case. ${ }^{34}$ I can sense and share your feeling of outrage that the Germans should reject a claim of a schizophrenic patient who spent four years in a concentration camp, on the grounds that there is no established causal connection between the persecution and the illness. As outrageous as it may seem, there is nevertheless a 1962 decision to that effect and a settlement reached giving certain other benefits to the claimant. I don't see how we can now reopen that decision.

33 Unterschrift fehlt auf archivalischer Kopie.

34 Die Person wurde anonymisiert. 
As far as I know there has been no general change in the German decisions on this subject and it frequently happens that a claim is rejected for the absence of proven causal connection which is shocking.

If the causal connection between persecution and illness is not established, there is no claim for the medical costs. The argument therefore that the claimant could not waive the JDC's costs ceases to be relevant.

Just to double-check, however, that I am not overlooking something I am sending a copy of this to Dr. Katzenstein and asking him to double-check just to make sure that nothing more can be done. I am particularly interested in the possibility of reopening this case on the basis of more recent favorable decisions if any can be found to apply to this situation.

It's a good thing you are not practicing in Germany - you would be crying or screaming all the time. With warm regards,

Cordially

Benjamin B. Ferencz

c.c. Dr. Seidenberg

Dr. Katzenstein

BBF: rkl

\section{Dokument 142}

Benjamin B. Ferencz

Ohne Ortsangabe, Oktober/November 1972

Maschinenschriftliches Memorandum, 2 Seiten

$R G 12.012 .01 * 09$

Re: CLAIMS OF JEWISH ORGANIZATIONS FOR REIMBURSEMENT OF MEDICAL EXPENSES

Memorandum: Report on Meetings in Germany, October-November 1972 From: Benjamin B. Ferencz

I. Meetings

A number of meetings and discussions took place in Germany between 27 October and 2 November with Dr. Seidenberg, Dr. Katzenstein, Dr. May of 
the U.R.O. and Daniel Lack, who came to Frankfurt and reviewed all the Malben cases on 27 October as well as phone conversations with Dr. von Bubna, of Munich, and Dr. Weisz, of Berlin.

\section{The Freezing and Thawing of the Claims}

Since my last comprehensive report dated June 9 1972, almost all of the cases were brought to a complete standstill as a result of action initiated by the State of Bavaria. As then reported, the German Supreme Court had held ( stein $\mathrm{v}$. North-Rhein Westphalia [sic]) that where a welfare agency incurred expenses for a persecutee who had no legal obligation to repay the agency, no claim for compensation need be paid. Bavaria had already taken the position $(\underline{F} \text {. case })^{35}$ that the recent signing of obligations to repay Malben/Nyana clients was merely a collusive device to circumvent the law. A similar decision had been reached in the State of Hesse (K. case) ${ }^{36}$ With this background the head of the Bavarian indemnification agency in Munich, Dr. Kaizik ${ }^{37}$ (who had always opposed any recognition of such organizational claims), sent a circular letter to all of the other States asking them whether they nevertheless would continue to settle such claims. The letter had the desired chilling effect. Almost all the States stopped all further settlements. The question was set down for reconsideration by a conference of all of the States on November 7th.

Long legal memoranda reasserting the validity of the organizational claims were prepared by Dr. Katzenstein, Dr. Seidenberg, Dan Lack and the undersigned, and these were submitted to various State representatives by Dr. Katzenstein. On 27 October, at my request and in my presence, Dr. Katzenstein phoned Dr. Kaizik, who indicated that he had been persuaded by some of the memoranda, and that he would personally go to the November 7 th conference to represent the matter. He said that it was not necessary to make any further representations to any of the other States.There was a clear implication, though no commitment, that he would no longer seek to block further settlements.

At the same time, I sent a letter to Dr. Schem, of Hannover, who had acted for all of the States when we had concluded our understanding regarding the settlement of these claims in 1969. I expressed my dismay at what appeared to be a breach of faith on their part. Dr. Schem replied promptly that he, too, was at a loss to understand the new position and that he would instruct

35 Die Person wurde anonymisiert.

36 Die Person wurde anonymisiert.

37 Hier scheint eine Verwechslung vorzuliegen. Präsident des Bayerischen Landesentschädigungsamts war von 1967 bis 1980 Heinz Meier (1912-1993). 
his representative at the meeting to make my position as well as his known. (Copies of this correspondence are attached.)

[|2|] A few days ago Dr. Katzenstein was able to reach Dr. Kaizik and he reported on the outcome of the November 7th conference. Dr. Kaizik had apparently, on legal grounds, continued to oppose any payments but in view of the contrary position taken by the other States, he agreed to go along and to instruct his agency to continue handling the Malben/Nyana claims. How that promise will be implemented remains to be seen.

\section{Status Report}

MALBEN: Dan Lack has been keeping the AJDC comprehensively informed of progress and problems with regard to the Malben claims, and the details need not be repeated here. Of the 149 Malben cases submitted, 26 have been settled for a total of DM245,968 (about $\$ 76,000.00$ ). Of the 123 cases still pending, 45 are in Bavaria, and the amount claimed for those 45 cases alone is about DM 600,000 (about \$186,000.00). How much will actually be paid on those claims is uncertain and unpredictable.

NYANA: Of the total of 34 NYANA claims being handled by the U.R.O., 11 have already been settled for DM113,199 (about \$35,000.00). The 23 cases still pending claim close to $\$ 60,000.00$. Almost half of those are in Bavaria. All the U.R.O. cases were reviewed and appropriate instructions for action given. No action was taken with reference to the approximately 21 NYANA cases still being handled by private lawyers, where the amounts claimed are about $\$ 67,000.00$.

\section{Disposition of the Funds on Hand}

All funds received are deposited in a special U.R.O. trust account. Since distribution to the agencies might provoke demands for participation on the part of all the agency clients, which at this stage might be administratively, as well as legally, vexatious, it was Dan Lack's feeling, which I shared, that payout should be deferred and reconsidered later in 1973 after additional settlements have been concluded.

\section{New Problems}

The most recent crisis is a new German decision to pay claims on the basis of the value of the DM at the time the compensation is paid. ${ }^{38}$ Since the DM

38 Gemeint ist vermutlich eine Auseinandersetzung um die Rückerstattung der in US-Dollar entstandenen Kosten für ein Heilverfahren eines jüdischen Verfolgten. Die zuständige Entschädigungsbehörde hatte die Kosten auf Grundlage des 1973 gültigen Wechselkurses erstattet. Da infolge der in diesem Jahr erfolgten Abkehr vom 
is now very high, this has the effect of diminishing the amounts paid on the basis of the previous official scale which was based on the converted DM value at the time the expense was incurred. We shall try to oppose this unilateral alteration of the payment scale, but at this stage of the indemnification program such protests usually fall on very deaf ears.

\section{Prospects}

The claims of the Jewish organizations should be disposed of during $1973,{ }^{39}$ but they will be settled in an atmosphere of increasing hostility from the German agencies. It is, therefore, impossible to predict the ultimate outcome with any degree of certainty at this time.

\section{c.c. Sam Haber}

Phil Soskis

${ }^{*}$ Dan Lack

Dr. Katzenstein-- Dear Ernst: Your air mail letter of September 17th on Dr. Seidenberg Malben, properly addressed and stamped, was delivered here on November 15th. BBF

${ }^{*}$ Dear Dan: Thanks for your 1 November memo to Lou Morowitz which was precise and perceptive. I have not passed it on since I didn't know if you wanted me to do so. BBF

\section{Dokument 143}

Benjamin B. Ferencz an Samuel L. Haber und Philip Soskis

New York, 12. November 1973

Maschinenschriftliches Memorandum, 3 Seiten; gedruckter Briefkopf aufSeite 1 RG $12.012 .01^{\star} 10$

Bretton-Woods-System die Deutsche Mark gegenüber dem US-Dollar deutlich aufgewertet wurde, reduzierte sich der Auszahlungsbetrag erheblich. Siehe zu dieser Auseinandersetzung sowie zum darauf folgenden Rechtsstreit das Urteil Bundesgerichtshof, IX ZR 116/74, [In fremder Währung entstandene Heilverfahrenskosten sind nach dem Kurswert, der zur Zeit der Aufwendung maßgebend war, in Deutsche Mark umzurechnen], Karlsruhe, 12. Juni 1975.

39 Das BEG-Schlussgesetz von 1965 hatte für die Anmeldung neuer Ansprüche das Jahresende 1969 festgelegt, die Bearbeitung der Anträge zog sich jedoch noch einige weitere Jahre hin. 
[Ferencz fasst die jüngsten Entwicklungen in den Auseinandersetzungen um die Übernahme medizinischer Kosten für Verfolgte des Nationalsozialismus durch die Bundesrepublik zusammen. Er erläutert anhand diverser Einzelfälle, verschiedener Gerichtsentscheidungen sowie statistischer Aufstellungen die gegenwärtige westdeutsche Entschädigungspraxis in dieser Angelegenheit.]

\title{
Taylor, Ferencz \& Simon \\ COUNSElors at LAW
}

Telford Taylor
Of Counsel
Benjamin B. Ferencz
Kenneth Simon

TO: $\quad$ Sam Haber Phil Soskis
LiNCOLN BUILDING

60 EAST 42ND STREET

NeW YoRK, N. Y. 10017

***

MO 1-0934

November 12, 1973

\author{
MEMORANDUM \\ Subject: Medical Expense Claims
}

My last memo to you on June 13, 1973 was geared to Sam Haber's penchant for a punchy report. I gave it to him in one word: "Nothing!" I don't want you to begin to feel that I'm in a rut. Let me, therefore, bring you up to date with another word. "Grim!"

I know you both like more optimistic reports and I would like to oblige, but "Truth über alles". Since Sam has already filed this memo without reading any further, let me include a few of the gory details.

First, as to the present German attitude. There is no doubt that the Germans, on all levels, have had it as far as the indemnification program is concerned. They have disposed of over 4 million claims, have paid out over 50 billion DM, are committed to pay a total which will exceed 80 billion DM (which is 32 billion dollars at the current rate), and with over half of the population not having even been born during the Nazi persecutions, and East Germany seeming to get away with paying nothing, the Federal Republic is eager to slam the door shut.

The medical expense claims are viewed as recent inventions by wealthy American or Zionist agencies seeking to bleed more money from the German Treasury on flimsy legal doctrines unacceptable to German courts. The arguments are repeatedly heard that the American welfare agencies acted on their 
own initiative, collected money for relief purposes from willing donors, never expected to get repaid, and have collusively arranged to have it appear that the claim is on behalf of the individual persecutee. They feel fully vindicated, therefore, if they can find any theory to eliminate or decimate the claim for reimbursement of medical expenses.

The same attitude prevails regarding the claims for damage to health on which the medical expense claim is dependent. Let me illustrate with an actual NYANA case. Frieda S. lost her children and husband to the Nazis. Beaten over the head with an iron ring by an SS man she was found bloody and unconscious and was blinded for 3 months. Somehow she survived and managed to get to America where she remarried and started a new family. It was not long before she became suicidal and had delusions that she was still being pursued by the SS. A claim for damage to $|2|$ her health was filed. After many years, and many difficulties, the German doctors were prepared to give her the minimum pension in acknowledging that she had suffered concussion as a result of persecution. The illness deteriorated. She underwent a lobotomy, and finally ended up in an institution suffering from schizophrenia. She could only be released intermittently during lucid periods. A clear and common case, but how did the German agencies respond to the claim for medical expenses?

A 28 (or was it 38?) page "Expert Opinion" was rendered. It was signed by the Head of a Clinic at Heidelberg and his assistant, a "Dr. Dr." (Just like the first "Dr. Dr." I ever met, my Einsatzgruppen defendant, Dr. Dr. Rasch who was responsible for the massacre of 32,000 Jews in 2 days at Babi Yar). They concluded with many learned citations that German responsibility was limited to the conctu $\{s\}$ sion only, and that since schizophrenia frequently followed a lobotomy - for which they were not responsible, they could find no basis for paying medical costs related to schizophrenia! The NYANA claim was rejected.

The URO lawyers handling the case concluded that the matter was hopeless. I began to scream bloody murder about the idiots who could not see the causal connection between the schizophrenia and the persecution. I succeeded in getting very agitated, in getting everyone around me alarmed and fearfully promising to appeal to the bitter end. I doubt if I succeeded in anything else. They were probably right.

Munich, where most of the claims are still pending, adheres to its legal position that the claimant's obligation to repay the Jewish agencies is a fabricated collusion to circumvent the legal provisions that only the victim himself has a claim. An increasing number of indemnification agencies have now gone over to the view that in computing the amount of DM payable the most disadvantages $\{\mathrm{d}\}$ rate of exchange is to be applied. (The rate at the date of 
payment, since the current DM rate is very high, as against the prior practice of computing the marks at the rate in effect when the expense was incurred. $)^{40}$ An acknowledgement of liability to repay by heirs of a deceased persecutee is not considered valid by the German agencies. They enrich themselves by the death of the claimant without embarrassment. Unless specific bills, often demanded in the original, can be presented to show that every item of expense was directly related to the recognized persecution-caused disability, the claim is immediately rejected. The softer atmosphere, which I thought I had worked out in a "deal" with the German Laender, has disappeared as new people have come up the scene.

We have refused to accept these positions and we are in deadlock. Our only resource is to go to the courts - which would not only take years but where our miserable prospects get worse daily. Otherwise everything is fine!

So much for the alibis. Now let me tell you where we stand and what is still pending. I personally reviewed every one of the pending claims with the URO lawyer handling the case and wherever it was possible to give it a push or a kick I did so. I know you do not want the details, but everything that can be done is being done, and occasionally we will have to go back to our faithful Bess Kuttner for some new piece of evidence demanded in the hope that we will not be able to produce. I am attaching a statistical chart showing the breakdown and status of the 37 NYANA claims:

|3| 13 have been settled for DM 131,538, which at the current rate is about $\$ 52,000$. 6 have either been rejected or they soon will be, and 18 cases are still pending with assorted legal problems of the nature indicated above. The amount claimed on those cases is about $\$ 49,000$ - and the amount which we may actually hope to recover is substantially less.

The JDC picture (if Sam should happen to be peeking) is comparable but on a larger scale. I have also reviewed every single case but the absence of Dan Lack and the supporting staff in Israel (which was somewhere in Sinai) makes matters even more difficult.

48 Malben claims have been settled for a gross amount of DM 513,305, which at the current rate is about $\$ 205,000$. About 20 claims are either rejected or will be rejected soon, and the amount claimed in the remaining 72 cases is about 2 million DM. The rate of exchange problem is crucial, as well as the absence of specific bills related to the recognized disability. How much we can still manage to squeeze from the stone is almost anybody's guess.

40 Siehe Kapitel 8, Fußnote 38. 
Five other cases for 3 other agencies have also been settled for DM 158,200 (about $\$ 63,000$ ), and about half a dozen more are pending and of dubious value.

All of the funds are on deposit in trust accounts in Germany and are earning very high interest rates. The value of the DM in relation to the dollar has begun to weaken a bit, but because of the compensating interest rates I am not inclined to recommend that the funds be converted into dollars at this time.

I shall, of course, continue to follow the progress of the claims closely. The Germans are also eager to be rid of them and it may be anticipated that some meager settlement offers will yet be forthcoming. We will jump off each bridge as we come to it.

With warm regards,

\{Ben\}

BENJAMIN B. FERENCZ

BBF: aa

(Dictated, but not read by Benjamin B. Ferencz)

c.c: Dan Lack

\section{Dokument 144}

Benjamin B. Ferencz an Ernst Katzenstein

New Rochelle, N. Y., 7. März 1974

Maschinenschriftlicher Brief, 1 Seite; gedruckter Briefkopf

$R G 12.012 .01{ }^{\star} 12$

Benjamin B. Ferencz

14 BAYBERRY LANE

New Rochelle, New York

$\star * *$

(914) NE 2-3717 
Dr. Ernst Katzenstein: Frankfurt

Dear Ernst:

My letter of 27 Feb. anticipated yours of Mar. 3 dealing with your Bavarian friends. Let me try to give you a calm suggestion. It's not easy.

I think you should call Dr. Dorge and suggest to him that he familiarize himself a little more with both the law and the background of these particular claims. You can suggest that he read the long memoranda which you and I submitted when the global claim was begun, and that he also read the replies given by Dr. Schem on behalf of ALL the German laender. You can invite his attention to the settlement reached with Kupot Holim in recognition that in such matters a strict adherence to the text was not considered mandatory, to the letter given by Martin Hirsch confirming that it was never the intention of the legislature to enrich itself at the expense of the Jewish charities, to the fact that the JDC alone spent over \$ 75 million aiding Nazi victims with medical care up to 1966 alone (when we made the accounting), to the fact that we have proceeded precisely along the lines set down by Dr. Schem and that most of the German states have not created the kind of problems we now encounter in Bavaria, and the German courts have themselves taken a much more sympathetic position to claims of this sort. As far as the organizations are concerned there are political and humanitarian ramifications as well as legal ones.

So much for the background to educate Dorge. He can then be told to reconsider the recommendation of Kaizik that DM 170,000 be paid to wind up the whole problem and reminded that what was seen as a clear offer was transmitted, evaluated, and only reluctantly accepted by a major Jewish charitable organization. We stand by that willingness. If he is not prepared to implement Kaizik's recommendation, then issue awards in such lesser amounts as he thinks he can defend. We shall then demand full payment plus interest and take our battle to the courts and to the public, and he personally can assume the responsibility for the consequences.

Of course, it would be better if you can talk to him and Kranz, since the latter can't be worse than the former. I must leave it to you to decide whether it's worth a trip to the vicinity of Dachau.

Warm regards,

$\{$ Ben $\}$

CC: D. Lack 


\section{Dokument 145}

Benjamin B. Ferencz an Samuel L. Haber und Philip Soskis

New York, 19. Juli 1974

Maschinenschriftlicher Brief, 2 Seiten; gedruckter Briefkopf mit maschinenschriftlich eingefügtem Datum auf Seite 1

$R G 12.012 .01 * 12$

Taylor, Ferencz \& Simon

COUNSElors at LaW

Telford TAylor

OF COUNSEL

Benjamin B. Ferencz

KenNeth Simon
LINCOLN BUILDING

60 EAST 42ND STREET

New York, N. Y. 10017

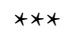

MO 1-0934

Subject: Medical Expense Claims

To: $\quad$ Sam Haber

Phil Soskis

This is a brief interim summary report following my recent return from Europe. It is intended as a supplement to my reports of Nov. 12, 1973 and June 4, 1974 which should be reviewed in order to get a more comprehensive picture.

Upon Dr. Katzenstein's advice that my presence was both useful and essential I joined him in meetings with the head of the indemnification agency in Munich. Of the 45 Malben cases pending there we finally settled 35 and are trying to negotiate an early settlement of the remaining 10 . We agreed to settle all of the pending NYANA cases.

The 34 Malben claims should produce about DM 287,000. On the 10 cases we challenged they offered about 73,000 DM and we are asking for an additional DM 312,000. Of 11 NYANA claims 5 are hopeless, 4 will be settled for about $\$ 16,000$, and 2 handled by Mr. Alberti should be settled for about $\$ 10,000$. The reason the figures are uncertain is that I finally told the head of the agency to do as he pleased. He assured me that I would not be dissatisfied. He's wrong.

As far as Malben is concerned practically all of the remaining cases are pending in Berlin. I therefore met with the URO lawyers there and reviewed 
each claim. There are 4 or 5 principle legal questions in dispute between us and the others. These relate primarily to the appropriate rate of exchange, whether heirs can sign an obligation or authorization, whether care in an old age or rehabilitation institution qualifies as "medical" care, specific questions of proof of connection between the persecution and the expense incurred, and any other difficulty they can conceive. The NYANA has similar problems, but there are only a few NYANA claims now remaining and I am working on those with a view to early settlement.

[|2|] I am hopeful that once the damm is broken at Munich we will be able to force some progress in other areas. If I can do the same in Berlin as was done in Munich there will be practically nothing left but a mop up operation of a couple of claims still pending in a few other agencies. I am hopeful that I can complete it all by the end of the year. I do anticipate that there will be some administrative problems which will arise when the lower officials sit down to implement the agreements reached while I was in Germany.

The attitude of the officials is cold-blooded and immovable. Mr. Kaizik of Bavaria made it clear that he resented any claims by welfare agencies since he felt they never anticipated repayment when they came to the aid of their co-religionists, and other agencies such as Caritas, helping non-Jews never made such claims. They will pay only what they are compelled to pay by law, and if there is any doubt they will settle only on their terms. Our alternative is to take the case to the courts, wait for years of expensive litigation, and then probably lose completely.

Before the meeting I visited Dachau, ${ }^{41}$ which is in a suburb of Munich, and which I had not seen since liberation. I picked up some pamphlets showing what it was like as I remembered it. My reference of the scene in the course of my discussions with the Munich officials evoked only anger. They resent any suggestion that they have not done enough.

All this has been reported and discussed in detail with Dan Lack in Geneva. I have also advised the URO Comptroller that when the fixed term deposit of the special medical expense account falls due on Aug. 27th that the full sum of about DM770,000 be transferred into a dollar account and continue to be kept in trust in a U.S. bank. We will be in touch before that date to confirm the details. The reason for the action is that there is now some concern about the stability of German banks, U.S. accounts now pay higher interest, and I am hopeful that we may be able by the end of the year or shortly thereafter to prepare a final accounting statement showing exactly what has happened to each claim and who is entitled to what.

41 Gemeint ist die KZ-Gedenkstätte Dachau, die ab 1965 eingerichtet und 1968 eröffnet wurde. 
Till then - forget it,

With warm regards,

$\{$ Ben $\}$

Benjamin B. Ferencz

CC: D. Lack

\section{Dokument 146}

Benjamin B. Ferencz an Ernst Katzenstein

New York, 6. November 1974

Maschinenschriftlicher Brief, 1 Seite; gedruckter Briefkopf mit maschinenschriftlich eingefügtem Datum

$R G 12.012 .01^{\star} 12$

Taylor, Ferencz \& Simon

COUNSElors at LAW

Telford TAYlor

Of Counsel

Benjamin B. Ferencz

Kenneth Simon
LiNCOLN BUILDING

¡Nov. 6, 1974! 60 EAST 42ND STREET New York, N. Y. 10017 ***

MO 1-0934

Dr. Ernst Katzenstein; URO Frankfurt

Dear Ernst:

I have received a copy of Dr. v. Bubna's letter to you of 30.10.1974. As far as I can see it recapitulates exactly what the situation was when we left Munich on 1 July 1974. There are 10 Malben cases where we refused to accept their offers, and they have simply repeated their offers.

We claimed over DM300,000. They offered about DM 107,000. 6 of the 10 cases are $\mathrm{TBC}^{42}$ cases, 3 are mental cases, and 1 is a chronic bronchitis case,

42 Tuberculosis. 
where the claimant has died waiting for payment, and where Bavaria now seeks to reap the benefit by paying nothing. I will not again review the facts of each case. The BLEA ${ }^{43}$ approach in each case is precise, pedantic, narrow, restrictive, and absolutely inhuman.

The best illustration is the Rachel R. case, where we have the benefit of an analysis by Dr. med. E. Dworsky of Munich dated 1.8.1974. The learned Doctor acknowledges that the woman, now aged 71, suffered organic brain damage with Parkinsonism and related psychological disturbances. For about 5 years he grudgingly admits the patient was in various institutions where Bavaria should pay almost all of the costs, but then she entered other institutions where she was apparently able to care for herself on a sufficient basis, so our learned Doctor could conclude that she was only "behandlungsbedurftig" [sic] and not "pflegebedurftig" [sic], so Bavaria should not pay. Besides, says the Doctor, "she had to live someplace anyway". Then he makes the great discovery that apparently they gave up trying to cure her and stopped psychiatric examinations, from which he concludes that she was really fine, and notes with glee that someone even said she didn't have Parkinsonism, but only "Schüttelneurose".

Now\#here does the learned Dr. Dworsky mention or seem to know or care that Rachel R. saw her 11 year-old son murdered in Auswitz [sic], that her husband was murdered in nearby Dachau, and that she spent a year in Auschwitz before she was released as a human cabbåg̊e. I don't know whether to call it Parkinsonism or "Schuttelneurose" [sic], but I do know why Mrs. R. shakes. Perhaps you can persuade Dr. Kaiz̊ike.

Wiedergutmachung! Ugh!

$\{$ Ben $\}$

\section{Dokument 147}

Benjamin B. Ferencz an Ernst Katzenstein

New Rochelle, N. Y., 27. Februar 1975

Maschinenschriftlicher Brief, 1 Seite; gedruckter Briefkopf

RG $12.012 .01^{\star} 13$

43 Bayerisches Landesentschädigungsamt. 


\author{
Benjamin B. Ferencz \\ 14 BAYBERRY LANE \\ New Rochelle, New York \\ $\star * *$
}

(914) NE 2-3717

27 February 1975

Dr. Ernst Katzenstein: Frankfurt

Dear Ernst:

The Bavarians ${ }^{44}$ are simply incredible! On July 1, 1974 you and I met with Kaizik and Ross and settled all but 10 cases then pending in Munich. The 10, as listed in your memo of July 2, involved a total claim of DM 360,000. Bavaria felt they could only offer DM 107,000. We agreed that they would reconsider the cases once more and see if a satisfactory figure could be mutually agreed upon.

On Oct. 24, 1974 Dr. von Bubna went over the individual claims with Dr. Winkler who was not prepared to take any step forward. The offer of 107,000 was again repeated.

On Dec. 13 you met with Kaizik, Winkler and Dorge, and Kaizik said the most he could recommend was DM 170,000. We agreed that the DM 170,000 should be accepted. On 31 Jan. 1975 Bavaria said they couldn't recommend more than DM 103,589!

I am inclined to agree with Dr. Seidenberg's recommendation of 10 Feb. 1975 that we should ask for decisions and then file appeals. You and I both reviewed each of the 10 cases and came to the conclusion that the higher figure was fully justified. We should now add to it a demand for interest retroactive as far back as we can possibly justify it. Dr. von Bubna feels that if they are required to issue awards in each case then the total will only amount to DM 15,000. Let them! It will only serve to make more obvious how outrageous is the Bavarian conception of "Wiedergutmachung". It was never the intent of the legislature to enrich the German fiscus at the expense of the Jewish charities, and I am hopeful that a higher German court can be persuaded that our cause is just.

Kaizik also promised that the NYANA cases would be settled. I told him then to do what he thought was right. So far they have done nothing. Is there

44 Das Wort ist im Original eingekringelt. 
no one there - Franz Joseph Strauss ${ }^{45}$ - or someone similar, who has enough intelligence and influence to recognize that the present beaurocrats [sic] are behaving like mean idiots? If you can't think of a political step, then I say: "On to the courts"!

With warm regards,

$\{$ Ben $\}$

CC: Lack, Seidenberg

\section{Dokument 148}

Benjamin B. Ferencz an Daniel Lack

Ohne Ortsangabe, 9. Dezember 1979

Maschinenschriftlicher Brief, 1 Seite

$R G 12.012 .01 * 16$

December 9, 1979

Dan Lack Esq.

Dear Dan:

It is not that I have forsaken you, but I have forsaken the world. I am trying to finish a two-volume book on an International Criminal Court before the end of the year. ${ }^{46} \mathrm{My}$ wife has been deported to Florida and when I'm not out cooking, shopping, cleaning, doing house repairs, running a law office, trying to solve the world's problems and answering phone calls from people who want my free advice on everything I am trying to finish the manuscript. I won't make it, so I'm writing you.

45 Der bayerische CSU-Politiker Franz Josef Strauß (1915-1988) hatte zahlreiche landes- und bundespolitische Ämter inne. Zur Zeit des Schreibens war er Mitglied des Bundestags, Fraktionssprecher für finanz- und wirtschaftspolitische Themen und Mitglied des Auswärtigen Ausschusses.

46 Ferencz, An International Criminal Court. 
How are you and the family?

That takes care of that:

I'm fine. I think.

The New York Times book review today carried a full page plus review of Less Than Slaves by Prof. Martin Gilbert. ${ }^{47}$ There was also another review by a regular columnist in the same issue. The President of Harvard Press called in advance to tell me that they were "rave reviews" - or maybe he said the reviewers were raving mad. In any case I'm delighted. It couldn't have been better. Since the book in its first chapter has what one Holocaust professor called the best summary of Holocaust in the English language (or did she say it was another Holocaust on the English language?) I suggested to Sigi Roth ${ }^{48}$ that the Congress try to arrange to distribute it as part of their Holocaust education jobb. He replied that he was thinking about it but couldn't think of anything intelligent. I'm not surprised. Perhaps the Geneva branch can do better. The publisher sells the books for $\$ 9$ in lots of 10 , or $\$ 15$ each. If my friends won't buy it, who will?

Warm regards to all, ${ }^{49}$

\section{Dokument 149}

Benjamin B. Ferencz an Ernst Katzenstein

Ohne Ortsangabe, 13. Januar 1970

Maschinenschriftlicher Brief, 2 Seiten

$R G 12.011 .01 * 08$

January 13, 1970

$\{\mathrm{BEG}\}$

Dr. Ernst Katzenstein

JRSO

Gruneburgweg [sic] 119

Frankfurt

47 Martin Gilbert, Working for Farben, in: The New York Times, 9. Dezember 1979, 1.

48 Gemeint ist Siegfried Roth.

49 Unterschrift fehlt auf archivalischer Kopie. 


\section{Dear Ernst:}

I have been reading your very interesting reports about the Post- 65 problem. ${ }^{50}$ The newspaper article regarding the flight of Jews from Roumania to Sweden was a chilling reminder of 1939. It emphasises, as you have correctly concluded, that all the Jews of Poland may soon be Post- 65 refugees, and the only facts which need be estimated or ascertained is the percentage which were also victims of the Nazis.

If the trend seems to be to accept an open-ended obligation then the precise number of claimants should not be of major importance to the Conference, although I recognize that Koppe, ${ }^{51}$ and particularly Féaux ${ }^{52}$ will want some figures when making his presentation to the cabinet. Of greater significance would be the amount to be paid. I agree that a valid distinction can and should be made regarding the payments under the bilateral agreements, since in those cases the beneficiaries were primarily non-Jews and the length and duration of their suffering was not comparable. ${ }^{53}$ Whatever the average was under the bilateral agreements should be at least doubled when dealing solely with Jewish claimants.

I was very pleased to see that Koppe is eager to take on the administration of whatever agency may be established. Tell him for me not to be such a precise jurist and to simplify matters by making a one-time payment to all

50 Die Bundesrepublik hatte das BEG-Schlussgesetz 1965 unter der Prämisse beschlossen, dass die JCC künftig keine neuen Forderungen erheben würde. Als seit dem Ende der 1960er Jahre jedoch zunehmend jüdische Verfolgte aus Osteuropa, die bislang keine Entschädigung erhalten hatten, in den Westen emigrieren konnten, trat die JCC mit neuen Forderungen zugunsten der Gruppe der sogenannten Post-65-Fälle auf. Erst nach fast zehnjährigen Verhandlungen kam durch einen Kabinettsbeschluss ein als "Abschlussgeste Wiedergutmachung " bezeichneter Härtefonds in Höhe von 440 Millionen DM zustande, der von der JCC verwaltet wurde. Siehe Goschler, Schuld und Schulden, 323-344.

51 Fritz Koppe war Ministerialrat im Bundesministerium für Finanzen und arbeitete dort im Sachgebiet Wiedergutmachung.

52 Ernst Féaux de la Croix.

53 Gemeint sind vermutlich die zwischen 1959 und 1964 abgeschlossenen bilateralen Abkommen mit elf westeuropäischen Staaten, in denen sich die Bundesrepublik zu globalen Entschädigungsleistungen für Verfolgte des Nationalsozialismus aus diesen Ländern in Höhe von insgesamt 876 Millionen DM verpflichtete. Die Höhe der Einzelleistungen unterschied sich von Land zu Land. So entfielen beispielsweise in Frankreich auf den einzelnen Berechtigten im Durchschnitt 4.000 DM, in den Niederlanden hingegen durchschnittlich nur etwa 2.500 DM. Siehe dazu Goschler, Schuld und Schulden, 233-244; Hockerts/Moisel/Winstel, Grenzen der Wiedergutmachung. 
these claimants, which I think would be more appreciated and probably just as "equitable". Of course, the Conference should give him a farewell party. There is no single individual in the Finance Ministry to whom we are more indebted.

I have responded to Baum of London as per the attached. I have also spoken to Katzki who told me that Akiba [sic] Kohani ${ }^{54}$ of the JDC Geneva was recently in Copenhagen and should know the position |2| regarding the Jews arriving from Poland. Apparently, the Danish Refugee Committee ${ }^{55}$ is treating it as a non-Jewish affair and the Danish government, like the Swedes, has simply opened its doors to persons from Poland. The Swedish situation is no doubt accurately known to the Mosaiska ${ }^{56}$ in Stockholm and you may want to be in touch with them. In the light of Koppe's position perhaps the German government could even be persuaded to set up some sort of advance fund for the relief of Nazi victims arriving in the Scandinavian countries. I'm sure that $5,000 \mathrm{DM}$ or even less would go a long way toward helping the newcomers find roots and you may want to follow up on the idea.

I see you're having fun.

With warm regards, Cordially yours,

Benjamin B. Ferencz

BBF: js

cc. Mr. Saul Kagan

\section{Dokument 150}

Benjamin B. Ferencz an Ernst Katzenstein

Ohne Ortsangabe, 1. Februar 1971

Maschinenschriftlicher Brief, 1 Seite; gedruckte Kopfzeile

$R G 12.011 .01^{\star} 10$

54 Akiva Kohani arbeitete für das JDC in Genf und war für die Unterstützung von Juden in Polen zuständig.

55 Gemeint ist vermutlich der 1956 gegründete Danish Refugee Council (DRC), ein Dachverband von 33 Mitgliedsorganisationen, der weltweit Hilfsaktionen für Flüchtlinge durchführt.

56 Mosaiska församlingen, die jüdische Gemeinde in Stockholm. 
Taylor, Scoll, Ferencz \& Simon

Dr. Ernst Katzenstein

Feb. 1, 1971.

Conference on Jewish Material Claims

Against Germany

Friedensplatz 9

Bonn, West Germany

Dear Ernst:

I enjoyed your letter of January 20th dealing with late hardship claims. Enjoyed it because I like to see you in your young fighting spirit. It shows me that you are well, and that you haven't forgotten your training or your job.

We have a juxtaposition of interest. The Germans are saying: "We've got to stop sometime - and we're not going any further" - a familiar theme. You are saying: "Hardship can know no deadline - it was agreed that you would receive claims in case of need, and need will certainly arise as long as the Nazi victims still live." From the response thus far, I fear you will not persuade them. This is 1971, as you would say, SPD time.

The test cases you suggest you apparently do not expect to win. You hope that the negative decisions will spotlight the problem and demonstrate the need for a legislative correction. I think it is more likely to evoke an attitude of do nothing now but wait for the highest courts final word, and then you will be told: "What do you want, even the courts say you have no rights. Do you expect us to write new laws in 1975?"

So to my experienced eye it looks hopeless. Conclusion: Fight on! Fight on! Anybody can win the easy ones.

With warm regards

Benjamin B. Ferencz

c.c. Dr. Kurt May

Mr. Saul Kagan

BBF: rkl 


\section{Dokument 151}

Benjamin B. Ferencz an Ernst Katzenstein

New York, 5. Februar 1974

Maschinenschriftlicher Brief, 3 Seiten; gedruckter Briefkopf mit maschinenschriftlich eingefügtem Datum auf Seite 1

$R G 12.007 .02^{*} 03$

[Ferencz nimmt zu einer brieflichen Auseinandersetzung zwischen Katzenstein und einem bundesdeutschen Staatssekretär Stellung, in dem die Frage der Übertragung von überschüssigen Mitteln aus dem 1952 vereinbarten Härtefallfonds für nicht-bekennende jüdische Verfolgte des Nationalsozialismus an die JCC den Ausgangspunkt bildet..$^{57}$ Er weist die Einwände gegen eine Übertragung der Gelder zurück, die auf Kritik an der bisherigen Verwendung der Mittel aus dem Globalabkommen durch die JCC beruhen, rekapituliert hierfür die in Den Haag geführten Verhandlungen und entwickelt Gegenargumente.]

\section{TAYLOR, Ferencz \& Simon \\ COUNSElors OF LAW}
Telford TAYlor
Of Counsel
Benjamin B. Ferencz
KenNeth Simon

LINCOLN BUILDING

|5 February 1974|

60 EAST 42ND STREET

New York, N. Y. 10017

$* * *$

MO 1-0934

Dr. Ernst Katzenstein: Frankfurt

Dear Ernst:

I have read with great interest the exchange of correspondence between you and Staatssekretär $\operatorname{Her}\{\mathrm{m}\}$ sdorf $^{58}$ of the Finance Ministry regarding the return to the Claims Conference of the residue of funds unused by the

57 Siehe dazu auch die Erläuterungen in der Einleitung, 66.

58 Der sozialdemokratische Politiker Hans Hermsdorf (1914-2001) war von 1964 bis 1974 Mitglied des SPD-Parteivorstands und wurde als Haushaltsexperte 1971 zum Parlamentarischen Staatssekretär des Bundeswirtschafts- und Finanzministeriums ernannt. Mitte des Jahres 1974 wechselte er zur Landeszentralbank Hamburg, deren Präsident er wurde. 
Hardship Fund for Non-Professing Jews (HNG) ${ }^{59}$ It is particularly interesting because it reflects so well the change of attitude and perspective of what really happened between the Federal Republic and the Jews. Let me give you my interpretation in the hope that it may prove helpful.

When The Hague negotiations were in progress in 1952 a point was reached when the Bund indicated a willingness to pay a global amount of 3.5 billion DM, in addition to enacting an improved indemnification program for the individual claimants. This was to settle the claim of all those whom Hitler persecuted because they were Jews. When the question arose about those who professed adherence to some other religion but were persecuted as racial Jews the Conference made it clear that they could not adopt the Hitler racial theories and could only speak for those $\{$ whoo $\}$ considered themselves Jews by religion.

A deal was finally made according to which the Bund would itself set up a special fund for the non-professing Jews. It was estimated that they would not number more than $10 \%$ of the others, and the Bund insisted upon cutting $10 \%$ off of the 500 Million DM which was to be the Claims Conference share. So the 50 million DM HNG Fund was born.

After 20 years had passed it appeared that 50 Million DM had been too deep a cut. Less than 20 million had been spent. Dr. Goldmann and you accordingly turned to the Bund and said: "Nu, so where is the change?".

|2| In response Herr Hermsdorf discloses that from his point of view it is the Conference which has diddled the Bund and not vice versa. He argues that the 450 million DM given to the Conference was intended for individual hardship claims and was in fact diverted for other purposes. ${ }^{60}$ As a result about 100 million DM has had to be paid out of a general hardship fund in the BEG to take care of those whom the Conference has ignored. In response to your outrage that the HNG-Fund has no cut-off date whereas all other hardship claims were excluded after 31 Dec. 1969, Dr. Hermsdorf has simply replied that it was the non-professing Jews who were already disadvantaged

59 Von der 1952 in Wassenaar zugunsten jüdischer Verfolgter vereinbarten Globalentschädigung von 500 Millionen DM für die JCC waren 50 Millionen DM für nicht-bekennende Juden bestimmt, deren Vertretung die JCC nicht übernehmen wollte. Der daraus entstandene sogenannte Härtefonds für Nicht-Glaubensjuden (HNG-Fonds) wurde von verschiedenen Organisationen verwaltet, die die von der nationalsozialistischen Rassengesetzgebung betroffenen Christen vertraten und sich im Hilfswerk für die von den Nürnberger Gesetzen Betroffenen nicht-jüdischen Glaubens zusammengeschlossen hatten. Siehe Goschler, Schuld und Schulden, 286.

Siehe ebd., 239. 
and before the final claim is met, in the long distant future, there will be no money left anyway out of the 50 million.

I feel that Herr Hermsdorf is in error on several points which should politely be drawn to his attention. Basically he misconstrues the nature of the original settlement. What was concluded at The Hague was a political agreement based on moral considerations. There never was any agreement or any intent that the funds received by the Conference (or by Israel) would be used as a hardship fund in the German sense or practice. For this reason we were very careful to insist that the needs would be met "as determined by the Conference". (Protocol 2, Art. 2). The conclusion is unmistakable if one considers the subsequent events.

Every year the Conference, as specifically required by the agreement, reported to the Bund "the amounts expended as well as the manner in which such expenditures had been incurred". If there were any differences the agreement contained provisions for arbitration. Never once in 20 years did the Bund ever allege or even suggest that the Conference was violating either the letter or the spirit of the agreement. For Herr Hermsdorf now, in 1974, to say that, in his view, the Conference has not carried out the 1952 agreement is to demonstrate an enormous lack of understanding of the nature of the agreement and its content.

Hermsdorf's argument that the Conference obtained undue advantage because Jews for whom the Conference had received special funds were eligible for payments out of the general hardship fund (Art. 171) is, in my judgment, equally without merit. The wording of Protocol 1, Sec. I, Art. $14,{ }^{61}$ and the attached letters dated 8 Sept. $1952,{ }^{62}$ was intended to make it possible for Jews in need to turn to the general hardship fund which the Germans agreed to create.

|3| Hermsdorf makes reference to the fact that the German Supreme Court has confirmed the conclusion that the individual Jewish claimant had no vested legal rights against the Claims Conference, but he refused to accept the validity of his own court's decision.

Unfortunately, I no longer have in my possession the minutes of the meetings in The Hague when these issues were discussed. The foregoing

61 Für den Wortlaut des Protokolls siehe Deutscher Bundestag, Gesetz betreffend das Abkommen vom 10. September 1952 zwischen der Bundesrepublik Deutschland und dem Staate Israel, Bonn, 21. März 1953, in: Bundesgesetzblatt Teil II (1953), Nr. 5, 35-97, hier $88 \mathrm{f}$.

62 Siehe Brief von Moses A. Leavitt an den Vorsitzenden der Deutschen Delegation, 8. September 1952, in: ebd., $93 \mathrm{f}$. 
observations are based only on my memory, which should be checked against the records.

I am therefore asking Dr. Weisman [sic] to search through the Claims Conference minutes at The Hague (which I believe I prepared), covering the period around July and August 1952, to see if anything can be found to further clarify the intent of the parties.

In the meanwhile the above is the best that my rusty old mind can do.

With warm regards,

$\{$ Ben $\}$

CC: S. Kagan
A. Pins
E. Weisman [sic]

\section{Dokument 152}

Benjamin B. Ferencz

Ohne Ortsangabe, 3. Oktober 1983

Maschinenschriftliches Memorandum, 1 Seite

$R G 12.007 .01 * 10$

\section{Claims Conference file memo:}

While on a trip to Washington with Saul Kagan on Sept. 30. 1984\{3\} I raised the question of my retainer from the Claims Conference. I noted that I had never agreed to accept a retainer from the Hardship Fund, and I was surprised when he mentioned in passing, some time ago, that $\$ 5,000$ of my $\$ 10,000$ retainer was being billed to the Fund for administrative convenience. I noted that my $\$ 10,000$ retainer had remained constant for perhaps more than 20 years, which I thought was scandalous, and that my responsibilities and time spent on the GDR problem was worth very much more.

Mindful of the financial crisis in which the CC now finds itself (depleting its reserves to meet current operating deficits) and the fact that there is no one with whom Saul could discuss the problem (Miller is an interim Pres. 
until July 1984 and Jack Spitzer, ${ }^{63}$ the Treas ${ }^{64}$ knows nothing about it) Saul suggested that he leave the old $\$ 10,000$ retainer as is, and add a new one of an additional \$5,000 from the Hardship Fund since I also did legal work and consultation for the Fund. Faut [sic] de mieux, I agreed and suggested it be made retroactive.

On Oct. 3rd Saul said that the accounts for the fiscal year had ended on Sept. 30 and had been closed and he was sorry that the $\$ 5,000$ increase could only go into effect per Pct. [sic] $1,198 \#\{3\}$. He asked that in future my quarterly bills be addressed to the CC as heretofore but be increased to $\$ 15,000$ per $a^{65}$ or $\$ 3,750$ per quartwe [sic].

We also discussed the situation that would arise should the GDR agree to pay the CC $\$ 100$ million. We would then reconsider the situation with a view toward reaching a more equitable amount. $<$ This was not a point that Saul stressed or paid too much attention to!>

\section{Dokument 153}

Benjamin B. Ferencz an Saul Kagan

New Rochelle, N. Y., 5. Juni 1984

Maschinenschriftlicher Brief, 3 Seiten; gedruckter Briefkopf mit maschinenschriftlich eingefügtem Datum auf Seite 1, handschriftliche Unterstreichungen, Einfügung am unteren Textrand auf Seite 1

$R G 12.007 .01 * 11$

[Ferencz nimmt zur angespannten Finanzlage der JCC Stellung. In einer Aufstellung erläutert er die wesentlichen Ursachen der finanziellen Schieflage. Im Anschluss unterbreitet er verschiedene Lösungsvorschläge zur Refinanzierung der Organisation.]

Benjamin B. Ferencz

Counselor of Law

'June 5, 1984|

14 Bayberry Lane, New Rochelle, N. Y. 10804

914 632-3717

63 Der Bankier Jack J. Spitzer (1917-2004) war seit 1979 Vizepräsident der JCC. Er engagierte sich in zahlreichen jüdischen Organisationen und wirkte von 1978 bis 1982 als internationaler Präsident von B'nai B'rith.

64 Treasurer.

65 Per annum. 
Saul Kagan, Claims Conference NY

Dear Saul:

The financial problems of the Claims Conference that we are to discuss on June 7th are, in my judgment, so serious and important that I am listing the items of my deep concern as a means of assuring your attention and action.

1- The Claims Conference Deficits: The CC has earned income from investments which amount to about $\$ 144,000$ per annum. Its expenses exceed its income by an amount that seems to fluctuate between about $\$ 30,000$ and $\$ 70,000$ per annum. The primary responsibility of the CC is to safeguard the rights and interests of Nazi victims. That is done via the so-called "Legislative programs" - the cost of which has been reduced from about $\$ 100,000$ a few years ago to its current level of below $\$ 30,000$. The normal administrative expenses of the CC have been reduced from about $\$ 100,000$ to between $\$ 20,000$ and $\$ 30,000$. The CC is in deficit because, for historical reasons, the validity of which in my judgment are no longer persuasive, it has been paying out over $\$ 80,000$ to "Righteous Gentiles" ${ }^{\prime 66}$ and about $\$ 30,000$ to $\$ 40,000$ to former Community Leaders. ${ }^{67}$

The first order of CC business must be to halt the continuing drain on CC capital - which, if allowed to go unchecked, may destroy the capacity of the CC to fulfill its responsibilities to Nazi victims. The obvious solution is for the $\mathrm{CC}$ to divest itself of the costs of $\{$ the $\}$ latter two programs, that can more appropriately be carried by other agencies.

2-The UROReserve: The CC has undertaken to hold in trust for possible URO use the amount which the URO repaid to the CC for past allocations. This "trust" fund originally amounted to $\$ 2,492,389$. In order to help the CC meet its operating deficits, the URO Board, at my behest, agreed that each year an amount of up to $5 \%$ of that reserve could be removed from the reserve trust in order to enable the CC to pay its current bills. You have interpreted that agreement to mean that the CC, as long as it has a deficit on its balance sheet,

661963 etablierte die JCC das Righteous Gentiles Program, um finanziell hilfsbedürftige Nichtjuden zu unterstützen, die während des Holocaust ihr eigenes Leben riskiert hatten, um Juden zu retten. Siehe The Conference on Jewish Material Claims Against Germany, Claims Conference 2007 Annual Report With 2008 Highlights, 87, <http:// www.claimscon.org/forms/CC_AR_2007.pdf> (26. Juli 2018).

671954 etablierte die JCC den Community Leader Fund. Dieser ermöglichte monatliche Beihilfen an unterstützungsbedürftige ehemalige Führungspersönlichkeiten jüdischer Gemeinden, die während des Holocaust zerstört worden waren. Siehe ebd. 
can automatically draw $\$ 124,620$ (5\%) out of the Trust. I can assure you that the URO board had no such intent. The "up to" clause made clear that only the actual operating deficit for each year could be covered by the invasion of the Trust. An adjustment is therefore required which would credit the Trust with the excess amounts withdrawn. $[\ldots]^{68}$

|2| The most serious problem affecting the URO Reserve is the fact that the CC has depleted its assets to a point where the amount which was pledged to be held in reserve to meet the needs of providing legal assistance to Nazi survivors is no longer held by the CC. The Sept. 30, 1983 balance sheet shows the size of the URO reserve to be $\$ 1,370,809$, which is the original sum less annual reductions of the $5 \%$ maximum since 1975 . I have indicated my view that the amount removed from the Trust was excessive. I would guess that an adjustment in line with URO's intent would add about $\$ 500,000$ more to the amount that the CC is obliged to hold in trust. Thus the CC, in accordance with its commitments, should be holding about $\$ 1.8$ million in Trust for possible future URO needs. In fact, however, the current market value of all of the CC assets, is only about $\$ 1,147,000$ (per Sept. 30, 1983).

3-The Debt to the URO: In addition to the above, CC has borrowed another \$124,620 from the URO to help cover cash needs, and the CC has pledged specific CC securities to guarantee repayment of the loan. The loan is due in Dec. 1985. I fear that a repayment of the loan will further jeopardize CC capacity to discharge its responsibilities.

4-Debt to Memorial Foundation: ${ }^{69}$ The balance sheet also shows a debt to the Memorial Foundation of $\$ 137,080$. The same fears expressed in the preceding paragraph apply here. There is the additional fear that the Foundation will press for treatment as a preferred creditor - without full awareness of other CC obligations and committments [sic].

5-. The Accounting and Financial Problems of the "Hardship Fund": The funds made available by the German government do not appear to be adequate to enable the CC to discharge its obligation to administer the fund. This is a problem that requires immediate attention by the German government. Should the CC, of necessity, in order to get the job done, spend more than the allocated fund for administration, it would open the CC to the sharpest criticism and the possibility of even more severe German action. The administrator would be the first one to be roasted.

68 Es folgt eine verwaschene und kaum lesbare fünfzeilige handschriftliche Notiz zu Rücksprachen mit Saul Kagan und Kurt May.

69 Die Memorial Foundation for Jewish Culture wurde 1965 von Nahum Goldmann gegründet, um nach dem Holocaust die Erinnerung und Pflege jüdischer Kultur zu fördern. 
I do not understand why the Hardship Fund accounts are co-mingled with the other CC accounts. I think it would be much clearer, cleaner and simpler to keep the accounts completely separate so that all possible confusion is removed.

What seems called for is a meeting of the responsible officers of the organizations involved in order to put the CC's financial house in order. The objective of such a meeting should be to see to it that the CC has adequate income to cover its primary responsibilities to the survivors of Nazi persecutions without invading its limited and restricted capital until its mission is accomplished. The official German estimate is that it will continue to pay pensions to Nazi survivors till the year 2007.

|3| RECOMENDATIONS:

1- Re RCDeficitits: CC should immediately halt all payments to "Righteous Gentiles" and "Community Leaders". These are programs that are certainly important and worthwhile but if the CC has the choice of protecting the interests of the survivors of the camps or of making the above payments out of CC limited funds then priority must go to those for whose protection the $\mathrm{CC}$ was created. In the total context of Jewish spending, the amounts required to continue the above two programs are not significant and they should be absorbed by such other organizations as the Jewish Agency, or the American Joint Distribution Committee or others.

2- The URO Board must understand why it was necessary for the CC to invade the URO Truste fund. It should be possible to persuade the URO to forego any retroactive accounting for the amounts that were "overdrawn" from the Trust beyond the amount the URO intended to authorize. In future, only the amounts actually required to cover operational deficits (excluding the allocations to the two programs referred to above) should be drawn from the Trust.

3- The debt to the URO that is due in Dec. 1985 should be rolled over and consideration should be given to making the loan interest free in order to help the CC meet its obligations.

4- The debt to the Memorial Foundation should also be extended. This would encourage the URO to go along with the recommendation in 3 above. Both debts could be reconsidered at the next biennial meeting of the CC.

5- The Hardship Fund accounts should be completely separated from other CC accounts. A comprehensive statement of the operations from inception to date should be prepared and presented to the Zentralrat and German government as early as possible with a view toward obtaining official consent to spending whatever reasonable sum is necessary to discharge the responsibilities accepted by the CC. The objective should be to obtain a pooling of the administrative funds allocated to CC and Zentralrat, permission 
to use accumulated interest for administrative purposes and an undertaking by the German government to reconsider the position in two years time to see whether additional administrative or other funds may be required to accomplish the purposes of the Fund. ${ }^{70}$

THE SOONER THE BETTER!

Sincerely,

$\{$ Ben $\}$

\section{Dokument 154}

Benjamin B. Ferencz an Ulrich Herbert ${ }^{71}$

New Rochelle, N. Y., 18. Oktober 1987

Maschinenschriftlicher Brief, 1 Seite

$R G 12.009 .03$

\section{BENJAMIN B. FERENCZ}

Counsellor at Law

Adjunct Professor

Pace Law School
14 Bayberry Lane

New Rochelle, N. Y. 10804

(914) 632-3717

October 18, 1987

Ulrich Herbert

Institute for German History

Tel Aviv University

Ramat Aviv, 69978 Tel Aviv

Dear Ulrich Herbert:

Thank you for your letter of Oct. 2 and the copy of your manuscript dealing with compensation by the FRG for those who were forced laborers during the

70 Der letzte Absatz ist durch handschriftliche Klammern hervorgehoben.

71 Ulrich Herbert $\left({ }^{\star} 1951\right)$ ist seit 1995 Professor für Neuere und Neueste Geschichte an der Universität Freiburg. 1987/1988 war er Research Fellow am Institut für deutsche Geschichte in Tel Aviv. 
Nazi years. ${ }^{72}$ You are to be congratulated for your careful study and for the courageous conclusions you have reached.

I quite agree that a major injustice has been done. Bad legal arguments have, for political, financial, and perhaps even racial reasons, been allowed to defeat claims which are both morally and legally justified. I hope that your study will be appreciated in Bonn and that some corrective measures can still be taken.

I am particularly pleased to note that the problems of Wiedergutmachung are still being seriously addressed by the new German generation. I believe that the problem of Germany's obligations to all of its victims and the matter of Germany's reputation and respect for the rule of law is, in the first instance, a German problem. Certainly, at this stage of history it is not for outsiders like me to point the finger of shame. In my book LESS THAN SLAVES (Lohn des Grauens) I have merely told the truth as I see it and let it to the readers to form their own judgments.

Now I am busy trying to prevent an even greater holocaust, as you will note from the attached list of some of my books on world peace. But I do hope you will continue your writing on Wiedergutmachung and I am asking my friends in Germany to look for the forthcoming book by the Institute fur Zeitgeschichte, ${ }^{73}$ which I shall read with great interest and appreciation.

With best wishes for your further work in Israel,

$\{$ Sincerely

Ben Ferencz\}

$\left\{\right.$ Saul - Please share this with Ernst Katz. $\left.{ }^{74}\right\}$

\section{Dokument 155}

Benjamin B. Ferencz

Ohne Ortsangabe, 19. Mai 1988

Maschinenschriftliche Aktennotiz, 1 Seite

$R G 12.007 .02^{*} 10$

72 Ulrich Herbert, Fremdarbeiter. Politik und Praxis des "Ausländer-Einsatzes« in der Kriegswirtschaft des Dritten Reiches, Berlin/Bonn 1985.

73 Herbst/Goschler (Hg.), Wiedergutmachung in der Bundesrepublik Deutschland.

74 Ernst Katzenstein. 
Saul Kagan reported on phone: He had spoken to Galinski yesterday who stated that about 20 to 30 million DM seemed to be missing from Nachman's ${ }^{75}$ interest account. ${ }^{76}$ There was about 5 million DM cash on hand. The auditors report might take 3 weeks.

Ginsburg ${ }^{77}$ seemed incoherent when Saul spoke to him. Brozik said Ginsburg had retained a lawyer, since he was a co-signatory on $\mathrm{HF}^{78}$ account. Levinski $[\mathrm{sic}]^{79}$ had called Saul and urged that Conference not remain passive but contact Finance Ministry and others to continue the flow of funds. He would be in Frankfurt from 6 June to about 14 June and would be available to accompany Saul where needed.

75 Werner Nachmann (1925-1988) war Unternehmer und engagierte sich im Wiederaufbau jüdischen Lebens in Deutschland nach dem Zweiten Weltkrieg. 1954 übernahm er den Vorsitz der Jüdischen Gemeinde Karlsruhe. Von 1969 bis 1988 war er Vorsitzender des Zentralrats der Juden in Deutschland. Nach seinem Tod übernahm dieses Amt Heinz Galinski.

76 Nach dem Tod Werner Nachmanns 1988 wurde bekannt, dass dieser die über die Konten des Zentralrats laufenden Mittel aus dem 1980 von der JCC mit der Bundesregierung ausgehandelten sogenannten Post-65-Härtefonds für private Zwecke missbraucht hatte. Dadurch war ein Schaden von 30 Millionen DM entstanden. Siehe dazu die Einleitung, 67.

77 Der Jurist Alexander Ginsburg (1915-1996) war 1946 in die britische Besatzungszone gelangt, nachdem er den Holocaust überlebt hatte. Zunächst arbeitete er für jüdische Hilfsorganisationen bei der Betreuung von DPs. Ab 1948 war er für das Land Nordrhein-Westfalen im Bereich der Restitution tätig und engagierte sich im Vorstand der Kölner Synagogengemeinde beim Wiederaufbau jüdischen Lebens in Deutschland. Von 1973 bis 1988 war Ginsburg Generalsekretär des Zentralrats der Juden in Deutschland.

78 Die Abkürzung steht für Hardship Fund und bezeichnet die 1980 mit der Bundesrepublik vereinbarten Leistungen für die nach 1965 aus dem Ostblock ausgewanderten Juden in Höhe von 400 Millionen DM, wozu noch 40 Millionen DM für den Zentralrat der Juden in Deutschland kamen. Siehe Goschler, Schuld und Schulden, 323-344.

79 Gemeint ist der Verbandsfunktionär, Diplomat und Manager Akiva Lewinsky (19182000). Er emigrierte 1934 ins britische Mandatsgebiet Palästina und war in den 1930er und 1940er Jahren Mitarbeiter der Jugend-Alija, einer zionistischen Organisation, die versuchte, möglichst viele jüdische Kinder und Jugendliche aus dem nationalsozialistischen Deutschland nach Palästina zu bringen. Von 1952 bis 1954 vertrat er Israel im Intergovernmental Committee for European Migration der Vereinten Nationen. In den 1960er und 1970er Jahren arbeitete er als Manager und Berater im Bankgewerbe. 1978 bis 1987 wirkte er als Schatzmeister der Jewish Agency und war in gleicher Funktion sowie als Vizepräsident für die JCC tätig. 
I asked Saul about the HF needs. He said another 10 million DM was needed for claims and about 1 million for administration, in addition to the 5 million still on hand in the Zentralrat account, to cover the end of the year. They could continue the flow until August out of present funds on hand. The Germans had allocated DM \#\# 50 million for 1989 and 50 for 1990. Saul had been asking for an additional 125 for more claims and additional sums for extreme hardship. This would be discussed in Bonn during the next weeks as a follow up of meetings which SK had with Krause, ${ }^{80} \mathrm{Gerster}^{81}$ and Lueder $^{82}$ of CDU and FDP. SK felt he should be in Germany to continue those talks and try to get favorable action. He felt it would be seen as a retreat if he failed to show up and went into "hiding" in the cellar. (As I had urged him to do.)

He still had about DM4 1/2 million of interest earned by the CC on its accounts in Germany. That could carry the admin. for about 2 years.

I urged him NOT to go to Germany now. Instead to ask Brozik and (he suggested Nippold) to go to Bonn and talk to Krause, or anyone else in the Finance Ministry, asking how they intended to assure the flow of money to pay the claims in light of the leak that had sprung up in their pipeline. They could also talk to the SPD and the FDP or any of the party people to see if any immediate action was required which might compel Saul to be present.

I warned that Lewinsky was a competent man with not enough to do and that he might be on the prowl in ways that would be detrimental to Saul's interests, Saul poo-poohed the idea, but noted it.

I think the Germans should be able to divert from the 198950 million which is primarily intended for homosexuals, gypsies and new categories, an amount of DM 10 to 12 [million] to meet the current CC needs until the new appropriation can be voted on. I fear the chilling effect of the new scandal. I told Saul that in my view he should NOT go into Germany until the affair

80 Vermutlich ist der CSU-Politiker Rudolf Kraus (1941-2018) gemeint, der von 1976 bis 2005 Mitglied des Deutschen Bundestags war und zwischen 1989 bis 1992 als Parlamentarischer Geschäftsführer der CDU/CSU-Bundestagsfraktion wirkte.

81 Der CDU-Politiker Johannes Gerster ( $\left.{ }^{\star} 1941\right)$ war von 1972 bis 1976 und von 1977 bis 1994 Mitglied des Deutschen Bundestags. Zwischen 1987 und 1992 wirkte er als innenpolitischer Sprecher der Unionsfraktion. Zudem war er über 20 Jahre zunächst stellvertretender Vorsitzender und später Vorsitzender der Deutsch-Israelischen Parlamentariergruppe. Von 1982 bis 2006 war er als Vizepräsident der DeutschIsraelischen Gesellschaft tätig.

82 Wolfgang Lüder (1937-2013) war ein Politiker der FDP und von 1987 bis 1994 Abgeordneter im Deutschen Bundestag sowie stellvertretender Vorsitzender des Innenausschusses. Zwischen 1970 und 1988 sowie ab 1990 gehörte er dem Bundesvorstand der FDP an. 
dies down. If he goes where it stinks, the smell will rub off on him and he will ebe unable to avoid the publicity which the German media will be seeking.

\section{Dokument 156}

Benjamin B. Ferencz an Israel Miller

New Rochelle, N. Y., 8. Juni 1988

Maschinenschriftliches Memorandum, 2 Seiten

$R G 12.007 .02 * 10$

BENJAMIN B. FERENCZ

Counsellor at Law

Adjunct Professor

Pace Law School
14 Bayberry Lane

New Rochelle, N.Y. 10804

(914) 632-3717

June 8,1988

Memo To: Dr. Israel Miller, President, Claims Conference

Subject: Responsibility for Safeguarding Funds of the (Goldmann) Hardship Fund ${ }^{83}$

On 14 Oct. 1980, the FRG, published the official rules regarding payments under the above Hardship Fund ${ }^{84}$ It announced that DM 400 million would be made available for Jewish claimants who met specific eligibility requirements set forth in the rules (Sec. 1, 2). Grants could only be made upon application and there was no legal entitlement bestowed upon any intended beneficiary

83 Der sogenannte Post-65-Härtefonds wurde auch als Goldmann-Härtefonds bezeichnet, da er über Jahrzehnte durch Nahum Goldmann verhandelt worden war. Siehe Carole Fink, Negotiating after Negotiations: Nahum Goldmann, West Germany, and the Origins of the 1980 Hardship Fund, in: Jahrbuch des Simon-Dubnow-Instituts/Simon Dubnow Institute Yearbook 15 (2016), 287-305.

84 Am 25. Juli 1980 verabschiedete das Bundeskabinett die vom Bundesfinanzministerium ausgearbeiteten Richtlinien, nach denen die Vergabe einer "Abschlussgeste» von bis zu 400 Millionen DM plus 40 Millionen DM für den Zentralrat der Juden in Deutschland erfolgen sollte. Am 3. Oktober 1980 wurden die »Richtlinien für die Vergabe von Mitteln an jüdische Verfolgte zur Abgeltung von weiteren Härten in Einzelfällen im Rahmen der Wiedergutmachung « im Bundesanzeiger veröffentlicht. Siehe Brodesser u. a., Wiedergutmachung und Kriegsfolgenliquidation, 122 f.; Goschler, Schuld und Schulden, 342. 
(Sec. 3). Individual grants were set at DM 5,000 (Sec. 4). $5 \%$ of the total could be used to support institutions that cared for Nazi victims (Sec. 7).

It was specifically provided that the funds would be placed at the disposal of the Central Council of Jews in Germany (Zentralrat). The subsequent distribution of the funds was to be made by the Claims Conference after it had examined the claims and determined their eligibility pursuant to the rules (Sec. 8).

The Federal Comptroller's Office (Bundesrechnungshof) was authorized to obtain information at any time regarding the use of the funds, including on-site inspection. Furthermore, the Zentralrat was specifically required to render an account at the end of each year regarding the use of the funds (Sec. 9).

It may be noted that the FRG did not require the Claims Conference to report on the use of the funds - that being the sole responsibility of the Zentralrat.

It is clear from the foregoing official publication that the Zentralrat was designated by the FRG as its sole agent for making monies available to the Claims Conference to meet the objectives of the Fund.

The Claims Conference was to serve as the agent of the FRG to examine and validate the claims if they met the requirements of the official rules and to disburse the DM 5,000 to the approved claimants, after the required funds were requested and received from the Zentralrat.

It may also be noted that the final version of the official rules were [sic] negotiated between representatives of the FRG and Dr. Werner Nachmann, head of the Zentralrat (Report by.E.K.15/10/80..$^{85}$

|2| CONCLUSION:

It is basic law that an agent is responsible for his own wrongdoing. The principal is also responsible for the wrongdoing of an agent acting in the course of official business.

The Zentralrat acted as paying agent for the FRG. It acted through Dr. Nachmann. If there has been misappropriation of funds a liability for restitution lies, in the first instance, with the wrongdoer or his estate. If the fraud should have been detected, there is also liability on the part of the controlling agency.

The Federal Republic, which is the principal on whose behalf the funds were received by the Zentralrat, must also be held responsible. It was the FRG, through its Comptroller that had the sole right and duty under the law

85 Die Angabe in Klammern ist im Original eingekringelt. 
to see to it that all funds were properly handled. Failure to do so was a clear dereliction of duty that made the loss possible.

Neither the Claims Conference nor any of its officers had any responsibility for controlling the use of the funds by Dr. Nachmann or the Zentralrat. The Conference could only request money from the Zentralrat to pay the approved claims. It had neither a right nor an obligation to control the Zentralrat.

For its part, the Claims Conference rendered regular reports to the Zentralrat showing precisely how many claims had been approved, what funds were required for the claimants as well as for administering the Fund. The German authorities in the Finance Ministry were also kept fully and regularly informed of all activities by the Claims Conference and indicated complete satisfaction with the way the claims were being handled by the Conference representatives.

Since neither the Claims Conference nor the intended beneficiaries bear any responsibility whatsoever for whatever misappropriation of funds may have taken place, they should not be required to absorb whatever loss may have occurred. The wrongdoing parties are each and severally liable to make complete restitution. The loss must be made good and reinstated into the Hardship Fund if the original intent of the legislation is to be carried out.

$\{$ Ben $\}$

Benjamin B. Ferencz

General Counsel

\section{Dokument 157}

Benjamin B. Ferencz

Ohne Ortsangabe, 28. Juni und 1. Juli 1988

Maschinenschriftliche Aktennotiz, 1 Seite; handschriftliche Notiz am unteren Rand

$R G 12.007 .02^{\star} 10$

Israel Miller phoned, very upset. A reporter from the NY Post, Lucette Legnato - who had worked for columnist Jack Anderson - was doing a story on the Nachman scandal. She had called the Jewish Community Relations 
Council and inquired about Ginsburg - whom she thought worked for the CC. She referred to Kagan's trial for misappropriation of bank funds. ${ }^{86} \mathrm{He}$ wanted to know what to do or say. He had pleaded ignorance.

I explained that he would have to deal with the questions on the merits. I asked whether he, or Nachmann had set Saul's Hardship Fund salary. He said he had nothing to do with it. On further questioning he felt that he knew the total (about $\$ 70,000$ ) but did not set it, although he knew that some years ago Saul had received a significant increase on the CC share (about $\$ 20,000$ raise, he thought. I indicated that a hostile questioner might argue that Saul could not and did not press Nachman for an accounting since Nachmann had to approve Saul's HF salary - even though the amount might be fully justifiable. I indicated my own concern - that I had voiced years ago - about taking a retainer out of the Hardship Fund - despite the fact that it was modest for the time spent on HF problems.

Miller was quite despondent. Spoke about quitting. I told him he couldn't. It would be seen as running away. He had to take his lumps and expect that today's headline would be tomorrow's fish-wrapper and it would all blow over. "This too shall pass."

July 1,1988

Miller called in AM. Quite upset. The NY Post story was not out but the reporter was continuing to pursue it. She had approached Ben Mead [sic] $]^{87}$ and asked how the Nazi victims organization could accept the administration of a fund by a convicted felon. ${ }^{88}$ Mead knew nothing and called Miller. The Israel Bond office had also been approached. Miller was apprehensive. He had asked Ken Bialkin, ${ }^{89}$ who knew someone at the Post, to intervene. I suggest

86 Saul Kagan hatte in den 1970er Jahren das Amt des Präsidenten der New Yorker American Trust and Bank Company übernommen. 1979 wurde er im Zusammenhang mit dieser Tätigkeit der Veruntreuung angeklagt. Siehe dazu Dokument 158.

87 Benjamin Meed (1918-2006) war im Zweiten Weltkrieg Mitglied des jüdischen Widerstands im Warschauer Ghetto und emigrierte 1946 in die Vereinigten Staaten. Seit den 1980er Jahren engagierte er sich in Organisationen jüdischer Holocaustüberlebender, initiierte Bildungsprogramme zum Holocaust und zum jüdischen Widerstand. Er wirkte als Berater an der Gründung des United States Holocaust Memorial Museum mit und war bis 2004 im United States Holocaust Memorial Council, dem Aufsichtsrat des Museums, tätig. Zudem war er seit 1981 Präsident des von ihm mitgegründeten American Gathering of Jewish Holocaust Survivors.

88 Gemeint ist Saul Kagan.

89 Kenneth J. Bialkin $\left({ }^{\star} 1929\right)$ war Rechtsanwalt und hatte in zahlreichen jüdischen Organisationen leitende Ämter inne. So wirkte er als Vorsitzender der Anti-Defamation League von 1982 bis 1986 und von 1984 bis 1986 als Vorsitzender der Conference of Presidents of Major American Jewish Organizations. 
that he call Bialkin again and suggest that Bialkin note the irresponsible journalism of failing to note the acquittal and the judge's conclusion that Kagan should never have been tried.

Miller was disgusted about the American Jewish Congress's having sent a letter to the Jewish Community Relations Council taking credit for payments that might be made by Austria. He was fed up with the antics of Bronfman ${ }^{90}$ and Galinski trying to take credit for payments by the GDR which had not in fact been made. ${ }^{91}$

I tried to calm him. I explained Kagan's innocence and the injustice of accusing him falsely. He asked for a memo, which I sent at once. See attached. ${ }^{92}$ I told him he had only one course - to continue to do the right thing and if others want to claim credit, they only belittle themselves in the long run. $\mathrm{He}$ heaved a sigh and agreed. $[\ldots]^{93}$

\section{Dokument 158}

Benjamin B. Ferencz an Israel Miller

New Rochelle, N. Y., 1. Juli 1988

Maschinenschriftlicher Brief, 2 Seiten

$R G 12.007 .02 * 10$

Counsellor at Law

Adjunct Professor

Pace Law School
BENJAMIN B. FERENCZ

$\{$ BF File $\}$

14 Bayberry Lane

New Rochelle, N.Y. 10804

(914) 632-3717

July 1,1988

Dr. Israel Miller

Yeshiva University

2540 Amsterdam Ave. N. Y. 10033

90 Der Unternehmer Edgar Miles Bronfman sen. (1929-2013) war zwischen 1979 und 2007 Präsident des Jüdischen Weltkongresses.

$91 \mathrm{Zu}$ den Verhandlungen mit der DDR siehe Kapitel 7.

92 Siehe Dokument 158.

93 Es folgt eine kurze und größtenteils unleserliche handschriftliche Notiz zu Saul Kagan. 
Dear Israel:

As I expected when we spoke this morning, I no longer have readily available my file regarding Saul Kagan's legal problems some years ago. My son wrote an article on the case for the Pace Law Review (Fall 1982) ${ }^{94}$ and I turned my entire file over to him. He is now travelling on vacation. Rather than keep you waiting on a matter that I know vexes your mind, I will give you the essential facts as I recall them. I can, if you wish, supplement this summery at a later date when I have the decision before me.

Around 1981, several officers of the American Bank and Trust Co. (ABT), including Saul Kagan as its President, were indicted for "misapplication" of bank funds by allowing the owner of the bank, David Graiver to borrow from the bank in excess of the limits set by the banking law. Each such transaction was listed as a separate felony. Graiver had apparently been transferring funds to another bank he owned in Europe and making a profit on the overdraft before the money was returned to the ABT. Graiver was killed in an aircraft explosion shortly before the bank examiners closed the bank.

At no time was it alleged that any of the defendants had obtained any personal profit or advantage from the transactions, or indeed that the bank had suffered any loss. Nonetheless, a jury (from which all Jews were excluded) found the defendants guilty of violating the banking regulations. A $\$ 40,000$ fine was imposed on Saul.

On appeal, the appellate division affirmed the conviction, holding that fraudulent intent was not relevant - if the regulatory limits were exceeded the defendants were guilty. A strong dissenting opinion was filed by Judge Kupferman ${ }^{95}$ who argued that the defendants had been made scapegoats for the machinations of the deceased Graiver.

The Court of Appeals (the highest appellate court in the State) reversed the lower court decisions. Saul was given back the full amount of the fine and the court made plain that he should never have been tried in the first place. Although he was fully vindicated and cleared, in the meanwhile Saul had lost his job, his reputation and spent all of his savings.

[|2|] To now hold this tragic experience against him would be to compound the injustice. I am sure that you will present the facts accurately whenever and wherever this unfortunate incident is raised.

94 Donald M. Ferencz, People v. Kagan and New York Banking Law Section 673: A Study in Misapplication, in: Pace Law Review 3 (1982), H. 1, 169-182.

95 Theodore R. Kupferman (1920-2003) war republikanisches Mitglied des Repräsentantenhauses der Vereinigten Staaten und Richter am Obersten Gerichtshof des Staats New York. 
Warm greetings, ${ }^{96}$

$\{\mathrm{BC} \mathrm{SK}\}$

\section{Dokument 159}

Benjamin B. Ferencz an Israel Miller

New Rochelle, N. Y., 24. August 1988

Maschinenschriftlicher Brief, 1 Seite

$R G 12.007 .02 * 10$

\section{BENJAMIN B. FERENCZ}

Counsellor at Law

Adjunct Professor

Pace Law School
14 Bayberry Lane

New Rochelle, N. Y. 10804

(914) 632-3717

August 24, 1988

Rabbi Israel Miller: Yeshiva University

Dear Israel:

I have considered a draft of a letter to Finance Minister Stoltenberg, ${ }^{97}$ but I would appreciate some further guidance. You can certainly thank Stoltenberg for his assurance that his government shares our desire to complete the Hardship Fund payments as quickly as possible. You can note that you sent your Executive Director ${ }^{98}$ to Germany immediately to assure complete cooperation with his Ministry and that such collaboration is continuing. I fear that expressing too much concern (or implying dire consequences) at this stage may be "protesting too much." A "panic" tone might be counterproductive.

96 Unterschrift fehlt auf archivalischer Kopie.

97 Der CDU-Politiker Gerhard Stoltenberg (1928-2001) war von 1982 bis 1989 Bundesminister der Finanzen. Zuvor war der Haushaltsexperte zwischen 1965 und 1969 Bundesminister für wissenschaftliche Forschung und von 1971 bis 1982 Ministerpräsident von Schleswig-Holstein gewesen. Von 1989 bis 1992 bekleidete er das Amt des Verteidigungsministers.

98 Gemeint ist Saul Kagan. 
Saul has already obtained verbal permission to use accumulated interest for administrative expenses for the balance of this year. By the beginning of next year, the Germans should have a pretty good overall picture. I expect that their complaints against the Conference will be picayune. They may be unhappy about some expenditures but that will not be too serious. They will, undoubtedly, note that more was spent on administration than was authorized, but that too is answerable. For political reasons, they won't want to make a big issue of it. Nor will they want us to dump the whole thing back into their lap. They have too much invested to risk ending it all with a foul smell - from which they will not be immune.

I feel that Saul (or even our people in Germany) should be able to persuade Hubrich ${ }^{99}$ not to pull the plug. If the financial picture is not clarified by Jan. 1989, Hubrich will probably have to agree that the CC can continue to use interest to cover overhead - which may have to be reduced to keep him happy.

If by then the Germans have not decided how much additional money they will put into the Jewish pot, the Fund can continue to process claims for another year or more. The accumulation of awards for which no funds are available will increase the pressure of the Finance Ministry. The fact that the non-Jewish Fund may make more generous grants is also a negotiating advantage for us in the long run. The more they spend for that purpose, the more powerful our argument becomes.

I fear that - for understandable reasons - both you and Saul are too exhausted, discouraged and overwrought. My advice is: Play it cool. Let's you and I [sic] have a nice quiet lunch together at the Harvard Club <I'll pay the bill!> I guarantee that you'll come away refreshed.

Warm greetings,

$\{$ Ben $\}$

CC: S. Kagan

99 Eberhard Hubrich (1926-2014) durchlief zwischen 1963 und 1992 diverse Stationen im Bundesfinanzministerium. Von 1982 bis 1992 war er Leiter der Abteilung VI für Rechtsangelegenheiten und Liquidation des Krieges. 


\section{Dokument 160}

Benjamin B. Ferencz an Saul Kagan

New Rochelle, N. Y., 14. April 1990

Maschinenschriftlicher Brief, 2 Seiten

RG $12.007 .01 * 14$

Counsellor at Law

Adjunct Professor

Pace Law School

\section{BENJAMIN B. FERENCZ}

14 Bayberry Lane

New Rochelle, N.Y. 10804

(914) 632-3717

April 14, 1990

Dear Saul:

I am writing this letter primarily to clear my own mind. Since it also may affect you and what you are doing, I am sharing my thoughts with you in a form which may also enable you to focus more readily on the problems raised.

Having passed my 70th birthday, I asked myself what I wanted to do with my remaining years. My conclusion was that I wanted more time to study and write about world peace problems (preventing a larger Holocaust) to spend more time with Gertrude and the family and just to be able to relax and think without the pressure of other matters. Like you I have been much too busy and I have definitely decided to alter that condition as quickly as I can.

As far as the Claims Conference is concerned, you may recall that last summer I offered to waive my retainer so that the $\$ 15,000$ savings might be available to increase your own salary. You graciously declined. When we talked at Yeshiva University and on the phone recently, I repeated my desire to resign from the CC. You felt that I should wait until the end of 1991. We agreed that I would stay till after the CC Board meeting in July; presumably we could then re-examine the issue.

Having given the matter further thought, it now seems to me most unlikely that I can remain with the CC until 1991. I anticipate that there will be a flood of new claims arising from the merger of the two Germanys. I do not see any quick or easy solutions. I want to decrease, not increase, my involvement.

I am very mindful of my "responsibilities." But, after having spent my entire adult life trying to help Nazi victims, the time has finally come for me to shift to other priorities. I am a bit concerned that I have not informed Israel Miller of my thinking. I would not want him to feel that I had let him down 
without adequate notice. He may also feel "betrayed" should I be re-elected in July only to announce my departure some months later. Please feel free to discuss this with him and let me have your views.

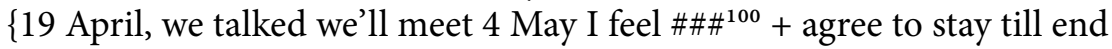
of 1990$\}^{101}$

[|2|] Nor do I wish to leave you in the lurch. As you know, I feel that you are already very overworked and desperately in need of help. My withdrawal may offer an incentive to seek such help. I am mindful of the limited CC finances. It is not within my competence to make specific recommendations, but I am available to express my opinion on this subject to you, Dr. Miller or any other CC Board members - should my views be desired. I am repeating my willingness to discuss with them the making of suitable financial arrangements with you so that you need not be forced to keep running on the treadmill till you drop - simply because you have no viable alternatives. Please let me know specifically, if and when and with whom any intervention on my part is desired.

Similar considerations apply to the URO. My present feeling is that the URO may have to be wound down, or its structure changed fairly soon. This is something I wish to discuss further with Wolff and to consider after I have reviewed the scene in Israel and Frankfurt. My mind is still open regarding the nature of my involvement with URO, and how long that can go on. My desire would be to step down as soon as that can be done without jeopardizing the successful conclusion of URO's mission.

We shall be discussing these problems during the next few months, but I wanted you to have my thoughts before you in black and white so that it stays on the front burner. Do not hesitate to let me have your views on any issues which may arise as a result of these considerations.

Warm greetings,

$\{$ Ben $\}$

Saul Kagan

220 E. 72 St.

NY 10021

100 Eventuell Miller.

101 Handschriftliche Notiz am unteren Seitenrand. 


\section{Dokument 161}

Benjamin B. Ferencz an Saul Kagan

New Rochelle, N. Y., 4. Februar 1991

Maschinenschriftlicher Brief, 2 Seiten

RG $12.007 .01 * 16$

$\{\mathrm{HF}\}$

Counsellor at Law

Adjunct Professor

Pace Law School

\section{BENJAMIN B. FERENCZ}

14 Bayberry Lane

New Rochelle, N. Y. 10804

(914) 632-3717

February 4, 1991

Saul Kagan CC NY

Dear Saul:

As part of my comprehensive review of the URO NY office, I had occasion to go over some Hardship Fund files with Yulia Trifel and Vadim Glushakov. Since I am leaving for Florida in the morning and may not have occasion to speak to you, let me share some impressions and suggestions.

A case which I picked up from the desk at random showed that an 82 year-old SSI-recipient-claimant ${ }^{102}$ seemed qualified under the guidelines, but Mr. Goldscheider had requested additional information about the circumstances or date of death of the claimants parents, who apparently, according to HIAS files, had died in Kiev in 1941. The fact that no mention had been made of the parents seemed to bother our late friend Goldscheider. Since that fact seemed irrelevant to me, and I am particularly sensitive about claims from Kiev where the Einsatzgruppen murdered all the Jews they could catch, I called Gerda Feigen [sic] to see if I could understand the basis for the inquiry.

Gerda knew the case and explained that "the Germans" required, as part of the explanation of the persecution history, some explanation about the parents. I do not know who "the Germans" are that decide upon the Jewish

102 Wahrscheinlich ist das amerikanische Unterstützungsprogramm Supplemental Security Income gemeint, das bedürftigen alten Menschen oder Personen mit Behinderungen finanzielle Unterstützung gewährt. 
claims, but surely I do not recall any such requirement under the agreed Richtlinien. She indicated that the $\mathrm{CCHF}^{103}$ had about 200 similar cases.

It seemed to me to be outrageous to reject a survivor of the Einsatzgruppen massacres on the grounds that she didn't include any reference to her dead parents. I must admit that I got a bit unnerved and asked Gerda to approve the case and just let me know which German had rejected it on the ground stated and that I would raise the sharpest protest at the highest levels of German government. She said that such decisions were now up to you and I asked her to pass along my views to you with a request that you call me at the URO so that we could discuss it.

|2| A review of other cases at the URO indicated that there are other serious differences regarding the approval of HF claims. The URO staff feel that the CCHF very frequently requests information or proof which simply cannot be obtained, which is irrelevant and hence unnecessary, or which has already been submitted. There were other complaints about proving the degree of medical disability. Although I did not quite grasp the nature of his involvement, they felt that "Dr. Bubna's" determinations of disability were arbitrary and restrictive.

I think it would be beneficial to all if a conference between the parties (You, Gerda, Yulia, Vadim, Lily Rosenbaum ${ }^{104}$ and Gutter) could be arranged to see if these differences can be reconciled.

Another thought which occurred to me - which you are free to disregard is the advisability of trying to reach the claimants at the source; before they are scattered all over the globe and subject to the blandishments of "machers" [sic] or others. You might wish to consider opening an office in Moscow to which emigrants could turn before they leave the country. Such an office, staffed by knowledgeable Soviet citizens who would serve as representatives of the CC (and, I would suggest, the FRG) could dispose of cases on the spot. If additional evidence is required, it can more readily be obtained. I feel it would be quicker, cheaper and a more effective means of getting help to the claimants when they are most in need. I know it's a shocking idea but think about it.

We will talk about other URO problems after I have completed my study. I'll call you after I'm back from Florida.

Happy Valentine’s Day.

PS: In 1990 , it cost the URO about $\$ 75,000$ total to handle the HF claims, which produced URO income of about $\$ 90,000$.

103 Claims Conference Hardship Fund.

104 Lilly Rosenbaum war langjährige Mitarbeiterin des URO-Büros in New York. 


\section{Dokument 162}

Benjamin B. Ferencz an Werner Wolff

Ohne Ortsangabe, 4. Januar 1993

Maschinenschriftlicher Brief, 1 Seite; handschriftliche Korrekturen

$R G 12.007 .01 * 16$

PERSONAL

Jan. 4, 1993

My dear Werner:

The attached letter is for the record. But I feel I owe you more than simply saying: "So sorry" in response to your warm and moving letter of Sept. 21. I would not like you to have the feeling that I have let you down. I cherish your friendship and have the greatest respect and affection for you so I feel I must share with you some of the considerations which I did not think necessary or appropriate in a letter intended for the files. I know you did not want your present job and I feel some guilt for sticking you with it, but I'm afraid I can not help you any more.

You wr\{o\}te: "No father can leave his child in the lurch when it needs him." The URO is no longer a child. It is an old man and \{time for $\}$ the father is even older $\{$ to let it go\}. What now passes for URO is an adopted child of quite uncertain paternity. As you know, I was ready to help close down the organization and leave\{transfer\} its residual responsibilities to new and younger hands which would be available to complete the job in the distant future. That did not prove acceptable. Instead, URO embarked in directions which I felt I could not embrace. I remember when our only goal was to help poor claimants who could not help themselves - an objective I could support with enthusiasm. What I see as URO's future is an organization competing to grab clients in order to gain enough profit to keep its bureaucracy going. Where the clients are the poorest of the poor - who are entitled to receive assistance free of charge \#\# my enthusiasm \{for the job\} disappears. I have lost all respect for the Jewish organizations which are the self-declared \{spokesmen\} of the Jewish people. Surely it should have been possible to create a section of some existing \{social\} agency to help new immigrants with their hardship and double-hardship claims. This is not a legal function nor one for which the old URO is qualified. I do not believe for a moment that URO is needed to help needy people with property claims in the former GDR. I fear that the Claims Conference will sink in the morass it is creating for itself. It all makes me so unhappy that I don't want to see it. I want to be completely removed from all 
of it. I hope I am wrong and that my child will live and be well and happy. But I shall be happier if I consider my job done and wish all of those who come after me the very best of luck.

I look forward to seeing you in Frankfurt, where you can also cry on MY shoulder. That is an offer that remains oppen to you at any time you feel it can be helpful.

Warmest greetings, in which Gertrude joins,

$\{$ Ben $\}$ 
9. Weltfrieden und internationale Strafjustiz 



\section{Dokument 163}

Benjamin B. Ferencz an The Foundation for the Establishment of an International Criminal Court ${ }^{1}$

Ohne Ortsangabe, 18. Juni 1970

Maschinenschriftlicher Brief, 1 Seite

$R G 12.013 .01{ }^{*} 02$

June 18, 1970

The Foundation for the Establishment of an International Criminal Court, Inc. 9171 Wilshire Boulevard

Beverly Hills, Calif.

\section{Gentleman:}

The June 1970 letter to members of the American Society of International Law announced the establishment of your Foundation. I was formerly a prosecutor at the Nuremberg War Crimes Trials and deeply involved in the concept of crimes against humanity and the functioning of an international criminal court. I am now renewing my interest in this area and will be devoting an increasing amount of time to the problems connected with the definition of aggression with a view toward helping in the establishment of international penal jurisdiction on matters of war and peace.

In this regard, I have recently been at the European Court of Human Rights in Strasbourg and the Rene Cassin Foundation which is located there. I shall also be attending the U.N. meetings in Geneva next month which will be dealing with the definition of aggression.

I will be very grateful for any information which you may have about the present or planned activities of your Foundation and I hope that we may be able to work out some effective collaboration.

Sincerely yours,

Benjamin B. Ferencz

1 Die Foundation for the Establishment of an International Criminal Court wurde 1970 in Los Angeles auf Initiative von Robert Kurt Woetzel gegründet. 
\{reply from Robert Woetzel, ${ }^{2} \mathrm{P} \#$ \# on $\left.7 / 17\right\}$

BBF: js

\section{Dokument 164}

Benjamin B. Ferencz an Sheila M. Woetzel ${ }^{3}$

Ohne Ortsangabe, 1. Februar 1971

Maschinenschriftlicher Brief, 2 Seiten; gedruckte Kopfzeile aufSeite 1, Kopfzeile auf Seite 2 (gedruckt: »TAYLOR, SCOLL, FERENCZ \& SIMON «, maschinenschriftlich: »Mrs. Sheila M. Woetzel 2/1/71«)

$R G 12.013 .01 * 02$

Mrs. Sheila M. Woetzel

Projects Coordinator

Foundation for the Establishment of an International Criminal Court

286 Central Street

Auburndale, Mass. 02166

Dear Mrs. Woetzel:

Thank you for your letter of the 18th and the enclosures. I was sorry to hear that the Fort [sic] Foundation ${ }^{4}$ has apparently come back with an unfavorable response, - but I am not surprised. The request seemed to me to be much too modest for the usual Ford dimension. Perhaps you will have better luck with Lake Como. $^{5}$

2 Robert Kurt Woetzel (1930-1991) war Professor für Internationales Recht und publizierte zahlreiche Bücher in diesem Themenbereich, u. a. zu den Nürnberger Prozessen. Darüber hinaus war er Vorsitzender der Foundation for the Establishment of an International Criminal Court.

3 Sheila M. Woetzel (geb. Barry) war Projektkoordinatorin in der von Robert Woetzel gegründeten Stiftung und ab 1975 in verschiedenen Positionen für UNICEF tätig.

4 Die Ford Foundation wurde 1936 gegründet und dient der Förderung von Wissenschaft, Bildung und Wohlfahrt.

5 Gemeint ist vermutlich das Bellagio Center in der Villa Serbelloni am Comer See, wo die Rockefeller Foundation seit 1959 Programme und Veranstaltungen fördert, die der internationalen Verständigung dienen. 
In the light of your letter I have taken no action toward opening a bank account in New York, for which the incorporation papers might have been required. The absence of an account will cramp our style a bit since I was eager to start functioning as a regular office, with name, account, stationery, phone etc. I would much prefer to do it that way than to be appearing to be running it out of my vest pocket.

As I did not wish to burden the Foundation with any costs, I also had in mind to obtain from other sources the funds needed to cover the New York operations. I doubt whether I can obtain contributions for the general Foundation purposes, since the contributors would be largely motivated by my own assurance that I would supervise the disbursement of funds donated at my request.

I did not detect anything in the incorporation papers which would prevent the opening of a New York bank account for the maintenance of the New York office - particularly since it is clear that its activities would be solely in furtherance of the Foundation's stated purposes and there would be no liability or obligation whatsoever on the part of the Foundation or its Directors. If Robert ${ }^{6}$ still feels that we should wait for the Board to decide this question next summer, we will simply have to wait.

|2| In order to be accepted as a non-governmental organization at the U.N. it will be necessary to complete the attached questionnaire. You may list me as the Representative in Question 4 and give my New York address and phone number as the address. Learning from you and Robert, you may list my wife Gertrude Ferencz as the alternative representative - at least for the time being. I would suggest in Question 12 that you indicate some interest in the Definition of Aggression on which, as you probably know, a Special Committee is now working. I hope to be able to attend most of their sessions as I did last summer in Geneva. Please sign the copies and return both of them to me. I will then sign as the New York representative and submit the papers to the appropriate UN office where I hope for early action.

I am looking forward to hearing from Robert in the proposed work of the Committee and to receiving some of the draft materials he already has. I very much doubt whether it will be possible to have anything ready for consideration by mid-February as we had planned. There have just been too many things crowding in on me which I had hoped would quietly go away. But one of these days we will be able to settle down to establishing an international court, or world peace, or something easy like that! 
I hope you and Robert will be in New York again soon, so that we may discuss some of the problems together in greater detail.

Sincerely

Benjamin B. Ferencz

BBF: rkl

Enc.

\section{Dokument 165}

Benjamin B. Ferencz an Harold E. Hughes

Ohne Ortsangabe, 5. April 1971

Maschinenschriftlicher Brief, 1 Seite; handschriftliche Notiz am unteren Seitenrand $R G 12.014 .03^{*} 02$

April 5, 1971.

Senator Harold E. Hughes

United States Senate

Washington, D. C.

Dear Senator Hughes:

An article in The New York Times this morning quoted you as saying that you would propose "The creation of an international commission of leading jurists to set standards for assessing blame when innocent civilians are killed in a war". ${ }^{8}$ I think your idea is splendid.

I was formerly Executive Counsel at the Nurnberg [sic] war crimes trials and am Chairman of a sub-committee of the American Society of International Law dealing with related problems.

7 Harold E. Hughes (1922-1996) war ein amerikanischer Politiker der Demokratischen Partei. Von 1963 bis 1969 war er Gouverneur von Iowa, bevor er diesen Bundesstaat von 1969 bis 1975 im Senat vertrat.

8 Anonymus, Hughes to Propose Panel to Fix War Crimes Blame, in: The New York Times, 5. April 1971, 12. 
I would very much appreciate being kept advised of any action you may take in this area, and if I can be of any help to either you or your staff, please do not hesitate to call upon me.

Sincerely yours

Benjamin B. Ferencz

$\left\{9^{30} \mathrm{AM}\right.$

4/9/71 - I received a call from Charles Stevenson ${ }^{9}$ of Hughes Staff: (207) 225-3755. Senator is writing an op. ed. for N. Y. Times - deadline tonight. Also needs a Senate resolution by next week. Wants to know what to propose. What kind of international group, what new standards are needed, if any. (See 1949 Geneva Conventions + U.N. Resolution $\# 6^{10}$ ) to diminish civilian casualties. I told him to che̊ck the op. e̊d. + call me back at $2 \mathrm{pm}$. I suggested he may pose the publicaatioon + not try to set billi [to] the̊ definitive solutions - Crime \#\#\#\#\# see attached.\}

BBF: rkl

\section{Dokument 166}

Benjamin B. Ferencz an The New York Times

New York, 18. Juni 1971

Gedruckter Zeitungsausschnitt (Leserbrief), ${ }^{11} 1$ Seite

$R G 12.013 .01^{\star} 02$

The New York Times

Friday, June 18, 1971

Letters to the Editor

9 Charles A. Stevenson war seit 1970 Mitarbeiter und Berater verschiedener Senatoren, zunächst von Harold E. Hughes. Zudem arbeitete er als Universitätsdozent.

10 Die Raute steht an dieser Stelle als Nummernzeichen.

11 Benjamin B. Ferencz, Comment on Pentagon Study, in: The New York Times, 18. Juni 1971, 38. 


\section{Comment on Pentagon Study}

\section{To the Editor}

The Pentagon Study of the Vietnam War (June 13) is a disclosure of Machiavellian duplicity. ${ }^{12}$ We have sent our young people to die in battle, we have devastated vast areas and we have slaughtered countless civilians on the pretense that we were defending allies from aggression. The record now seems clear that we betrayed our ideals as we arrogantly applied our power to further our political goals.

U.S. Secretary of State Frank Kellogg ${ }^{13}$ gave his name to the 1928 pact outlawing war as an instrument of national policy. ${ }^{14}$ The U.N. Charter required all governments to refrain from the threat or use of force against the territorial integrity or political independence of any state. ${ }^{15}$ At the Geneva Conference in 1954, the U.S. emphatically reaffirmed that peoples are entitled to determine their own future. ${ }^{16}$ The U.S. defined aggression to include the use of force, overt or covert, against the political independence of any other state or interference with the affairs of another state.

The study shows that our motivation and policy was to avoid Communist control of South Vietnam at all costs and to demonstrate our ability to have our way in world affairs. We opposed a compromise settlement between the Vietnamese themselves. We opposed neutralization. We opposed any Vietnam conference. We engaged in sabotage, covert operations, bombardment

121971 veröffentlichte The New York Times Teile der sogenannten Pentagon-Papiere, ein geheimes Dokument des Verteidigungsministeriums. Damit bewies die Zeitung, dass die Regierung der Vereinigten Staaten die amerikanische Öffentlichkeit vorsätzlich über die Gründe des Vietnamkriegs getäuscht hatte.

13 Frank B. Kellog (1856-1937) war unter Präsident Calvin Coolidge von 1925 bis 1929 Außenminister der Vereinigten Staaten.

14 Am 27. August 1928 unterzeichneten elf Nationen den Briand-Kellogg-Pakt, der Kriege völkerrechtlich ächtete.

15 Siehe Artikel 2 Absatz 4 der am 24. Oktober 1945 ratifizierten Charta der Vereinten Nationen, die zuvor Vertreter von 50 Nationen auf der Konferenz von San Francisco verabschiedet hatten: »All Members shall refrain in their international relations from the threat or use of force against the territorial integrity or political independence of any state, or in any other manner inconsistent with the Purposes of the United Nations."

161954 fand in Genf eine Konferenz über den Indochinakrieg und den Koreakrieg statt, an der neben Frankreich und den Vietminh auch Großbritannien, die Sowjetunion, die Vereinigten Staaten und die Volksrepublik China teilnahmen. 
of North Vietnam, and sent emissaries to threaten unlimited armed attack to achieve our national aims.

Vietnamese forces under our command provoked counterattacks which we then used as a pretext for assaults which we called reprisals. The President obtained unrestricted power at a time when we were already ignoring the humanitarian requirements of proportionality. The Congress and the public were systematically misled.

The saddest mistake America made was to try to use military might as a substitute for the rule of law. We relied on the patterns of past history and failed to recognize the hopes of the future. Only when nations are tolerant enough to accept divergent systems and wise enough to build international institutions with authority to resolve disputes will we find enduring peace.

Benjamin B. Ferencz

Former Executive Counsel

Nuremberg War Crimes Trials

New York, June 13, 1971

\section{Dokument 167}

Benjamin B. Ferencz an Andrew F. Loomis, ${ }^{17}$ Bruce Rabb, ${ }^{18}$ Don Harkleroad ${ }^{19}$ und Hope Eastman ${ }^{20}$

Ohne Ortsangabe, 11. August 1971

Maschinenschriftliches Memorandum, 2 Seiten; Kopfzeile aufSeite 2 (»CONFIDENTIAL MEMO (Continued) «)

$R G 12.014 .03^{*} 02$

17 Andrew F. Loomis war ein amerikanischer Jurist. Er engagierte sich zu Beginn der 1970er Jahre in der American Society for International Law (ASIL) und wirkte in dem Panel »International Human Rights Law and its Implementation« der Organisation.

18 Der Jurist Bruce Rabb $\left({ }^{\star} 1941\right)$ war von 1969 bis 1970 Mitarbeiter des amerikanischen Presidenten Richard Nixon. Zudem fungierte er als Rechtsberater für gemeinnützige Organisationen und war seit 1980 in verschiedenen Funktionen für Human Rights Watch tätig.

$19 \mathrm{Zu}$ dieser Person konnten keine biografischen Informationen ermittelt werden.

20 Die Rechtsanwältin Hope Eastman war in den 1970er Jahren für die American Civil Liberties Union tätig, engagierte sich in der ASIL und wirkte in deren Panel »International Human Rights Law and its Implementation« mit. Anschließend spezialisierte sie sich auf Arbeitsrecht. 
August 11, 1971

\section{CONFIDENTAL MEMO}

TO: $\quad$ Andrew F. Loomis, Esq.

Shoarman \& Sterling

53 Wall Street

New York, N. Y. 10005

Bruce Rabb, Esq.

Strook \& Lavan

61 Broadway

New York, N. Y.
Don Harkleroad, Esq.

Simpson, Thatcher \& Bartlett

1 Battery Park Place

New York, N. Y.

Hope Eastman

American Civil Liberties Union

1424 - 16th St. N.W. Suite 501

Washington, D. C. 20036

I trust that all of you have been having a pleasant summer and that you will not allow it to be disrupted by the present memo.

You will recall that at our luncheon meeting on June 14th, we considered the possibility of bringing a civil suit against Lieut. Calley and all of his superiors for compensation to the My Lai victims. ${ }^{21}$ The primary objective would be to emphasize and draw public attention to the fact that there may be personal financial responsibility for human rights violations, and that the Human Rights Conventions provide for compensation as one of the rights of the victim. This would also be in line with the latest direction indicated by the Chairman of the ASIL Panel on the Human Rights Implementation ${ }^{22}$ that we try to concentrate on test cases as a specific technique for emphasizing various human rights points. Our initial thrust of surveying what is being done to implement human rights in armed conflicts has accordingly been somewhat deflected, and my new suggestion was an attempt to comply with "superior orders" - which as you know, is no defense.

Hope had volunteered to check with some contacts on TIME Magazine and elsewhere, to ascertain the names of the Calley victims and whether com-

21 Gemeint ist das Massaker im südvietnamesischen My Lai, wo amerikanische Soldaten während des Vietnamkriegs am 16. März 1968 etwa 500 Zivilisten töteten. Der Offizier der US-Army William Laws Calley jr. $\left({ }^{*} 1943\right)$ hatte das Kommando über die Einheit inne, die das Massaker verübte. 1971 wurde er dafür zu lebenslanger Haft verurteilt. Präsident Nixon wandelte die Haftstrafe einen Tag nach dem Urteil in Hausarrest um und begnadigte Calley 1974. Siehe dazu auch die Einleitung, $69 \mathrm{f}$.

22 Gemeint ist das Panel »International Human Rights Law and its Implementation«, dessen Vorsitzender in der ersten Hälfte der 1970er Jahre der Völkerrechtler Frank C. Newman war. 
pensation had been granted by the U.S. Don and Bruce, and possibly Andy indicated some interest in checking out the question of which court would have jurisdiction. I would work on the theory of responsibility, the measure of damages, and the invalidity of any waiver which might have been signed.

While in Strasbourg in July, I had occasion to discuss the subject briefly with Frank Newman ${ }^{23}$ and Tom Buergenthal. ${ }^{24}$ Both seemed to find the idea exciting, and Tom volunteered some help in some of the jurisdictional problems. Having heard nothing further from anyone, I hereby do petition that if anyone has done anything more than indicated above, [|2|] to please transmit the fruits of his or her labor, or such other comments or suggestions as may be deemed appropriate.

After the passage of a respectable interval, I shall then be in touch with you again about further steps to be taken.

And so back to the swimming pool.

With warm regards

$\{$ Ben $\}$

Benjamin B. Ferencz

Info copy to: $[\ldots]^{25}$

23 Frank C. Newman (1917-1996) lehrte als Professor für Internationales Recht an der University of California in Berkeley und engagierte sich im Bereich der Menschenrechte und ihrer Durchsetzung. Darüber hinaus war er zwischen 1977 und 1982 Richter am Supreme Court von Kalifornien.

24 Thomas Buergenthal $\left({ }^{*} 1934\right)$ überlebte als Kind den Holocaust und wanderte 1951 in die Vereinigten Staaten aus. Ab 1962 lehrte er als Professor für Rechtswissenschaft bzw. für Internationales Recht und Menschenrechte an verschiedenen amerikanischen Universitäten. Er wirkte an der Gründung des Interamerikanischen Gerichtshofs für Menschenrechte mit, an dem er von 1979 bis 1991 als Richter tätig war. Zwischen 1995 und 1999 gehörte er dem Menschenrechtsausschuss der Vereinten Nationen an. Von 2000 bis 2010 war Buergenthal Richter am Internationalen Strafgerichtshof.

25 Hier folgen die Adressen von Frank C. Newman, Thomas Buergenthal, Gideon Gottlieb, Edward Weisband und John Lawrence Hargrove. 


\section{Dokument 168}

Benjamin B. Ferencz an Ved P. Nanda ${ }^{26}$

Ohne Ortsangabe, 22. September 1971

Maschinenschriftlicher Brief, 1 Seite

$R G 12.013 .01 * 06$

22 Sept. 1971

Professor Ved P. Nanda

200 West 14th Ave.

Denver, Colo. 80204

Dear Ved:

Having returned to my desk, I just wanted to let you know how much I enjoyed meeting you and working with you at Wingspread. I don't know when there will be an International Criminal Court, but it was fun sharing thoughts and ideas even if the net effect of our initial efforts was simply to get rid of our (definitions of) aggressions.

My perceptive spouse pointed out that it's cold in Denver during the early part of the year and I must confess that this dampened some of my enthusiasm for a visit at that time. If I do manage to pass through there, I will surely advise you in good time so that we may consider the feasibility of a lecture to some of the law students while I am there. (A topic which comes to mind at the moment is Nurnberg [sic] - Past, Present and Future - to explain what it was about, how it relates to Vietnam, Calley, etc., and the hopes for a permanent court for international crimes.)

In any case I look forward to seeing you again and I do hope that we will continue to remain in touch.

Sincerely

Benjamin B. Ferencz

BBF: rkl

26 Ved P. Nanda ( $\left.{ }^{\star} 1934\right)$ lehrte seit 1965 Rechtswissenschaft an der Denver University und trug in den folgenden Jahrzehnten maßgeblich zur Weiterentwicklung des internationalen Rechts bei. Er leitet das 2006 gegründete Ved Nanda Center for International and Comparative Law. 


\section{Dokument 169}

Benjamin B. Ferencz an Hope Eastman

Ohne Ortsangabe, 22. November 1971

Maschinenschriftlicher Brief, 2 Seiten; Kopfzeile auf Seite 2 (»Miss Hope Eastman $11 / 22 / 71$ «)

$R G 12.014 .03^{*} 02$

Nov. 22, 1971

Miss Hope Eastman

Acting Director

A.C.L.U. ${ }^{27}$

$1464-16$ th St. N. W. Suite 501

Washington, D. C. 20036

\section{Dear Hope!}

"Never give up hope" say I! Your letter of Nov. 10th was received upon my return from Europe and I was pleased to see that you have not forsaken. Thank you very much for the pleadings in the civil action against Calley et al. As you will see from the attached copy of my letter to Frank Newman of Oct. 18th - (which I had expected would be circulated and therefore sent you no copy) the Pentagon had already sent me some of the papers. I did not however have the content of the motions, so your effort has not been in vain, and is much appreciated. My general thoughts were contained in the paper I submitted in Compensating Victims, ${ }^{28}$ etc., which I suppose you have received.

The only point which concerns me in the dismissed case is the statute of limitations argument. I don't know whether the United States would raise such a "tainted" argument, which in Europe at least is not considered very honorable. I notice that it was not raised by the Assistant U.S. Attorney. We would also have to explore further whether the Statute is not tolled while the defendant is out of the country in which the offense was committed, or during

27 Die American Civil Liberties Union ist eine amerikanische Bürgerrechtsorganisation. 1920 wurde sie mit dem Ziel gegründet, das Recht auf freie Meinungsäußerung des Einzelnen gegen staatliche Einschränkungen zu schützen. Während des Vietnamkriegs vertrat sie zahlreiche Wehrdienstverweigerer und Kriegsgegner.

28 Ferencz, Compensating Victims of the Crimes of War. 
the period when the plaintiff could not know the identity of the defendant. Other arguments against applicability of the Statute should also be sought.

I was particularly interested in your indication that no compensation of any kind has been paid to any of the victims. The pleadings refer to an Exh. $\mathrm{A}^{29}$ of the complaint which presumably is a list of the My Lai survivors. Can you lay hands on that? I suppose if I asked the Pentagon for it, I could get it, but I'm not too eager to press them further at this stage.

I now understand from the papers you sent me why I couldn't reach the Plaintiff's attorney in Amsterdam. It looks like he skipped to Idaho and I don't suppose he can really add much to our knowledge. I am bit fascinated though by his reference to "the Chau Kin Dinh, I. D. Card Number 02779308 of the Saigon Republic of Viet Nam as translator for the Vietnamese witnesses". I wonder what he knows?

|2| Should you hear anything from the State Department about the names of the victims, please let me know. One Pentagon bird whom I met at a meeting told me that the bodies had never been identified, and that the Calley trial had simply referred to the killing of 22 unidentified Asiatics or something like that. It made me so damn mad that I made a special point of identification in my paper.

I'm waiting to see what kind of a feed-back if any I get on my observations. The absence of a plaintiff removes some of the urgency. If you have any further thoughts, please let me know.

With warm regards, Sincerely

Benjamin B. Ferencz

c.c. Frank Newman

Tom Buergenthal

J. L. Hargrove ${ }^{30}$

BBF; rkl

Enc.

29 Exhibit A.

30 John Lawrence (Larry) Hargrove war ein amerikanischer Jurist, bis 1992 geschäftsführender Direktor der ASIL und bis 1994 deren Director of Studies. 


\section{Dokument 170}

Benjamin B. Ferencz an Edward M. Kennedy

Ohne Ortsangabe, 1. Mai 1972

Maschinenschriftlicher Brief, 1 Seite

$R G 12.014 .03^{\star} 02$

May 1, 1972

Hon. Edward M. Kennedy

Senator from Massachussetts [sic]

United States Senate

Washington, D. C.

Dear Senator Kennedy:

I enjoyed hearing your address at the American Society of International Law, and the lively meeting at what is frequently normally a rather stodgy gathering of that learned society.

You will be pleased to know that during the following days several persons thanked me for having drawn their attention to your article in the April issue of the VIRGINIA JOURNAL OF INTERNATIONAL LAW, ${ }^{31}$ where they had an opportunity to consider your views in International Humanitarian Assistance in greater detail.

The same issue also carried an article of mine on COMPENSATING VICTIMS OF THE CRIMES OF WAR which I think complements and supplements your own views. I have also recently submitted an outline to the New York representative of the Bangladesh Government enumerating the problems they would have to face and resolve in connection with the reported war crimes trials being planned in that country. ${ }^{32}$

Should you be further involved in any of these problems, I would be very pleased to be of assistance. It has been some time since I had the pleasure of

31 Edward M. Kennedy, International Humanitarian Assistance: Proposals For Action, in: Virginia Journal of International Law 12 (1972), H. 3, 299-308.

32 Ferencz bezieht sich auf die Pläne in Bangladesch, pakistanische Militärs in Kriegsgefangenschaft vor Gericht zu stellen, die während des Bangladesch-Kriegs von 1971 an Kriegsverbrechen beteiligt waren. 
working with you, Jim Flug ${ }^{33}$ and Mark Schneider ${ }^{34}$ on the amendment of the War Claims Bill for all of the Churches and Charities, ${ }^{35}$ and I would welcome an opportunity to show my appreciation for all of your help at that time.

If I can be of service in any of the above areas, please feel free to contact me at any time. With warm regards,

Sincerely yours

Benjamin B. Ferencz

BBF: rkl

\section{Dokument 171}

Benjamin B. Ferencz an World Magazine

Ohne Ortsangabe, 13. September 1972

Maschinenschriftlicher Leserbrief, 1 Seite

$R G 12.015^{\star} 08$

September 13, 1972

Norman Cousins, President

World Magazine Inc.

488 Madison Ave. New York 10022

Dear Norman:

I've been enjoying the new World and renew my congratulations and best wishes. I hope the following will prove suitable for your "Letters from Readers".

All the best,

33 Der Jurist und Politikberater James F. Flug war von 1967 bis 1973 Mitarbeiter und Berater von Senator Edward M. Kennedy.

34 Mark L. Schneider $\left({ }^{\star} 1941\right)$ war von 1970 bis 1977 Mitarbeiter von Edward M. Kennedy und 1999 bis 2001 Direktor von Peace Corps.

35 Siehe dazu Dokument 102. 
Brave to World and William Korey for spotlighting our shameful failure to ratify the Genocide Convention, ("On Banning Genocide", September 26). ${ }^{36}$ Ratification will not eliminate either the crime or its causes, but it will indicate our abhorrence of the offense and our willingness to endorse certain international standards prohibiting criminal conduct.

Genocide, like aggression, terrorism, drug traffic, and crimes against humanity, feeds on the outdated concept that states must remain free to determine for themselves the limits of permissible behavior. Until international anarchy yields to an international tribunal with authority and power to resolve internecine disputes there can be no permanent peace. It is high time that we all began [sic] to move toward a more humane and rational world order.

Benjamin B. Ferencz

Former Executive Counsel

Nuremberg War Crimes Trials

\section{Dokument 172}

Benjamin B. Ferencz an das Verteidigungsministerium der Vereinigten Staaten von Amerika

Ohne Ortsangabe, 1. April 1974

Maschinenschriftlicher Brief, 1 Seite

$R G 12.014 .06^{\star} 02$

1 April 1974

Department of the Army

HQDA (DAJA-LTT) ${ }^{37}$

Wash $^{38}$ D. C. 20310

36 William Korey, On Banning Genocide: >We Should Have Been the First‘, in: World Magazine, 26. September 1972, 28-32.

37 Es handelt sich hierbei um ein Kürzel aus dem Code of Federal Regulations (CFR). In den Bundesverordnungen werden unter dieser Chiffre Rechtsstreitigkeiten zu medizinischer Fürsorge und Eigentumsansprüchen geregelt.

38 Washington. 
Gentlemen:

As a member of the American Branch of the International Association of Penal Law I am presently engaged in a study dealing with the problems of compensating victims of various international crimes. For some years the United Nations has been considering the problem of compensating victims of crimes against humanity and war crimes, and this too forms part of my own study.

One of the questions which has arisen relates to the compensation which the United States government may have provided to persons in Vietnam who may have been victims of illegal acts, such as those civilians who were killed at My Lai.

I would therefore be very grateful if you could provide me with whatever information is available which might shed some light on U.S. practices and policies in this area. Specifically I would like to know whether the U.S. has ever paid compensation, and if so, on what basis was the amount determined, and what, if any general principles have been formulated to deal with similar situations. If your reply could be coordinated with the State Department and any other governmental departments which may be involved with this question it would be much appreciated.

Very truly yours,

Benjamin B. Ferencz

\section{Dokument 173}

Benjamin B. Ferencz an Charles S. Rhyne $e^{39}$

New York, 3. März 1975

Maschinenschriftlicher Brief, 1 Seite; gedruckter Briefkopf mit maschinenschriftlich eingefügtem Datum

$R G 12.013 .01 * 23$

39 Der Rechtsanwalt Charles S. Rhyne (1912-2003) war 1957 bis 1958 Präsident der amerikanischen Anwaltskammer und initiierte 1963 die Gründung des World Peace Through Law Center, das er in der Folge bis 1991 als Präsident leitete. Zwischen 1971 und 1973 war er unter US-Präsident Nixon Sonderbotschafter der Vereinigten Staaten beim Hohen Flüchtlingskommissar der Vereinten Nationen. 


\section{Taylor, Ferencz \& Simon \\ Counselors at LaW}

Telford Taylor

of Counsel

Benjamin B. Ferencz

Kenneth Simon
LinCOLN BUILDING

60 EAST 42ND STREET

New York, N. Y. 10017

***

MO 1-0934

Charles S. Rhyne, President

World Peace Through Law Center ${ }^{40}$

400 Hill Building

Washington D.C. 20006

Dear Mr. Rhyne:

The latest issue of The World Jurist reports on the U.N. adoption of the definition of aggression and conclusion that the definition of aggression should be an interesting item of discussion next fall. At the same time I received your brochure on the forthcoming Conference and your urging that we send you our comments and suggestions.

For about the past 5 years I have been following the work of the Special Committee to Define Aggression ${ }^{41}$ and have been the only non-governmental observer to attend the sessions in New York and Geneva. I have written a number of scholarly articles on the subject which have appeared in the American Journal of International Law, the International and Comparative Law Quarterly, the Columbia Journal of Transnational Law and elsewhere. Oceana Press is publishing my 2-volume work "Defining International Aggression, the Search for World Peace - a Documentary History and Analysis", with an introduction by Professor Louis B. Sohn. ${ }^{42}$ It is expected to appear in May

40 Das World Peace Through Law Center (WPLC) ist eine Nichtregierungsorganisation, die sich als weltweites Forum für Juristen und Experten versteht, die sich der Stärkung völkerrechtlicher Prinzipien und Institutionen weltweit verschrieben haben. Sie wurde 1963 gegründet, 1991 in World Jurist Association umbenannt und besitzt einen beratenden Status im Wirtschafts- und Sozialrat der Vereinten Nationen.

41 Zur Entstehung des Special Committee on the Question of Defining Aggression der UN-Generalversammlung siehe Louis Sohn (Hg.), International Organization and Integration, Dordrecht u. a. 1986, 310.

42 Louis B. Sohn (1914-2006) war Professor für Internationales Recht. Er stammte aus Lemberg und emigrierte kurz vor Beginn des Zweiten Weltkriegs in die Vereinigten 
and analyzes the consensus definition accepted by the General Assembly in Dec. 1974.

From your preliminary agenda, it occurs to me that you might wish to include as a specific topic of discussions "The Consensus Definition of Aggression". It could appropriately be included as part of the Criminal Law Section or preceding a discussion on an International Criminal Court. Should you agree and wish me to assure responsibility for all or part of that discussion please let me know and further details can then be arranged with whoever is doing the detailed planning.

I look forward to hearing from you soon.

With all good wishes,

Benjamin B. Ferencz

\section{Dokument 174}

Benjamin B. Ferencz an Amelito R. Mutuc ${ }^{43}$

Ohne Ortsangabe, 28. Januar 1976

Maschinenschriftlicher Brief, 1 Seite

$R G 12.013 .01{ }^{\star} 24$

January 28, 1976

Amelito R. Mutuc, President

World Association of Lawyers of the World Peace Through Law Center ${ }^{44}$

Staaten. Seit 1941 war er an der Harvard-Universität tätig, von 1981 bis 1991 wirkte er zudem an der University of Georgia. Sohn war 1945 an der Ausarbeitung von Teilen der Charta der Vereinten Nationen beteiligt. Er setzte sich für die Entwicklung der Vereinten Nationen ein und war Verfechter von Menschenrechten und militärischer Abrüstung.

43 Der Rechtsanwalt und Politiker Amelito R. Mutuc ( $\left.{ }^{*} 1919\right)$ war von 1962 bis 1964 Botschafter der Philippinen in den Vereinigten Staaten. Zwischen 1975 und 1978 bekleidete er das Amt des Präsidenten der World Association of Layers.

44 Die World Association of Lawyers (WAL) wurde 1975 vom WPLC gegründet. Sie versteht sich als weltweite Vereinigung von Rechtsanwälten und widmet sich transnationalen juristischen Fragen. 
400 Hill Building

Washington, D. C. 20006

Dear Mr. Mutuc:

I am flattered and honored to be invited to become the Chairman of the Criminal Law Committee of the World Association of Lawyers. I am pleased to accept that designation and wish to extend to you my deep appreciation for your consideration and kindness.

There are several questions which immediately come to my mind and I hope that we will have an opportunity to meet personally in order to review them. I am in Washington from time to time and will be in touch with the World Peace through Law Center to ascertain your whereabouts or to go over the problems with Mr. Lockwood ${ }^{45}$ or whoever may be competent. I would, for example, like to know more about the techniques for cooperation and collaboration between the WAL and the World Association of Judges and Law Professors. I would also like to be more closely informed about the activities of the other groups.

I think it is only fair to warn you that I am now heavily engaged in writing a book on a subject not directly related to criminal law, and it is likely that the book will absorb most of my attention for at least the balance of this year. This will certainly affect the amount of time I will have available in the near future to launch the activities which you no doubt hope to see undertaken by the Criminal Law Committee. If you feel that this limitation makes it necessary or desirable for you to seek another Chairman, please let me know and you may be assured of my full understanding.

Within the limits of my other unavoidable obligations, I shall, of course, do my best to fulfill the responsibilities of the Committee Chairman. I hope I may look forward to our cordial and effective cooperation in helping advance the very laudable objectives of the World Peace Through Law Center.

Sincerely,

Benjamin B. Ferencz

P.S. Please continue to write to my home address: 14 Bayberry Lane, New Rochelle, N.Y. 10804

45 Der Rechtswissenschaftler Bert B. Lockwood arbeitete zwischen 1974 und 1976 für das WPLC. Seit 1980 ist er an der University of Cinncinatti tätig und zudem Direktor des dort angesiedelten Urban Morgan Institute for Human Rights. 


\section{Dokument 175}

Benjamin B. Ferencz an die argentinische Botschaft in Washington New York, 23. Dezember 1976

Maschinenschriftlicher Brief, 1 Seite; gedruckter Briefkopf mit handschriftlich eingefügtem Datum, handschriftliche Notiz am unteren Seitenrand $R G 12.015^{\star} 02$

\section{Taylor, Ferencz \& Simon \\ COUNSElors at LaW}

Telford TAYlor

OF COUNSEL

Benjamin B. Ferencz

KenNeth Simon
LINCOLN BUILDING

|December 23, 1976|

New York, N. Y. 10017

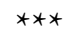

MO 1-0934

Argentine Embassy

Washington D.C.

1600 New Hampshire Ave. N.W.

Gentleman:

There have been public reports that Dr. Mario Gerado [sic] Yacub, ${ }^{46}$ President of the Association of Lawyers of Buenos Aires, has been arrested and is now imprisoned by the authorities of your government. I am unable to judge whether such reports are accurate or what may have prompted such action if it has been taken, but I feel impelled to write in order that your government may be informed about some reactions to the report.

I am Chairman of the Committee for an International Criminal Court of the World Association of Lawyers. The Association is affiliated to the World Peace Through Law Center which is honored to have among its members many Argentinian lawyers. We are therefore particularly concerned about any news regarding the fate of so prominent a lawyer as Dr. Yacub.

46 Der argentinische Rechtsanwalt Mario Gerardo Yacub $\left({ }^{*} 1939\right)$ hatte sich nach dem Militärputsch in Argentinien im März 1976 für politische Gefangene eingesetzt. Im November 1976 wurde er aus seiner Kanzlei in Buenos Aires entführt und gilt seither als vermisst. 
We would welcome any information you may be able to give us on this subject. We are confident that your government is mindful that the open administration of justice and respect for human rights can only enhance the reputation of Argentina in the eyes of the public throughout the world.

Sincerely,

\{Benjamin B. Ferencz $\}$

Benjamin B. Ferencz

$[\ldots]^{47}$

\section{Dokument 176}

Benjamin B. Ferencz an Hans-Heinrich Jescheck ${ }^{48}$

Ohne Ortsangabe, 29. Mai 1978

Maschinenschriftlicher Brief, 1 Seite; handschriftliche Notiz am unteren Seitenrand

$R G 12.013 .01 * 24$

Prof. Dr. Hans Heinrich Jescheck

May 29, 1978

Max Planck Institute $\{-$ (0671) 71058\}

Freibourg [sic] i. B., Gunterstalstrasse 72

Dear Prof. Jescheck:

It has been some time since we last met or corresponded regarding International Aggression, but I find that our paths may shortly cross again. I represent the Grand Duchess of Weimar-Saxony and Eisenach in a very interesting case

47 Am unteren Seitenrand folgt eine kurze und unleserliche handschriftliche Notiz.

48 Der deutsche Jurist Hans-Heinrich Jescheck (1915-2009) war Professor für deutsches und internationales Strafrecht an der Universität Freiburg. Ab 1954 leitete er das Universitätsinstitut für ausländisches und internationales Privatrecht, das 1966 als Max-Planck-Institut für ausländisches und internationales Strafrecht in die MaxPlanck-Gesellschaft aufgenommen wurde. Daneben war er u. a. Richter am Oberlandesgericht in Karlsruhe. 
pending in New York. ${ }^{49}$ She lives in Freiburg and I am planning to visit there sometime between June 22 and July 10th. If you should happen to be around during that period it would add to my pleasure if we could arrange to meet.

You may be interested to know that I have just agreed to write a new book on Anternational [sic] Criminal Court. The book will trace the development of the idea from the earliest days, through the League and up to the current position at the U.N. I propose to include all of the relevant documents, including the drafts for the composition of the court and the various conventions dealing with international crimes such as terrorism, genocide, war crimes, apartheid etc. The purpose of the book is to encourage the world's decision-makers to move toward the acceptance of a court rather than war as the means for settling disputes.

I am of course familiar with your own impressive writings in the field. If we can meet I would welcome it since we are both laboring in the same vineyard. I shall not trouble you now with a specific appointment, but I will take the liberty of phoning you when I arrive in Frankfurt around June 22nd. I hope that we can then arrange for a convenient meeting time.

I look forward to seeing you again.

With all good wishes, ${ }^{50}$

\{25 June - I called his home. He was out. An e̊ldereilyo lady suggested I call the Institute \#\#

26 June - I called. His secr. ${ }^{51}$ Frl. Köcher said he was in class + was leaving for vacation in Switzerland on 28 June till July 10. Suggested I call him at home again $4 \mathrm{pm}-(\theta 6710761) 73733$. I said I'd call there at 5.

I called + we agreed that we'd meet at the Institute \#\# $12^{50}$ on 27 June IT\#\}

49 Bei dem Prozess ging es um zwei Dürer-Portraits, die bei Kriegsende aus den Weimarer Kunstsammlungen in den Besitz eines US-Soldaten gelangt waren. Siehe dazu Kurt Siehr, 50 Jahre nach Entdeckung der Dürer-Portraits in New York - Zum Rechtsstreit »Kunstsammlungen zu Weimar v. Elicofon«, in: Matthias Weller/Nicolai B. Kemle/Thomas Dreier (Hg.), Kunst und Recht - Rückblick, Gegenwart und Zukunft. Tagungsband des Zehnten Heidelberger Kunstrechtstags am 21. und 22. Oktober 2016, Baden-Baden 2017, 103-128.

50 Unterschrift fehlt auf archivalischer Kopie.

51 Secretary. 


\section{Dokument 177}

Benjamin B. Ferencz an Robert Sand ${ }^{52}$

Ohne Ortsangabe, 2. Juni 1978

Maschinenschriftlicher Brief, 1 Seite

$R G 12.013 .01 * 24$

June 2, 1978

Robert Sand, Esq.

WPLC

1000 Connecticut Ave.

Washington DC 20036

\section{Dear Bob:}

I was pleased to note in the latest "Jurist"53 that you have made reference to an INTERNATIONAL CRIMINAL COURT and that it is one of the subjects tentatively suggested for the 1979 Conference program. Unfortunately I will not be able to attend the 1978 preparatory meetings in Madrid, but I am planning on attending the $197\{9\}$ Conference and would be willing to Chair a Panel on an International Criminal Court to deal with Terrorism and other International Crimes similar to what was done on Aggression, at the 1975 Conference in D.C. I would appreciate it if you would discuss this suggestion with Mr. Rhyne and let me know if it fits in with his plans.

I have heard from Prof. Schwarzenberg in Rome that he would like to deliver a paper about the political and juridical problems connected with the murder of Mr. Moro. ${ }^{54}$ I think that would work in very nicely with what I have in mind, but I shall defer any definitive response until I have heard from you.

Let me at the same time raise another problem which has been giving me some concern. There are a number of very distinguished professors and scholars who might be willing to participate in the work toward an International Criminal Court within the framework of the WPLC or the WAL, but

$52 \mathrm{Zu}$ der Person konnten keine biografischen Informationen ermittelt werden.

53 Wahrscheinlich bezieht sich Ferencz auf The World Jurist, das Mitteilungsblatt des WPLC und seit 1991 der World Jurist Association.

54 Aldo Moro (1916-1978), ein führender Politiker der Partei Democrazia Cristiana und ehemaliger Ministerpräsident Italiens, wurde 1978 von den Roten Brigaden entführt und ermordet. 
I fear that there will be some inhibition because of the expenses involved by way of membership fees, registration fees, travel expenses etc. Frankly I am also reluctant to approach them and at the same time ask them to accept such burden. I am mindful of the costs involved in carrying on the work of the WPLC but the loss of serious talent because of the costs may not really be in the interest of either the work or the agency.

Please let me know to what extent, if any, there are the equivalents of "scholarships" or other funding possibilities. I have in mind specifically extending invitations to Prof. Hans Jescheck of the Max Planck Institute in Freiburg and Prof. Röling ${ }^{55}$ of Groningen but I would not do so until I knew that funding would be available should it be required. I would appreciate hearing from you on this before the 17th as I shall be leaving for Europe for a few weeks.

Best regards ${ }^{56}$

\section{Dokument 178}

Benjamin B. Ferencz an M. Cherif Bassiouni ${ }^{57}$

Ohne Ortsangabe, 12. September 1978

Maschinenschriftlicher Brief, 1 Seite

$R G 12.013 .01 * 03$

Prof. M. Cherif Bassiouni

DePaul University

25 E. Jackson Boulevard

Chicago, Ill. 60604

55 Bert Röling (1906-1985) war ab 1949 Professor für Strafrecht und Kriminologie in Groningen und Mitglied der niederländischen Delegation bei den Vereinten Nationen. 1957 wurde seine Professur um einen Schwerpunkt im Bereich Völkerrecht erweitert.

56 Unterschrift fehlt auf archivalischer Kopie.

57 M. Cherif Bassiouni (1937-2017) war von 1964 bis 2009 Professor für Rechtswissenschaft an der DePaul University in Chicago und Gründungsmitglied des dortigen International Human Rights Law Institute. Er war ein führender Experte für internationales Strafrecht und Menschenrechte und arbeitete als Berater für die Vereinten Nationen in verschiedenen Kommissionen. Zudem war er Mitglied des Vorbereitungskomitees für den Internationalen Strafgerichtshof. 
Dear Cherif:

The latest newsletter of the International Association of Penal Law encourages me to write to its distinguished Secretary-General on a matter which I know is of common concern. I see that you have organized a committee to draft an International Criminal Code and you may therefore be interested in some of my latest endeavors in a related area.

I have just completed a book, on a completely different subject, ${ }^{58}$ which the Harvard University Press will publish some time next year and I have started a new book for Oceana, which published my book on Defining International Aggression. The new book will also be a historical analysis and collection of documents dealing with An International Court for Transatlantic Crimes. ${ }^{59}$ It will trace the efforts to create an international criminal court from the Post-World-War I period until today, and will of course, make use of the studies referred to by you and Vad [sic] Nanda. The connection between an International Criminal Code and an International Criminal Court is obvious, and it seemed to me therefore that it would certainly be worth including whatever new material will arise as a consequence of your recent efforts.

You undoubtedly know that the upcoming session of the General Assembly has included (as the last item) on its provisional agenda a Draft Code of Offenses Against the Peace and Security of Mankind ${ }^{60}$ You may want to circularize all of the members of the Association to urge them to support some constructive action by the Assembly. I'm not quite clear in my own mind whether the item should best be referred to a Special Committee, to the Sixth Committee or to the International Law Commission with a request that it be given urgent consideration. I'm inclined to favor them in that order but if no one gets behind it I fear it will simply be deferred or tabled indefinitely as untimely. You may want to think about it.

58 Ferencz, Less Than Slaves.

59 Beim ersten Buch handelt es sich um Defining International Aggression. Anschließend bezieht sich Ferencz wahrscheinlich auf den zweiten Teil seiner Weltfriedenstrilogie, der 1980 unter dem Titel An International Criminal Court erschien.

601978 bat die Generalversammlung der Vereinten Nationen ihre Mitgliedstaaten und die zuständigen Organisationen um eine Stellungnahme zum Draft Code of Offences Against the Peace and Security of Mankind und einen Bericht für die Generalversammlung. Siehe United Nations General Assembly, A/RES/33/97, Draft Code of Offences Against the Peace and Security of Mankind, New York, 16. Dezember 1978 sowie Benjamin B. Ferencz, The Draft Code of Offences Against the Peace and Security of Mankind, in: American Journal of International Law 75 (1981), H. 3, 674-679. 
In any case let us keep in touch. Please send me whatever you think I ought to have and I will try to do the same.

With best regards,

Cordially, ${ }^{61}$

\section{Dokument 179}

Benjamin B. Ferencz an M. Cherif Bassiouni

Ohne Ortsangabe, 1. Oktober 1978

Maschinenschriftlicher Brief, 1 Seite

$R G 12.013 .01{ }^{*} 03$

Okt. 1,1978

Prof. M. Cherif Bassiouni

DePaul University

25 E. Jackson Blvd.

Chicago, Ill. 60604

Dear Cherif:

Thank you for your letter of Sept. 19th and the Draft International Criminal Code. I have noted that it is for my "personal information," and I shall therefore make no further use of it until and unless I have your authorization. In perusing it quickly I was struck by the absence from the code of the crime of "aggressive war" or aggression. You may want to reconsider that or have a look at Ferencz, Defining International Aggression, Vol. II, pp. 42-45.

My purpose here is not to comment on the Code but to answer the questions raised in your letter. I have chatted with Erik Suy, ${ }^{62}$ the U.N.'s General

61 Unterschrift fehlt auf archivalischer Kopie.

62 Eric Suy $\left({ }^{*} 1933\right)$ war Professor für Internationales Recht an der Universität Leuven und von 1967 bis 1973 Rechtsberater des belgischen Außenministeriums. Von 1969 bis 1972 wirkte er als Mitglied der belgischen Delegation bei der Generalversammlung der Vereinten Nationen und 1972 als Vorsitzender des sechsten Hauptausschusses. Im Anschluss leitete er von 1973 bis 1983 als Untergeneralsekretär den Bereich Rechtsangelegenheiten des UN-Sekretariats und von 1983 bis 1987 das Büro der Vereinten Nationen in Genf. 
Counsel about what role the Int. Ass. ${ }^{63}$ of Penal Law might play in furthering action on the Draft Code of Offenses. He felt that it might be useful to push for a Special Commission to codify International Criminal Law. Gerhard Mueller, ${ }^{64}$ under whose department that might come, felt that the U. N.'s aversion to Special Commissions would defeat the idea. He thought an academy to study the question might have a better chance. Louis Sohn seemed to share my initial feeling that a Special Committee of the U.N. should be appointed to deal with the Draft Code, but others in the U.N. were skeptical about its chances. Historically the subject was dealt with by the International Law Commission, but its agenda is loaded for the next 10 years and the prospects for getting the Assembly to refer it to the ILC $^{65}$ with a request for urgent attention also seem remote. In short no one has a very clear idea about what should be done to further the objective of having the international community accept an international criminal code.

In the face of such uncertainty I have no hesitation in putting forward some specific suggestions. I am attaching a text for distribution to the National Groups of the AIDP. ${ }^{66}$ (I assume this is what you were suggesting - although I am not sure.) The role I can play is to try to "lobby" the U.N. delegates to support the position. I am also perfectly willing to do anything else which you think may be helpful.

With best regards and good wishes, ${ }^{67}$

\section{Dokument 180}

Benjamin B. Ferencz an M. Cherif Bassiouni

Ohne Ortsangabe, 17. November 1978

Maschinenschriftlicher Brief, 1 Seite

$R G 12.013 .01^{\star} 03$

63 International Association.

64 Als Experte für Internationales Recht leitete Gerhard Mueller (1926-2006) von 1974 bis 1982 die Abteilung für Verbrechensverhütung und Strafjustiz der Vereinten Nationen. Daneben war er mit weiteren hochrangigen Posten bei den Vereinten Nationen betraut und lehrte ab 1982 an der Rutgers University internationales Recht.

65 International Law Commission. Die 1947 von der UN-Generalversammlung eingesetzte Kommission erarbeitet Entwürfe zur Weiterentwicklung des Internationalen Rechts.

66 Association Internationale de Droit Pénal.

67 Unterschrift fehlt auf archivalischer Kopie. 
Prof. M Cherif Bassiouni

DePaul University

25 E. Jackson Blvd. Chicago Ill. 60604

Dear Cherif:

I have just returned from Europe to find your letter of Oct. 24th in which you invite my comments on the section of your draft International Criminal Code dealing with "Unlawful Use of Force". I have re-read it and I assume from your statement that the code contains the Crime of Aggression [and] that you feel that aggression is adequately defined within its terms. If, as you indicate, you propose to submit your code to the U.N. I fear that many of the U.N. delegates will not be able to agree with you.

The definition of aggression which was accepted by consensus of the U.N. in $1974^{68}$ was the product of many years of labor by many legal experts and U.N. committees. Your brief extract, which contains only a brief reference to a few elements which play some role in the determination of what constitutes aggression, seems to pay no attention whatsoever to the laborious work done at the U.N. For example, the U.N. limited the acts of aggressions to acts by states and included the use of armed force against the "sovereignty" as well as the territorial integrity and political independence, and there were many other comments and restrictions which would have to be considered. \{Pre\#\#\# \#\#\# was deliberately c̊e̊rioified by Hq. U.N.\}

I also noted that in defining "Crimes against Humanity" you restricted the offense to acts done in connection with any crime against peace or any war crime. That was the position taken by the IMT and its Charter, but it was subsequently modified in Control Council Law No. $10^{69}$ to eliminate the requirement of a connection to a war. There were 2 of the subsequent Nurnberg [sic] proceedings which applied the broadened definition in reaching convictions for crimes against humanity and your draft might therefore be viewed as retrogressive if it failed to take that into account.

The Sixth Committee of the U.N. should be considering the Draft Code of Offenses in about 10 days. I shall be in Florida and may miss the debate

68 United Nations General Assembly, A/RES/3314, Definition of Aggression, New York, 14. Dezember 1974.

69 Alliierter Kontrollrat in Deutschland, Gesetz Nr. 10, Bestrafung von Personen, die sich Kriegsverbrechen, Verbrechen gegen den Frieden oder gegen die Menschlichkeit schuldig gemacht haben, Berlin, 20. Dezember 1945. 
but I will pick up the Summary Records. If you have been able to circulate the text of my letter, I would appreciate a copy. If not, then I fear that there will still be time next year.

Best regards ${ }^{70}$

\section{Dokument 181}

Benjamin B. Ferencz an Gerhardt Grebing ${ }^{71}$

Ohne Ortsangabe, 9. Oktober 1979

Maschinenschriftlicher Brief, 1 Seite

$R G 12.013 .01 * 07$

\section{October 1979}

Prof. Dr. Gerhardt Grebing

Kurpfalzstr. 14

6945 Hirschberg-Leutersh. ${ }^{72}$

Germany

Dear Prof. Grebing:

I was very pleased to find upon my return from Germany that you had sent me copies, in both German and French of your fine article on an International Criminal Court. ${ }^{73}$ I shall certainly quote your article and your conclusions in my forthcoming book "An International Criminal Court - a Step Toward World Peace." The book will consist of two volumes, and like my book on "Defining International Aggression" will assemble all of the leading documents tracing the history of the subject. I hope to deliver the final manuscript to the publisher within the next few months. Should you be interested in

70 Unterschrift fehlt auf archivalischer Kopie.

71 Gerhardt Grebing (1942-1982) war Professor für internationales Strafrecht. Seit 1977 lehrte er an der Universität Heidelberg und ab 1980 an der Universität Gießen.

72 Hirschberg-Leutershausen.

73 Wahrscheinlich ist gemeint: Gerhardt Grebing, Zur Frage der Schaffung eines Internationalen Strafgerichtshofes, in: Goltdammer's Archiv für Straftrecht 1976, 97-113. 
writing a review for a German or French periodical please let me know and I will pass your name to the publisher with the suggestion that he send you a complimentary copy.

Sorry that I had to run away from Hamburg before the AIDP ${ }^{74}$ meeting was over and that I had so little time to become better acquainted with more of the participants. I am frequently in Germany however and I hope that our paths will cross again. I gather from the return address that you are now at Heidelberg, and I guess that the address shown above is somewhere in that area. Since I am in Frankfurt about twice a year, I am hopeful that it will be possible.

May I urge you to contact your Auswertiges [sic] Amt and encourage the Rechtsabteilung to support the U.N. efforts to draft a code of offenses against the peace and security of mankind. So far there seems to be very little interest in it but it will be on the agenda for the next sessions of the General Assembly. I would be pleased to receive a copy of any representations you may be able to make to your government and I will be able to follow up on it here in New York.

With all good wishes,

\section{$\{\text { B. Ferencz }\}^{75}$}

Prof. Dr. Gerhardt Grebing

Juristisches Seminar der

Universität Heidelberg

Friedrich-Ebert Anlage 6-10

6900 Heidelberg 1

Telefon: \#\#/547679 76

74 Association Internationale de Droit Pénal.

75 Die Unterschrift ist im Original stark verblasst und nur teilweise erkennbar.

76 Die Kontaktinformationen von Gerhardt Grebing sind auf einer an den Brief angehängten Visitenkarte abgebildet. Die Vorwahl der Telefonnummer ist nicht mehr lesbar. 


\section{Dokument 182}

Benjamin B. Ferencz an The New York Times

New York, 21. Dezember 1979

Gedruckter Zeitungsausschnitt (Leserbrief), ${ }^{77} 1$ Seite

$R G 12.013 .01^{\star} 07$

The New York Times

Friday, December 21, 1979

Letters

Toward a World Tribunal That Tries People

To the Editor:

The Nov. 29 Op-Ed piece ${ }^{78}$ by Robert Glynn ${ }^{79}$ and Andreas Lowenfield [sic] ${ }^{80}$ dismisses too lightly the utility of an international criminal tribunal to help defuse the Iranian crisis. ${ }^{81}$ True, the statutes of the International Court of Justice limit jurisdiction to consenting states, and the World Court has no authority over individuals, but it is time to create a new agency to deal with world needs.

For nearly half a century almost all international law societies have favored the establishment of an international criminal court to deter aggression, terrorism and crimes against humanity - including the persecution of a state's own nationals. The Nuremberg precedent and principles and the feasibility of a permanent court were debated in minute detail by U.N. experts. Almost all agreed that such a tribunal would be desirable. The majority concluded in 1954, that "the time was not yet ripe." It's getting riper every day.

77 Benjamin B. Ferencz, Toward a World Tribunal That Tries People, in: The New York Times, 21. Dezember 1979, 34.

78 Robert B. Glynn/Andreas F. Lowenfeld, A Tribunal on Iran?, in: The New York Times, 29. November 1979, 27.

79 Robert B. Glynn (1929-2002) war Rechtsanwalt mit einem Schwerpunkt auf internationalem Recht.

80 Andreas F. Lowenfeld (1930-2014) war Professor für Internationales Recht. Ab 1967 bis zu seiner Emeritierung 2009 war er an der rechtswissenschaftlichen Fakultät der New York University beschäftigt und lehrte u. a. an der The Hague Academy for International Law.

81 Zur »Iranian Crisis« siehe Dokument 186. 
The Security Council, responsible for peace and security, could convene an ad hoc tribunal composed of seven impartial judges nominated by the International Law Commission, which is a diverse group of experts already appointed by the General Assembly. The courthouse at The Hague has all needed facilities. Charges could be based on existing international law, and no one would be immune from trial. Enforcement could be as directed by the Security Council.

Opportunities to advance the rule and role of law should be seized and not lost by silence or a superficial dismissal without full consideration of all of the facts.

Benjamin B. Ferencz

New Rochelle, N. Y., Dec. 13, 1979

\section{Dokument 183}

Benjamin B. Ferencz an Ernst Katzenstein

Ohne Ortsangabe, 1. Februar 1980

Maschinenschriftlicher Brief, 1 Seite

RG 12.011.001*19

Feb. 1, 1980

Dear Ernst:

A few days ago I finally delivered the complete manuscript to the publisher of another two-volume monstrosity. This one on An International Criminal Court. (See their ad.) Now I can breathe a bit and extend my apologies to all the friends I have been neglecting these past months. You wanted to know how does one forsch frieden [sic]. Now you see. I think it's easier to make war.

Thanks for the quick response to appeal for help to Saul. I'm sure he's grateful. He will, I'm afraid, still be in debt for some time but at least he's a free $\operatorname{man}^{82}$ and that's a great relief to us all. Since the banking business is closed to him, we can expect him to renew his old interest and activities in the Jewish area. You probably know that Nahum has offered him the Executive responsibility for the Fund and Saul is already busy making plans.

82 Siehe dazu Dokument 158. 
I have read your most interesting reports, and you and I having been trained in the same school, remain wary until it is a reality. It's clear to me that the Finance Ministry Officials would like to sabotage it. I don't know who Matthofer [sic] ${ }^{83}$ listens to but some leaning on him by Schmidt ${ }^{84}$ or someone else could only be helpful. I'm sure you are mindful of Genscher's ${ }^{85}$ and others sensitivity to possible Arab protests and that may be a good reason to avoid any stirring of the pot that might leak. ${ }^{86}$ Watchful caution and gentle stirring is the word.

Less Than Slaves has been a smash hit - for a book of that kind. I am most pleased that Hilda was still able to find some satisfaction in reading it. I'm sure it was, as it should have been, a source of pride in her husband and that Michael and Doris and the grandchildren should also cherish it as a tribute to grandpa and his work. Harvard has just brought out the 2nd printing. I am having fun on radio and some TV appearances. Incredible! But not a word from Yehuda Bauer or anyone in Israel. Also incredible.

Now I'm off to join my dear spouse in sunny Florida. I may have occasion to drop in on Nahum since my plane lands at Palm Beach and we're not far away. We'll see. Mostly I need some rest.

I'm sure these are still difficult days for you my dear friend but what can we do? Make the most of every day.

Warm regards, ${ }^{87}$

83 Hans Matthöfer (1925-2009) war von 1961 bis 1987 SPD-Abgeordneter im Deutschen Bundestag und von 1978 bis 1982 Finanzminister unter Bundeskanzler Helmut Schmidt.

84 Helmut Schmidt (1918-2015) war von 1974 bis 1982 der fünfte Bundeskanzler der Bundesrepublik Deutschland. Zuvor war der SPD-Politiker u. a. Verteidigungs- sowie anschließend Finanzministerminister unter Willy Brandt.

85 Hans Dietrich Genscher (1927-2016) war Politiker für die FDP. Im Kabinett Willy Brandts war er Bundesminister des Inneren (1969-1974). Anschließend wurde er Außenminister, zunächst unter Helmut Schmidt (1974-1982), anschließend bis 1992 unter Helmut Kohl.

86 Der Hinweis auf die drohende Gefährdung der Beziehungen zur arabischen Welt gehörte zum festen Bestandteil der bundesdeutschen Auseinandersetzung um jüdische Entschädigungsforderungen und spielte auch im Zusammenhang mit dem Post-65-Härtefonds eine wichtige Rolle. Tatsächlich drohten 1975 Kuwait, Libyen, Syrien und die PLO mit "Maßnahmen«, sollte die Bundesrepublik weitere Entschädigungsleistungen an Juden vereinbaren. Siehe Goschler, Schuld und Schulden, 327, $329,335 \mathrm{f}$. und 338 .

87 Unterschrift fehlt auf archivalischer Kopie. 


\section{Dokument 184}

Benjamin B. Ferencz an Seymour Rubin

Ohne Ortsangabe, 23. Februar 1980

Maschinenschriftlicher Brief, 1 Seite; unleserliche handschriftliche Notiz am linken unteren Rand

$R G 12.014 .01{ }^{\star} 04$

Feb. 23, 1980

Dear Sy:

Thank you for your supportive note to Oscar Schachter ${ }^{88}$ Who could resist such a compelling compliment as to be admired by the two great Rubins? I haven't heard from him yet.

But that is not why I write. I have some vague recollection of having suggested that the Society add my name to that of Miss Winkelmann as the ASIL rep ${ }^{89}$ at the U.N. I'm too busy to look for the correspondence, but my present accreditation, via the Co-Ordinating Board of Jewish Organizations (B'nai B'rith) has, I believe, expired. Although I am quite sure that the B'nai B'rith has included me on their list, as they have for many years, I would prefer to carry the Society pass. Not that I love B'nai B'rith less, but the Arabs love it less, and I love my life more.

It's no big deal either way. I think I'll survive. As far as I can see, all that is involved is a letter from the Society adding my name to that of Miss Winkelman and anyone else now on the list kept by the NGO Branch of the Office of Public Information at the UN. I will try to avoid having to get a new NGO card issued until I hear from you.

A more important suggestion relates to Lesss Than Slaves. I appreciate your comment regarding your partial reading. Stop while you're ahead say I. The Harvard Press can make books available for $\$ 9$ each. The list price is $\$ 15$. If the Society, at its annual meeting, puts them put even at a discount of $20 \%$

88 Der Jurist Oscar Schachter (1915-2003) war seit ihrer Gründung eng mit den Vereinten Nationen verbunden. Ab 1946 arbeitete er als Stellvertreter und ab 1952 als Leiter der UN-Rechtsabteilung. In der Folge hatte er verschiedene leitende Posten bei den Vereinten Nationen inne. 1975 wurde er auf eine Professur für Internationales Recht an der Columbia University berufen.

89 Representative. 
that would produce a profit for the Society of $331 / 3 \%$. (Not counting my 90 \& royalty!) The distinguished author will be available to sign copies. (I may also be sitting on two-volumes of my latest An International Criminal Court, in order to reach the table.) For the sake of the Society and our dear alma mater, as well as my heirs, is it possible and feasible to offer the book via the Society? Since the Society would only pay for what they sell I see no risk, but I would not want to appear to be using the Society for any personal advantage. (Not for $90 \$$ anyway.) The Harvard Press likes to know early so they can print a few more copies. I think they do them in batches of twelve since they indicated they are planning to go into the third printing. Let me know. ${ }^{90}$

Saul is getting back into full swing.

Warm regards, ${ }^{91}$

\{Reply filed in Promotion HUீP $\}$

\section{Dokument 185}

Benjamin B. Ferencz an Patricia M. Mische ${ }^{92}$

Ohne Ortsangabe, 10. März 1980

Maschinenschriftlicher Brief, 1 Seite; handschriftliche Unterstreichungen

$R G 12.016^{\star} 05$

March 10, 1980

Pat Mische

Global Education Associates

552 Park Ave.

East Orange, N. J. 07107

90 Auf der linken Marginalie befindet sich eine handschriftliche unleserliche Notiz.

91 Unterschrift fehlt auf archivalischer Kopie.

92 Patricia M. Mische gründete 1973 gemeinsam mit Gerald F. Mische Global Education Associates, eine Nichtregierungsorganisation, die sich dem internationalen Austausch mit dem Ziel widmet, zu einer humaneren und gerechteren Weltordnung beizutragen. Sie wirkte als Präsidentin von Global Education Associates und lehrte in verschiedenen Positionen im Bereich der Peace Studies, unter anderem am Antioch College. 
Dear Pat:

Would you believe that the pile of books and papers on my desk has gradually been thinned out and there now appears on the top your letter of Nov. 9, 1978 regarding an old promise that I would write something for the Whole Earth Papers. Mary Alban Bouchard ${ }^{93}$ phoned me in January and we discussed what she was planning to write on the State of Human Rights and World Order and I got the impression that she would call again in a few weeks to see if anything more was required of me. I have heard nothing, and I suppose I should stop while I'm ahead but I feel a bit guilty unless you tell me that I'm liberated.

I have glanced at some of the materials you sent me and it seems to me that, should you so desire, I could prepare something on International Crimes against World Order. The paper would be based on materials I have already published (see enclosed) and would deal with offences containing a political element rather than such things as drug traffic, slavery, counterfeiting and the like. I could touch upon potential economic crimes in a more ethically developed international society, but basically I would explain man's striving for a more tranquil order by seeking to define such crimes as aggression and crimes against humananity. The conventions condemning genocide apartheid, and the many forms of terrorism would be explained as well as the reasons why they are not effective and what still needs to be done. I could point to the progress that has been made and the fact that a Code of Offences against the Peace and Security of Mankind is again on the UN agenda after an absence of more than a quarter of a century. My final pitch is always for an International Criminal Court to hold persons responsible for international crimes. The situation in Iran and Afghanistan may make these themes more interesting than they would normally be.

If, as your letter indicates, you would rather deal with this theme in another context please do not hesitate to let me know that my thought is not useful at this time. I shall do nothing further on it until I hear from you.

All good wishes, ${ }^{94}$

93 Mary Alban Bouchard (gest. 2013) war eine Nonne aus dem Konvent der St. Josephs Schwestern Toronto. Sie engagierte sich für Frieden, soziale Gerechtigkeit und gegen Waffengewalt. Zudem pflegte Bouchard Kontakte zu Global Education Associates. Ihre Schwesternschaft vertrat sie, ebenso wie Pax Christi, von 1983 bis 1989 bei den Vereinten Nationen.

94 Unterschrift fehlt auf archivalischer Kopie. 


\section{Dokument 186}

Benjamin B. Ferencz an Robert Rosenstock ${ }^{95}$

Ohne Ortsangabe, 8. Mai 1980

Maschinenschriftlicher Brief, 1 Seite

$R G 12.013 .01 * 07$

May 8, 1980

Robert Rosenstock Esq.

US Mission to the UN

799 UN Plaza NY 10017

Dear Bob:

I was delighted to receive your letter taking me over the coals. I am always glad to learn and even to stand corrected. I am particularly grateful for the letter to the Security Council, dated 25 April, that I was unaware of when I dispatched my letter to the editor in the morning of the 28th. At least the President, through his able representatives at the UN, sought to cover the action by meeting the reporting requirements of Art. 51, and I am gratified for the effort to cloak the action with the sanctity of law.

I can not share your argument that the term "inherent" in Article 51 allows, or should allow, unilateral military intervention even as a rescue operation against illegal seizure of hostages by a group supported by the foreign government. ${ }^{96}$ An "armed attack" need not involve a declaration of war or the other attributes you cite, and there we agree, but the last phrase of Art. 2 of the definition of aggression that you cite also refers to a requirement that a first use of force not be considered if the provocative acts "or their consequences are not of sufficient gravity." I feel deeply for any 50 or more

95 Robert Rosenstock (1935-2004) war Rechtsberater der Ständigen Vertretung der Vereinigten Staaten bei den Vereinten Nationen sowie von 1992 bis 2003 Mitglied der International Law Commission der UN.

96 Diese Überlegungen beziehen sich wahrscheinlich auf die Vorgänge um die Geiselnahme von US-Amerikanern in Teheran zwischen 1979 und 1981. Seit dem 4. November 1979 wurden im Verlauf der iranischen Revolution 52 Diplomaten in der Botschaft der Vereinigten Staaten in Teheran als Geiseln gefangen gehalten. Im April 1980 scheiterte ein militärischer Befreiungsversuch. Erst nach 444 Tagen kamen die Geiseln am 20. Januar 1981 wieder frei. 
persons held against their will but coming from a city where more people than that are murdered each month, I think the harm must be weighed against the risk of a much larger catastrophe should unilateral military force be applied to correct the evil.

You're quite right that I seize every straw to proselytize for an International Court and I sure wish we had such a tribunal to try terrorists, hostage-takers, and even heads of state who tyranize [sic] or plunder their own people. I see no way to bring the hostages out safely by the use of force. Even if the attempt had succeeded (and we would then justify it legally as a superior justice a la Eichmann's abduction, Entebbe or Mogadishu) I fear other hostages would have been seized instead. I approve of all of the past patience and advocate more of the same. As long as the hostages are noot harmed time is on their side. (Standard terrorist therapy). We can debate it further at lunch. But I'm off to Europe in a few days and won't be back till June. I fear the hostages will still be there. Please talk to the President and tell him to relax. I'd like the world also to be there when I get back.

See you then. All the best, ${ }^{97}$

\section{Dokument 187}

Benjamin B. Ferencz an Sidney Liskofsky ${ }^{98}$

Ohne Ortsangabe, 16. Oktober 1980

Maschinenschriftlicher Brief, 2 Seiten; handschriftliche Ergänzungen, Korrekturen und Unterstreichungen

$R G 12.015^{\star} 08$

Oct. 16,1980

Sidney Liskofsky

165 E. 56th St. NY 10022

AJC

97 Unterschrift fehlt auf archivalischer Kopie.

98 Sidney Liskofsky (gest. 2005) arbeitete seit den 1940er Jahren bis 1992 für das American Jewish Committee. Er engagierte sich im Bereich Menschenrechte, publizierte zu diesem Thema und gründete 1971 das Jacob Blaustein Institute for the Advancement of Human Rights, das er bis 1992 leitete. 


\section{Dear Sid:}

Thank you for your letter of the 6th and your kind invitation to attend the meeting on oct. 27th. I have read the memoranda on which you requested my comments. It is obvious that these thought documents have been prepared by capable and intelligent experts. Since I am mindful that my own UN contacts have been more limited it is with some trepidation that I add my brief observations regarding U.S. policy toward the UN.

It seems to me that the U.S. position has been steadily eroding over the past several years. The issue: What should be the U.S. response? The alternatives range from picking up our marbles and calling the game over or to continue what seems to be a losing contest. I feel that we must look to the causes before venturing a prescription.

In my view one of the prime causes for our dilemma has been our inability. to articulate a coherent persuasive and consistent policy regarding many of the issues faced by the UN. Even our friends have often been unable to ascertain whether the feeble American trumpet was sounding \{"\}retreat\{"\} or \{'\}charge\{'\}. I suggest that must first put our act together. I need not itemize the issues, but peace, securrity, human rights would be high on the list.

I perceive fundamental philosophical differences among nations. Ours seems to be a paternalistic approach of telling less developed countries to just be patient and papa will send some more bread as soon as we're ready - and if they behave. Why are we surprised when such a view encounters antagonism? I fear that we have failed to recognize that the end of colonialism has inevitably inaugurated a major social upheaval. I would like to see the U.S. taking a positive role in helping to create social justice on a world-wide scale. A peaceful world is a matter of U.S. self-interest. The price we have been willing to pay for the carrot has, as McNamara has recently noted, been trivial. We cannot inspire anybody with such an approach.

|2| We continue to neglect the creation of adequate institutions to cope with contemporary problems. Both the League and the UN were undermined when the powerful states refused to surrender any part of their sovereignty to any impartial agency. The resulting international anarchy can not fairly be blamed on nations that did not then exist. We are moving in the right direction by the dispute-settlement machinery in the Law of the Sea, but the trend must be broadened.

I am troubled by the fact that we talk peace but allow the Soviets to steal the initiative while we adopt a skeptical, if not cynical and negative stance. I have in mind such issues as the definition of aggression, the non-use of force, and most recently the code of offenses against the peace and security of 
mankind - which the U.S. would like to bury. I am shocked that my country, which pioneered the advance that aggression, genocide and crimes against humanity were punishable offenses, even if committed by the head of state, should now seem to be back-tracking furiously. A state cannot aspire to world leadership by always saying "No". We thus find ourselves in the small minority on such issues. And rightly so!

We fail to speak up on other issues where our voice should be loud and firm. Thus we accept by consensus a host of resolutions which enclourage terrorism and every excess by allowing the final documents to contain exemptions for those who would use unrestrained violence to attain selfdetermination, freedom from alien domination or foreign occupation. We sit silently while Israel is verbally abused in obvious propaganda attacks, instead of rising to set the record straight and rallying all independent thinkers to speak up on behalf of principle. Abstaining is not inspirational.

Most of the world's problems can not be quickly solved. We must overcome what seems to be an American inclinationt to expect instant solutions. We must help to create new norms of international behavior, even if acceptance is on the distant horizon. Too often we hear: "The time is not ripe." Must we wait for the next atomic war?

In short, in my view, it is not so much U.S. policy toward the UN that needs reassessment as U.S. policy itself. Once that is clarified, every means, bilateral, multilateral, UN and other agencies should become the instrumentality for regaining world leadership and acceptance of an articulated and reasonable world-order policy.

Cordially,

\{Ben\}

\{You still want the ailter\#?\} 


\section{Dokument 188}

Benjamin B. Ferencz an Philip M. Klutznick

Ohne Ortsangabe, 6. April 1981

Maschinenschriftlicher Brief, 1 Seite

$R G 12.013 .01{ }^{*} 07$

Philip Klutznick

April 6, 1981

875 North Michigan Ave

Chicago, Ill. 60611

Dear Phil:

May I convey my appreciation for the wisdom in your thoughtful NJM article: Rethinking the Jewish Condition..$^{99}$ I share your view that "we have not yet begun to learn the simple lesson of true security," and your courageous call for reconciliation must be admired.

Nowadays I spend most of my time working for world peace - and am therefore considered a nut. (See attached.) $\{\text { My article is coming }\}^{100}$ I have focused on the need for an international tribunal with compulsory authority to settle disputes and, a la Nuremberg, to convict those who commit crimes against peace and humanity. Everywhere I hear: "The time is not yet ripe." I therefore particularly enjoyed your question: "If this is not the place and the time, then where or when?"

Keep plugging. I'm with you!

I hope to see you in Madrid in July, if not sooner.

All the best, and warmest regards, ${ }^{101}$

99 Philip M. Klutznick, Rethinking the Jewish Condition, in: National Jewish Monthly 95 (April 1981), H. 8, 41-44.

100 Seitlich in das Dokument eingefügter handschriftlicher Kommentar von Ferencz.

101 Unterschrift fehlt auf archivalischer Kopie. 


\section{Dokument 189}

Benjamin B. Ferencz an Ved P. Nanda

Ohne Ortsangabe, 16. Dezember 1982

Maschinenschriftlicher Brief, 1 Seite

$R G 12.014 .01^{\star} 06$

Dec. 16, 1982

Prof. Ved P. Nanda

College of Law

U. of Denver

200 West 14th Ave. Denver Col. 80204

Dear Ved:

Thank you for your letter of Dec. 3 regarding the April meeting of the Society. I discussed your letter with Paul Szasz ${ }^{102}$ with a view of finding something concrete that could be said about the UN without invoking the usual rhetoric. Many thoughts came to mind, such as "How to Improve the UN - Specific Suggestions" as well as discussions around some "hot" current UN topic such as the Manila Declaration. ${ }^{103}$ In the end, however, we both (as they say here) "reached a consensus" which we both agreed was brilliant. It was: Forget it!

What inspired this wisdom was my review of your preliminary draft program which Paul showed me. I noted that you had a planned panel dealing with Management of Legal Constraints on the Use of Force, which is very much a UN item. I also noticed that you had listed Bob Rosenstock as a suggested panelist. I had spoken to Bob about my thoughts and he had indicated a willingness to participate. I also noted that you had provisionally included a workshop on the UN, scheduled for 8. A. M.!

102 Paul C. Szasz (1929-2002) arbeitete für zahlreiche internationale Organisationen, darunter die Internationale Agentur für Atomenergie (1958-1966), die Weltbank (1966-1971) und die Rechtsabteilung des Hauptquartiers der Vereinten Nationen (1971-1989), wo er zuletzt den Posten des Stellvertreters des UN-Rechtsberaters innehatte. Zudem lehrte er, mit einem Schwerpunkt auf Internationalem Recht, unter anderem an der Cornell University, der New York University, am Pace Peace Center und an der University of California, Berkeley.

103 United Nations General Assembly, A/RES/37/10, Manila Declaration on the Peaceful Settlement of International Disputes, New York, 15. November 1982. 
Dear Friend: You may be trying to take your revenge for my having drafted you into a panel in Madrid when you had obviously more exciting things on your mind. But $8 \mathrm{~A}$. M. is too unkind - unless the Society would like to hear my views while I'm asleep. (It might be an improvement.)

You already have an overcrowded agenda, so perhaps next year the Society can manage to do something on the UN, or this year you can work it in on Larry Hargrove's panel on the use of force. Should anyone want a trouble-maker and iconoclast to foment a riot, I am available - in a non-forceful way.

May the bird of peace and happiness nestle on your head and bring you joy in the New Year.

Cordially, ${ }^{104}$

CC: Sy Rubin

Paul Szasz

\section{Dokument 190}

Benjamin B. Ferencz an Thomas M. Franck ${ }^{105}$

New York, 28. August 1984

Maschinenschriftlicher Brief, 2 Seiten

$R G 12.014 .01^{\star} 06$

TO THE EDITORS IN CHIEF:

August 28, 1984

When two such legal giants as Professors W. Michael Reisman ${ }^{106}$ and Oscar Schachter tangle, as they did in the Editorial Comments of the July, 1984

104 Unterschrift fehlt auf archivalischer Kopie.

105 Thomas M. Franck (1931-2009) war von 1984 bis 1993 Chefredakteur des American Journal of International Law. Seit 1957 lehrte er Rechtswissenschaft mit einem Schwerpunkt auf Internationalem Recht an der New York University, war Rechtsberater der US-Regierung und als Richter und Anwalt am Internationalen Strafgerichtshof tätig.

106 W. Michael Reisman $\left({ }^{\star} 1939\right)$ ist Professor für Internationales Recht und seit 1965 an der Yale Law School tätig. Neben zahlreichen Publikationen und Beratertätigkeiten zu Völkerrechtsfragen ist Reisman Ehrenpräsident der ASIL. 
OURNAL, ${ }^{107}$ it is the law itself that gets trampled. Reisman is certainly right in noting that Article 2 (4) of the U.N. Charter ${ }^{108}$ can not be interpreted in a vacuum. Its prohibitions against the threat or use of force were part and parcel of a collective security plan that envisaged peaceful settlement of disputes and an international military force. His frustration with the ineffectiveness of the world organization prompted his argument that if the political independence of a people - a major goal of international law - is being subverted by a repressive regime aided by a foreign source, it is within the spirit of the Charter for another state to intervene militarily to preserve the political independence of the suppressed community. Prof. Schachter acknowledges the importance of self-rule but doubts that it is secondary. ${ }^{109}$ to such competing aims as the maintenance of peace. He warns that weakening the restraints of Article 2 (4) only increase the risks of armed intervention by powerful states claiming to be responsive to the popular will. He finds Reisman's contention to be flawed and ominous: "it is not, will not, and should not be law" (p. 650). Such diametrical views by outstanding experts may cause the perplexed reader to conclude that international law is confused, ambiguous or useless.

What should be noted is the fact that humankind's effort to control armed violence is part of a long evolutionary process which has not yet reached maturity. Every nation, town and village has recognized that a tranquil community requires clear laws, courts and an effective system of law enforcement. In international society, these essential ingredients are still in an early stage of development. But there is no reason for despair. The U.N.'s consensus definition of aggression, work now being done on a draft Code of Offenses against the Peace and Security of Mankind, and the Law of the Sea illustrate progress in the codification and clarification of norms. The Nuremberg trials to punish aggressors, the Courts of Human Rights and those of the European Community demonstrate the importance of the judicial progress. Proposals to improve the U.N., revise the Charter and strengthen peace-keeping missions reflect other efforts to make international law enforcement more effective. Worldwide demands for demilitarization indicate the urgent need for restructuring the existing world order.

107 Gemeint ist das American Journal of International Law. Ferencz bezieht sich auf die Editorial Comments von W. Michael Reisman, Coercion and Self-Determination: Construing Charter Article 2(4), in: American Journal of International Law 78 (1984), H. 3, 642-645 sowie Oscar Schachter, The Legality of Pro-Democratic Invasion, in: American Journal of International Law 78 (1984), H. 3, 645-650.

108 Siehe Kapitel 9, Fußnote 15.

109 Das Wort ist im Original eingekringelt und am linken Rand mit einer Marginalie versehen, die allerdings nicht lesbar ist. 
|2| Progress is never made in a straight line; there is frequent regression, as illustrated by the refusal of many nations to accept compulsory jurisdiction of the International Court of Justice, the failure to honor the pledges of the Charter (and the Covenant of the League) that an international force would be created, and the reliance instead of weapons of mass destruction as guardians of the peace. Unilateral use of the armed force - for whatever reason - represents the greatest threat to world order for it may become the spark to ignite the tinder box.

Editorial debates are useful to highlight some of the difficulties, but they should not serve to diminish the enthusiasm for law or determination to pursue all of the many measures that will be required before international law can be truly effective as an instrumentality for world peace.

\section{BENJAMIN B. FERENCZ}

Of the New York Bar

Prof. Thomas M. Franck

Editor in Chief

The American Journal of International Law

2223 Massachusetts Ave. N. W.

Washington D.C.

Dear Tom:

I know it will be a very tough act to follow Oscar Schachter and Lou Henkin, ${ }^{110}$ but I'm sure you'll be up to it. They couldn't have picked a better man. Best wishes and congratulations!

I hope you'll find the above useful for inclusion under Notes and Comments - Correspondence!

Warm regards, ${ }^{111}$

110 Louis (Eliezer) Henkin (1917-2010) galt als einer der führenden Menschenrechtsexperten. Seit 1962 als Professor für Rechtswissenschaft an der Columbia University tätig, gründete er dort 1978 das Center for the Study of Human Rights sowie 1998 das Human Rights Institute. Zuvor war Henkin u. a. für das US-Außenministerium bei der UN und in Europafragen tätig und an den Verhandlungen zur UN-Flüchtlingskonvention von 1951 beteiligt. Er gehörte von 1953 bis 1969 dem Ständigen Schiedshof in Den Haag und von 1999 bis 2002 dem UN-Menschenrechtsausschuss an. Von 1978 bis 1984 war er Mitherausgeber des American Journal for International Law und von 1992 bis 1994 Präsident der ASIL.

111 Unterschrift fehlt auf archivalischer Kopie. 


\section{Dokument 191}

Benjamin B. Ferencz an Alfonse D'Amato ${ }^{112}$

New Rochelle, N. Y., 24. Januar 1985

Maschinenschriftlicher Brief, 1 Seite; gedruckter Briefkopf mit maschinenschriftlich eingefügtem Datum

$R G 12.016^{*} 15$

Benjamin B. Ferencz

Counsellor of Law

'January 24, 1985'

14 Bayberry Lane, New Rochelle, N. Y. 10804

914 632-3717

The Hon. Senator Alfonse D'Amato

United States Senate

Washington D.C. 20510

Re: Appointment Under P.L. 98-525

United States Institute for Peace ${ }^{113}$

Dear Senator D’Amato:

The above Act requires the President, with the advice and consent of the Senate, to appoint 11 individuals to the Board of Directors of a newly created U.S. Institute of Peace. May I respectfully invite your attention to my qualifications and availability for such an assignment.

General background: I am graduate of the Harvard Law School. After serving in the infantry during World War II, I became Executive Counsel at the Nuremberg War Crimes Trials and Chief Prosecutor for the United States against SS extermination squads that had murdered over a million

112 Alfonse D’Amato $\left({ }^{\star} 1937\right)$ ist Rechtsanwalt und ein republikanischer Politiker aus New York. Von 1980 bis 1999 gehörte er dem Senat der Vereinigten Staaten an.

1131984 verabschiedete der Kongress der Vereinigten Staaten das Gesetz zur Schaffung des United States Institute of Peace, das von Ronald Reagan unterzeichnet wurde (USIP; United States Congress, Public Law No. 98-525, The United States Institute of Peace Act, Washington D. C., 19. Oktober 1984). Das USIP widmet sich der Erforschung und Verhinderung von gewaltsamen Konflikten. Die Gründung des Instituts galt auch als ein Mittel, um die wachsende Antiatomkraftbewegung in den Vereinigten Staaten zu beschwichtigen. Siehe dazu English, The United States Institute of Peace sowie die Einleitung, 71. 
people. Pursuant to U.S. Military Government law, I was appointed the Director-General of the Jewish Restitution Successor Organization to recover the heirless property of murdered Jews. I played a leading role in establishing and implementing the restitution programs in Germany and I continue to advise all major Jewish organizations on that subject. For many years, I was General Counsel to the B'nai B'rith in Washington. I have also represented the Coordinating Council of Religious and Welfare Agencies with War Damage Awards, an umbrella organization for the world missions of such leading churches as the United Methodists, Seventh Day Adventists, American Babtists [sic], ${ }^{114}$ Presbyterian Church in the U.S. and the Episcopal Church. General Telford Taylor (now a Professor at Columbia) who was Chief of Counsel at Nuremberg, was my law partner for many years. I am 64 years of age.

Peace Activities: I am the author of six volumes on world peace, as described in the attached brochure. I have also written the prize-winningbook (Harvard University Press) LESS THAN SLAVES, that appeals for a more humane world. I was a Vice-President of The American Society of International Law, whose JOURNAL has published many of my writings. I have written many articles and have lectured at universities and at peace institutes such as The World Peace Thru Law Center (Washington D. C.), Global Education Associates, World Peace News, World Federalists, and the Max Planck Institute of International Law at Heidelberg. I am one of the Founding Members of the National Peace Academy Campaign and testified in person and in writing in support of the creation of a Peace Academy.

I hope I may look forward to your support.

Sincerely,

$\{$ Benjamin B. Ferencz $\}$

\section{Dokument 192}

Benjamin B. Ferencz an Philip M. Klutznick

New Rochelle, N. Y., 31. Januar 1985

Maschinenschriftlicher Brief, 1 Seite; gedruckter Briefkopf mit maschinenschriftlichen Einfügungen

$R G 12.016^{\star} 15$

114 Gemeint ist die American Baptist Convention, eine Vereinigung baptistischer Kirchen in den Vereinigten Staaten, seit 1972 American Baptist Churches USA. 
Benjamin B. Ferencz

Counsellor of Law
|5:30 A. M.

Jan. 31, 1985!

14 Bayberry Lane, New Rochelle, N. Y. 10804

914 632-3717

Philip M. Klutznick

875 North Michigan Ave. Suite 4044

Chicago, Ill. 60611

Dear Phil:

At about 5 A. M. this morning, whoever puts thoughts into my head tapped me on the noggin with a brilliant idea. If your name must intrude into my sleep, I would appreciate it if your Geist would come calling at a later hour. The inspiration that came to me is that YOU would be the perfect person to guide the work of the newly created a UNITED STATES INSTITUTE OF PEACE!

As you probably know, on Oct. 19, 1984, Congress, over the objections of the Administration enacted P.L. 98-525, creating a U.S. Institute of Peace. Its powers are vested in a 15-member Board which includes representatives of the state and Defense Departments (the Secretaries) as well as the Director of the Arms Control Agency and the National Defense University. The 11 other members must be appointed by the president "by and with the advice and consent of the Senate." No more than 8 of the Directors may come from the same political party. The President, who will designate the Chairman, must nominate the 11 Directors by April 20th. Now that's where you come in!

Congress authorized six million dollars for fiscal-85 and another ten million for fiscal-86. With that much money, it should be possible to begin educating Americans and the rest of the world about what is really required for a more tranquil international society. What I fear, however, is that the Institute will be so staffed and directed that it will be kept impotent. I was involved as one of the founders of the National Peace Academy Campaign, the lobby that (much to my surprise) pushed this law through. When I recently discussed my fears with the new N-PAC director, he suggested that I contact Senator D'Amato's office and offer myself as one of the 22 Directors for the Institute. I did so, as you will see from the attached letter. I want to assure you, however, that although I am thoroughly dedicated to the objectives of peace, I care absolutely nothing about any positions of prominence. I think that you would be an ideal man for the Board, and I would hope that you would agree.

You will know what needs to be done. If I can be helpful in any way, either now or when you are on the Board, I am at your service. At the moment, however, I'm going back to sleep. 
Warm regards to Ethel,

$\{$ Ben $\}$

PS: I never heard from Ken Stein in response to your letter to me of Aug. 21. I have about given up on finding a trade publisher but the one who produced my 6 volumes will be happy to publish my latest work as a COMMON SENCE GUIDE TO WORLD PEACE. It should be out this year.

\section{Dokument 193}

Benjamin B. Ferencz an John J. McCloy

Ohne Ortsangabe, 1. März 1985

Maschinenschriftlicher Brief, 1 Seite; handschriftliche Notiz am unteren Seitenrand $R G 12.016^{\star} 15$

March 1, 1985

John J. McCloy

One Chase Manhattan Plaza

New York, N. Y. 10005

Dear Mr. McCloy:

I am writing on a matter that I know is of deep concern to you - that of world peace. You may know that Congress recently enacted a law calling for the establishment of a U.S. Institute of Peace, which is designed primarily to be educational. It will be guided by a 15 -member Board led by the Depts. of State, Defense, Arms Control and National Defense University. The President must appoint the other 11 members, on a bi-partisan basis, by April 20th. I believe that I can make a useful contribution on that Board. If you share that view, I hope you will be able to help.

My credentials are indicated on the attached copy of my letter to Senator D'Amato. I was advised by his office that additional political support would promote serious consideration. As I have indicated in some of my books, I believe the McCloy-Zorin agreement was a high-point in U.S. peace efforts, and I trust therefore that you will not view my suggestion as an imposition.

A recent review, by a distinguished legal scholar, of my six volumes on world peace, concluded: 
"But when the political atmosphere changes, as sooner or later it must, Ferencz's assiduous compilations will be the quarry out of which the new - or renewed - structure of international law and international relations can be hewed."

I would like to carry forward the great tradition of such outstanding Americans as Elihu Root and John McCloy and would therefore eagerly accept the burdens I now seek.

If you are so inclined and can have a word with someone at the White House, or elsewhere, it would be much appreciated.

I am looking forward to seeing you in your usual chipper mood at one of your birthday parties to which I have been invited.

With every good wish,

Sincerely, ${ }^{115}$

$[\ldots]^{116}$

\section{Dokument 194}

Benjamin B. Ferencz an John J. McCloy

Ohne Ortsangabe, 4. April 1985

Maschinenschriftlicher Brief, 1 Seite

$R G 12.016^{\star} 15$

John J. McCloy

April 4th, 1985

One Chase Manhattan Plaza

New York, N. Y. 10005

Dear Mr. McCloy:

I just had to write to tell you again how much I enjoyed last night's dinner in your honor. Not only was it a gathering of old and admiring friends, but an opportunity for even the unofficial representatives of the German government to convey their gratitude. I found particularly touching the remarks that your son was willing to share with strangers when he declared his love

115 Unterschrift fehlt auf archivalischer Kopie.

116 Es folgt eine kurze und unleserliche handschriftliche Notiz. 
and appreciation. There was every reason for your heart to swell with pride and joy.

Shep Stone was kind enough to tell me that he had studied the tapes that I contributed toward your memoirs and he felt that they would be very helpful in setting the record straight; that only added to the pleasure of the evening. ${ }^{117}$ I know how very difficult it must be to be unjustly maligned regarding your motives in granting clemency to war criminals - particularly since you can hardly speak up for yourself - and if there is anything more I can do to correct the calumny you may be sure that I will do so.

Your role in supporting restitution for Nazi victims is another chapter of your glory that has not been adequately told and can not be adequately appreciated. I was amused that you recalled the "embezzlement" that produced the fund that made the restitution program - or at least the search for heirless Jewish property - possible. You may be assured that should you be indicted for the offense, I will gladly defend you free of charge and confess that I was the instigator of the "crime".

It occurred to me that perhaps I had again imposed upon unfairly when, in my letter of March 1st, I suggested that you support my candidacy for one of the non-salaried positions as a director of the planned U.S. Institute of Peace. After all, you may not know now my views on that subject. I am therefore enclosing a paper which I recently sent to the World Peace Through Law Center for their July convention in Berlin. If, after perusing it, you still feel that I can make a constructive contribution, you may want to drop a note to that effect to the President.

With unending admiration and appreciation,

Sincerely, ${ }^{118}$

\section{Dokument 195}

Benjamin B. Ferencz an Patricia M. Mische

New Rochelle, N. Y., 30. Mai 1985

Maschinenschriftlicher Brief, 1 Seite; gedruckter Briefkopf mit maschinenschriftlich eingefügtem Datum

$R G 12.016^{*} 15$

117 Möglicherweise das Gespräch zu Dokument 14.

118 Unterschrift fehlt auf archivalischer Kopie. 
Benjamin B. Ferencz

Counsellor of Law
'May 30, 1985'

14 Bayberry Lane, New Rochelle, N. Y. 10804

914 632-3717

Mrs. Patricia Mische

College of Saint Teresa

Winona, Minn. 55987

Dear Pat:

Many thanks for your very prompt transmittal of the letter from Senator Boschwitz, ${ }^{119}$ dated 22, 1985. A letter from George W. Armstrong, Associate Director, Presidential Personnel, The White House, dated May 14th, (copy attached) informed me that I had not been selected to serve as a member of the U.S. Peace Institute and that the tentative selections were still pending. A rational person would conclude (probably correctly) that there was no chance for me being appointed. But, being an old infantry sergeant, I have learned that one battle does not mean the end of the war, and that the cause of peace is worth fighting for even against impossible odds.

It seems to me that there is nothing to lose by trying to rally those forces that believed that a U.S. Institute for Peace could play a useful role in creating a more tranquil international society. Knowing that Senator Boschwitz was one of the sponsors of the bill which led to the creation of the Institute and noting the personal ties you seem to have with him, perhaps he can be induced to continue the good fight. I must emphasize that I have no personal ambitions whatsoever to acquire this non-salaried post and that the only reason I have become involved is my fervent desire to do what I can in the cause of peace. Should the President be considering the appointment of persons who are more dedicated or qualified, I would immediately lend my support to them. But what I fear is that the Administration which opposed the bill, and which has introduced an amendment to water it down to a point of near impotence, will seek to stack the Institute with persons who are either unqualified or simply prepared to go along with the official policies without seeking improvements.

119 Rudolph Boschwitz $\left({ }^{\star} 1930\right)$ war ein amerikanischer Politiker und Unternehmer. Er wurde 1978 für den Staat Minnesota in den Senat gewählt und übte das Amt bis 1991 aus. 
I am attaching copies of a number of letters of endorsement: Secretary Shultz, Jeane Kirkpatrick, ${ }^{120}$ John J. McCloy, Senator Pell, ${ }^{121}$ and heads of every major American Jewish organization. If these credentials, coupled with my list of publications and peace activities is not as good as any of the other candidates, I would gladly yield. But if it is better, then perhaps Senator Boschwitz would be willing to rally the original supporters of the Institute in order to prevent defeat from being snatched from the jaws of victory. You may want to pass this suggestion along him together with my expression of deep gratitude for his interest and support.

Sincerely,

$\{$ Ben $\}$

\section{Dokument 196}

Benjamin B. Ferencz an Soedjatmoko ${ }^{122}$

New Rochelle, N. Y., 4. September 1985

Maschinenschriftlicher Brief, 1 Seite; gedruckter Briefkopfmit maschinenschriftlich eingefügtem Datum

$R G 12.016^{*} 13$

Benjamin B. Ferencz

Counsellor of Law

'Sept. 4, 1985'

14 Bayberry Lane, New Rochelle, N. Y. 10804

914 632-3717

120 Jeane D. Kirkpatrick (1926-2006) war seit 1973 Professorin für Politikwissenschaft an der Georgetown University, Washington, D. C. Während des Präsidentschaftswahlkampfs von Ronald Reagan arbeitete sie als dessen außenpolitische Beraterin. Von 1981 bis 1985 vertrat Kirkpatrick als Botschafterin die Vereinigten Staaten bei den Vereinten Nationen.

121 Claiborne de Borda Pell (1918-2009) war von 1961 bis 1997 demokratischer Senator für Rhode Island.

122 Der indonesische Sozialwissenschaftler Soedjatmoko (1922-1989) leitete von 1980 bis 1987 die United Nations University in Tokio. Zuvor war Soedjatmoko unter anderem Botschafter in den Vereinigten Staaten. 
Soedjatmoko

Rector

The United Nations University

Toho Seimei Building

15-1 Shibuya 2-chome, Shibuya-ku

Tokyo 150, Japan

\section{Dear Rector:}

Please allow me to introduce myself. I am a retired international lawyer, the author of several books on international peace, and now an Adjunct Professor of International Law teaching The Law of Peace. The attached pamphlet will briefly outline my views.

I write to you now on two subjects that I know are of common concern: both are closely related to your program area of peace and conflict resolution. The first concerns the creation of an association between $\mathrm{UNU}^{123}$ and the university where I now teach. I would like to see an expansion of the university's interest in peace studies but before I broach the question with competent authorities here, I would like to know more about what is involved and whether such an association would be welcomed from your side.

The second subject relates to the dissemination of educational information on the problems of world peace. I have recently completed a small (130 page) book: A COMMON SENSE GUIDE TO WORLD PEACE, which synthesizes the results of more than 15 years of study, to produce an optimistic yet realistic picture of what has been done, what should be done and what can be done to create a more tranquil international society. The Introduction is by Professor Louis Sohn, of Harvard (Emeritus) who shares the view of other outstanding scholars that this new book is a unique and exiting contribution to the field. The book is now at the printers and should be available for release in connection with the 40th anniversary celebrations of the United Nations.

The publisher has agreed to produce an inexpensive paperback edition for bulk distribution. I have agreed to waive all of my royalties in favor of any cooperating agency. Several NGO's have already expressed an interest in distributing the book to their constituencies and others. Would it be possible for the UNU to arrange to be a co-publisher or distributor of the book? The publisher would, of course, be pleased to send you an advance copy of the book, should you be interested in seeing it. My hope is that it could be considered by a wide audience and thereby serve the cause of peace. 
I would be very pleased to hear from you soon.

Sincerely,

\{Benjamin B. Ferencz $\}$

CC: Dr. Elise Boulding

Dartmouth College, New Hampshire

\section{Dokument 197}

Benjamin B. Ferencz

Ohne Ortsangabe, Herbst 1985

Maschinenschriftliche Ankündigung einer Lehrveranstaltung, ${ }^{124} 1$ Seite

$R G 12.014 .05^{\star} 01$

\section{NEW COURSE ON LAW AND WORLD PEACE \\ INTERNATIONAL LAW SEMINAR \\ 2 CREDIT HOURS: Wed. 6 to 8 P.M. \\ Fall Semester 1985}

This seminar on the International Law and Search for World Peace will explore the role of law in the maintenance of peace. It will consider codes, courts and international law enforcement, problems of defining aggression, codifying norms of international conduct, the function of international courts, the Nuremberg Tribunals, improving the United Nations, arms control, economic sanctions, an International Peace Force and the connection between social justice and world order.

There will be no exam but a research paper of at least 15 pages will be required.

The seminar will be limited to 20 students; auditors will be welcome.

Readings will be assigned at the first meeting.

Benjamin B. Ferencz

124 Ein Foto und eine Autorenvorstellung des Oceana-Verlags sind der Ankündigung beigefügt. Diese sind nicht wiedergegeben. 


\section{Dokument 198}

Benjamin B. Ferencz an Margaretha M. Henneberry ${ }^{125}$

Ohne Ortsangabe, 22. Oktober 1985

Maschinenschriftlicher Brief, 1 Seite

$R G 12.013 .01 * 19$

Oct. 22, 1985

Margaretha M. Henneberry

World Peace Through Law Center

1000 Conn. Ave. NW

Washington DC 20036

Dear Margaret:

This morning I received a phone call from Phil Cohen, ${ }^{126}$ the publisher of Oceana Publications. The first printing of my book A COMMON SENSE GUIDE TO WORLD PEACE is sold out and a second printing of 10,000 copies should be ready in about a week. On the 18th, Global Education Associates ordered 3,000 copies for distribution to a largely catholic network and they generously commended Oceana "for the vision to publish such quality materials." The Center for UN Reform Education ${ }^{127}$ is distributing to all heads of political science departments across the country. Cohen called with a suggestion for the World Peace Through Law Center.

He suggested that WPLC order 501 copies at the bulk price of $\$ 2.50$ per copy. (100 to 500 costs $\$ 3$ and 1,001 to 2,000 is $\$ 2$ while 2,001 to 3,000 is $\$ 1.75$ etc. down to $\$ 1$ for 10,000$)$. The book will retail at $\$ 5$. Cohen felt that the Center could offer the book as a $<$ Xmas? > gift to donors or could advertise

125 Margaretha M. Henneberry (1929-2010) war Mitgründerin des WPLC (1991 umbenannt in World Jurist Association), für das sie zwischen 1967 bis 2010 als Schatzmeisterin, geschäftsführende Direktorin und schließlich als Vizepräsidentin tätig war.

126 Philip F. Cohen (1911-1998) gründete 1945 das Verlagshaus Oceana Publishing Inc., das er bis 1995 leitete.

127 Das 1978 gegründete Center for UN Reform Education mit Sitz in New York ist eine unabhängige, überparteiliche und gemeinnützige politikwissenschaftliche Forschungsorganisation, die sich für die Weiterentwicklung der Vereinten Nationen einsetzt. 
it for sale in its Bulletin. The total initial investment for 501 copies would be $\$ 1,252$, and that could be recouped if only half the books were sold. Hopefully, the books would be a source of additional revenue as well as a demonstration of the WPLC's dedication to peace through law - as espoused in the book. A covering letter from Charles Rhyne could indicate that the author's views are his own but that WPLC thinks it should be considered.

Of course, I raised the question whether Oceana would accept the return of books that might not be sold. Cohen, who is not accustomed to paperback sales, declined. I, being a man of action and unaccustomed to such trivia, found an immediate solution. Whatever you can't sell, I will take back at cost since I can give them away as part of my own dedication to world peace.

You and Charley will know best what WPLC can handle and how to go about it. The hardcover is expected in about 4 weeks and will sell for $\$ 15$, with a $20 \%$ discount to dealers. You may find that for certain donors the hardcover may be more appropriate despite the cost. I know you will discuss this with Charley and he may then want to call Phil Cohen (914) 693-5956, who sends his best regards.

Please let me know your thinking.

Warm regards to you and Charley. ${ }^{128}$

\section{Dokument 199}

Benjamin B. Ferencz an Judith Tritschler ${ }^{129}$

New Rochelle, N. Y., 20. November 1985

Maschinenschriftlicher Brief, 1 Seite; gedruckter Briefkopfmit maschinenschriftlich eingefügtem Datum, handschriftliche Einfügungen

$R G 12.016^{*} 02$

Benjamin B. Ferencz

Counsellor at Law

¡20 Nov. 1985!

14 Bayberry Lane, New Rochelle, N. Y. 10804

$914632-3717$

128 Unterschrift fehlt auf archivalischer Kopie.

$129 \mathrm{Zu}$ dieser Person konnten keine biografischen Angaben ermittelt werden. 
Judith Tritschler

Center for UN Reform Education

139 East McClellan Ave. \{(201) 994-1016-992-8350\}

Livingston, N.J. 17039

Dear Judith:

Thank you very much for sending the list of political science teachers who are to receive my book. As I told you on the phone, the selection was carefully done and the few doubtful cases were so scarce that it is hardly worth searching them out. I am sending you a supplementary list drawn from the membership of the American Branch of the International Law Association and I think these should also be included among the distributees.

I assume that you will have new letterheads printed to reflect your new address. I also hope that the letterhead will show that any donations to the Center are tax-deductible. <If not, add it to the text of the letters sent out.> I would suggest a revised text along the following lines:

Dear Friends:

THE CENTER FOR UN REFORM EDUCATION, in commemoration of the 40th anniversary of the United Nations and the designation of 1986 as "The Year of Peace," is pleased to send you herewith a complimentary copy of A COMMON SENSE GUIDE TO PEACE by Benjamin B. Ferencz.

Professor Ferencz is a graduate of the Harvard Law School, former US Prosecutor at the Nuremburg War Crimes Trials and the author of several widely acclaimed volumes dealing with world peace. Although the author's views are his own, it is our hope that this informative and optimistic little book will serve to stimulate thought and help to move us closer to our common goal of a more tranquil international society.

We would be pleased to send you additional information about the work of our organization. Please feel free to contact us at any time.

Sincerely, <or with Holiday greetings $>$

I'm not sure that it's a good idea to try to sell books by mail order. Too much bother. Whatever books may be left can better be sold during conferences. You may, however, want to include the publisher's brochure so that those who want bulk purchases may know where to turn. 
Best of luck at Mohonk ${ }^{130}$ and in your new offices. I hope to drop in there to give you my best wishes in person soon.

Cordially,

$\{$ Ben $\}$

$[\ldots]^{131}$

\section{Dokument 200}

Benjamin B. Ferencz an Donald F. Keys ${ }^{132}$

Ohne Ortsangabe, 16. Dezember 1985

Maschinenschriftlicher Brief, 1 Seite

$R G 12.017^{\star} 06$

Donald Keys, President

Dec. 16, 1985

Planetary Citizens

POB 2722 San Anselmo, CA 94960

\section{Dear Don:}

Please find attached a small contribution to your worthy cause. $\{\$ 50 \# \# 383\}^{133}$ I was pleased to learn from Global Education Associates that they used my book A COMMON SENSE GUIDE TO WORLD PEACE (copy of which I believe I gave you when last we met at the UN) as a fund-raiser. They offered

130 Gemeint ist vermutlich das Mohonk Mountain House, ein historisches Resort am Lake Mohonk in Ulster County, New York, das mehrfach als Austragungsort politischer Konferenzen diente.

131 Es folgt eine kurze, teils unleserliche handschriftliche Gesprächsnotiz vom 10. Januar 1986, wonach Judith Tritschler den Versand der Briefe bestätigt habe.

132 Donald F. Keys (1924-2008) war Friedens- und Menschenrechtsaktivist sowie Redenschreiber von UN-Generalsekretär U Thant. Gemeinsam mit U Thant und Norman Cousins gründete er 1974 die Organisation Planetary Citizens, als deren Präsident er wirkte. Darüber hinaus repräsentierte er von 1969 bis 1982 die World Federalist Association bei den Vereinten Nationen.

133 Handschriftliche Notiz auf dem rechten Seitenrand. 
it as a special gift to donors and I was delighted to learn from them that it had been the most successful fundraising device they had ever had. Perhaps it can do as well for Planetary Citizens.

The way it might worksis [sic] as follows:

Planetary Citizens orders 1001 books at $\$ 2$ each (Greater quantities cost less, as you will note from the attached Oceana brochure). Total investment $\$ 2002$. You send out solicitation letters early in 1986 to commemorate The Year of Peace and offer the book as a special gift to all donors of say $\$ 25$. If you don't recoup your entire investment, I will contribute any shortfall and take back any books that you have on hand. Any surplus you keep.

If you believe that such a joint effort might serve the cause of peace please let me hear from you or be in touch with the publisher directly. (The person in charge at Oceana is Edith Ratshin, Phone (914) 693-1733). I shall be away in Florida until January 8th. <Phone (305) 499-8642> You will, I hope, recognize that my book is fully supportive of the goals of Planetary Citizens and it is up to you to decide to what extent a distribution (in the suggested, or any other form) is helpful. You will note that the costs per volume diminish as the quantity rises, and at 3001 copies it's only $\$ 1.50$ per book. It sells at the UN Bookstore for the retail price of $\$ 5$. The hardcover sells at $\$ 15$. The publisher is not much interested in selling the inexpensive paperback except in large quantities. All of my royalties are donated to peace organizations, and since I know that most of them are always in financial straits, I have invented the above technique as a means of being of service.

Let me hear from you. All good wishes for happiness in the New Year. ${ }^{134}$

\section{Dokument 201}

Benjamin B. Ferencz an Kinhide Muskakoji ${ }^{135}$

New Rochelle, N. Y., 21. Januar 1986

Maschinenschriftlicher Brief, 1 Seite; gedruckter Briefkopf mit maschinenschriftlichen Einfügungen

$R G 12.016^{\star} 13$

134 Unterschrift fehlt auf archivalischer Kopie.

135 Der japanische Politikwissenschaftler Kinhide Mushakoji $\left({ }^{*} 1929\right)$ war Professor für Internationale Beziehungen und im Bereich der Friedensforschung aktiv. Er leitete von 1976 bis 1989 die Regional and Global Studies Division an der Universität der Vereinten Nationen in Tokio. 
Benjamin B. Ferencz

Counsellor of Law

|Adjunct Professor

'21 Jan. 1986!

Pace University Law School!

14 Bayberry Lane, New Rochelle, N. Y. 10804

914 632-3717

Dr. Kinhide Mushakoji, Vice-Rector

Regional and Global Studies Division

United Nations University

Tokyo

Dear Dr. Mushakoji:

A few days ago, I had the pleasure of listening to an inspiring talk by Dr. José Abueva ${ }^{136}$ when he addressed a group of NGO's regarding the work of the U.N. University. Although I was, of course, familiar with the important work being done by UNU, I was encouraged to meet later with Dr. Abueva in order to explore what I might be able to do to assist in furthering our common goals of world peace.

You may notice from the attached brochure that I am a retired international lawyer who has written extensively on the subject. At Pace University, in White Plains, New York, I teach "The International Law of Peace." My focus has been primarily in the area of your "theme I" and I have dealt with the problems of peace, security and global transformation from a legal perspective. It seems to me that such an approach complements some of the major themes being addressed by your researchers and may add a new or different dimension to your current considerations.

To give you some idea of my thinking, I have asked Dr. Abueva to send you and Dr. Rajni Kothari ${ }^{137}$ a copy of a little book that has just been published

136 Von 1977 bis 1987 war der philippinische Politikwissenschaftler José V. Abueva $\left.{ }^{*}{ }^{*} 1928\right)$ in verschiedenen Positionen an der Universität der Vereinten Nationen in Tokio tätig. Von 1987 bis 1993 leitete er als Präsident die Universität der Philippinen und übernahm anschließend dort die Professur für Politikwissenschaft und öffentliche Verwaltung.

137 Der indische Politik- und Sozialwissenschaftler Rajni Kothari (1928-2015) gründete 1963 das Centre for the Study of Developing Societies, an dem er u. a. zum politischen System Indiens forschte. Darüber hinaus war er von 1982 bis 1984 Generalsekretär und im Anschluss bis 1986 Präsident der People's Union for Civil Liberties, einer 1976 gegründeten indischen Organisation, die sich zivilgesellschaftlichen Themen und Menschenrechtsangelegenheiten widmet. Mit dem von ihm initiierten Forum Lokayan - Dialogue of the People erhielt er 1985 den Right Livelihood Award. 
and which synthesizes some views contained in my larger work. It is my hope that you will find the book, A COMMON SENSE GUIDE TO WORLD PEACE, to be a useful contribution.

I am trying to persuade Pace University to create a Pace Peace Center for broader dissemination of knowledge in the area. In that connection, I recall having seen a UNESCO publication some years ago which listed the peace organizations all over the world and provided details of their capacities, funding etc. It seemed to me that if you could bring about an up-date of that publication it would be most helpful for those who seek a clear overview of the existing international peace network. I would be pleased to receive a copy of any similar consolidation you may have.

If you believe it might be useful, I would be pleased to participate in any seminars or research in which my particular expertise or focus may prove helpful. If you will advise me or Dr. Abueva of your thinking, you may be assured of my full cooperation.

Sincerely,

Dr. Benjamin B. Ferencz

CC: Dr. Rajni Kothari

Dr. José Abueva

\section{Dokument 202}

Benjamin B. Ferencz an Ulrich Albrecht ${ }^{138}$

Ohne Ortsangabe, 26. Februar 1986

Maschinenschriftlicher Brief, 1 Seite

$R G 12.016^{\star} 13$

Feb. 26, 1986

Adjunct Professor

Pace Law School

138 Ulrich Albrecht (1941-2016) hatte seit 1972 die Professur für Friedens- und Konfliktforschung am Otto-Suhr-Institut der Freien Universität Berlin inne und leitete die Forschungsstelle der Berghof Stiftung für Konfliktforschung. Er nahm seit 1970 an den internationalen Pugwash Conferences on Science and World Affairs teil. 
Dr. Ulrich Albrecht

Berghof Institute

Fachbereich (15) Politische Wissenschaft der Freien Universität

Kiebitzweg 3

1000 Berlin 33

Dear Dr. Albrecht:

A letter I have just received from the office of Prof. Kothari in Delhi suggests that I be in touch with you "to arrange for a participation in his UNU-Berlin University seminar." I had written to Prof. Kothari to draw his attention to my latest book, A COMMON SENCE GUIDE TO WORLD PEACE, and to suggest that the Programme on Peace and Global Transformation be expanded to include some greater attention to the use of world law as a means of attaining a more peaceful international order. Ciri Doshinger of his office seemed to agree that the legal dimension had indeed been missing as a major focus in their research program and that somehow my appearance at your seminar might help to correct that deficiency.

I am writing because the suggestion came as a surprise. Although I am somewhat familiar with some of your publications regarding disarmament and "Friedensforschung", I know nothing about your seminar. I mentioned that I am frequently in Berlin and indeed I may be there during the week of July 15th. My last visit was during the summer of 1985 where I presented a paper at the World Peace Through Law Conference ${ }^{139}$ at the Kongresshalle. Should you believe that I can make some useful contribution to the cause of peace during my next Berlin visit, I would be pleased to hear from you.

To give you some idea of my thinking, I am enclosing a copy of my latest small book, which incorporates ideas contained in six scholarly volumes. Another book of mine, LESS THAN SLAVES, that was published by the Harvard University Press, appeared in German under the title Lohn des Grauens (Campus Verlag Frankfurt) and was the basis for a documentary film produced by Lea Rosh of Berlin for the SFB under the title Vernichtung durch Arbeit. A friend of mine, Dr. Ossip Flechtheim ${ }^{140}$ (Rohlfstr. 18, Dahlem,

139 Gemeint ist die 1985 vom WPLC veranstaltete Berlin Conference on the Law of the World.

140 Der Jurist und Politikwissenschaftler Ossip K. Flechtheim (1909-1998) floh aufgrund seiner jüdischen Herkunft und politischen Betätigung 1935 vor den Nationalsozialisten aus Deutschland und gelangte 1939 in die Vereinigten Staaten, wo er als Universitätsdozent an verschiedenen Einrichtungen arbeitete. Nach Kriegsende war er für das OCCWC in Berlin tätig und gehörte zu den Mitarbeitern des von Ferencz 
phone 823-2051) may tell you more. He is a former Prof. at the Free University and colleague from the Nuremberg trials, where I served as Chief Prosecutor against the Einsatzgruppen.

I should be pleased to hear from you, including any comments you may wish to make regarding my book. You may find it suitable for review in some appropriate journal. The Max Planck Institute at Heidelberg has published several articles by me in their encyclopedia prepared by Prof. Bernhardt, ${ }^{141}$ and I have also lectured there. Please feel free to reply in German, if that is more convenient for you.

Cordially yours, ${ }^{142}$

\section{Dokument 203}

Benjamin B. Ferencz an Lucille Green ${ }^{143}$

Ohne Ortsangabe, 26. Mai 1986

Maschinenschriftlicher Brief, 1 Seite

$R G 12.017^{\star} 06$

May 26, 1986

Lucille Green Usitt

774 Colusa Ave.

El Cerritto, CA 94530

geleiteten Rechercheteams zur Vorbereitung der Nürnberger Prozesse. Anfang der 1950er Jahre kehrte er nach Deutschland zurück und war zunächst an der Deutschen Hochschule für Politik sowie ab 1959 an der Freien Universität Berlin Professor für Politikwissenschaft.

141 Der Völkerrechtler Rudolf Bernhardt $\left({ }^{*} 1925\right)$ war seit 1970 Leiter des Max-PlanckInstituts für ausländisches öffentliches Recht und Völkerrecht in Heidelberg. 1981 wurde er zum Richter am Europäischen Gerichtshof für Menschenrechte ernannt und wirkte ab 1998 als dessen Präsident. Bei der Enzyklopädie, auf die Ferencz sich bezieht, handelt es sich um die von Bernhardt herausgegebene Encyclopedia of Public International Law.

142 Unterschrift fehlt auf archivalischer Kopie.

143 Lucille Green (1917-2005) lehrte von 1957 bis 1977 am Merritt College in Oakland und engagierte sich für eine friedliche Weltgesellschaft. Green war Präsidentin des World Citizens Assembly sowie Gründerin und Vizepräsidentin der World Government Organization Coalition. 
Dear Lucille:

Gertrude and I wish to thank you again most sincerely for all of your hospitality during our recent visit to your area. It was a great pleasure to get to know you better and I am confident that this new friendship will endure in the common cause of world peace.

I was quite impressed to learn that there are over 500 groups in California that are actively engaged in seeking a more tranquil international society. Since I have been buried for years in doing my own "homework" as reflected by my six volumes, I have not taken the time to notice the groundswell that is taking place on the part of those who can no longer rely on governments - as you have correctly noted in some of your own writings. I still hope that my concise COMMON SENSE GUIDE TO WORLD PEACE can help to focus attention on some of the many things that need to be done and I do appreciate all of your help in disseminating the message.

I have not forgotten my promise to talk to Oceana Publications about the possibility of their distributing some of the tapes that you have made of the lectures in your World Peace series. I shall meet with the publisher next week and shall suggest that they be in touch with you directly should they see some possibility for cooperation on a mutually beneficial basis.

Sorry that I really didn't know enough about the World Citizen's Assembly and your own leadership role in it to give it the mention it deserved in some of my talks. I am grateful for the materials that you gave me and I have read them carefully. Please accept the attached donation of \$50.- as a modest indication of my support for its objective.

All in all, I had fun in California and I am very satisfied with the trip. I wish I had more time to meet with the many peace groups; perhaps some day there will be a more comprehensive coalition that will make everyone's work easier and more effective. I hope so.

Please convey my appreciation to Minister Boeke, ${ }^{144}$ whose regards I have transmitted to Rev. and Mrs. Nichols in New York.

With warm regards, Cordially, ${ }^{145}$

144 Richard F. Boeke ( $\left.{ }^{\star} 1931\right)$ war von 1973 bis 1995 Pfarrer der First Unitarian Church of Berkeley.

145 Unterschrift fehlt auf archivalischer Kopie. 


\section{Dokument 204}

Benjamin B. Ferencz an Philip M. Klutznick

New Rochelle, N. Y., 12. Dezember 1986

Maschinenschriftlicher Brief, 1 Seite

$R G 12.016^{\star} 15$

Counsellor at Law

Adjunct Professor

Pace Law School

\section{BENJAMIN B. FERENCZ}

14 Bayberry Lane

New Rochelle, N. Y. 10804

(914) 632-3717

December 12, 1986

Philip M. Klutznick Esq.

737 North Michigan Ave.

Chicago, Ill. 60611

My dear Phil:

I have just returned from Florida to find your letter of December 1 and your generous suggestion that I might be a suitable candidate for the position of President of the U.S. Institute of Peace. I really do appreciate your thoughtfulness but I fear that the time has passed for me to consider any full-time employment.

Please allow me to share my thinking with you. I was one of the founding members of the lobby that led to the creation of the Institute of Peace. I met Bob Turner ${ }^{146}$ and he made a fine impression. I know John Norton Moore ${ }^{147}$ and he had some very kind things to say about my book on world peace somewhat to my surprise. Many of the Board members are noted for views which do not seem to be compatible with my more moderate approach. I fear

146 Robert F. Turner $\left({ }^{\star} 1944\right)$ ist Professor für Internationales Recht an der University of Virginia sowie Mitgründer und stellvertretender Direktor des dort angesiedelten Center for National Security Law. 1986 wurde er zum ersten Präsidenten des USIP ernannt und übte das Amt bis 1987 aus.

147 John Norton Moore $\left({ }^{\star} 1937\right)$ wurde 1966 zum Professor für Rechtswissenschaft an der University of Virginia berufen. Von 1985 bis 1991 war er Vorsitzender des Board of Directors des USIP, zudem wirkte er mehrfach als Berater für die amerikanische Regierung. 
that as a President subject to their control I would face more frustration than satisfaction.

I am a man of modest tastes and no personal ambitions. I do not need the title or the money that goes with it. On the other hand, I am thoroughly dedicated to the search for world peace and am willing to do anything in my power to help achieve that vital goal. But I cherish my freedom to say and do as I please. No government employee enjoys that luxury.

You may recall that I was very much interested in an appointment to the Board of Directors. In addition to your own approach to Secretary Shultz, several others intervened on my behalf: John McCloy, Jeane Kirkpatrick, Claiborne Pell, Rudy Boschwitz, Alan Cranston, ${ }^{148}$ Presidents of major Jewish organizations and several peace groups. I would still welcome such an appointment since I feel that I may make a constructive contribution by trying to persuade others who may have a contrary view. I continue to hope that the Institute of Peace will live up to the aspirations of its sponsors.

I hesitate to nominate any candidate for the position of President, but I shall be in touch with a few people with the suggestion that they contact Morris Leibman ${ }^{149}$ directly.

May I extend to you and Ethel and the family my sincerest good wishes for health and happiness in the New Year.

Warm regards, ${ }^{150}$

\section{Dokument 205}

Benjamin B. Ferencz an Patricia und Gerald F. Mische ${ }^{151}$

New Rochelle, N. Y., 17. Dezember 1986

Maschinenschriftlicher Brief, 2 Seiten

$R G 12.016^{\star} 06$

148 Alan Cranston (1914-2000) war ein amerikanischer Politiker der Demokratischen Partei und vertrat von 1969 bis 1993 Kalifornien im Senat der Vereinigten Staaten.

149 Der Jurist Morris I. Leibman (1911-1992) gehörte dem Gründungsumfeld des USIP an, leitete das Foreign Policy Research Institute und war seit 1986 Mitglied des Board of Directors des USIP.

150 Unterschrift fehlt auf archivalischer Kopie.

151 Gerald F. Mische (1926-1995) gründete 1973 gemeinsam mit Patricia M. Mische die Nichregierungsorganisation Global Education Associates, für die er lange Zeit als Präsident tätig war. 


\section{BENJAMIN B. FERENCZ}

Counsellor at Law

Adjunct Professor

Pace Law School
14 Bayberry Lane

New Rochelle, N. Y. 10804

(914) 632-3717

December 17, 1986

Dear Pat and Jerry:

On reviewing my Xmas giving list, I find that somehow this year has rushed by and there was no donation to one of my favorite causes - GEA. ${ }^{152}$ I am not unmindful that the contribution in 1985 was more than had been anticipated, but I am not one to weep over past miscalculations and I know that current bills must still be paid. I am therefore pleased to enclose my check for $\$ 500$, which I hope will help.

You can do something in return - and that is to give me the benefit of your advice on behalf of our common goals. The Center of UN Reform Ed. (which has now moved to Washington) has bought 10,000 copies of my last book. They are in the process of trying to distribute them where they can do most good, and hopefully in a manner that will produce enough income to enable them to acquire additional copies and keep the cycle rolling. They want my guidance as to where the books may effectively be sent. I am really a novice in such matters and your experience is much greater than my own.

I recall your 1985 project to distribute 20,000 of Pat's fine book on STAR WARS ... ${ }^{153}$ As far as I know, only a much lesser number ever went out and the donations that flowed therefrom were less than had been hoped for. What have you learned that can be helpful to the Center for UN Reform? All suggestions would be gratefully received.

When last we met, I mentioned that Ken Keyes ${ }^{154}$ has asked for permission to reprint 100,000 copies of my book on a non-profit basis. I must talk to my publisher about that first, but I still wonder what he will do with all those copies? Is there anything in your experience to indicate that such a vast

152 Global Education Associates.

153 Patricia M. Mische, Star Wars and the State of Our Souls. Deciding the Future of Planet Earth, Minneapolis, Minn., 1985.

154 Gemeinsam mit dem New-Age-Autor Ken Keyes jr. (1921-1995) veröffentlichte Ferencz 1988 das Buch PlanetHood. The Key to Your Survival and Prosperity. In dem Lebensratgeber werden Ansätze zum individuellen Beitrag zu einer freien und sicheren Welt vermittelt. Keyes publizierte daneben zahlreiche Ratgeber und Handbücher zur Selbsthilfe und persönlichen Entwicklung. Siehe auch die Einleitung, $72 \mathrm{f}$. 
number (he even spoke of eventually distributing a million) can actually be put to good use?

On another topic of mutual interest - Pace University has just given permission to have an account opened for a Center for Peace Studies. That is the toe in the door. All I have to do now in order to be able to get full support from the administration is to raise a few million dollars. I am the world's worst fund raiser, and I know that if you knew how to do that your own financial condition would be much improved. But I thought you'd like to know. I'll try. [|2|] On that merry thought, may I extend to both of you and to Harriet and your families, my very best wishes for all good things in the coming year.

Peace to all, ${ }^{155}$

Mische’s, 475 Riverside

$\left\{\$ 500\right.$ Check attached $\left.\#^{156} 3923\right\}$

\section{Dokument 206}

Benjamin B. Ferencz an Rozanne L. Ridgway

New Rochelle, N. Y., 29. Juni 1987

Maschinenschriftlicher Brief, 1 Seite; gedruckter Briefkopf mit maschinenschriftlich eingefügtem Datum

$R G 12.006 .01 * 15$

Benjamin B. Ferencz

\{Hold for SK\}

Counsellor at Law

'June 29, 1987|

14 Bayberry Lane, New Rochelle N. Y. 10804

914 632-3717

Rozanne L. Ridgway

Asst. Secretary of State

State Dept.

Washington D.C.

155 Unterschrift fehlt auf archivalischer Kopie.

156 Die Raute steht an dieser Stelle als Nummernzeichen. 


\section{Dear Roz:}

Pardon me for not being able to resist a favorable comment on the New York Times story of today regarding "Arms and the Woman." ${ }^{157}$ Of course, I agree completely with your observations.

I thought you might want to have a confirming footnote. A few weeks ago, I attended a Five College Program in Peace and World Security Studies at Amherst. Arthur Hartman was one of the speakers and it was a highly professional convocation. There were very few women on the program.

By far the most impressive speaker - who spoke on "The Soviet Military in the Gorbachev Era" was a young lady. Prof. Dr. Condoleezza Rice, ${ }^{158}$ a Special Assistant of the Joint Chiefs, made your point that women are quite as capable (and some, obviously, more capable) of dealing with arms problems as anyone else. If you don't already know her, it would be worth the effort to make her acquaintance.

Have a good summer. No reply to this letter is expected.

Warmest regards,

$\{$ Ben $\}$

$\{$ For SK - \# See over $\}$

\section{Dokument 207}

Benjamin B. Ferencz an James A. R. Nafziger ${ }^{159}$

New Rochelle, N. Y., 18. Januar 1988

Maschinenschriftlicher Brief, 1 Seite; gedruckter Briefkopf mit maschinenschriftlich eingefügtem Datum

$R G 12.014 .01^{\star} 07$

157 Anonymus, Arms and the Woman, in: The New York Times, 29. Juni 1987, B6.

158 Condoleezza Rice $\left({ }^{\star} 1954\right)$ war seit 1981 am Institut für Politikwissenschaft der Stanford University tätig und forschte zu Themen der internationalen Sicherheitspolitik. Seit 1982 in der Republikanischen Partei aktiv, arbeitete sie ab 1989 in verschiedenen Positionen für die Regierung von George H.W. Bush. 2001 bis 2005 war sie Nationale Sicherheitsberaterin und 2005 bis 2009 Außenministerin unter Präsident George W. Bush.

159 Der Rechtswissenschaftler James A. R. Nafziger $\left({ }^{\star} 1940\right)$ ist Professor am College of Law der Williamette University und engagiert sich in verschiedenen juristischen Gesellschaften, etwa der ASIL, für die er als Verwaltungsdirektor tätig war. 
Benjamin B. Ferencz

Counsellor at Law

|Jan. 18, 1988|

14 Bayberry Lane, New Rochelle, N. Y. 10804

914 632-3717

Prof. James Nafziger

Willamette University College of Law

250 Winter St. SE

Salem, Oregon 97301

Dear Jim:

An exciting new development in international law is the recent Gorbachev proposal for a comprehensive system of international security. ${ }^{160}$ Very little about it has appeared in the American press. It appeared in the Soviet press on 16. Sept. 1987 and served as the basis for a Soviet initiative at the United Nations. 70 nations voted to take it seriously.

The Soviets have put forward many propositions which are quite startling. In fact, many of the ideas originated (some years ago) with the United States, which has "poo-pooed" the new Soviet blue-print. Gorbachev is now talking of exploring not merely comprehensive arms controls and the elimination of nuclear weapons, but the elimination of all bases in foreign countries, getting out of Afghanistan, respect for the Charter, an international tribunal to deal with terrorism, economic and ecological security, fundamental human rights in dignity for all, protection of cultural heritages, acceptance of the International Court of Justice, and "the primacy of international law in politics." He is willing to support an Advisory Board or Council of the world's intellectual elite. In fact, it even looks like he has adopted most of the ideas I put forward in my COMMON SENSE GUIDE TO WORLD PEACE.

I think it is the United States that should be seizing the initiative in such matters. Surely it is a subject that should be discussed by the American Society of International Law. I don't know whether Gorbachev is serious with the "initial blueprint", but we shouldn't just let it wither on the vine.

If you can still work this into the panels of the ASIL, I think it would be a constructive contribution. Of course, I would be willing to help in every way on April 21 or 22, when I plan to be in Washington for the meetings.

160 Am 17. September 1987 erschien in der Prawda ein Grundsatzartikel des Generalsekretärs der KPdSU Michail Gorbatschow mit dem Titel Realität und Garantien für eine sichere Welt, in dem er zum Gedankenaustausch über die Gestaltung eines umfassenden Systems der internationalen Sicherheit einlud. 
I look forward to hearing from you and seeing you soon.

$\{$ Ben $\}$

PS The attached brochure and press clipping may be of interest.

\{cc L. Hargrove\}

\section{Dokument 208}

Benjamin B. Ferencz an John Lawrence Hargrove

New Rochelle, N. Y., 2. April 1988

Maschinenschriftlicher Brief, 1 Seite; gedruckter Briefkopf mit maschinenschriftlich eingefügtem Datum, handschriftliche Notiz rechts unterhalb des Briefkopfs

$R G 12.014 .01^{\star} 07$

Benjamin B. Ferencz

Counsellor at Law

'April 2, 1988'

14 Bayberry Lane, New Rochelle, N. Y. 10804

914 632-3717

\{22 Apr. He said he' d send copies to all panelists. I spoke to \#\#\# Lèbiơie̊l + \#\#\# another 100 in request to K. Keys, saying I said OK\}

John Lawrence Hargrove

Executive Director

ASIL

2223 Mass Ave. NW

Washington DC 20008-2864

Dear Larry:

Don't be frightened, but I am sending you 100 copies of my latest book PLANETHOOD. It's a gift to the Society. I would suggest that you set them up on a table of offerings by the ASIL and ask $\$ 2$ per copy. I'll bet the Society will be $\$ 200$ richer before the annual meeting is over.

I must confess that the book is not the usual scholarly tome to which we are both accustomed. But my co-author, Ken Keyes Jr. - who distributed over 
a million copies of his book THE HUNDREDTH MONKEY ${ }^{161}$ - must be doing something right and so I have relied on his style to be able to reach the broad public. It is written in the Talmud: "Look not a gift book in the mouth!" (Ferencz revised edition.)

As you will see, the book is a call for planetary thinking if we are able to have a peaceful world. It tells the public what it can and should do and tries to convince them that the situation is not hopeless and they are not helpless. It is also a plea for international law and order - an appropriate theme for the Society.

When Burns Weston ${ }^{162}$ reviewed my COMMON SENSE GUIDE TO WORLD PEACE, he challenged me to write another one explaining how we get from here to there. ${ }^{163}$ In part, this latest book is my response. It took him a long time to review the first one, so I am somewhat hesitant about suggesting him as a logical reviewer for the sequel. Any of your distinguished VicePresidents would be suitable - but that decision is, of course, up to Detlev Vagts. ${ }^{164} \mathrm{I}$ am enclosing an inscribed copy for you and for him and ask that you send it along with my compliments.

I look forward to seeing you at the annual meeting.

Happy Easter and Shalom

$\{$ Ben $\}$

CC: Prof. Vagts

161 Ken Keyes, The Hundredth Monkey, Coos Bay, Oreg., 1982.

162 Burns H. Weston (1933-2015) war Professor für Rechtswissenschaft an der University of Iowa und seit 1974 Mitglied des Herausgebergremiums des American Journal of International Law. 1999 gründete er das University of Iowa Center for Human Rights.

163 Siehe Burns H. Weston, Review of A Common Sense Guide to World Peace, by Benjamin B. Ferencz, in: The American Journal of International Law 81 (1987), H. 2, 501-503.

164 Detlev F. Vagts (1929-2013) war von 1962 bis 2005 Professor für Internationales Recht an der Harvard-Universität und für das American Journal of International Law tätig, als dessen Mitherausgeber er zwischen 1993 und 1998 fungierte. 


\title{
Dokument 209
}

Benjamin B. Ferencz an Daniel J. Monaco ${ }^{165}$

White Plains, N. Y., 25. April 1988

Maschinenschriftlicher Brief, 1 Seite; gedruckter Briefkopf mit maschinenschriftlich eingefügtem Datum

$R G 12.013 .01^{\star} 16$

Pace Peace Center

\author{
$\diamond \diamond \diamond^{166}$ \\ Pace University \\ New York $\cdot$ Westchester \\ |April 25, 1988| \\ 78 NORTH BROADWAY \\ White Plains, N. Y. 10603
}

(914) 633-0005

Daniel J. Monaco, Esq.

400 S. El Camino Real

San Mateo, CA 94402

Dear Mr. Monaco:

Thank you for your letter of April 20 and the interesting enclosures. I am pleased to give you my "general input" regarding your plan for a Citizen-Initiated Private International Tribunal. ${ }^{167} \mathrm{I}$ will restrict myself to only two points at this time.

The Title: In my book A COMMON SENSE GUIDE TO WORLD PEACE (p. 89-91) I proposed the establishment of a Permanent Council for Peace composed of renowned thinkers, spiritual, community and business leaders who could "go over the heads of governments to reach the eyes, ears, hearts and minds of people everywhere." I deliberately stayed away from calling it a tribunal because it would lack the powers of investigation or subpoena

165 Der Jurist Daniel J. Monaco (1922-2007) war Professor für Internationale Wirtschaft an der Florida University. Er engagierte sich u. a. in der World Jurist Association, der er von 1999 bis 2001 als Präsident vorstand.

166 Logo der Pace University.

167 Daniel J. Monaco hatte 1996 in einem Beitrag für den World Jurist die Idee eines Citizens' World Court vertreten. Siehe Daniel J. Monaco, A Citizens' World Court, in: The World Jurist 33 (1996), H. 6, 9. 
ordinarily associated with a court. Because, as you have recognized, the Russell Tribunal ${ }^{168}$ fell into disrepute, I did not wish to evoke negative images. Perhaps a better title can be found.

It may be worth noting that General Secretary Gorbachev, in his Comprehensive Security Plan of Sept., 1987, called for "the establishment under United Nations auspices of a world advisory council comprising the world's intellectual elite." ${ }^{169}$ This idea confronted US and other opposition and was not pressed when it was debated at the UN.

Criminal Jurisdiction: Some years ago, I became Chairman of the WPLC Committee for the Establishment of an International Criminal Court. As far as I could see, I was about the only person interested in doing anything about it. You may wish to look at my two-volume book, AN INTERNATIONAL CRIMINAL COURT, for the history of efforts to create such a tribunal. Much of it is very relevant to what you are proposing. Feasibility has been debated at length and the reports are worth reading.

Your plan should be expanded to include international criminal jurisdiction, particularly regarding crimes that affect the peace, such as aggression (See my two-volumes DEFINING INTERNATIONAL AGGRESSION), terrorism, apartheid and crimes against humanity.

Please pass these comments to the other committee members.

With all good wishes,

$\{$ Ben $\}$

Benjamin B. Ferencz

Executive Director

168 Das internationale Russell-Tribunal, auch Vietnam War Crimes Tribunal genannt, wurde 1966 von dem Philosophen und Literaturnobelpreisträger Bertrand Russell (1872-1970) sowie weiteren prominenten Kritikern des Vietnamkriegs initiiert. Es tagte 1967, um Informationen über die amerikanischen Kriegsverbrechen in Vietnam zu sammeln, diese zu dokumentieren und zu verhandeln. Der französische Schriftsteller und Philosoph Jean-Paul Sartre (1905-1980) agierte als Präsident des Tribunals. Juristische Entscheidungsbefugnis besaß die Versammlung trotz quasi-justizieller Strukturen nicht. Neben der Dokumentation der Verbrechen wurde besonders die moralische Anklage als politisches Mittel genutzt. Siehe dazu Philipp Gassert, Amerika vor Gericht. Das Russell Tribunal 1966/67, die Nürnberger Prinzipien und die Politik des "Blaming and Shaming «, in: Norbert Frei/Annette Weinke (Hg.), Toward A New Moral Order? Menschenrechtspolitik und Völkerrecht seit 1945, Göttingen 2013, 149-163.

169 Siehe dazu Dokument 207. 


\section{Dokument 210}

Benjamin B. Ferencz an The New York Times

New York, 22. Mai 1988

Gedruckter Zeitungsausschnitt (Leserbrief), ${ }^{170} 1$ Seite

$R G 12.016^{\star} 01$

\section{THE NEW YORK TIMES, SUNDAY, MAY 22, 1988}

What's Bad for Glasnost Is Bad for Us

To the Editor:

David K. Shipler's ${ }^{171}$ perceptive article (May 8$)^{172}$ describes the struggle of apprehensive Soviet citizens grappling toward a society of openness and new political thinking. This striving to move away from totalitarianism and repression offers hope and opportunity to people everywhere. It merits strong American support lest this emerging glasnost process perish in the cradle.

Mikhail Gorbachev's Pravda article of Sept. 17, 1987, ${ }^{173}$ offered a comprehensive plan for international security. He called for total nuclear disarmament - a goal shared by President Reagan - and the abolition of "all weapons of mass destruction" as well as a balance in conventional weapons of all kinds.

The Soviet leader appealed for the "peaceful settlement of disputes," the creation of an international tribunal to cope with international terrorism, "respect for human rights and dignity" and "co-operation in all fields, military, political, economic, ecological, humanitarian and so forth." He even suggested giving the International Court of Justice binding jurisdiction in "a universal

170 Benjamin B. Ferencz, What's Bad for Glasnost Is Bad for Us, in: The New York Times, 22. Mai 1988, 28.

171 David K. Shipler $\left({ }^{\star} 1942\right)$ war Auslandskorrespondent von The New York Times und Schriftsteller. 1987 gewann er für sein Buch Arab and Jew. Wounded Spirits in a Promised Land den Pulitzerpreis.

172 David K. Shipler, In Soviet, Change Struggles to Emerge, in: The New York Times, 8. Mai 1988, 1.

173 Siehe dazu Kapitel 9, Fußnote 159. 
legal order which will ensure the primacy of international law in politics." These are ideals traditionally espoused by the United States.

The Gorbachev plan was all but ignored by the American press. It was officially greeted by the United States with skepticism and disdain. Although only an "initial blueprint," the U. S. denounced it as "dangerous" at the United Nations on Nov. 25, 1987, standing almost alone against it. We cannot be a world leader simply by saying no. Our negativism was not consistent with our best traditions.

If Mr. Gorbachev's movement toward democratic processes fails, he will be defeated by the authoritarian wing within his own society. The Soviet people will face new repressions and despair. We all will be condemned to a continuation of the arms race, which robs us of resources to improve the human condition.

Let America resume its leadership role as a visionary for democracy and peace. In this time of struggle within Soviet society and other totalitarian states, let us discreetly lend our support to all the democratic forces by showing that we welcome such movements as we join together to create a more humane and peaceful world.

BENJAMIN B. FERENCZ

Exec. Dir., Pace Peace Center

Pace University School of Law

White Plains, May 8, 1988

\section{Dokument 211}

Benjamin B. Ferencz an Robert Pickus ${ }^{174}$

White Plains, N. Y., 22. Juni 1988

Maschinenschriftlicher Brief, 1 Seite; gedruckter Briefkopf mit maschinenschriftlich eingefügtem Datum

$R G 12.017^{*} 14$

174 Robert Pickus (1923-2016) war ein amerikanischer Friedensaktivist und Publizist. Er engagierte sich für juristische und politische Konfliktlösungsstrategien als Alternativen zu militärischen Konflikten. Zu diesem Zweck gründete und leitete er mehrere Organisationen der Friedensbewegung, etwa Act for Peace und World Without War Council. 


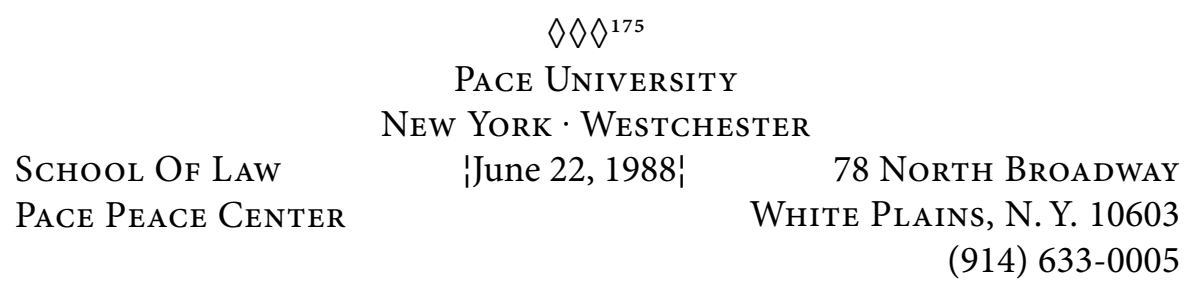

Robert Pickus, President

World Without War Council

1730 Martin Luther King Jr. Way

Berkeley, CA 94709

Dear Bob:

Since you made the presentation I heard at the USIP Conference, you are being rewarded (or punished) by a prize. I have just mailed to you a book that relates to the subject of your discourse. I hope you will find ENFORCING INTERNATIONAL LAW (2 volumes) useful on our combined quest for world peace. You may note that I have tried to do what you recommended: aim for the overview function - the synthesis job. All constructive criticism is gratefully received.

I am a great admirer of Myres McDougal. ${ }^{176} \mathrm{He}$ concluded from his monumental overview that the greatest challenge that lawyers could face was to create a lawful order where minimum standards of human dignity could be maintained. I addressed that problem in six volumes. (Relax - I have not sent them all to you.) The gist of my thinking can be found in my COMMON SENSE GUIDE TO WORLD PEACE, which you will find somewhere under those piles in your office. PLANETHOOD is my effort (with the help of Ken Keyes Jr. of HUNDREDTH MONKEY fame) to arouse the broad public.

I have no illusions whatsoever about how long it will take to move from the present war system to a more rational world order. You have recognized that there is a new wind blowing and perhaps we have set sail. I don't know whether Gorbachev is really serious or that he can prevail, but I think we've got to take a chance and explore "new thinking" in a very serious way. (See my attached letter to the NY Times.)

175 Logo der Pace University.

176 Myres S. McDougal (1906-1998) war Professor für Internationales Recht an der Yale University. 
If you agree that PLANETHOOD is a step "in the right direction," you may wish to send or offer copies to your Evangelicals or any others on your distribution network.

It was good seeing you again. When I visited you in your office about 2 years ago, you had just recovered from an operation and were rather down. Now I was happy to note that you looked fine and cheerful and could refer to your "past depression." Keep moving forward and let me hear from you.

Warm greetings and peace.

$\{$ Ben $\}$

Benjamin B. Ferencz

\{Reply to my home

i4 BAYBERRY LANE

New Rochelle N.Y. 10804\}

\title{
Dokument 212
}

Benjamin B. Ferencz an Samuel W. Lewis ${ }^{177}$

White Plains, N. Y., 23. Juni 1988

Maschinenschriftlicher Brief, 1 Seite; gedruckter Briefkopf mit maschinenschriftlich eingefügtem Datum, unleserliche handschriftliche Notiz am unteren Textrand

RG $12.017^{\star} 14$

School Of LaW

Pace Peace Center

\author{
$\diamond \diamond \diamond^{178}$ \\ Pace University \\ NeW York $\cdot$ Westchester \\ IJune 23, 1988! \\ 78 North BroadWAY \\ White Plains, N. Y. 10603 \\ (914) 633-0005
}

177 Der amerikanische Diplomat Samuel W. Lewis (1930-2014) war von 1987 bis 1993 zweiter Präsident des USIP und entwickelte dessen programmatische Ausrichtung weiter. Zuvor war Lewis von 1977 bis 1985 amerikanischer Botschafter in Israel und hatte an den Friedensverhandlungen zwischen Israel und Ägypten mitgewirkt.

178 Logo der Pace University. 
Samuel W. Lewis, President

United States Institute of Peace

1150 M St. NW, Washington DC 20050-1708

Dear Sam:

Let me again thank you for your kind invitation to attend the USIP conference at Airlie House. After having heard so much about you from Phil Klutznick and Rabbi Israel Miller, it was a pleasure to make your acquaintance. I share their enthusiasm.

I was one of the founding members of the Peace Academy Campaign. I must confess that I didn't really think it would get off the ground. When, after long labor, USIP was finally born, I feared for the life of what seemed a deformed child. I admired your courage, if not your judgement, when you adopted the infant. I was therefore particularly delighted to find that, under your guidance, USIP now holds great promise.

If the bird of peace is to fly, both the right wing and the left wing must learn to work in harmony. It won't be easy. Dialogue is vital. I would have welcomed more time in smaller groups so that diverse views could be debated to conclusion. The Conference was an excellent beginning of what I hope will be an ongoing and refined process.

The focus of my scholarly tomes has been on replacing the law of force by the force of law. The creation of a system of acceptable laws that guarantee human dignity, of international courts and of effective enforcement will take many years - and it is a race with catastrophe. USIP can become the most useful tool in educating the public on what needs to be done as we seek to replace the prevailing international anarchy with international law and order and the rational management of this little planet.

With every good wish, Shalom!

\{Ben $\}$

Benjamin B. Ferencz

Executive Director 


\section{Dokument 213}

Benjamin B. Ferencz an The New York Times

White Plains, N. Y., 18. Oktober 1988

Maschinenschriftlicher Leserbrief, 2 Seiten; gedruckter Briefkopf mit maschinenschriftlich eingefügtem Datum auf Seite 1

$R G 12.017^{\star} 22$

School Of LaW

Pace Peace Center

\section{$\Delta \diamond \diamond^{179}$ \\ Pace University \\ New York $\cdot$ Westchester \\ 'October 18, 1988'}

White Plains, N. Y. 10603

(914) 633-0005

To the Editor:

A.M. Rosenthal (Op-Ed, Oct. 18) ${ }^{180}$ has appropriately remembered Raphael Lemkin $^{181}$ as the man who inspired the Genocide Convention which now awaits the President's signature. ${ }^{182}$ Deserved tribute also belongs to retiring Senator William Proxmire ${ }^{183}$ and William Korey of B'nai B'rith who picked up Lemkin's torch in finally obtaining U.S. acceptance of this delayed gesture towards humankind. The time has come to supplement symbolism with substance.

Shocked by the disclosures at the Nuremberg trials, the first assembly of the United Nations declared genocide to be a crime under international law.

179 Logo der Pace University.

180 Abraham M. Rosenthal (1922-2006) war seit 1943 für The New York Times tätig, zunächst als Reporter, 1977 bis 1988 als Chefredakteur und anschließend bis 1999 als Kolumnist. Bei dem Artikel handelt es sich um Abraham M. Rosenthal, A Man Called Lemkin, in: The New York Times, 18. Oktober 1988, A31.

181 Raphael Lemkin (1900-1959) war ein polnisch-jüdischer Jurist, der den Begriff Genozid prägte. Er arbeitete 1947 für die Vereinten Nationen einen Gesetzentwurf zur Bestrafung von Völkermord aus, auf dem die im folgenden Jahr verabschiedete UN-Genozidkonvention basierte.

182 Die Vereinigten Staaten ratifizierten die UN-Genozidkonvention im Jahr 1988.

183 Der amerikanische Politiker William Proxmire (1915-2005) war Mitglied der Demokratischen Partei und von 1957 bis 1989 Senator für Wisconsin. Zwischen 1967 und 1986 hielt er an jedem Tag, an dem der Senat tagte, eine Rede, in der er die Ratifikation der UN-Genozidkonvention durch die Vereinigten Staaten forderte. 
A convention was drafted in 1947 requiring punishment of guilty individuals, regardless of rank. ${ }^{184}$ Recognizing that genocide usually involves connivance by state, the draft provided that if a national tribunal was not prepared to try the offense, the accused was to be handed over to an International Criminal Court. When the convention was adopted by the U.N., that enforcement provision was removed. There exists no international criminal court to try those guilty of genocide, terrorism, drug-trafficking, apartheid or other crimes against humanity. Little wonder that such crimes have continued unabated.

[|2|] The United States must stand for more than symbolism if it is to remain the leader of the free world. Congressman Jim Leach ${ }^{185}$ of Iowa has authored a resolution for the creation of an International Criminal Court with jurisdiction over crimes of terrorism, genocide and torture. Senator Arlen Specter ${ }^{186}$ of Pennsylvania is supporting similar action. These efforts deserve the support of all who wish to convert Lemkin's vision into reality.

\{Benjamin B. Ferencz\}

Benjamin B. Ferencz

Executive Director

NY Times

229 W. 43 St. NY 10038

Dear Editor: Alternate titles: Former Prosecutor, Nuremberg War Crimes Trials; or Author of A COMMON SENSE GUIDE TO WORLD PEACE

I can best be reached by phone before 9 . A. M.

\section{Dokument 214}

Benjamin B. Ferencz an Daniel J. Monaco

Ohne Ortsangabe, 8. Oktober 1988

Maschinenschriftlicher Brief, 1 Seite

$R G 12.013 .01^{\star} 16$

184 United Nations General Assembly, A/RES/180, Draft Convention on Genocide, New York, 21. November 1947.

185 James Albert Smith Leach $\left({ }^{*} 1942\right)$ war von 1977 bis 2007 Abgeordneter der Republikanischen Partei im Repräsentantenhaus der Vereinigten Staaten.

186 Von 1981 bis 2011 war Arlen Specter (1930-2012) Senator für Pennsylvania und langjähriges Mitglied des Justizausschusses des Senats der Vereinigten Staaten. 
Daniel J. Monaco, Esq.

400 South El Camino Real

San Mateo, CA 94402

Dear Mr. Monaco:

Thank you for your letter of Sept. 20 with the most recent draft of the proposed Statute of the Citizen's World Court. My present comments may be taken as a supplement to what I wrote on April 25, 1988. You may wish to share them with your group.

I have noted with approval the comments made by Voitto Saario ${ }^{187}$ of Finland and Dr. Aguda of Nigeria. ${ }^{188}$ I also appreciate your own awareness that the problem of organizing, maintaining and functioning such a Court are yet to be resolved.

It seems to me that the best that can be hoped for is some symbolic assemblage of qualified jurists who may comment on some specific problem which affects international peace and which has not been dealt with by the International Court of Justice.

The idea of a permanent institution sitting somewhere in The Hague, with regular staff and salaries and receiving petitions from individuals from any part of the world is, in my judgement, completely unrealistic in the political climate of the world today. The difficulties and historical record is contained in my two-volume book AN INTERNATIONAL CRIMINAL COURT - A Step Toward World Peace (Oceana, 1980).

Some progress is possible and should be vigorously pursued. Mr. Gorbachev has offered a Comprehensive Security Plan which indicates some Soviet willingness - for the first time - to consider binding international jurisdiction for a world court and an international criminal court to deal with terrorism. The U.S. bar association and other groups have also come out in support of the latter.

I am enclosing my recent correspondence with the Legal Adviser of the State Dept., Senator and Congressman Leach who introduced a joint

187 Voitto Saario (1912-2001) war Richter am Obersten Gerichtshof Finnlands und gehörte zwischen 1956 und 1980 finnischen Delegationen bei UN-Generalversammlungen an. Er beschäftigte sich insbesondere mit Menschenrechtsfragen und dem Schutz von Minderheiten.

188 Der nigerianische Richter Akinola Aguda (1923-2001) leitete ab 1979 das neu gegründete Nigerian Institute of Advanced Legal Studies und engagierte sich dort gegen Korruption in Nigeria. 
resolution calling for the creation of an international criminal court. If you can support these endeavors, and the other members of your committee can do the same in their countries, we may be able to make progress toward an institution which is backed by governmental support. Your statute can be useful in that context.

With best wishes,

Benjamin B. Ferencz

Executive Director

\section{Dokument 215}

Benjamin B. Ferencz an Ronald J. Glossop ${ }^{189}$

New Rochelle, N. Y., 27. Januar 1989

Maschinenschriftlicher Brief, 2 Seiten; handschriftliche Ergänzungen und Unterstreichungen, handschriftliche Notiz unten auf Seite 1 (»Rec a check of $\$ 278$ Feb. 28/sq (dated Feb. 8) «)

$R G 12.017^{\star} 26$

\section{BENJAMIN B. FERENCZ}

Counsellor at Law

Adjunct Professor

Pace Law School
14 Bayberry Lane

New Rochelle, N.Y. 10804

(914) 632-3717

January 27, 1989

$\{22-4$ April $\}$

Ronald J. Glossop, Chairman

World Federalist Association of Greater St. Louis

8894 Berkay Ave.

Jennings, Missouri 63136

189 Der Philosophieprofessor Ronald J. Glossop $\left({ }^{\star} 1933\right)$ war an der Southern Illinois University tätig und koordinierte dort das Peace Studies Program. Zudem engagiert er sich seit 1979 bei der World Federalist Association. 2016 nominierte Glossop Benjamin B. Ferencz für den Friedensnobelpreis. Das Schreiben ist einsehbar unter $<$ http://www.nobelwill.org/ferencz_pace_nomination2016.pdf> (28. Juli 2018). 
Dear Ron:

Thank you for your letter of 21 Jan. I phoned you and spoke to your wife this morning to confirm that I am pleased to accept your kind invitation to address both the Federalists and the Ethical Society of St. Louis.

I have accepted your suggestions regarding my flying plans. Knowing that peace organizations are usually strapped for funds, I have managed to book a Super-Saver flight on TWA. ${ }^{190}$ Their confirmation of the flights and roundtrip price of $\$ 278$ is attached. (The regular price is $\$ 572$.) I am planning to fly to St. Louis Saturday evening 22 April on TWA \#367 ${ }^{191}$ which arrives there at 9:19 P.M. I shall fly back to LaGuardia airport NY on Monday morning 24 April on TWA $\# 140^{192}$ which leaves St. Louis at 10:59 A. M.

I have noted your willingness to purchase the tickets and mail them to me, but I believe it will be simpler if I ask my travel agent here to issue the tickets and you can reimburse me for expenses later. I appreciate your willingness to put me up in your home, but I would have no objection to staying at a modest motel if that is convenient for you. I must warn you that I'm on a lowcholesterol diet (oatmeal, fish, chicken, tea and similar funny foods ostensibly designed to keep me alive forever). In the cause of peace, on this planet and at home, I do not wish to impose unnecessary burdens on Mrs. Glossup [sic]. I leave it to your good judgement.

Let me confess that I am a rotten P.R. man. I don't have anything resembling a good press handout - despite the fact that I am very often asked for one. I am enclosing a few news clippings from which something can be extracted, and I am also enclosing the blurb used by the World Federalists ${ }^{193}$ of Pittsburgh when I addressed them some time ago. The introduction to PLANETHOOD also contains material which can be used to suit the tastes of the good citizens of St. Louis. Since I have never been there, I must again leave that to your judgement. An old [|2|] photo is thrown in for good measure but I have no idea when it was taken. Any resemblance is purely coincidental.

Since I do not speak from any written script, the topic title is also flexible. Following your lead, I might talk to the Ethical Society. about "Progress Toward a Peaceful and Ethical Planet." I would tell them how far we've come

190 Trans World Airline.

191 Die Raute steht an dieser Stelle als Nummernzeichen.

192 Die Raute steht an dieser Stelle als Nummernzeichen.

193 Das World Federalist Movement ist eine 1947 gegründete internationale Bürgerbewegung, die sich für die Einrichtung starker globaler, föderaler und demokratischer Institutionen einsetzt, die über die am Prinzip nationalstaatlicher Souveränität orientierten Strukturen der Vereinten Nationen hinausführen sollen. 
and not to give up hope. I would tell them if they want to know what to do and where we're going, come to the evening meeting of the Federalists. The evening topic could be something like "What You Can Do to Create a Peaceful Planet." Please feel free to make any modifications you wish and put on any title that will attract your intended audiences. I will adapt to the needs of the situation. <I'm an expert on everything - but nothing else!>

I understand that Ken Keyes Jr. has donated 100,000 copies of PLANETHOOD to [the] World Federalists in Washington. You should therefore be able to get enough copies from Eric Cox to provide a free copy to everyone who attends either meeting. In Pittsburgh, the Federalist Exec. Tim Barner ${ }^{194}$ (a great guy), pushed each participant at the dinner to take " 5 copies for 5 bucks." It went very well and can be an added fund-raiser for both groups. $<$ You keep the money or, if you wish, order additional copies from Ken Keyes in Coos Bay, Oregon.> They can give copies to friends, enemies, public officials etc. It's cheaper than a greeting card and suitable for every occasion. I am, of course, willing to autograph copies, which enhances the value by at least 3 cents.

Let me know if all of this is agreeable and I would suggest that you send me copies of whatever publicity material you prepare. If you can round up some of the young people from the local university or other schools, or some of the other peace groups or churches so much the better. I am also available within the stated time frame for radio talk shows, TV interviews, or other appearances which may serve the cause of peace. What more can anyone ask?

Perhaps we shall meet in Washington on Feb. 24-26. I look forward to hearing from you and meeting you all.

Peace,

$\{$ Ben $\}$

194 Timothy Barner war Geschäftsführer der World Federalist Association of Pittsburg (seit 2003 Citizens for Global Solutions) und ist Vizepräsident der US-amerikanischen United Nations Association sowie Director for Leadership Development des Friends Committee on National Legislation. 


\section{Dokument 216}

Benjamin B. Ferencz an Elie Wiesel ${ }^{195}$

New Rochelle, N. Y., 15. April 1989

Maschinenschriftlicher Brief, 1 Seite

RG $12.014 .05^{\star} 02$

\{File PP\#\}

Counsellor at Law

Adjunct Professor

Pace Law School
14 Bayberry Lane

New Rochelle, N. Y. 10804

(914) 632-3717

April 15, 1989

Prof. Elie Wiesel

Boston College

85 Centre St.

Newton, MA 02159

Dear Elie:

Although I know how very busy you are, I must write in response to your article "Are We Afraid of Peace?" (Parade Magazine, Mar. 19, 1989). No, I don't think we are afraid of peace; quite the contrary. There is a universal longing for peace, but humankind does not know how to achieve it and help is desperately needed.

I suppose that ever since I witnessed the liberation of Buchenwald and other camps, and prosecuted the Einsatzgruppen, it was inevitable that I would dedicate my life to trying to create a more humane and peaceful world.

195 Der Schriftsteller Elie Wiesel (1928-2016) überlebte den Holocaust und machte diese Erfahrung sowie die Erinnerung an die Opfer zum Gegenstand seiner literarischen Texte. Zwischen 1980 und 1986 war er Vorsitzender des United States Holocaust Memorial Council, dem Aufsichtsgremium des United States Holocaust Memorial Museum. Für sein Engagement für Frieden und Menschenrechte erhielt er 1986 den Friedensnobelpreis.

196 Handschriftliche Notiz oberhalb des Briefkopfs bezüglich einer Adresskorrektur am 1. Mai. 
$<$ My wife, who is from Satu Mare, ${ }^{197}$ says someone up there is guiding me, but not being a Hasid like you, I have no explanation.>

You ask why there are no universities, or so few, teaching the means of attaining peace. I am probably the only one in the country teaching "The International Law of Peace" and directing a Peace Institute (which is me) concentrating on creating a world of peace through law rather than violence.

My latest book, PLANETHOOD (not copyrighted and given away at cost,) has gone into 300,000 copies thus far. I am not enclosing it you [sic] since I gave you a copy of my more comprehensive COMMON SENSE GUIDE TO WORLD PEACE, together with my book LESS THAN SLAVES, when we met at McGill in Nov. 1987. I hope you had a chance to look at them. Should you wish a copy of Planethood, ${ }^{198}$ I would be pleased to oblige.

The article reported that your foundation is sponsoring a series of seminars on the theme "Beyond Hate." The thrust of my writing has always been that we must go beyond hate to build a better world. If I can be of any help in connection with those seminars, I would surely try to do so. Please let me know. It would be good to have some word from you.

With warm greetings and all good wishes, ${ }^{199}$

\section{Dokument 217}

Benjamin B. Ferencz an Rick Alexander ${ }^{200}$

New Rochelle, N. Y., 12. Mai 1989

Maschinenschriftlicher Brief, 1 Seite

$R G 12.017 * 26$

Counsellor at Law

Adjunct Professor

Pace Law School

\section{BENJAMIN B. FERENCZ}

14 Bayberry Lane

New Rochelle, N. Y. 10804

(914) 632-3717

May 12, 1989

197 Kreishauptstadt des gleichnamigen Kreises in Rumänien.

198 Das Wort ist im Original eingekringelt.

199 Unterschrift fehlt auf archivalischer Kopie.

$200 \mathrm{Zu}$ dieser Person konnten keine biografischen Informationen ermittelt werden. 
Rick Alexander

Church of Scientology

118 North Ft. Harrison Ave.

Clearwater, Florida 34615

Dear Rick:

Thank you for your letter of May 8 and the interesting Plan for World Peace by Dr.L. Ron Hubbard. ${ }^{201}$ I have perused it quickly and am pleased to give you my observations - bearing in mind that I have not had the time to give it detailed and profound consideration.

I agree with the basic goal of Scientology to create a peaceful world order. The idea of a centralized authority to control arms and to maintain peace without interfering in individual activities more than is essential, certainly has my support. I also agree that the UN need reform.

I must say, however, that many of the specific steps of the program seem to be quite unattainable in the foreseeable future. I do not see how it will be possible, for example, to persuade all governments to turn all of their nuclear weapons over to the UN and to move their operational capitals to a new International City. The present UN has done effective work in controlling certain diseases world-wide and the attempt to exclude the UN from such activities (Step 10) seems to me to be unnecessary. The financing and economic provisions seem to be vague or cumbersome. The program also excludes the UN from activities which it does not presume to have (Step 17). The idea for a Charter that would not be subject to amendment seems to assume that the world will never change.

In short, I fear that the author has underestimated the difficulties and has not adequately perceived the complications of carrying out the plan. In the 26 years since it was devised, it has apparently not been taken very seriously and is not on anyone's active agenda - as far as I know.

My own thoughts about how to create a peaceful world are contained in my many books (See brochure). I do not purport to have all of the answers and welcome any improvements. But I fear that Dr. Hubbard has not made out a persuasive case.

With best wishes,

$\{$ Ben $\}$

201 L. Ron Hubbard (1911-1986) war ein Science-Fiction-Autor und gründete 1954 die Scientology-Kirche. Der erwähnte Text ist wahrscheinlich: L. Ron Hubbard, Scientology: Plan for World Peace, East Grinstead 1964. 


\title{
Dokument 218
}

Benjamin B. Ferencz an Walter F. Hoffmann ${ }^{202}$

White Plains, N. Y., 18. August 1989

Maschinenschriftlicher Brief, 1 Seite; gedruckter Briefkopf

$R G 12.013 .01^{\star} 08$

School Of LaW

78 NORTH BROADWAY

Pace Peace Center

\author{
$\triangle \diamond \Delta^{203}$ \\ PaCe University \\ New York $\cdot$ Westchester
}

White Plains, N. Y. 10603

(914) 633-0005

August 18, 1989

Walter Hoffman [sic], Executive Vice-President

Campaign for UN Reform

418 Seventh St. SE

Washington DC 20003

Re: International Criminal Court

Dear Walter:

Yesterday, I was visited by Ambassador Marjorie Thorpe, ${ }^{204}$ head of the Permanent Mission of Trinidad and Tobago to the UN. (675 Third Ave., NY 10017, Tel. (212) 687-7620) She was joined by First Secretary, Evans L. King, and Second Secretary Delia M. Chatoor. ${ }^{205} \mathrm{I}$ was informed that, on the

202 Walter F. Hoffmann (1924-2014) war ein Bürgerrechtsanwalt und Friedensaktivist. Er engagierte sich in zahlreichen Nichtregierungsorganisationen, war Mitglied des WPLC, Direktor der World Federalist Association in Washington und Initiatior sowie geschäftsführender Vizepräsident der Campaign for UN Reform.

203 Logo der Pace University.

204 Marjorie Thorpe $\left({ }^{\star} 1941\right)$ vertrat von 1988 bis 1992 Trinidad und Tobago als Botschafterin bei den Vereinten Nationen. Zuvor lehrte sie englische Literatur an der University of the West Indies in St. Augustine, Trinidad und Tobago.

205 Delia Chatoor arbeitete seit den 1980er Jahren für das Außenministerium Trinidad und Tobagos, unter anderem als Beraterin in Angelegenheiten des internationalen 
suggestion of Prime Minister, A.N.R. Robinson, ${ }^{206}$ they would welcome my views on a draft $\mathrm{UN}$ resolution and memo regarding the establishment of an international criminal court. Of course, I was pleased to oblige.

Since your office has been active in promoting such a court, and since you met with the Prime Minister during his visit to Washington last April, I thought you would be interested in knowing of this development and in lending it every support.

The resolution calls for the inclusion in the agenda of the up-coming 45th UN session of an item entitled: "International Criminal Responsibility of Individuals and Entities engaged in the Illegal Trafficking in Drugs across National Frontiers: Establishment of an International Criminal Court with Jurisdiction over such Offences." 207

I understand the proposal will be submitted to the Secretary General on Aug. 21. I am hereby suggesting to the Ambassador that she send you, and me, a copy of the revised text. I am sure that I can count on you and Eric Cox to take whatever steps are appropriate at the UN and in Washington to obtain support for this constructive proposal.

Warm greetings,

$\{$ Ben $\}$

Benjamin B. Ferencz

Executive Director

CC: Amb. Thorpe

Rechts und der Menschenrechte. Von 1988 bis 1996 wurde sie in die Ständige Vertretung Trinidad und Tobagos bei den Vereinten Nationen entsandt.

206 Arthur N. R. Robinson (1926-2014) war von 1986 bis 1991 Premierminister und von 1997 bis 2003 Präsident von Trinidad und Tobago.

207 Siehe United Nations General Assembly, A/RES/44/39, International Criminal Responsibility of Individuals and Entities Engaged in Illicit Trafficking in Narcotic Drugs Across National Frontiers and Other Transnational Criminal Activities: Establishment of an International Criminal Court With Jurisdiction Over Such Crimes, New York, 4. Dezember 1989. 


\section{Dokument 219}

Benjamin B. Ferencz an The New York Times

New Rochelle, N. Y., 27. August 1989

Maschinenschriftlicher Leserbrief, 1 Seite

RG $12.013 .01 * 08$

Counsellor at Law

Adjunct Professor

Pace Law School

\section{BENJAMIN B. FERENCZ}

\author{
14 Bayberry Lane
}

New Rochelle, N. Y. 10804

(914) 632-3717

August 27, 1989

$\{\# \#$ \#

To the Editor:

All praise to Walter Hoffman's [sic] appeal for a Nuremberg-style international court to try terrorists and drug traffickers (Aug. 27). ${ }^{208}$ In addition to backing House Concurrent Resolution $66,{ }^{209}$ we should also support a new initiative in the United Nations. Trinidad and Tobago has called for an international tribunal to deal with drug-traffickers. It may be easier to reach agreement on this more-limited approach as a first step - if the United States will support it.

The international community has, thus far, been unable to reach consensus on either an unqualified definition of terrorism or the need for an international criminal court. Surely, the supranational criminality spawned by those who trade in lethal drugs is a form of terrorism that needs and merits universal punishment. To condemn international crimes for which there is no

208 Walter Hoffmann, We Need an International Court on Terrorism, in: The New York Times, 27. August 1989, 18.

209 Die Resolution sprach sich für die Einrichtung eines internationalen Strafgerichtshofs aus und forderte den Präsidenten der Vereinigten Staaten auf, eine internationale Konferenz einzuberufen, um Verhandlungen über ein multilaterales Abkommen zur Errichtung eines internationalen Strafgerichtshofs voranzutreiben. United States House of Representatives, H. Con. Res. 66, Calling for the Creation of an International Criminal Court With Jurisdiction Over Internationally Recognized Crimes of Terrorism, Illicit International Narcotics Trafficking, Genocide, and Torture, as those Crimes are Defined in Various International Conventions, Washington, D. C., 2. März 1989. 
international court is to mock justice and encourage criminality. It is time for the world community to unite in wiping out this scourge.

\{Benjamin B. Ferencz\}

Benjamin B. Ferencz

Former Executive Counsel, Nuremberg War Crimes Trials

Editor: Alternative titles;

Executive Director, Pace Peace Center, Pace University School of Law

NY Times

229 W. 43 St. NY 10036

\title{
Dokument 220
}

Benjamin B. Ferencz

Ohne Ortsangabe, 28. August 1989

Maschinenschriftlicher Bericht, 2 Seiten; gedruckter Briefkopf mit maschinenschriftlich eingefügtem Datum auf Seite 1, maschinenschriftliche Unterstreichungen $R G 12.014 .05^{\star} 02$

School Of LaW

78 North BRoAdWAY

Pace Peace Center

\author{
$\Delta \diamond \nabla^{210}$ \\ Pace University \\ New York $\cdot$ Westchester
}

|August 28, 1989; White Plains, N. Y. 10603

(914) 633-0005

\section{THE PACE PEACE CENTER - A BRIEF REVIEW AND CURRENT REPORT}

ORIGIN AND PURPOSE: After nearly two years of indecision, the Peace Center was finally approved by the University and Law School authorities in mid-1987. Its planned programs to educate for peace were as set forth in the attached brochure. Since neither funds nor space was immediately available, seed money (less than $\$ 15,000$ ) was raised by the Executive Director, who (in addition to teaching "the International Law of Peace" as an Adjunct Professor)

210 Logo der Pace University. 
agreed to serve without pay and to launch the Pace [sic] Center from his home in New Rochelle.

FUNDING: With the help of the Development Office, requests for grants were submitted to a number of foundations. The first year only $\$ 300$ for a Speaker's Bureau was forthcoming (Juniata College OPTIONS program). An additional \$500 was granted in 1989. The United States Institute of Peace offered $\$ 10,000$ for a bibliography of peace books suitable for law libraries and a similar listing of video and audio tapes. That grant is shared by Pace Law student Richard Duffee and Pace employee Dr. Rose Cooper to whom the work has been assigned. A leading law publisher has expressed interest in publishing the results.

ACTIVITIES: Because of the shortage of funds, it was not possible to employ even secretarial staff or to engage in any costly programs. $\$ 1,000$ was allocated to the Pace law library to acquire books on law and peace. Liaison was established with an expanding number of academic peace groups in the U.S. and throughout the world - including Israel, Australia, Germany, Scandinavia, Canada, Japan, and the USSR. Information was exchanged but, unfortunately, funds were not available to enhance.

At practically no expense, the Peace Center co-sponsored a film festival on anti-war films, Blaine Sloan ${ }^{211}$ lectures and major international conferences in Canada, The Hague, Washington D. C., N. Y., Santa Barbara and Seattle. From mid-1987 through 1989, the Director was invited to deliver at least 40 lectures in various locations including Heidelberg, Montreal, California, Florida, Pennsylvania, Virginia, Washington D.C., Missouri, Illinois, New Mexico, Kansas and New York. These were frequently accompanied by press, radio and television appearances. The theme stressed everywhere was the need to replace the law of force by the force of law.

|2| The latest book by the Executive Director - PLANETHOOD - reached a printing of 300,000 copies (not counting German and French editions) and, together with his COMMON SENSE GUIDE TO WORLD PEACE was widely distributed - many of them free of charge. International publications with broad circulation made favorable references to the books, the University, the Law School and the Pace Peace Center. The widespread publicity stimulated considerable worldwide correspondence. It was necessary to decline invitations to appear in China, India, Australia, the Soviet Union, Canada,

211 Frank Blaine Sloan (1920-2012) arbeitete seit 1947 in verschiedenen Positionen für die Vereinten Nationen. Er war unter anderem für das Hilfswerk für Palästinaflüchtlinge im Nahen Osten (UNRWA) und als Rechtsberater in verschiedenen Bereichen tätig. Von 1978 bis 1987 war er Professor für Internationales Recht an der Pace University. 
Holland, Denmark, and at universities and meetings throughout the United States. Applications from students in Africa, India and Canada seeking to study at the Peace Center had to be turned down.

With the help of Sandra Bendfeldt Voss, a Paw Law School graduate who visited the Soviet Union, efforts are now being made to fund and arrange a conference in New York with Soviet lawyers qualified to deal with certain international legal problems - such as codification of law and acceptance of international courts - that would enhance peace prospects. The Executive Director attends UN sessions regularly to follow such developments and has lectured to Congressional aides in the Capitol on the necessity for an international criminal court to combat terrorism.

CONCLUSION: All of the specific programs for peace envisaged when the Peace Center was established are being carried out to some extent. A continuous flood of correspondence encompassing a broad variety of related problems is dealt with promptly. But the absence of adequate funding, staff and space (not even a desk!) is a serious handicap and restricts the effectiveness of the Peace Center.

Appreciation is due particularly to Prof. Prakash Sinha, ${ }^{212}$ Assistant Deans Wendy Porterfield and Norma Sachs, and Sylvia Milberg of the Development Office for assistance and encouragement. It is the unfortunate truth, however, that the Pace Peace Center still remains, to larger extent, a one-man operation. There are limits to what one 69-year old can do. Apparent indifference by the administration is beginning to dampen enthusiasm.

If Pace University or Pace Law School believes there is any benefit in maintaining a Peace Center, it will have to demonstrate a greater degree of concern and a greater willingness to help the Peace Center achieve its true potential.

\{Ben\}

Benjamin B. Ferencz

Executive Director

PPCREPT4 $4^{213}$

212 Surya Prakash Sinha (gest. 2005) war Professor für Rechtswissenschaft und lehrte von 1979 bis 1996 an der Pace University.

213 Es handelt sich hierbei vermutlich um ein Aktenkürzel, das auf Unterlagen zum Pace Peace Center verweist. 


\section{Dokument 221}

Benjamin B. Ferencz an John E. Brooks ${ }^{214}$

New Rochelle, N. Y., 22. Oktober 1989

Maschinenschriftlicher Brief, 1 Seite; handschriftliche Ergänzung am unteren Textrand

$R G 12.017 * 39$

Counsellor at Law

Adjunct Professor

Pace Law School

Rev. John E. Brooks, S.J.

College of the Holy Cross

Worcester, Mass. 01610

\section{BENJAMIN B. FERENCZ}

14 Bayberry Lane

New Rochelle, N.Y. 10804

(914) 632-3717

October 22, 1989

$\{$ Thurss Mar 1/90\}

Dear Father Brooks:

Thank you very much for your kind letter of 11 Oct. I am much touched by the idea of a joint celebration of a "Holocaust Evening at Holy Cross." Of course, I would be pleased to adapt my presentation to whatever concerns are of special interest to your particular audience.

I do not speak from any prepared text. My usual procedure is to mix with the audience before the lecture and then to address the topics suggested. I usually deliver a lecture of about 30-40 minutes and, if the circumstances allow, I welcome all questions from the floor. I try to offer new facts and perspectives and to deliver a message of hope and inspiration. It seems to work very well.

The most suitable date among those you mentioned would be Thursday March $1 .<$ I will probably have classes on Wednesdays. $>$ I would then plan to come up from NY on Thursday in time to get there before the 5:30 reception. I would welcome your suggestions as to the best way to reach you from New Rochelle. Our nearest airport is LaGuardia. Since the speaking program is

214 Der Jesuitenpater John E. Brooks (1923-2012) leitete von 1970 bis 1994 das College of the Holy Cross in Worcester. Er setzte sich für eine stärkere Durchmischung der vormals fast ausschließlich weißen Studierendenschaft ein und öffnete das College auch für Frauen. 
scheduled to begin at $8 \mathrm{P}$. M., I would appreciate a hotel reservation for the night and I would plan to return to NY on Friday morning. An alternate date would be Tuesday Feb. 27.

I recall several lectures I gave some years ago to the Facing History and Ourselves-group of Brookline, Mass. We spoke about Nuremberg, Crimes against Humanity, Holocaust etc. The programs were organized by Margot Stern Strom ${ }^{215}$ and aided by Father Robert Bullock, Chairman of their Board. You may wish to inform them of your commemorative program.

Please let me know the definite date as soon as you can. If you need any additional information, please do not hesitate to let me know.

I look forward to meeting you and Jacob Hiatt ${ }^{216}$ and being with you for this important event.

Sincerely,

$\{$ Ben $\}$

$[\ldots]^{217}$

\section{Dokument 222}

Benjamin B. Ferencz an Daniel P. Moynihan ${ }^{218}$

White Plains, N. Y., 17. November 1989

215 Die Lehrerin Margot Stern Strom $\left({ }^{\star} 1941\right)$ initiierte 1976 die Organisation Facing History and Ourselves, die sich der historisch-politischen Bildung und dem Abbau gesellschaftlicher Vorurteile widmet. Zentrale Themen in der Bildungsarbeit sind die Geschichte des Nationalsozialismus und des Holocaust.

216 Jacob Hiatt (1905-2001) war ein jüdisch-amerikanischer Geschäftsmann und Philanthrop. 1935 emigrierte er mit seiner Familie aus Litauen in die Vereinigten Staaten und ließ sich in Worcester nieder. 1960 wurde Hiatt in den Vorstand der nordamerikanischen Sektion des Jüdischen Weltkongresses berufen. Ab 1962 war er im Vorstand des College of the Holy Cross in Worcester tätig. 1990 stiftete er dort eine Professur für Judaic Studies und eine Bibliotheksabteilung zur Holocaustforschung.

217 Es folgt eine unleserliche handschriftliche Ergänzung.

218 Der amerikanische Soziologe und Politiker Daniel P. Moynihan (1927-2003) vertrat von 1977 bis 2001 den Bundesstaat New York im Senat der Vereinigten Staaten. Zuvor hatte er u.a. in Harvard zum Einfluss von Ethnizität auf Sozialstrukturen geforscht. Sein sogenannter Moynihan Report (1965) sorgte für kritische Debatten, besonders in Kreisen der Bürgerrechtsbewegung. 
Maschinenschriftlicher Brief, 1 Seite; gedruckter Briefkopf mit maschinenschriftlich eingefügtem Datum

$R G 12.014 .05^{\star} 02$

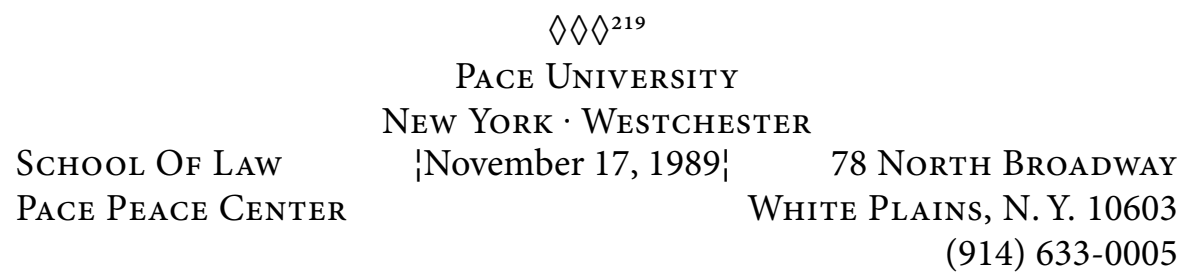

Hon. Daniel P. Moynihan

Senator from New York

United States Senate

Washington D.C.

Dear Senator Moynihan:

It was a very pleasant surprise to receive a copy of your insertion into the Congressional Record of my letter to the New York Times published on October 23rd. ${ }^{220}$ I wish there were more occasions when I could praise the Bush administration for its support of the rule of law in international affairs.

My letter (copy attached) also urged support for the current efforts at the United Nations to create an international criminal court to deal with drug traffickers. Despite the President's declaration of war against such criminals, the United States has opposed the creation of any such tribunal. Opposition has been masked by urging that the problem be referred to the International Law Commission - a favorite burial ground. I have no doubt that within the next days a resolution to that effect will be adopted; with the U.S. claiming victory and rejoicing at the funeral.

Our hypocrisy is making us the laughing stock of other nations. Instead of leading the world, as we once did, our officials lack any clear vision of what it takes to create a more peaceful world in the nuclear and high-tech age. I am therefore particularly grateful for your sounding the clarion call for the rule of law - without which we are back to barbarism.

219 Logo der Pace University.

220 Benjamin B. Ferencz, Bush Deserves Praise for Restraint on Noriega, in: The New York Times, 23. Oktober 1989, A18. 
Is there anything more that you, or I, can do to enlighten our government and our people?

With great respect and every good wish,

Sincerely,

$\{$ Ben $\}$

Benjamin B. Ferencz

Executive Director

\section{Dokument 223}

Benjamin B. Ferencz an Mirtille Romegialli221

New Rochelle, N. Y., 12. Mai 1990

Maschinenschriftlicher Briefmit Memorandum, 3 Seiten; handschriftliche Notiz am unteren Rand von Seite 1

$R G 12.017^{\star} 45$

[Ferencz wirbt für seine Bemühungen zur Etablierung eines internationalen Strafgerichtshofs im Nachklang eines Auftritts bei der Friedrich-NaumannStiftung. In einem beigefügten Memorandum erläutert er schlagwortartig wesentliche Vorzüge, Hemmnisse und Perspektiven einen solchen Gerichtshofs.]

$\{\text { Seminar fut. }\}^{222}$

\section{BENJAMIN B. FERENCZ}

Counsellor at Law

Adjunct Professor

Pace Law School
14 Bayberry Lane

New Rochelle, N. Y. 10804 (914) 632-3717

May 12, 1990

Mirtille Romegialli

Friedrich Naumann Foundation

823 UN Plaza, Suite 717

New York NY 10017

$221 \mathrm{Zu}$ dieser Person konnten keine biografischen Angaben ermittelt werden.

222 Future. Der vollständige Seminartitel lautete »Future Challenges of the International Legal System«. 
Dear Mirtille:

It was a pleasure meeting you at the seminar sponsored by the Friedrich-Naumann-Stiftung and I wish to thank you again for the important contribution you have made toward the development of international law in the cause of peace. Please convey these sentiments to the members of your Board.

Since the Stiftung is concerned with civic education and political dialogue, I am enclosing a copy of the review in the Frankfurter Allgemeine of WEGE ZUM WELTFRIEDEN, ${ }^{223}$ which is the German edition of my book A COMMON SENSE GUIDE TO WORLD PEACE. ${ }^{224}$ If you have had a chance to look at the copy I gave you, you will see that it is very supportive of many goals and policies of the FDP. In fact, in the Nachwort Zur Deutschen Ausgabe I quote Foreign Minister Genscher and use his observations as a guide.

May I therefore suggest that the Stiftung consider distributing the book (which sells for less than DM 15) to educational institutions which might benefit from it. We donated close to a thousand copies to the Hessische Stiftung fur [sic] Friedens- and Konfliktforschung and related institutions as our contribution to world peace. You may wish to suggest to your Board that contact be made with the Publisher, Frank Schwoerer, Campus Verlag, Heerstrasse 149, 6000 Frankfurt 90, Phone (069) 7682041.

I shall be in Germany (Berlin, Frankfurt, Heidelberg) from July 10 to July 27. If I can do anything during that time to further our common goals, please let me know and I will try to oblige.

I look forward to receiving the summary of our symposium, to which I have just submitted a 2-page condensation of my views.

With my very best wishes,

Cordially,

$\{$ Ben $\}$

CC: F. Schwoerer

You may wish to contact them. (See over) I'll phone you when I'm in your area.

All the best,

223 Dieter Senghaas, Es gibt Grund zum Optimismus. Wie das Recht den Frieden sichert, in: Frankfurter Allgemeine Zeitung, 3. November 1989, 14.

224 Benjamin B. Ferencz, Wege zum Weltfrieden. Was bisher getan wurde, was zu tun wäre, was man jetzt tun kann, Frankfurt a. M./New York 1989. 
$\{$ Ben $\}$

$[\ldots]^{225}$

[|2|] Memo to: Friedrich Naumann-Stiftung seminar on "Future Challenges of the International Legal System."

From: Prof. Benjamin B. Ferencz, former Nuremberg Prosecutor, Director of the The Pace Peace Center, Pace University School of Law, White Plains, NY

The Needs and Challenges:

Every peaceful society is built upon a foundation of three parts: 1 - Laws - to define the minimum standards of acceptable behavior; 2 - Courts - to decide if the laws have been violated and to serve as a forum for the amicable resolution of disputes, and 3 - A system of effective law enforcement; this requires (a) management on a global scale - which means an improved United Nations (b) international arms control as envisaged in the Covenant of the League of Nations (c) An alternative system of economic or military sanctions as required by the UN Charter, and (d) enhanced social justice so that the new regime will allow all human beings to live in peace and dignity regardless of their race, creed or ideology.

The present international legal system is deficient in all of its components. The Secretary-General has referred to it as "international anarchy." Since all of the parts are interrelated and one depends upon the other, the Decade of International $\mathrm{Law}^{226}$ should seek to remedy the prevailing shortcomings in each and every component of the international legal structure.

1 - In the area of improved international laws, we must eliminate the ambiguities and inconsistencies deliberately written into legal instruments in order to achieve a deceptive consensus. For example, the loopholes which seek to justify aggression as "self-defense" or to permit terrorism, crimes against diplomats and the taking of hostages if done in pursuit of "self-determination" or "freedom from alien domination" makes a mockery of international law. The challenge is to work out the meaningful compromises which make such legal instruments unequivocal and binding upon all. New instruments must be drawn to meet new needs. It can be done if that is the accepted goal.

225 Es folgt eine kurze, teils verblasste und unleserliche handschriftliche Notiz.

2261990 proklamierte die UN-Generalversammlung die Völkerrechtsdekade der Vereinten Nationen. Wichtige Ziele waren die Förderung wirksamer Mittel zur friedlichen Lösung internationaler Konflikte und die Stärkung der Rolle des Internationalen Gerichtshofs. 
2 - In the area of improved courts, we must increase the compulsory jurisdiction of the International Court of Justice and create new international or regional courts to deal with the emerging problems of the 21 st century. For example, an international criminal court is essential if we are to be more effective in curbing such international crimes as terrorism, genocide, apartheid, and other crimes against humanity. We can begin with minimum jurisdiction, such as against drug-traffickers, to demonstrate that courts are more effective than the current methods which often reflect a "wild-west" mentality. The growth of new international tribunals to deal with Human [|3|] Rights violations, Law of the Sea problems, European Community problems and a host of commercial and other disputes demonstrates that it can be done if there is the will to do so.

3 - in the area of enforcement, the principal agency - the United Nations Security Council - simply does not work as it should. The crippling veto power must be eliminated and the Council expanded to reflect a broader spectrum of interests and concerns. International control over the means of mass destruction is vital. The crushing burden of arms races must be eliminated. An alternative security system, through sanctions or an international military force, must be put in place. The present system of stabbing and grabbing must be replaced by a new international ethic of caring and sharing.

\section{The Obstacles:}

The greatest obstacles to the formation of an improved international system comes [sic] from the absence of vision, imagination and courage on the part of those who mismanage the present order. Self-interest and adherence to an obsolete status quo based upon medieval needs and notions paralyzes those in power. The world is in a process of convulsive transformation where individuals everywhere are asserting their newly-discovered human rights. Dwight D. Eisenhower warned that "people want peace so much that one of these days governments had better get out of their way and let them have it." ${ }^{227}$ The Decade of International Law should make Eisenhower's predicition a reality.

227 US-Präsident Dwight D. Eisenhower erklärte am 31. August 1959 in einer Radiound Fernsehsendung gegenüber dem britischen Premierminister Harold Macmillan: »I like to believe that people, in the long run, are going to do more to promote peace than our governments. Indeed, I think that people want peace so much that one of these days governments had better get out of the way and let them have it.« Dwight D. Eisenhower, Radio and Television Broadcast With Prime Minister Macmillan in London. August 31, 1959, in: Dwight D. Eisenhower, Public Papers of the Presidents of the United States, 1959. Containing the Public Messages, Speeches, and 


\section{Needed Programs:}

The most important program for the Decade is to educate the public about what needs to be done and to energize them to take the lead. If the leaders won't lead, the public will - and the "leaders" can follow. All of the tools of mass media must be mobilized - TV, radio, news, books, publications, the churches, schools, NGO's, and all of the other techniques for generating public action - to challenge the existing system and demand peaceful change.

\{"\}Business as usual\{"\} will not do. National needs must be subordinated to international needs. Life can only be sustained on this planet if there is global planning and action on matters or such vital common concern as the environment and the minimum economic and physical well being of everyone. In this interdependent world, absolute state sovereignty is absolutely obsolete. The notion of "neighborhood" gave way to the idea of "nationhood". Now PLANETHOOD is on the march as a new way to a better life for all. This should be the goal of the Decade of International Law and those who share this ideal must do all they can to move it toward reality.

May 12, 1990

\section{Dokument 224}

Benjamin B. Ferencz an Delia Chatoor

New Rochelle, N. Y., 21. Mai 1990

Maschinenschriftlicher Brief, 1 Seite

RG $12.013 .01^{*} 09$

Counsellor at Law

Adjunct Professor

Pace Law School

\section{BENJAMIN B. FERENCZ}

\author{
14 Bayberry Lane \\ New Rochelle, N.Y. 10804 \\ (914) 632-3717
}

May 21, 1990

Delia Chatoor

Trinidad and Tobago Mission of the UN

675 Third Ave. New York NY 10017

Statements of the President. January 1 to December 31. 1959, Washington, D.C., 1960, 621-628, hier 625. 
Dear Delia:

Thank you for your letter of May 16 and the attached copy of the ILC Report of 6 April regarding an International Criminal Court. I am pleased to give you some preliminary comments. A more comprehensive memo would take more time than I now have available, but I did not wish to let your letter go unanswered. I hope you will forgive me therefore for simply sending you copies of letters I have already written on the subject.

The present submission by the ILC can only be viewed as a very preliminary document. I believe that it would be far more constructive to go back to the more comprehensive 1953 report of the Committee of International Criminal Jurisdiction (GAOR ${ }^{228} 9$ th Sess. Supp. 12 (A/2645)). ${ }^{229}$ That instrument was the subject of consideration by the Foundation for the Establishment of an International Criminal Court during the early 1970's which produced a number of suggested changes. Prime Minister Robinson ${ }^{230}$ participated in some of those deliberations. I am attaching a copy of some comments I submitted on Dec. 4, 1972 which might also be applicable to the current ILC draft.

I am also enclosing comments I sent a few days ago to Prof. Blakesley ${ }^{231}$ regarding a proposal by Prof. Bassiouni for a Regional Criminal Court which was considered during a symposium we had at the U.S. Senate.

During the last week of June, I shall be meeting with a delegation of legal experts from the Institutes of State and Law in Moscow and Kiev. I hope we will be able to address the question of International Criminal Jurisdiction and make some constructive suggestions. I shall be in touch with you before the issue comes up again at the Sixth Committee.

Because I am hosting the Soviet delegation's visit to the Pace Peace Center (and then proceeding to meetings in Europe), I shall be unable to attend the meetings in Siracusa organized by Prof. Bassiouni to consider his draft. I know that Prime Minister Robinson has also been invited. I am hopeful that some useful ideas will emerge. Please share these views with your Prime

228 United Nations General Assembly Official Records.

229 United Nations, Report of the 1953 Committee on International Criminal Jurisdiction, New York 1954. Vgl. dazu Çakmak, A Brief History of International Criminal Law.

230 Gemeint ist Arthur N. R. Robinson.

231 Christopher L. Blakesley $\left({ }^{\star} 1945\right)$ war Professor für Rechtswissenschaft an der University of Nevada, Las Vegas. Die Schwerpunkte seiner Arbeit liegen im internationalen Recht und vergleichenden Strafrecht. 
Minister Robinson and Ambassador Thorpe to both of whom I send my warm greetings and best wishes.

Cordially,

$\{$ Ben $\}$

\section{Dokument 225}

Benjamin B. Ferencz an Burns H. Weston

New Rochelle, N. Y., 4. Dezember 1990

Maschinenschriftlicher Brief, 1 Seite

$R G 12.014 .01{ }^{*} 08$

Counsellor at Law

Adjunct Professor

Pace Law School

\section{BENJAMIN B. FERENCZ}

\author{
14 Bayberry Lane \\ New Rochelle, N.Y. 10804 \\ (914) 632-3717
}

December 4, 1990

Prof. Burns Weston

University of Iowa

Iowa City, Iowa 52242

Dear Burns:

Sure, I owe you an apology for not having even acknowledged receipt of your new book. ${ }^{232}$ The excuse is one that I hope you will understand, if not appreciate. I've simply been busy as hell!

I know you don't care about specifics but in the last few months I have produced three new books. The revised Planethood you already have. (Many thanks for your fine endorsement.) A bibliography of a thousand books on The International Law of Peace has just been issued by Oceana (You are listed at least 3 times.) A new book WORLD SECURITY FOR THE 21st CENTURY,233

232 Burns H. Weston (Hg.), Alternative Security. Living Without Nuclear Deterrence, Boulder, Colo., 1990.

233 Ferencz (Hg.), World Security for the 21st Century. 
which is the transcript (all decoded, typed and edited by me alone) of a conference I organized this summer with Soviet and other legal experts will appear in a few weeks. (Oceana.) This, of course, in addition to a hundred other duties. I haven't even had time to read my own books.

But I have not forgotten you! I'll take the book down to Florida and gladly write a review. I have the feeling that reviews are only published if the magazine editor has requested it. I have therefore written to Dettlef [sic] IVagts, as per copy enclosed. If you can give me a list of publishers or publications which are likely to print something sent "over the transom," I will do my best to oblige. Preferably, give my name to the editors and suggest that they invite me to write a review. I can then tailor it to meet their audience and interests. Greater love hath no man! ${ }^{234}$

You can use my video-tape to keep your class occupied when you don't feel like teaching. You can get as many free copies of PLANETHOOD as you can use effectively. Just dial 1-800 HATE WAR (The World Federalists in Washington DC) and they will send you cases of 100 for only the postage (about $\$ 10$ per case.) It's cheaper than a Xmas card, so give it way freely to all of your students, friends, relatives and enemies. BLESSED BE THE PEACEMAKERS!!235

Have a Happy Holiday. Warm greetings,

$\{$ Ben $\}$

\section{Dokument 226}

Benjamin B. Ferencz an George H. W. Bush ${ }^{236}$

New Rochelle, N. Y., 16. Januar 1991

Maschinenschriftlicher Brief, 2 Seiten

RG $12.014 .05^{\star} 02$

234 Es handelt sich um ein abgewandeltes Bibelzitat. Die Passage lautet: „Greater love hath no one than this, that someone lay down his life for his friends." (Joh 15,13).

235 Ferencz wandelt ein Bibelzitat ab. Vollständig lautet die Passage: »Blessed are the peacemakers, for they shall be called sons of God.« (Mt 5,9).

236 George H. W. Bush (1924-2018) war von 1989 bis 1993 der 41. Präsident der Vereinigten Staaten. Zur Zeit der Niederschrift des Briefs fand der Zweite Golfkrieg statt. Einen Tag nach Ferencz' Schreiben griffen die Truppen der von den Vereinigten Staaten angeführten und durch eine Resolution des UN-Sicherheitsrats legitimierten Koalition den Irak an. Im April 1991 wurde ein Waffenstillstand zwischen den Konfliktparteien vereinbart. 


\section{BENJAMIN B. FERENCZ}

Counsellor at Law

Adjunct Professor

Pace Law School
14 Bayberry Lane

New Rochelle, N.Y. 10804

(914) 632-3717

January 16, 1991

Hon. George Bush

President of the United States

The White House

Washington D.C.

Dear Mr. President:

As a veteran of every campaign in Europe in World War II, I write to you as Commander-in-Chief. As one who has dedicated the last 25 years of my life to seeking a more peaceful world and the author of nine scholarly volumes on that subject (see attached) I write to offer whatever assistance I can give to you, my country and the world during this very perilous time.

Specifically, may I suggest the following:

1 - After our air force and missiles have destroyed Iraq's offensive capacity do NOT send in ground forces to liberate Kuwait but rely on improved sanctions to finish the job.

2 - Call upon the United Nations to

A - Gradually replace the existing allied armies on the Saudi Arabian border with UN Peacekeeping forces. With Iraq's offensive capacity destroyed, these forces can be minimal.

B - Request the International Court of Justice for an advisory opinion regarding any border or other disputes between Iraq and Kuwait. This will demonstrate our willingness to address their concerns in a lawful way.

C - Establish a committee, similar to the International Monetary Fund, to work out a plan for the fair sharing among all nations of the burdens and profits - that arise from comprehensive sanction. $<$ The necessity for this was recognized by committees of the League of Nations, but never implemented.>

D - Have the Security Council convene an International Criminal Court of impartial judges to try Saddam Hussein ${ }^{237}$ (if necessary, in absentia)

237 Saddam Hussein (1937-2006) war von 1979 bis 2003 Präsident des Iraks. Er wurde im Zuge des Zweiten Irakkriegs gestürzt. 
for aggression and war crimes. As a former Nuremberg Chief Prosecutor and Executive Counsel at the Subsequent Nuremberg Trials, I feel that this reassertion of our respect for law can only win friends for our cause. It will assure Arabs that their case will be heard in open court.

|2|

3 - Launch a mass media campaign to persuade the people of the Arab world that A - The U.S. has no quarrel with them.

B - We will welcome all defections from the Iraqi armed forces and defectors will be employed to help rebuild their shattered country. Those who bring military equipment will be suitably rewarded.

C - The United States remains firmly committed to finding a peaceful means for meeting the legitimate concerns of the Palestinian people and for establishing permanent security in the entire area in the shortest possible time.

This is, of course, a simplified outline. It is primarily designed to minimize the loss of human life. It is a compromise with those who oppose the use of force. It is consistent with all UN resolutions. It is a move toward the "new world order" of which you spoke and which attracted the most support of the American public as justification for our intervention.

I realize that this suggestion might require more time than an all-out frontal assault. But I am convinced that it would safe many lives. Let it never be said that we sacrificed our fine and brave young people because you ran out of patience.

If I can be of any help, it would be a privilege and honor.

Sincerely, ${ }^{238}$

Executive Director, Pace Peace Center

Senior Special Fellow, UNITAR ${ }^{239}$

Books by B. Ferencz:

Oceana Publications, Dobbs Ferry, NY:

DEFINING INTERNATIONAL AGGRESSION: The Search for World Peace 2 volumes (1975); AN INTERNATIONAL CRIMINAL COURT: A Step Toward World Peace, 2 volumes (1980); ENFORCING INTERNATIONAL LAW: A Way to World Peace, 2 volumes (1983); A COMMON SENSE GUIDE TO WORLD PEACE (1985); WORLD SECURITY FOR THE 21st CENTURY - Challenges and Solutions (1991).

238 Unterschrift fehlt auf archivalischer Kopie.

239 United Nations Institute for Training and Research. 
Harvard University Press, LESS THAN SLAVES (1979).

Vision books, Coos Bay, Oregon, PLANETHOOD (Revised ed. 1991).

\section{Dokument 227}

Benjamin B. Ferencz an Daniel P. Moynihan

New Rochelle, N. Y., 3. August 1991

Maschinenschriftlicher Brief, 1 Seite

$R G 12.013 .01 * 11$

\section{BENJAMIN B. FERENCZ}

Counsellor at Law

Adjunct Professor

Pace Law School

August 3, 1991

\author{
14 Bayberry Lane \\ New Rochelle, N. Y. 10804 \\ Phone (914) 632-3717 \\ FAX (914) 633-0005
}

Senator Daniel Moynihan

Senate Office Building

Washington DC 20510

Dear Senator Moynihan:

Last April, the Senate Committee on Foreign Relations held hearings dealing with the Persian Gulf: The Question of War Crimes. I would appreciate receiving a copy of the hearings on that subject.

It seems that Saddam Hussein has been convinced that aggression, war crimes and crimes against humanity, including attempted genocide against the Kurds, is nothing but a passing peccadillo, which the world has already forgotten. Has the United States repudiated its own precedents at Nuremberg?

How long will the United States tolerate Saddam's thumbing his nose at the UN, and the US. Knowing what a strong advocate you are of the rule of law, I ask you: isn't it time for us to begin to set up an international criminal tribunal to bring such outlaws to justice? Or is it still politics over principle?

Thanks for your help.

Cordially,

$\{$ Ben Ferencz $\}$ 
Copy to Prof. Anthony D’Amato: ${ }^{240}$

Dear Tony: $:{ }^{241}$ Thanks for the extract. Sorry I didn't acknowledge it sooner, but I've been running around the world (Tokyo, China, Hong Kong, Germany, etc.) doing as much damage as I can.

I enjoyed your testimony but best of all was Senator Helms' comment to you and the late demented Woetzel: "I would say to you guys, I would like to sit down with you some time." You really must have charmed him. Warm greetings and good wishes,

$\{$ Ben $\}$

\section{Dokument 228}

Benjamin B. Ferencz an Blaine Sloan

New Rochelle, N. Y., 24. Januar 1992

Maschinenschriftlicher Brief, 2 Seiten

$R G 12.014 .05^{\star} 02$

$\{1991$ Report $\}$

\{\#y file

\section{BENJAMIN B. FERENCZ}

Counsellor at Law

Adjunct Professor

Pace Law School

January 24, 1992
14 Bayberry Lane

New Rochelle, N. Y. 10804

Phone (914) 632-3717

FAX (914) 633-0005

Prof. Blaine Sloan, Colorado

Dear Blaine:

Having recently returned from Florida and almost caught up with the accumulated backlog, it occurs to me that I haven't heard from you for some time. I had looked forward to seeing you at the lectures at the University of Denver

240 Anthony D’Amato (ca. 1937-2018) war Professor für Rechtswissenschaft an der Northwestern University mit den Schwerpunkten internationales Recht und Menschenrechte.

241 Die Wörter sind im Original eingekringelt. 
Law School at the end of October and was disappointed that I heard nothing from you. I hope that all is well with you and yours and I extend my belated best wishes for the New Year.

At the end of each year I make an index of some of my files, including those dealing with the Pace Peace Center. For the first few years I also prepared an annual PPC report, intended primarily for the Supervisory Committee. Prakash circulated them to his "dear colleagues" but they evoked practically no response, and no one notices when I discounted year-end summaries in 1990. It became increasingly clear to me that Pace had other priorities.

Since you were the Godfather, I feel I owe you in particular, as well as the other "Supervisors", some brief report. The goals set forth in our brochure (copy attached) have remained our guiding star. In some respects we have accomplished more than expected. In other respects, it has been disappointing.

We set up a world-wide network of cooperating peace institutions, co-sponsored many important scholarly meetings, seminars and colloquia and lectured in universities across the country and the globe. We provided some funds to enrich our law library, published and distributed books, and bibliographies on peace, wrote many articles, made many television and radio appearances on peace themes, and convened an international conference on World Security for the 21st Century, which was published under the Pace Law School banner by a leading law publisher. All of this gave the impression that the Pace Peace Center was a flourishing institution. I hope it enhanced the reputation of the school and university.

|2| On the other hand, I was getting concerned that the image was deceptive. The Pace Peace Center remained basically a one (unpaid) man operation located in my home. Despite small grants from the United States Institute of Peace, a few foundations and some friends, I was unable to raise the funds needed to put the Center on a more normal footing. The fact that (despite a request from Prakash) the Law School was not prepared to offer any space whatsoever, other than a mail-drop, was particularly discouraging, as was the recognition that the faculty did not share my perception of the vital link between peace and law.

But I carry on as best I can and do what I must - for reasons I do not fully understand. We still have over $\$ 7,000$ in our account and I do not intend to try to raise more. I continue to be much too busy trying to save the world. I am grateful that there are people like you and Prakash and Nick Robinson ${ }^{242}-$ as

242 Nicholas A. Robinson ist Professor für Rechtswissenschaft an der Pace University mit dem Schwerpunkt internationales Umweltrecht. 
well as a few others - who are doing the same. Who knows, some day we might make it!

Warm greetings,

$\{$ Ben $\}$

CC; Prof. P. Sinha

Prof. N. Robinson

\section{Dokument 229}

Benjamin B. Ferencz an Louis Henkin

New Rochelle, N. Y., 26. September 1992

Maschinenschriftlicher Brief, 1 Seite

RG $12.014 .01{ }^{\star} 08$

\{\#\#\# ASIL File $\}$

\section{BENJAMIN B. FERENCZ}

Counsellor at Law

Adjunct Professor

Pace Law School

September 26, 1992

\author{
14 Bayberry Lane \\ New Rochelle, N.Y. 10804 \\ Phone (914) 632-3717 \\ FAX (914) 633-0005
}

Prof. Louis Henkin, President

American Society of International Law

2223 Mass. Ave. NW

Washington DC 20008-2864

Dear Lou:

The idea of creating an international criminal court is going to be a hot topic at the UN this year. The ILC is coming out in favor of it and the Sixth Committee will probably call for approval in principle by governments. The U.S. is dragging its heels, despite support from the NY $\mathrm{Bar}^{243}$ and some from 
the ABA. ${ }^{244}$ It should be a beautiful subject for discussion at the Society meeting in April.

I recently suggested to Cherif Bassiouni, who has been one of the leaders in promoting such a court, that he might suggest a panel, with himself as Chairman and inviting the State Department's point-man Michael Scharf ${ }^{245}$ to represent the opposition. I have not yet heard from him. I could, if desired, be the advocate in favor of the Court. (An article of mine on the topic is expected momentarily in your Columbia J. of Tr. L. $)^{246}$ The head of Codification Division of the UN, Vladimir Kotliar, told me he would be delighted to join. Perhaps someone from Justice - which opposes justice - might participate. It could be lively and productive.

Since I don't know the current status of programming, I hope you will forgive me for intruding at the top. I know the object of deterring aggression, war crimes and crimes against humanity is close to your heart. Telford Taylor, who obviously favors the idea, encouraged me to write. I am sending a copy to Barry Carter ${ }^{247}$ in the hope that it will be considered in the appropriate channel. I would appreciate being informed as soon as possible whether the suggestion meets with approval and any role I may be expected to play.

With warm greetings and best wishes for the New Year,

Cordially,

$\{$ Ben $\}$

\{cc. B. Carter

Oct. 8) Prof. Bassiouni\}

244 American Bar Association.

245 Michael P. Scharf $\left({ }^{*} 1963\right)$ ist Professor für Internationales Recht an der Case Western University. In den Regierungen der amerikanischen Präsidenten George H.W. Bush und Bill Clinton war er Rechtsberater im Außenministerium und amerikanischer Delegierter bei der Menschenrechtskommission der Vereinten Nationen.

246 Benjamin B. Ferencz, An International Criminal Code and Court: Where They Stand and Where They're Going, in: Columbia Journal of Transnational Law 30 (1992), H. 2, 375-399.

247 Barry E. Carter (1942-2014) war ab 1979 Professor für Rechtswissenschaft an der Georgetown University und auf internationales (Straf-)Recht spezialisiert. Von 1993 bis 1996 unterbrach er seine universitäre Tätigkeit und arbeitete im Handelsministerium der Vereinigten Staaten unter der Regierung Bill Clintons. 


\section{Dokument 230}

Benjamin B. Ferencz an Bill Clinton ${ }^{248}$

New Rochelle, N. Y., 21. Januar 1993

Maschinenschriftlicher Brief, 1 Seite

RG $12.014 .05 * 02$

Counsellor at Law

Adjunct Professor

Pace Law School

January 21, 1993

President Bill Clinton

The White House

Washington D.C.

\section{BENJAMIN B. FERENCZ}

\author{
14 Bayberry Lane \\ New Rochelle, N. Y. 10804 \\ Phone (914) 632-3717 \\ FAX (914) 633-0005
}

Dear Mr. President:

Continuing mass rapes, "ethnic cleansing" and other crimes against humanity must be stopped without delay. ${ }^{249}$ As a former Nuremberg Prosecutor who was present at the liberation of many Nazi concentration camps - and one driven by the cry: "Never Again!" - I cannot refrain from appealing to you so soon in what I hope will be a new administration where the force of law will replace the law of force.

My view is sketched in the attached "Op-ed" piece. A detailed analysis is contained in the copy of my recent article in the Columbia Journal of Transnational Law. ${ }^{250}$ I shall spare you my many volumes on world peace. In brief, I feel passionately that the United States must take the lead, rather

248 William »Bill« Clinton $\left({ }^{*} 1946\right)$ war von 1993 bis 2001 der 42. Präsident der Vereinigten Staaten.

249 Ferencz bezieht sich auf die gewalttätigen Vorgänge, die seit 1991 im Zuge des Auseinanderbrechens Jugoslawiens einsetzten und denen die internationale Gemeinschaft zunächst abwartend gegenüberstand. Siehe dazu Philipp Ther, Die dunkle Seite der Nationalstaaten. »Ethnische Säuberungen« im modernen Europa, Göttingen 2011, 239-257.

250 Wahrscheinlich ist gemeint: Ferencz, An International Criminal Code and Court. 
than dragging its heels, in upholding the rule of law if we are ever to have a peaceful world.

Former Secretary of State Eagleburger agreed in principle that war criminals should be put on trial. Others in his Department had doubts. U.S. policy floundered while aggressors and war criminals thumbed their noses at the U.S. and the UN. There is urgent need for a top-level policy decision about what is to be done about it.

I assume you will want to consult with Secretary Christopher ${ }^{251}$ and Mrs. Albright. ${ }^{252}$ Copies of the article are enclosed for their convenience.

To all of you I extend my heartfelt congratulations and the hope that together - you can "bring forth the vision and courage to reinvent America" 253 for the benefit of all humankind.

With every good wish,

Sincerely,

$\{$ Ben Ferencz $\}$

\section{Dokument 231}

Benjamin B. Ferencz an Blaine Sloan

New Rochelle, N. Y., 5. April 1993

Maschinenschriftlicher Brief, 1 Seite

$R G 12.014 .05^{\star} 02$

251 Warren M. Christopher (1925-2011) war von 1993 bis 1997 Außenminister der Vereinigten Staaten. Im Bosnienkrieg (1992-1995) vermittelte er zwischen den Konfliktparteien.

252 Die Politikerin und Diplomatin Madeleine Korbel Albright $\left({ }^{\star} 1937\right)$ wurde 1993 zur Botschafterin der Vereinigten Staaten bei den Vereinten Nationen ernannt. Von 1997 bis 2001 war sie Außenministerin unter Präsident Bill Clinton. Während ihrer Amtszeit setzte Albright sich unter anderem für die Osterweiterung der NATO ein.

253 Ferencz zitiert hier aus der 1993 gehaltenen Amtseinführungsrede von Bill Clinton, siehe: William J. Clinton, First Inaugural Address, 20. Januar 1993, in: The Avalon Project. Documents in Law, History and Diplomacy $<$ http://avalon.law.yale.edu/20th _century/clinton1.asp> (29. Januar 2019). 


\section{BENJAMIN B. FERENCZ}

Counsellor at Law

Adjunct Professor

Pace Law School

April 5, 1993
14 Bayberry Lane

New Rochelle, N.Y. 10804

Phone (914) 632-3717

FAX (914) 633-0005

Dear Blaine:

About a week or so ago I received a phone message from Wendy Porterfield that you had sent a $\$ 100$ donation to the Pace Peace Center. You are, as always, very kind and thoughtful and I wish to convey my appreciation for your generosity and encouragement. Truth is that I've given up fundraising. I found, as I expected, that I was rotten at it. Besides, I'm much too busy. So I'm letting the account run down slowly. The Law School couldn't care less. I'm amazed at their total indifference.

I carry on like a house on fire. Two of my recent law review articles on an International Criminal Court ${ }^{254}$ were very well received by the new administration which has reversed course. ${ }^{255}$ As you probably know, your former colleagues at the UN are now frantically trying to put together an ad hoc tribunal to try war crimes in former Yugoslavia. Some of them wish they had taken my advice years ago and now had something workable in place. The ASIL put the topic on the program at the last minute and it received much attention. The Court is by no means a done thing, despite clear Security Council language. I fear there may be an amnesty in exchange for peace even before the court is created. That would mean that genocide would continue elsewhere later.

I'm terribly busy on my new book ${ }^{256}$ and have cited you repeatedly. I call for a new thinking about old notions such as sovereignty, self-defense, intervention, self-determination, etc. I try to rely on existing norms and systems wherever possible and only change what must be changed to make it work. I am developing the thesis that the $S .{ }^{257}$ Council has authority to do anything needed to maintain peace so they should pass a few clear resolutions (which I have drafted) mandating universal disarmament (along McCloy/Zorin

254 Gemeint sind vermutlich Benjamin B. Ferencz, The Nuremberg Principles and the Gulf War, in: The St. John's Law Review 66 (1992), H. 3, 711-732 sowie Ferencz, An International Criminal Code and Court.

255 Am 20. Januar 1993 löste Bill Clinton seinen Vorgänger George H. W. Bush als Präsident der Vereinigten Staaten ab.

256 Wahrscheinlich Ferencz, New Legal Foundations for Global Survival.

257 Security. 
lines), ${ }^{258}$ peaceful settlement without exceptions and minimum social justice (including environmental and human rights.) To enforce it, the $\mathrm{SC}^{259}$ can create a few new organs (which I am outlining) backed by Chap. VII.

On April 13 I'm off to Europe, will attend some ILC meetings in Geneva and other stops at Heidelberg, Strasbourg, etc. seeking models and views on my crazy ideas. Stay well and happy.

Regards to Mrs. S. from The Man of La Mancha, ${ }^{260}$

Sloan: CO.

\section{Dokument 232}

Benjamin B. Ferencz an diverse Empfänger (Walter F. Hoffmann, Tim Barner, Myron W. Kronish, ${ }^{261}$ Richard Hudson, ${ }^{262}$ Gerald F. Mische, David Krieger, ${ }^{263}$ Stanley Platt, ${ }^{264}$ Louis Henkin und Harris O. Schoenberg ${ }^{265}$ )

258 Gemeint ist das McCloy-Zorin-Abkommen von 1961. Vgl. hierzu auch Dokument 14. 259 Security Council.

260 Unterschrift fehlt auf archivalischer Kopie. The Man of La Mancha ist ein 1965 in New York uraufgeführtes Musical, das auf Miguel de Cervantes' Roman Don Quijote basiert.

261 Der Jurist Myron W. Kronisch $\left({ }^{\star} 1926\right)$ war in den 1990ern Geschäftsführer des Center for UN Reform Education und Mitglied des Beirats der World Federalist Association. Ebenso gehörte er dem Vorstand des Center for War/Peace Studies in New York an.

262 Richard Hudson (gest. 2006) war Journalist und Friedensaktivist. 1961 gründete er die Zeitschrift War/Peace Report, die thematisch auf die Stärkung der Vereinten Nationen, Abrüstung und Friedenssicherung ausgerichtet war. Ab 1977 war er Geschäftsführer des Center for War/Peace Studies.

263 Der Jurist und Politikwissenschaftler David Krieger ist Präsident der Nuclear Age Peace Foundation, einer Nichregierungsorganisation, die sich für die Abschaffung von Atomwaffen einsetzt und einen beratenden Status beim Sozial- und Wirtschaftsrat der Vereinten Nationen besitzt.

264 Stanley Platt $\left({ }^{\star} 1906\right)$ war Geschäftsmann und seit 1947 Mitglied der World Federalist Association. Er hatte über viele Jahre zahlreiche leitende Posten in der Organisation inne.

265 Harris O. Schoenberg $\left({ }^{\star} 1942\right)$ leitete seit 1978 das Büro von B’nai B’rith bei den Vereinten Nationen. Zudem war er Präsident des Center for UN Reform Education sowie geschäftsführender Direktor des Coordinating Board of Jewish Organizations. 
New Rochelle, N. Y., 3. Juni 1993

Maschinenschriftlicher Brief, 3 Seiten

$R G 12.014 .05^{\star} 02$

[Anlässlich der bevorstehenden Gründung eines Internationalen Strafgerichtshofs zur Ahndung von schweren Verbrechen während der Jugoslawienkriege bringt sich Ferencz für ein Richteramt ins Spiel und bittet um Unterstützung. Im Anschluss gibt ein beigefügter Lebenslauf Auskunft über die wesentlichen Stationen seines Lebenswegs bis in das Jahr 1993.]

Counsellor at Law Adjunct Professor

Pace Law School

\section{BENJAMIN B. FERENCZ}

14 Bayberry Lane New Rochelle, N.Y. 10804

Phone: (914) 632-3717

FAX (914) 633-0005

Dear Friends:

Yesterday, I was asked at the UN Secretariat whether I would be interested in becoming the prosecutor or a judge of the International Criminal Court that is now being created to try those accused of genocide, mass rapes, and other crimes against humanity in former Yugoslavia.

I am not looking for employment. But the establishment of a criminal tribunal to deter and vindicate such crimes has been a leading goal of my life since my experiences as a war crimes investigator during World War II. I was therefore unable to decline to serve if it would help the cause of world peace.

Because I am now 73, I did not feel that I could do justice to the role of prosecutor that I carried at Nuremberg when I was 27. I indicated that, if asked to do so, I would accept a post as one of the 11 judges, but I would not campaign for that or any other position. I was persuaded to prepare a curriculum vitae and to contact a few friends who might be interested in supporting such an idea at the State Department or with other governments that are now in the process of submitting nominees. That explains this letter. Please pardon the impersonal format.

Security Council Resolution 827 of 25 May 1993, ${ }^{266}$ and the adopted statutes, require states to submit nominees to the Secretary-General for trans-

Zwischen 1992 und 1993 wirkte er als Sekretär der von Präsident George H. W. Bush eingesetzten United States Commission on Improving the Effectiveness of the United Nations.

266 United Nations Security Council, S/RES/827. 
mittal to the Council which will then narrow the list for vote by the General Assembly. The process is already in rapid motion. The time to act is NOW.

I am making these facts known to a few friends with whom I have been pleased to be associated in peace endeavors over the years. Should you believe that my designation as a judge would serve the public interest, you may wish to take such action as may be helpful. Nomination by the U.S. (State Dept.) would seem to be a pre-condition. I must leave the rest to you. Thank you for whatever you may choose to do. I am now going back into hibernation, working on my new book.

Warm greetings to all, $\{$ Ben $\}$

(addressees on reverse side)

\{3 June 93$\}$

$[|2|]^{267}$

$[|3|]$

CURRICULUM VITAE

BENJAMIN B. FERENCZ, 14 Bayberry Lane, New Rochelle NY 10804 Phone: (914) 632-3717. Born in Rumania [sic] in 1920; educated in the U.S. Juris Doctor. ${ }^{268}$ Harvard Law School, Adjunct Professor of International Law, Pace University School of Law, White Plains, NY, teaching "The International Law of Peace." Founder and Executive Director of the Pace Peace Center.

OCCUPATIONS: Former Executive Counsel, Nuremberg War Crimes Trials and Chief Prosecutor for the US in Einsatzgruppen case. Director-General of legal organizations to recover heirless property of Nazi victims and obtain compensation for survivors. (Staff: 1200, offices in 19 countries.) Legal Adviser, Hague Reparations Negotiations with West Germany in 1952. Partner in NY law firm (with Telford Taylor, former Chief of Counsel, Nuremberg) specializing in international law.

267 Auf Seite zwei sind die Adressen der Empfänger des Schreibens aufgelistet.

268 Mit der Umstellung der juristischen Abschlüsse in den Vereinigten Staaten vom Bachelor of Laws (LLB) zum Juris Doctor (JD) in den 1960er Jahren erhielten Absolventen die Möglichkeit, ihren bestehenden Abschluss umzuwandeln. Ferencz nutzte diese Option. Siehe Hofmann, Benjamin Ferencz, 201. 
MAJOR PUBLICATIONS:

DEFINING INTERNATIONAL AGGRESSION (2 vols. 1975)

AN INTERNATIONAL CRIMINAL COURT (2 vols. 1980)

ENFORCING INTERNATIONAL LAW (2 vols. 1983)

A COMMON SENSE GUIDE TO WORLD PEACE (1985) Transl: Wege zum Weltfrieden (1989)

LESS THAN SLAVES (Harvard University, 1979, paperback, 1981, Transl: LOHN DES GRAUENS, TV Documentary Vernichtung Durch Arbeit.)

PLANETHOOD (with Ken Keyes, 1988, 2[n]d ed. 1991; French edition: Planethood ou Les Cityoens [sic] du Monde 1989)

WORLD SECURITY FOR THE 21st CENTURY (Ed., 1991)

In preparation: NEW LEGAL FOUNDATIONS FOR GLOBAL SURVIVAL.

Author of many monographs, encyclopedia articles for the Max Planck Institute, Heidelberg (topics: Aggression; Crimes Against Humanity; An International Criminal Court). Numerous writings in professional journals, newspapers, book reviews and commentaries (including radio and TV) primarily on matters of international law, need for an international criminal court and peace.

MEMBERSHIPS: American Society of International Law (Former Vice-President); World Peace Through Law Center; Nuclear Age Peace Foundation; Global Education Associates; Center for UN Reform; Association International de Droit Penal; Center for War/Peace Studies; and many others. Senior Special Fellow of UNITAR (1991). Current NGO representative at the UN of the ASIL and the International Association of Educators for World Peace.

READY TO SERVE as a Judge, or Consultant in connection with the proposed International Criminal Court for crimes in Yugoslavia.

June 1993. 


\section{Anhang}





\section{Abkommen, Deklarationen und Gesetze}

Abkommen über deutsche Auslandsschulden [Londoner Schuldenabkommen], London, 27. Februar 1953.

Abkommen zwischen der Bundesrepublik Deutschland und dem Staate Israel [Luxemburger Abkommen], Luxemburg, 10. September 1952.

Alliierter Kontrollrat in Deutschland, Gesetz Nr. 10, Bestrafung von Personen, die sich Kriegsverbrechen, Verbrechen gegen den Frieden oder gegen die Menschlichkeit schuldig gemacht haben, Berlin, 20. Dezember 1945.

Bundesgerichtshof, IX ZR 116/74, [In fremder Währung entstandene Heilverfahrenskosten sind nach dem Kurswert, der zur Zeit der Aufwendung maßgebend war, in Deutsche Mark umzurechnen], Karlsruhe, 12. Juni 1975.

Bundesgerichtshof, VI ZR 186/61, [Abweisung der Revision gegen das Urteil des 10. Zivilsenats des Kammergerichts in Berlin vom 12. Juli 1961 über die Zulässigkeit der Geltendmachung von Schadensersatzanspruch], Karlsruhe, 17. März 1964.

Bundesgerichtshof, VI ZR 187/61, [Abweisung der Revision gegen das Urteil des 10. Zivilsenats des Kammergerichts in Berlin vom 12. Juli 1961 über die Zulässigkeit der Geltendmachung von Schadensersatzanspruch], Karlsruhe, 17. März 1964.

Deutscher Bundestag, Gesetz zur Durchführung der Vierten, Siebenten und Achten Richtlinie des Rates der Europäischen Gemeinschaften zur Koordinierung des Gesellschaftsrechts (Bilanzrichtlinien-Gesetz - BiRiLiG), Bonn, 19. Dezember 1985.

Deutscher Bundestag, Bundesergänzungsgesetz zur Entschädigung für Opfer der nationalsozialistischen Verfolgung (BEG), Bonn, 18. September 1953.

Deutscher Bundestag, Drittes Gesetz zur Änderung des Bundesergänzungsgesetzes zur Entschädigung für Opfer der nationalsozialistischen Verfolgung, Bonn, 29. Juni 1956.

Deutscher Bundestag, Gesetz betreffend das Abkommen vom 10. September 1952 zwischen der Bundesrepublik Deutschland und dem Staate Israel, Bonn, 21. März 1953.

Deutscher Bundestag, Gesetz über den Aufruf der Gläubiger der I. G. Farbenindustrie Aktiengesellschaft in Abwicklung, Bonn, 27. Mai 1957.

Deutscher Bundestag, Gesetz über den Lastenausgleich (Lastenausgleichsgesetz - LAG), Bonn, 14. August 1952.

Deutscher Bundestag, Bundesgesetz zur Regelung der rückerstattungsrechtlichen Geldverbindlichkeiten des Deutschen Reichs und gleichgestellter Rechtsträger (Bundesrückerstattungsgesetz - BRüG), Bonn, 19. Juli 1957.

Deutscher Bundestag, Zweites Gesetz zur Änderung des Bundesentschädigungsgesetzes (BEG-Schlußgesetz), Bonn, 14. September 1965.

Länderrat des amerikanischen Besatzungsgebiets, Gesetz zur Wiedergutmachung nationalsozialistischen Unrechts [USEG], Stuttgart, 26. April 1949. 
Office of Military Government for Germany (U.S.), Militärregierungsgesetz Nr. 59, Rückerstattung feststellbarer Vermögensgegenstände [USREG], Berlin, 10. November 1947.

United Nations, Charter of the United Nations and Statute of the International Court of Justice, San Francisco, Calif., 26. Juni 1945.

United Nations General Assembly, A/RES/33/97, Draft Code of Offences against the Peace and Security of Mankind, New York, 16. Dezember 1978.

United Nations General Assembly, A/RES/37/10, Manila Declaration on the Peaceful Settlement of International Disputes, New York, 15. November 1982.

United Nations General Assembly, A/RES/44/39, International Criminal Responsibility of Individuals and Entities Engaged in Illicit Trafficking in Narcotic Drugs Across National Frontiers and Other Transnational Criminal Activities: Establishment of an International Criminal Court With Jurisdiction Over Such Crimes, New York, 4. Dezember 1989.

United Nations General Assembly, A/RES/3314, Definition of Aggression, New York, 14. Dezember 1974.

United Nations General Assembly, A/RES/180, Draft Convention on Genocide, New York, 21. November 1947.

United Nations Security Council, S/RES/827, International Criminal Tribunal for the Former Yugoslavia, New York, 25. Mai 1993.

United States Congress, Public Law No. 87-846, An Act to Amend the War Claims Act of 1948, as Amended, to Provide Compensation for Certain World War II Losses [War Claims Act of 1962], Washington, D. C., 22. Oktober 1962.

United States Congress, Public Law No. 91-571, An Act to Amend Section 213 (a) of the War Claims Act of 1948 With Respect to Claims of Certain Non-Profit Organizations and Certain Claims of Individuals, Washington, D. C., 24. Dezember 1970.

United States Congress, Public Law No. 98-525, The United States Institute of Peace Act, Washington, D. C., 19. Oktober 1984.

United States House of Representatives, H. Con. Res. 66, Calling for the Creation of an International Criminal Court With Jurisdiction Over Internationally Recognized Crimes of Terrorism, Illicit International Narcotics Trafficking, Genocide, and Torture, as those Crimes are Defined in Various International Conventions, Washington, D. C., 2. März 1989.

Volkskammer, Antrag aller Fraktionen der Volkskammer der Deutschen Demokratischen Republik zu einer gemeinsamen Erklärung, Berlin,12. April 1990. 


\section{Bibliografie}

Abendschein-Angerstein, Tanja, Internationale Verrechtlichung, in: Informationen zur politischen Bildung 325 (2015), 10-16.

Aden, Mareike, Ben Ferencz. Der letzte Mann von Nürnberg, Deutschlandfunk, 15. September 2016, <http://www.deutschlandfunk.de/ben-ferencz-der-letzte-mann-vonnuernberg.1773.de.html?dram:article_id=365892> (17. März 2018).

Amos, Jennifer, Unterstützen und Unterlaufen. Die Sowjetunion und die Allgemeine Erklärung der Menschenrechte, 1948-1958, in: Stefan-Ludwig Hoffmann (Hg.), Moralpolitik. Geschichte der Menschenrechte im 20. Jahrhundert, Göttingen 2010, 142-168.

Angrick, Andrej, Besatzungspolitik und Massenmord. Die Einsatzgruppe D in der südlichen Sowjetunion 1941-1943, Hamburg 2003.

Anonymus, Entschädigung. Sklaven des Reichs, in: Der Spiegel, 13. Mai 1964, 59-61.

Anonymus, Hughes to Propose Panel to Fix War Crimes Blame, in: The New York Times, 5. April 1971, 12.

Anonymus, Mit Israel auf einer Linie. Auch die DDR müßte zu den Zahlungen für Kriegsgeschädigte einen Beitrag leisten, in: Sudetenpost. Offizielles Organ der Sudetendeutschen Landsmannschaft in Österreich, 19. Januar 1973, 1.

Anonymus, Arms and the Woman, in: The New York Times, 29. Juni 1987, B6.

Anonymus, Nazi Experimentation Victims Are Helped by United Nations, in: United Nations Bulletin, 15. März 1952, $270 \mathrm{f}$.

Anonymus, Rheinmetall. Schüsse gegen Wunderwaffe, in: Der Spiegel, 7. März 1966, 52-54. Anonymus, The Case of Adolf Eichmann, in: The Times [London], 25. Mai 1960, 13.

Anonymus, Unterstützung für Verfolgte des Naziregimes in den USA, in: Neues Deutschland, 23. November 1976, 2.

Assmann, Aleida/Frevert, Ute, Geschichtsvergessenheit - Geschichtsversessenheit. Vom Umgang mit deutschen Vergangenheiten nach 1945, Stuttgart 1999.

Bästlein, Klaus, Der Fall Globke. Propaganda und Justiz in Ost und West, Berlin 2018.

Bass, Gary Jonathan, Stay the Hand of Vengeance. The Politics of War Crimes Tribunals, Princeton, N. J./Oxford 2000.

Baumann, Stefanie Michaela, Menschenversuche und Wiedergutmachung. Der lange Streit um Entschädigung und Anerkennung der Opfer nationalsozialistischer $\mathrm{Hu}$ manexperimente, München 2009.

Bazyler, Michael, Holocaust, Genocide, and the Law. A Quest for Justice in a Post-Holocaust World, New York 2016.

Belknap, Michal R., The Vietnam War on Trial. The My Lai Massacre and the CourtMartial of Lieutenant Calley, Lawrence, Kans., 2002.

Bentwich, Norman, The United Restitution Organization 1948-1968. The Work of Restitution and Compensation for Victims of Nazi Oppression, London 1969.

Benz, Wolfgang, Der Wollheim-Prozeß. Zwangsarbeit für I. G. Farben in Auschwitz, in: 
Ludolf Herbst/Constantin Goschler (Hg.), Wiedergutmachung in der Bundesrepublik Deutschland, München 1989, 303-326.

Benz, Wolfgang, Deutsche Juden im 20. Jahrhundert. Eine Geschichte in Portraits, München 2011.

Benz, Wolfgang/Distel, Barbara (Hg.), Der Ort des Terrors. Geschichte der nationalsozialistischen Konzentrationslager, 9 Bde., München 2005-2009.

Benz, Wolfgang/Distel, Barbara (Hg.), Flossenbürg. Das Konzentrationslager Flossenbürg und seine Außenlager, München 2007.

Bevers, Jürgen, Der Mann hinter Adenauer. Hans Globkes Aufstieg vom NS-Juristen zur Grauen Eminenz der Bonner Republik, Berlin 2009.

Borggräfe, Henning, Zwangsarbeiterentschädigung. Vom Streit um »vergessene Opfer« zur Selbstaussöhnung der Deutschen, Göttingen 2014.

Brandt, Leo, Über den Anteil jüdischer Persönlichkeiten an der Entwicklung der deutschen Elektroindustrie, in: Allgemeine Wochenzeitung der Juden in Deutschland 15 (1960), H. 6, 49, 51.

Brandt, Leo, Zur Erinnerung an Leo Löwenstein, in: Allgemeine Wochenzeitung der Juden in Deutschland 15 (1960), H. 25, 49, 64.

Breitman, Richard/Goda, Norman J. W., Hitler's Shadow. Nazi War Criminals, U. S. Intelligence, and the Cold War, Washington, D. C., 2004.

Brenner, Michael/Frei, Norbert, Zweiter Teil: 1950-1967. Konsolidierung, in: Michael Brenner (Hg.), Geschichte der Juden in Deutschland von 1945 bis zur Gegenwart. Politik, Kultur und Gesellschaft, München 2012, 153-293.

Breunig, Marion, Von Nürnberg nach Vietnam: Das »Russell-Tribunal« von 1967 in historischer Perspektive, in: Manfred Berg/Philipp Gassert (Hg.), Deutschland und die USA in der Internationalen Geschichte des 20. Jahrhunderts. Festschrift für Detlev Junker, Stuttgart 2004, 115-136.

Brodesser, Hermann-Josef u.a., Wiedergutmachung und Kriegsfolgenliquidation. Geschichte - Regelungen - Zahlungen, München 2000.

Brown-Fleming, Suzanne, Nazi Persecution and Postwar Repercussions. The International Tracing Service and Holocaust Research, Lanham, Md., 2016.

Brunner, José/Goschler, Constantin/Frei, Norbert (Hg.), Die Globalisierung der Wiedergutmachung. Politik, Moral, Moralpolitik, Göttingen 2013.

Bundespresseamt, Mitteilung des Presse- und Informationsdiensts der Bundesregierung Nr. 651/51, 26. Juli 1951.

Buscher, Frank M., Bestrafen und erziehen. »Nürnberg « und das Kriegsverbrecherprogramm der USA, in: Norbert Frei (Hg.), Transnationale Vergangenheitspolitik, Göttingen 2006, 94-139.

Buscher, Frank M., The U.S. War Crimes Trial Program in Germany, 1946-1955, New York 1989.

Bush, Jonathan A., New Dealer, Flüchtlinge und Radikale? Die Nürnberger Ankläger im Profil, in: Kim C. Priemel/Alexa Stiller (Hg.), NMT. Die Nürnberger Militärtribunale zwischen Geschichte, Gerechtigkeit und Rechtsschöpfung, Hamburg 2013, 547-585.

Çakmak, Cenap, A Brief History of International Criminal Law and International Criminal Court, Basingstoke/New York 2017. 
Chapin, Chip (Hg.), The Story of the 115th A.A.A. Gun Battalion, $2001<$ http://www. 115th-aaa-gun-bn.com/Story/frontcover.php> (10. Dezember 2018).

Clinton, William J., First Inaugural Address, 20. Januar 1993, in: The Avalon Project. Documents in Law, History and Diplomacy, 2008, <http://avalon.law.yale.edu/20th_ century/clinton1.asp> (29. Januar 2019).

Darnstädt, Thomas, Nürnberg. Menschheitsverbrechen vor Gericht 1945, München/Berlin 2015.

Deutscher Bundestag, [Entschließungsantrag der SPD-Fraktion zur Entschädigung weiblicher Mitglieder der polnischen Widerstandsbewegung], Stenografischer Bericht der 112. Sitzung, Bonn, 5. Mai 1960, 6359.

Diner, Dan, Rituelle Distanz. Israels deutsche Frage, München 2015.

Domke, Martin, The War Claims Act of 1962, in: The American Journal of International Law 57 (1963), H. 2, 354-372.

Earl, Hilary, Beweise, Zeugen, Narrative: Der Einsatzgruppen-Prozess und die historische Forschung zur Genese der »Endlösung«, in: Kim C. Priemel/Alexa Stiller (Hg.), NMT. Die Nürnberger Militärtribunale zwischen Geschichte, Gerechtigkeit und Rechtsschöpfung, Hamburg 2013, 127-157.

Earl, Hilary, The Nuremberg SS-Einsatzgruppen Trial, 1945-1958. Atrocity, Law, and History, New York 2009.

Eichmüller, Andreas, Die SS in der Bundesrepublik. Debatten und Diskurse über ehemalige SS-Angehörige 1949-1985, Berlin/Boston, Mass., 2018.

Eisenhower, Dwight D., Radio and Television Broadcast With Prime Minister Macmillan in London. August 31, 1959, in: Dwight D. Eisenhower, Public Papers of the Presidents of the United States, 1959. Containing the Public Messages, Speeches, and Statements of the President. January 1 to December 31. 1959, Washington, D. C., 1960, 621-628.

English, Michael D., The United States Institute of Peace. A Critical History, Boulder, Colo., 2018.

Erdheim, Stuart G., Could the Allies Have Bombed Auschwitz-Birkenau?, in: Holocaust and Genocide Studies 11 (1997), H. 2, 129-170.

Erker, Paul (Hg.), Rechnung für Hitlers Krieg. Aspekte und Probleme des Lastenausgleichs, Heidelberg 2004.

Feldenkirchen, Wilfried, Siemens. 1918-1945, München 1995.

Ferencz, Benjamin B., A Common Sense Guide to World Peace, London/Rom/New York 1985.

Ferencz, Benjamin B., A Visionary for World Peace. Stories of the Life and Times of Benjamin B. Ferencz, <http://www.benferencz.org/stories.html> (13. Dezember 2018).

Ferencz, Benjamin B., An International Criminal Code and Court: Where They Stand and Where They're Going, in: Columbia Journal of Transnational Law 30 (1992), H. 2, 375-399.

Ferencz, Benjamin B., An International Criminal Court. A Step Toward World Peace. A Documentary History and Analysis, 2 Bde., London/Rom/New York 1980.

Ferencz, Benjamin B., Bush Deserves Praise for Restraint on Noriega, in: The New York Times, 23. Oktober 1989, A18. 
Ferencz, Benjamin B., Compensating Victims of the Crimes of War, in: The Virginia Journal of International Law 12 (1972), H. 3, 343-353.

Ferencz, Benjamin B., Defining Aggression: Where it Stands and Where it's Going, in: American Journal of International Law 66 (1972), H. 3, 491-508.

Ferencz, Benjamin B., Defining International Aggression. The Search for World Peace. A Documentary History and Analysis, 2 Bde., Dobbs Ferry, N. Y., 1975.

Ferencz, Benjamin B., Enforcing International Law. A Way to World Peace. A Documentary History and Analysis, 2 Bde., London/Rom/New York 1983.

Ferencz, Benjamin B., Ferencz Addresses Rome Conference, Juni 1998, <http://www. benferencz.org/lectures.html\#rome> (6. April 2018).

Ferencz, Benjamin B., From Nuremberg to Rome: A Personal Account, in: Mark Lattimer/ Philippe Sands (Hg.), Justice for Crimes Against Humanity, Oxford/Portland, Oreg., 2003, 31-45.

Ferencz, Benjamin B., Hostile French Civilians, in: Journal of Criminal Law and Criminology 35 (1944-1945), H. 4, 228-232.

Ferencz, Benjamin B., Less than Slaves. Jewish Forced Labor and the Quest for Compensation, Cambridge, Mass., 1979.

Ferencz, Benjamin B., Lohn des Grauens. Die Entschädigung jüdischer Zwangsarbeiter. Ein offenes Kapitel deutscher Nachkriegsgeschichte, Frankfurt a. M./New York 1986.

Ferencz, Benjamin B., Make Law Not War, in: The World Today 54 (1998), H. 6, $152 \mathrm{f}$.

Ferencz, Benjamin B., New Legal Foundations for Global Survival. Security Through the Security Council, Dobbs Ferry, N. Y., 1994.

Ferencz, Benjamin B., Rehabilitation of Army Offenders, in: Journal of Criminal Law and Criminology 34 (1943-1944), H. 4, 245-247.

Ferencz, Benjamin B., Remarks Made at the Opening of the ICC, März 2003, <http://www. benferencz.org/lectures.html\#remarks> (6. April 2018).

Ferencz, Benjamin B., Restitution to Nazi Victims: A Milestone in International Morality, in: Harry Schneiderman (Hg.), Two Generations in Perspective. Notable Events and Trends 1896-1956, New York 1957, 300-310.

Ferencz, Benjamin B., Summary of New Legal Foundations for Global Survival, <http:// www.benferencz.org/assets/summaryglobalsurvival.pdf> (6. April 2018).

Ferencz, Benjamin B., The Draft Code of Offences Against the Peace and Security of Mankind, in: American Journal of International Law 75 (1981), H. 3, 674-679.

Ferencz, Benjamin B., The Einsatzgruppen Trial, in: Herbert R. Reginbogin/Christoph J. M. Safferling (Hg.), The Nuremberg Trials. International Criminal Law Since 1945. 60th Anniversary International Conference/Die Nürnberger Prozesse. Völkerstrafrecht seit 1945. Internationale Konferenz zum 60. Jahrestag, München 2006, 153-163.

Ferencz, Benjamin B., The Nuremberg Principles and the Gulf War, in: The St. John's Law Review 66 (1992), H. 3, 711-732.

Ferencz, Benjamin B., War Crimes Law and the Vietnam War, in: American University Law Review 17 (1968), H. 3, 403-423.

Ferencz, Benjamin B., Wege zum Weltfrieden. Was bisher getan wurde, was zu tun wäre, was man jetzt tun kann, Frankfurt a. M./New York 1989.

Ferencz, Benjamin B., West Germany: Supreme Court Bars Claims of Forced Laborers 
Against German Industrial Concerns, in: The American Journal of Comparative Law 15 (1966-1967), H. 3, 561-566.

Ferencz, Benjamin B. (Hg.), World Security for the 21st Century: Challenges and Solutions. A Colloquium Between American and Soviet Legal Experts, Dobbs Ferry, N. Y., 1991. Ferencz, Benjamin B./Keyes Jr., Ken, Comunidad planetaria, Madrid 1992.

Ferencz, Benjamin B./Keyes Jr., Ken, Planethood, ou, Les citoyens du monde. La clé pour réaliser la paix et l'abondance planétaires pour tous dès aujourd'hui, Knowlton, Que., 1989.

Ferencz, Benjamin B./Keyes Jr., Ken, PlanetHood. The Key to Your Survival and Prosperity, Coos Bay, Oreg., 1988.

Ferencz, Donald M., People v. Kagan and New York Banking Law Section 673: A Study in Misapplication, in: Pace Law Review 3 (1982), H. 1, 169-182.

Ferriday, Caroline, Les «Amis de l'A.D.I.R.» d'Amerique obtiennent des indemnités substantielles pour 136 cobayes (Hongrois et Polonais), in: Voix et Visages (Januar/Februar 1962), H. 82, 5-8.

Figaj, Thilo, Heinz Jost und der Holocaust in Weißrussland 1942. Korrektur eines Täterbildes, Norderstedt 2018.

Fink, Carole, Negotiating after Negotiations: Nahum Goldmann, West Germany, and the Origins of the 1980 Hardship Fund, in: Jahrbuch des Simon-Dubnow-Instituts/ Simon Dubnow Institute Yearbook 15 (2016), 287-305.

Finkelstein, Norman G., Die Holocaust-Industrie. Wie das Leid der Juden ausgebeutet wird, München 2001.

Frei, Norbert u. a., Flick. Der Konzern, die Familie, die Macht, München 2009.

Fritz, Ulrich, Oederan, in: Wolfgang Benz/Barbara Distel (Hg.), Der Ort des Terrors, Bd. 4: Flossenbürg, Mauthausen, Ravensbrück, München 2006, 219-223.

Fukuyama, Francis, The End of History?, in: The National Interest 16 (1989), 3-18.

Gassert, Philipp, Amerika vor Gericht. Das Russell Tribunal 1966/67, die Nürnberger Prinzipien und die Politik des »Blaming and Shaming «, in: Norbert Frei/Annette Weinke (Hg.), Toward A New Moral Order? Menschenrechtspolitik und Völkerrecht seit 1945, Göttingen 2013, 149-163.

Gerstle, Nathalie, Callsen-Prozess (Babij Jar), in: Torben Fischer/Matthias N. Lorenz (Hg.), Lexikon der »Vergangenheitsbewältigung « in Deutschland. Debatten- und Diskursgeschichte des Nationalsozialismus nach 1945, Bielefeld ${ }^{3} 2015,154 \mathrm{f}$.

Gilbert, Martin, Auschwitz und die Alliierten, München 1982.

Gilbert, Martin, Working for Farben, in: The New York Times, 9. Dezember 1979, 1.

Glueck, Sheldon, War Criminals. Their Prosecution and Punishment, New York 1944.

Glynn, Robert B./Lowenfeld, Andreas F., A Tribunal on Iran?, in: The New York Times, 29. November 1979, 27.

Gorbatschow, Michail, Realität und Garantien für eine sichere Welt - Vorschläge für ein effizienteres VN-System, in: Günther Doeker/Helmut Volger (Hg.), Die Wiederentdeckung der Vereinten Nationen. Kooperative Weltpolitik und Friedensvölkerrecht, Opladen 1990, 217-229.

Goschler, Constantin, Schuld und Schulden. Die Politik der Wiedergutmachung für NS-Verfolgte seit 1945, Göttingen ${ }^{2} 2008$. 
Goschler, Constantin, Streit um Almosen. Die Entschädigung der KZ-Zwangsarbeiter durch die deutsche Nachkriegsindustrie, in: Dachauer Hefte 2 (1986), 175-194.

Goschler, Constantin, Wiedergutmachung. Westdeutschland und die Verfolgten des Nationalsozialismus 1945-1954, München 1992.

Goschler, Constantin/Kauders, Anthony, Dritter Teil: 1968-1989. Positionierungen, in: Michael Brenner (Hg.), Geschichte der Juden in Deutschland von 1945 bis zur Gegenwart. Politik, Kultur und Gesellschaft, München 2012, 295-378.

Gotto, Klaus (Hg.), Der Staatssekretär Adenauers. Persönlichkeit und politisches Wirken Hans Globkes, Stuttgart 1980.

Grebing, Gerhardt, Zur Frage der Schaffung eines Internationalen Strafgerichtshofes, in: Goltdammer's Archiv für Strafrecht 1976, 97-113.

Greiner, Bernd, Krieg ohne Fronten. Die USA in Vietnam, Hamburg 2007.

Gross, Raphael/Renz, Werner (Hg.), Der Frankfurter Auschwitz-Prozess (1963-1965). Kommentierte Quellenedition, 2 Bde., Frankfurt a. M./New York 2013.

Hagan, John, Justice in the Balkans. Prosecuting War Crimes in the Hague Tribunal, Chicago, Ill./London 2003.

Hankel, Gerd, Die Leipziger Prozesse. Deutsche Kriegsverbrechen und ihre strafrechtliche Verfolgung nach dem Ersten Weltkrieg, Hamburg 2003.

Hansen, Niels, Aus dem Schatten der Katastrophe. Die deutsch-israelischen Beziehungen in der Ära Adenauer und David Ben Gurion. Ein dokumentierter Bericht, Düsseldorf 2002.

Heigl, Peter, Konzentrationslager Flossenbürg in Geschichte und Gegenwart. Bilder und Dokumente gegen das zweite Vergessen, Regensburg 1989.

Henry, Marilyn, Confronting the Perpetrators. A History of the Claims Conference, London/Portland, Oreg., 2007.

Herbert, Ulrich, Fremdarbeiter. Politik und Praxis des "Ausländer-Einsatzes« in der Kriegswirtschaft des Dritten Reiches, Berlin/Bonn 1985.

Herbert, Ulrich, Von Auschwitz nach Essen. Die Geschichte des KZ-Außenlagers Humboldtstraße, in: Dachauer Hefte 2 (1986), 13-34.

Herbst, Ludolf, Einleitung, in: Ludolf Herbst/Constantin Goschler (Hg.), Wiedergutmachung in der Bundesrepublik Deutschland, München 1989, 7-32.

Herbst, Ludolf/Goschler, Constantin (Hg.), Wiedergutmachung in der Bundesrepublik Deutschland, München 1989.

Herzog, Dagmar (Hg.), Brutality and Desire. War and Sexuality in Europe's Twentieth Century, Basingstoke/New York 2009.

Hockerts, Hans Günter, Anwälte der Verfolgten. Die United Restitution Organization, in: Ludolf Herbst/Constantin Goschler (Hg.), Wiedergutmachung in der Bundesrepublik Deutschland, München 1989, 249-271.

Hockerts, Hans Günter, Wiedergutmachung in Deutschland. Eine historische Bilanz 1945-2000, in: Vierteljahrshefte für Zeitgeschichte 49 (2001), H. 2, 167-214.

Hockerts, Hans Günter/Moisel, Claudia/Winstel, Tobias (Hg.), Grenzen der Wiedergutmachung. Die Entschädigung für NS-Verfolgte in West- und Osteuropa 1945-2000, Göttingen 2006. 
Hoffmann, Stefan-Ludwig (Hg.), Moralpolitik. Geschichte der Menschenrechte im 20. Jahrhundert, Göttingen 2010.

Hoffmann, Walter, We Need an International Court on Terrorism, in: The New York Times, 27. August 1989, 18.

Hofmann, Tom, Benjamin Ferencz. Nuremberg Prosecutor and Peace Advocate, Jefferson, N.C., 2014.

Holmes, Oliver Wendell, The Path of Law, in: Harvard Law Review 10 (1897), H. 8, 457-478.

Hopmann, Barbara u. a., Zwangsarbeit bei Daimler-Benz, Stuttgart ${ }^{2} 2017$.

Hubbard, L. Ron, Scientology: Plan for World Peace, East Grinstead 1964.

Hughes, Michael L., Shouldering the Burdens of Defeat. West Germany and the Reconstruction of Social Justice, Chapel Hill, N. C./London 1999.

Huston, Luther A., Supreme Court Frees Bridges Under Statute of Limitations, in: The New York Times, 16. Juni 1953, 1.

Ikenberry, G. John, Liberal Leviathan. The Origins, Crisis, and Transformation of the American World, Princeton, N. J., 2011.

International Military Tribunal, Trial of the Major War Criminals Before the International Military Tribunal, 42 Bd., Nürnberg 1948.

Irvin-Erickson, Douglas, Raphaël Lemkin and the Concept of Genocide, Philadelphia, Pa., 2017.

James, Harold, Krupp. Deutsche Legende und globales Unternehmen, München 2011.

Jefferson, Thomas, Notes on the State of Virginia, Philadelphia, Pa., 1788.

Jelinek, Yeshayahu A., Deutschland und Israel 1945-1965. Ein neurotisches Verhältnis, München 2004.

Käppner, Joachim, Berthold Beitz. Die Biographie, Berlin 2010.

Kagan, Saul/Weismann, Ernest H., Report on the Operations of the Jewish Restitution Successor Organization 1947-1972, New York o. J. [1973].

Kempter, Klaus, Joseph Wulf. Ein Historikerschicksal in Deutschland, Göttingen/Bristol, Conn., ${ }^{2} 2014$.

Kennedy, Edward M., International Humanitarian Assistance: Proposals For Action, in: Virgina Journal of International Law 12 (1972), H. 3, 299-308.

Keyes, Ken, The Hundredth Monkey, Coos Bay, Oreg., 1982.

Klein, Peter (Hg.), Die Einsatzgruppen in der besetzten Sowjetunion 1941/42. Die Tätigkeits- und Lageberichte des Chefs der Sicherheitspolizei und des SD, Berlin 1997.

Klewitz, Bernd, Die Arbeitssklaven der Dynamit Nobel. Ausgebeutet und vergessen. Sklavenarbeiter und KZ-Häftlinge in Europas größten Rüstungswerken im 2. Weltkrieg, Schalksmühle 1986.

Klutznick, Philip M., Rethinking the Jewish Condition, in: National Jewish Monthly 95 (April 1981), H. 8, 41-44.

Knill, Christoph/Preidel, Caroline/Nebel, Kerstin, Einleitung. Moralpolitik als Analysegegenstand, in: Christoph Knill u. a. (Hg.), Moralpolitik in Deutschland. Staatliche Regulierung gesellschaftlicher Wertekonflikte im historischen und internationalen Vergleich, Wiesbaden 2015, 15-24.

Korey, William, On Banning Genocide: `We Should Have Been the First`, in: World Magazine, 26. September 1972, 28-32. 
Krausnick, Helmut/Wilhelm, Hans-Heinrich, Die Truppe des Weltanschauungskrieges. Die Einsatzgruppen der Sicherheitspolizei und des SD 1938-1942, Stuttgart 1981.

Kreikamp, Hans-Dieter, Deutsches Vermögen in den Vereinigten Staaten. Die Auseinandersetzung um seine Rückführung als Aspekt der deutsch-amerikanischen Beziehungen 1952-1962, Stuttgart 1979.

KZ-Gedenkstätte Flossenbürg (Hg.), Konzentrationslager Flossenbürg 1938-1945. Katalog zur ständigen Ausstellung, Göttingen 2008.

Lattimer, Mark/Sands, Philippe (Hg.), Justice for Crimes Against Humanity, Oxford/Portland, Oreg., 2003.

Lersner, Kurt von, Die Auslieferung der deutschen "Kriegsverbrecher «, in: Heinrich Schnee/Hans Draeger (Hg.), Zehn Jahre Versailles, Bd. 1: Der Rechtsanspruch auf Revision/Der Kampf um die Revision/Die wirtschaftlichen Folgen des Versailler Vertrages, Berlin 1929, 15-27.

Library of Congress, 2011525367, Clio E. Straight, Report of the Deputy Judge Advocate for War Crimes, European Command. June 1944 to July 1948.

Lillteicher, Jürgen, Raub, Recht und Restitution. Die Rückerstattung jüdischen Eigentums in der frühen Bundesrepublik, Göttingen 2007.

Littmann, Friederike, Vom Notstand eines Haupttäters. Zwangsarbeit im Flick-Konzern, in: 1999. Zeitschrift für Sozialgeschichte des 20. und 21. Jahrhunderts 1 (1986), H. 1, 4-43.

Lommatzsch, Erik, Hans Globke (1898-1973). Beamter im Dritten Reich und Staatssekretär Adenauers, Frankfurt a. M./New York 2009.

Ludi, Regula, Reparations for Victims in Postwar Europe, Cambridge, Mass., u. a. 2012.

Lustig, Jason, Who Are to Be the Successors of European Jewry? The Restitution of German Jewish Communal and Cultural Property, in: Journal of Contemporary History 52 (2017), H. 3, 519-545.

Maguire, Patrick, Telford Taylor, in: The Independent, 25. Mai 1998, 16.

Mallmann, Klaus-Michael/Böhler, Jochen/Matthäus, Jürgen, Einsatzgruppen in Polen. Darstellung und Dokumentation, Darmstadt 2008.

Manchester, William, The Arms of Krupp. 1587-1968, Boston, Mass., 1968.

Marrus, Michael R., Some Measure of Justice. The Holocaust Restitution Campaign of the 1990s, Madison, Wis., 2009.

McNeill, John H., Book Review: Planethood: The Key to Your Survival and Prosperity, in: The American Journal of International Law 85 (1991), H.1, $227 \mathrm{f}$.

Mégret, Frédéric, International Criminal Justice as a Juridical Field, in: Champ Pépenal/ Penal Field 13 (2016), <http://journals.openedition.org/champpenal/9284> (1. Februar 2019).

Meining, Stefan, Im Schatten der Vergangenheit. Ostdeutsch-jüdisch-amerikanische Beziehungen (1974-1989), in: Heiner Timmermann (Hg.), Diktaturen in Europa im 20. Jahrhundert - der Fall DDR, Berlin 1996, 695-720.

Meining, Stefan, Kommunistische Judenpolitik. Die DDR, die Juden und Israel, Hamburg 2002.

Mendelsohn, John/Detwiler, Donald S. (Hg.), The Holocaust. Selected Documents, 18 Bde., New York 1982. 
Mische, Patricia M., Star Wars and the State of Our Souls. Deciding the Future of Planet Earth, Minneapolis, Minn., 1985.

Moisel, Claudia, Frankreich und die deutschen Kriegsverbrecher. Politik und Praxis der Strafverfolgung nach dem Zweiten Weltkrieg, Göttingen 2004.

Moisel, Claudia, Pragmatischer Formelkompromiss: Das deutsch-französische Globalabkommen von 1960, in: Hans Günter Hockerts/Claudia Moisel/Tobias Winstel (Hg.), Grenzen der Wiedergutmachung. Die Entschädigung für NS-Verfolgte in West- und Osteuropa 1945-2000, Göttingen 2006, 242-284.

Monaco, Daniel J., A Citizens' World Court, in: The World Jurist 33 (1996), H. 6, 9.

Moyn, Samuel, Human Rights and the Uses of History, New York/London 2014.

Neufeld, Michael J./Berenbaum, Michael (Hg.), The Bombing of Auschwitz. Should the Allies Have Attempted It?, New York 2000.

Nuernberg Military Tribunals, Trials of War Criminals Before the Nuernberg Military Tribunals Under Control Council Law No. 10, Nuernberg October 1946-April 1949, 15 Bde., Washington, D. C., 1949-1953.

Ogorreck, Ralf, Die Einsatzgruppen und die »Genesis der Endlösung«, Berlin 1996.

Ogorreck, Ralf/Rieß, Volker, Fall 9: Der Einsatzgruppenprozeß (gegen Otto Ohlendorf und andere), in: Gerd R. Ueberschär (Hg.), Der Nationalsozialismus vor Gericht. Die alliierten Prozesse gegen Kriegsverbrecher und Soldaten 1943-1952, Frankfurt a. M. 1999, 164-175.

Parkinson, Cyril Northcote, Parkinson's Law, and Other Studies in Administration, Boston, Mass., 1957.

Pendas, Devin O., Der Auschwitz-Prozess. Völkermord vor Gericht, München 2013.

Piper, Ernst (Hg.), Gibt es wirklich eine Holocaust-Industrie? Zur Auseinandersetzung um Norman Finkelstein, Zürich 2001.

Pohl, Dieter, Die Einsatzgruppe C 1941/1942, in: Peter Klein (Hg.), Die Einsatzgruppen in der besetzten Sowjetunion 1941/42, Berlin 1997, 71-87.

Polish Ministry of Information (Hg.), The Black Book of Poland, New York 1942.

Priemel, Kim C., Der Sonderweg vor Gericht. Angewandte Geschichte im Nürnberger Krupp-Prozess, in: Historische Zeitschrift 294 (2012), H. 2, 391-426.

Priemel, Kim C., Flick. Eine Konzerngeschichte vom Kaiserreich bis zur Bundesrepublik, Göttingen 2007.

Priemel, Kim C., Tradition und Notstand. Interpretations- und Konfliktlinien im Fall Krupp, in: Priemel, Kim C./Stiller, Alexa (Hg.), NMT. Die Nürnberger Militärtribunale zwischen Geschichte, Gerechtigkeit und Rechtsschöpfung, Hamburg 2013, 434-463.

Priemel, Kim C./Stiller, Alexa (Hg.), NMT. Die Nürnberger Militärtribunale zwischen Geschichte, Gerechtigkeit und Rechtsschöpfung, Hamburg 2013.

Raithel, Thomas, Das Landsberger Gefängnis vor und nach 1945, in: Volker Dotterweich (Hg.), Landsberg in der Zeitgeschichte - Zeitgeschichte in Landsberg, München 2010, 407-430.

Raymond, Jack, Pentagon Scored on Gun Purchase. B'nai B’rith Protests Plan to Buy from German Plant That Used Slave Labor, in: The New York Times, 6. Februar 1966, 1.

Reisman, W. Michael, Coercion and Self-Determination: Construing Charter Article 2(4), in: American Journal of International Law 78 (1984), H. 3, 642-645. 
Republic of Poland Ministry of Foreign Affairs (Hg.), German Occupation of Poland. Extract of Note Addressed to the Allied and Neutral Powers, New York 1942.

Rice, Rondall, Bombing Auschwitz: US 15th Air Force and the Military Aspects of a Possible Attack, in: War in History 6 (1999), H. 2, 205-229.

Rodgers, Daniel T., Atlantic Crossings. Social Politics in a Progressive Age, Cambridge, Mass., 2000.

Rodgers, Jennifer, From the `Archive of Horrors` to the sShop of Window Democracy The International Tracing Service 1942-2013, Diss., University of Pennsylvania 2014.

Röder, Werner/Strauss, Herbert A. (Hg.), Biographisches Handbuch der deutschsprachigen Emigration nach 1933, 3 Bde., München u. a. 1980-1983.

Rombeck-Jaschinski, Ursula, Das Londoner Schuldenabkommen. Die Regelung der deutschen Auslandsschulden nach dem Zweiten Weltkrieg, München 2005.

Rosenthal, Abraham M., On my Mind. A Man Called Lemkin, in: The New York Times, 18. Oktober 1988, A31.

Rudenstine, David, The Day the Presses Stopped. A History of the Pentagon Papers Case, Berkeley, Calif./Los Angeles, Calif./London 1996.

Rüss, Hartmut, Kiev/Babij Jar 1941, in: Gerd R. Ueberschär (Hg.), Orte des Grauens. Verbrechen im Zweiten Weltkrieg, Darmstadt 2003, 102-113.

Rüter, Christiaan F./Mildt, Dirk Welmoed de (Bearb.), Justiz und NS-Verbrechen. Sammlung deutscher Strafurteile wegen nationalsozialistischer Tötungsverbrechen 1945-1999, Bd. 31: Die vom 31. Oktober 1968 bis zum 14. März 1969 ergangenen Strafurteile, Amsterdam/München 2004.

Rupieper, Hermann-Josef, Der besetzte Verbündete. Die amerikanische Deutschlandpolitik 1949-1955, Opladen 1991.

Sachse, Carola, Zwangsarbeit jüdischer und nichtjüdischer Frauen und Männer bei der Firma Siemens 1940 bis 1945, in: Internationale wissenschaftliche Korrespondenz zur Geschichte der deutschen Arbeiterbewegung 27 (1991), H. 1, 1-12.

Sagi, Nana, German Reparations. A History of the Negotiations, Jerusalem 1980.

Sagi, Nana, Wiedergutmachung für Israel. Die deutschen Zahlungen und Leistungen, Stuttgart 1981.

Sands, Philippe, Rückkehr nach Lemberg. Über die Ursprünge von Genozid und Verbrechen gegen die Menschlichkeit. Eine persönliche Geschichte, Frankfurt a. M. 2018.

Schachter, Oscar, The Legality of Pro-Democratic Invasion, in: American Journal of International Law 78 (1984), H. 3, 645-650.

Schaller, Dominik J./Zimmerer, Jürgen (Hg.), The Origins of Genocide. Raphael Lemkin as a Historian of Mass Violence, New York 2009.

Schmid, Carlo, Erinnerungen, Bern/München/Wien 1979.

Schrafstetter, Susanna, Verfolgung und Wiedergutmachung. Karl M. Hettlage: Mitarbeiter von Albert Speer und Staatssekretär im Bundesfinanzministerium, in: Vierteljahrshefte für Zeitgeschichte 56 (2008), H. 3, 431-466.

Schreiber, Ruth, New Jewish Communities in Germany after World War II and the Successor Organizations in the Western World, in: Journal of Israeli History 18 (1997), H. 2/3, 167-190.

Schwartz, Thomas Alan, Die Begnadigung deutscher Kriegsverbrecher. John J. McCloy 
und die Häftlinge von Landsberg, in: Vierteljahrshefte für Zeitgeschichte 38 (1990), H. 3, 375-414.

Schwarz, Walter, Rückerstattung nach den Gesetzen der Alliierten Mächte, München 1974

(Die Wiedergutmachung nationalsozialistischen Unrechts durch die Bundesrepublik Deutschland, hg. v. Bundesminister der Finanzen in Zusammenarbeit mit Walter Schwarz, Bd. 1).

Seidel, Irmgard, Sömmerda, in: Wolfgang Benz/Barbara Distel (Hg.), Der Ort des Terrors. Geschichte der nationalsozialistischen Konzentrationslager, Bd. 3: Sachsenhausen und Buchenwald, München 2006, 575-577.

Segev, Tom, Simon Wiesenthal. Die Biographie, München 2010.

Seliger, Hubert, Politische Anwälte? Die Verteidiger der Nürnberger Prozesse, BadenBaden 2016.

Senghaas, Dieter, Es gibt Grund zum Optimismus. Wie das Recht den Frieden sichert, in: Frankfurter Allgemeine Zeitung, 3. November 1989, 14.

Shipler, David K., In Soviet, Change Struggles to Emerge, in: The New York Times, 8. Mai 1988, 1.

Siegert, Toni, Das Konzentrationslager Flossenbürg. Ein Lager für sogenannte Asoziale und Kriminelle, in: Martin Broszat/Elke Fröhlich (Hg.), Bayern in der NS-Zeit, Bd. 2: Herrschaft und Gesellschaft im Konflikt, München/Wien 1979, 429-492.

Siehr, Kurt, 50 Jahre nach Entdeckung der Dürer-Portraits in New York - Zum Rechtsstreit »Kunstsammlungen zu Weimar v. Elicofon«, in: Matthias Weller/Nicolai B. Kemle/ Thomas Dreier (Hg.), Kunst und Recht - Rückblick, Gegenwart und Zukunft. Tagungsband des Zehnten Heidelberger Kunstrechtstags am 21. und 22. Oktober 2016, Baden-Baden 2017, 103-128.

Sigel, Robert, Die Dachauer Prozesse 1945-1948 in der Öffentlichkeit: Prozesskritik, Kampagne, politischer Druck, in: Jörg Osterloh/Clemens Vollnhals (Hg.), NS-Prozesse und deutsche Öffentlichkeit. Besatzungszeit, frühe Bundesrepublik und DDR, Göttingen 2011, 131-148.

Sohn, Louis (Hg.), International Organization and Integration, Dordrecht u. a. 1986.

Steinberger, Petra (Hg.), Die Finkelstein-Debatte, München 2001.

Steiner, André, Von Plan zu Plan. Eine Wirtschaftsgeschichte der DDR, Berlin 2007.

Stengel, Katharina, Hermann Langbein. Ein Auschwitz-Überlebender in den erinnerungspolitischen Konflikten der Nachkriegszeit, Frankfurt a. M./New York 2012.

Stiepani, Ute, Die Dachauer Prozesse und ihre Bedeutung im Rahmen der alliierten Strafverfolgung von NS-Verbrechen, in: Gerd R. Ueberschär (Hg.), Der Nationalsozialismus vor Gericht. Die alliierten Prozesse gegen Kriegsverbrecher und Soldaten 1943-1952, Frankfurt a. M. 1999, 227-239.

Takei, Ayaka, The »Gemeinde Problem«: The Jewish Restitution Successor Organization and the Postwar Jewish Communities in Germany, 1947-1954, in: Holocaust and Genocide Studies 16 (2002), H. 2, 266-288.

Taylor, Telford, Nuremberg and Vietnam. An American Tragedy, Chicago, Ill., 1970.

Taylor, Telford, Re-Educating Germany With Nazi History. A Prosecutor at Nuremberg Urges That Facts Disclosed There Be Used to Teach Democracy, in: The New York Times, 28. Mai 1950, 115-123. 
The Conference on Jewish Material Claims Against Germany, Claims Conference 2007 Annual Report With 2008 Highlights, <http://www.claimscon.org/forms/CC_AR_ 2007.pdf> (26. Juli 2018).

Ther, Philipp, Die dunkle Seite der Nationalstaaten. »Ethnische Säuberungen« im modernen Europa, Göttingen 2011.

Timm, Angelika, Alles umsonst? Verhandlungen zwischen der Claims Conference und der DDR über »Wiedergutmachung« und Entschädigung, Berlin 1996.

Timm, Angelika, Jewish Claims Against East Germany. Moral Obligations and Pragmatic Policy, Budapest 1997.

Torpey, John, Introduction. Politics and the Past, in: John Torpey (Hg.), Politics and the Past. On Repairing Historical Injustices, Lanham, Md., u. a. 2003, 1-34.

Troebst, Stefan, "Sozialistisches Völkerrecht" und die sowjetische Menschenrechtsdoktrin, in: Norbert Frei/Annette Weinke (Hg.), Toward a New Moral World Order? Menschenrechtspolitik und Völkerrecht seit 1945, Göttingen 2013, 94-104.

Ueberschär, Gerd R. (Hg.), Der Nationalsozialismus vor Gericht. Die alliierten Prozesse gegen Kriegsverbrecher und Soldaten 1943-1952, Frankfurt a. M. 1999, 164-175.

United Nations, Report of the 1953 Committee on International Criminal Jurisdiction, New York 1954.

United States Office of the US High Commissioner for Germany, Landsberg. A Documentary Report, Frankfurt a. M. 1951.

Weindling, Paul, Der Nürnberger Ärzte-Prozess. Entstehungsgeschichte, Verlauf, Nachwirkungen, in: Priemel, Kim C./Stiller, Alexa (Hg.), NMT. Die Nürnberger Militärtribunale zwischen Geschichte, Gerechtigkeit und Rechtsschöpfung, Hamburg 2013, 158-193.

Weindling, Paul, Nazi Medicine and the Nuremberg Trials. From Medical War Crimes to Informed Consent, Basingstoke/New York 2004.

Weinke, Annette, Die Nürnberger Prozesse, München 2006.

Weinke, Annette, »Von Nürnberg nach Den Haag«? Das internationale Militärtribunal in historischer Perspektive, in: Justizministerium des Landes NRW (Hg.), Leipzig Nürnberg - Den Haag. Neue Fragestellungen und Forschungen zum Verhältnis von Menschenrechtsverbrechen, justizieller Säuberung und Völkerstrafrecht, Düsseldorf 2008, 20-33.

Weisz, Christoph (Hg.), OMGUS-Handbuch. Die amerikanische Militärregierung in Deutschland 1945-1949, München 1994.

Weston, Burns H. (Hg.), Alternative Security. Living Without Nuclear Deterrence, Boulder, Colo., 1990.

Weston, Burns H., Review of A Common Sense Guide to World Peace, by Benjamin B. Ferencz, in: The American Journal of International Law 81 (1987), H. 2, 501-503.

Wiegand, Lutz, Der Lastenausgleich in der Bundesrepublik Deutschland 1949 bis 1985, Frankfurt a. M. u. a. 1992.

Wildt, Michael, Generation des Unbedingten. Das Führungskorps des Reichssicherheitshauptamtes, Hamburg 2002.

Willeke, Stefan, »Wer lügt, wird erschossen«. Benjamin Ferencz, der letzte noch lebende Chefankläger der Nürnberger Kriegsverbrecherprozesse, über die Suche nach Hitler und die fatale Kriegslogik von Donald Trump, in: Die Zeit, 28. März 2018, 12. 
Winstel, Tobias, Verhandelte Gerechtigkeit. Rückerstattung und Entschädigung für jüdische NS-Opfer in Bayern und Westdeutschland, München 2006.

Wittmann, Rebecca, Beyond Justice. The Auschwitz Trial, Cambridge, Mass./London 2005.

Wojak, Irmtrud, Fritz Bauer (1903-1968). Eine Biographie, München 2016.

Wolfson, Leah, Jewish Responses to Persecution. 1944-1946, Lanham, Md., 2015.

Workman, Debra, Engendering the Repatriation: The Return of Female Political Deportees to France Following the Second World War, in: The Proceedings of the Western Society for French History 35 (2007), 263-275.

Yearbook of the International Law Commission 3 (1951), Bd. 2: Documents of the Third Session Including the Report of the Commission to the General Assembly, New York 1957.

Zimmermann, Michael, Essen (Humboldtstraße), in: Wolfgang Benz/Barbara Distel (Hg.), Der Ort des Terrors. Geschichte der nationalsozialistischen Konzentrationslager, Bd. 3: Sachsenhausen und Buchenwald, München 2006, 436-439.

Zweig, Ronald W., German Reparations and the Jewish World. A History of the Claims Conference, London/Portland, Oreg., ${ }^{2} 2001$. 


\section{Register}

\section{Personenregister}

Abs, Hermann Josef 207, 210, 346-347

Abueva, José 621-622

Acheson, Dean 185

Adam, Isabella 224

Adam, Wilhelm 224

Adenauer, Konrad 30, 161, 183, 206-207, 243, 410, 438, 452

Aguda, Akinola 643

Alberti, ? 497, 523

Albrecht, Ulrich 622-623

Albright, Madeleine 675

Alexander, Edward 455

Alexander, Kurt 241

Alexander, Rick 648

Anderson, Jack 547

Apter, David 365

Armstrong, George W. 612

Auerbach, ? 266

Aurelio, Thomas 106

Avner, Gershon 91-92

Baer, Thomas 494

Bahr, Egon 428

Barner, Timothy 464, 677

Bartl, Edmund 304-306, 331, 343, 345

Bassiouni, M. Cherif 69-70, 74, 584, 586-588, 664, 673

Bauer, Fritz 173

Bauer, Yehuda 40, 593

Beck, ? 386

Beck-Broichsitter, Helmut 160

Beil, Gerhard 448, 456

Beitz, Berthold 294, 297, 301-302

Bendfeldt Voss, Sandra 655

Benenson, Jeanne 385, 388, 391-392, 394-395, 397, 399
Bennett, Jack 209

Bental, ? 242

Benton, Edward 494

Bentwich, Norman 241, 244

Berg, Fritz 307

Berger, Gottlob 164

Berger, Hans 376-378

Bergmann, ? 274

Bernet, Otto 281

Bernhardt, Rudolf 624

Bialkin, Kenneth J. 548-549

Biberstein, Ernst 158

Bingham, Jonathan B. 330, 462-464

Bisgyer, Maurice 94, 409, 414

Blakesley, Christopher L. 664

Blaustein, Jacob 271, 294, 296-297, 347

Blessin, Georg 378, 401

Blobel, Paul 149, 159, 190-191

Blume, Ernst 319, 330

Blume, Walter 158

Blumenthal, Roy 369-370

Bode, Günther 320-321, 326

Boden, Hans 284

Boeke, Richard F. 625

Böhm, Franz 375

Boldt, John 157

Borchardt, Frederick 267

Borda Pell, Claiborne de 613, 627

Born, ? 377, 383, 386, 397

Boschwitz, Rudolph 612-613, 627

Bouchard, Mary Alban 596

Boukstein, Maurice 91, 226, 229-230, 236

Boulding, Elise 615

Brandt, Leo 316, 318

Brandt, Willy 61

Braune, Werner 159, 190-191 
Bridges, Harry 225

Brinckmann, Rudolf 332

Brody, David A. 419-420, 422

Bronfman, Edgar Miles sen. 549

Brooks, John E. 656

Brotman, Adolph G. 244

Brozik, Karl 360-361, 488, 543-544

Bubna, Ulrich von $495,512,515,525$, 527, 556

Buchwald, ? 265

Buehle, ? 300

Buergenthal, Thomas 569, 572

Bullock, Robert 657

Bush, George H.W. 73, 630, 658, 666-667, 673, 676, 678

Bush, George W. 474

Caesar, Otto Paul 288, 319, 330

Calley, William Laws jr. 69-70, 568, 570-572

Capra, Frank 109

Carroll, Wallace 108

Carter, Barry E. 673

Cassin, René 37, 561

Celler, Emanuel 330, 346

Chatoor, Delia M. 650, 663

Chau, Kin Dinh 572

Chidester, Rick 462

Christopher, Warren M. 675

Churchill, Randolph 204

Churchill, Winston 204, 216

Clark, Bruce 467

Clay, Lucius D. 145-146, 154-155, 157, 193-194, 206, 208-209, 216, 241

Clinton, William (Bill) 44, 73, 474, 673-676

Cohen, Marga 339, 342

Cohen, Philip F. 616-617

Coleman, Helen 428

Coolidge, Calvin 566

Cooper, John S. 444-445, 447, 449-450

Cooper, Rose 654

Cousins, Norman 60, 372, 375, 380-381, 385-386, 388-389, 391, 393-396, 398, 574,619
Cox, Eric 646, 651

Cranston, Alan 627

Crowley, Ed 317-319, 333, 337

Curtius, Klaus 508

Dam, Hendrik van $258-259,266,308$

D'Amato, Alfonse 606, 608-609

D'Amato, Anthony 670

Devers, Jacob L. 113

Dierig, Christian Gottfried 286

Dithmar, Karl 157

Dobrosielski, Marian 389-390, 392, 397-399

Dorge, ? 522, 527

Doshinger, Ciri 623

Duffee, Richard 654

Dworsky, E. 526

Eagleburger, Lawrence S. 465-466, 675

Easterman, Alex 91

Eastland, James O. 420

Eastman, Hope 567-568, 571

Edelsberg, Herman 402, 404, 422, 433

Ehlers, Hermann 156

Ehrlich, Ernst Ludwig 411

Eichmann, Adolf 53, 166-173, 598

Einicke, Ludwig 443-446, 448

Eisenhower, Dwight D. 112, 232, 421, 662

Elkan, Frederick W. 292

Epstein, Benjamin 94

Eran, Avraham 293, 295-296

Erhard, Ludwig 36, 323

Fagan, Edward 35

Farbstein, Leonard 327

Féaux de la Croix, Ernst 62, 415-416, 530

Feigin, Gerta 487

Felmy, Hellmuth 164

Ferencz, Carol 92

Ferencz, Donald M. 92

Ferencz, Gertrude 25-26, 33, 49-50, 90, 92-93, 107, 140, 223, 225-226, 230 $231,238-239,270,553,558,563,625$ 
Ferencz, Joseph 88

Ferencz, Nina 92, 238

Ferencz, Pearl 88

Ferencz, Robin 92, 238

Ferriday, Caroline W. 34, 59, 61, 365, 367-368, 370-371, 379, 383, 385, 388-389, 391-392, 394-397, 399-400, 404-405

Fink, Helen 91

Fischer, Bruno 298, 332

Fischer, Fritz 189

Fischer, Oskar 459, 465-467, 470-471, $473,477-480,482-483$

Fischer, ? 300

Flechtheim, Ossip K. 623

Flick, Friedrich 33, 58, 157-158, 249, 270, 294, 298-300, 308, 310, 325, 337-338, $346,349,353$

Flick, Friedrich Christian 353

Flick, Friedrich Karl 354

Florin, Peter 438, 441

Flug, James F. 574

Franck, Thomas M. 603, 605

Franke-Gricksch, Alfred 160

Frenzel, Alfred 376

Freundorfer, Joseph 184

Fried, Gertrude $\rightarrow$ Ferencz, Getrude

Friedel, Samuel N. 420-421

Friedemann, Max 452-453, 458, 461

Friedman, Harry 494

Friedmann, Tuviah 347-348

Froehlich, ? 263-264

Fuerth, Leon 473

Fukuyama, Francis 43

Funke, Otto 448, 450, 452-453, 458-461, 464, 466

Galinski, Heinz 455, 543, 549

Gallopin, Roger 382-383, 386-387

Gallub, Jeff 469-470

Gaulle-Anthonioz, Geneviève de 384

Genscher, Hans-Dietrich 593, 660

Gentz, Manfred 359-360

Genzken, Karl 190
Gerling, Heinz 352-353

Gershwin, ? 266

Gerster, Johannes 544

Geyer, Hans-Martin 448

Gilbert, Martin 203-204, 529

Giles, Andrea 180

Gilmore, Harry 475

Ginsburg, Alexander 543, 548

Globke, Hans 376, 378

Glossop, Ronald J. 644

Glueck, Sheldon 22-25, 69

Glushakov, Vadim 555-556

Glynn, Robert B. 591

Goetz, Cecelia 270

Goldberger, Alfred 275

Goldenberg, Herbert 270

Goldman, Guido 195

Goldmann, Nahum 31, 92, 94, 243-244, $255,260-261,302,428-430,432$, 437-438, 442-447, 449, 453-456, 459-460, 464, 466, 534, 539, 545

Goldscheider, ? 555

Goldschmidt, Fritz 91, 228, 241, 243-244, 248

Gollancz, Victor 183

Gorbatschow, Michail 72, 481, 630-631, 635-638, 643

Gore, Albert A. (Al) 473-474

Göring, Hermann 153

Görner, Gunter 436-437, 442, 454-455

Gottlieb, Gideon 569

Gownley, Hugh 333

Graiver, David 550

Gray, Victor 462

Grebing, Gerhardt 589-590

Green, Lucille 624

Gringauz, Samuel 258, 266, 280

Gromyko, Andrei 222

Grove, Brendon 446-447, 451

Gruenbaum, ? 495

Grunert, Horst 463, 465, 468

Gur-Guttmann, Martin 266

Gurlitt, Hildebrand 137

Gutter, Simon 296, 307, 341, 556 
Haber, Samuel 507-509, 517-518, 523

Haberstock, Karl 89, 137

Haensel, Gerhard 442-443

Handloser, Siegfried 190

Handy, Thomas T. 157, 160

Hannemann-Strauss, ? 295

Hargrove, John Lawrence 569, 572, 603, 632

Harkleroad, Donald 568-569

Hartman, Arthur A. 444, 448-449, 456, 630

Harvey, Mary 396

Hasfurther, Donald J. 448

Hausfeld, Michael 35

Hayes, Saul 508

Hays, George P. 146

Hazard, John 95

Heath, James 26

Hellenbroich, ? 283

Helmer, Rudolf 452-455, 464, 466

Helms, Jesse 670

Henkin, Louis 605, 672, 677

Henneberry, Margaretha M. 616

Hennings, ? 503

Herbert, Ulrich 541

Herder, Gerhard 476-478, 480

Hermann, ? 441

Hermsdorf, Hans 533-535

Hesler, Algy 103-104

Heusinger, Adolf 214

Heuss, Theodor 410

Hiatt, Jacob 657

Hirsch, Lotte 416, 506

Hirsch, Martin 62, 416, 506-507, 522

Hirschberg, Ernst 502-503

Hitler, Adolf 89, 113, 136-137, 141, 150, $153,157-158,162,181,224,233,345$, $411,439,466,485,534$

Hoffmann, Walter F. 650, 677

Holmes, Oliver Wendell 283

Holstein, ? 307

Honecker, Erich 430, 434, 437, 442-447, 449-450, 457, 466, 478

Hopkins, Harry 204
Hruska, Roman L. 420-421

Hubbard, L. Ron 649

Hubrich, Eberhard 552

Hudson, Richard 677

Hughes, Harold E. 564-565

Hussein, Saddam 73, 667, 669

Ickes, Harold L. 106

Ingeborg, ? 267

Isenburg, Helene Elisabeth von 161

Jackson, Robert H. 154, 196

Jacobson, Gaynor I. 508-509

Jacobson, Jerome J. 91

Jacobson, ? 252, 255, 382-383, 387

Janner, Greville 432

Janz, Friedrich 378

Javits, Jacob K. 316, 325, 346, 419-421, 442

Jefferson, Thomas 112

Jescheck, Hans-Heinrich 581, 584

Jessup, Philip C. 222

Joftes, Saul 94

Joseph, Henry Oscar 237-238

Josephthal, Giora 91-92

Jost, Heinz 149, 164-165

Joyce, William 172

Kagan, Elizabeth 223

Kagan, Saul 65-66, 68, 93-94, 223, 225-227, 229, 237, 243, 248-249, 255, 260-261, 267-269, 271, 273, 275, 278, 280, 282-286, 288-293, 297-300, 302, 304, 306-309, 311, 313-314, 317, 320-322, 324-326, 332, 335, 337, 339, 341-342, 344-346, 349, 354, 356-361, 401, 417, 425, 429, 431-435, 441-442, 447, 449-451, 455-456, 464-466, 468, 470, 473-476, 478-479, 481-482, 485, 487-488, 501, 531-532, 536-539, 542-544, 548-555, 592, 595

Kaizik, Heinrich 504, 515-516, 522, 524, 527

Kaltenbrunner, Ernst 201 
Kaplan, Armand 432, 447-448

Kapralik, Charles 426, 500, 508-509

Katz, Label A. 94

Katzenstein, Ernst 66, 227, 238, 258, 273, 278, 281-283, 286-287, 289-292, 294-295, 297-301, 303-306, 308-309, $313-315,317-318,320,323-324,331$, $333,335,337,341,344-345,347-349$, 351-352, 354, 358, 401, 425-427, 429, 433-434, 437, 440, 449, 453-456, 464, 501-502, 510, 512-517, 521-523, 525-527, 529-533, 542, 592

Katzki, Herbert 456, 531

Kaufman, Jay 323-324, 328, 335, 415, 419, 422

Kaufman, Joseph 270

Kaufmann, Eugene 234-235

Kellog, Frank 566

Kennedy, Edward M. 419-421, 573-574

Kennedy, John F. 322, 325

Kennedy, Robert F. 325

Kent, ? 318-319

Kesselheim, Walter 280-281

Keyes, Ken jr. 628, 632, 638, 646, 680

Keys, Donald F. 619

King, Evans L. 650

Kirkpatrick, Jeane D. 613, 627

Kissinger, Henry 442

Klatte, ? 132-133

Klein, Julius 58, 94, 326-328, 333

Klein, Ruth 266

Klein, ? 410

Klingelhöfer, Woldemar 150, 214

Klutznick, Ethel 609, 627

Klutznick, Philip M. 94, 322, 326, 413, $422,464,601,607-608,626,640$

Knappstein, Karl Heinrich 322-323, 327, 335, 378, 390-391, 394, 397, 414

Knoll, ? 273

Koblenzer, Elizabeth $\rightarrow$ Kagan, Elizabeth

Koch, Ilse 154-155

Koch, Karl O. 154

Köcher, ? 582

Kohani, Akiva 531
Koppe, Fritz 530-531

Korey, William 433, 464, 575, 641

Kornblum, John C. 448

Kosterlitz, Edith 465

Kothari, Rajni 621-623

Kotliar, Vladimir 673

Kranz, ? 522

Kranzbühler, Otto 288

Krapf, Franz 376, 378

Kraus, Rudolf 544

Kreutzberger, ? 252

Krieger, David 677

Kroll, Siegfried 497-499

Kronish, Myron 677

Kronstein, Heinrich 347

Krupp von Bohlen und Halbach, Alfried 157, 194-197, 199-200, 203, 210, 212, 270, 294, 297, 301-302

Krupp von Bohlen und Halbach, Gustav 195

Küster, Otto 250, 375

Kupferman, Theodore R. 550

Lack, Daniel 351, 506-507, 510-513, 515-517, 520-522, 524-525, 528

Lammers, Hans 164

Landfer, Bill 337

Lane, Jim 475-476

Langbein, Hermann 273-274

Laor, Eran 239, 455-456

Laor, Helen 244

Lauterpacht, Hersch 9

Leach, James Albert Smith 642-643

Leavitt, Moses 91, 226-227, 229, 243244, 535

LeCoque, ? 283

Legnato, Lucette 547

Leibman, Morris I. 627

Lemkin, Raphael 9, 27, 38, 45, 641-642

Levene, ? 104, 114, 132

Levinson, ? 497

Lewinsky, Akiva 543-544

Lewis, Samuel W. 639-640

Liebermann, Max 211 
Lipschitz, Joachim 382, 468

Liskofsky, Sidney 598

Litvinov, Maxim 202

Lockwood, Bert B. 579

Logan, Andy 221

Löhnis, Rudolf 262

Loomis, Andrew F. 567-568

Lotarski, Susanne 470

Lowenfeld, Andreas 591

Lowenthal, Ernst Gottfried 288, 312

Ludwig, ? 265

Lüder, Wolfgang 544

Majak, Roger 463

Mattern, Theodore 263, 265

Matteson, Robert E. 201

Matthöfer, Hans 593

Maunoir, Jean-Pierre 390, 392-394, 397-398

Maurer, Ely 317-318, 333, 337

May, Kurt 94, 227, 236, 242-243, 247-249, 252, 255, 290, 292-293, $302,313-314,323,326,352,356,453$, 455-456, 495, 511, 514, 532, 539

McCarthy, Joseph 55, 225

McClellan, John L. 420

McCloy, Ellen 184

McCloy, John J. 48, 52, 59, 145-146, 152 , 155-157, 159, 161, 163-165, 178-218, 297, 309, 346-347, 609-610, 613, 627

McCormack, John W. 421

McCormick, Keith 469

McDougal, Myres S. 38, 638

McHaney, James M. 166

McKinley Dirksen, Everett 420

McNamara, Robert 312, 314, 324, 330, 599

Meckie, ? 236

Meed, Benjamin 548

Meier, Heinz 515

Meissner, H. 436-437

Melamed, Max 447-448

Mendelsohn, John 404

Merry, E. Wayne 475
Meyer, Hans J. 299, 308, 325

Meyer, ? 263, 265

Meyrowitz, Henri 433

Milberg, Sylvia 655

Miller, Edith 422

Miller, Israel 463-465, 467-468, 473, 475, 477-479, 482, 484-485, 488, 536, 545, 547-549, 551, 553-554, 640

Miller, Ruth 478

Mische, Gerald F. 595, 627-628, 677

Mische, Particia M. 595-596, 611-612, 627-628

Monaco, Daniel J. 634, 642-643

Monnier, ? 386

Moore, John Norton 626

Moran, Frederick A. 188

Moro, Aldo 583

Morowitz, Lou 517

Moynihan, Daniel P. 657-658, 669

Mueller, Gerhard 587

Mueller, ? 249

Müller-Dethard, Helmut 335

Muller, ? 267

Muller, ? 280

Mushakoji, Kinhide 620-621

Musmanno, Michael 218

Mutius, Carl von 370

Mutuc, Amelito R. 578-579

Nachmann, Werner $67,543,546-548$

Nafziger, James A. R. 630-631

Nanda, Ved P. 95, 570, 585, 602

Nathan, Eli 91-92

Naumann, Erich 149-150, 159, 190-191

Nenno, William 447, 451

Neumann, Karl 156

Newman, Frank C. 568-569, 571-572

Nichols, ? 625

Nichols, ? 625

Niklas, Manfred 478

Niles, Thomas M.T. 469-471, 474

Nippold, ? 544

Nixon, Richard 69, 421,442, 476, 567568,576 
Northcote Parkinson, Cyril 293

Nosske, Gustav 164-165

Oberlauter, ? 511

Ohlendorf, Käthe 177

Ohlendorf, Otto 26-28, 53, 148, 152, 159-160, 164-165, 176-177, 190-191, 197-199, 214, 218, 234

Oppenheim, Friedrich Carl von 207

Oppenheim, Waldemar von 207

Ormond, Henry 247-249, 252-253, 255, $260,266,272$

Ott, Adolf 159

Paine, Thomas 42

Patton, George Smith 23, 133, 135

Patzig, Helmut 157

Peck, David W. 186, 188, 191

Perle, Richard 473

Pferdmenges, Robert 207

Pick, Fritz 266

Pickus, Robert 637-638

Pins, Arnulf M. 429, 433, 441, 536

Platt, Stanley 677

Pölnitz, Gerhard von 137

Pohl, Oswald 160, 190

Polansky, Sol 451, 453, 455-456

Pomrenze, Seymour 237

Porter, Suzanne 462-463

Porterfield, Wendy 655, 676

Postel-Vinay, Anise 383-384

Proxmire, William 641

Rabb, Bruce 567-568

Raemaekers, Louis 199

Rasch, Otto 200, 215, 519

Ratshin, Edith 620

Raymond, Jack 57, 321-324

Raymond, John M. 163, 194

Reagan, Ronald 71-72, 476, 606, 613, 636

Reichmann, Hans 228, 241, 243-244, 247, 252

Reisman, W. Michael 603-604
Rendulic, Lothar 164

Reuter, Edzard 359

Reuter, ? 498

Rhyne, Charles S. 576-577, 583, 617

Rice, Condoleezza 630

Rice, James P. 493-495

Ridgway, Rozanne L. 470, 473-476, 629

Riegner, Gerhart M. 434

Robinson, Arthur N. R. 651, 664-665

Robinson, Jacob 9, 37, 92

Robinson, Nehemiah 92, 147, 252, 255, 261, 275, 282, 672

Robinson, Nicholas A. 671

Rockwell, Alvin 194

Röchling (Fam.) 289, 318, 335

Röchling, Ernst 318

Röchling, Hermann 318

Röling, Bert 584

Rom, ? 356

Romegialli, Mirtille 659

Roosevelt, Eleanor 193

Roosevelt, Franklin D. 55, 106, 193, 204

Root, Elihu 201-202, 212, 610

Rosen, Pinhas 53, 166-167, 170, 173

Rosenbaum, Lilly 556

Rosenberg, Ludwig 506-507

Rosenman, Samuel 203

Rosenne, Shabtai 430, 456-457

Rosenstock, Robert 597, 602

Rosenthal, Abraham M. 641

Rosenthal, Karl 228, 255, 313-314, 323

Rosh, Lea 182, 623

Ross, ? 527

Roth, Siegfried 431-432, 434, 529

Rubin, Seymour 91, 416-417, 594, 603

Rusk, David Dean 322, 324

Ryan, Charles 312, 314, 324

Saalheimer, Manfred 285-286

Saario, Voitto 643

Sachs, Henry B. 299, 311

Sachs, Norma 655

Sagi, Nana 180

Samson, Benvenuto 249 
Sand, Robert 583

Sapir, Pinhas 430

Sarre, Marie-Louise 181, 184

Schachter, Oscar 594, 603-605

Scharf, Michael P. 673

Schem, Peter 505, 511, 515, 522

Schildbach, Karl-Heinz 258, 262, 265267, 287

Schlabrendorff, Fabian von 181, 184, 298, 300, 308-311, 325, 337-339, 341-342, 347

Schlomai, ? 251-252, 255

Schluroff, ? 410

Schmid, Carlo 182-183, 382

Schmidt, Helmut 593

Schmidt, Walter 249-252, 267

Schmitt, Carl 16

Schneider, Mark L. 574

Schoenberg, Harris O. 677

Schoenfeldt, Herbert 227, 249-250, 252, 255

Scholl (Fam.) 181

Scholl, Hans 181

Scholl, Inge 181, 184

Scholl, Sophie 181

Schoyer, Adolf 411

Schubert, Heinz 164-165

Schumacher, Kurt 182-183

Schwartz, Joseph J. 240

Schwarz, Walter 260

Schwarzenberg, ? 583

Schwebel, Stephen M. 456-457, 462

Schwelb, Egon 368-369

Schwoerer, Frank 660

Scott, Hugh D. 421

Segall, Aryeh 237

Seidenberg, Hans 252, 312, 314, 317, 320, $323,326,514-515$

Selowsky, Ludwig 495

Shanahan, Michael G. 175-176, 178

Shapiro, Judah J. 93

Sharett, Moshe 31, 92

Sherman, A. Joshua 352, 456

Shinnar, Felix E. 91-92
Shipler, David K. 636

Shultz, George P. 476, 479-480, 613, 627

Sieber, Rolf 446-447

Sieburg, ? 266

Siewert, ? 410

Simon, Bernard 322, 328, 422

Simon, ? 478

Sinauer, Hannah 412, 416, 422

Sinha, Surya Prakash 655, 672

Six, Franz 149

Sklover, Joseph 416, 422

Sloan, Patricia 677

Sloan, Frank Blaine 654, 670, 675, 677

Sloop, ? 114-115, 129, 131-132

Small, David 429

Smith, Michael 475

Snow, Conrad 188-189

Snyder, ? 297

Sobotker, Martin 231

Soedjatmoko 613-614

Sohn, Louis B. 39, 41, 577-578, 587, 614

Soskis, Philip 491-492, 495, 507-509, 517-518, 523

Specter, Arlen 642

Spitzer, Jack J. 537

Sprecher, Drexel A. 90, 269, 271

Stackelberg, Herbert von 335

Staden, Berndt von 462

Staggers, Harley O. 421

Steimle, Eugen 158

Stein, Ken 609

Stein, Max 274-275, 281, 283-285, 288, 290-291, 293, 313

Stevenson, Charles A. 565

Stoltenberg, Gerhard 551

Stone, Shepard 189, 611

Strauß, Franz Josef 528

Strom, Margot 657

Süß, Herbert 444

Sutterlin, James S. 428, 430

Suy, Eric 586

Szasz, Paul C. 602-603 
Tardu, Maxime 368-369

Taylor, Telford 25, 28, 36, 38, 40, 48, 52, $55,152,160,163,166,169,185,188$, 191-196, 212, 214, 224-226, 229, 607, 673, 679

Thompson, Allan 469-471

Thorpe, Marjorie 650-651, 665

Timberland, ? 121

Treichel, James A. 447-448

Trifel, Yulia 555

Tritschler, Judith 617-619

Trobe, Harold 506

Truman, Harry S. 161

Tuch, Hans 300, 312, 316, 410-411

Turner, Robert F. 626

Tyler, William 318-319

U Thant, Sithu 619

Vagts, Detlev F. 633, 666

Vance, Cyrus R. 314-315, 318-319

Veith, Werner 261

Vest, George S. 462

Vogel, Theodor 183

Voigt, ? 266

Wangenheim-Winterstein, Elisabeth von 581

Warburg, Eric 294, 298-300, 307, 310, 325, 332, 339, 347

Warburg, Max M. 294

Ward, John 448-449

Warlimont, Walter 215

Watkins, Arthur V. 366

Wehle, Kurt 266-267, 343

Weidenbeck, Rainer 463

Weinstein, Maurice 422
Weis, George 227

Weisband, Edward 569

Weismann, Ernest H. 299, 352, 417, 465, 536

Weisz, ? 515

Werner, Alfred 263, 265, 284

West, Mary Beth 470

Weston, Burns H. 633, 665

Wexler, William A. 323-324, 326-328, $335,417-418,504$

Whitehead, John C. 479

Wieczorek, Bernhard 285

Wiesel, Elie 647

Wiesenthal, Simon 348, 426-427

Wilkinson, James 474

Wilson, H. Donald 385, 388, 391-392, 394-395, 397, 399

Winkelmann, ? 594

Winkler, ? 527

Winzer, Otto 437, 442

Wirtz, J. J. Paul 332

Woessner, William M. 474

Woetzel, Robert Kurt 70, 561-563, 670

Woetzel, Sheila M. 562

Wolf, Hans 262, 266

Wolff, Werner 68, 356-357, 554, 557

Wollheim, Norbert 55, 247, 249-250, 253, 260-261, 263, 266

Wourgaft, Serge 383-384

Wulf, Joseph 444-445

Wurzner, ? 266

Yacub, Mario Gerardo 580

Yaeger, Edith 416

Zorin, Valerian 201

Zorn, Rudolf 386 


\section{Ortsregister}

Ägypten 233, 441, 491, 639

Afghanistan 40, 596, 631

Afrika 655

Alençon 129-130

Amherst 630

Amsterdam 94, 299, 459, 549, 572

Argentinien 53, 167, 580-581

Arkansas 420

Auburndale, Mass. 562

Auschwitz $\rightarrow$ Sachregister: Konzentrations-, Arbeits- und Vernichtungslager

Australien 110, 654

Avranches 127

Babi Jar $\rightarrow$ Sachregister

Bad Arolsen 251

Bad Harzburg 315

Bad Homburg 435

Baden-Württemberg 30, 222, 250, 498

Baltimore, Md. 234-235, 271, 277, 297, 409

Bangladesch 573

Bayern 30, 145, 151, 209, 222, 224, 242, 496-498, 515-516, 522, 524, 526-527

Bayeux 126

Belgien 130, 154

Belle Vue $\rightarrow$ Manchester

Berkeley, Calif. 569, 602, 625, 638

Berlin 26, 29-30, 57, 61, 63-64, 95, 135, 212-213, 222, 228, 236-237, 240, 242, 258, 260, 262, 265-267, 287, 289, 299-300, 303, 312, 382, 409-411, 413, 428-429, 438, 441, 443, 446-448, 450-451, 455-458, 464, 466-467, 469, 472, 474-476, 485, 497-498, 504, 506, $515,523-524,611,622-624,660$

Bern 411, 444

Bethesda, Md. 271

Bethlehem, Conn. 370

Beverly Hills, Calif. 561

Blackpool 116
Bonn $60-61,155,243,287-288,319,323$, 373-375, 378-380, 384, 387, 391-392, 394-395, 397, 399, 410-411, 428, 430, $532,542,544$

Boryslaw 294

Bosnien und Herzegowina 73

Bremen 30, 145, 222, 242, 258, 504

Bremerhaven 230

Breslau 280

Brookline, Mass. 657

Brüssel 135, 302, 462

Buchenwald $\rightarrow$ Sachregister: Konzentrations-, Arbeits- und Vernichtungslager

Buenos Aires 580

Bulgarien 452, 459

Burlington County, N. J. 107

Cambridge, Mass. 208

Carentan 126

Charmes 131

Châteaudun 130

Chemnitz 277

Cherbourg 126-127

Chicago 322, 493, 584, 586

China 452, 566, 654, 670

Clearwater, Fla. 649

Colorado 195, 201, 670

Comer See 562

Commercy 133

Coos Bay, Oreg. 646

Dachau $\rightarrow$ Sachregister: Konzentrations-, Arbeits- und Vernichtungslager

Dänemark 655

Darmstadt 177

Davos 496

Delhi 623

Den Haag 10, 46, 48, 74, 201, 207, 232, 234, 242-243, 284, 439-440, 486, 533-536, 591-595, 605, 643, 654

Denver, Colo. 570, 602 
Dobbs Ferry, N. Y. 102

Dresden 480

Düsseldorf 277, 288, 330, 333-334, 503

England 101, 109, 111-112, 115-118, 120-121, 123, 140-141, 172, 230, 241, 334, 432; siehe auch Großbritannien

Entebbe 598

Enville 133

Erlangen 136

Esch an der Alzette 134

Essen 291, 295

Europa 24, 26, 29, 36, 50, 59, 62, 122, 138-139, 154, 157, 225-227, 229, 240, 241, 299, 330, 365, 371, 380, 389, 391-392, 397, 413, 417, 449, 464, 493, 506-508, 523, 550, 571, 584, 588, 598, $664,667,677$

Falmouth 123

Finnland 470, 643

Flims 434

Florida 528, 555-556, 588, 593, 620, 626, $649,654,666,670$

Frankfurt am Main 28, 55-56, 66, 92, $136,173,242,247,254,261-262$, 265-267, 278, 307, 319, 352, 355-356, $358,361,411,426,453,455,495,504$, $515,543,554,558,582,590,660$

Frankreich 23, 34, 50, 101, 118, 120-124, $128,130-131,137,139-140,273,299$, 383-384, 428, 448, 454, 493, 506, 530, 566

Freckleton 115-116

Freiburg im Breisgau 582, 584

Garmisch-Partenkirchen 224

Gelsenkirchen 289

Genf 38, 70, 162, 202, 237, 351, 380, 382$383,386,390-392,394,397,399,403$, 430-431, 434, 472, 476, 512-513, 524, $529,531,561,563,566,577,586,677$

Griechenland 164, 336

Groningen 584
Großbritannien 23, 46, 50, 153, 172, 204, 227-228, 241, 247, 258, 285, 288, 292, 300, 368, 402, 426, 431, 436, 566; siehe auch England

Haifa 348

Haiti 44

Hamburg 258, 300, 329, 498, 502, 504, 590

Hameln 227

Hannover 498, 515

Hanoi 174-175

Heidelberg 38, 519, 607, 624, 654, 660, 677,680

Helsinki 472

Hessen 30, 145, 222, 242, 322, 515

Hirschberg-Leuterhausen 589

Hong Kong 670

Idaho 572

Illinois 654, 420

Indien 621, 654-655

Iowa 564,642

Irak 46, 73, 205, 666-667

Iran 556

Isigny-sur-Mer 126

Israel 10, 19, 29-31, 37, 53-54, 64, 91-92, 166-172, 180, 183, 207, 209-210, 223, 232-235, 237, 239, 242, 251, 254, 260, 264, 266, 284, 332, 334, 348, 352, 355, $361,375,380,402,413,429-430,439$ 441, 445, 457, 467, 472, 475, 485-486, 501, 504-506, 509, 511-512, 520, 535, $542-543,554,593,600,639,654$

Italien 105, 493, 506, 583

Japan 106, 139, 614, 654

Jennings, Mo. 644

Jerusalem 167, 170, 237-238, 289, 353, $361,414,446,457$

Joinville 130

Jugoslawien 44-45, 70, 73, 403, 418-419, $465,475,674,676,678,680$

Kalifornien 569, 625, 627, 654 
Kanada 285-286, 441, 446, 463, 469, 476, 508, 654-655

Kansas 654

Karlsruhe 543

Kiew 215, 555, 664

Köln 161, 207, 356

Kopenhagen 376, 531

Krim 148, 165

Kuwait 44, 73, 593, 667

Lancaster 116

Landsberg am Lech $28,148,155-157$, 183,279

Lateinamerika 472,508

Le Mans 130

Leipzig 156

Lettland 487

Libanon 476

Libyen 593

Linz 426

Litauen 258, 279, 657

Liverpool 110, 113

Livingston, N. J. 618

Locarno 238

London 30, 32, 108, 116-117, 121, 135, $145,183,228,243,248,272,368,389$, $402,426,432,500,506,531$

Lunéville 132-133

Luxemburg (Land) 50, 130, 134

Luxemburg (Stadt) 31, 66, 135, 284

Madrid 322, 583, 601, 603

Mainz 512

Malmedy 154

Manchester 50, 111-114, 121

Marokko 507

Massachusetts 327, 419, 573

Missouri 654

Mogadischu 598

Montreal 285-286, 501, 507, 654

Moskau 395, 475, 556, 664

München 140, 155, 187, 224, 262, 266, $298,495-497,504,512,515,519$, 523-527
My Lai 37, 69, 568, 572, 576

Naher Osten 232, 441, 472

Nancy 134

Nebraska 420

New Hampshire 615

New Jersey 107, 477

New Mexico 654

New Rochelle, N. Y. 33, 93, 427, 433, 579, 654,679

New York (Bundesstaat) 188, 550, 619, $621,654,657$

New York City 20, 24, 26, 28, 33, 35-36, $38,43,48,60,62-63,65-66,68,70$, $88,101-102,106,111,140,216,222$, 226, 230-232, 234-235, 241, 254, 257-258, 262-267, 270, 276, 278, 296, $299,316,322,324-325,330,351-352$, $365,369,372,397,410,414,416,427$, 429-430, 442, 453-454, 456-458, 468, 470, 477, 491, 497, 507-508, 548, 556, $563-564,573,577,590,606,616,625$, 655,677

- Bronx 21, 124

- Hell's Kitchen 20

Niederlande 130, 258, 266, 296, 334, 454, $457,530,655$

Nigeria 643

Nordrhein-Westfalen 316, 498, 515, 543

Norfolk, Va. 103

Normandie 23, 122, 124, 205

North Carolina 101

Nürnberg 15, 25-28, 33, 36, 48, 53, 57, 70-71, 74, 89-91, 136, 151-154, 160-161, 167-168, 174-176, 179, 187, $195,198,206,208,234,281,283,288$, 294, 301-302, 318, 374, 564, 570, 588, $607,669,678-679$

Oklahoma 195

Omaha Beach, Normandie 124

Orangetown, N. Y. 108

Oregon 238, 646

Orléans 130 
Österreich 137-139, 228, 241, 263, 273, 427, 493, 506, 549

Österreich-Ungarn 20

Palästina 29, 166, 227, 239-241, 260, 266, 274, 352, 429-430, 498, 543

Palm Beach, Fla. 593

Paris 93, 130, 208, 240, 368-369, 380, 383, $386,432-434,444,447,452-454,456$

Pennsylvania 421, 642, 654

Périers $127-128$

Persischer Golf 669

Philippinen 105-106, 578

Pittsburgh, Pa. 645-646

Polen 22, 151, 232, 234, 274, 279-280, $375,377,379,382,386-387,390$, 392-393, 396-399, 401, 403, 430, 436, $452,530-531$

Poole 119-120

Potsdam 64, 280

Prag 360

Preston 116

Puerto Rico 37

Rastatt 318

Ravensbrück $\rightarrow$ Sachregister: Konzentrations-, Arbeits- und Vernichtungslager

Rheinhausen 297, 319

Rhode Island 613

Riesa 452

Riga 149

Rom 45, 583

Rostow am Don 159

Ruanda 44, 45

Rumänien 20-21, 332, 380, 648, 679

Saargemünd 133

Saint-Lô 130

Salisbury 121

Satu Mare 648

Scharfenstein 277

Schweden 457, 530

Schweiz 228, 247, 258, 393, 411, 434, 459, 493, 496, 582
Seattle, Wash. 654

Sens 130-131

Simferopol 165, 190

Sizilien 121

Skandinavien 231, 531, 654

Slowakei 239

Smolensk 128, 149

Somalia 44

Southampton 119, 124

Sowjetunion $26,40,45,52,151,158-159$, $165,168,177,185,200-202,215$, 232-234, 322, 350, 436, 448, 464, 472, $475,481,483,491,566,654$

Spanien 110, 273

Springfield, Mass. 312-314, 317, 324, 327

St.-Dizier 130

St.-Hilaire 128

St.-Laurent-sur-Mer 126

St. Louis 645

Stockholm 531

Straßburg 163, 561, 569, 677

Stuttgart 156, 177, 210, 260, 267, 304$305,317,330$

Südosteuropa 164, 321

Syrakus 664

Syrien 441,593

Teheran 597

Tel Aviv 241, 350

Thüringen 336, 437

Tirol 138

Tokio 154, 613, 620, 621, 670

Toronto 596

Trier 136

Trinidad und Tobago 650-652

Tschechoslowakei 303, 360, 368, 402403, 506

Ukraine 148-149, 158, 177, 475

Ungarn 20-21, 232, 301, 386-387, 403, $431,452,475$

USA $\rightarrow$ Vereinigte Staaten von Amerika USSR $\rightarrow$ Sowjetunion 
Utah 366

Utah Beach, Normandie 124

Vereinigte Staaten von Amerika 20, 23, 25-26, 28, 33-36, 39, 42-44, 46, 50-54, 57-58, 60, 62-66, 69-74, 106-109, $112,122,138,141-142,149,161,163$, $165,168,174,185-186,194,196,198$, 200-202, 204, 206, 216, 225, 227-228, 230-232, 234, 237, 240-241, 257-258, 262-263, 267, 283, 294, 299, 312-316, 318-319, 321-322, 325, 327, 334, $338-339,347,355,366,368-370$, $372-374,381-382,412,414-418$, 420-421, 425, 428-429, 435-437, $442,444,446-448,451-452,454-455$, 459-466, 469-470, 473-476, 479-480, 491, 499, 519, 548, 550, 566-567, 569, 571, 575-578, 597, 606-607, 613, 623, $627,631,637,641-642,652,658,666$, 668-669, 673-676, 679

Vietnam 69-70, 174, 566-567, 570, 576, 635

\section{Sachregister}

115th Anti-Aircraft Artillery Gun Battalion $23,49,101,117,130,133-134$

Abrüstung (Disarmament) 44, 200-202, $478,481,578,623,636,676-677$

Advisory Board on Clemency for War Criminals $\rightarrow$ Peck Panel

AEG 33, 57-58, 258, 262-263, 266, 268, $280,282-285,336,350$

Agricola GmbH 277

Aktiengesellschaft für Berg- und Hüttenbetriebe 287

Allgemeine Erklärung der Menschenrechte (Human Rights Convention) $37,70,162,568$

Alliierte Hohe Kommission für Deutschland (High Commission for Occupied
Vilnius 225

Vitry-le-François 130

Virginia 102-103, 107, 159, 654

Warschau 22, 390, 399

Washington, D.C. 46, 73, 101, 145, 155, $161,185,270,299,314,318-319,322$, $335,338,371-373,376,389,394,397$, 409, 412, 416-417, 419-421, 428, 443, 446, 447-449, 452-453, 455, 462, 468, 470, 472-474, 499, 536, 579, 607, 613, $628,631,646,650-651,654,666$

Wassenaar 19, 31, 64, 91, 147, 227-228, $375,439,534$

Weißrussland 149, 159, 165

White Plains, N. Y. 621, 679

Wien 426, 452

Wingspread 570

Worcester, Mass. 656-657

Württemberg-Baden 145, 242, 250

Würzburg 89, 228

Zaire (Kongo) 446

Germany, HICOG) $146,155,160,164$, $179,186,205,212$

Alliierter Kontrollrat 27, 208, 588

American Civil Liberties Union 567-568, 571

American Congress $\rightarrow$ Kongress der Vereinigten Staaten

American Jewish Committee (AJC) 240, $271,382,598$

American Jewish Congress 549

American Jewish Joint Distribution Committee (AJDC) $\rightarrow$ Joint Distribution Committee

American Society of International Law $416,561,564,567-568,572-573$, $594,603,605,607,630-632,672,676$ 680 
Anti-Fascist Committee $\rightarrow$ Komitee der Antifaschistischen Widerstandskämpfer

Antikommunismus 55, 61, 168, 185, 225, $233,378,401,566$

Antisemitismus 20, 23, 48, 58, 60-61, 94, 208, 232-233, 401, 463, 466, 483, 487

»Arisierung « 157, 207

Association Internationale de Droit Pénal (International Association of Penal Law) 70, 576, 585, 587, 590

Association nationale des anciennes déportées et internées de la Résistance (ADIR) 34, 365-371, 380, 383-384, 400-402

Atomwaffen $\rightarrow$ Kernwaffen

Auschwitz $\rightarrow$ Konzentrations-, Arbeitsund Vernichtungslager

Auschwitz-Prozesse 173-174, 247, 274

Außenministerium der Vereinigten Staaten (United States Department of State) 63-64, 74, 105, 163, 188-189, 317-321, 330, 333-334, 336-338, $368,395,416,425,427-428,430,434$, 443-444, 447-448, 450-451, 456, 462-463, 467, 469, 471, 474-475, 479, $482,572,576,605,609,629,643,673$, 678-679

Auswärtiges Amt (German Foreign Office) $149,156,322,373,376-377$, 379, 382-383, 386, 397

Auto Union AG 277

B'nai B'rith $36,57,61-62,312,321-325$, 334-335, 337, 342, 402, 407-422, 433, 464, 497, 504, 537, 594, 607, 641, 677

Babi Jar 149, 177, 200, 215, 519

BEG $\rightarrow$ Bundesentschädigungsgesetz

Begnadigung verurteilter deutscher

Kriegsverbrecher 52-53, 148, 151-165, 179-191, 195-198, 214, 234, 611; siehe auch Peck Panel

Behandlungskosten, medizinische (medical expenses) 65-66, 372, 491-528
Berlin Document Center 57, 300, 312

Bilanzrichtliniengesetz (1985) 357

Blue Cross 497

Blue Shield 497

Borsig AG 267, 287, 289

BRABAG (Braunkohle-Benzin AG) 258, 262-263, 266, 343-344, 349

Briand-Kellogg-Pakt (1928) 566

British Army 117

Buchenwald $\rightarrow$ Konzentrations-, Arbeitsund Vernichtungslager

Buchenwald-Prozess 155

Büssing-Automobil-Werke-AG 349

Bundesentschädigungsgesetz (BEG, 1956) $31,65,227,242,251,261,309,369$, 378,534

- BEG-Schlussgesetz (1965) 36, 65-67, 496, 503, 506, 517, 530

Bundesergänzungsgesetz (1953) 31, 242

Bundesgerichtshof (German Federal Supreme Court) 56, 285, 303-305, 316, 343, 345, 507, 515, 517, 535

Bundeskanzleramt 373, 376, 378, 428

Bundesministerium der Justiz (German Ministry of Justice) 165,415

Bundesministerium der Verteidigung (German Ministry of Defense) 315-316, 320, 326, 334

Bundesministerium für Finanzen (German Finance Ministry) 60, 345, 373, 381-383, 386, 394-395, 401, 410, $415,507,530-531,533,543-544,547$, 552, 593

Bundesrechnungshof 546

Bundesregierung (German Government) $59,145,161,169,180,217,227,235$, $284,315,336,366-370,372,374-375$, 378, 381-395, 403-405, 414, 432, 492, 494, 500-501, 503, 507, 511, 531, 539-541, 543, 551, 556, 590, 610

Bundesrückerstattungsgesetz (1957) 61, 414

Bundestag (German Parliament) 56, 62, 156, 182-183, 207, 261, 373, 375-376, 
381-382, 410-411, 416, 498, 503, 506, $528,544,593$

- Ausschuss für Wiedergutmachung 62, 376

Bundesverband der Deutschen Industrie (BDI, German Chamber of Commerce) 261-263, 304-305, 307-308, 343, 349

Bundesverfassungsgericht (Federal Constitutional Court) 303, 305, 316, 344,416

Bürgerrechtsbewegung (in den Vereinigten Staaten) 35, 657

Campaign for UN Reform 650

Canadian Jewish Congress 508

Caritas 524

CDU $\rightarrow$ Christlich Demokratische Union Deutschlands

Center for UN Reform Education 616-618, 628, 677, 680

Central Archives for the History of the Jewish People 237

Central British Fund for Jewish Relief and Rehabilitation (World Jewish Relief) 237-238, 240, 426, 500

Central Council of Jews in Germany $\rightarrow$ Zentralrat der Juden in Deutschland

Christlich Demokratische Union Deutschlands (CDU) 156, 161, 207, $322,375,544,551$

Claims Conference $\rightarrow$ Conference on Jewish Material Claims Against Germany

Colt Industries 314

Committee of Former Jewish Slave Laborers in Germany 262

Committee of International Criminal Jurisdiction $\rightarrow$ Vereinte Nationen

Compensation Treuhand (CT) 58, 253, $288,292,307,312,340,345,350-352$, $354,356-358,360-361$

Conference on Jewish Material Claims Against Germany (JCC, CC) 10, 19, 30-35, 37, 48, 54-59, 62-68, 91-92, $94,147,168,207,225-230,232,235$,
237-238, 242-244, 248-255, 258-269, 271-272, 274, 277-278, 283-285, 288, 292, 296-297, 299, 301-302, 304-305, $307-308,310,322$, 325, 327, 330, 332$333,338,342,345,348-349,351-352$, 354, 356-361, 375, 416, 425, 428-432, 437-446, 450-475, 477-487, 530-541, 543-549, 551-554, 556-557

Continental Gummi-Werke AG 349

Council of Jews from Germany 228, 238, 241, 352, 411

Crimes against humanity $\rightarrow$ Verbrechen gegen die Menschlichkeit

D-Day 122-123

Dachau $\rightarrow$ Konzentrations-, Arbeits- und Vernichtungslager

Dachauer Prozesse 24, 154

Daimler-Benz AG 359-360

Darmstädter Einsatzgruppenprozess 177

Displaced Persons (DPs) 139, 155, 209 210, 242, 251, 258, 330, 493, 497, 543

Dynamit Nobel AG 58, 294, 298-299, 306, 308-311, 325, 337-338, 341-343, $346,354-358$

Eichmann-Prozess 53, 166-173

Eigentum, erbenlos gewordenes jüdisches (heirless Jewish property) 10, 29-30, $152,168,180,205-206,208,221-222$, $234,240,439,445,450,467,484-485$, 487, 607, 611, 679

Einsatzgruppen der Sicherheitspolizei und des Sicherheitsdienstes 26-27, 148-151, 158-160, 164-165, 176-178, $190,200,215,234,240,519,555-556$, 606

Einsatzgruppenprozess von Darmstadt $\rightarrow$ Darmstädter Einsatzgruppenprozess

Einsatzgruppenprozess von Nürnberg $\rightarrow$ Nürnberger Prozesse

Eisenhower-Doktrin 232

Eiserner Vorhang (Iron Curtain) 283, $375,377,379,381,385,387,394$ 
Ernst Heinkel AG 262, 267, 304-306, 317, 331, 343-345, 349

Ethania Sanatorium (Davos) 496-497

Ethnische Säuberungen 73, 674

Europäischer Gerichtshof für Menschenrechte (European Court of Human Rights, Straßburg, seit 1959) 561

FDP $\rightarrow$ Freie Demokratische Partei

Friedrich Flick KG 33, 157, 337, 353

Fliegermorde 24, 154

Flüchtlinge 29, 44, 66, 223-224, 232, 241, $288,367,411,416,491,493,501,506$, 530-531

Forced Labor $\rightarrow$ Zwangsarbeit

Ford Foundation 562

Ford Motor Company 437

Foreign Claims Settlement Commission (FCSC) 470-471, 473

Foundation for the Establishment of an International Criminal Court 70, 561-562, 664

Frankfurter Auschwitzprozess $\rightarrow$ Auschwitz-Prozesse

Fraternisierungsverbot 137-138

Freie Demokratische Partei (FDP) 544, 593, 660

Freimaurer 156, 183

Friedensnobelpreis 38, 201, 644, 647

Friedrich Krupp AG 33, 57-58, 157, 195 , 262-265, 268, 271-274, 276, 283-284, 290-291, 294-297, 301-302, 319

Friedrich-Naumann-Stiftung 659-661

Friends of ADIR, Inc. 34, 365-367

Gefangenenanstalt Landsberg 28, 52, 147-148, 151, 155-158, 161-165, 179, $183,188-189,214,297$

Generalversammlung der Vereinten Nationen $\rightarrow$ Vereinte Nationen

Genozid 10, 18, 27, 37-38, 45, 162, 464, 641

Genozidkonvention der Vereinten Nationen $\rightarrow$ UN-Genozidkonvention
German Chamber of Commerce $\rightarrow$ Bundesverband der Deutschen Industrie

German Federal Supreme Court $\rightarrow$ Bundesgerichtshof

German Finance Ministry $\rightarrow$ Bundesministerium für Finanzen

German Foreign Office $\rightarrow$ Auswärtiges Amt

German Government $\rightarrow$ Bundesregierung

German Parliament $\rightarrow$ Bundestag

Gesellschaft m.b.H. zur Verwertung chemischer Erzeugnisse (Verwertchemie) 310-311

Gestapo 61, 136, 212

Gesundheitsschäden (infolge von Zwangsarbeit/Haft in Konzentrationslagern) 55, 66, 146, 206, 251, 351, 380, 440, 491-528, 556

Global Education Associates 595-596, 607

Golfkrieg, Dritter (2003) 46

Golfkrieg, Zweiter (1990/1991) 44, 73, 666-668

Guzik \& Boukstein 226, 230

Habonim 231-232, 267

Härtefonds 67-68, 251, 254-255, 466, $483,487,530,532,534-537,539-540$, 543-548, 551, 555-557, 593

Harvard Law School 22, 101, 234, 269, $606,618,679$

Hebrew Immigrant Aid Society (HIAS) 66, 234-235, 491, 493-496, 499, 506-509, 555

Heinkel AG $\rightarrow$ Ernst Heinkel AG

Hessische Stiftung Friedens- und Konfliktforschung 660

High Commission for Occupied Germany (HICOG) $\rightarrow$ Alliierte Hohe Kommission für Deutschland

Holocaust 22-23, 27, 37-38, 54, 66, 136-137, 147-150, 152-153, 158-160, $165,167,173,176-177,195,197$, 204-205, 212-213, 215, 217, 221, 225, $234,237,240,251,256,258,301-302$, 
404, 440, 444, 455, 484-485, 491, 495, $504,526,529,538-539,542-543,548$, $553,555,569,606-607,647,656,657$

Holzmann $\rightarrow$ Philipp Holzmann AG Humanexperimente $\rightarrow$ Medizinische Humanexperimente

Human Rights $\rightarrow$ Menschenrechte

Human Rights Convention $\rightarrow$ Allgemeine Erklärung der Menschenrechte

I. G. Farben 33, 55-58, 158, 247, 249-257, 259-265, 269, 272, 283-284, 298, 310

Indemnification agencies $\rightarrow$ Landesentschädigungsämter

Institute of Jewish Affairs 147, 432

International Association of Penal Law $\rightarrow$ Association Internationale de Droit Pénal

International Criminal Code 585-588

International Law Commission $\rightarrow$ Vereinte Nationen

International League for the Rights of Man 441

Internationaler Gerichtshof (International Court of Justice, Den Haag, seit 1946) $456,591,605,631,636,643,661-662$, 667

Internationaler Militärgerichtshof (International Military Tribunal, Nürnberg, 1945/1946) 25, 27-28, 49, 51, 152-154, 157-158, 169, 171, 190, 195-196, 269, 288, 301-302, 588, 615

Internationaler Strafgerichtshof (International Criminal Court, Den Haag, seit 2002) 10, 18, 45-46, 569, 584,603

Internationaler Strafgerichtshof (Konzept) 40, 44-45, 53-54, 70-71, $151,163,167,169,171-172,174,198$, 200, 528, 561-562, 570, 575, 578, 580, $583,585,589,591-592,595-596,598$, 601, 631, 634-636, 642-644, 650-652, $655,658-659,662,664,667-669,672$, $676,678,680$
Internationaler Strafgerichtshof für das ehemalige Jugoslawien (International Criminal Tribunal for the former Yugoslavia, ICTY, Den Haag, 1993-2017) $45,70,73-74,676,678,680$

Internationaler Suchdienst (International Tracing Service, Bad Arolsen) 251

Internationales Auschwitz-Komitee 274

Internationales Komitee vom Roten Kreuz $\rightarrow$ Rotes Kreuz

Irakkrieg, Erster $\rightarrow$ Golfkrieg, Zweiter

Jewish Agency 226, 239-241, 243, 260, $352,430,540,543$

Jewish Claims Conference $\rightarrow$ Conference on Jewish Material Claims Against Germany

Jewish Community Relations Council 488, 547-549

Jewish Restitution Successor Organization (JRSO) 28-30, 32, 54, 91, 168, 180, 205-206, 222-223, 225-228, 230, 232, 234, 236-238, 240-243, 249, 258, 262, 267, 273, 278, 281, 283, 287, 289-290, 292, 295, 298-301, 303, 305-306, 308-309, 312, 317, 320, 324, 331, 333, $335,337,341,344,401,416,502,510$, 529,607

Jewish Trust Corporation (JTC) 237-238, 300, 426, 433, 500

Joint Distribution Committee (JDC) 93, 226, 240-241, 243, 299, 351, 382, 429, 456, 493, 504, 506-508, 512-514, 516, $520,522,531,540$

Judge Advocate Section der US-Streitkräfte $23,133,136,138-139$

Jüdischer Weltkongress (World Jewish Congress) 147, 164, 240, 243, 312, 323, 351, 428, 430-432, 434, 447, 484-485, 549, 657

Justizministerium der Vereinigten Staaten (United States Department of Justice) $257,343,347,422,470,673$ 
Kalter Krieg 10, 33, 35, 40, 43-45, 52, 60, $68,185,481$

Kernwaffen 153, 472, 631, 636, 649, 677

Kolonialismus 106, 599

Komitee der Antifaschistischen Widerstandskämpfer (KdAW, Anti-Fascist Committee) 63-64, 443, 448, 450-454, 456-461, 464, 466

Kongress der Vereinigten Staaten (United States Congress) 58, 62, 64, $154,257,314,316,326,330,334,346$, $366,390,418-421,450,459,462-464$, $470,473,475,478-479,482-483,567$, 606, 608-609, 642-643, 655, 658

Konzentrations-, Arbeits- und Vernichtungslager 23-24, 34, 51, 66, 73, 137-138, 153-154, 157, 160, 167-168, 181-182, 190, 251, 278, 296, 299, 329, $348,354-355,360,365,374,426,439$, $455,496,511,540,647,674$

- Allendorf 311

- Altaussee 138

- Auschwitz 173, 198, 203-205, 208, 251, 273-274, 444, 526

- Auschwitz-Monowitz/Buna 55, 249-251, 254, 257, 260, 264, 270, 296

- Bergen-Belsen 266, 301

- Buchenwald 24, 154-155, 195, 285 , 289, 291, 301, 310-311, 383, 461, 478, 647

- Dachau 24, 154, 160, 165, 273, 279, 282, 522, 524, 526

- Ebensee 24, 137

- Essen-Humboldtstraße 291

- Flossenbürg 136, 277

- Fünfteichen 280

- Gera 340

- Groß-Rosen 280

- Jaworzno 279

- Kaufering/Landsberg 279

- Langenbielau 286, 295

- Markstädt 280

- Mauthausen 24, 137

- Mühldorf 279
- Nekla 279

- Oederan 277

- Oranienburg 306

- Posen-Gutenbrunn 279

- Ravensbrück 34,60, 181, 189, 365, 383-384, 390, 403-404

- Reval/Tallinn 279, 282

- Sachsenhausen 228, 296, 453

- Schmiedeberg/Waldenburg 279

- Sömmerda 289,330,333, 336

- Utting am Ammersee 279

- Wapniarka 380

- Westerbork 266

- Wittenberge 279

- Września 279

- Žiežmariai 279

Koreakrieg 186, 566

Krankenhäuser 65, 238, 251, 295, 314, 496-497, 511

Kriegsgefangene 116, 154, 573

Kriegsgefangenenlager 116, 138

Kriegsministerium der Vereinigten Staaten (United States Department of War, 1789-1947) 25, 108, 117, 138, 211

Krupp $\rightarrow$ Friedrich Krupp AG

Kunst- und Kulturgüter, durch die Nationalsozialisten geraubte 24, 89, 137-138, 149, 237, 318

$\mathrm{KZ} \rightarrow$ Konzentrations-, Arbeits- und Vernichtungslager

Länderrat des amerikanischen Besatzungsgebiets 145, 208, 242

Landesentschädigungsämter (Indemnification agencies) 66, 495-497, 502, $515,519,523,526$

League of Nations $\rightarrow$ Völkerbund Leipziger Prozesse (1921-1927) 156-157

Leonhard Moll KG 262, 266, 279, 348

Londoner Schuldenabkommen (1953) 207, 210, 303, 310, 316, 343

Londoner Viermächte-Abkommen (Londoner Charta/Nürnberger Charta, 1945) 24-25, 169, 171, 588 
Luftwaffe 23, 128, 137, 153

Luxemburger Abkommen (1952) 10, 19, $31,63-64,66,91-92,147,227-228$, $243,284,375,439,486,534$

MALBEN 429, 504, 506, 509-511, 515-517, 520, 523, 525

Malmedy-Massaker 154

Manila Declaration on the Peaceful Settlement of International Disputes (1982) 602

Massenvernichtungswaffen 605, 636, 662

Max-Planck-Institut für ausländisches öffentliches Recht und Völkerrecht, Heidelberg 38, 607, 624, 680

Max-Planck-Institut für ausländisches und internationales Strafrecht, Freiburg 581, 584

Medical expenses $\rightarrow$ Behandlungskosten, medizinische

Medienkampagnen/Medienarbeit $\rightarrow$ Public Relations

Medizinische Humanexperimente 19, 34, 59-61, 153, 189-190, 363-405

Meistbegünstigungsklausel (most favored nation) $63-64,446,449,459,462-464$, $468,471,473$

Memorial Foundation for Jewish Culture 352, 539-540

Menschenrechte (Human Rights) 15, $44-45,68,70,183,331,368,446,464$, 567-569, 578, 581, 584, 596, 598-599, 604-605, 619, 621, 631, 633, 636, 643, $647,651,662,670,677$

Menschenrechtscharta der Vereinten Nationen $\rightarrow$ Allgemeine Erklärung der Menschenrechte

Messerschmitt AG 349

Militärgouverneur der amerikanischen Besatzungszone 145-146, 154, 241

Militärregierung, amerikanische in Deutschland (US Military Government in Germany) $17,28,35,145-147,165$, 206, 208, 211, 222, 234, 240, 607
Militärregierungsgesetz Nr. 59 (USREG, 1947) $28,168,208,222$

National Peace Academy Campaign 71, 607-608

Nationalsozialistische Deutsche Arbeiterpartei (NSDAP) 138, 300, 312, 319, 376 NATO $182,186,429,448,675$

New Deal 21, 106

New York Association for New Americans (NYANA) 66, 351, 491-492, 494-497, 499, 502, 504, 507, 509, 515-516, 519-520, 523-524, 527

Nuklearwaffen $\rightarrow$ Kernwaffen

Nürnberger Charta $\rightarrow$ Londoner Viermächte-Abkommen

Nürnberger Prozesse 30, 38-39, 45-46, $49,51-54,57-59,70-74,152,155$, 161-162, 164, 168-169, 173-175, 179, 185, 189-190, 193, 198, 214, 218, 221 , 249, 271, 299, 301-302, 310, 318, 374, 561-562, 564, 567, 570, 575, 591, 601, 604, 606, 615, 624, 641-642, 652-653, $657,661,668-669,674,678-679$

- Hauptkriegsverbrecherprozess 25, 38, 153-154, 269, 288

- Nachfolgeprozesse 10, 15, 17, 25-28, $33,47,49,51,148,153-154,160,164$, $168-169,188,195,218,249,264$, 269-270, 288, 374, 404, 588, 668

- Fall I: Ärzteprozess 153, 155, 166, 189-190, 374, 405

- Fall II: Milch-Prozess 218

- Fall IV: Prozess gegen das Wirtschafts-Verwaltungshauptamt der SS (Pohl-Prozess) 160, 166, 190, 218, 270

- Fall V: Flick-Prozess 158, 249, 270, 294, 353

- Fall VII: Prozess gegen Generäle in Südosteuropa (Geiselmordprozess) 164

- Fall VIII: Prozess gegen das Rasseund Siedlungshauptamt der SS 166 
- Fall IX: Einsatzgruppenprozess 10-11, 15, 17, 26-28, 49, 51-53, 90, 147-152, 158-160, 164-165, 167, 176-178, 187, 190, 200, 212-213, 218, 234, 240, 606, 679

- Fall X: Krupp-Prozess 57, 157, 195, 264, 270, 283, 301-302

- Fall XI: Wilhelmstraßen-Prozess 164

- Fall XII: Prozess gegen das Oberkommando der Wehrmacht 215

Oberster Gerichtshof der Vereinigten Staaten (Supreme Court) 106, 155, 161, 194, 196, 283, 569

Office of Strategic Services (OSS) 138, 299

Operation Desert Storm $\rightarrow$ Golfkrieg, Zweiter

Pace Peace Center (PPC) 71, 602, 622, 634, 637-639, 641, 650, 653-655, 658, $661,664,668,671,676,679$

Pariser Reparationsabkommen (1946) 366

Peck Panel (Advisory Board on Clemency for War Criminals) 151, 155, 179, 186-192, 196-197; siehe auch Begnadigung deutscher Kriegsverbrecher

Pentagon $\rightarrow$ Verteidigungsministerium der Vereinigten Staaten

Philipp Holzmann AG 262, 266-267, 278-282, 348

Post-65-Härtefonds $\rightarrow$ Härtefonds

Potsdamer Abkommen 64, 436, 438, 466, 483

Public Relations 17, 57-58, 69, 73, 198, 322, 327, 367, 369-370, 372, 390, 437, 446

Rassismus 23, 48, 50, 101, 112

Ravensbrück $\rightarrow$ Konzentrations-, Arbeitsund Vernichtungslager

Ravensbrueck Lapins Project 34-35, 60, 365-405
Red Cross $\rightarrow$ Rotes Kreuz

Regierung der Vereinigten Staaten

(United States Government) 46, 69, 72-73, 146, 201, 269, 325, 444, 470, $566,603,626,630,673$

Reichswerke »Hermann Göring « 287

Rene Cassin Stiftung 561

Renten 146, 366, 369, 374, 379-380, 382, 387, 452, 483, 519, 540

Repräsentantenhaus der Vereinigten Staaten (United States House of Representatives) 64, 257, 327, 330, 366, 390, 419-421, 450, 459, 473-475, $478-479,482,529,550,567,606$, 608-609, 642

Rheinmetall Berlin AG 33, 58, 285-289, 303-305, 312-338, 342, 346

- Rheinmetall-Borsig 287

Röchlingsche Eisen- und Stahlwerke $\mathrm{GmbH} 287$

Rotes Kreuz (Red Cross) 60, 109, 111, 380, 382, 386-387, 389, 397, 401, 403

- Internationales Komitee vom Roten Kreuz 382-383, 386, 389-394, 396, 398, 403, 405

- Polnisches Rotes Kreuz 389-390, 398-399

- Ungarisches Rotes Kreuz 387

Rückerstattungsgesetze $\rightarrow$ Militärregierungsgesetz Nr. 59; Bundesrückerstattungsgesetz

Rüstungsindustrie 58, 287, 303, 310, 314, $320,345,356$

Rüstungskontrolle (arms control) 201, $608-609,615,631,661$

Salzgitter AG 287

Schoah $\rightarrow$ Holocaust

Schutzstaffel (SS) 24, 51, 123, 136, 149-150, 153-154, 158-160, 164, 166-167, 181, 189-190, 200, 234, 240, $273,281,376,380,453,519,606$

Scientology 649 
SED $\rightarrow$ Sozialistische Einheitspartei

Deutschlands

Senat der Vereinigten Staaten (United

States Senate) $257,325,330,366,410$, 420-422, 564-565, 573, 606, 608, 612, $627,641,657-658,664,669$

Senat von Berlin 409

Sicherheitsrat der Vereinten Nationen $\rightarrow$ Vereinte Nationen

Siemens AG 58, 262, 267, 273-274, 289, 340

Sozialdemokratische Partei Deutschlands (SPD) 182-183, 191, 373, 376, 381-382, 409, 416, 428, 506, 532-533, 544,593

Sozialistische Einheitspartei Deutschlands (SED) 430, 437-438, 443, 445, 448, 454, 459

Special Committee on the Question of Defining Aggression $\rightarrow$ Vereinte Nationen

SS $\rightarrow$ Schutzstaffel

Staatenlose 366,369

Stille Hilfe für Kriegsgefangene und Internierte 161

Supreme Court $\rightarrow$ Oberster Gerichtshof der Vereinigten Staaten

Telefunken AG 33, 57, 258, 262-263, 265-266, 268, 280, 282-284, 316

Terrorismus 42, 64, 575, 582-583, 591, $596,598,600,631,635-636,642-643$, $652,655,661-662$

Todesmärsche 136

Todesstrafe 53, 150-152, 154, 157-159, $161,164,172,176,180,182,190-191$, $198,212,234$

UN-Genozidkonvention 45, 162, 464, $575,582,596,641-642$

UN-Menschenrechtscharta $\rightarrow$ Allgemeine Erklärung der Menschenrechte

United Jewish Appeal 240, 323, 497, 504
United Restitution Organization (URO) 32-33, 37, 54, 67-68, 168, 226-230, $235,238-244,248,257-267,272$, 276-278, 285-286, 305, 319, 332, $334,343,351-360,434,450,494-496$, 519-520, 523-525, 538-540, 554-557

United States Army 23-24, 48, 50, 52, $55,101-140,145-147,154,157,162$, $168,205,209,226,232,237,334,461$, 568

United States Congress $\rightarrow$ Kongress der Vereinigten Staaten

United States Department of Defense $\rightarrow$ Verteidigungsministerium der Vereinigten Staaten

United States Department of Justice $\rightarrow$ Justizministerium der Vereinigten Staaten

United States Department of State $\rightarrow$ Außenministerium der Vereinigten Staaten

United States Department of War $\rightarrow$ Kriegsministerium der Vereinigten Staaten

United States Government $\rightarrow$ Regierung der Vereinigten Staaten

United States House of Representatives $\rightarrow$ Repräsentantenhaus der Vereinigten Staaten

United States Institute of Peace (USIP) 71, 606, 608-611, 626-627, 638-640, 654,671

United States Senate $\rightarrow$ Senat der Vereinigten Staaten

US Military Government in Germany $\rightarrow$ Militärregierung, amerikanische in Deutschland

USREG $\rightarrow$ Militärregierungsgesetz Nr. 59

Verbrechen gegen die Menschlichkeit (Crimes against humanity) 10, 27, 73, $149,163,168,174,198,561,575-576$, $588,591,596,600,635,642,657,662$, $669,673-674,678,680$ 
Vereinte Nationen (United Nations) 37-40, 42-45, 53, 63, 70, 72-74, 139, $162,198,201-202,322-323,366-371$, $377,394,428,430,432-433,436-438$, 441-442, 459, 471, 476-477, 543, 563, 566, 569, 576-578, 584-587, 592, 594, 596-597, 599-605, 613-621, 631, $635,637,641,645-646,649-654,658$, 661-662, 666-669, 672-673, 675-680

- Charta der Vereinten Nationen 566, 578, 604-605, 631, 649, 661

- Committee of International Criminal Jurisdiction 664

- Generalversammlung (General Assembly) $39,162,201,434,436,441,459$, 471-472, 477, 577-578, 585-587, 590, $592,597,643,661-662,667,676-679$

- Sicherheitsrat (Security Council) 38-41, 44, 72-73, 432-433, 454, 592, 597, 662, 666-667, 676-678

- Special Committee on the Question of Defining Aggression 577

- Völkerrechtskommission (International Law Commission) 162, 430, 456-457, $585,587,592,597,658,664,672,677$

Vergeltung 15, 25, 53, 168

Verjährung (Statute of Limitations) 56, 259, 261, 263, 304-305, 310, 343, 345, 571

Versailler Vertrag 156

Verteidigungsministerium der Vereinigten Staaten (United States Department of Defense) 58, 71, 161, 312-319, 321, $324,328,330,333-334,336,473,475$, $566,571-572,575-576,608-609$

Verwertchemie $\rightarrow$ Gesellschaft m.b.H. zur Verwertung chemischer Erzeugnisse

Vietnamkrieg 15, 37, 53, 68-70, 174, 314, 566-572, 576, 635

Völkerbund (League of Nations) 38-39, 202, 582, 599, 667

- Satzung des Völkerbunds 605, 661

Völkermord $\rightarrow$ Genozid
Völkermordkonvention der Vereinten Nationen $\rightarrow$ UN-Genozidkonvention

Völkerrechtskommission $\rightarrow$ Vereinte Nationen

War Claims Act $36,62,418,574$

War Criminal Prison No. $1 \rightarrow$ Gefangenenanstalt Landsberg

Warschauer Ghetto 160, 548

Warschauer Pakt 60, 322, 382, 448, 483

Wehrmacht 23, 128, 160, 164, 190, 214-215, 224, 386

Weiße Rose 181

Weißes Haus 203-204, 422, 610, 612, 667,674

Wettrüsten 472, 637, 662

Wiedervereinigung Deutschlands 37, 63, $68,233,478,481$

WMF AG 349

World Association of Judges and Law Professors 579

World Association of Lawyers 70, 578-580

World Federalist Association 73, 607, 619, 644-646, 650, 666, 677

World Jewish Congress $\rightarrow$ Jüdischer Weltkongress

World Peace Through Law Center (WPLC, World Jurist Association) 70, 95, 576-580, 583-584, 611, 616-617, $623,634-635,650,680$

World Without War Council 637-638

Yad Vashem 294, 348, 356

Zentralrat der Juden in Deutschland (Central Council of Jews in Germany) 67, 249, 258-259, 455, 483, 540, 543-547

Zwangsarbeit (slave labor, forced labor) 19, 33, 40, 55-60, 63, 128, 136, 153, 157-158, 180, 195, 245-361, 411, 427, $431,438,541$ 